\title{
Janusz Myszczyszyn
}

\section{Wpływ kolei ielaznych na wzrost gospodarczy Niemiec}

(1840-1913) 



\section{Janusz Myszczyszyn}

\section{Wpływ kolei ielaznych na wzrost gospodarczy Niemiec (1840-1913)}
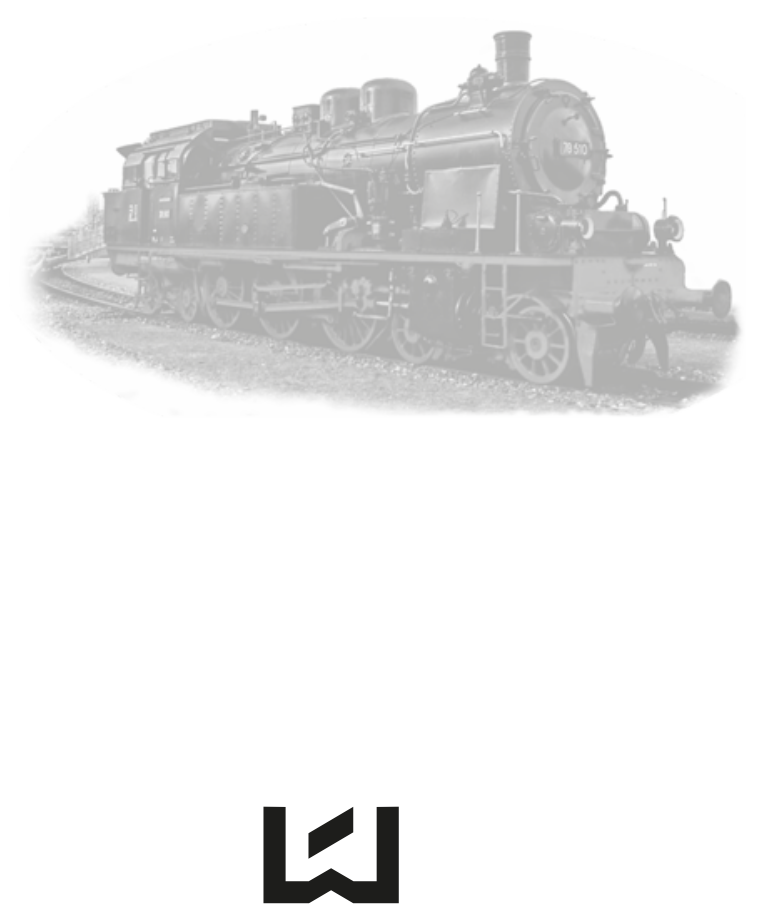

WYDAWNICTWO

UNIWERSYTETU

ŁÓDZKIEGO

ŁóDź 2013 


\title{
Janusz Myszczyszyn - Katedra Ekonomii, Wydział Ekonomiczny
} Zachodniopomorski Uniwersytet Technologiczny w Szczecinie

71-210 Szczecin, ul. Żołnierska 47

\section{RECENZENT}

Janusz Skodlarski

\author{
REDAKTOR WYDAWNICTWA UŁ \\ Elżbieta Marciszewska-Kowalczyk
}

\begin{abstract}
SKŁAD I ŁAMANIE
\end{abstract}
$A G E N T P R$

PROJEKT OKŁADKI

Łukasz Orzechowski

(C) Copyright by Zachodniopomorski Uniwersytet Technologiczny, Szczecin 2013

(C) Copyright for this edition by Uniwersytet Łódzki, Łódź 2013

\section{Wydane przez Wydawnictwo Uniwersytetu Łódzkiego}

Wydanie I. W.06223.13.0.X

ISBN 978-83-7525-882-0

\author{
Wydawnictwo Uniwersytetu Łódzkiego \\ 90-131 Łódź, Lindleya 8 \\ www.wydawnictwo.uni.lodz.pl \\ e-mail ksiegarnia@uni.lodz.pl \\ tel. (42) 6655863 , faks (42) 6655862 \\ Druk i oprawa: Quick Druk
}




\section{SPIS TREŚCI}

WSTEP

Uzasadnienie podjętego tematu ..................................................................................................... 7

Cel główny i cele cząstkowe $\ldots$

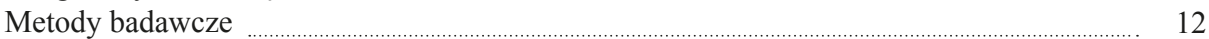

I. UKSZTALTOWANIE SIE SYSTEMU KAPITALISTYCZNEGO _................................... 21

1. Kapitalizm wolnokonkurencyjny w Anglii, Francji i Stanach Zjednoczonych ......................... 21

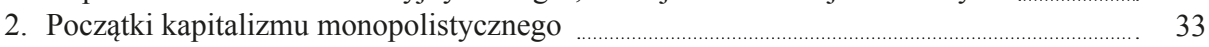

II. ROZBUDOWA I WZROST ZNACZENIA TRANSPORTU _.............................................. 43

1. Ocena stanu transportu wodnego i lądowego w początkach XIX wieku ........................... 43

2. Koleje żelazne - rewolucja w transporcie i komunikacji .................................................... 52

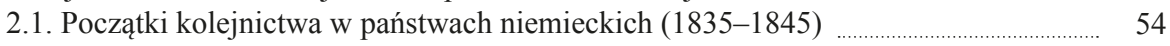

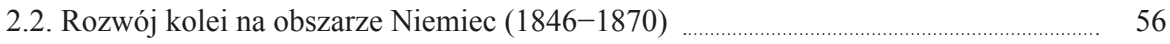

2.3. Kolej niemiecka po 1870 roku ..................................................................................................... 62

3. Rywalizacja pomiędzy transportem wodnym i kolejowym na przykładzie obszaru Łaba-

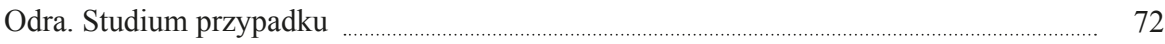

4. Wpływ kolei na wzrost gospodarczy w Stanach Zjednoczonych i w Europie Zachodniej 86

III. CZYNNIKI WZROSTU GOSPODARCZEGO NIEMIEC _.......................................... 97

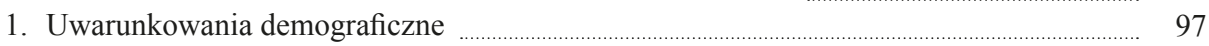

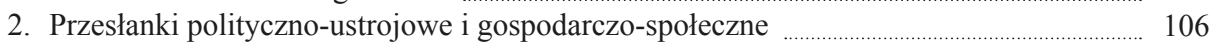

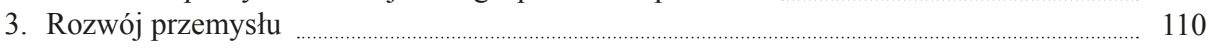

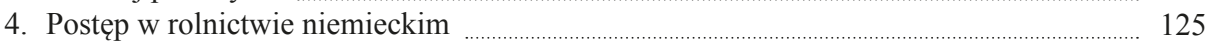

5. Wymiana handlowa w okresie Niemieckiego Związku Celnego. Handel zagraniczny

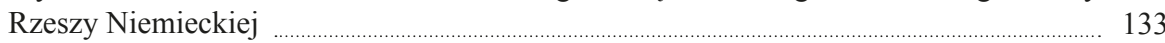

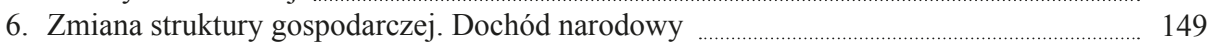

IV. ZASTOSOWANIE WYBRANYCH MIAR I MODELOWANIA EKONOMETRYCZNEGO W WERYFIKACJI ISTOTNYCH CZYNNIKÓW WZROSTU GOSPODARCZEGO NIEMIEC

1. Wzrost produktywności w wiodących sektorach gospodarki na przykładzie kolei i innych rodzajów transportu

. Wpływ kolei na wzrost gospodarczy: capital term, społeczne oszczędności (social savings) z wykorzystaniem nadwyżki konsumenta

3. Rachunek wzrostu z wykorzystaniem całkowitej produktywności czynników produkcji (TFP), produkcji (output), wskaźnika input na przykładzie sektora kolejowego

4. Wykorzystanie modelowania ekonometrycznego w ocenie wpływu kolei żelaznych i innych czynników na wzrost PKB 
ANEKS

214

BIBLIOGRAFIA

SPIS TABEL

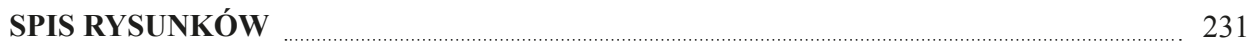

OD REDAKCJI 


\section{WSTĘP}

\section{UZASADNIENIE PODJĘTEGO TEMATU}

Na początku XXI w. jedynie 30 krajów osiągnęło wysoki poziom rozwoju gospodarczego, podczas gdy ponad 5 miliardów ludzi wciąż żyje w społeczeństwach o gospodarkach o niskim i średnim poziomie zaawansowania ${ }^{1}$.

Stąd szczególną rolę w poszukiwaniach i próbach zapewniania dobrobytu społecznego odgrywa identyfikacja i ocena procesów ekonomicznych i społecznych zachodzących w XIX i początkach XX w., które wpłynęły na ukształtowanie obecnych światowych mocarstw gospodarczych.

Ważnym czynnikiem determinującym wzrost gospodarczy był kapitał fizyczny. Do połowy lat pięćdziesiątych XX w. kapitał fizyczny postrzegano, jako z jednej strony kluczowy czynnik wzrostu, a jego słaby rozwój, jako główną barierę wzrostu i rozwoju ekonomicznego. W kolejnych dekadach, przedstawiciele różnych szkół ekonomii uzasadniali istotną rolę kapitału ludzkiego i kapitału spolecznego ${ }^{2}$.

Nowa teoria wzrostu nawiązująca do prac Roberta Solowa, zapoczątkowana pracami Paula Romera i Roberta E. Lucasa, opiera się na podstawowym założeniu, że wielkość produkcji jest funkcją kapitału oraz aktualnego poziomu technologicznego. Poziom techniczny nie jest jednak wielkością egzogeniczną, ale tworzony jest poprzez duże nakłady sektora prywatnego i państwa, czyli ma charakter endogeniczny.

Czynnikiem niezbędnym dla zapewnienia wzrostu dochodu, który związany jest $\mathrm{z}$ akumulacją kapitału ludzkiego jest proces szeroko rozumianego uczenia się przez działanie, obejmujący: learning-by-doing (nauka przez produkcję, działanie), knowledge spill-over (,,rozlewanie się" się wiedzy i umiejętności), knowledge (wiedza), jako wypadkowe uczenia się przez działanie, procesu rozprzestrzeniania się kwalifikacji i umiejętności pracowników, aktywności sektora B\&R itd.

\footnotetext{
${ }^{1}$ Rozwój polskiej gospodarki - perspektywy i uwarunkowania, red. G. Kołodko, Warszawa 2002, s.7.

${ }^{2}$ Por. J.J. Sztaudynger, Wzrost gospodarczy, rodzina a godność życia, [w:] „Nauka-Etyka-Wiara” 2011, s. 377-391; J.J. Sztaudynger, W. Zatoń, Kryzys gospodarczy a kryzys rodziny - analizy symulacyjne, „Prakseologia” 2010, nr 150, s. 109-128; J.J. Sztaudynger, Wzrost gospodarczy a kapitat spoleczny, prywatyzacja i inflacja, Warszawa 2005.
} 
Jak dowodzi P. Romer, częściej barierą dla rozwoju jest luka know-how niż luka w poziomie inwestycji.

Stąd uzasadniona jest potrzeba nieustannego poszukiwania odpowiedzi na pytania o drogi prowadzące do wyższej konkurencyjności gospodarek oraz podnoszenia standardu życia społeczeństw. Ważne jest, aby w miarę rozwoju metod badawczych, stosować je dla wyjaśnienia rzeczywistych czynników startu wzrostu i rozwoju gospodarczego współczesnych mocarstw gospodarczych.

Jednym $\mathrm{z}$ takich zagadnień jest określenie roli transportu, $\mathrm{w}$ tym kolei w etapie wczesnego wzrostu gospodarczego w XIX w. Rozwój transportu był i jest ważnym elementem przemysłu krajowego - z jednej strony, transport determinuje szybki wzrost innych sektorów gospodarki narodowej, z drugiej szybki rozwój gospodarki krajowej wymaga rozwiniętego transportu.

Założenie, że innowacje technologiczne były jedną z sił napędowych wzrostu gospodarczego w XIX w. wydaje się bezsporne. Koleje, jako jedna z ważniejszych innowacji w XIX w. i zarazem okresu przewrotu technicznego, były wielokrotnie przedmiotem badań ekonomistów, a różnorodne metody badawcze zostały rozwinięte w latach sześćdziesiątych XX w. ${ }^{3} \mathrm{Na}$ fali krytyki dotychczasowych metod powstał paradygmat New Economic History $(\mathrm{NEH})^{4}$. Badacze związani z tym nurtem, powszechnie zwani kliometrykami, wykorzystują historyczne dane statystyczne, aby później poddawać je szczegółowym badaniom przy użyciu metod ekonometrycznych. Głównym celem badawczym jest dążenie do weryfikacji utartych twierdzeń i obiegowych prawd. Przykładem takiej obiegowej prawdy, jest stwierdzenie, że koleje żelazne, jako nowy środek komunikacji odegrały w warunkach XIX w. jedną z ważniejszych ról w rozwoju gospodarczym państw europejskich i USA ${ }^{5}$.

Słynny badacz historii gospodarczej Walt Rostow analizując rolę sektora kolejowego w USA wskazywał, że "The introduction of the railroad has been historically the most powerful single initiator of take-offs. It was decisive in the United States, France, Germany, Canada, Russia..." [Wprowadzenie kolei było historycznie, jednym z najważniejszych czynników startu gospodarek (take-off). W przypadku USA, Francji, Niemiec, Kanady i Rosji był to czynnik decydujący] $]^{6}$. W zasadzie w latach pięćdziesiątych XX w. nikt nie podważał znaczenia kolei na etapie startu gospodarek do samoczynnego rozwoju. Jeszcze w 1959 r. Chri-

${ }^{3}$ A. Fishlow, American Railroads and the Transformation of the Antebellum Economy, Cambridge 1965; R. W. Fogel, A Quantitative Approach to the Study of Railroads in American Economic Growth: A Report of Some Preliminary Findings, „Journal of Economic History” 1962, no. 22, s. 163-197; W.W. Rostow, The Process of Economic Growth, New York 1962.

${ }^{4}$ Zapoczątkowany w latach pięćdziesiątych XX w. przez dwóch młodych naukowców J. Meyera i A. Conrada.

${ }^{5}$ Por. R. Fogel, Railroads and American Economic Growth: Essays in Econometric History, Baltimore 1964.

${ }^{6}$ W.W. Rostow, The Stages of Economic Growth - A Non Communist Manifesto, Cambridge 1990, s. 55. 
stopher Savage dowodził, że rola kolei w rozwoju gospodarczym USA jest nie do przecenienia ${ }^{7}$. Robert Fogel i później Albert Fishlow wykorzystując m.in. koncepcję social savings udowodnili, że znaczenie kolei w rozwoju gospodarczym USA nie było tak wielkie, jak opisywał W. Rostow i jak powszechnie uważano.

Mimo że praca R. Fogla Railroads and American Economic Growth: Essays in Econometric History dotycząca USA jest powszechnie znana i wpływa na doskonalenie warsztatu ekonomisty (ekonometryków) i rozwoju metod naukowych ${ }^{8}$, w tym metod ilościowych, badanie przyczyn wczesnego wzrostu gospodarczego Niemiec w ocenie autora jest istotnym problemem naukowym?

Jak zauważają inni naukowcy, w tym badający historię gospodarczą Niemiec, kliometria mimo, jej rozkwitu w USA i Wielkiej Brytanii nadal jest mało popularna na kontynencie europejskim, także w Niemczech i w Polsce ${ }^{10}$. Wartość i przydatność weryfikacyjna dorobku naukowego R. Fogla, Douglasa Northa, A. Fishlowa, a także sukces gospodarczy jaki osiągnęły Niemcy, oraz brak dorobku naukowego z zakresu New Economic History w Polsce, są głównym powodem podjęcia tego zagadnienia $w$ ramach rozprawy habilitacyjnej.

Dotychczasowe prace badawcze $\mathrm{w}$ tym zakresie prowadzone były z użyciem tradycyjnych metod, które szczegółowo w polskiej metodologii opisuje Witold Kula $^{11}$. Założenia paradygmatu New Economic History, mimo opracowania metodologicznego już w połowie lat osiemdziesiątych XX w., są nadal mało znane w Polsce i trudno doszukać się prac badawczych z tej problematyki ${ }^{12}$.

Powstanie takiej pracy mogłoby zapoczątkować podjęcie dalszych badań w Polsce z uwzględnieniem metod ekonometrycznych i stworzyłoby możliwość naukowej krytyki prac z tego zakresu innych kliometryków w świecie. Przed historią gospodarczą w Polsce stoją ważne i nowe wyzwania dotyczące weryfikacji wielu utartych twierdzeń i prawd obiegowych.

${ }^{7}$ Ch Savage, An Economic History of Transport, London 1959, s. 184.

${ }^{8}$ Dotyczy to także włączania do modelowania ekonometrycznego innych czynników wzrostu, np. wspomnianego kapitału społecznego, procesów migracyjnych, edukacji, nauki itd.

${ }^{9}$ R. Fogel, op. cit.

${ }^{10}$ Por. R. Dumke, Clio's Climacteric? Betrachtungen über Stand und Entwicklungstendenzen der Cliometrischen Wirtschaftsgeschichte, „Vierteljahrschrift für Sozial- und Wirtschaftsgeschichte“ 1986, Nr. 73, s. 4; S. Eddie, Cliometric: what is it, whither came it forth?, eds. J. Komlos, S. Eddie, Selected Cliometric Studies on German Economic History, Stuttgart 1997, s. 12-16; R. Tilly, Cliometrics in Germany: An Introductory Essay, eds. J. Komlos, S. Eddie, Selected Cliometric Studies on German Economic History, Stuttgart 1997, s. 33.

11 W. Kula, Problemy i metody historii gospodarczej, Warszawa 1983.

12 Paradygmat New Economic History. Studium z teorii rozwoju nauki, Lublin 1986 [to tytuł rozprawy habilitacyjnej prof. J. Pomorskiego]. 


\section{CEL GLÓWNY I CELE CZĄSTKOWE}

W literaturze niemieckiej dostępne są prace dotyczące znaczenia rozwoju kolei w XIXw., szczególnie znana praca klasyka - Emila Saxa ${ }^{13}$. Dorobek naukowy dotyczący wpływu kolei żelaznych na wzrost gospodarczy pomnożyły publikacje kliometryków: R. Fogla, A. Fishlowa i Gary’ego Hawke’a w latach sześćdziesiątych i siedemdziesiątych XX w. Ważnym etapem w rozwoju niemieckiej historii gospodarczej były prace Friedricha Henninga i Rainera Fremdlinga, które są przykładem wykorzystania metod kwantytatywnych w badaniu historii gospodarczej (w tym kolei) tego kraju.

Praca F.W. Henninga Eisenbaubau und Entwicklung der Eisenindustrie in Deutschland ukazuje rolę kolejnictwa w rozwoju przemysłu hutniczego w Niemczech $^{14}$. Opracowanie R. Fremdlinga Eisenbahnen und deutsches Wirtschaftswachstum 1840-1879 (1973), dotyczy rozwoju kolei żelaznych w Niemczech praktycznie od ich powstania do końca lat siedemdziesiątych XIX w. Wcześniejsze publikacje statystyczne: Walthera Hoffmanna dotycząca niemieckiej gospodarki w XIX i początkach XX w. Das Wachstum der deutschen Wirtschaft seit der Mitte des 19. Jahrhunderts oraz R. Fogla Railroads and American Economic Growth, A. Fishlowa American Railroads and the Transformation of the Antebellum Economy ułatwily zadanie R. Fremdlingowi.

W drugim wydaniu, w 1985 r., wspomnianej pracy R. Fremdling wykazuje na większą rolę kolei w rozwoju niemieckiego przemysłu ciężkiego niż miało to miejsce w przypadku Wielkiej Brytanii i USA oraz właściwie mało istotną rolę, jaką odegrały względy militarne w rozwoju sieci kolejowej. Unaocznia także niewielką rolę państwa w początkowej fazie rozbudowy kolei żelaznych w państwach niemieckich oraz rozwija teorię nierównomiernego rozwoju A. Hirschmana ${ }^{15}$.

Jednocześnie R. Fremdling próbuje udowodnić, że koleje były w niemieckiej rewolucji przemysłowej podstawowym sektorem wzrostu. Dalej, krytykując R. Fogla, jako przedstawiciela szkoły New Economic History i prezentowanej przez niego teorii neoklasycznej, wyjaśnia, że w procesie industrializacji nie tylko ważne jest odnoszenie się do parametrów ekonomicznych, jak wzrost ekonomiczny, ale także do modernizacji, wzrostu produktywności nowoczesnych sektorów, łącznie z określeniem ich znaczenia. Nawiązuje również do koncepcji kluczowych sektorów gospodarki i teorii rozwoju J. Schumpetera. ${ }^{16}$

${ }^{13}$ E. Sax, Die Verkehrsmittel in Volks- und Staatswirtschafts, Berlin 1918-1922.

${ }^{14}$ F.W. Henning, Eisenbahnbau und Entwicklung der Eisenindustrie in Deutschland, Archiv und Wirtsch. Jg. 1973, Nr. 6 s. 1-20.

15 A.O. Hirschmann, The Strategy of Economic Development, New Haven 1958.

${ }^{16}$ J.A. Schumpeter, Teorie der wirtschaftlichen Entwicklung. Einer Untersuchung Unternehmergewinn, Kapital, Kredit, Zins und Konjunkturzyklen, Berlin 1964; R. Fremdling, Eisenbahnen und deutsches Wirtschaftswachstum 1840-1879. Ein Beitrag zur Entwicklungstheorie und zur Theorie der Infrastruktur, Dortmund 1985, s. 5-7. 
W konkluzjach i wnioskach końcowych R. Fremdling podkreśla rolę sektora kolejowego, jako podstawowego czynnika wzrostu. Po raz kolejny, poprzez falsyfikację tezy R. Fogla, udowadnia, że w Niemczech koleje, jako innowacja były przełomowe dla wzrostu gospodarczego w XIX w.

Pewną ułomnością pracy R. Fremdlinga $\mathrm{w}$ aspekcie oceny roli sektora kolejowego i założeniami niniejszej pracy jest analiza znaczenia kolei do 1879 r. R. Fremdling koncentruje się głównie na zobrazowaniu skali wpływu kolei żelaznych na inne sektory gospodarki, w tym przedstawia wybrane przypadki rozwoju kolejnictwa dotyczące wielkich ośrodków przemysłowych (Zagłębie Ruhry, Górny Śląsk, Berlin), pomijając ogromne zróżnicowanie w rozwoju regionalnym, w tym obszaru określanego, jako Ostelbien (East Elbia).

W przekonaniu autora proces nacjonalizacji kolei, budowa kolejnych szlaków, dalszy spadek taryf przewozowych, rywalizacja z transportem wodnym i rozwój innych sektorów gospodarki są wystarczającymi powodami, aby takiej analizy dokonać do 1913 r. W swojej pracy jedynie dość ogólnie R. Fremdling ocenia rozwój i znaczenie największego konkurenta dla kolejnictwa - transportu wodnego śródlądowego, w tym rozbudowy kanałów.

W literaturze niemieckiej pomija się także rozwój transportu śródlądowego i dynamikę wzrostu przewozów szlakami wodnymi, choć dynamika ta u schyłku XIX w. była porównywalna, a w niektórych momentach nawet większa od dynamiki wzrostu transportu kolejowego ${ }^{17}$.

Wobec przedstawionego stanu badań dotyczących kolei w Niemczech i dorobku w tym zakresie w innych krajach oraz rozwoju nowych metod badawczych praca wypełnia lukę dotychczasowych badań w ramach paradygmatu New Economic History.

Autor stawia następującą hipotezę badawczą:

Społeczne oszczędności z kolejnictwa w początkach $\mathrm{XX}$ w. $\mathrm{w}$ przypadku Niemiec były relatywnie niewielkie, a kolej byla tylko jednym $z$ wielu czynników wpływających na wzrost gospodarczy kraju.

Uzasadnienie hipotezy badawczej:

- wnikliwa analiza prowadzi do wniosków, że transport kolejowy wcale nie był tani w porównaniu do alternatywnych środków transportu (np. wodnego transportu śródlądowego);

- polityka taryfowa była często chwiejna i niejednolita, co przyczyniało się do wykorzystania innych alternatywnych (tańszych) rodzajów transportu;

- późniejszy rozwój transportu kołowego potwierdził tezę, że część sieci kolejowej z powodu niskiej rentowności musiała zostać zlikwidowana;

- rozbudowa niektórych szlaków kolejowych podyktowana była względami militarnymi, politycznymi, natomiast z punktu widzenia ekonomii była co najmniej wątpliwa.

${ }^{17}$ Por. E. Heubach, Die Verkehrsentwickelung auf dem Wasserstrassen und Eisenbahnen des Elbe-Oder Gebietes in dem Zeitraum von 1882-1895, Berlin 1898, s. 24-25. 
Autor zakłada realizację następujących celów pomocniczych:

- ocenę wpływu przewrotu technicznego na wzrost gospodarczy, ze szczególnym uwzględnieniem roli transportu, w tym także transportu śródlądowego i morskiego;

- ukazanie niskiej efektywności sektora kolejowego ze względu na wysokie stawki frachtu i brak jednolitej polityki taryfowej;

- analizę porównawczą efektów liberalnej polityki handlowej prowadzonej w ramach Niemieckiego Związku Celnego i polityki wysokich ceł oraz kartelizacji gospodarki w aspekcie wzrostu gospodarczego;

- przedstawienie i analizę innych istotnych czynników wpływających na wzrost i rozwój gospodarczy Niemiec,

- wykazanie użyteczności modelowania ekonometrycznego w badaniach ekonomicznych, a w szczególności badaniach wzrostu gospodarczego Niemiec.

\section{METODY BADAWCZE}

Podstawą paradygmatu NEH jest budowa alternatywnych modeli rozwojowych i weryfikacja hipotezy wyjściowej, tzw. wnioskowanie kontrfaktyczne. Nawiązując do paradygmatu NEH, w celu weryfikacji założonej hipotezy autor wykorzystał, zaproponowany przez R. Fogla, model społecznych oszczędności (social savings). Obok społecznych oszczędności, wobec rozwoju innych metod użyte zostały także: koncepcja nadwyżki konsumenta, całkowitej produktywności czynników produkcji, budowa prostego jednorównaniowego modelu ekonometrycznego ${ }^{18}$.

Jak zauważa Edward Longinotti, powołując się Patricka O'Briena, wnioskowanie kontrfaktyczne „może być, użyte, jeśli są dostępne wiarygodne alternatywy, do tego muszą być odpowiednio określone"19. Stąd koncepcja social savings użyta przez R. Fogla, zakładała, że oszczędności społeczne, które pojawiły się w wyniku rozbudowy kolei konfrontowane były najczęściej w porównaniu do sieci dróg wodnych.

Koleje żelazne, ich powstanie i rozwój w XIX w. należy traktować jako zmianę technologiczną, a także przykład kapitału rzeczowego (fizycznego). W neoklasycznym modelu R. Solowa (1956) wzrost gospodarczy determinowany jest przez egzogeniczny, określony postęp technologiczny, natomiast podstawowymi czynnikami produkcji są: praca oraz kapitał fizyczny. Najczęstszym sposobem badania łącznej wysokości wkładu zmian technologicznych do generowanego wzrostu i rozwoju gospodarczego jest oszacowanie tzw. reszty Solowa (Solow Residual) na podstawie typowej funkcji produkcji Cobba-Douglasa.

18 T. Leunig, Social savings, [w:] D. Greasley, L. Oxley, Economics and History. Surveys in Cliometrics, Oxford 2011, s. 21.

19 P. O'Brien, The New Economic History Of The Railways, London-Worcester 1977, s. 23. 


$$
Y=A K^{\alpha} L^{1-\alpha}
$$

Pojęcie funkcji produkcji, jako zaangażowania nakładów kapitału i pracy zostały opracowane w 1920 r. przez Paula Douglasa i Charlesa Cobba w prostej formie podlegającej określeniu zależności przy wykorzystaniu statystycznej estymacji parametrów. Ale ich wyniki przy użyciu dostępnych danych nie były wystarczająco przekonujące, i wywołały sceptyczne komentarze m.in. Johna Clarka.

Na pierwszym spotkaniu w trakcie konferencji Research in Income and Wealth w 1936, M. Copeland sugerował, że związek pomiędzy wartością realnego produktu a rzeczywistymi kosztami kosztów czynników produkcji (nakładów), jest narzędziem do mierzenia poziomu efektywności w rachunku produktów i dochodu narodowego.

Pierwszą empiryczną próbę zmierzenia całkowitej wydajności czynników produkcji przygotował Jan Tinbergen w 1942 r. Niestety, godny uwagi artykuł J.Tinbergena, w którym zaprezentował on szacunki TFP (Total Factor Productivity) dla czterech krajów, w tym USA, został zlekceważony. Pierwsze szacunki TFP opracowane przez Georga Stiglera ${ }^{20}$ opublikowano w 1947 r.

Pojęcie całkowitej wydajności czynników produkcji dokładniej zostało przedstawione przez Johna Kendricka w 1951 r. podczas konferencji ds. dochodu i bogactwa. TFP, jako metoda wykorzystana była m.in. przez National Bureau of Economic Research do badań mających na celu oszacowanie całkowitych i częściowych trendów dla produktywności sektora prywatnego w USA.

W latach pięćdziesiątych XX w. R. Solow, użył założeń dla funkcji produkcji, przyczyniając się do stworzenia modelu wzrostu i operacyjnego użycia TFP. W swoim artykule z 1957 r. Solow odnotował znaczną część resztkowej różnicy stóp wzrostu realnego produktu w stosunku do ważonych stóp wzrostu nakładów pracy i kapitału. Ta pozostałość została określona przez Miltona Abramovitza, jako „miara naszej niewiedzy”21.

Resztę Solowa starał się wyjaśnić Edward Denison na dwa sposoby:

- jako wpływ pracy, z podkreśleniem roli edukacji, zmian w wieku produkcyjnym, innych czynników, które zmieniły jakość czynnika pracy,

- próbę oszacowania tego wpływu na wzrost innych nakładów.

Uwzględnienie ograniczonej substytucji między zasobami pracy i kapitałem fizycznym przemawiało na korzyść wyodrębnienia i rozpatrywania w długim okresie zmian w technologii.

Koleje, podobnie jak pozostałe innowacje, wpływały na trzy czynniki wzrostu produkcji:

${ }^{20}$ G. Stigler, Trends in Output and Employment, New York 1947.

${ }^{21}$ M. Abramovitz, Resource and Output Trends in the United States since 1870, Occasional Paper 52, National Bureau of Economic Research, New York 1956. 
- kapitał,

- pracę,

- całkowitą produktywność czynników produkcji.

Reszta Solowa $(\triangle \mathrm{A} / \mathrm{A})$ została pierwotnie interpretowana jako całkowity wzrost produktywności czynników produkcji TFP i, przy użyciu nowych technologii, jest określona na podstawie następującego równania:

$$
\frac{\Delta(Y / L)}{(Y / L)}=\frac{S_{K} \Delta(K / L)}{(K / L)}+\frac{\Delta A}{A}
$$

gdzie:

$Y$ - całkowita produkcja,

$L$ - całkowita liczba przepracowanych godzin,

$K$ - usługi świadczone przez zasoby kapitału,

$S_{k}$ - przychody z kapitału.

Niektóre z badań na temat wkładu informacji i komunikacji na wzrost gospodarczy opierają się na wyrażeniu (2), które ma na celu włączenie hipotezy endogenicznego charakteru innowacji i zawartych zmian technologicznych. S. Oliner i D. Sichel, na przykład, stosują zagregowaną wersję równania (2), w której wyodrębniają różne rodzaje kapitału i rozróżniają składniki wzrostu TFP, wówczas po przekształceniu otrzymujemy:

$$
\frac{\Delta(Y / L)}{(Y / L)}=\frac{S_{\mathrm{K} 0} \Delta\left(K_{0} / L\right)}{\left(K_{0} / L\right)}+\gamma\left(\frac{\Delta A}{A}\right)_{0}+\frac{S_{\mathrm{KITC}} \Delta\left(K_{\mathrm{ITC}} / L\right)}{\left(K_{\mathrm{ITC}} / L\right)}+\varphi\left(\frac{\Delta A}{A}\right)_{\mathrm{ITC}}
$$

gdzie:

$K_{\text {ITC }}, K_{0}$ - usługi kapitału (ITC - informacja i komunikacja, 0 - pozostałe sektory),

$S_{\mathrm{KITC}} S_{\mathrm{K} 0}$ - część dochodów z kapitału (ITC - informacja i komunikacja, 0 pozostałe sektory),

$A$ - poziom TFP oznaczony przez indeks (ITC, pozostałe sektory),

$\varphi, \gamma$ - poziom ITC w całkowitej produkcji i pozostałych sektorów w całkowitej produkcji.

Wkład nowej technologii do wzrostu wydajności pracy może wynikać z sumy dwóch ostatnich składników równania (3), które to podejście, odpowiednio uwzględnia, „wkład kapitałowy” i „wkład TFP” nowej technologii. W rzeczywistości jest to dolne ograniczenie oszacowanego wpływu jej zastosowania . Nie jest uwzględnione np. przenikanie (rozlewanie się) efektów z danego sektora, w którym zastosowano technologię do reszty gospodarki, pośrednich skutków ubocznych ${ }^{22}$.

${ }^{22}$ S. D. Oliner, D. E. Sichel, Information technology and productivity: where are we now and where are we going, ,Federal Reserve Bank of Atlanta Economic Review” 2002, vol. 87, no. 3, s. $15-44$. 
Dla przykładu w warunkach Wielkiej Brytanii określono wpływ sektora kolejowego poprzez porównanie jednostkowych kosztów transportu w stosunku do jednostkowych kosztów głównych konkurentów (głównie transportu wodnego i żeglugi przybrzeżnej) i wpływu kolei na łączny wzrost brytyjskiego TFP (bez efektów ubocznych), co może być odpowiednim podejściem do wzrostu TFP w sektorze kolejowym.

$$
\frac{\Delta A}{A}=\frac{S_{K} \Delta r}{r}+\frac{S_{L} \Delta w}{w}-\frac{\Delta P}{P}
$$

gdzie:

$r$ - stopa zysku,

$w$ - płaca,

$P$ - cena wyjściowa.

Jeśli przyjąć, że koszty produkcji są stałe, wzrost TFP jest równy tempu nominalnego spadku cen wówczas użyć można społecznych oszczędności mierzonych $\mathrm{w}$ roku t, w porównaniu do roku $\mathrm{t}-1$, wyrażonych, jako część dochodów z kolei:

$$
\frac{\left(P_{t-1}-P_{t}\right) q_{t}}{P_{t} q_{t}}=\frac{P_{t-1}}{P_{t}}-1=\frac{A}{A_{t-1}}-1
$$

lub równanie wyrażone, jako udział w $P K B(G D P)$ :

$$
\left(\frac{A}{A_{t-1}}-1\right)\left(\frac{P_{t} q_{t}}{P K B(G D P)_{t}}\right)
$$

Społeczne oszczędności z kolei w proporcji do PKB pomnożone przez współczynnik produkcji kolejowej do PKB obrazują zmianę procentową w TFP w branży kolejowej.

Jak dowodzi Nicholas Crafts podejście, które wykorzystuje społeczne oszczędności jest równoważne $\mathrm{z}$ określeniem TFP, bez uwzględnienia kapitału z innowacji. Jak zakładał R. Fogel, kapitał niezbędny do rozwoju kolei równał się zyskom normalnym tożsamym z kosztem alternatywnym. N. Crafts jednocześnie zauważa, że podejście social savings jest też praktycznym sposobem, aby obliczyć TFP.

J. Kendrick i B. Vaccara zauważają, że przed II wojną światową estymacja produktywności ograniczała się do prostych statystyk typu: produkcja końcowa na jednego zatrudnionego, produkcja w jednostce czasu. Szybko rosła świadomość konieczności badania produktywności i efektywności zarówno dla poszczególnych sektorów, jak i całej gospodarki ${ }^{23}$. Według najnowszych koncepcji teoretycznych, a także w świetle badań empirycznych akumulacja kapitału (rzeczowego i ludzkiego) nie jest jedyną i najważniejszą determinantą wzrostu gospo-

${ }^{23}$ J. Kendrick, B. Vaccara, New Developments in Productivity Measurement, Chicago 1980, s. 3. 
darczego, zwłaszcza dla krajów, które dzieli dystans rozwojowy i technologiczny. Marian Noga dodaje, że kraje, które zanotowały większy niż przeciętny przyrost produkcji przeważnie też zwiększyły poziom zatrudnienia, zakumulowały więcej kapitału, polepszyły jakość siły roboczej i zanotowały wzrost całkowitej (wieloczynnikowej) produkcyjności czynników produkcji (TFP) ${ }^{24}$.

Całkowita produktywność czynników produkcji w gospodarce w stosunku do sektora kolejowego szacowana jest na podstawie koncepcji społecznych oszczędności spopularyzowanej w literaturze kliometrycznej przez R. Fogla ${ }^{25}$. Istotą jest różnica $\mathrm{w}$ cenach dostarczenia usług $\mathrm{w}$ wyniku zastosowania nowej i starej (dotychczasowej) technologii. Wzrost TFP interpretowany jest jako wskaźnik realnego obniżania kosztów transportu ${ }^{26}$.

W rachunku społecznych oszczędności określa się, jakie koszty społeczeństwo ponosiłoby, gdyby nie było innowacji. Stąd można zapisać, że:

Social savings $(S S)=\left(C_{T 0}-C_{T 1}\right) Q_{T}$

gdzie:

$C$ - koszt krańcowy,

$Q$ - całkowita ilość,

$T_{0}$ - czas przed innowacją,

$T_{1}$ - czas po innowacji.

Zakładając, że rynek jest w pełni konkurencyjny, ceny rynkowe można potraktować, jako miarę kosztów, wówczas społeczne oszczędności, określane są, jako:

Social savings $(S S)=\left(P_{T 0}-P_{T 1}\right) T_{1}$

gdzie:

$P_{T 0}$ - cena alternatywnego środka komunikacji, np. transportu wodnego śródlądowego,

$P_{T 1}$ - ceny transportu kolejowego,

$T_{1}$ - ilość transportu kolejowego.

Założenie o konkrecyjności rynków jest celowe, gdyż dane dotyczące kosztów, w przeciwieństwie do cen są zazwyczaj niedostępne lub bardzo trudne do zdobycia. Należy jedynie przypomnieć, ze w myśl założeń mikroekonomicznych w długim okresie w warunkach konkurencji doskonałej ceny równają się kosztom (firmy osiągają jedynie zyski normalne).

${ }^{24}$ M. Noga, Co decyduje o rozwoju gospodarczym, [w:] Wzrost gospodarczy a innowacje, red. J. Koch, Wrocław 2008.

${ }^{25}$ R. Fogel, Railroads and American Economic Growth: Essays in Econometric History, Baltimore 1964.

${ }^{26}$ N. Crafts, Steam as a General Purpose Technology: A Growth Accounting Perspective, Working Paper 2003, no. 75. 
R. Fogel założył także górną granicę, że popyt na transport jest doskonale nieelastyczny (wskaźnik elastyczności prostej popytu wynosi 0). Według niego metodologia społecznych oszczędności polega na obliczaniu oszczędności w którymkolwiek analizowanym okresie, z określeniem różnicy między rzeczywistym kosztem np. frachtu, przewozu osób w tym roku, a kosztem alternatywnym, np. użyciem żeglugi śródlądowej do transportu dokładnie tego samego towaru. Tym samym teoretycznie zostaje wyeliminowana kolej.

Po publikacji badań metodologię R. Fogla, jako kontrfaktyczną, zastosowano w niektórych krajach do oszacowania wpływu kolei na wzrost gospodarczy. Autor niniejszej pracy obliczył społeczne oszczędności dla gospodarki Niemiec dla roku 1909. Przy analizie społecznych oszczędności uwzględniono również stopień elastyczności prostej popytu (inny niż 0), w tym celu zastosowano koncepcję nadwyżki konsumenta.

W celu realizacji hipotezy badawczej i założonych celów badawczych, obok koncepcji social savings, nadwyżki konsumenta, indeksu TFP, output i input autor zastosował zróżnicowane metody badawcze, w tym modelowanie ekonometryczne.

W tym celu autor zbudował główny arkusz statystyczny w postaci szeregu czasowego opisującego różne determinanty gospodarki Niemiec, ze szczególnym uwzględnieniem statystyk dotyczących kolei i innych środków komunikacji, zmian w strukturze gospodarki i społeczeństwa. Główny arkusz dla lat 1840-1913 zawierał ponad 140 zmiennych statystycznych.

W początkowej fazie doboru odpowiednich danych statystycznych wykorzystano analizę skupień, w tym wybrano metodę aglomeracji. W metodzie aglomeracji przy formowaniu skupień wykorzystano odległość euklidesową, zgodnie z zapisem:

$$
\text { Odległość }(x, y)=\left\{\sum_{i}\left(x_{i}-y_{i}\right)^{2}\right\}^{1 / 2}
$$

W kolejnym etapie wykorzystano statystyki opisowe, w tym wykresy rozrzutu z określeniem stopnia korelacji $r$ Pearsona, pasów regresji oraz budowy dla wybranych zmiennych kandydatek i zmiennej objaśnianej macierzy korelacji.

W celu ilościowego ujęcia związków pomiędzy wieloma zmiennymi niezależnymi (objaśniającymi) a zmienną zależną (PKB per capita Niemiec w cenach z 1913 r.) wykorzystano analizę regresji wielorakiej, w tym regresję krokową, m.in. z wykorzystaniem testu t-Studenta, zmiennych binarnych. W budowie modelu ekonometrycznego nie pominięto również analizy reszt czynnika losowego, do czego posłużył m.in. test Durbin-Watsona.

Chcąc określić związek pomiędzy zmienną endogeniczną (PKB per capita) a zmiennymi niezależnymi opisującymi stan gospodarki Niemiec, autor poddał analizie m.in.: liczbę szlaków kolejowych, odsetek liczby zatrudnionych w rolnictwie, odsetek liczby uczniów i studentów, procesy emigracyjne, poziom i dynamikę inwestycji. Autor nawiązał m.in. do jednorównaniowego modelu ekonome- 
trycznego zbudowanego m.in. przez Michaela Clemensa i Jeffreya Williamsona, zaimplementowanym również przez Marię Matę i Josepha Love'a, w których m.in. użyto danych dotyczących liczby szlaków kolejowych jako kapitału rzeczowego ${ }^{27}$.

Po odpowiednim doborze zmiennych zbudowano dwa modele ekonometryczne: model poziomu PKB per capita oraz model dynamiki PKB per capita.

$\mathrm{W}$ ocenie autora modele zawierają istotne determinanty typowe dla etapu gospodarek kapitalistycznych w XIX w. i początkach XX w., ponadto nawiązują do teorii neoklasycznej w ekonomii, ale także uwzględniają aspekty ekonomii rozwoju podnoszone np. przez P. Romera. Do modelu włączono np. liczbę uczniów i studentów, wskaźnik emigracji. Część zmiennych dotyczących kapitału społecznego (np. liczba zawartych małżeństw) okazała się silnie skorelowana z innymi zmiennymi kandydatkami, stąd pominięto je w poniższym modelu.

Model w swojej pierwotnej postaci zawierał osiem regresorów dotyczących stanu infrastruktury kolejowej, kapitału ludzkiego, w tym: zatrudnienia w rolnictwie, poziomu produkcji przemysłowej, importu i eksportu, inwestycji, zgodnie z symbolicznym zapisem:

$$
Y_{t}=\beta_{0}+\beta_{I} x_{t 1}+\beta_{2} x_{t 2}+\beta_{3} x_{t 3}+\beta_{4} x_{t 4}+\beta_{5} x_{t 5}+\ldots \beta_{n} x_{t n}+\varepsilon
$$

gdzie:

$Y_{t}$-zmienna endogeniczna,

$X_{t t}, x_{t 2}, \ldots, x_{t n}-$ zmienne objaśniające, $\mathrm{n}=1,2, \ldots, \mathrm{n}$

$\beta_{0}, \beta_{1, \ldots} \beta_{\mathrm{n}}$-parametry strukturalne, $n=0,1,2, \ldots, \mathrm{n}$

$\varepsilon-$ składnik losowy.

Dodać należy, że w modelach zastosowano dla wybranych zmiennych opóźnienia czasowe $(t-n)$. Miało to na celu eliminację endogeniczności tych zmiennych. Szczegółowa postać modelów ekonometrycznych zastosowanych przez autora jest zobrazowana w IV rozdziale pracy.

Na potrzeby analizy i prezentacji wyników badań empirycznych, w tym rozległych szeregów czasowych autor wykorzystał także inne techniki analityczne, $\mathrm{np}$. analizę tabelaryczną oraz analizę graficzną.

W celu określenia znaczenia alternatywnych rodzajów transportu, w tym rywalizacji transportu wodnego z sektorem kolejowym oraz ich znaczenia dla wzrostu gospodarczego Niemiec autor posłużył się również studium przypadku (case study). W rozdziale II przedstawił rozwój przewozów śródlądowych, i komparację ilości i jednostkowych cen frachtu przewozów kolejowych i śródlądowych wodnych m.in. w dorzeczach dwóch głównych rzek: Odry i Łaby (Elby).

${ }^{27}$ M. Clemens, J. Williamson, Why did tariff-growth correlation reverse after 1950?, NBER Working Paper 2002, vol. 9181; M. Mata, J. Love, A Reversal in the Historical Role of Tariffs in Economic Growth? The Cases of Brazil and Portugal, Est. econ., São Paulo 2008, vol. 38, no. 3, s. 461-492. 
W pracy autor wykorzystał zgromadzone dane statystyczne charakteryzujące gospodarkę Niemiec z okresu 1840-1913. Dane statystyczne zostały zebrane z różnych źródeł, m.in.: roczników statystycznych Niemieckiego Związku Celnego z lat 1834-1866 autorstwa O. Hübnera, A. Bienengräbera, roczników statystycznych Cesarstwa Niemieckiego z okresu 1873-1916, roczników Królestwa Prus z okresu 1870-1917. Wykorzystano także współczesne źródła statystyczne, w tym statystyki sporządzone przez W.G. Hoffmanna, S. Kuznetsa, A. Maddisona, R. Fremdlinga, B.R. Mitchela oraz wielu innych autorów. 



\section{ROZDZIAL I \\ UKSZTALTOWANIE SIE SYSTEMU KAPITALISTYCZNEGO}

\section{KAPITALIZM WOLNOKONKURENCYJNY W ANGLII, FRANCJI I STANACH ZJEDNOCZONYCH}

Początki nowego systemu społeczno-gospodarczego wiążą się nierozerwalnie $\mathrm{z}$ angielską rewolucją burżuazyjną (1640-1660). Podłożem zmian ustrojowych były głębokie przeobrażenia ekonomiczne w Anglii w końcu XVI i na początku XVII w.

W Anglii znoszenie stosunków pańszczyźnianych rozpoczęło się już pod koniec średniowiecza i zakończyło się w XVI w. Ziemia należąca do chłopów była ich wyłączną własnością ${ }^{1}$ W XVIII w. jednocześnie z podziałem gruntów gminnych i akcją ogradzania upadła warstwa drobnych posiadaczy ziemi - freeholders i tworzyły się kapitalistyczne gospodarstwa rolne. W XIX w. utrwaliła się charakterystyczna dla Anglii struktura gospodarstw rolnych. Dokonał się proces koncentracji ziemi. Farmy liczące co najmniej 100 akrów (40,5 ha) zajmowały $78 \%$ powierzchni upraw ${ }^{2}$.

Rolnictwo w Anglii było podstawowym źródłem gromadzenia kapitałów i siły roboczej. Punktem wyjścia akumulacji stała się akcja ogradzania, która polegała na wywłaszczaniu chłopów przez wielkich właścicieli ziemskich i tworzeniu dużych pastwisk do hodowli owiec. W Anglii pierwsza faza ogradzania przypada na XV-XVI w., druga zaś - na XVII w. Główną przyczyną akcji ogradzania był wzrost zapotrzebowania na wełnę $\mathrm{w}$ związku z rozwojem przemysłu tekstylnego. Koncentracja ziemi natomiast była wynikiem rosnącego popytu na żywność, zwłaszcza na zboże. W latach 1797-1820 włączono do wielkiej własności 3,3 mln akrów $(1 \mathrm{akr}=0,4 \mathrm{ha})^{3}$. Ruch ogradzania pomnażał nie tylko bogactwo landlordów, ale też wielkich dzierżawców, działających, jako ich główni agenci (wywodzili się oni spośród farmerów) ${ }^{4}$.

${ }^{1}$ J. Kuliszer, Powszechna historia gospodarcza średniowiecza i czasów nowożytnych, t. II, Warszawa 1961, s. 428.

2 J. Skodlarski, Historia gospodarcza, Warszawa 2012, s. 86.

3 J. Kuliszer, op. cit., s. 428-429.

${ }^{4}$ G.M. Traveleyan, Historia Anglii, Warszawa 1965, s. 722. 
Szczególną funkcję spełniły w Anglii zewnętrzne źródła gromadzenia kapitału. Główny strumień środków finansowych płynął do Anglii z handlu europejskiego. Na przełomie XVII i XVIII w. tylko ok. 15\% eksportu angielskiego szło na rynki pozaeuropejskie 5 . Ważnym źródłem zasilania gospodarki brytyjskiej były dochody z kolonii. Wysokie zyski osiągały zwłaszcza kompanie handlowe.

W XVI i na początku XVII w. władcy Anglii potrzebowali pieniędzy, głównie na prowadzenie wojen. $\mathrm{Z}$ tego powodu Korona rozpoczęła sprzedaż majątków ziemskich - własnych dziedzicznych i skonfiskowanych olbrzymich dóbr kościelnych i klasztornych (skutki reformacji) - za ok. 6,5 mln funtów według wartości z $1630 \mathrm{r}^{6}$ Najwięcej na transakcjach ziemią skorzystała gentry - nowa szlachta, która w przeciwieństwie do starej arystokracji, zerwała $\mathrm{z}$ dawną zasadą, że handel ziemią jest niemoralny. Gentry rekrutowała się spośród przedstawicieli zamożniejszego mieszczaństwa, które chętnie lokowało swoje kapitały w ziemi, a także spośród wzbogaconych żeglarzy i kaprów.

Bogacącej się nowej szlachcie, a także średniej burżuazji handlowo-przemysłowej nie odpowiadał system feudalny. Posiadali oni środki materialne, ale nie mieli władzy politycznej. Ich dalsza ekspansja gospodarcza napotykała na bariery. W kraju pogłębiał się stan nierównowagi społecznej i gospodarczej. Wywoływało to tarcie między tradycyjnymi reprezentantami władzy, Koroną, hrabstwami, wyższym duchowieństwem i arystokracją a rosnącymi w siłę gentry i średnią burżuazją ${ }^{7}$.

W XVI w. gospodarka angielska nabierała cech kapitalistycznych. Sukiennictwo, które stanowiło podstawowe zajęcie ludności (poza rolnictwem) wkroczyło w etap manufaktur scentralizowanych. Elementy układu kapitalistycznego pojawiły się w górnictwie, hutnictwie i handlu8.

Duży wpływ na postawę klas średnich wywarł angielski purytanizm. Ideologia ta wywodziła się w prostej linii z kalwinizmu. Purytanie głosili walkę z feudalizmem we wszystkich jego przejawach. Uważali oni, że człowiek został powołany przez Boga do solidnej pracy i osiągania zwycięstwa nie w klasztorze, ale na polu bitwy, w kantorze i na rynku. Purytanizm angielski stanowił solidny fundament moralny dla rodzącego się kapitalizmu' Przyjęła się nowa etyka kapitalistyczna. Wyrażała się ona $\mathrm{w}$ regule dotrzymywania zobowiązań, w pracowitości i oszczędzaniu oraz w żądaniu swobody w działalności przemysłowej i handlowej ${ }^{10}$.

Nowa siła społeczna, głównie gentry i średnia burżuazja parła do wystąpień przeciwko feudalnej arystokracji i monarchii. Sojusz burżuazji z nową szlachtą

${ }_{5}$ A. Lubbe, Imperium europejskie? Ekspansja Europy a powstanie gospodarki światowej, Warszawa 1982, s. 58.

${ }^{6}$ Z. Wójcik, Historia powszechna XVI-XVII wieku, Warszawa 1991, s. 414.

${ }^{7}$ L. Stone, The Causes of the English Revolutions 1529-1642, London 1972.

${ }^{8}$ H. Zins, Historia Anglii, Wrocław 2009, s. 187-188.

9 Z. Wójcik, op. cit., s. 419.

${ }^{10}$ Zob. W. Sombart, Der moderne Kapitalismus, Bd. II, Teil 1, Kapitel IV, München 1928. 
stanowił podstawową siłę napędową rewolucji angielskiej. Głównym ośrodkiem organizacyjnym zwolenników rewolucji stał się Długi Parlament (1640-1653). W I połowie XVII w. parlament angielski reprezentował wyłącznie interesy klas posiadających. W Izbie Lordów zasiadali najwięksi feudałowie świeccy oraz biskupi. W skład Izby Gmin wchodzili również ludzie zamożni ${ }^{11}$.

Po długoletniej wojnie domowej, w której zginęło ok. 100 tys. Anglików, armia parlamentu dowodzona przez Oliwera Cromwella, pokonała wojska królewskie. W 1649 r. specjalny trybunał wydał wyrok śmierci na króla Karola I. Została zniesiona Izba Lordów oraz instytucja monarchii. Najwyższą władzę otrzymała Izba Gmin. W styczniu 1649 r. proklamowano republikę. W uchwalonej ustawie stwierdzono, że wolne państwo angielskie będzie rządzone przez najwyższą władzę narodu, tj. reprezentantów ludu wybranych do parlamentu ${ }^{12}$.

Mimo że po 11 latach nastąpił powrót monarchii (Stuartów), jednak najwyższą władzą ustawodawczą pozostał parlament, a władzę wykonawczą sprawował rząd. Przyjęło się wówczas trafne powiedzenie, że w Anglii „król panuje, ale nie rządzi”. Parlament uchwalał prawa, corocznie ustalał wysokość budżetu i mógł pociągać do odpowiedzialności królewskich ministrów. Anglia stała się krajem rządzonym przez oligarchię szlachecko-burżuazyjną i dlatego kapitalizm w tym kraju miał sprzyjające warunki do dalszego rozwoju ${ }^{13}$. Nowy system władzy przyniósł poprawę ładu w finansach państwa, bardziej racjonalny system podatkowy i zmniejszenie biurokracji. Kontrola parlamentarna nie tłamsiła wolności gospodarczej. W rezultacie brytyjscy przedsiębiorcy cieszyli się wyjątkową swobodą i możliwościami, w porównaniu z resztą świata ${ }^{14}$.

Nowy ustrój wpłynął w sposób zasadniczy na uruchomienie rewolucji przemysłowej. Nie oznacza to, że należy pomijać znaczenie presji demograficznej, postępu intelektualnego, etyki protestanckiej, czy innych czynników ${ }^{15}$. Po rewolucji burżuazyjnej pojawiły się na Wyspach Brytyjskich szczególnie pomyślne warunki do rozwoju gospodarczego. Przedsiębiorcy angielscy dysponowali wszystkimi niezbędnymi czynnikami produkcji, tj. kapitałem, surowcami, siłą roboczą i rynkiem zbytu (wewnętrznym i zewnętrznym). Na przeszkodzie przyśpieszenia produkcji stały jednak ówczesne możliwości techniczne przemysłu. W tej sytuacji przystąpiono do prac nad skonstruowaniem maszyn i wynalezieniem nowych źródeł energii.

${ }^{11}$ H. Zins, op.cit., s. 189.

12 G. Aymler, The State's Servants the Civil Service of the English Republic, 1649-1660, London 1973

${ }^{13}$ H. Zins, op.cit., s. 199-201.

${ }^{14}$ R. Cameron, Historia gospodarcza świata. Od paleolitu do czasów najnowszych, Warszawa 1996, s. 177.

15 J. Williamson, Ch. Milner, The World Economy. A Textbook in International Economics, New York 1991, s. 3-4; M. Weber, Die Protestantische Ethik und der Geist des Kapitalismus, „Archiv für Sozialwissenschaften" 1904/1905. 
Przewrót przemysłowy zapoczątkowało zastosowanie maszyn w przemyśle włókienniczym (maszyn przędzalniczych i tkackich). Praca maszyn była niemożliwa bez przezwyciężenia najważniejszej bariery stojącej na drodze postępu technicznego, tj. niedostatku energii. Zasadniczy postęp w produkcji dokonał się z chwilą skonstruowania maszyny parowej. Maszynę parową po raz pierwszy zastosowano w górnictwie. Jej głównym twórcą był James Watt (1769 r.) ${ }^{16}$.

W następnych latach zasięg rewolucji przemysłowej rozszerzał się na inne dziedziny gospodarki: górnictwo, hutnictwo, przemysł maszynowy i transport. Innowacje w przemyśle, energetyce i transporcie doczekały się bogatej literatury. Klasyczny przebieg rewolucji przemysłowej w Anglii zawdzięczamy Paulowi Mantoux ${ }^{17}$.

Ze względu na charakter pracy, uważam za zasadne przedstawić kilka istotnych informacji dotyczących przewrotu technicznego w transporcie i komunikacji.

Udane próby zastosowania maszyn parowych w górnictwie skłoniły konstruktorów do zainstalowania ich do napędu statków. W 1807 r. Robert Fulton uruchomił pierwszy na świecie statek parowy „Clermont”. W 1821 r. otwarto regularną linię żeglugową między Dover i Calais ${ }^{18}$.

Rewolucyjne zmiany w transporcie rozpoczęły się wraz ze skonstruowaniem lokomotywy parowej. W budowę parowozu, obok Jamesa Watta, wniosło wkład wielu inżynierów. Dopiero jednak samouk George Stephenson odniósł pełny sukces. W 1813 r. skonstruował stacjonarną maszynę parową do przewożenia pustych wagoników na węgiel. W 1825 r. osobiście poprowadził swą „Rakietę” na linii Stockton-Darlington. Lokomotywa osiągnęła, jak na owe czasy, zawrotną szybkość - ok. $45 \mathrm{~km} /$ godz. W 1830 r. oddano do użytku linię kolejową o znaczeniu przemysłowym, łączącą Manchester z Liverpoolem ${ }^{19}$.

Kolejnictwo stawało się ,,symbolem i instrumentem industrializacji” ${ }^{20}$. Pobudziło zapotrzebowanie na żelazo, węgiel i drewno, a ponadto wymagało stworzenia trwałego parku maszyn i urządzeń. W sektorze kolejowym znajdowało zatrudnienie coraz więcej ludzi. W połowie XIX w. do obsługi kolei w Anglii potrzeba było ponad 50 tys. pracowników, a przy budowie nowych linii kolejowych pracowało blisko 200 tys. osób ${ }^{21}$.

Konsekwencją rewolucji przemysłowej była industrializacja, rozwój rolnictwa, handlu, finansów i bankowości, a w rezultacie wzrost dochodu narodowego. W prze-

16 T.S. Ashton, The Industrial Revolution (1760-1830), London 1948.

17 P. Mantoux, Rewolucja przemystowa w XVIII w. Zarys dziejów powstania wielkiego nowoczesnego przemystu w Anglii, Warszawa 1957.

${ }_{18}$ W. Rusiński, Zarys historii gospodarczej powszechnej. Czasy nowożytne i najnowsze (1500-1939), Warszawa 1970, s. 174.

19 Tamże.

${ }^{20}$ R. Cameron, op. cit., s. 218.

${ }^{21}$ H.B. Court, A Concise Economic History of Britain from 1750 to Recent Times, Cambridge 1954, s. 165. 
myśle angielskim największy postęp dokonał się w przemyśle tekstylno-odzieżowym. Anglia stała się potentatem światowym w produkcji sukna, wyrobów lnianych, bawełnianych i jedwabniczych. W okresie stulecia 1770-1870 roczna wartość produkcji włókienniczej Anglii zwiększyła się ponad dwudziestokrotnie ${ }^{22}$. Wzrost produkcji przemysłu tekstylnego stymulował podobne efekty w pozostałych gałęziach. W XVIII w. na ścieżkę szybkiego wzrostu weszło też angielskie górnictwo i hutnictwo. Wydobycie węgla kamiennego wzrosło z $5 \mathrm{mln} \mathrm{Mg}$ rocznie w latach 1760-1780 do $110 \mathrm{mln} \mathrm{Mg} \mathrm{w} 1870 \mathrm{r}^{23} \mathrm{~W}$ szybkim tempie rozwijała się metalurgia i hutnictwo żelaza, stymulowane rosnącymi potrzebami przemysłu zbrojeniowego. W latach 1788-1870 produkcja żelaza wzrosła z 68 tys. $\mathrm{Mg}$ do $6 \mathrm{mln} \mathrm{Mg}^{24}$.

Od 1870 r. Wielka Brytania wysunęła się zdecydowanie na pierwsze miejsce w światowej produkcji przemysłowej $(31,8 \%)$, wyprzedzając Stany Zjednoczone $(23,3 \%)$ i Niemcy $(13,2 \%)^{25}$.

Konsekwencją zmian, które zaszły w przemyśle i rolnictwie była ekspansja handlowa. Sprzyjało jej też umocnienie dominacji kolonialnej Anglii. Wielka Brytania stała się pierwszą potęgą handlową świata. Jej udział w handlu globalnym wahał się w XIX w. od ok. 20\% do 30\%. Centrum finansów światowych umiejscowiło się w Londynie ${ }^{26}$.

Kształtowaniu się gospodarki rynkowej towarzyszył rozwój systemu finansowego. I w tym sektorze palma pierwszeństwa należała do Anglii. Bank Angielski - centralny bank państwowy, założony w 1694 r., był pierwszym nowoczesnym bankiem na świecie. Wykonywał niemal wszystkie znane dzisiaj operacje bankowe. W II połowie XVIII w. zaczęły powstawać banki prowincjonalne. W 1810 r. było ich prawie $800^{27}$.

Banki odegrały istotną rolę w procesie industrializacji, ale też wzrost gospodarczy przyśpieszył rozwój sektora finansowego ${ }^{28}$. Już w końcu XVI w. pojawiły się w Anglii pierwsze spółki akcyjne. W 1571 r. uruchomiono giełdę londyńską. Na kapitale akcyjnym rosła potęga kompanii handlowych. Największe dochody osiągała Kompania Wschodnioindyjska. Akcjonariusze otrzymywali regularnie wysokie dywidendy w granicach $15-25 \%{ }^{29}$.

Wraz z rozwojem przemysłu i handlu ulegała zmianie struktura gospodarki. W 1870 r. w rolnictwie angielskim pracowało tylko 23\% ogółu zatrudnionych.

${ }^{22}$ W. Rusiński, op. cit., s. 181.
S. Viljoen, Economic Systems in World History, London 1974, s. 179; W. Rusiński, op.cit., s. 181.

${ }^{24}$ W. Rusiński, op. cit., s. 182.

${ }^{25}$ W.G. Hoffman, British Industry 1700-1950, Oxford 1955, s. 184.

26 J. Skodlarski, R. Matera, Gospodarka światowa. Geneza i rozwój, Warszawa 2004, s. 118-121.

27 J. Kaliński, Historia gospodarcza XIX i XX w., Warszawa 2008; J. Skodlarski, op. cit., s. 109.

${ }^{28}$ N. Ferguson, Potęga pieniądza. Finansowa historia świata, Kraków 2010, s. 55.

${ }^{29}$ W. Rusiński, op. cit., s. 116 
Systematycznie rosła rola sektora usług $(35 \%)^{30}$. Mimo spadku zatrudnienia w rolnictwie dochody globalne, dzięki wysokiej wydajności, były coraz większe. Towarowość rolnictwa angielskiego należała do najwyższych w Europie. Najwyższą wydajność osiągali rolnicy duńscy.

Przyśpieszony wzrost gospodarczy w XIX w. przyniósł społeczeństwu angielskiemu wyraźną poprawę stopy życiowej. Wielka Brytania osiągnęła najwyższy przyrost PKB na mieszkańca w latach 1820-1870 - z 1756 USD do 3263 USD (siła nabywcza z 1990 r.). Następne w kolejności Holandia i Belgia miały po 485 USD mniej (w roku 1870) 31. Zmieniła się korzystnie jakość życia społecznego oraz pozycja kobiet w pracy i w rodzinie. Tak pisze o tym wybitny historyk angielski George M. Trevelyan:

Postęp humanitaryzmu, demokracji i oświaty oraz przemiany w metodach wytwórczości, które wytworzyły wielkie skupiska pracowników obu płci w biurach i fabrykach - wszystko to łącznie doprowadziło do powstania nowych pojęć o roli kobiety w społeczeństwie. Wykształcenie kobiet, które dawniej było niemal całkowicie zaniedbane, w ciągu kilku pokoleń zrównało się z wykształceniem mężczyzn. Prawo zmieniło pozycję kobiet w rodzinie, a bardziej jeszcze zmieniła ją praktyka i opinia publiczna. W końcu dążenie do nadania im praw wyborczych przestało wydawać się czymś absurdalnym.

Wszystkie te ogromne zmiany nigdy nie mogłyby się dokonać bez katastrofy, gdyby nie pokój, dobrobyt i bezpieczeństwo, jakie charakteryzowały Wielką Brytanię w XIX wieku. Z wyjątkiem epizodu wojny krymskiej ogólna polityka Brytanii polegała na powstrzymywaniu się od udziału w zmaganiach narodów kontynentalnych - zanim wybuchły one na nowo w czterdzieści lat po Waterloo. Ponieważ równowaga sił była na razie dość pewnie ustalona, nie zachodziła potrzeba, abyśmy musieli walczyć celem niedopuszczenia do podboju Europy przez jeden naród i jego wasali ${ }^{32}$.

Znany badacz historii gospodarczej Anglii T.S. Ashton również pisał w 1948 r., że zmiany, które nastąpiły w XVIII w. nie dotyczyły samej produkcji przemysłowej, ale również miały charakter społeczny i intelektualny ${ }^{33}$.

W sytuacji, gdy ustrój polityczno-gospodarczy w Anglii demokratyzował się, we Francji w XVII w. umacniał się absolutyzm. Król Ludwik XIV był jednym z największych despotów wszystkich czasów. Gospodarka francuska, dzięki przedsięwzięciom znakomitego ministra Jeana Baptiste'a Colberta, rozwijała się pomyślnie. Jednak wieloletnie wojny prowadzone przez Ludwika XIV niemal $\mathrm{z}$ całą Europą doprowadziły kraj do ruiny finansowej ${ }^{34}$.

W II połowie XVIII w. ustrój feudalny we Francji istniał, ale miał oparcie już tylko w niewielkiej grupie społecznej wywodzącej się niemal wyłącznie spośród szlachty i wyższego duchowieństwa. Stopniowo narastał antagonizm między du-

\footnotetext{
${ }^{30}$ A. Madison, Phases of Capitalist Development, Oxford 1982, s. 205.

${ }^{31}$ J. Skodlarski, R. Matera, op. cit., s. 130.

32 G.M. Trevelyan, op. cit., s. 234.

${ }_{33}$ T.S. Ashton, op. cit.

${ }^{34}$ Z. Wójcik, op. cit., s. 490, 502 i 522.
} 
chowieństwem i szlachtą a trzecim stanem, do którego zaliczani byli mieszczanie i wolni chłopi (99\% ogółu społeczeństwa). Konflikt przyśpieszyła sama monarchia, prowadząc walkę z parlamentem i starając się utrzymać zdyskredytowaną władzę absolutną.

Podłożem intelektualnym rewolucji była racjonalistyczna filozofia i literatura polityczna okresu oświecenia. Dla przemian w duchu kapitalistycznym wielkie znaczenie miały poglądy Jeana Jacquesa Rousseau, który w dziele Umowa społeczna postulował równość społeczną, podporządkowanie się woli zbiorowej i poszanowanie wspólnego dobra. Naród będący suwerenem mógł odebrać władzę rządzącym i ustanowić nowy ład społeczny ${ }^{35}$. Bezpośredni wpływ na kształtowanie się nowożytnego systemu władzy wywarła rozprawa Charles'a-Louisa Montesquieu $O$ duchu praw. Uznał on za konieczny podział władzy na ustawodawczą, wykonawczą i sądowniczą ${ }^{36}$. Prądy oświeceniowe propagowały liberalne koncepcje jednostki, społeczeństwa i gospodarki ${ }^{37}$.

Nieurodzaje w 1787 i 1788 r. powodujące zjawiska głodu pobudziły atmosferę rewolucyjną. Zaistniały wówczas warunki do gruntownej zmiany ustroju Francji. Zebranie się Stanów Generalnych, a następnie przekształcenie ich w Zgromadzenie Narodowe (17.06.1789 r.) i utworzenie (7.07.1789 r.) Konstytuanty (ciało ustawodawcze dla przygotowania przyszłej konstytucji) stanowiło pierwszy, rewolucyjny krok burżuazji, zmierzający do przejęcia władzy ${ }^{38}$.

Przechodząc do kapitalizmu prawie wszystkie kraje w Europie przeszły przez stadium rewolucji burżuazyjnej, ale we Francji była ona najbardziej gwałtowna i krwawa. W ciągu dwóch lat, od czerwca 1789 r. do września 1791 r. dokonała się całkowita zmiana ustroju polityczno-społecznego we Francji. Podstawę stanowiła konstytucja z 14.09.1791 r. Wstępem do niej była Deklaracja praw człowieka i obywatela uchwalona już $26.08 .1789 \mathrm{r}$.

Deklaracja praw człowieka i obywatela odwoływała się do naturalnych i niezbywalnych praw człowieka: wolności, własności, braterstwa i przeciwstawiania się uciskowi. Na straży zachowania tych praw powinna stać organizacja państwowa. W związku z tym deklaracja głosiła zasadę suwerenności ludu, równość obywatelską wobec prawa, tolerancję religijną, wolność słowa i prasy oraz udział wszystkich - pośredni i bezpośredni - w uchwalaniu prawa i podatków. Zdecydowanie wypowiadała się w kwestii własności stwierdzając, że własność prywatna jest prawem nienaruszalnym i świętym i nikt nie może być jej pozbawiony, chyba że wymaga tego dobro publiczne i pod warunkiem wypłaconego uprzednio sprawiedliwego odszkodowania ${ }^{39}$.

\footnotetext{
35 J.J. Rousseau, Umowa spoleczna, Warszawa 1918.

${ }^{36}$ Montesquieu, O duchu praw, Warszawa 1957.

37 J. Kaliński, op. cit., 2008, s. 30.

${ }_{38}$ M. Żywczyński, Historia powszechna, 1789-1870, Warszawa 1990, s. 19-30.

39 Tamże, s. 39.
} 
Deklaracja umożliwiała rozwój gospodarki rynkowej we Francji. Likwidowała ostatecznie ustrój stanowy i proklamowała stosunki ekonomiczne oparte na prawie własności i swobodzie jednostki w dziedzinie gospodarczej.

Mocą konstytucji z września $1791 \mathrm{r}$. władza została podzielona (wzorem amerykańskim) na ustawodawczą, wykonawczą i sądowniczą. Wprowadzała cenzus wyborczy - prawo wyborcze zostało uzależnione od wysokości płaconego podatku od posiadanego majątku. Ponadto ustalała nowy podział administracyjny kraju (na departamenty). Monarchię obalono i ogłoszono Francję republiką $(10.07 .1793 \text { r. })^{40}$.

Po kilku latach władzę we Francji przejął Dyrektoriat, a następnie Napoleon Bonaparte, który w 1804 r. koronował się na cesarza Francuzów. Pełniąc władzę absolutną utrwalił podstawowe zasady rewolucji burżuazyjnej, a prowadząc liczne wojny przyczynił się do zmian ustrojowych w wielu krajach. Na obszarze Włoch utworzył demokratyczną Republikę Liguryjską, Republikę Cispadańską i Republikę Cisalpińską. Przyśpieszył również rewolucję społeczną w Szwajcarii i zapoczątkował przemiany kapitalistyczne w Prusach i Księstwie Warszawskim ${ }^{41}$.

Rewolucja francuska pozostawiła przyszłym pokoleniom ogromną spuściznę. Na arenę polityczną wkroczyły grupy społeczne, które w XIX w. będą kształtowały rzeczywistość gospodarczo-społeczną. Stworzone zostały fundamenty wolności ekonomicznej. Nastąpiła likwidacja cechów, zakaz stowarzyszania się robotników i zniesienie wewnętrznych barier celnych. Wielu posiadaczy ziemskich i chłopów skorzystało z likwidacji dziesięcin i opłat senioralnych. Ponadto lata po 1789 r. umożliwiły awans społeczny piastującym urzędy państwowe oraz spekulantom trudniącym się handlem ziemią i dostawami dla wojska. Przeprowadzenie reformy administracyjnej powiększyło znacznie zdolność państwa do interwencji społecznej ${ }^{42}$.

Zmiana ustroju we Francji nie przyśpieszyła od razu rozwoju gospodarczego. Rewolucja niemal wcale nie zmieniła istoty gospodarki przedindustrialnej. Wiele aspektów struktur gospodarczych i społecznych przetrwało aż do lat czterdziestych XIX w. Stan ten powodował, że przeważała mała wydajność w rolnictwie, wysokie koszty powolnego transportu, brakowało też dobrze rozwiniętej sieci handlowej i przemysłu manufakturowego na dużą skalę ${ }^{43}$.

Bodźcem do zmian strukturalnych $\mathrm{w}$ gospodarce francuskiej był wzrost popytu związany ze znacznym przyrostem ludności (w latach 1750-1800 z 17 do $27,3 \mathrm{mln}$ ) oraz wpływem innowacji technicznych i technologicznych. Rewolucja przemysłowa, w szerszym zakresie, wkroczyła do Francji dopiero w la-

\footnotetext{
40 J. Szpak, Historia gospodarcza powszechna, Warszawa 2003, s. 134.

${ }^{41}$ M. Żywczyński, op. cit., s. 116-118.

${ }^{42}$ R. Price, Historia Francji, Poznań 2001, s. 148-150.

${ }_{43}$ Tamże, s. 149 i 152-153.
} 
tach trzydziestych XIX w. W pierwszym etapie była głównie dziełem Anglików. W 1848 r. w przemyśle metalurgicznym pracowało 15 tys. inżynierów i robotników angielskich. Z francuskich wynalazców na uwagę zasługuje Philippe Girard, wynalazca maszyny do przędzenia lnu oraz chemicy - Cloude de Berthollet (chlor jako wybielacz) i Nicolas Leblanc (produkcja alkaliów przy użyciu chlorku sodowego lub zwykłej soli). Inżynierowie francuscy, Emil i Piotr Martinowie, opracowali metodę wytapiania stali w piecach płomiennych, ulepszoną przez inżyniera niemieckiego, pracującego w Anglii Wilhelma Simensa ${ }^{44}$.

W okresie 1830-1850 dokonał się postęp w zakresie wdrażania innowacji, które miały znaczący wpływ na komunikację, handel oraz produkcję tkanin, metalurgię i mechanikę. W ciągu trzech - czterech dziesięcioleci, wprowadzono tyle ważnych innowacji, ile wcześniej przez kilka wieków ${ }^{45}$.

Decydującą rolę w rewolucji przemysłowej we Francji odegrały koleje żelazne. Zaczęto je budować już w 1828 r. Pierwsza linia kolejowa została uruchomiona w 1832 r. Od samego początku państwo brało udział w budowie kolei, inicjując i częściowo finansując inwestycje w tym sektorze. We Francji wcześniej niż w Anglii skoordynowano prace kolei z przewozami na wodach śródlądowych oraz opracowano (w 1842 r.) generalny plan rozbudowy kolejnictwa na dalsze lata. Tempo budownictwa kolejowego we Francji wzrosło po 1852 r. Długość linii kolejowych powiększała się następująco: 1850 r. - 3083 km, 1860 r. -9528 km, w 1870 r. -17931 km. W Europie Francja ustępowała w tym zakresie tylko Anglii $(1870 \text { r. }-24999 \text { km })^{46}$.

Rozwój kolejnictwa spowodował obniżenie kosztów transportu towarów. Większa wydajność transportu stymulowała rozrost produkcji i rozszerzała pojemność rynków zbytu. Postęp w transporcie miał niewątpliwie głęboki wpływ na przestrzenną strukturę aktywności gospodarczej. Kolej docierała na tereny równinne, gdzie można było uzyskać większą wydajność, wyższe dochody i lepsze możliwości inwestycyjne. Poszczególne ośrodki przemysłowe nie były już od siebie odizolowane. Kolejnictwo we Francji stanowiło jeden z najważniejszych „motorów” napędzających rozwój gospodarczy ${ }^{47}$.

W 1815 r. Francja była jeszcze krajem na ogół rolniczym. Przemysł w stosunku do angielskiego był słabo rozwinięty. W końcu XVIII w. zaczęły się rozwijać manufaktury. Dopiero po 1830 r. powstawały duże przedsiębiorstwa kapitalistyczne. Przemysł tekstylny rozwijał się w Normandii, Alzacji, Paryżu i Lyonie. Zakłady hutnicze w Creusot, kierowane przez braci Schneiderów stały się słynne w całej Europie. W Lotaryngii dobrze prosperował przemysł metalurgiczny ${ }^{48}$.

\footnotetext{
${ }^{44}$ M. Żywczyński, op. cit., s. 209 i 427.

${ }^{45}$ R. Price, op. cit., s. 157.

46 W. Rusiński, op. cit., s. 228 i 240.

47 R. Price, op. cit., s. 154-155, 157-158.

${ }^{48}$ M. Żywczyński, op. cit., s. 260; W. Rusiński, op. cit., s. 184.
} 
W latach sześćdziesiątych wzrosło tempo produkcji przemysłowej i wynosiło 3,5\% rocznie; dla porównania do $1830 \mathrm{r}$ - ok. $2 \%{ }^{49}$. W tym czasie produkcja wyrobów per capita dorównywała, a w niektórych latach przewyższała wskaźniki dotyczące Anglii. Od 1840 do 1870 r. energia wytwarzana przez silniki parowe wzrosła 10-krotnie. Wydobycie węgla kamiennego w latach 1850-1869 zwiększyło się z 4,4 mln Mg do 13,4 mln Mg, co stawiało Francję na 4 miejscu w świecie. Produkcja żelaza i stali rosła również w szybkim tempie: 1860 r. - ponad 100 tys. $\mathrm{Mg}, 1869 \mathrm{r}$. - ponad $1 \mathrm{mln} \mathrm{Mg}^{50}$.

Dochód na jednego mieszkańca i cały cykl rozwoju gospodarczego zależał w znacznej mierze od wzrostu produkcji rolnej. Rolnictwo zapewniało ludności żywność, a przemysłowi niektóre surowce. Największe osiągnięcia odnotowano w hodowli zwierząt gospodarskich. We wszystkich podstawowych rodzajach hodowli Francja zajmowała pierwsze miejsce w Europie. W 1862 r. pogłowie poszczególnych zwierząt przedstawiało się następująco: owce - 24,5 mln sztuk, bydło - $11 \mathrm{mln}$, nierogacizna $-6 \mathrm{mln}$, konie $-3,5 \mathrm{mln}$ sztuk $^{51}$.

Dochód narodowy we Francji na jednego mieszkańca rósł powoli, zgodnie ze wzrostem gospodarczym. W latach 1825-1834 przypadało rocznie na jednego mieszkańca 325,6 franków, a w okresie 1865-1874-602 franki ${ }^{52}$. W $1870 \mathrm{r}$. Francja znalazła się na 10 miejscu w świecie pod względem PKB na jednego mieszkańca, osiągając 1858 USD (siła nabywcza z 1990 r.). Francję wyprzedzały w Europie: Wielka Brytania, Holandia, Belgia, Szwajcaria, Dania i Niemcy ${ }^{53}$.

Od momentu uzyskania niepodległości w 1776 r. Stany Zjednoczone uzyskały dogodne warunki do tworzenia systemu kapitalistycznego. Deklaracja niepodległości, ogłoszona 4.07.1776 r., stworzyła podstawy ustroju demokratycznego. W pierwszej części deklaracja mówi o prawie do życia, wolności i dążeniu do szczęścia. Prawa te zabezpiecza rząd, a źródłem jego władzy jest zgoda tych, którymi rządzi. Gdy rząd przeciwstawia się realizacji celów, do których został ustanowiony, jest ,prawem ludu zmienić formy rządu albo obalić i stworzyć nowy rząd" ${ }^{\prime 4}$. Zjednoczone kolonie miały prawo prowadzenia wojny, zawierania pokoju, zawiązywania sojuszów, prowadzenia handlu i wykonywania wszystkich aktów i czynności, które niepodległe państwa mają prawo czynić.

Podstawy ustroju Stanów Zjednoczonych stanowiła konstytucja z 17.09.1787 r. Opierała się ona na zasadzie trójpodziału władz: na władzę ustawodawczą, wykonawczą i sądowniczą oraz na zasadzie równowagi władz. Konstytucja ta obowiązuje do dziś. Konstytucja zawiera tylko postanowienia dotyczące ustroju Unii. Nie normuje natomiast wewnętrznego ustroju stanów, z wyjątkiem

\footnotetext{
${ }^{49}$ Tamże, s. $185-186$.

${ }^{50}$ J. Skodlarski, R. Matera, op. cit., s. 114-115.

51 J. Skodlarski, op. cit., s. 137.

${ }_{52}$ R. Price, op. cit., s. 153.

53 J. Skodlarski, R. Matera, op. cit., s. 130.

${ }^{54}$ K. Koranyi, Powszechna historia państwa i prawa, t. IV, Warszawa 1967, s. 197.
} 
postanowienia, gwarantującego każdemu stanowi ustrój republikański. Przyjmuje też zasadę wyższości konstytucji federalnej i traktatów zawartych przez Stany Zjednoczone nad konstytucją stanową i prawami stanowymi ${ }^{55}$.

Władzę ustawodawczą sprawuje Kongres złożony z dwóch Izb: Izby Reprezentantów oraz z Senatu. Uprawnienia Kongresu są bardzo szerokie. Konstytucja wylicza w pierwszej kolejności gospodarcze, do których należały sprawy podatkowe, celne, monetarne oraz regulowanie handlu zagranicznego i międzystanowego. Władzę wykonawczą sprawuje prezydent Stanów Zjednoczonych. Posiada on duże uprawnienia. Jest najwyższym wodzem armii i floty, mianuje urzędników federalnych, sędziów Sądu Federalnego oraz przedstawicieli dyplomatycznych. Do obowiązków prezydenta należy czuwanie, aby prawa były właściwie przestrzegane ${ }^{56}$.

Konstytucja stworzyła stabilne podstawy rozwoju demokracji i gospodarki rynkowej w Stanach Zjednoczonych. Od 1787 r. zaczął kształtować się system dwupartyjny. Początkowo federaliści, zwolennicy silnej władzy centralnej, banku centralnego i pomocy państwa dla przemysłu, zdobyli przewagę nad antyfederalistami. Prezydentura Tomasza Jeffersona przyniosła postęp demokracji politycznej. W latach 1803-1867 nastąpiło rozszerzenie terytorium Stanów Zjednoczonych: zakupiono od Francji Luizjanę, a od Hiszpanii Florydę, przyłączono Teksas i część terytorium meksykańskiego (Nowy Meksyk i Kalifornię) oraz wykupiono od Rosji Alaskę ${ }^{57}$.

W latach pięćdziesiątych XIX w. nasiliły się trudności wewnętrzne w Stanach Zjednoczonych. Antagonizm między stanami północnymi i południowymi osiągnął apogeum w okresie 1857-1861. Jego podłożem były problemy natury ekonomicznej i ideowej. W stanach północnych znajdowało się 4/5 wszystkich zakładów przemysłowych i kopalń oraz 2/3 linii kolejowych. Do tej części Ameryki przybywali emigranci z Europy, bo tu mogli znaleźć pracę. Natomiast stany południowe miały prawie wyłącznie charakter rolniczy - plantatorski. Na plantacjach stosowano system pracy niewolniczej. W 11 stanach południa na $9 \mathrm{mln}$ ludności było ok. 4 mln niewolników - Murzynów ${ }^{58}$.

Do połowy XIX w. większość opinii publicznej w Stanach Zjednoczonych była obojętna w kwestii niewolnictwa. Antagonizm rozpoczął się wówczas, gdy przemysłowcy północnoamerykańscy zaczęli domagać się w interesie ich rozwiniętego przemysłu ceł ochronnych (przed eksportem towarów europejskich), a przeciwni temu byli plantatorzy z Południa. Następnie politycy Północy wysunęli postulat zniesienia niewolnictwa ${ }^{59}$.

\footnotetext{
55 Tamże, s. 228.

56 Tamże, s. 229-231.

57 J. Szpak, op. cit., s. 154.

58 M. Żywczyński, op. cit., s. 478.

59 Tamże, s. 479.
} 
Krwawa wojna domowa, zwana secesyjną (1861-1865), zakończyła się zwycięstwem Północy i zniesieniem niewolnictwa. Po zakończeniu wojny nastąpił dynamiczny rozwój gospodarki kapitalistycznej.

W latach sześćdziesiątych XIX w. narodził się w Stanach Zjednoczonych przemysł fabryczny. Wdrażano w tym czasie masowo europejskie zdobycze rewolucji przemysłowej. Nie ograniczano się jednak do importu zagranicznych innowacji. W Stanach skonstruowano m.in. żniwiarkę McCormicka, maszynę do szycia Singera, maszynę do pisania, kombajn do zbioru zboża, wrębiarki do górnictwa węglowego ${ }^{60}$.

Na rozległym obszarze Stanów Zjednoczonych szczególnie doniosłe znaczenie miał transport. Najpierw budowano drogi bite i uruchamiano żeglugę śródlądową. Dopiero jednak rozwój kolejnictwa spowodował rewolucję w transporcie. W latach 1828-1830 wybudowano pierwszą linię kolejową łączącą Baltimore z Ohio. W 1840 r. istniało już w Stanach 4,5 tys. km kolei. Następne lata przyniosły prawdziwy boom w kolejnictwie. W 1870 r. długość linii kolejowych w Stanach Zjednoczonych przekroczyła 90 tys. $\mathrm{km}^{61}$.

Koleje zmieniły mapę przemysłową Stanów Zjednoczonych. Dzięki nim uprzemysłowienie objęło stopniowo stany środkowe, zwłaszcza te tereny, które nie miały dotąd dogodnych połączeń wodnych z portami i centrami przemysłowymi.

Po zakończeniu wojny domowej i w wyniku przewrotu przemysłowego postęp industrializacji w Stanach Zjednoczonych był imponujący. Przystąpiono do rozbudowy przemysłu ciężkiego. W szybkim tempie rosła produkcja żelaza. W $1800 \mathrm{r}$. wytworzono w USA zaledwie 40 tys. Mg tego surowca, w 1830 r. -180 tys. Mg, w 1850 r. -670 tys. Mg, a w 1870 r. -1670 tys. Mg. Kraj ten znalazł się na drugim miejscu w świecie (po Anglii) w produkcji żelaza. Po 1840 r. rozpoczęto wytop żelaza za pomocą koksu. Wydobycie węgla, zlokalizowane głównie na północnym zachodzie kraju, przekroczyło w 1860 r. już 13 mln Mg (również drugie miejsce na świecie). Amerykanie zaczęli także stosować kolejne źródło energii - ropę naftową. W okresie 1860-1865 jej wydobycie wzrosło z 90 Mg do 40 tys. Mg. Przełomowe znaczenie dla gospodarki amerykańskiej miało odkrycie złóż złota, najpierw w Kalifornii, a później w Kolorado i Newadzie. Masowa eksploatacja złota i skutki z nią związane przyczyniły się do rozwoju gospodarczego zachodnich wybrzeży Ameryki Północnej. Dobrze rozwijał się przemysł maszynowy, włókienniczy i spożywczy. Rósł udział przemysłu w kształtowaniu się dochodu narodowego z $19 \%$ w 1850 r. do $24 \%$ w 1870 r. Stany Zjednoczone stawały się stopniowo mocarstwem gospodarczym. W $1870 \mathrm{r}$. wysunęły się na drugie miejsce w światowej produkcji przemysłowej $(23 \% \text {, Wielka Brytania }-32 \%)^{62}$.

\footnotetext{
${ }^{60}$ W. Rusiński, op. cit., s. 288.

${ }_{61}$ Tamże, s. 292.

${ }^{62}$ W. Rusiński, op. cit., s. 298-299; J. Skodlarski, R. Matera, op. cit., s. 112, 114; M. Żywczyński, op. cit., s. 428.
} 
Po odzyskaniu niepodległości podstawą gospodarki Stanów Zjednoczonych było rolnictwo. Sprzyjały temu wielkie obszary urodzajnej ziemi, którą bez większych nakładów można było uprawiać. Gospodarka rolna od samego początku podporządkowana była zasadom kapitalistycznym. W całym niemal XIX w. trwało żywiołowe osadnictwo. Banki udzielały osadnikom kredytów na spłatę należności za ziemię, a do państwa należała dbałość o infrastrukturę. Istotne znaczenie dla rolnictwa amerykańskiego miała uchwała Kongresu z 1862 r., według której każda dorosła osoba zamieszkująca na wsi co najmniej 5 lat mogła otrzymać bezpłatnie 160 akrów gruntów państwowych ${ }^{63}$.

Rewolucja przemysłowa wyszła naprzeciw problemom, przed którymi stanęło amerykańskie rolnictwo (duże areały, brak najemnej siły roboczej). Od 1820 r. rozpoczął się proces mechanizacji rolnictwa. Do sprzętu zbóż zastosowano, wspomnianą wcześniej, żniwiarkę i kombajn. Tempo produkcji rolnej uległo wyraźnemu przyśpieszeniu. W latach 1840-1887 w Stanach Zjednoczonych nastąpił 4-krotny wzrost (w Europie najwyższy w Szwecji - 3-krotny). Największym producentem pszenicy (najpopularniejsze zboże w XIX w.) w świecie były Stany Zjednoczone. Ogólnie, kraj ten wysunął się zdecydowanie w II połowie XIX w. na pierwsze miejsce w świecie w globalnej produkcji rolnej (wyprzedził Rosję i Francję) ${ }^{64}$.

Wzrost gospodarczy w Stanach Zjednoczonych nie przekładał się równomiernie na poprawę stopy życiowej społeczeństwa amerykańskiego. W latach 1820-1870 roczny przyrost PKB wynosił 4,5\% i był najwyższy w świecie. Jednak w przeliczeniu na jednego mieszkańca zwiększał się tylko $1,5 \%$ rocznie. W 1870 r. Stany Zjednoczone uplasowały się w światowym rankingu PKB per capita na 6 miejscu. Na jednego mieszkańca przypadało 1858 USD $^{65}$. Największy udział $\mathrm{w}$ dochodzie mieli przedsiębiorcy, stosunkowo dobrze zarabiali wykwalifikowani robotnicy fabryczni, w najtrudniejszym położeniu znajdowali się emigranci przybyli świeżo na ziemię amerykańską.

\section{POCZĄTKI KAPITALIZMU MONOPOLISTYCZNEGO}

W końcu XIX w. i na początku XX w. w całej Europie, z wyjątkiem Francji, Szwajcarii i Portugalii, utrzymywał się ustrój monarchiczny. Monarchie europejskie miały jednak różne oblicza: od monarchii parlamentarnej (Wielka Brytania) do monarchii absolutnej (Rosja). Parlamentaryzm angielski służył za wzór wielu państwom. Sprawne funkcjonowanie parlamentu brytyjskiego zapewniał system dwupartyjny. Dwie silne, dobrze zorganizowane partie, konserwatystów i liberałów, zmieniały się u władzy zależnie od tego, która z nich zdobyła większość

63 W. Rusiński, op. cit., s. 285.

64 J. Skodlarski, R. Matera, op. cit., s. 108-109.

65 Tamże, s. 129-130. 
w Izbie Gmin. Model angielski usiłowały przeszczepić na swój grunt niektóre państwa. Udało się to przeprowadzić w krajach skandynawskich, w Belgii, Holandii, Hiszpanii i Portugalii. Swoisty układ stosunków polityczno-gospodarczych nie pozwolił na wprowadzenie systemu dwupartyjnego we Francji ${ }^{66}$.

W państwach o parlamentarnym systemie władzy silny był wpływ stronnictw politycznych na rządzenie krajem. Najwyraźniej przejawiało się to w Wielkiej Brytanii, Francji i Belgii. Inaczej było w państwach niemających rządów parlamentarnych, np. w Niemczech. Parlament niemiecki miał ograniczone kompetencje. Nie decydował o nominacji i dymisji kanclerza i sekretarzy stanu. Ustawy i budżet wymagały uchwały Rady Związkowej i parlamentu (szczegóły zob. rozdz. III). Parlament w cesarstwie austro-węgierskim, zwany Radą Państwa, dysponował niewielką władzą. Cesarz Franciszek Józef nie tylko panował, ale i rządził. Decydował osobiście o nominacjach premiera i ministrów w Austrii. Rząd pozostawał u władzy, póki cieszył się jego zaufaniem. Dużą rolę polityczną odgrywali posiadacze ziemscy na Węgrzech, w Czechach i Galicji. Przedstawiciele arystokracji zajmowali czołowe stanowiska w Cesarstwie Austro-Węgierskim. Burżuazja miała największe wpływy w Austrii i w Czechach. Sojusz z Niemcami w 1879 r. oraz napływ kapitału niemieckiego coraz silniej uzależniały monarchię habsburską od Niemiec ${ }^{67}$.

W omawianym okresie, z jednej strony umacniała się władza absolutna w Rosji, nasilał się imperializm niemiecki, dominowała nadal silna władza cesarza w Austro-Węgrzech, a z drugiej - demokratyzowało się życie polityczne w liczących się krajach Europy Zachodniej. Przyczyniło się do tego wprowadzenie głosowania powszechnego we Francji (1848 r.), w Cesarstwie Niemieckim (1871 r.), Belgii (1893 r.), we Włoszech (1912 r.) i w Anglii (1918 r.). Rozszerzono też czynne prawo wyborcze na coraz większą liczbę obywateli. Mandaty poselskie sprawowali nie tylko przedstawiciele szlachty i burżuazji, ale coraz liczniej politycy pochodzenia drobnomieszczańskiego, robotniczego i chłopskiego. W wielu państwach ulegało radykalizacji życie polityczne i społeczne. Była to w dużej mierze zasługa partii liberalnych, socjaldemokratycznych i chłopskich ${ }^{68}$.

Inaczej kształtował się system władzy w Stanach Zjednoczonych. W ostatnim ćwierćwieczu XIX w. i na początku XX w. obserwuje się tu przede wszystkim umacnianie władzy federalnej. Polityka wewnętrzna rządu w Waszyngtonie zmierzała do stworzenia silnego i w miarę scentralizowanego państwa. Dwie główne partie Stanów Zjednoczonych - partia Republikańska i Demokratyczna dążyły do realizacji tego samego celu, tj. przejęcia władzy. Zabiegały one o pozyskanie wyborców z szerokich kręgów społeczeństwa. Obie były partiami wielkiego kapitału. Cała władza była skupiona w rękach burżuazji. Burżuazji amerykańskiej

${ }^{66}$ J. Pajewski, Historia powszechna 1871-1918, Warszawa 1994, s. 24; S. Chodak, Systemy partyjne Europy Zachodniej. Pochodzenie, ewolucja, funkcje społeczne, Warszawa 1961.

${ }^{67}$ J. Pajewski, op. cit., s. 93, 115, 121.

${ }_{68}$ J. Pajewski, op. cit., s. 470. 
zależało na tym, aby nie pobudzać świadomości klasowej robotników. Wszyscy prezydenci tego okresu reprezentowali wpływowe grupy kapitału. Stanami Zjednoczonymi rządził jeden człowiek - prezydent; Kongres go tylko kontrolował ${ }^{69}$.

Podobnie było w Kongresie, gdzie dominowali sami kapitaliści, bądź też ludzie od nich uzależnieni. Murzynów w Kongresie nie było. Kobiety amerykańskie nie posiadały jeszcze praw wyborczych. Przygotowano zaplecze i środki do ekspansji zagranicznej Stanów Zjednoczonych ${ }^{70}$.

W czołowych państwach kapitalistycznych główne siły polityczne wspierały wielki kapitał i jego ekspansję gospodarczą. Jednakże okazało się w ostatnim ćwierćwieczu XIX w., że możliwości wzrostu ekonomicznego oparte na własności indywidualnej i wolnej konkurencji wyczerpały się. Kapitalizm wolnokonkurencyjny zaczął ustępować miejsca kapitalizmowi monopolistycznemu. Powstawały wielkie organizacje gospodarcze, dążące do monopolizacji produkcji i rynków zbytu. Jednym z głównych czynników torującym drogę nowemu układowi był przewrót przemysłowy, określany w literaturze mianem drugiej rewolucji przemysłowej (1870-1914).

Innowacje zastosowane w okresie drugiej rewolucji spowodowały powstanie przemysłów nowych: elektrotechnicznego, chemicznego, motoryzacyjnego itd. Ogromne znaczenie dla dalszego rozwoju gospodarczego miały nowe źródła energii: elektrycznej i ropy naftowej. Fizyk angielski Michael Faraday zbudował pierwszy model silnika elektrycznego, co pozwalało wytwarzać prąd o niewielkiej mocy. Konstrukcję prądnicy ulepszył genialny wynalazca Thomas A. Edison (opatentował on ponad 1000 wynalazków), a silnik elektryczny - Werner Siemens. Elektryczność umożliwiła wynalezienie telefonu (Aleksander G. Bell) i radiografu (Gugliemo Marconi, Aleksander Popow) ${ }^{71}$.

Pod koniec XIX w. ważnym źródłem energii stała się ropa naftowa. Wykorzystanie jej na wielką skalę było możliwe dzięki skonstruowaniu silnika benzynowego przez Gottlieba Daimlera, a następnie silnika spalinowego przez Rudolfa Diesla. Genialny konstruktor Henry Ford od 1907 r. rozpoczął masową produkcję samochodów. Samochód spowodował przełom w transporcie i komunikacji. Bracia Orville i Wilbur Wright otworzyli nową erę w dziedzinie awiacji. Przewrót technologiczny w metalurgii przyniósł konwertor skonstruowany w Anglii przez Henry'ego Bessemera. Paul Heroult zbudował elektryczny piec do wytopu stali, zwłaszcza wysokogatunkowej. Od połowy lat osiemdziesiątych. rozpoczęto produkcję aluminium. Duży postęp dokonał się w dziedzinie chemii i w przemyśle chemicznym, farmaceutycznym, spożywczym i gumowym ${ }^{72}$.

${ }^{69}$ L. Pastusiak, Prezydenci, t. 2, Stany Zjednoczone od Andrew Johnsona do Franklina D. Roosevelta, Warszawa 1987, s. 224.

70 Tamże, s. 225-229.

${ }_{71}$ J. Pajewski, op. cit., s. 10; J. Skodlarski, op. cit., s. 165.

${ }^{72}$ Zob. szerzej: J. Skodlarski, op. cit., s. 166-167. 
Do 1913 r. w zakresie innowacji technicznych zdecydowanie dominowała Anglia. Przed I wojną światową przodownictwo w dziedzinie postępu technicznego przejęły Stany Zjednoczone.

W okresie 1870-1913 nadal ważnym czynnikiem wzrostu gospodarczego było kolejnictwo. Długość dróg żelaznych na kuli ziemskiej zwiększyła się w tym czasie przeszło 5-krotnie ${ }^{73}$. Największy postęp w tym zakresie dokonał się w Stanach Zjednoczonych, gdzie długość linii kolejowych wzrosła w latach 1870-1913 z ok. 85 tys. km do prawie 411 tys. km. Na drugie miejsce wysunęły się Niemcy odpowiednio z ok. 43 tys. km do prawie 64 tys. km, a na trzecie Rosja (bez Syberii) - odpowiednio z ok. 31 tys. km do ok. 62 tys. km. Francja zajmowała czwartą pozycję (z ok. 37 do ok. 51 tys. km linii kolejowych), Kanada piątą (z ok. 4 do ok. 47 tys. km) i Austro-Węgry szóstą (z ok. 9,5 do ok. 46 tys. km) ${ }^{74}$.

Do największych osiągnięć $\mathrm{w}$ dziedzinie kolejnictwa należała budowa sieci transkontynentalnych. W Europie sieć kolejowa połączyła niemal wszystkie stolice znajdujące się na obszarze kontynentu. W 1905 r., po 15 latach, zakończono budowę wielkiej kolei syberyjskiej o długości 7 tys. km. W Stanach Zjednoczonych w II połowie XIX w. oddano do użytku trzy linie transkontynentalne, łączące odległe krańce tego wielkiego kraju, a na początku XX w. - kilka następnych ${ }^{75}$.

Dzięki udoskonaleniom technicznym wzrosła szybkość pociągów i moc lokomotyw, co umożliwiło przewożenie znacznie większych ładunków niż w poprzednim okresie, np. długość angielskich linii kolejowych zwiększyła się 1,5 raza, natomiast wielkość przewozów towarowych i osobowych wzrosła 3-krotnie. We Francji przewóz towarów w latach 1850-1913 wzrósł z 4,5 mln do $173 \mathrm{mln} \mathrm{Mg}^{76}$.

Znacznemu ulepszeniu uległa technika budowy linii kolejowych, co pozwoliło przezwyciężać trudności terenowe (góry, rzeki, bagna). W Europie wybudowano kilka tuneli o długości kilkunastu kilometrów.

Początkowo inwestycje kolejowe finansował przeważnie kapitał prywatny. We Francji linie kolejowe budował kapitał prywatny przy współudziale państwa. W Anglii właścicielem kolei były spółki akcyjne. W Niemczech koleje były budowane zarówno przez spółki prywatne (z pomocą finansową państwa), jak i bezpośrednio przez poszczególne rządy krajowe. Do 1890 r. niemal cała sieć kolejowa Rzeszy znalazła się pod zarządem państwowym. Podobną drogą poszła Austria i Rosja. W Stanach Zjednoczonych natomiast koleje pozostawały nadal własnością prywatnych spółek. W znacznej mierze był w nich zaangażowany kapitał angielski i niemiecki. Na początku XX w. 85\% dochodów z kolei Stanów Zjednoczonych pobierało 7 wielkich spółek ${ }^{77}$.

\footnotetext{
${ }^{73}$ J. Pajewski, op. cit., s. 10.

${ }^{74}$ W. Rusiński, op. cit., s. 368.

75 Tamże, s. 367-368.

76 Tamże, s. 369-370.

77 J. Pajewski, op. cit., s. 11.
} 
W przewozie towarów wzrosła rola transportu morskiego, co było zasługą rozwoju floty statków napędzanych parą. W latach 1870-1910 światowy tonaż okrętów zwiększył się z 15000 tys. Mg do 42000 tys. Mg, z tego na parowce przypadało w 1910 r. $90 \%$ tonażu, a na żaglowce tylko $10 \%$. W 1870 r. sytuacja była zgoła odmienna - na żaglowcach przewożono $85 \%$ ładunków, a na parowcach $-15 \%{ }^{78}$.

Gospodarka monopolistyczna nadała nowy impuls gospodarce rynkowej. W okresie 1870-1914, mimo licznych kryzysów i załamań koniunktury, świat wkroczył na drogę przyśpieszonego rozwoju ekonomicznego. W tych latach światowa produkcja przemysłowa zwiększyła się ponad 5-krotnie. Poszczególne panstwa w Europie osiągnęły następującą dynamikę produkcji: Niemcy - 5,5-krotny wzrost, Francja - 3-krotny i Wielka Brytania - przeszło 2-krotny ${ }^{79}$.

Podsumowaniem, które obrazuje rozwój produkcji przemysłowej jest rysunek 1. Uwzględniony został szereg czasowy dla lat 1850-1913 dla trzech krajów europejskich (Francja, Niemcy, Wielka Brytania) wraz z podaniem wartości indeksu dla produkcji przemysłowej, przy założeniu, że dla roku bazowego 1913 indeks równa się 100 .

Podstawą gospodarki przed I wojną światową była produkcja węgla i stali. Światowe wydobycie węgla wzrosło z $200 \mathrm{mln} \mathrm{Mg} \mathrm{w} 1870$ r. do $1000 \mathrm{mln} \mathrm{Mg}$ w 1913 r. Przez długi czas pierwsze miejsce w górnictwie węglowym zajmowała Anglia. W końcu XIX w. utraciła je na rzecz Stanów Zjednoczonych. W 1913 r. liderami w wydobyciu węgla były Stany (517 mln Mg rocznie), Wielka Brytania (292 mln Mg), Niemcy (277 mln Mg), Rosja (54 mln Mg) i Francja (41 mln Mg) ${ }^{80}$.

$\mathrm{W}$ produkcji żelaza również przez długi czas dominowała Anglia. W $1870 \mathrm{r}$. produkowała więcej żelaza niż wszystkie inne kraje na świecie razem wzięte. W 1913 r. sytuacja uległa jednak zmianie. Pierwszym producentem surówki żelaza zostały Stany Zjednoczone (31,5 $\mathrm{mln} \mathrm{Mg}$ ), na drugie miejsce wysunęły się Niemcy $(19,3 \mathrm{mln} \mathrm{Mg})$, a dopiero trzecie miejsce zajmowała Wielka Brytania $(10,4 \mathrm{mln} \mathrm{Mg})^{81}$.

Wskaźniki produkcji przemysłowej Niemiec przedstawione zostały na rys. 2.

Jak zauważa Janusz Kaliński, niezależnie od przyjętej sekwencji przewrotu technicznego (przemysł włókienniczy - przemysł ciężki: przemysł ciężki - przemysł włókienniczy) uważa się go za punkt startu do długookresowego wzrostu gospodarczego ${ }^{82}$.

\footnotetext{
${ }^{78}$ Tamże.

79 J. Skodlarski, R. Matera, op. cit., s. 141.

${ }^{80}$ J. Pajewski, op. cit., s. 13.

81 Tamże, s. 14.

82 J. Kaliński, op. cit., s. 47.
} 


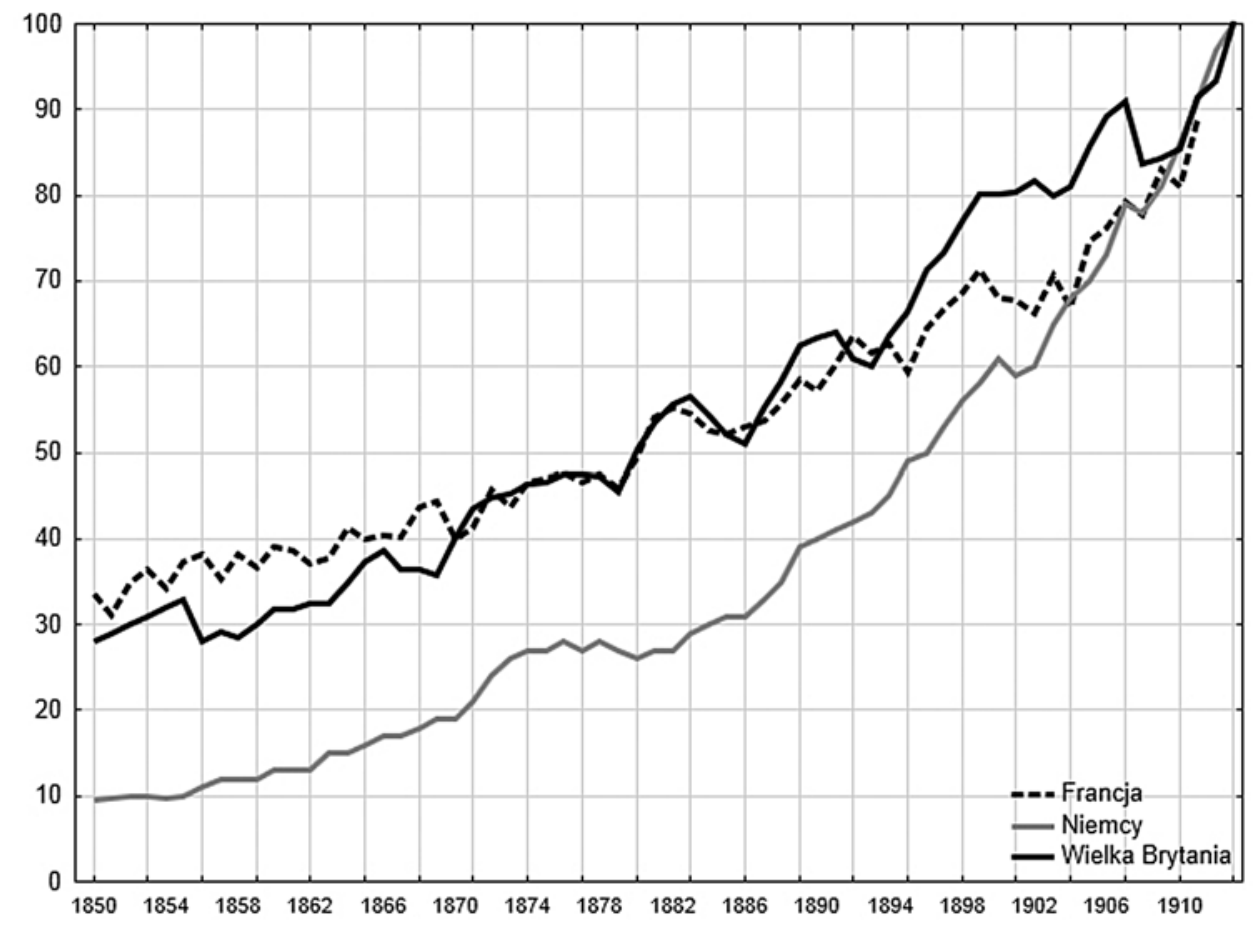

Rys. 1. Wskaźnik produkcji przemysłowej dla wybranych krajów europejskich w latach 1850-1913 $(1913=100)$

Źródło: opracowanie własne na podstawie danych źródłowych: B.R. Mitchell, International Historical Statistics: Europe, 1750-2000. London 2003, s. 422-424; W.G. Hoffmann, British Industry, 1700-1950, Oxford 1955.

Stopniowo i w innych działach przemysłu Wielka Brytania traciła prymat w świecie. Trzecie ćwierćwiecze XIX w. należy uważać za koniec etapu strukturalnego rozkwitu gospodarki brytyjskiej. Okres świetności Anglii przypadł na długie panowanie królowej Wiktorii (1837-1901). Charakterystyczną cechą wiktorianizmu była dążność do postępu. W działalności gospodarczej podejmowano wszelkie działania, które wzbogacały jednostkę, a przez to i kraj ${ }^{83}$. Główne zainteresowania Wielkiej Brytanii nie kierowały się w stronę wojny lub przygotowania do wojny - jak twierdzi G.M. Trevelyan - lecz w stronę rosnącego handlu zagranicznego oraz rozwoju jej imperium kolonialnego ${ }^{84}$.

83 J.Z. Kędzierski, Dzieje Anglii 1485-1939, t. II, 1830-1939, Wrocław-Warszawa-KrakówGdańsk-Łódź 1986, s. 389-391.

${ }^{84}$ G.M. Trevelyan, op. cit., s. 734. 


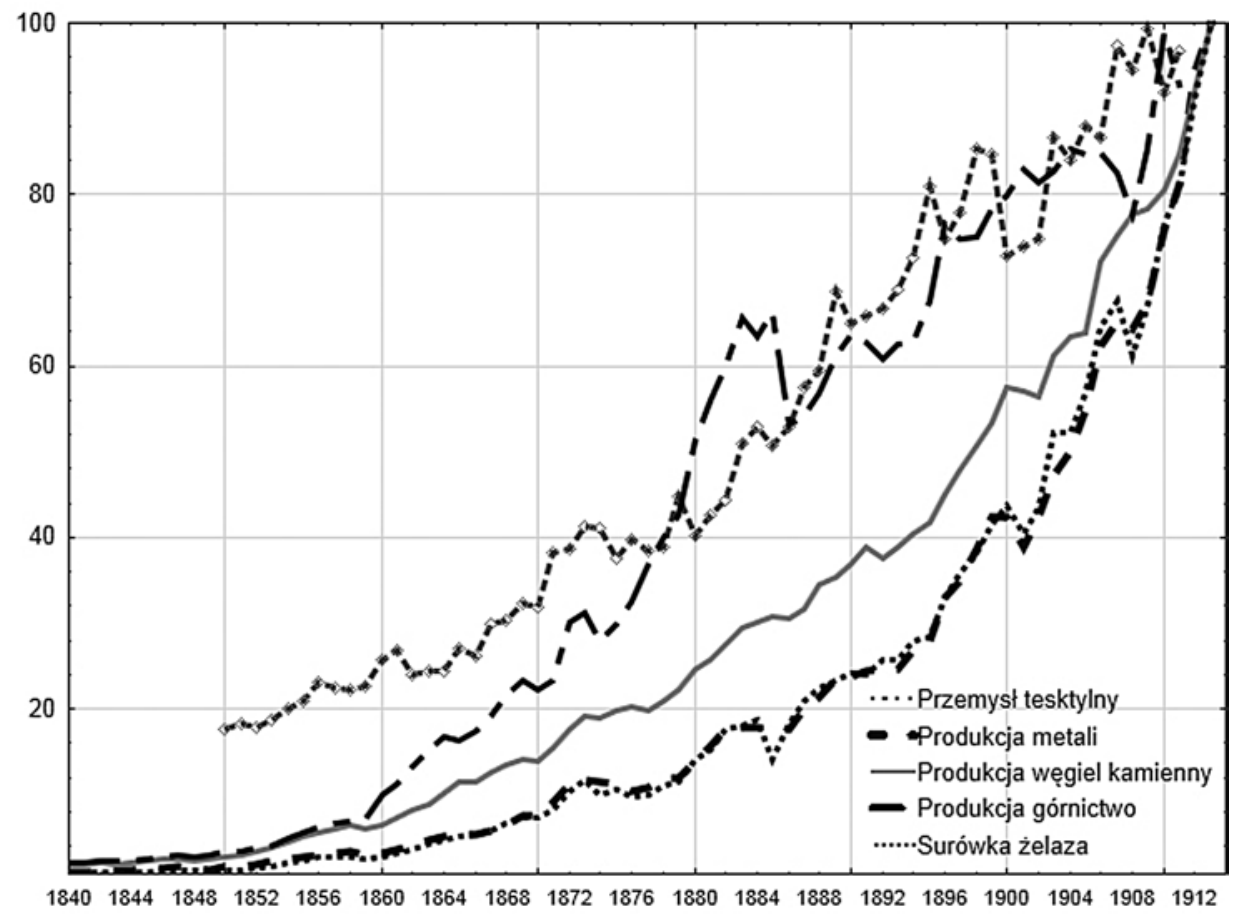

Rys. 2. Wskaźnik produkcji przemysłowej Niemiec z uwzględnieniem przemysłu tekstylnego, produkcji metali, surówki żelaza, górnictwa i wydobycia węgla kamiennego $(1913=100)$

Źródło: W.G. Hoffman, Das Wachstum der deutschen Wirtschaft seit der Mitte des 19. Jahrhunderts. Berlin 1965, s. 352-354, 368-370.

W okresie 1870-1913 udział Wielkiej Brytanii w światowej produkcji przemysłowej spadł z około $32 \%$ do $14 \%$. Na zahamowanie rozwoju przemysłowego złożyło się kilka istotnych przyczyn. Do najważniejszych należy zaliczyć: zmniejszenie zainteresowania przedsiębiorców wprowadzaniem innowacji (wpływało to na zmniejszenie wydajności pracy), niedostateczne zainteresowanie inwestycjami w nowoczesne przemysły, ujemne saldo bilansu handlowego (od początku XIX w.), zacofanie systemu oświaty i postawa roszczeniowa związków zawodowych ${ }^{85}$.

Wielka Brytania nadal utrzymywała prymat w handlu zagranicznym. Pod koniec XIX w. wzrost brytyjskich obrotów handlowych był dwukrotnie wyższy od produkcji przemysłowej. Podstawą potęgi handlowej była absolutna przewaga Anglii w dziedzinie żeglugi. Imperium kolonialne i zyski z inwestycji zagranicznych stanowiły podstawę dochodu narodowego (dawniej był nią monopol prze-

${ }^{85}$ J.Z. Kędzierski, op. cit., s. 389; H. Zins, op. cit., s. 318. 
mysłowy $)^{86}$. Wielka Brytania była jeszcze ciągle mocarstwem gospodarczym, ale z większym rozmachem rozwijały się Stany Zjednoczone, Niemcy i Japonia.

Największy postęp dokonał się w gospodarce Stanów Zjednoczonych. W latach 1860-1914 produkcja przemysłowa wzrosła 18-krotnie. Udział ich w światowej wytwórczości przemysłowej zwiększył się z ok. 23\% w 1870 r. do ok. 36\% w 1913 r. Przed wybuchem I wojny światowej Stany Zjednoczone stały się największym mocarstwem gospodarczym świata. W 1913 r. ich globalna produkcja przemysłowa była prawie równa produkcji wszystkich krajów europejskich ${ }^{87}$.

Do grona mocarstw gospodarczych awansowały także Niemcy (szerzej o tym w rozdz. III). Dotkliwe skutki gospodarczo-społeczne poniosła Francja po przegranej wojnie z Prusami (1870 r.). Utraciła na rzecz Niemiec zasobną w bogate surowce Alzację i część Lotaryngii oraz musiała zapłacić olbrzymią kontrybucję w wysokości 5 mld franków w złocie. Gospodarka francuska, mimo strat wojennych, potrafiła jednak przyśpieszyćs ${ }^{88}$. W latach 1880-1914 Francja podwoiła produkcję przemysłową. Duże dochody gospodarce francuskiej przynosiły inwestycje zagraniczne. Aż $45 \%$ inwestycji lokowano za granicą. Eksport kapitału wynosił 45 mld franków. Paryż był trzecim, po Nowym Jorku i Londynie, ośrodkiem finansowym świata, a Francja czwartym mocarstwem gospodarczym świata.

Struktura gospodarki europejskiej uległa zdecydowanej zmianie. Z upływem lat daje się zauważyć w większości krajów Europy Zachodniej odpływ ludności z pierwszego sektora do sektora przemysłowego i usługowego. Anglia była zdecydowanym liderem tych zmian. W 1913 r. w Wielkiej Brytanii w rolnictwie pozostawało już tylko $11,8 \%$ zatrudnionych, w Niemczech wskaźnik ten był ciągle wysoki i wynosił 34,5\%, w Austro-Węgrzech 59,5\%, w Hiszpanii 56,3\%, w Belgii $23,2 \%$.

Zestawienie wskaźników makroekonomicznych dla wybranych krajów w roku 1870 i 1913 zostało przedstawione w tab. 1.

$\mathrm{Z}$ danych zawartych $\mathrm{w}$ tab. 1 wynika, że zdecydowanie większy dochód per capita osiągnęły te państwa, w których wzrósł wydatnie udział w gospodarce sektora przemysłowego i usług. W Wielkiej Brytanii te dwa sektory zatrudniały w 1913 r. 88,2\% ogółu pracowników, a dochód per capita wzrósł z 3190 USD w 1870 r. do 4921 USD w 1913 r.

\footnotetext{
${ }^{86}$ H. Zins, op. cit., s. 318.

${ }^{87}$ W. Rusiński, op. cit., s. 331-332.

88 J. Baszkiewicz, Historia Francji, Wrocław-Warszawa-Kraków 2004, s. 491-493.
} 
Tabela 1. Wskaźniki makroekonomiczne dla wybranych krajów w roku 1870 i 1913

\begin{tabular}{|c|c|c|c|c|c|c|c|c|}
\hline \multirow{4}{*}{ Kraj } & \multirow{2}{*}{\multicolumn{2}{|c|}{$\mathrm{PKB}$ per capita }} & \multicolumn{6}{|c|}{ Zatrudnienie } \\
\hline & & & \multicolumn{2}{|c|}{ w rolnictwie } & \multicolumn{2}{|c|}{ w przemyśle } & \multicolumn{2}{|c|}{ w sektorze usług } \\
\hline & 1870 & 1913 & 1870 & 1913 & 1870 & 1913 & 1870 & 1913 \\
\hline & \multicolumn{2}{|c|}{ (w USD) } & \multicolumn{6}{|c|}{ (dane w \%) } \\
\hline $\begin{array}{l}\text { Austro- } \\
\text { Węgry }\end{array}$ & 1863 & 3465 & 67,0 & 59,5 & 15,5 & 21,8 & 17,5 & 18,7 \\
\hline Belgia & 2692 & 4220 & 44,4 & 23,2 & 37,8 & 45,5 & 17,8 & 31,3 \\
\hline Dania & 2003 & 3912 & 47,8 & 41,7 & 21,9 & 21,1 & 30,3 & 34,2 \\
\hline Finlandia & 1140 & 2111 & 75,5 & 69,3 & 10,1 & 10,6 & 14,4 & 20,1 \\
\hline Francja & 1876 & 3485 & 49,8 & 41,0 & 28,0 & 33,1 & 22,2 & 25,9 \\
\hline Grecja & 880 & 1592 & & 49,6 & & 16,2 & & 34,2 \\
\hline Hiszpania & 1207 & 2056 & 66,3 & 56,3 & 18,2 & 13,8 & 15,5 & 29,9 \\
\hline Holandia & 2757 & 4049 & 39,4 & 28,3 & 22,4 & 32,8 & 38,2 & 38,9 \\
\hline Niemcy & 1839 & 3648 & 49,5 & 34,5 & 29,1 & 37,9 & 21,4 & 27,6 \\
\hline Norwegia & 1360 & 2447 & 49,6 & 39,6 & 22,9 & 25,9 & 27,5 & 34,5 \\
\hline Portugalia & 975 & 1250 & 65,0 & 57,4 & 24,9 & 21,9 & 10,1 & 20,7 \\
\hline Szwajcaria & 2102 & 4266 & 42,3 & 26,8 & 41,8 & 45,7 & 15,9 & 27,5 \\
\hline $\begin{array}{l}\text { Wielka } \\
\text { Brytania }\end{array}$ & 3190 & 4921 & 22,2 & 11,8 & 42,4 & 44,1 & 35,4 & 44,1 \\
\hline Włochy & 1499 & 2564 & 61,0 & 55,4 & 23,3 & 26,6 & 15,7 & 18,0 \\
\hline
\end{tabular}

Źródło: opracowanie własne na podstawie: B.R. Mitchell, International Historical Statistics: Europe, 1750-2000, London 2003; W.G. Hoffman, Das Wachstum der deutschen Wirtschaft seit der Mitte des 19. Jahrhunderts, Berlin 1965; C.H. Feinstein, National Income, Expenditure and Output of the United Kingdom, 1855-1965, Cambridge 1972.

W omawianym okresie światowy PKB wzrósł prawie o 150\%. Mniejszy był przyrost dochodu $\mathrm{w}$ przeliczeniu na jednego mieszkańca, ale i tak podniósł się o ok. $80 \%$. Optymistyczne było to, że postęp gospodarczy umożliwił większej liczbie mieszkańców naszego globu poprawę warunków życia. Odnosi się to przede wszystkim do Europy, gdzie mimo szybkiego przyrostu ludności (ok. 500 mln - patrz rys. 3), stopa życiowa ludności miała trend rosnący. 


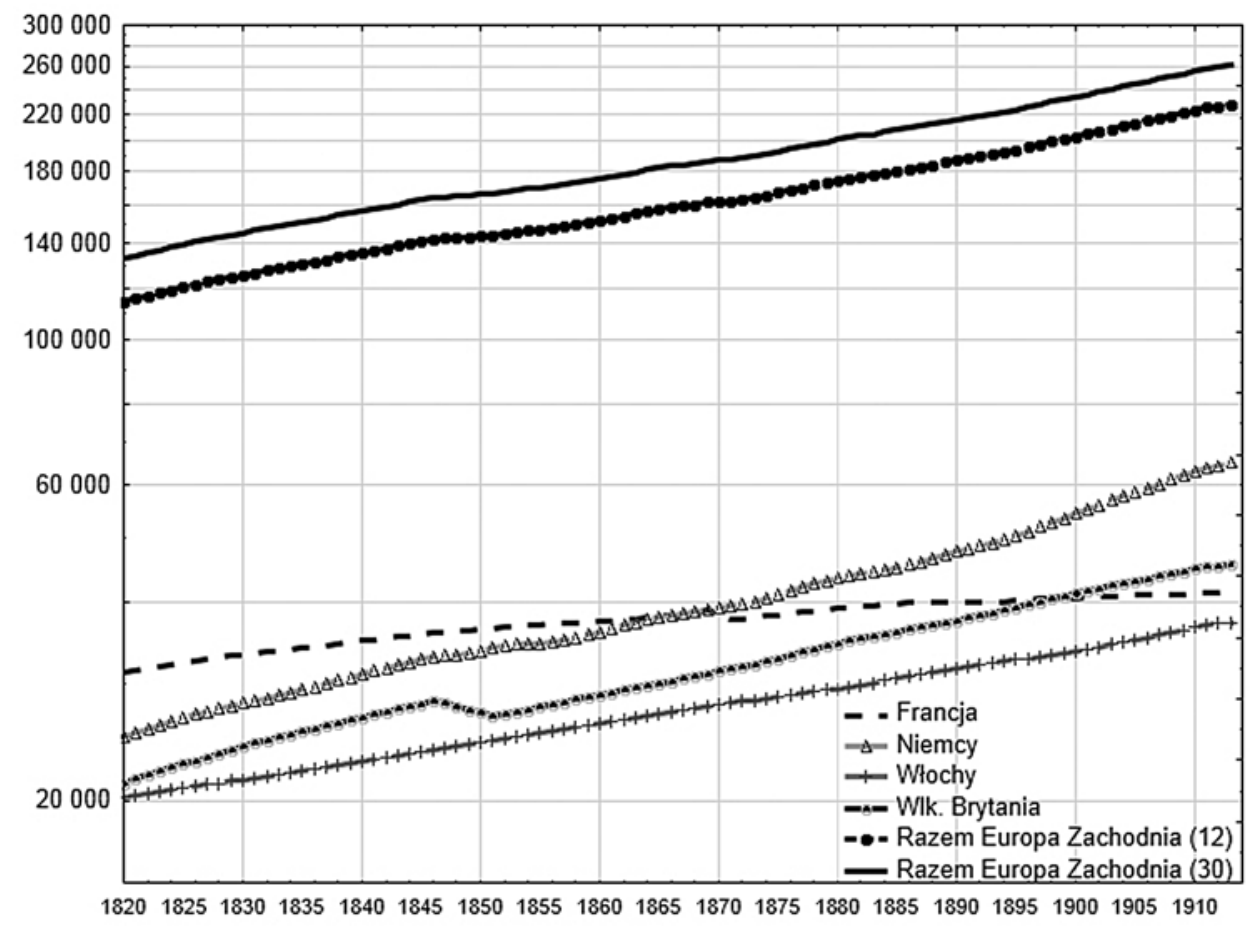

Rys. 3. Wzrost liczby ludności Europy Zachodniej z uwzględnieniem 12 krajów i 30 krajów na tle wzrostu liczby ludności Francji, Niemiec, Włoch i Wielkiej Brytanii (skala logarytmiczna)

Źródło: A. Maddison, Historical Statistics for the World Economy: 1-2003 AD, www.sais-jhu. edu/library/subjectquides/stats.htm [dostęp 10.11.2010].

W dwudziestce państw o najwyższym PKB per capita na świecie aż 14 pochodziło ze Starego Kontynentu. Charakterystyczne, że w krajach najbardziej rozwiniętych wystąpiła duża rozpiętość PKB na jednego mieszkańca. Pierwsze cztery państwa (Australia, Stany Zjednoczone, Nowa Zelandia i Wielka Brytania) miały 2-krotnie wyższy dochód w porównaniu z czterema ostatnimi (Włochy, Norwegia, Hiszpania i Finlandia) ${ }^{89}$. Głównymi beneficjentami wzrostu PKB była wielka burżuazja oraz właściciele i pracownicy banków i dużych spółek. Regres przeżywali przedsiębiorcy familijni i posiadacze ziemscy. W najtrudniejszym położeniu znajdowali się jak zawsze bezrobotni i biedota wiejska ${ }^{90}$.

\footnotetext{
${ }^{89}$ A. Maddison, The World Economy: A. Millennial Perspective, Paris 2002, s. $23-24$.

90 J. Baszkiewicz, op. cit., s. 494; J. Kędzierski, op. cit., s. 389.
} 


\section{ROZDZIAL II ROZBUDOWA I WZROST ZNACZENIA TRANSPORTU}

\section{OCENA STANU TRANSPORTU LĄDOWEGO I WODNEGO W XIX WIEKU}

W warunkach XIX w. rozbudowa i rozwój transportu została zdominowana przez upowszechnienie silnika parowego. Szczególną rolę odegrały koleje żelazne, rozwój transportu śródlądowego w tym: rozbudowa kanałów, regulacja rzek, a także rozwój transportu morskiego. Transport drogowy i lotniczy miały się rozwinąć w wieku XX.

Zwiększanie efektywności systemu transportowego wpływa pozytywnie na makroekonomiczny wzrost gospodarczy. Na rysunku 4 zobrazowano, jak rozwój transportu może oddziaływać na ograniczenie kosztów dotyczących przewozu surowców, towarów, osób, co z kolei ma ogromne znaczenie w podnoszeniu efektywności ekonomicznej. Niższe koszty produkcji wpływają na większe zyski przedsiębiorstw, umożliwiając jednocześnie większą produktywność. To z kolei przyczynia się do zapewnienia postępu w życiu gospodarczym, a także tworzeniu warunków wzrostu i rozwoju gospodarczego.

Jak zauważa Patrick O’Brien, europejskiemu wzrostowi gospodarczemu, który znacznie przyspieszył w drugiej połowie XVIII w. towarzyszyła ekspansja podaży usług transportowych. Popyt na usługi transportowe wzrastał, kiedy przemysłowcy i rolnicy (farmerzy) próbowali zakupić czynniki wytwórcze (surowce, narzędzia, maszyny) niezbędne w procesie produkcji z coraz większych odległości oraz sprzedać swoje produkty na rynkach oddalonych od miejsca wytworzenia ${ }^{1}$.

Wzrastała produkcja towarów, a efekty specjalizacji, szczególnie zauważalne w latach 1789-1914 prowadziły do wzmożenia obrotów handlowych pomiędzy firmami, farmerami i przemysłem. We wczesnym etapie rozwoju gospodarek europejskich produkcja wielu dóbr skoncentrowana była w określonych regionach.

W tym samym czasie kolejne innowacje prowadzily do wzrostu efektywności usług transportowych oferowanych w Europie, a tym samym spadku cen czynników wytwórczych w rolnictwie, przemyśle, rzemieślnictwie. Jednocześnie $\mathrm{w}$ wielu przypadkach spadały ceny wytworzonych towarów przemysłowych i rolnych.

${ }^{1}$ P. O’Brien, Transport and Economic Development in Europe 1789-1914, [w:] Railways and the Economic Development of Western Europe, 1830-1914, ed. P. O'Brien, Oxford 1983, s. 1. 


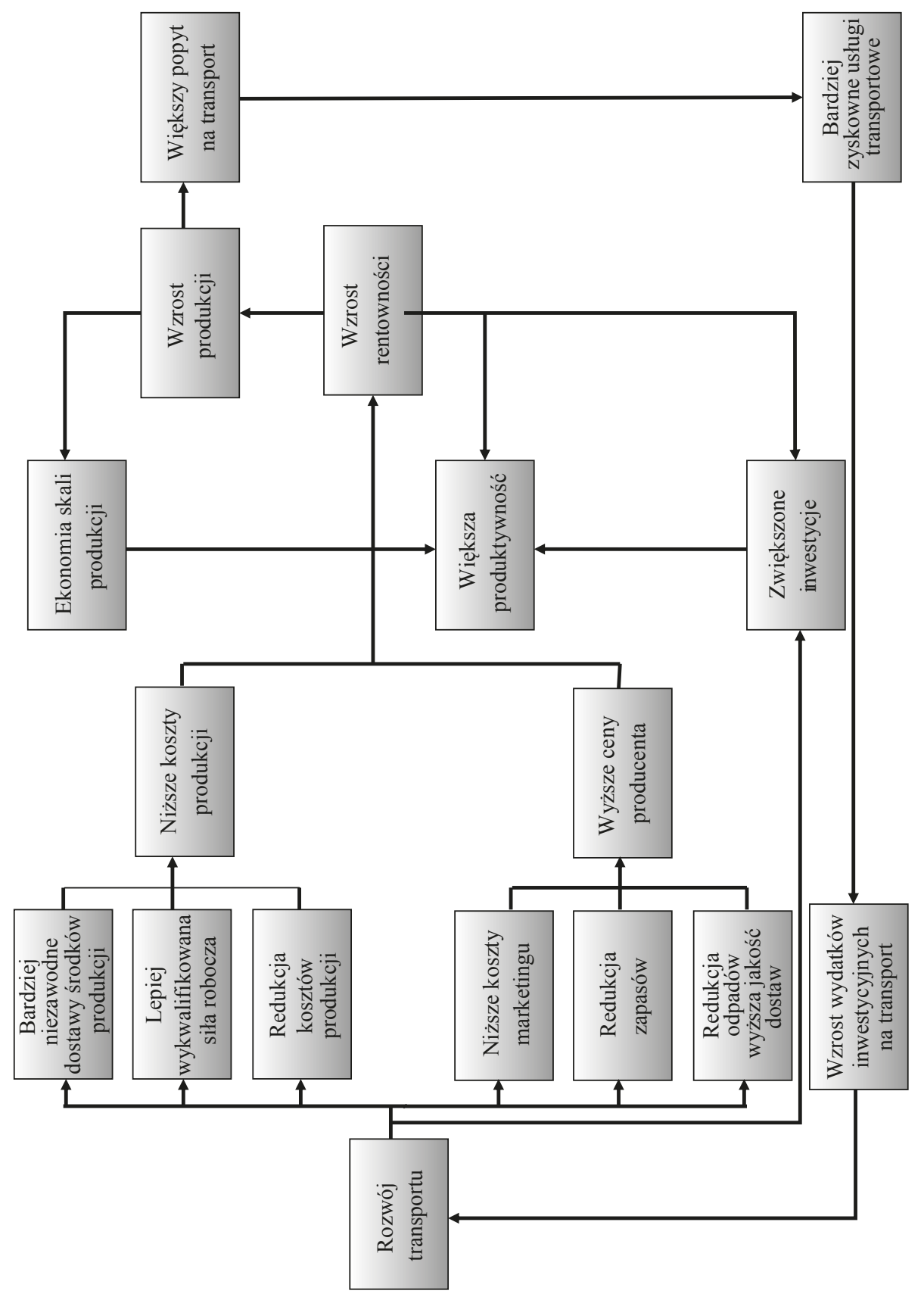

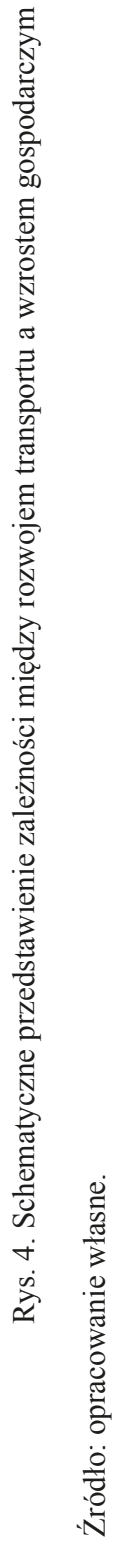


Innowacje, które dotyczyły transportu stopniowo docierały na cały kontynent europejski. Zaliczyć do nich można: utwardzanie dróg, rozwój dróg wodnych i kolejowych, a przede wszystkim zastosowanie siły pary i ograniczenie roli wiatru, wody, siły rąk ludzkich i siły zwierząt. Innowacje w transporcie oznaczały szybszą, tańszą i pewniejszą dostawę towarów i surowców, w szczególności węgla, surowców mineralnych, materiałów budowlanych, zbóż, towarów metalowych. Transport zapewniał także szybsze przemieszczanie się ludzi i szybszą dyfuzję wiedzy.

Rozwój kolei i ich znaczenie, jak wspomniano, przyczyniły się, że wielu naukowców, jak Walt Rostow, Rainer Fremdling określało sektor kolejowy, jako podstawowy sektor wzrostu (primare sector). Takiemu sektorowi towarzyszyły trzy efekty: „efekt w przód” (ang. forward linkages, niem. Vorwärtskopplungseffekte), „efekt w tył” (ang. backward linkages, niem. Rückwärtskopplungseffekte) oraz inne skutki uboczne.

Efektem rozwoju transportu był tzw. „efekt w przód” mierzony poprzez wpływ na strukturę cen względnych, wspieranie specjalizacji regionalnej i han$\mathrm{dlu}^{2}$. Jednocześnie efektem były zmiany w alokacji zasobów, migracje ludności, nasilony proces urbanizacji, rozwój i poziom zaangażowanego kapitału. Z kolei „efekt w tył” oznaczał zwiększone zapotrzebowanie na produkcję przemysłu hutniczego, górniczego, maszynowego. Rozwój transportu kolejowego i wodnego wymagał zapewnienia niezbędnych dóbr wytwarzanych przez przemysł jak: żelazo, stal, węgiel, konstrukcje inżynierskie (wiadukty, mosty, parowozy). Dla określenia siły tych powiązań (backward linkages) historycy gospodarczy mierzą poziom produkcji dostarczonej przez inne sektory sektorowi transportowemu. Próbują analizować stopień wpływu transportu na popyt, łącznie z efektem ekonomii skali produkcji i generowania szybszego postępu technicznego dla sektorów dostarczających.

Rozbudowa kolei i kanałów wodnych wymagała także zaangażowania inżynierów, brygadzistów, menedżerów, których umiejętności mogły być używane w innych sektorach gospodarki. Rozbudowa sztucznych szlaków wodnych i później kolei wymagała ogromnego zaangażowania kapitału i w krótkim okresie prowadziła do rozwoju pośrednictwa finansowego dla osiągnięcia w przyszłości określonych oszczędności.

Z upływem czasu stawka za $1 \mathrm{~km}$ przewozu kolejami zmniejszała się, zwłaszcza kiedy kolej zaoferowała podróże pasażerskie. Dla przykładu w XIX w. we Francji koszty podróżowania koleją były 2-3 krotnie niższe niż drogami lądowymi, podobnie dla roku 1860 w British Royal Commission podróż powozem w pierwszej klasie kosztowała około 2 szylingi za 1 milę, w tym czasie za tę samą odległość w pierwszej klasie pociągiem koszt ten wynosił około 2-3 pensy.

${ }^{2}$ Nie zawsze były to efekty oczekiwane przez społeczność, region, np. nadmierna podaż zbóż na rynek niemiecki i ochrona celna produktów rolnych. 
Pomiędzy 1855 a 1913 przewóz towarów drogami bitymi we Francji był nawet czterokrotnie wyższy ${ }^{3}$. W Wielkiej Brytanii koszt przewozu węgla kolejami stanowił 1/12 kosztu przewozu drogami bitymi.

Zupełnie inaczej przedstawiała się sytuacja dla transportu wodnego. Zastosowanie silnika parowego przyczyniło się do obniżki cen za fracht wodny. Transport wodny (śródlądowy i przybrzeżnymi wodami) skutecznie konkurował z transportem kolejowym, a w krajach takich jak Francja, Belgia, Włochy, Niemcy często był tańszy. Najbardziej optymalne było zastosowanie żeglugi śródlądowej do przewozów na średnie i dalsze odległości, przede wszystkim ładunków masowych.

Głównymi cechami tego rodzaju transportu były:

- przystosowanie środków transportu (barek) do przewozu w dużych partiach i towarów masowych;

- stosunkowo długi czas dostawy, wynikający z małych prędkości eksploatacyjnych taboru ${ }^{4}$;

- nieregularność przewozów, wynikająca z oddziaływania czynników naturalnych, a wpływających na czasowe ograniczenia lub zawieszenia transportu (niskie temperatury, niski stan wód);

- niskie koszty wykonywania przewozów, przy znacznej degresji kosztów jednostkowych przy przemieszczaniu na duże i średnie odległości;

- słabe dostosowanie przestrzennego rozmieszczenia dróg wodnych w stosunku do lokalizacji ośrodków przemysłowo-handlowych, znacznie ograniczających zastosowanie środków tej gałęzi transportus.

Dodać należy, że dla żeglugi śródlądowej zauważalne jest duże rozproszenie podaży usług, przy małym rozproszeniu popytu na usługi.

Wobec rozwoju produkcji przemysłowej i rozwoju wymiany handlowej w Europie ważną kwestią stało się zapewnienie wolności żeglugi po międzynarodowych drogach i kanałach. Ogólną zasadę wolności głosili uczestnicy kongresu wiedeńskiego w 1815 r. Wolność żeglugi państwom nadreńskim zapewniła konwencja międzynarodowa podpisana w Moguncji w 1831 r. a następnie konwencja o żegludze na Renie podpisana w 1868 r., tzw. akty mannheimskie (Revised Convention for the Rhine Navigation). Konwencja ustanowiła wolność żeglugi po rzece Ren na odcinku od Bazylei do Morza Północnego, równe traktowanie statków różnych bander, wyeliminowanie administracyjnych barier dla żeglugi, nieobciążanie jej opłatami nawigacyjnymi, jednolite zasady odpraw celnych, bezpieczeństwa żeglugi, zobowiązanie sygnatariuszy do utrzymywania w należytym stanie drogi wodnej.

${ }^{3}$ P. O’Brien, op. cit., s. 5.

${ }^{4}$ Zestaw pchany poruszający się z prądem rzeki może osiągać prędkość w granicach 10-15 $\mathrm{km} / \mathrm{h}$.

5 J. Neider, Transport międzynarodowy, Warszawa 2012, s. 102. 
Transport wodny śródlądowy od dawna był wykorzystywany w przemieszczaniu towarów. Jak szacuje Wilhelm Nördling długość żeglownych szlaków wodnych północnych Niemiec z włączeniem Renu wynosiła około 7770 km. Rolę transportu śródlądowego ograniczał często brak naturalnych połączeń pomiędzy żeglownymi rzekami. Stąd już w czasach merkantylizmu budowano kanały łączące kluczowe rzeki Niemiec. I tak, już w 1669 r. został otwarty Friedrich-Wilhelm-Kanal, który połączył Odrę z Łabą, z wykorzystaniem Sprewy. W 1847 r. Finow-Kanal połączył Łabę z Odrą przez Hawelę. Plauener Kanal łączący Łabę z Hawelą został wybudowany w latach 1743-1745, dzięki czemu droga z Magdeburga do Brandenburga uległa skróceniu o blisko $100 \mathrm{~km}$. Od 1774 r. dostępne były połączenia wodne z wykorzystaniem rzek i kanałów pomiędzy Kłajpedą, Królewcem, Berlinem, Wrocławiem, Dreznem, Hamburgiem6.

Karl Borchard szacuje, że w 1774 r., włączając 147,5 km sztucznych dróg wodnych, ogółem dostępnych i żeglownych szlaków wodnych było jedynie $1051,6 \mathrm{~km}$. Z tej liczby blisko $83 \%$ dróg wodnych należało do Prus. Pomiędzy 1786 r. a 1850 r. wybudowano w Prusach kolejne 206,2 km kanałów, w pozostałych częściach Niemiec około 161,2 km7. Zgodnie z obliczeniami K. Borcharda pomiędzy 1785 a 1850 r. w samych Prusach zainwestowano około $27 \mathrm{mln}$ marek w rozbudowę kanałów (około 0,4\% PKB z 1850 r.).

W początkach XIX w. starano się znieść bariery instytucjonalno-prawne dalszego rozwoju szlaków wodnych, łącznie z możliwością rozszerzenia wykorzystania kolejnych odcinków wód do celów żeglugi. Prowadzono prace mające na celu regulację rzek, pogłębianie koryt, budowę śluz itd.

Znaczenie transportu wodnego potwierdza przykład Berlina - jeszcze w 1860 r. wwóz brytyjskiego węgla kamiennego, który stanowił blisko $74 \%$ tego rynku, odbywał się w znakomitej większości z wykorzystaniem śródlądowych dróg wodnych (około $77 \%$ przewozów).

$\mathrm{Na}$ długo przed budową pierwszej linii kolejowej w Niemczech w $1835 \mathrm{r}$. w transporcie śródlądowym wykorzystano dorobek przewrotu technicznego, w tym maszynę parową. Dwa pierwsze parowce w Niemczech zbudowano już w 1816 r. ${ }^{8}$ W 1830 r. już 12 parowców regularnie kursowało po rzece Ren. Duża konkurencja w budowie kolejnych parowców pomiędzy Niemcami a Holandią sprawiały, że ceny frachtu spadały. Jak szacuje Oskar Teubert, cena frachtu za $100 \mathrm{~kg}$ towaru pomiędzy Kolonią a Rotterdamem zmniejszyła się z 2,45 marek (1830 r.), do 1,35 marek marek (1833 r.), a w 1835 r. do 0,96 marek $^{9}$. Rozbudowa

${ }^{6}$ W. Nördling, Die Selbstkosten des Eisenbahn-Transportes und die Wasserstrassen-Frage in Frankreich, Preussen und Oesterreichs, Wien 1885, s. 134.

${ }^{7}$ K. Borchard, Staatsverbrauch und öffentliche Investitionen 1780-1850, Göttingen 1968, s. 277.

${ }^{8}$ Nazwano je: „Weser”, „Princessin Charlotte” (ta ostatnia miała 40 m długości i 5,8 m szerokości).

${ }^{9}$ O. Teubert, Die Binnenschiffahrt. Ein Handbuch für alle Beteiligten, Leipzig 1912, s. 97. 
linii kolejowych w latach czterdziestych XIX w. nie wpłynęła jeszcze zasadniczo na zaostrzenie rywalizacji pomiędzy tymi rodzajami transportu.

W roku 1857 Prusy miały 55 barek, o wyporności blisko 19,5 tys. Mg oraz 25 parostatków o wyporności łącznej 1,3 tys. Mg; dla porównania na głównych rzekach (Ren, Men, Neckar, Lahn, Mozela, Ruhra, Lippe) pływało 2582 żaglowców o wyporności 227 tys. Mg.

W 1877 r. niemiecka sieć dróg wodnych śródlądowych (łącznie z kanałami) liczyła $12441 \mathrm{~km}^{10}$. W tab. 2 zaprezentowano żeglowne obszary poszczególnych dorzeczy.

Tabela 2. Niemieckie drogi wodne śródlądowe - stan na koniec $1877 \mathrm{r}$.

\begin{tabular}{|l|c|}
\hline \multicolumn{1}{|c|}{ Dorzecze } & Długość w km \\
\hline Niemen & 247,3 \\
\hline Pregoła & 397,3 \\
\hline Wisła (w tym: kanał Elbląski 195,8 km) & 438,1 \\
\hline Odra (w tym: kanał Bydgoski 26,5 km) & 1802,5 \\
\hline Laba (w tym: kanał Odra-Łaba 80,6 km) & 2606,6 \\
\hline Wezera (w tym: kanał Oste-Hamme 16,4 km) & 1175,4 \\
\hline Ems & 466,4 \\
\hline Ren (w tym kanały: Ostfriesische, Elsass-Lothringische 812 km) & 2789,8 \\
\hline Dunaj (w tym kanał: Men-Dunaj 136,4 km) & 746,8 \\
\hline Razem & 12441,1 \\
\hline
\end{tabular}

Źródło: Statistisches Jahrbuch für das Deutsche Reich, IX Verkehr und Verkehrsstraßen, Berlin 1880 , s. 104.

Poszczególne drogi wodne miały różną głębokość żeglowną. Jedynie 2139,2 $\mathrm{km}$ dróg wodnych posiadało zanurzenie powyżej 1,5 m, 4623,6 km powyżej 1,0 $\mathrm{m}, 2325,4$ powyżej $0,75 \mathrm{~m}$, a 3352,9 $\mathrm{km}$ poniżej $0,75 \mathrm{~m}$. Zgodnie ze współczesnymi danymi Bundesministerium für Verkehr, Bau und Stadtentwicklung (BMVBS) pomiędzy latami 1863-1917 zostało przeprowadzonych 27 dużych projektów dotyczących rozbudowy transportu wodnego śródlądowego. W wyniku tych prac zbudowano nowe kanały, przeprowadzono regulację rzecznych zatorów. Kilka największych inwestycji przedstawiono w tab. 3 .

${ }_{10}$ Statistisches Jahrbuch für das Deutsche Reich, IX Verkehr und Verkehrsstraßen, Berlin 1880, s. 104. 
Tabela 3. Wybrane inwestycje w ramach rozbudowy dróg wodnych w Niemczech (1880-1916)

\begin{tabular}{|l|c|}
\hline \multicolumn{1}{|c|}{ Lata } & Wykonane prace \\
\hline $1880-1887$ & Budowa kanału Ems-Jade-Kanal $(72,3 \mathrm{~km})$ \\
\hline 1884 & Regulacja zatorów na rzece Neckar \\
\hline $1884-1886$ & Regulacja zatorów na rzece Men od Frankfurtu w dół rzeki \\
\hline $1886-1895$ & Budowa kanału Kaiser-Wilhelm-Kanal \\
\hline $1877-1899$ & Budowa kanału Dortmund-Ems-Kanal \\
\hline $1896-1900$ & Budowa kanału Elbe-Trave-Kanal (Elbe-Lübeck-Kanal) \\
\hline $1906-1916$ & Budowa drogi wodnej Wisła-Odra \\
\hline $1906-1915$ &
\end{tabular}

Źródło: http://www.wsv.de/wasserstrassen/historisches/binnenschifffahrt/index.html

Przedstawiona krótka analiza dowodzi, że przed rozwojem transportu kolejowego, a także podczas rozbudowy szlaków kolejowych transport śródlądowy odgrywał istotną rolę w przewozie ładunków, będąc jednocześnie tańszą alternatywą dla przewozów kolejowych.

Rozwój sektora kolejowego determinowany był przez wspomniany już „efekt w przód". Węgiel przed erą rozbudowy kolejnictwa w Niemczech, praktycznie do połowy XIX w., oferowany był na miejscowych rynkach znajdujących się z pobliżu kopalń. Koszt transportu był zbyt wysoki, aby oferować ten surowiec na obszarach oddalonych od zagłębia. Dla przykładu Franz Urlich wskazuje, że koszt frachtu furmanką wynosił około $40 \mathrm{pf}$ za tkm, a transportu kolejowego 13-14 pf za tkm ${ }^{11}$. Cena węgla dla Hardensteiner Revirs przy kopalni wynosiła $3 \frac{1}{2}$ srebrnego grosza, a po przewiezieniu go do oddalonego o 4 mile Elberfeld koszt wzrastał do $10^{1 / 2}$ srebrnego grosza. Cena transportu na tak krótkim odcinku była dwukrotnie wyższa od ceny surowca.

Rozwój transportu lądowego, w tym transportu kolejowego w konkurencji z transportem śródlądowym, mógł doprowadzić do spadku cen frachtu. Wówczas pozycja niemieckich kopalń stawała się dużo korzystniejsza, aby konkurować $\mathrm{z}$ tańszym węglem brytyjskim ${ }^{12}$. Dla rynków oddalonych od kopalń, czyli w północnych i środkowych Niemczech oferowany był tańszy węgiel brytyjski. Jak już wspomniano, berliński rynek węgla zdominowany był przez węgiel brytyjski.

Dopiero subsydiowany transport kolejowy przyczynił się do częściowego wyparcia brytyjskiego węgla z rynku niemieckiego. Dynamikę przewozów wę-

${ }^{11}$ F. Urlich, Staffeltarife und Wasserstrassen, Berlin 1894, s. 58.

12 R. Fremdling, Eisenbahnen und deutsches Wirtschaftswachstum 1840-1879. Ein Beitrag zur Entwicklungstheorie und zur Theorie der Infrastruktur, Dortmund 1985, s. 62. 
gla, z uwzględnieniem rynku berlińskiego, w podziale na rodzaj transportu i tonaż w okresie 1846-1896 przedstawiono w tab. 4.

Tabela 4. Rywalizacja pomiędzy transportem wodnym i kolejowym - berliński rynek węgla w latach 1846-1910

\begin{tabular}{|c|c|c|c|c|}
\hline \multirow{2}{*}{ Pochodzenie węgla } & \multirow{2}{*}{ Ilość Mg } & \multicolumn{2}{|c|}{ Transport (w \%) } & \multirow{2}{*}{$\begin{array}{c}\text { Razem } \\
(\%)\end{array}$} \\
\hline & & wodny & kolejowy & \\
\hline \multicolumn{5}{|c|}{$1846 \mathrm{r}}$. \\
\hline Anglia & 95185 & 100,00 & 0,00 & 100,00 \\
\hline Niemcy & 0 & 0,00 & 0,00 & 0,00 \\
\hline Razem & 95185 & 100,00 & 0,00 & 100,00 \\
\hline \multicolumn{5}{|c|}{$1860 \mathrm{r}}$. \\
\hline Anglia & 203292,6 & 73,62 & 3,07 & 57,39 \\
\hline Niemcy & 150937,4 & 26,38 & 96,93 & 42,61 \\
\hline Razem & 354230,0 & 77,00 & 23,00 & 100,00 \\
\hline \multicolumn{5}{|c|}{$1871 \mathrm{r}}$. \\
\hline Anglia & 246597,7 & 83,14 & 0,44 & 22,98 \\
\hline Niemcy & 826499,3 & 16,86 & 99,56 & 77,02 \\
\hline Razem & 1073097 & 27,26 & 72,74 & 100,00 \\
\hline \multicolumn{5}{|c|}{$1886 \mathrm{r}}$. \\
\hline Anglia & 115559,9 & 70,30 & 0,90 & 6,70 \\
\hline Niemcy & 1609215,1 & 29,70 & 99,10 & 93,30 \\
\hline Razem & 1724775,0 & 9,40 & 90,60 & 100,00 \\
\hline \multicolumn{5}{|c|}{$1896 \mathrm{r}}$. \\
\hline Anglia & 329119,6 & 40,70 & 0,00 & 13,10 \\
\hline Niemcy, Czechy & 2183243,4 & 59,30 & 100,00 & 86,90 \\
\hline Razem & 2512363,0 & 32,10 & 67,90 & 100,00 \\
\hline
\end{tabular}

Źródło: R. Fremdling, Eisenbahnen und deutsches Wirtschaftswachstum 1840-1879. Ein Beitrag zur Entwicklungstheorie und zur Theorie der Infrastruktur, Dortmund 1985, s. 62-64.

Angielski węgiel transportowany był wyłącznie z wykorzystaniem transportu wodnego. Udział węgla angielskiego na rynku berlińskim w zasadzie spadł z niemal 100\% w latach czterdziestych XIX w. do 57,39\% w latach sześćdziesiątych, w 1871 r. wynosił blisko $23 \%$, a w 1896 r. już tylko $13,1 \%$. Stanowiło to ponad 329 tys. Mg. W odróżnieniu od angielskiego węgla, węgiel niemiecki (i czeski) transportowany był głównie na rynek niemiecki przy wykorzystaniu transportu kolejowego. W 1910 r. z $3333722 \mathrm{Mg}$ węgla $841078 \mathrm{Mg}$ pochodziło z Anglii. Udział węgla angielskiego ponownie wzrósł do $25,2 \%$. Udział transportu wodnego w dostawach węgla wynosił $57,1 \%{ }^{13}$.

${ }^{13}$ E. Zentgraf, Der Wettbewerb auf dem Berliner Kohlenmarkt mit besonderer Berücksichtigung der jüngsten Vergangenheit, Münster 1913, s.21. 
Na zalew berlińskiego rynku angielskim węglem miały wpływ wysokie koszty frachtu kolejowego. Da porównania, aby węgiel ze Śląska mógł być dostarczony w konkurencyjnej cenie koszt frachtu kolejowego nie powinien przekraczać $2,2 \mathrm{pf} / \mathrm{tkm}$. Pierwsze takie (specjalne) połączenia kolejowe zostały uruchomione w 1849 r. Angielski węgiel dominował do końca lat siedemdziesiątych XIX w. również w Hamburgu i Bremie

W latach 1875-1900 równolegle do rozbudowy szlaków kolejowych, został zreorganizowany transport śródlądowy wodny ${ }^{14}$. W odróżnieniu od ciągle rozwijających się dróg śródlądowych wodnych, krajowe drogi praktycznie do końca XVIII w. były w niezbyt dobrym stanie, co ograniczało możliwość ich efektywnego wykorzystania. Jak zauważa K. Borchard, na rozbudowę i poprawę bezpieczeństwa na drogach były przeznaczane niewielkie środki ${ }^{15}$. Pierwsze szosy z szybką nawierzchnią powstały na obszarze Niemiec w czasach hegemonii Napoleona Bonaparte. W 1816 r. w Prusach długość państwowych dróg krajowych, łącznie z drogami regionalnymi, powiatowymi, prywatnymi, komunalnymi i górniczymi wynosiła około 3836 km, w 1830 r.- 7301 km, w 1845 r.- 12817 km, w 1852 r. - $16689 \mathrm{~km}^{16}$. Przedstawione dane wskazują, że w latach 1816-1852 łączna długość dróg wzrosła ponad czterokrotnie, ale sieć dróg i ich stan techniczny dla szybkiego rozwoju przemysłu były niewystarczające.

W innych państwach niemieckich rozwój sieci dróg krajowych postępował w podobnym tempie. Gospodarcze znaczenie dróg było stosunkowo niewielkie. Wzrosło dopiero z końcem XIX w., wraz z wynalezieniem silnika czterosuwowego w Otto-Motors (1876 r.). Transport samochodowy miał szansę odegrania większej roli, obok sieci kolejowej i transportu wodnego, ale było to ciągle wyzwanie przyszłości.

Na rys. 5 przedstawiono rozwój transportu kolejowego i śródlądowego oraz udział kolei w transporcie ogółem. Zauważalny jest szybki wzrost i dominacja transportu kolejowego. Widoczna jest także pewna stabilizacja procentowego udziału przewozów kolejowych w całości - szczególnie po latach siedemdziesiątych XIX w. Do czasu wybuchu I wojny światowej udział transportu kolejowego oscylował w granicach $80 \%$.

\footnotetext{
${ }^{14}$ H. Moulton, Waterways versus Railways, Boston and New York 1912, s. 170.

${ }^{15}$ K. Borchard, op. cit., s. 260.

16 Tamże, s. 137.
} 


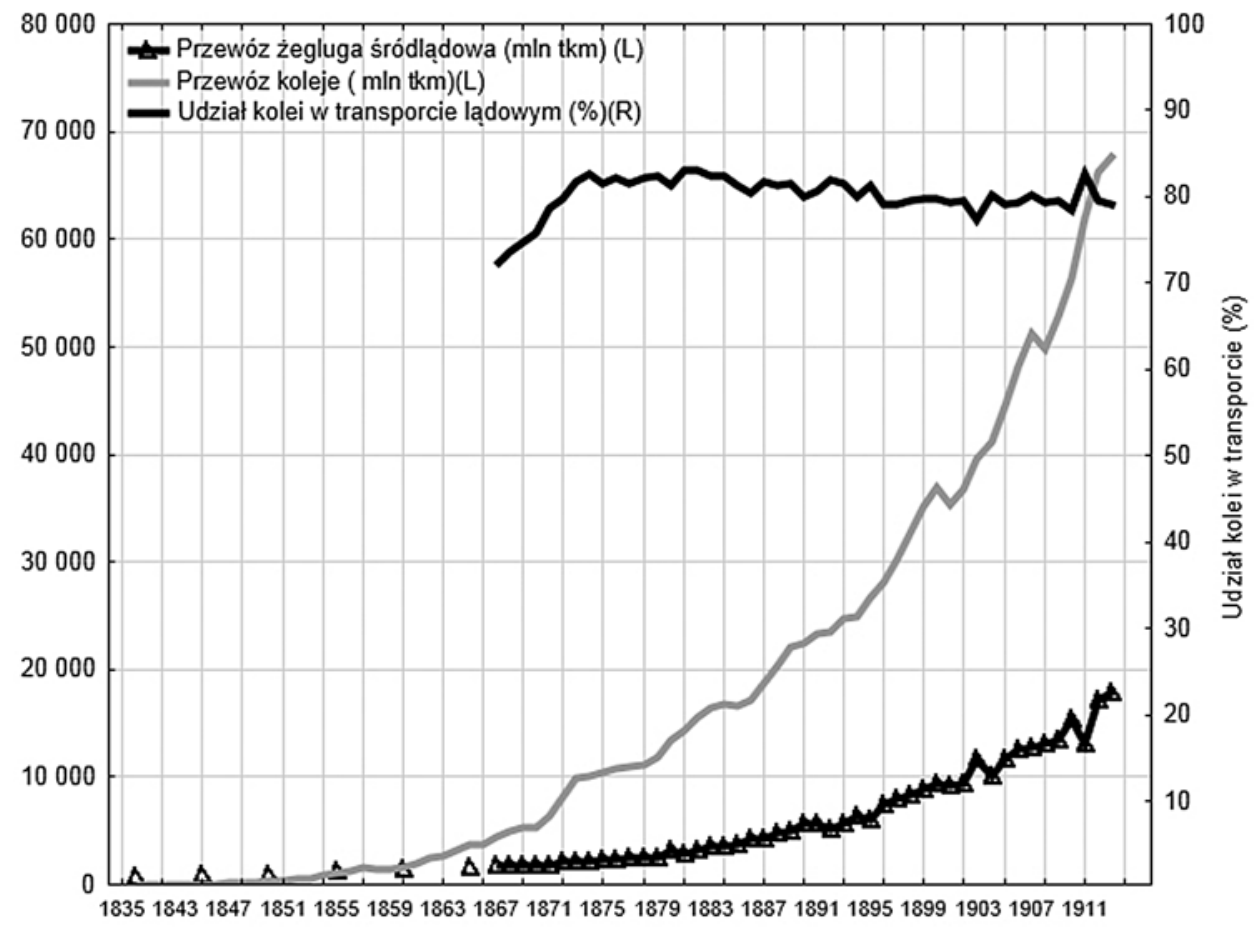

Rys. 5. Dynamika przewozów kolejowych i śródlądowych na tle udziału sektora kolejowego w transporcie w latach 1835-1913

Źródło: opracowanie własne na podstawie: W.G. Hoffmann, Das Wachstum der deutschen Wirtschaft seit der Mitte des 19. Jahrhunderts, Berlin 1965, s. 403.

\section{KOLEJE ŻELAZNE - REWOLUCJA W TRANSPORCIE I KOMUNIKACJI}

Przed wynalezieniem kolei ówczesne środki transportu stanowiły jedną z głównych przeszkód $\mathrm{w}$ procesie industrializacji. Z powodu braku naturalnych dróg wodnych oraz dużych odległości do pokonania przemysłowcy europejscy i amerykańscy musieli się ograniczyć do lokalnych rynków zbytu. Stąd też starano się przystosować maszynę parową, jako symbol epoki, użytą z powodzeniem do napędu pompy i silnika parowego, do napędu pojazdów szynowych ${ }^{17}$.

Komunikacja i transport były niezbędne, gdyż podstawą przemysłu, w tym i niemieckiego były wydobycie węgla i produkcja surówki żelaza. Od nich zależ-

17 J. Myszczyszyn, Wplyw maszyny parowej na rozwój gospodarczy świata w XIX i XX w., „Kultura i Historia” 2009, nr 16, http://www.kulturaihistoria.umcs.lublin.pl/archives/1473 
na była cała struktura przemysłu i częściowo handlu i to do tego stopnia, że stagnacja w przemyśle węglowym i żelaznym z natury rzeczy obniżała koniunkturę gospodarczą ${ }^{18}$. Rozwój kolei był niejako zbawienny dla przemysłu hutniczego, w którym kolejne wynalazki umożliwiały masowy wytop żelaza, a rozbudowa szlaków kolejowych, obok świadczenia transportu, potęgowała popyt na to dobro. Podobnie było z węglem, do tego jeszcze zastosowanie koksu w wytopie żelaza wzmagało popyt na ten surowiec mineralny ${ }^{19}$.

Właściwą politykę dotyczącą rozbudowy kolei przyjęły władze Prus. Niezbędne dla ich rozwoju i kontaktów handlowych z rozległymi prowincjami i miastami był wspomniany transport. Dla swego rozwoju Prusy potrzebowały surowców (żelaza i węgla). Kontakty z okręgami Saary i Ruhry - obszarami silnie uprzemysłowionymi były utrudnione ze względu na brak szlaków komunikacyjnych, które umożliwiałyby masowy i wydajny przewóz towarów.

Na początku XIX w., jak zauważają Toni Pierenkemper i Richard Tilly w krajach niemieckich dawało się zauważyć niewystarczającą sieć transportową w porównaniu do innych krajów europejskich, np. Francji ${ }^{20}$. Szlaki wodne, niestety, już nie mogły spełnić tego zadania, podobnie jak transport konny, ale mogła to zrobić kolej. Zdawał sobie z tego sprawę niemiecki ekonomista Friedrich List, który opublikował swe przemyślenia na temat niemieckiej sieci kolejowej już w $1833 \mathrm{r}$. Plan F. Lista zakładał połączenie siecią kolejową wszystkich większych miastach w całych Niemczech ${ }^{21}$. Na rys. 6 przedstawiono schemat sieci kolejowej, zaplanowanej przez tego ekonomistę.

Nie bez powodu autorzy publikacji Das deutsche Eisenbahnwesen der Gegenwart, wydanej w 1911 r. uznawali F. Lista za twórcę sieci niemieckich kolei żelaznych. Już w 1827 r. zamieścił on niektóre swoje myśli, w gazecie Augsburger Allgemeine Zeitung, omawiał m.in. projekty dróg, kanałów i budownictwo kolejowe w Ameryce, przedstawiając zalety transportu kolejowego ${ }^{22}$.

${ }^{18}$ Pamiętnik wystawy przemysłowej w Bochum od 19-27 lipca 1913 r., Oberhausen (Nadrenia) 1914, s. 14 .

19 Por. J. Myszczyszyn, Rola koksu i żelaza w industrializacji świata, „Kultura i Historia” 2009, nr 16, http://www.kulturaihistoria.umcs.lublin.pl/archives/1476.

${ }^{20}$ T. Pierenkemper, R. Tilly, The German Economy During the Nineteenth Century, New York-Oxford 2004, s. 58.

${ }^{21}$ F. List, Über ein sächsisches Eisenbahn-System als Grundlage eines allgemeinen deutschen Eisenbahn-Systems, und insbesondere über die Anlegung einer Eisenbahn von Leipzig nach Dresden, Leipzig 1833; F. List, Das Nationale System der Politischen Ökonomie, Jena 1910, s. 33 i n.

22 Das Deutsche Eisenbahnwesen der Gegenwart, Bd.1 und 2, Berlin 1911, s. 15. 


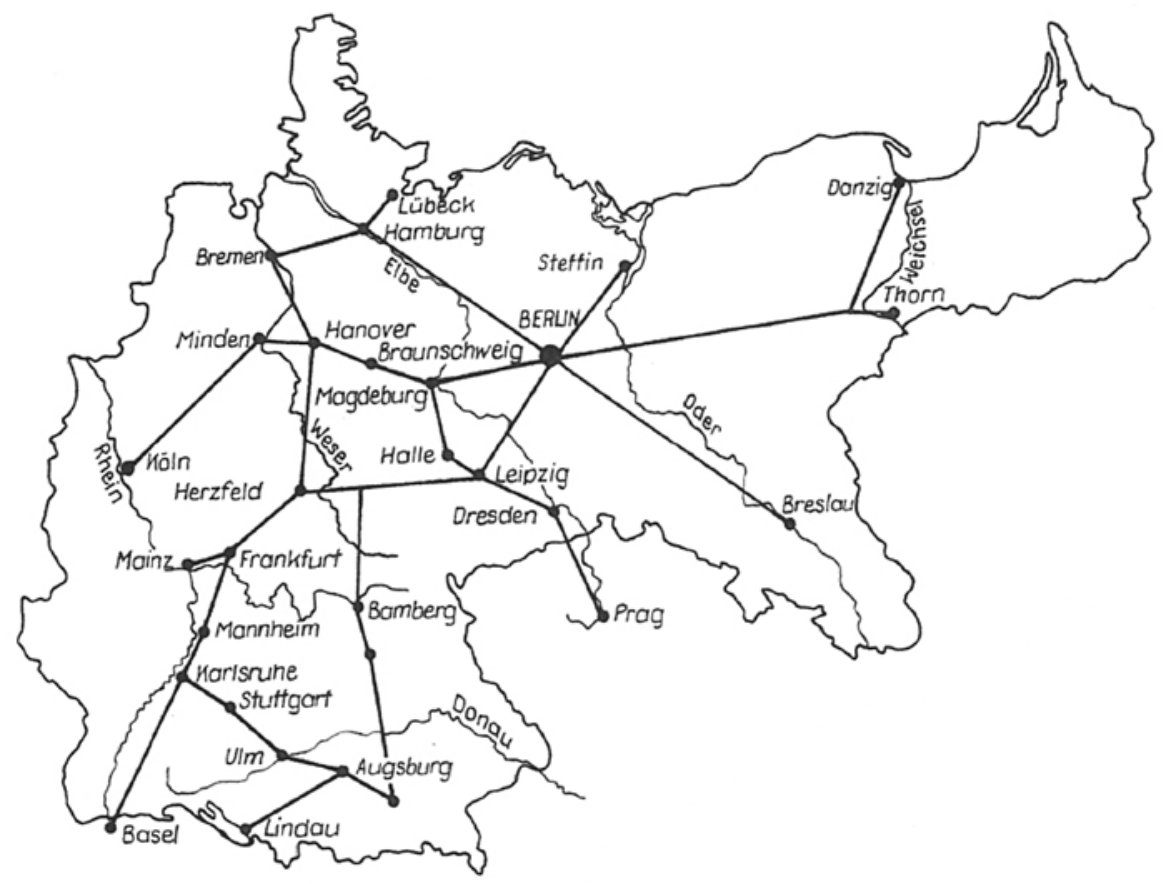

Rys.6. Niemiecka sieć kolei żelaznych według planów F. Lista (1833 r.)

Źródło: F. List, Über ein sächsisches Eisenbahn-System als Grundlage eines allgemeinen deutschen Eisenbahn-Systemes, und insbesondere über die Anlegung einer Eisenbahn von Leipzig nach Dresden, Leipzig 1833.

\subsection{Początki kolejnictwa w państwach niemieckich (1835-1845)}

W latach trzydziestych XIX w. stopniowo rozwija się kolej w poszczególnych rejonach Niemiec. Pierwszym połączeniem kolejowym z zastosowaniem parowozu w Niemczech była linia kolejowa w Bawarii: Norymberga - Fürth (1835/36). W Prusach w 1838 r. otwarto linię Berlin-Zehlendorf, a miesiąc później przedłużono ją do Poczdamu. W 1837 r. uruchomiono pierwszy odcinek linii kolejowej (Lipsk - Althen) Lipsk - Drezno, i był to pierwszy odcinek wyłącznie z trakcją parową. W 1839 r. oba miasta zostały połączone linią kolejową. Na zachodzie w 1838 r. otwarto odcinek Düsseldorf - Erkrath - pierwszą część kolei Bergisch - Märkische. W 1839/40 r. oddano do użytku pierwszy odcinek Taunusbahn: Frankfurt nad Menem - Hattersheim (Księstwo Nassau), linię Magdeburg Lipsk (odcinek Magdeburg - Kalbe) (Saksonia pruska, Ks. Anhalt), Rheinischen Bahn - odcinek Kolonia - Müngersdorf (Nadrenia pruska), Maximilainsbahn odcinek Monachium - Maisach (Bawaria). 
W roku 1840 przekazano do ruchu cały odcinek Frankfurt n. Menem - Wiesbaden (Księstwo Nassau), Magdeburg - Lipsk, początek Badische Staatseisenbahnen (Państwowej Kolei Badeńskiej), Mannheim - Heidelberg, Berlin-Anhalter Bahn (odcinek Cöthen - Dessau - Wittenberg).

Do końca 1840 r. na obszarze państw niemieckich było $518 \mathrm{~km}$ dróg żelaznych, ale w większości były to krótkie odcinki. Najdłuższym odcinkiem była linia Magdeburg - Lipsk -Drezno o długości $240 \mathrm{~km}$. Stolica Prus - Berlin, miała połączenie z pobliskim Poczdamem. Dopiero w 1841 r. rozpoczęto budowę odcinka Berlin - Wittenberg. W 1842 r. utworzono linię wschodnią (Bahnen des Ostens): Berlin - Angermünde, Berlin - Frankfurt nad Odrą, Wrocław - Brzeg. Hamburg (wolne miasto hanzeatyckie) rozpoczął budowę odcinka Bergedorf Berlin. Odcinek został oddany pod koniec $1846 \mathrm{r}$.

W 1845 r. było już $2162 \mathrm{~km}$ kolei - w stosunku do $1840 \mathrm{r}$. odnotowano przyrost o $1644 \mathrm{~km}$, średni przyrost to $328,8 \mathrm{~km}$ sieci rocznie.

Na dzisiejszym obszarze Polski (ówczesnym zaborze pruskim) pierwsza linia kolejowa zbudowana została na terenach Śląska. 24 lutego 1841 r. uzyskano koncesję, niedługo potem wmurowano kamień węgielny pod budowę dworca we Wrocławiu i powołano spółkę akcyjną Kolej Górnośląska (Oberschlesische Eisenbahn $A G$, w skrócie OSE). W rok później, 1 maja 1842 r., pierwszym oddanym do ruchu, liczącym $26 \mathrm{~km}$ odcinkiem Wrocław - Oława przejechał uroczyście pociąg. Następnie otwarto linię Bolesławiec - Legnica - Wrocław - Opole - Świętochłowice.

W Bawarii oprócz Ludwigsbahn były połączenia: Norymberga - Bamberg, Augsburg - Donauwörth, Monachium - Augsburg. Frankfurt n. Menem i Nassau miały tylko Taunusbahn, Badenia odcinek Mannheim do Fryburga, Nadrenia połączenie Kolonia - Bonn i Aachen, Deutz z Düsseldorfem, Aachen z Herbesthal, Elberfeld z Düsseldorfem. W Wirtembergii zgodnie z ustawą otwarto w $1843 \mathrm{r}$. pierwszy odcinek kolei państwowej z Canstatt do Eßlingen. Na północy w użyciu była linia Altona - Kiel, Neumünster - Rendsburg.

Pierwszą linią kolejową łączącą kraje niemieckie było połączenie Magdeburg (Prusy - Brandenburgia) z Lipskiem (Saksonia), której odcinek Calbe - Lipsk został otwarty w trakcie roku 1840. Pierwszy raz kolej przekroczyła granice Niemiec w 1843 r. - połączenie Kolonia przez Aachen do Herbesthal, do granicy z Belgią ${ }^{23}$.

Podróżni mogli wybierać przewóz w odpowiedniej klasie (I-III). Przejazd pierwszą klasą $1 \mathrm{~km}$ kosztował średnio 7-8 pf, w drugiej klasie 4-5 pf, dla III klasy 3-4 $\mathrm{pf}^{24}$.

Wymienione wyżej połączenia tworzyły regionalną sieć, ale sprawą przyszłości była unifikacja poszczególnych systemów, spółek w różnych państwach niemieckich.

${ }^{23}$ Das Deutsche Eisenbahnwesen..., s. 16-18.

${ }^{24}$ Była spotykana także IV klasa, np. na odcinku Monachium - Augsburg - cena za $1 \mathrm{~km}$ wynosiła 2,7 feniga. 
Podsumowując pierwszy, burzliwy okres budowy kolei żelaznych w państwach niemieckich należy podkreślić, że:

- zdecydowana większość linii kolejowych była budowana przez spółki $\mathrm{z}$ udziałem prywatnego kapitału;

- państwo wnosiło gwarancje korzystnych dla spółek kolejowych stóp procentowych (zagwarantowanie oprocentowania kapitału);

- tylko nieliczne państwa angażowały się bezpośrednio w budowę kolei.

Udział prywatnych finansów w budowie niemieckich kolei był bardzo wysoki i w roku 1840 wynosił około $92 \%$.

\subsection{Rozwój kolei na obszarze Niemiec (1846-1870)}

Wraz z budową linii kolejowych rozwija się jej park i zaplecze techniczne. W latach trzydziestych XIX w. powstaje w Monachium firma J.A. Maffei i w Berlinie firma Borsig (Borsigwerke), zajmujące się budową parowozów. W 1853 r., Borsig po 16 latach od założenia dostarczył 441 parowozów (z 729 wyprodukowanych) dla pruskich kolei. W $1858 \mathrm{r}$. świętowano wyprodukowanie tysięcznego parowozu, a po 20 kolejnych latach fabrykę opuściło 4000 parowozów. O rozwoju fabryk produkujących parowozy świadczą konkurenci firmy Borsig, m.in. wspomniany Maffei, Keßler, Egestorff i Hartmann. Ekspansję przeżywały zakłady Kruppa (Fried. Krupp A.G., Essen-Ruhr), które jeszcze w 1826 r. zatrudniały 7 pracowników, 1833 r. - 11, w 1836 r. - 60, w 1844 już 124, a w 1850 - około 1000 pracowników. W 1811 r. w Essen powstaje pierwsza stalownia.

Od lat czterdziestych XIX w. Krupp był znaczącym producentem lokomotyw i materiałów dla kolei (szyn, zwrotnic, mostów kolejowych). Krupp inwestował także w najnowsze technologie wytopu stali, m.in. za pomocą konwertorowego procesu Bessemera.

Od 1848 r. zaczął produkować wagony kolejowe. Był pierwszym producentem na świecie, który do produkcji kół kolejowych stosował walcowaną stal.

Rozbudowa szlaków kolejowych determinowała wzrost popytu na produkty przemysłu ciężkiego (żelazo, stal, węgiel). W latach 1846-1855, sieć niemieckich kolei żelaznych rozprzestrzeniła się we wszystkich niemal kierunkach.

W Prusach, największym państwie wśród niemieckich państw położonych w północnej części Związku Niemieckiego, obok istniejących prywatnych towarzystw kolejowych, powstawały koleje państwowe. W 1847 r. zadecydowano o budowie poszczególnych linii kolejowych przez państwo. Rząd był przekonany, że dla budowy linii na obszarach mało zaludnionych części wschodnich państwa nie będzie zaangażowany kapitał prywatny. Landtag odrzucił projekt, będący planem ministra Davida Hansemanna, aby wszystkie linie kolejowe znacjonalizo-

${ }_{25}$ W.W. Rostow, Politics and Stages of Growth, Warszawa 1973, s. 149. 
wać. Dopiero z końcem 1849 r. projekt energicznego ministra handlu Augusta von der Haydta, dotyczący budowy Kolei Wschodniej (Ostbahn), a także Kolei Westfalskiej (Königlich - Westfälische Eisenbahn), Kolei w Saarbrücken (Saarbrücker Eisenbahn), jako kolei państwowych uzyskał zgodę Landtagu. W połowie 1850 r.: Prusy, Bawaria, Hanower, Saksonia, Wirtembergia, Badenia, Hesja, Brunszwik były już właścicielami kolei państwowych.

Odtąd sieć linii kolejowych powstawała w szybkim tempie. Połączono stolicę Prus ze wschodem przez Szczecin do Poznania, na południowy zachód do Wrocławia i Mysłowic, a przez Racibórz do Wiednia, na południu przez Drezno do Pirny, z południowego zachodu przez Halle do Kassel, z zachodu przez Magdeburg, Brunszwik, Hanower do Bremy lub do Düsseldorfu, Elberfeld, Kolonii i Aachen, z północnego zachodu przez Hamburg do Kilonii, przez Schwerin do Rostoku. Linia Magdeburg - Lipsk - Drezno funkcjonowała jedynie do Drezna.

Mimo wspomnianych połączeń Niemcy południowe były jeszcze w niemal całkowitej separacji od Niemiec północnych. Nadal nie były gotowe mosty nad Renem. Pasma górskie oraz duże miasta tworzyły przeszkody dla połączeń szynowych. Luki w komunikacji na południu Niemiec zostały częściowo wypełnione dopiero w latach 1851-1852. W 1853 została ukończona budowa Kolei Wschodniej do Królewca (niem. Königsberg), ale jeszcze brakowało mostu pomiędzy Malborkiem i Tczewem. Most został oddany - w 1857 r., i był w tym czasie najdłuższym mostem w Europie (blisko 840 m długości).

Władze pruskie obawiały się rozbudowy dróg żelaznych w niektórych prowincjach, np. Wielkim Księstwie Poznańskim - długo przeciwstawiano się połączeniu kolejowemu pomiędzy Poznaniem a położoną w zaborze rosyjskim Warszawą ${ }^{26}$.

Do 1847 r. zaangażowanie prywatnych kapitałów w budowę kolei było znaczące. Świadczą o tym dane prezentujące wyniki wybranych spółek kolejowych zawarte w tab. 5.

Tabela 5. Wybrane niemieckie prywatne spółki kolejowe (1847 r.)

\begin{tabular}{|l|c|c|c|}
\hline \multicolumn{1}{|c|}{ Nazwa spółki } & $\begin{array}{c}\text { Rok otrzymania pierwszej } \\
\text { koncesji }\end{array}$ & $\begin{array}{c}\text { Długość wybudowanych } \\
\text { odcinków }(\mathrm{km})\end{array}$ & $\begin{array}{c}\text { Kapitał } \\
\text { (tys. talarów*) }\end{array}$ \\
\hline 1 & 2 & 3 & 4 \\
\hline Leipzig-Dresdener & 1835 & 115 & 9000,0 \\
\hline Bergisch-Märkische & 1844 & 88 & 39633,0 \\
\hline Köln-Mindener & 1843 & 280 & 62274,5 \\
\hline Rheinische & 1837 & 86 & 39500,0 \\
\hline
\end{tabular}

${ }^{26}$ S. Koźmian, O działaniach i dziełach Bismarcka, Kraków 1902, s. 47. Połączenie kolejowe Poznań - przez Ostrów Wlkp. z Łodzią i Warszawą, oraz połączenie Wrocławia z Warszawą przez Oleśnicę - Milicz - Krotoszyn - Łódź, nastąpiło dopiero w 1903 r. 
Tabela 5. (cd.)

\begin{tabular}{|l|c|c|c|}
\hline \multicolumn{1}{|c|}{1} & 2 & 3 & 4 \\
\hline Berlin-Hamburger & 1845 & 285 & 14000,0 \\
\hline $\begin{array}{l}\text { Berlin-Potsdam- } \\
\text { Magdeburg }\end{array}$ & 1845 & 120 & 14367,2 \\
\hline $\begin{array}{l}\text { Niederschlesisch- } \\
\text { Märkische }\end{array}$ & 1842 & 385 & 77270,0 \\
\hline Berlin-Stettiner & 1836 & 167 & 30324,0 \\
\hline
\end{tabular}

* Według kursu wymiany 1 talar $=3$ marki (1873 r.).

Źródło: opracowanie własne na podstawie: D. Ziegler, Eisenbahnen und Staat im Zeitalter der Industrialisierung. Die Eisenbahnpolitik der Deutschen Staaten im Vergleich”, „VSAG Beihefte“ 1996, Nr. 127, s. 94; V. Then, Eisenbahnen und Eisenbahnunternehmer in der Industriellen Revolution, Ein preußisch/deutsch-englischer Vergleich, „Kritische Studien zur Geschichtswissenschaft"1997, Bd. 120, s. 54.

W roku 1855, jak szacują autorzy publikacji Das deutsche Eisenbahnwesen der Gegenwart długość linii kolejowych w państwach niemieckich wynosiła 8652 km. W użyciu było 2077 lokomotyw, 4434 wagonów pasażerskich z 187252 miejscami (42 miejsca w wagonie), 34125 wagonów towarowych o nośności $197579 \mathrm{Mg}$ (średnio 5,8 Mg na wagon). Całkowity dochód z tytułu przewozów kolejowych wyniósł 184,2 mln marek, z tego blisko 60,5 mln marek z tytułu przewozów pasażerskich (32,8\% ogółu przychodów).

Przychody operacyjne z $1 \mathrm{~km}$ wyniosły średnio 21284 marek, przy kosztach operacyjnych 11206 marek (kapitał inwestycyjny na 1 km wyniósł 182947 marek, przychody z 1 pasażerokilometra (pkm) 4,21 pf, z 1 tonokilometra (tkm) 8,3 pf). Rentowność kapitału inwestycyjnego wynosiła średnio 5,51\% ${ }^{27}$.

Rozwój połączeń kolejowych, doprowadził do zwielokrotnienia pokonywania odległości w danej jednostce czasu; jeszcze w 1800 r. w ciągu 12 godzin człowiek mógł pokonać co najwyżej $50 \mathrm{~km}$, w pięćdziesiąt lat później już $400 \mathrm{~km}$. To dawało imponujący wskaźnik - ośmiokrotny wzrost ${ }^{28}$.

Rozbudowa kolejnych odcinków dróg żelaznych, wzrost szybkości przewozów osób i towarów masowych, wyraźnie przyczyniały się do rozwoju kultury i piśmiennictwa. Rozkwit przeżywała poczta - dostarczając szybko i sprawnie listy i inne przesyłki. Koleje determinowały rozwój rynku gazet (w tym dzienników), czasopism, książek, gdyż dobra te mogły być szybko dostarczone na znaczne odległości. Wzrastało znaczenie kolei w aspekcie działań militarnych. Użycie

${ }^{27}$ Das Deutsche Eisenbahnwesen..., s. 20. W statystyce zawarto również 1043 km linii austriackich.

${ }^{28} \mathrm{Z}$ końcem XIX w. pociągi pospieszne osiągały prędkość $75 \mathrm{~km} / \mathrm{h}$, co daje $900 \mathrm{~km}$ w ciągu 12 godzin. 
w 1849 r. telegrafu poprawiało bezpieczeństwo ruchu kolejowego, dając możliwości szybkiego przekazywania informacji.

Zdecydowanym liderem w budowie kolei były Prusy (39,29\% wszystkich szlaków w państwach niemieckich), wyprzedzając Bawarię (11,34\%) (zob. rys 7). Spośród $37022 \mathrm{~km}$ kolei żelaznych w Europie $10271 \mathrm{~km}$ leżało w państwach niemieckich (w tym w Austrii), co daje udział 27,74\% ${ }^{29}$. W tym czasie kraje niemieckie łącznie wyprzedziły w budowie kolei Francję (14,96\%). Zestawienie kapitału akcyjnego, przychodów i wydatków sektora kolejowego w przodujących krajach europejskich ilustrują dane zawarte w tab. 6.

Tabela 6. Kapitał akcyjny, przychody i wydatki kolei w wybranych krajach europejskich (1859 r.).

\begin{tabular}{|l|c|c|c|c|}
\hline \multirow{2}{*}{ Kraj } & \multicolumn{2}{|c|}{ Kapitał akcyjny } & \multirow{2}{*}{$\begin{array}{c}\text { Przychody na 1 } \\
\text { milę (marki) }\end{array}$} & $\begin{array}{c}\text { Wydatki na 1 } \\
\text { milę (tys.marek) }\end{array}$ \\
\cline { 2 - 3 } & \multicolumn{2}{|c|}{ razem } & na 1 milę & \\
\hline Prusy & 1050224 & 1452 & 156,7 & 73,1 \\
\hline Austria & 1059007 & 1638 & 216,2 & 97,6 \\
\hline Poz. kraje niemieckie & 932452 & 1399 & 141,2 & 74,0 \\
\hline Francja & 2904544 & 2410 & 278,2 & 125,2 \\
\hline Wlk. Brytania z Irlandią & 6440182 & 3129 & 247,2 & 118,7 \\
\hline
\end{tabular}

Źródło: opracowanie własne na podstawie: Jahrbuch für Volkswirtschaft uns Statistik von O. Hübner, Siebenter Jahrgang, Leipzig 1861, s. 199.

Kapitał akcyjny zaangażowany w sektorze kolejowym wynosił dla Niemiec (Prusy, łącznie z pozostałymi krajami niemieckimi) blisko 2 mld marek. Liderem pozostawała Wlk. Brytania z Irlandią, z 6,44 mld marek. Dla Prus i pozostałych krajów niemieckich kapitał akcyjny na 1 milę był zdecydowanie najniższy i wynosił około 1,45 mln marek.

Obraz niemieckich kolei żelaznych po pierwszym dwudziestoleciu ich funkcjonowania przedstawiał się bardzo korzystnie. Współzawodnictwo państwa i kapitału prywatnego w budowie kolejnych odcinków kolei nasuwał pytanie dotyczące formy własności - czy koleje powinny pozostawać w rękach prywatnych przedsiębiorstw (towarzystw, spółek) czy jednak powinny być państwowe?

Wraz z rozwojem kolejnictwa zmienił się także stosunek przychodów z tytułu transportu osób i towarów. W Niemczech w 1840 r. stosunek przychodów z transportu osób do transportu towarów wynosił 2:1, w 1850 r. 1:1, w pięć lat później już 1:2. W 1855 r. kolejami niemieckimi i austriackimi przewieziono to-

${ }^{29} \mathrm{Na}$ podstawie danych w: Jahrbuch für Volkswirtschaft und Statistik, Herausgegeben von O. Hübner, Fünfter Jahrgang, Leipzig, 1857, s. 77: udział Anglii wynosił ok. 35,8\%, a Francji $14,96 \%$. 
wary o łącznej wartości $44 \mathrm{mln}$ talarów i wadze $345 \mathrm{mln}$ cetnarów (około 17,5 $\mathrm{mln} \mathrm{Mg}$ ), dla porównania w 1850 r. 106,8 mln cetnarów (5,34 mln Mg) o wartości 14,2 mln talarów ${ }^{30}$.

W latach 1866-1970, w Niemczech, mimo braku wielu regulacji dotyczących kolei, mających związek z powstaniem federacji państw, długość linii kolejowych wzrosła o $4868 \mathrm{~km}$, a więc przyrastała o blisko $1000 \mathrm{~km}$ rocznie. Tylko w roku 1870 wybudowano $1510 \mathrm{~km}$ nowych połączeń.

Trzeba przypomnieć, że rządy (różnych) państw niemieckich były z reguły od początku przychylnie nastawione do rozwoju kolejnictwa, ale inicjatywy prywatne zdecydowanie przeważały w budowie nowych odcinków dróg żelaznych. Powszechnie zakładano towarzystwa akcyjne, które zajmowały się budową szlaków.

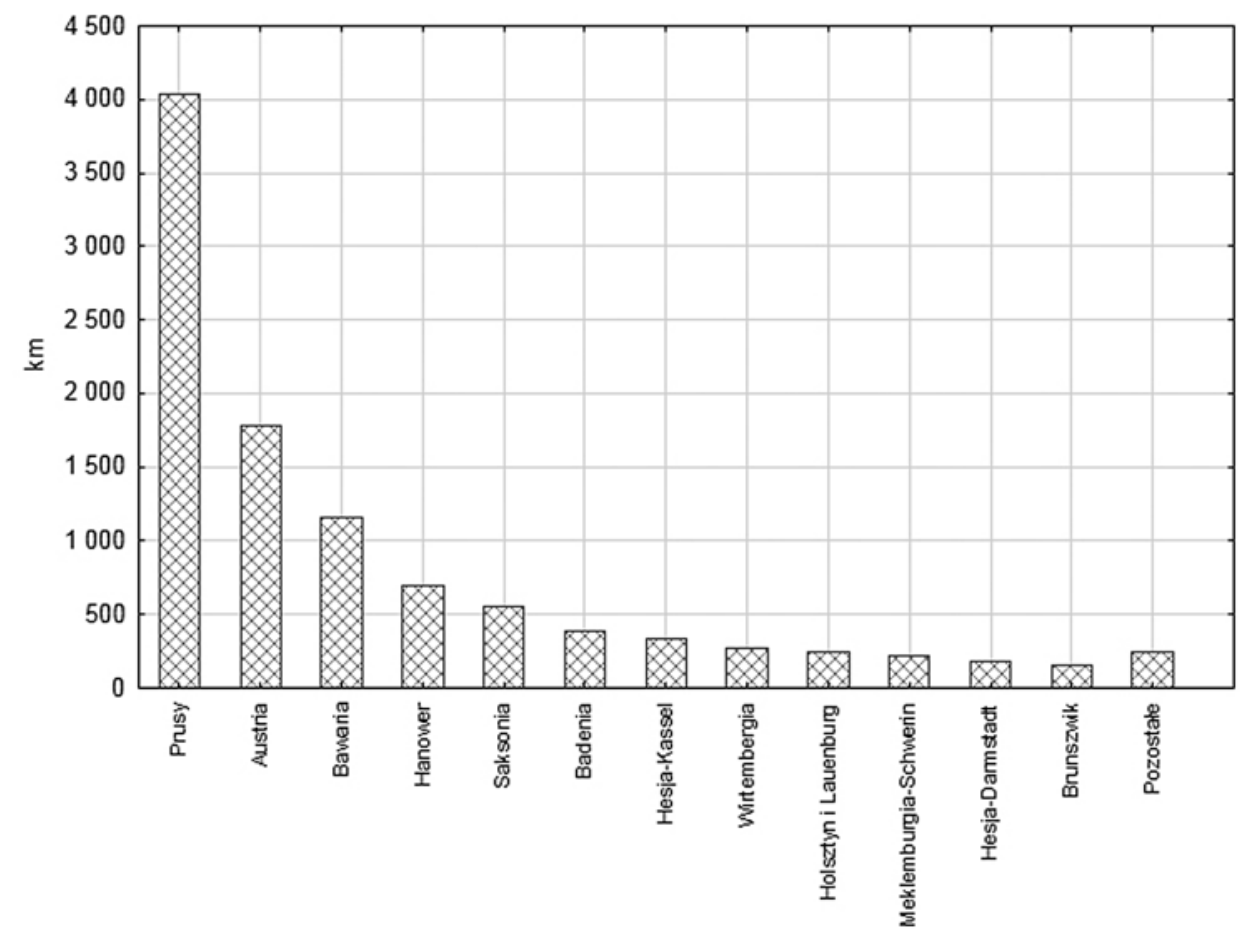

Rys. 7. Długość linii kolejowych w państwach niemieckich (z Austrią) w 1856 r.

Źródło: opracowanie własne na podstawie: Jahrbuch für Volkswirtschaft und Statistik, Herausgegeben von O. Hübner, Fünfter Jahrgang, Leipzig 1857, s. 77.

30 Tamże, s. 88. 
Pierwszą niemiecką kolej państwową założono w Brunszwiku w 1838 r., połączenie Brunszwik - Wolfenbüttel oddano do użytku 1 grudnia 1838 r. W Badenii, Królestwie Hanoweru od początku budowa kolei była w rękach państwa. Budowa kolei Main - Neckar (połączenie Frankfurtu n. Menem z Heidelbergiem) było wspólnym przedsięwzięciem trzech rządów: wolnego miasta Frankfurtu n. Menem, Badenii i Hesji.

W Bawarii w 1845 r. minister Karl von Abel w imieniu rządu jasno wyraził stanowisko, stwierdzając, że w żadnym razie budowa głównych odcinków kolei nie może być oddana $\mathrm{w}$ ręce prywatne ${ }^{31}$. W Wirtembergii pierwsze odcinki kolei państwowej otwarto w 1844 r., rząd stanowczo opowiadał się za zaangażowaniem państwa w tworzeniu sieci kolejowej. Podkreślano, że interesy prywatnych właścicieli nie mogą być w zgodzie z publicznymi potrzebami, bowiem dla nich najważniejszym celem będzie osiągany zysk. Saksonia rozpoczęła nacjonalizację swoich kolei poprzez przejęcie w 1847 r. Sächsisch-Bayerischen Eisenbahn-Compagnie.

W Prusach, jak wspomniano, rząd stosunkowo późno zdecydował się na uczestnictwo państwa w budowie kolei, mimo świadomości, że rząd w razie potrzeby musi zająć się tym zagadnieniem. Pruska ustawa z $1838 \mathrm{r}$. zapewniała państwu po upływie 30 lat od uruchomienia każdej kolei wykup (łącznie z osprzętem) od prywatnych właścicieli. Mimo pośredniego popierania państwowych inwestycji kolejowych, o właściwej polityce państwa w dziedzinie kolei można mówić począwszy od roku 1848. Od tego czasu państwo zdecydowało się na budowę sieci kolejowej i wykup dotychczas powstałych. W roku 1855 r. pruska sieć kolei państwowych liczyła 1063 km i zarządzała 480 km dróg żelaznych, w rękach prywatnych pozostawało jeszcze $2280 \mathrm{~km}$ szlaków kolejowych.

W połowie XIX w. na obszarze Niemiec przeważała jeszcze prywatna własność sieci kolejowej. W latach 1855-1856 z 8288 km dróg żelaznych, 4264 km było własnością prywatną, a $4024 \mathrm{~km}$ należało do państwa $(48,55 \%)$. Stan sieci kolejowej zobrazowano na rys. 8 .

${ }^{31}$ Rząd Bawarii nie był wierny tej zasadzie i już w 1856 r. wydał koncesję dla bawarskiej Ostbahnen, później za niemałe pieniądze znacjonalizował kolej. 


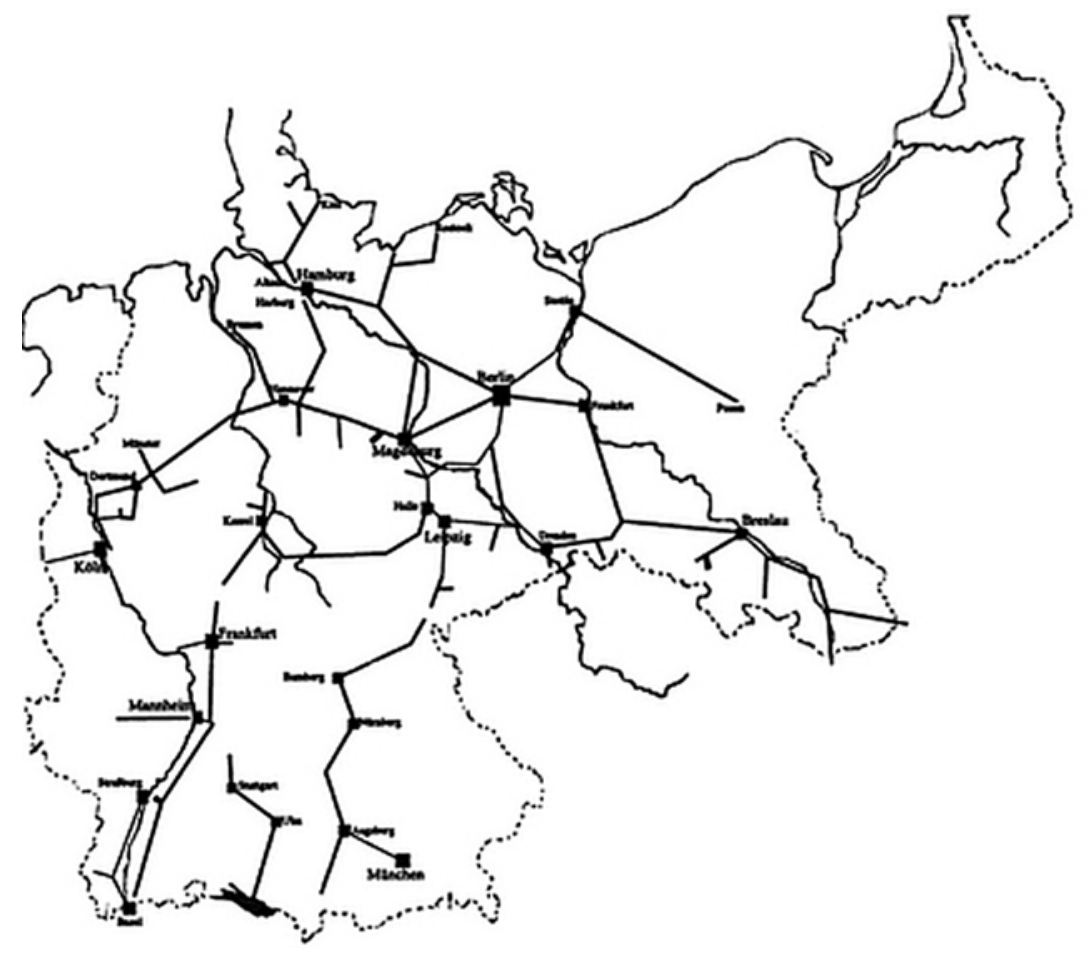

Rys. 8. Niemiecka sieć kolejowa stan na 1850 r.

Źródło: Eisenbahnen und Staat im Zeitalter der Industrialisierung, red. D. Ziegler, „VSWG” 1996, Beihefte 127, s. 565.

\subsection{Kolej niemiecka po 1870 roku}

Od 1870 r. państwa w coraz większym stopniu zaczęły przejmować prywatne linie. Jak podaje Julian Ginsbert, rząd pruski już od 1852 r. prowadził konsekwentną politykę wykupu istniejących biedniejszych kolei ${ }^{32}$. Przyczyn można się doszukiwać zarówno w planach militarnych, jak i polityce gospodarczej, której ważnym elementem były taryfy kolejowe. Prywatni właściciele, mając na względzie głównie własne interesy, często nie stosowali się do zaleceń rządu. Do końca XIX w. niemal wszystkie linie kolejowe były w rękach państwa, przed I wojną światową zaledwie 5\% linii kolejowych (głównie o zasięgu lokalnym) było zarządzanych przez prywatne spółki. Proces nacjonalizacji kolei prywatnych w latach 1868-1913 został zobrazowany na rys. 9.

32 J. Ginsbert, Drogi żelazne Rzplitej, Warszawa 1935, s. 35. 


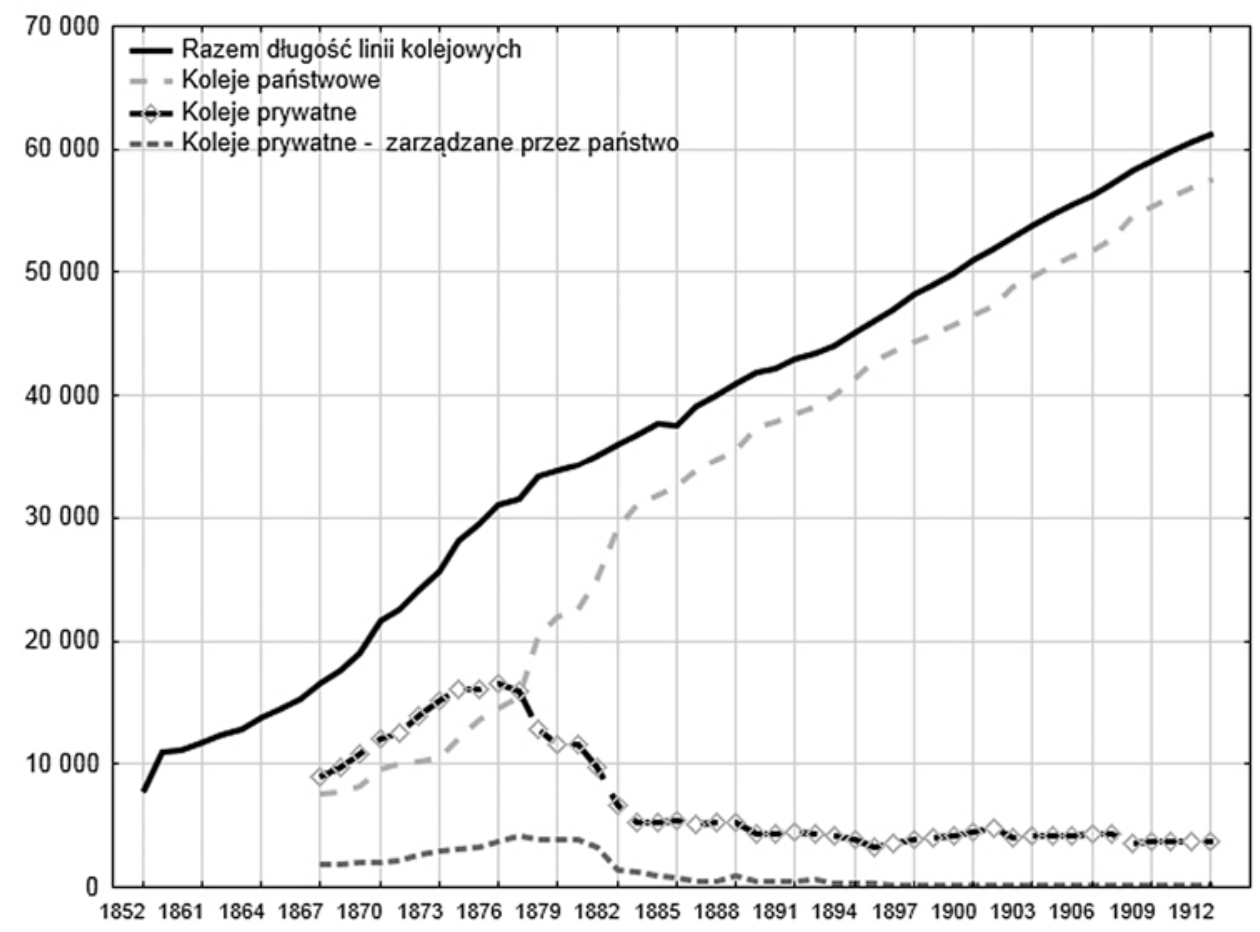

Rys. 9. Długość państwowych i prywatnych szlaków kolejowych w Niemczech na tle całkowitej długości linii kolejowych w latach 1860-1913 (km)

Źródło: opracowanie własne na podstawie: Statistisches Jahrbuch für das Deutsche Reich, VIII. Verkehrs und Verkehrsstraßen, Berlin 1881-1914.

Koleje prywatne w 1868 r. stanowiły ponad 54\% ogółu linii kolejowych, w 1879 r. udział ten spadł do około 38,5\% (12 $817 \mathrm{~km})$, w 1883 r. - do $18,31 \%$ $(6591 \mathrm{~km})$, w $1898 \mathrm{r}$ - - do zaledwie 7,24\% (3338 km), a tuż przed wybuchem wojny, w 1913 r. - do $6,01 \%(3678 \mathrm{~km})$. 
W pozostałych krajach europejskich powstawały również kolejne odcinki dróg żelaznych. Długość szlaków kolejowych w 1840, 1870 i 1914 r. w wybranych krajach europejskich została przedstawiona na rys. 10 .

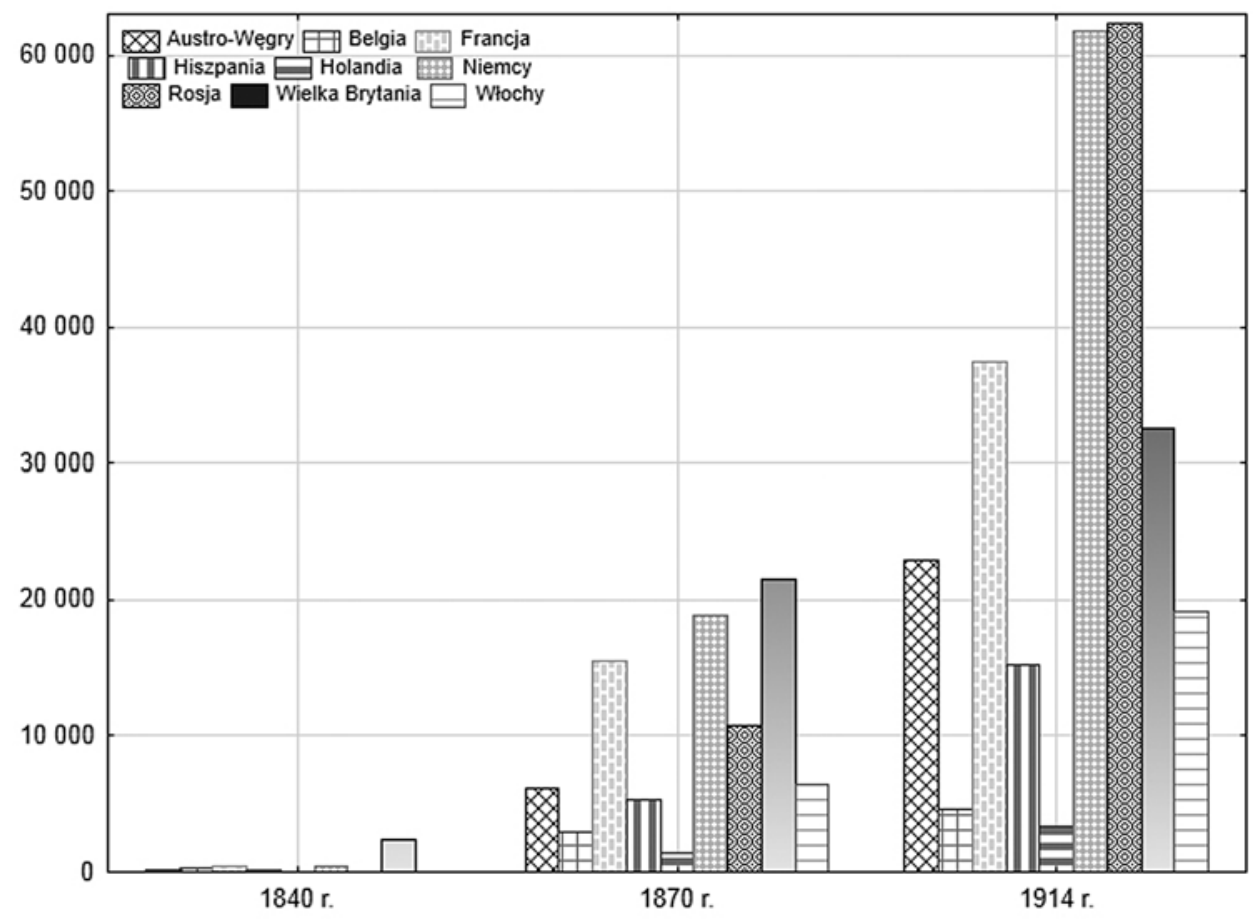

Rys. 10. Długość linii kolejowych w wybranych krajach europejskich w latach 1840-1914 (km)

Źródło: B. Mitchell, European Historical Statistics 1750-1970, New York 1975, s. 584. 
Stan sieci dróg żelaznych przed politycznym zjednoczeniem Niemiec (1870 r.) zobrazowany został na rys. 11. Główne linie kolejowe łączyły zagłębia przemysłowe z centrami portowymi, a także centrami finansowymi. Nadal słabo rozwinięta była sieć kolejowa w części wschodniej Królestwa Pruskiego.

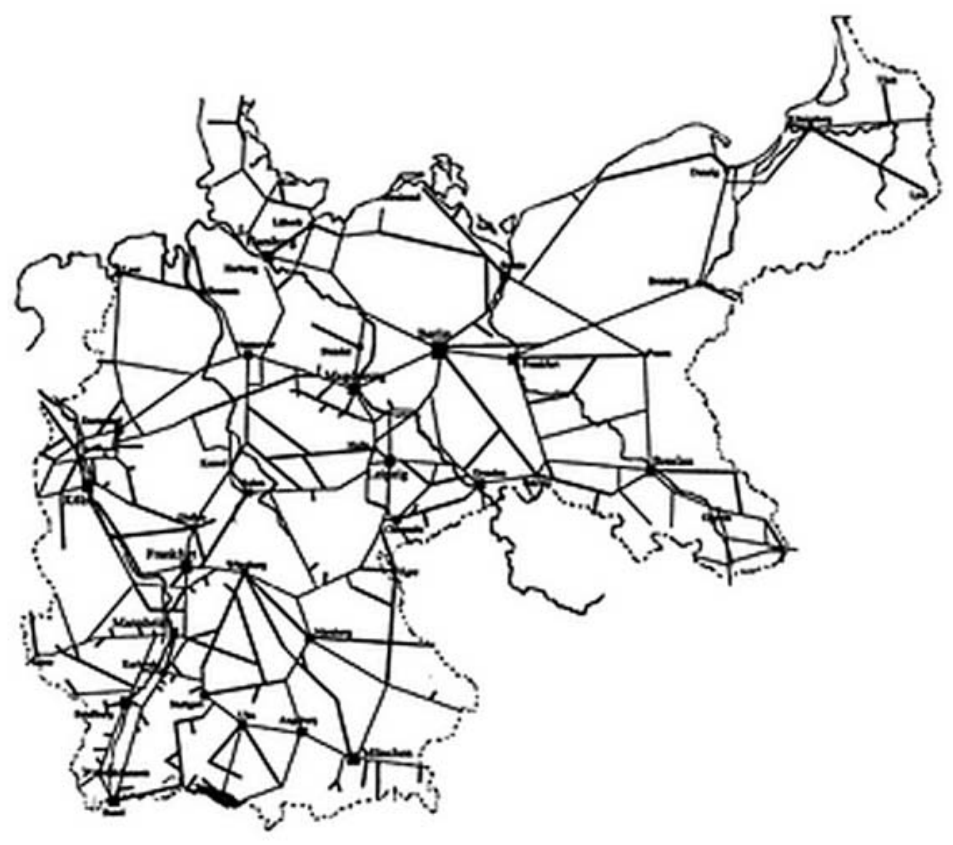

Rys. 11. Niemiecka sieć kolejowa stan na 1870 r.

Źródło: jak do rys 8, s. 567. 
Wraz z rozwojem sieci kolejowej wzrastała liczba przewożonych osób i towarów, co pokazano na rys. 12. Łatwo zauważyć, że wzrasta udział przewozów towarowych w ogólnej liczbie przewozów kolejowych.

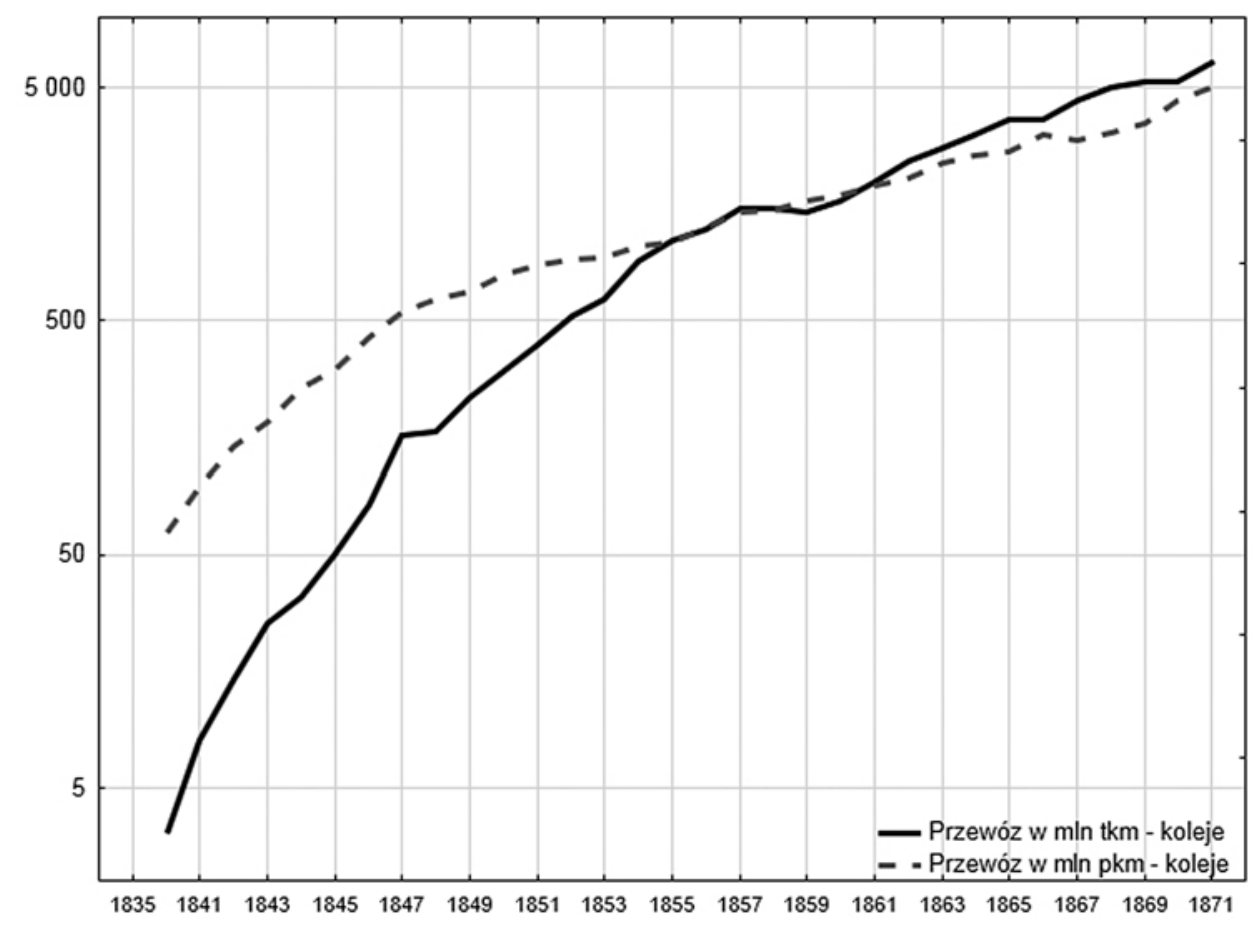

Rys. 12. Liczba przewiezionych towarów (mln tkm) i osób (mln pkm) w latach 1840-1871

Źródło: R. Fremdling, Eisenbahnen und deutsches Wirtschaftswachstum 1840-1879. Ein Beitrag zur Entwicklungstheorie und zur Theorie der Infrastruktur, Dortmund 1985, s. 17.

W 1855 r. w krajach Niemieckiego Związku Celnego liczba przetransportowanych towarów, wyrażona $\mathrm{w}$ tkm wyniosła niemal 1,1 mld i zrównała się z liczbą przewozów pasażerskich, wyrażonych w pkm. 
Na rys. 13 autor przedstawił długość szlaków kolejowych w km na 1000 km² i długość sieci kolejowej w przeliczeniu na 100 tys. mieszkańców. Zauważalne jest słabnące tempo rozbudowy linii kolejowych w przeliczeniu na liczbę mieszkańców, co wynika z szybkiego przyrostu demograficznego w Niemczech (szybszego niż przyrost linii kolejowych).

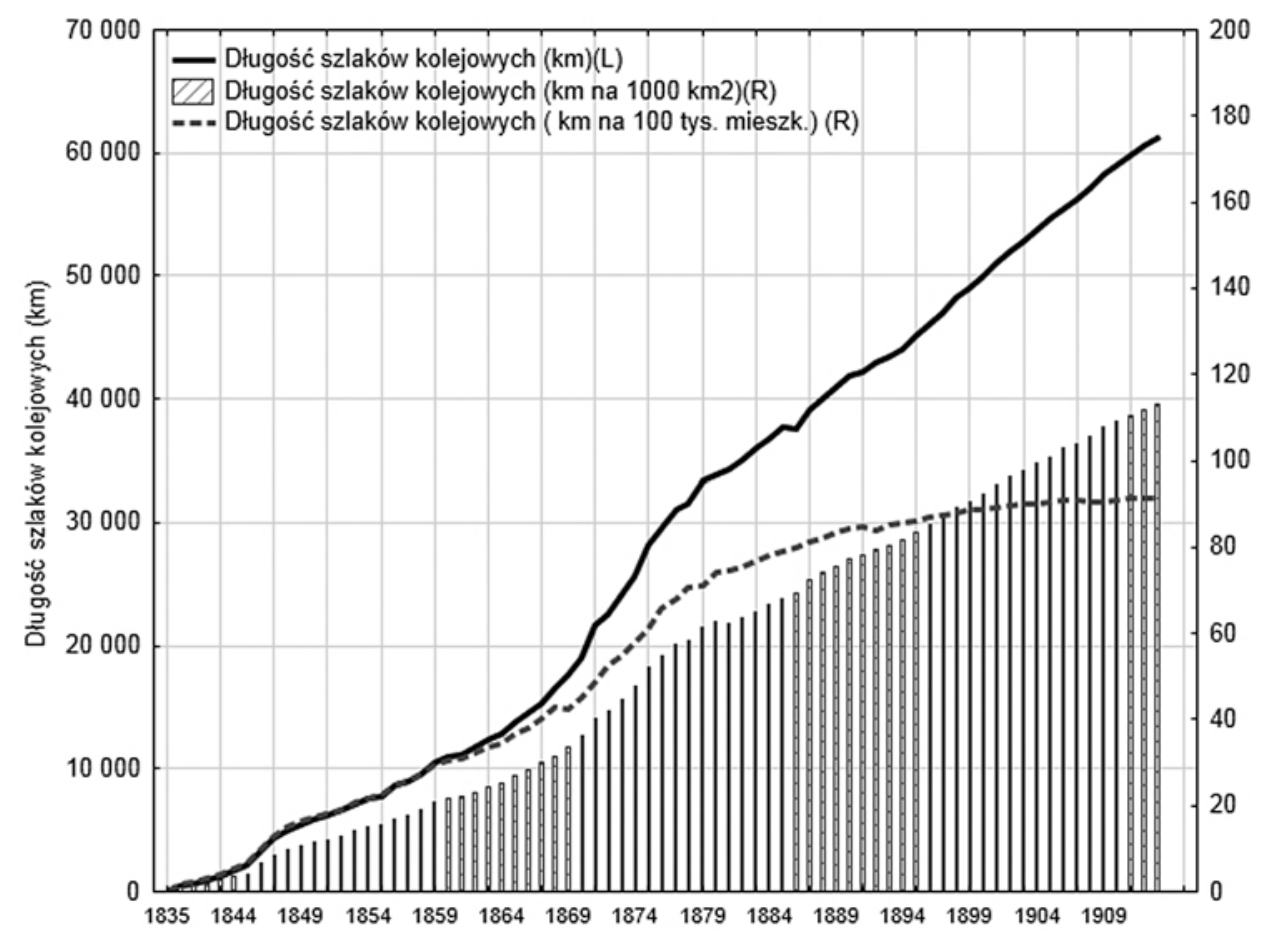

Rys. 13. Długość linii kolejowej (km) na tle gęstości kolejowej $\left(\mathrm{km} / 1000 \mathrm{~km}^{2}, \mathrm{~km} / 100\right.$ tys. mieszkańców) w latach $1835-1913$

Źródło: opracowanie własne na podstawie: Jahrbuch für Volkswirtschaft und Statistik, Herausgegeben von O. Hübner, Fünfter Jahrgang, Leipzig 1857; A. Bienengräber, Statistik des Verkehrs und Verbrauchs im Zollverein für die Jahre 1842-1864: Nach den veröffentlichten amtlichen Kommerzial-Übersichten etc. Berlin 1868; Statistisches Jahrbuch für das Deutsche Reich, Berlin $1880-1917$.

Do połowy lat pięćdziesiątych XIX w. w przewozach kolejowych przeważał transport pasażerski $(\mathrm{pkm})$. Średnia roczna stopa wzrostu w latach 1850-1879 w Niemczech wynosiła dla przewozów towarowych 15,1\%, zaś pasażerskich $7,4 \%$.

Dla przykładu w 1840 r. szacowane przez R. Fremdlinga przewozy pasażerskie wynosiły około $62,3 \mathrm{mln}$ pkm, w $1850 \mathrm{r}$. wzrosły niemal trzynastokrot- 
nie do poziomu $782,5 \mathrm{mln}$ pkm. W $1854 \mathrm{r}$. przekroczyły poziom $1 \mathrm{mld} \mathrm{pkm}$. W 1870 r. oscylowały w okolicach 4,5 mld pkm rocznie ${ }^{33}$.

Przewozy towarów w $1840 \mathrm{r}$. wynosiły zaledwie $3,2 \mathrm{mln}$ tkm, w $1850 \mathrm{r}$. przekroczyły $300 \mathrm{mln}$ tkm, w $1860 \mathrm{r}$. zbliżyły się do poziomu $1,7 \mathrm{mld}$ tkm, aby w 1870 r. wynieść blisko 5,9 mld tkm. Średnia prędkość pociągów pasażerskich pomiędzy stacjami w $1840 \mathrm{r}$. wynosiła około $30 \mathrm{~km} / \mathrm{h}$. Był to znaczny postęp w stosunku do podróży dyliżansem, w którym średnia prędkość przy zaprzęgu czterech koni szacowana była na około $4 \mathrm{~km} / \mathrm{h}$. W 1860 r., maksymalna prędkość składów pasażerskich osiągała $45 \mathrm{~km} / \mathrm{h}$, a w 1900 wynosiła nawet $100 \mathrm{~km} / \mathrm{h}$.

Rozwój transportu kolejowego, wyrażonego w długości linii kolejowych w km na tle przewozów morskich, śródlądowych i kolejowych (tkm) w latach 1840-1913 został zaprezentowany na rys. 14. Dostrzegalny jest silny wzrost przewozów każdego rodzaju, choć największy wzrost dotyczył transportu morskiego.

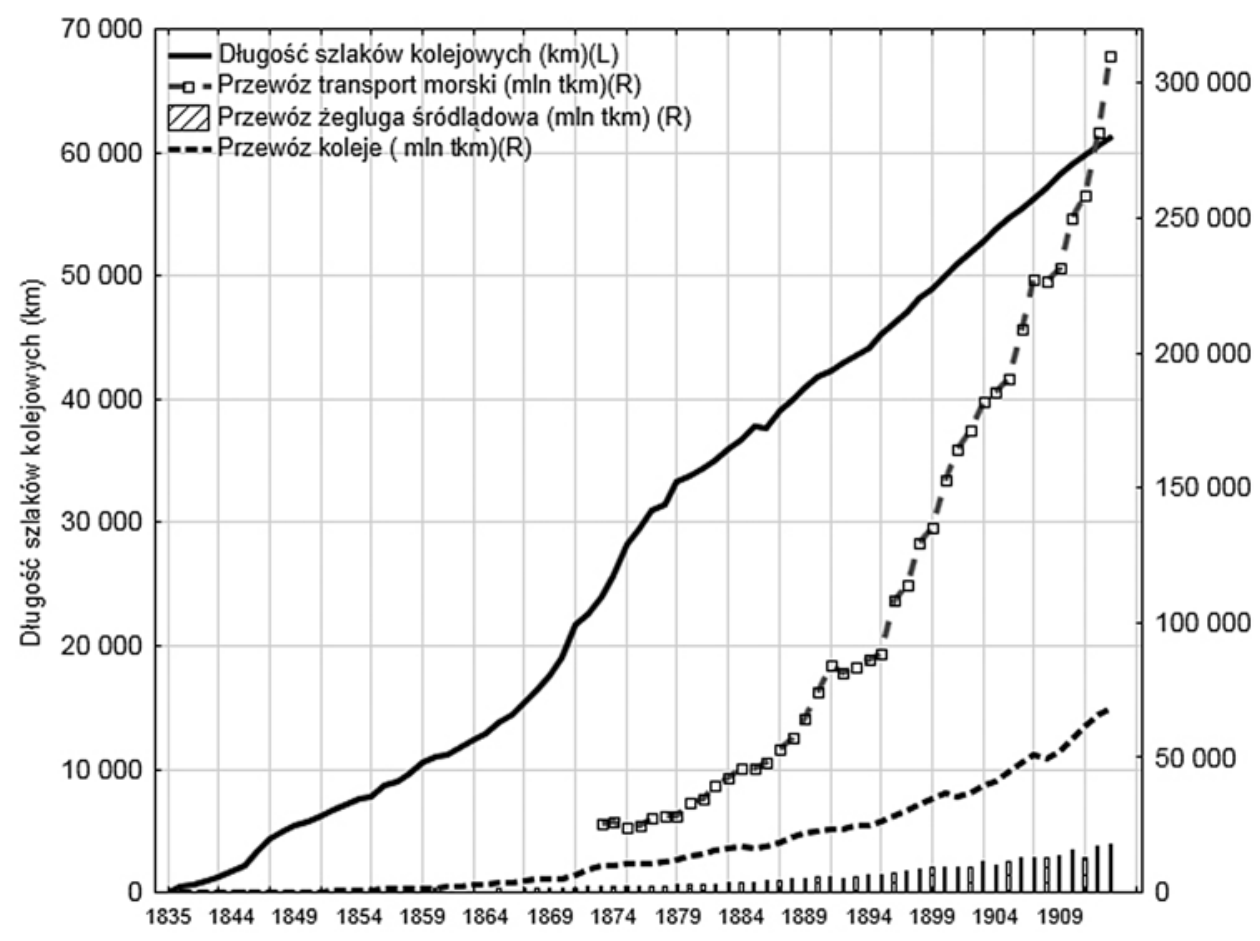

Rys. 14. Długość szlaków kolejowych $(\mathrm{km})$ na tle przewozów kolejowych, morskich i śródlądowych (mln tkm) w latach 1840-1913

Źródło: R. Fremdling, Eisenbahnen und deutsches Wirtschaftswachstum 1840-1879. Ein Beitrag zur Entwicklungstheorie und zur Theorie der Infrastruktur, Dortmund 1985, s. 17; W.G. Hoffmann, Das Wachstum der deutschen Wirtschaft seit der Mitte des 19. Jahrhunderts, Berlin 1965.

${ }^{33}$ R. Fremdling, op. cit., s. 17. 
W 1890 r. po procesie powszechnej nacjonalizacji kolei niemieckich w dalszym ciągu powstawały nowe szlaki kolejowe. Cały kraj pokryty był już dość gęstą siecią połączeń kolejowych. Na $1000 \mathrm{~km}^{2}$ średnio było 77,4 km linii kolejowych, a na 100 tys. mieszkańców Rzeszy średnio przypadało 84,4 km. Udział kolei w transporcie lądowym wynosił ponad $80 \%$. Tuż przed wybuchem I wojny światowej całe terytorium Niemiec pokryte było gęstą siecią kolejową, co przedstawiono na rys. 15.

W 1910 r. około 50\% przewiezionych towarów przez kolej zapewniał przemysł wydobywczy, około $25 \%$ stanowiły materiały budowlane i nawozy, zaś $17 \%$ towary dla rolnictwa i leśnictwa ${ }^{34}$.

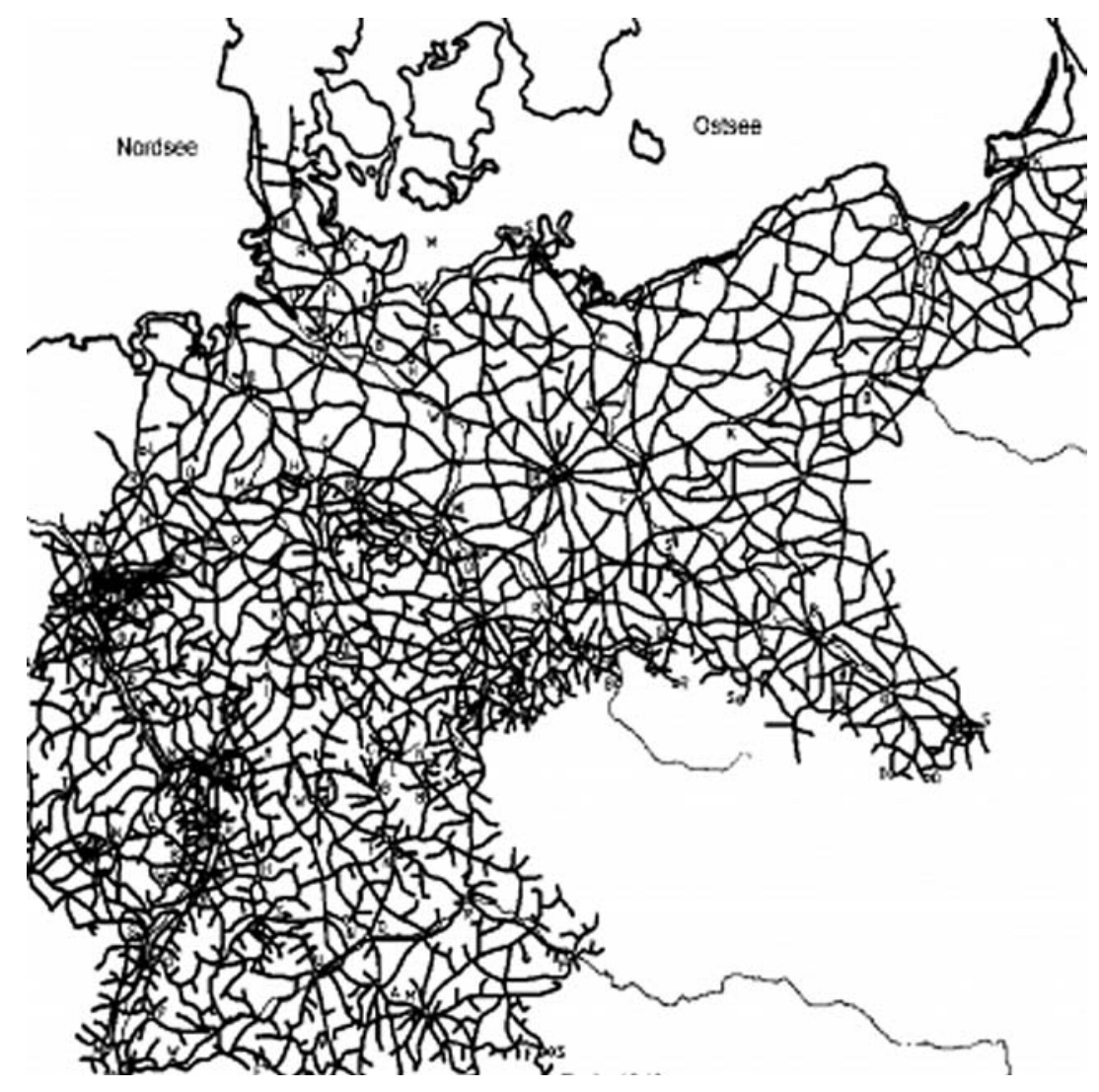

Rys. 15. Niemiecka sieć kolejowa stan na 1913 r.

Źródło: jak do rys. 8, s. 62.

${ }^{34}$ O. Blum, R. Jacobi, Verkehr und Betrieb der Eisenbahnen, Berlin 1925. 
Rozwój sieci kolejowej w poszczególnych krajach niemieckich, począwszy od 1839 r. do 1914 r. przedstawiono w tab. 7.

Tabela 7. Rozwój niemieckiej sieci kolejowej z podziałem na kraje w wybranych latach (1839-1914)

\begin{tabular}{|l|c|c|c|c|c|c|c|c|c|c|}
\hline \multirow{2}{*}{$\begin{array}{c}\text { Państwo/ } \\
\text { Region }\end{array}$} & 1839 & 1850 & 1870 & 1880 & 1890 & 1900 & 1910 & 1914 & 1914 \\
\cline { 2 - 11 } & \multicolumn{7}{|c|}{ k km } & $(\%)$ \\
\hline Prusy & 84,20 & 3549,50 & 10821,40 & 19653,60 & 25170,00 & 29967,20 & 36032,00 & 37943,20 & 61,45 \\
\hline Bawaria & 28,00 & 608,80 & 2756,40 & 4842,70 & 5530,10 & 6719,80 & 7988,70 & 8460,60 & 13,70 \\
\hline Saksonia & 115,50 & 436,10 & 1040,80 & 2041,10 & 2237,60 & 2447,40 & 2659,90 & 2678,70 & 4,34 \\
\hline $\begin{array}{l}\text { Wirtem- } \\
\text { bergia }\end{array}$ & - & 250,00 & 1028,20 & 1437,20 & 1502,60 & 1617,30 & 1918,50 & 1998,20 & 3,24 \\
\hline Badenia & - & 302,60 & 951,40 & 1316,60 & 1484,30 & 1779,90 & 2025,30 & 2114,10 & 3,42 \\
\hline Hesja & - & 110,60 & 597,80 & 781,20 & 924,50 & 1180,00 & 1471,00 & 1505,60 & 2,44 \\
\hline $\begin{array}{l}\text { Meklem- } \\
\text { burgia }\end{array}$ & - & 226,20 & 397,80 & 533,00 & 1207,20 & 1420,50 & 1452,70 & 1477,50 & 2,39 \\
\hline Oldenburg & - & - & 159,50 & 326,50 & 410,10 & 561,70 & 659,50 & 684,90 & 1,11 \\
\hline Brunszwik & 11,90 & 84,00 & 221,50 & 339,10 & 440,40 & 513,70 & 659,20 & 647,80 & 1,05 \\
\hline Anhalt & - & 92,10 & 164,90 & 238,80 & 267,90 & 294,80 & 293,90 & 294,10 & 0,48 \\
\hline Turyngia & - & 147,30 & 430,90 & 828,00 & 1095,70 & 1423,80 & 1676,40 & 1707,30 & 2,76 \\
\hline Lippe & - & 24,70 & 24,70 & 53,70 & 53,70 & 122,30 & 133,60 & 133,80 & 0,22 \\
\hline $\begin{array}{l}\text { Alzacja- } \\
\text { Lotaryngia }\end{array}$ & - & - & 766,00 & 1143,60 & 1342,50 & 1642,80 & 1826,90 & 1837,80 & 2,98 \\
\hline Razem* & 239,60 & 5856,40 & 18667,20 & 33644,80 & 41666,60 & 49878,40 & 59030,90 & 61749,40 & 100,00 \\
\hline
\end{tabular}

*Z włączeniem Waldeck, Lubeki, Bremy i Hamburga.

Źródło: H. Kiesewetter, Industrielle Revolution in Deutschland: Regionen als Wachstumsmotoren, Stuttgart 2004, s. 241. 
Natomiast na rys. 16 zobrazowano główne kierunki kolejowych przewozów towarowych w Rzeszy Niemieckiej. Jak zauważa Leo Sympher największe znaczenie gospodarcze miały połączenia z zakładami produkcyjnymi, oraz zagłębiami surowcowymi ulokowanymi w Zagłębiu Ruhry i na Górnym Śląsku oraz Berlinem i miastami hanzeatyckimi ${ }^{35}$.

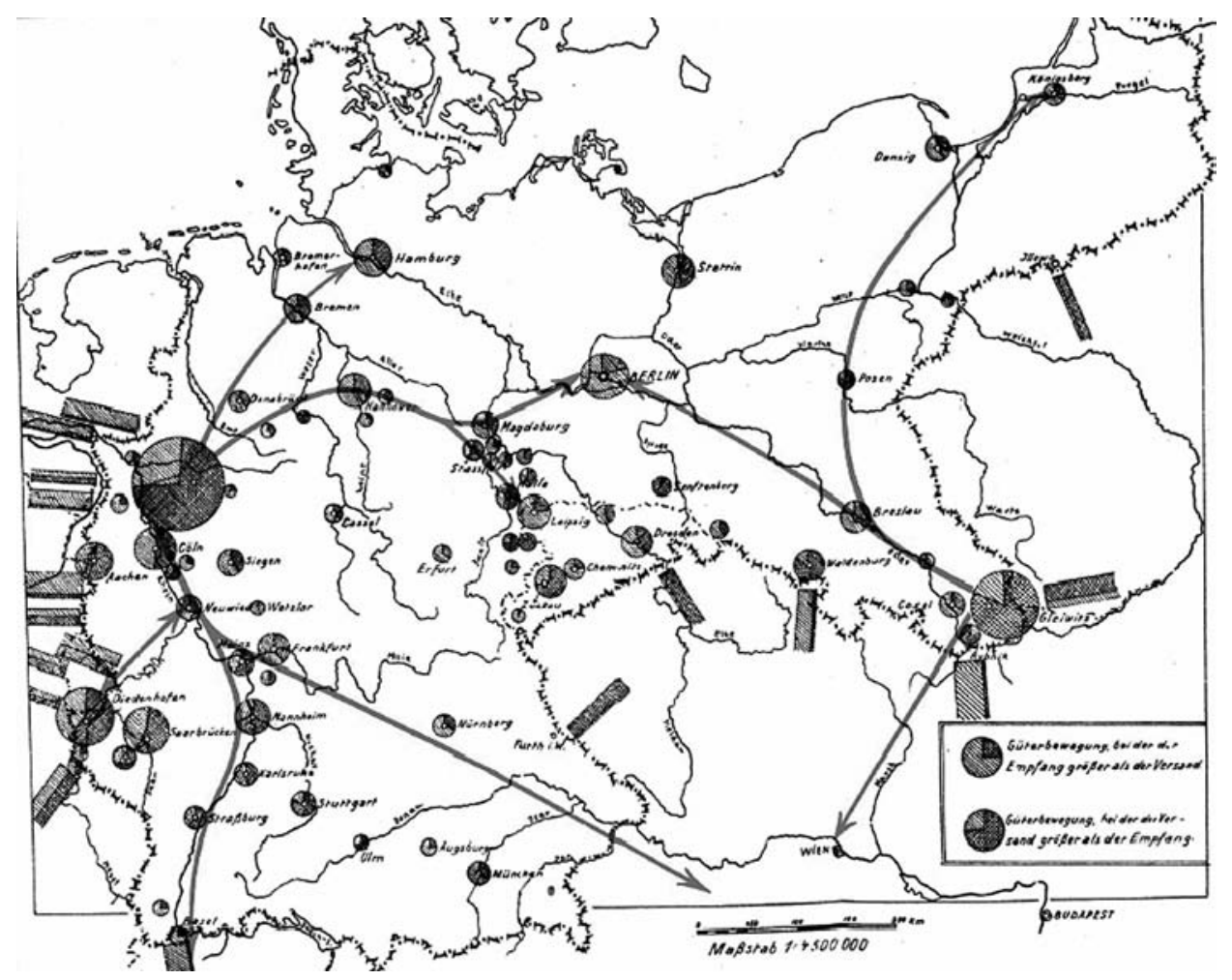

Rys. 16. Główne kierunki transportu kolejowego towarów z uwzględnieniem ilości przesyłanych i odbieranych

Źródło: L. Sympher, Die zukünftige Entwicklung, der deutschen Wasserwirtschaft, Deutsche Weltwirtschaftliche Gesellschaft, Vereinsschriften, Heft 9, Berlin 1918.

${ }^{35}$ L. Sympher, Die zukünftige Entwicklung der deutschen Wasserwirtschaft, Deutsche Weltwirtschaftliche Gesellschaft, Vereinsschriften, Heft 9, Berlin 1918, s. 8. 


\section{RYWALIZACJA POMIĘDZY TRANSPORTEM WODNYM I KOLEJOWYM NA PRZYKLADZIE OBSZARU LABA-ODRA. STUDIUM PRZYPADKU}

W dostępnej literaturze niemieckiej z przełomu wieku XIX i XX wiele miejsca poświęca się analizie porównawczej dotyczącej transportu kolejowego i transportu wodnego śródlądowego, zdecydowanie mniejszą uwagę zwraca się na tą kwestię w opracowaniach w XX w. Daje się zauważyć prezentowanie różnych stanowisk dotyczących efektywności i konkurencyjności dwóch najpoważniejszych środków transportu. Zwolennicy transportu kolejowego nie omieszkali widzieć $\mathrm{w}$ transporcie śródlądowym głównego i niebezpiecznego konkurenta. Franz Urchich w książce Staffeltarife und Wasserstrassen dowodził, że rozwój przewozów śródlądowych był szkodliwy dla wzrostu sektora kolejowego ${ }^{36}$. W latach trzydziestych i czterdziestych XIX w., czyli w fazie wstępnej budowy sieci kolejowych, kolej w zasadzie nie była chroniona i wspierana przez państwo i nie odgrywała dużej roli w gospodarce.

W latach pięćdziesiątych XIX w. zauważalna staje się konkurencja transportu wodnego i kolejowego. Wspomniany F. Urlich z końcu XIX w. określał koszty transportu kolejowego, które uzależnione były zarówno od stałych obciążeń (spłata kredytów, odsetek, innych kosztów funkcjonowania), jak i kosztów zmiennych (materiałów, oświetlenia, budynków, budowli, zatrudnionych osób itd.). Wykazywał jednocześnie, że jednostkowe koszty stałe mogłyby być niższe, gdyby liczba przewożonych tkm była większa, co oznaczałoby spadek taryf. Podał przykładowe obliczenia, w których wykazał, że w zależności od odległości przewożonych towarów koszt transportu kolejowego o masie $100 \mathrm{~kg}$ na odległość $500 \mathrm{~km}$ był ponad trzykrotnie niższy niż dla odległości $10 \mathrm{~km}$ (odpowiednio 0,47pf i 1,7pf). Podobnie jak współcześni badacze niemieckiej historii gospodarczej, w tym T. Pierenkamper, R. Tilly, R. Fremdling ubolewają, że ważny dla rozwoju gospodarczego węgiel kamienny na rynku niemieckim, często był tańszy u konkurentów zagranicznych (Anglia) ze względu na obowiązujące wysokie stawki niemieckiego frachtu kolejowego. Koszty transportu węgla sprawiały, że cena surowca była dwu- trzykrotnie wyższa od ceny wydobycia (rynek berliński). Dla porównania, cena zbóż chlebowych transportowanych koleją z regionów wschodnich Niemiec (Prusy Wschodnie, Pomorze) średnio wzrastała o 30\% ${ }^{37}$. To sprawiało, że na dalsze odległości transport kolejowy był rzadko używany do przewozów towarów masowych, a ograniczał się m.in. do przewozów towarów o znacznej wartości. Wówczas relatywnie wysokie koszty transportu nie miały aż tak dużego wpływu na cenę finalną.

W latach osiemdziesiątych XIX w. zboże rosyjskie, ale także z Prus Wschodnich, przewożone było drogą morską (korzystano z portów w Odessie, Rydze,

${ }^{36}$ F. Urlich, Staffeltarife und Wasserstrassen, Berlin 1894.

37 Tamże, s. 35-37. 
Królewcu, Gdańsku, Szczecinie), a dalej było transportowane wodnymi drogami śródlądowymi na południe Niemiec (Odra, Łaba, Ren). Podobnie, jak dowodzi August Köttgen w Staatwissenschaftliche Studien (1890 r.). zboże (głównie pszenica) z okręgu wrocławskiego, wobec wysokich kosztów frachtu kolejowego przewożone było drogą wodną przez Szczecin, Rotterdam, Mannheim na południe Niemiec ${ }^{38}$.

W odróżnieniu od Niemiec - zarówno Francja, Belgia, Austro-Węgry, jak i Rosja w swoich krajach stosowały z reguły taryfy uzależnione od długości trasy przewożonych towarów (tzw. Staffeltarife).

Ernst Heubach zauważał także, że wzrost przewozów całkowitych mógłby oznaczać spadek jednostkowych kosztów zmiennych. Stąd też wykazywał, że należy promować transport kolejowy na dalsze odległości poprzez uzależnienie stawki frachtu od odległości, na którą jest przewożony towar. Uważał jednocześnie, że obecnie obowiązujące specjalne taryfy (niższe) dla wybranych rodzajów przewozów kolejowych, nie są właściwym kierunkiem działań z punktu widzenia interesu narodowego; podobnie jak dalsza rozbudowa dróg wodnych. W przywołanym cytacie widać zaniepokojenie autora: „Nun ist aber gerade dem FernTransport unserer Eisenbahnen ein gefährlicher Mitbewerber in den Wasserstrassen erwachsen, deren Verkehr sich in den letzten zwanzig Jahren in geradezu überraschender Weise entwickelt hat" 39 [Ale obecnie dalekobieżny transport naszymi (niemieckimi) kolejami dochował się groźnego konkurenta w postaci dróg wodnych. Ten rodzaj transportu (wodnego) w ostatnich 20 latach rozwinął się wprost w niespodziewanym kierunku].

Dane wynikające z roczników: Statistisches Jahrbuch für das Deutsche Reich ukazują stosunek i dynamikę przewozów kolejowych i śródlądowych. Dla lepszego zobrazowania obu rodzajów transportu zamieszczono układ wodnej sieci śródlądowej obszarów składających się na Cesarstwo Niemieckie (rys. 17).

W celu porównania efektów w funkcjonowaniu transportu śródlądowego i kolejowego w latach dziewięćdziesiątych XIX w. autor posłużył się studium przypadku, analizując obszar rzek Łaba-Odra. W tym celu zostały wzięte pod uwagę następujące szlaki:

- Laba - od granicy Niemiec w Schandau do Hamburga,

- Odra - od Wrocławia do Szczecina,

- trasa marchijska z odcinkami:

- Laba (Nigripp, Parey i dolna Hawela) Plaue - Spandau - Berlin - Odra (Brieskow i Fürstenberg), czyli dolna Hawela, Plauer kanał, środkowa Hawela, Sprewa, kanał Odra - Sprewa i kanał Friedrich-Wilhelm,

- Hawela z Spandau - Liebenwalde - Eberswalde - Hohensaaten - Odra (Kanał Hawela-Finow).

${ }^{38}$ A. Köttgen, Studien über Getreideverkehr und Getreidepreise in Deutschland, „Staatwissenschaftliche Studien" 1890, Bd. 3, Heft 2, s. 64-67.

${ }^{39}$ E. Heubach, Die Verkehrsentwickelung auf dem Wasserstrassen und Eisenbahnen des Elbe-Oder Gebietes in dem Zeitraum von 1882-1895, Berlin 1898, s. 37. 


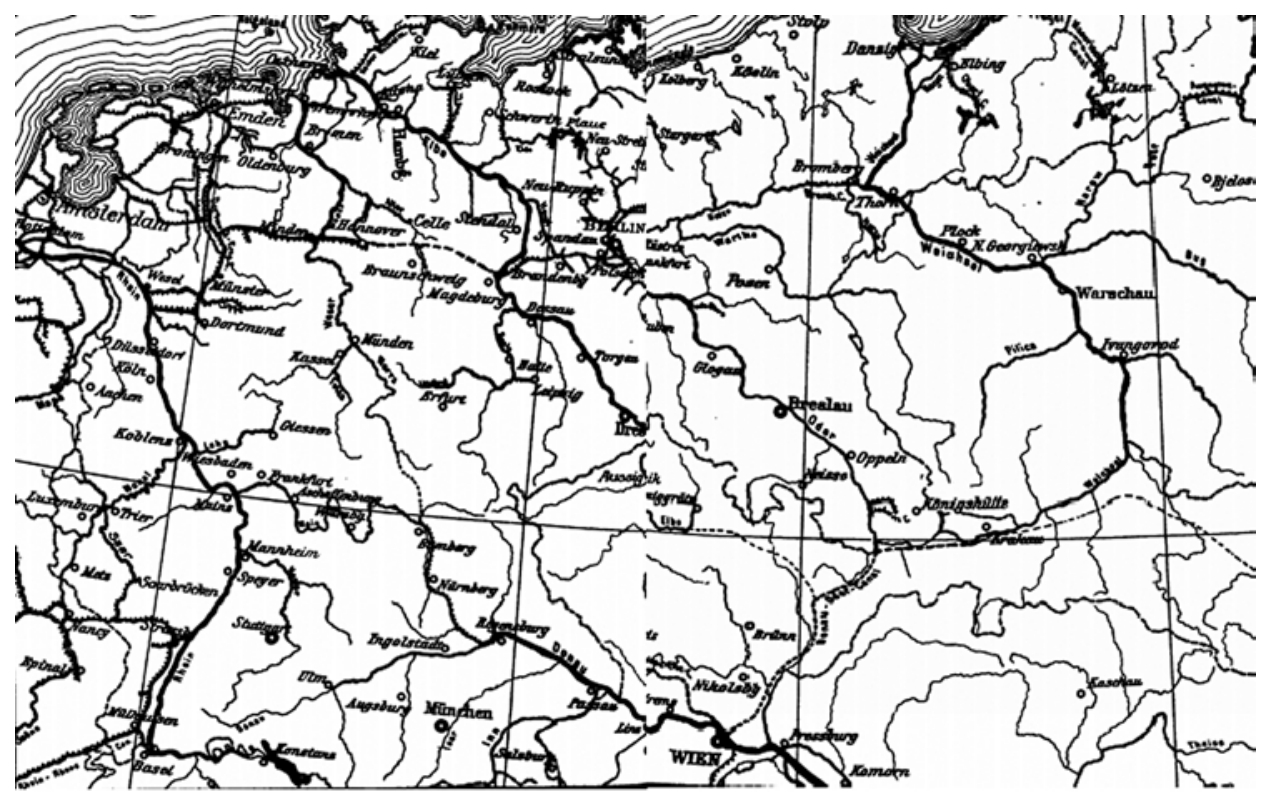

Rys. 17. Szlaki wodne śródlądowe na obszarze Niemiec

Źródło: O. Teubert, Die Binnenschiffahrt. Ein Handbuch für alle Beteiligten, Leipzig 1912, s. 45 .

Na tym samym obszarze analizą objęto przewozy kolejowe dotyczące prowincji: Brandenburgia, Saksonia, Śląsk, Berlin. Na rys. 18 przedstawiono rozwój transportu wodnego z uwzględnieniem rzek: Łaba, Odra, Märkischen Wasserstraßen w latach 1882-1895.

Wyraźny jest wzrost przewozów śródlądowych wodnych dla analizowanych szlaków wodnych (1883-1895):

- przewozy Odrą wzrosły o blisko 420\% (z 139 mln tkm w 1882 r. do 724 mln tkm w 1895 r.),

- przewozy Łabą zwiększyły się o prawie 90\% (z $1124 \mathrm{mln}$ tkm w 1882 do $2131 \mathrm{mln}$ tkm w 1895 r.),

- przewozy Märkischen Wasserstraßen wzrosły o 99\% (z 395 mln tkm w 1882 do 786 mln tkm w 1895 r.).

Dla wszystkich powyższych szlaków wodnych w analizowanym okresie czasu przewozy wzrosły z $1658 \mathrm{mln}$ tkm do $3642 \mathrm{mln}$ tkm, co daje wzrost o $220 \%$. 


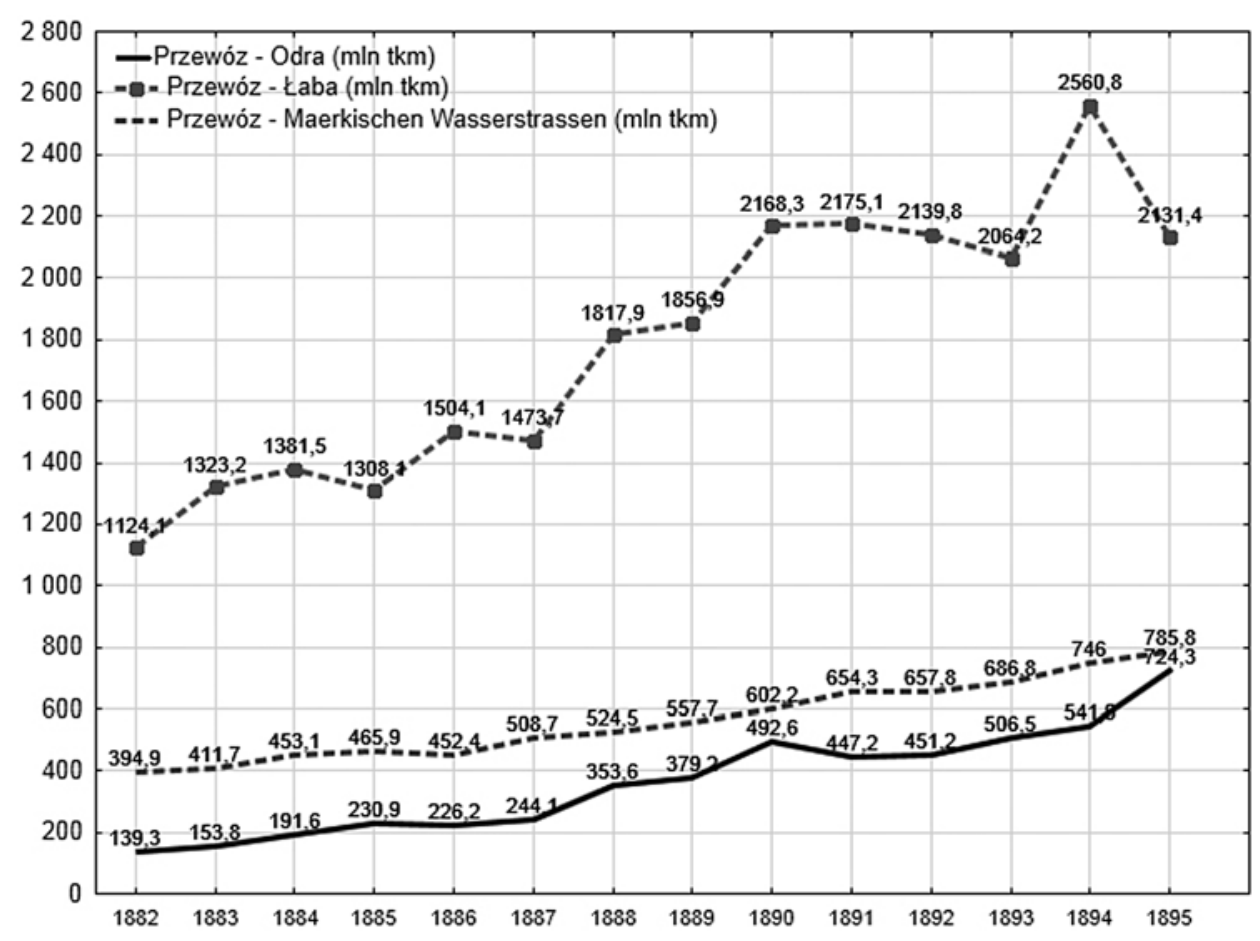

Rys. 18. Rozwój przewozów śródlądowych w latach 1882-1895 (mln tkm)

Źródło: E. Heubach, Die Verkehrsentwickelung auf dem Wasserstrassen und Eisenbahnen des Elbe-Oder Gebietes in dem Zeitraum von 1882-1895, Berlin 1898, s. 4-18.

Pierwsza linia kolejowa w dorzeczu Łaby została wybudowana w $1839 \mathrm{r}$. (Lipsk - Drezno), w 1840 r. oddana została kolejna linia Magdeburg - Lipsk i Berlin - Köthen. W kolejnych latach dostępne były kolejne odcinki: Berlin Magdeburg (1846), Magdeburg - Halberstadt, Magdeburg - Wittenberg (1849). Jak zauważa O. Teubert, powyższe linie kolejowe nie odegrały większego znaczenia gospodarczego, stało się to dopiero po 1863 r., kiedy oddano do użytku linię Magdeburg - Halberstädter.

W tym czasie daje się zauważyć tendencję, że kolejami przewożono towary wartościowe, nie tylko z powodu szybkości przewozów kolejowych, ale przede wszystkim z powodu tańszego przewozu w przeliczeniu na jednostkę. Po uiszczeniu wszelkich opłat transport $1 \mathrm{Mg}$ towaru na odcinku Magdeburg - Hamburg żaglowcem wynosił 29 marek, parowcem 30,5 marek, koleją 25 marek. W $1866 \mathrm{r}$. na Łabie pojawiły się holowniki, których napędem był zespół kół łańcuchowych poruszanych silnikiem parowym, zwiększało to efektywność statków rzecznych, w porównaniu do napędu łopatkowego. 
W 1883 r. na odcinku Laube - Hamburg stawki frachtu śródlądowego na Łabie kształtowały się następująco:

- cukier rafinowany $-2,9 \mathrm{pf} / \mathrm{km}$,

- zboża i mąka - $1,7 \mathrm{pf} / \mathrm{tkm}$.

Stawki frachtu śródlądowego dla Łaby zostały przedstawione w tab. 8.

Tabela 8. Stawki frachtu na rzece Łabie dla wybranych towarów i kierunków w latach 1871-1892 $(\mathrm{pf} / \mathrm{tkm})$

\begin{tabular}{|c|c|c|c|c|c|c|c|}
\hline \multirow{2}{*}{ Rok } & \multicolumn{7}{|c|}{ Hamburg - Drezno $(581 \mathrm{~km})$} \\
\cline { 2 - 8 } & $\begin{array}{c}\text { ładunki } \\
\text { masowe }\end{array}$ & kawa & $\begin{array}{c}\text { ropa } \\
\text { naftowa }\end{array}$ & żywica & bawełna & zboże & $\begin{array}{c}\text { surówka } \\
\text { żelaza }\end{array}$ \\
\hline 1871 & 2,68 & 2,58 & 2,75 & 2,40 & 2,58 & - & 1,89 \\
\hline 1876 & 2,06 & 2,06 & 2,16 & 1,80 & 2,06 & 1,54 & 1,46 \\
\hline 1880 & 1,80 & 1,89 & 1,80 & 1,54 & 1,67 & 1,37 & 1,27 \\
\hline 1885 & 1,35 & 1,40 & 1,20 & 1,08 & 1,08 & 0,90 & 0,91 \\
\hline 1890 & 1,15 & 1,15 & 0,81 & 0,77 & 0,77 & 0,76 & 0,71 \\
\hline 1891 & 1,05 & 1,05 & 0,76 & 0,74 & 0,74 & 0,71 & 0,69 \\
\hline 1892 & 1,10 & 1,10 & 0,95 & 0,80 & 0,84 & 0,82 & 0,82 \\
\hline
\end{tabular}

\begin{tabular}{|c|c|c|c|c|c|}
\hline \multirow{2}{*}{ Rok } & \multicolumn{2}{|c|}{ Drezno - Hamburg $(581 \mathrm{~km})$} & \multicolumn{2}{|c|}{ Aussig - Hamburg $(671 \mathrm{~km})$} & Aussig - Magdeburg $(371 \mathrm{~km})$ \\
\cline { 2 - 6 } & zboże & $\begin{array}{c}\text { cukier } \\
\text { surowy }\end{array}$ & $\begin{array}{c}\text { węgiel } \\
\text { brunatny }\end{array}$ & $\begin{array}{c}\text { cukier } \\
\text { buraczany }\end{array}$ & węgiel brunatny \\
\hline 1872 & 1,72 & 1,31 & - & - & 1,82 \\
\hline 1877 & 1,37 & 1,46 & 0,90 & 1,49 & 1,46 \\
\hline 1882 & 0,74 & 0,82 & 0,48 & 0,64 & 0,85 \\
\hline 1890 & 0,79 & 0,64 & 0,48 & 0,70 & 0,74 \\
\hline
\end{tabular}

Źródło: F. Urlich, Staffeltarife und Wasserstrassen, Berlin 1894, s. 71.

W 1884 r. stawki za przewóz zbóż i mąki spadły do 0,66 pf/tkm, a stawki średnie oscylowały ok. 0,92 pf/tkm. Stawki na kierunku Hamburg - Laube w przypadku surówki żelaza w $1884 \mathrm{r}$. wynosiły $0,98 \mathrm{pf} / \mathrm{tkm}$. Łatwo zauważyć, że ceny frachtu $\mathrm{w}$ analizowanym okresie spadły ponad $50 \%$.

Szczególnie użyteczne do analizy dane opublikowane zostały przez Pruskie Ministerstwo Robót Publicznych ${ }^{40}$.

Uderzający jest ciągły spadek opłat frachtowych, nie tylko dla towarów masowych jak węgiel, dla którego cena najniższego frachtu wynosiła $0,5 \mathrm{pf} / \mathrm{tkm}$, ale tyle samo wynosiła stawka dla bardziej wartościowych towarów, jak zboże i cu-

${ }^{40}$ Preussischen Ministerium der öffentlichen Arbeiten, Führers auf den deutschen Schiffartstrassen, Berlin 1893, Tab. IV. 
kier. Dla innych ładunków najniższa cena frachtu wynosiła w granicach $1 \mathrm{pf} / \mathrm{tkm}$. W tym czasie taryfy kolejowe były zdecydowanie wyższe; i tak regularne taryfy w zależności od rodzaju towaru kształtowały się w granicach 2,2-22 pf/tkm. Taryfy specjalne, jak np. przy przewozach węgla wynosiły do $1,25 \mathrm{pf} / \mathrm{tkm}$, przy zbożu do 2,5 pf/tkm, dla pozostałych ładunków masowych do 3,5 pf/tkm.

W 1885 r. szlakami kolejowymi Prus przewieziono $10866 \mathrm{mln}$ tkm w 1885 r., po 10 latach aż $19104 \mathrm{mln}$ tkm towarów. Tempo wzrostu przewozów kolejowych w dziesięcioleciu wzrosło ok. $76 \%$.

Struktura przychodów (1039 mln marek) przewozów kolejowych dla roku 1895 kształtowała się następująco:

- $47,8 \%$ z tytułu taryf specjalnych (niskich 2,7 pf za $1 \mathrm{tkm}$ ),

- $42,5 \%$ z tytułu taryf I-III,

- 4,8\% fracht ekspresowy,

- $4,9 \%$ pozostałe.

Szczególnie ważne jest odniesienie powyższych danych do ruchu kolejowego na obszarze analizowanych cieków wodnych. W tym celu zostały włączone do statystyki dane dotyczące Królewskich Kolei Pruskich w prowincjach: Brandenburgia, Saksonia, Śląsk i okręg berliński (tab. 9).

Tabela 9. Stawki frachtu na rzekach Łabie i Odrze w latach dziewięćdziesiątych XIX w. dla wybranych odcinków i towarów (pf/tkm)

\begin{tabular}{|l|c|c|c|}
\hline \multicolumn{1}{|c|}{ Rzeka/Odcinek } & Najniższa & Średnia & Najwyższa \\
\hline \multicolumn{4}{|c|}{ Łaba } \\
\hline \multicolumn{4}{|c|}{ Węgiel } \\
\hline \multicolumn{4}{|c|}{3} \\
\hline Aussig - Hamburg & 0,4 & 1,0 & 0,7 \\
\hline Aussig - Magdeburg & 0,7 & 2,2 & 2,0 \\
\hline Aussig - Drezno & 1,8 & 1,2 & 2,9 \\
\hline Aussig - Branderburg & 0,7 & 1,1 & 1,9 \\
\hline Hamburg - Berlin & 0,5 & 1,3 & 1,9 \\
\hline \multicolumn{4}{|c|}{ Zboże i cukier } \\
\hline Hamburg - Magdeburg & 0,8 & 0,8 & 1,7 \\
\hline Hamburg - Drezno & 0,6 & 1,3 & 1,2 \\
\hline Magdeburg - Hamburg & 1,0 & 0,7 & 2,1 \\
\hline Drezno - Hamburg (cukier) & 0,5 & 0,9 & 0,9 \\
\hline Bodenbach - Hamburg & 0,7 & 0,9 & 1,3 \\
\hline Aussig - Hamburg & 0,8 & 1,5 & 1,4 \\
\hline Aussig - Magdeburg & 1,2 & 1,6 & 2,3 \\
\hline Hamburg - Halle & 1,5 & 0,8 & 1,8 \\
\hline Berlin - Hamburg & 0,5 & 1,2 \\
\hline
\end{tabular}


Tabela 9. (cd.)

\begin{tabular}{|c|c|c|c|}
\hline 1 & 2 & 3 & 4 \\
\hline \multicolumn{4}{|c|}{ Ładunki } \\
\hline Hamburg - Magdeburg & 1,2 & 1,5 & 2,2 \\
\hline Hamburg - Szczecin & 1,5 & 1,9 & 2,4 \\
\hline Hamburg - Drezno & 0,8 & 1,2 & 1,8 \\
\hline Hamburg - Bodenbach & 1,3 & 1,7 & 2,1 \\
\hline Hamburg - Aussig & 1,4 & 1,8 & 2,3 \\
\hline Hamburg - Berlin & 1,3 & 2,2 & 3,2 \\
\hline Berlin - Hamburg & 1,3 & 2,2 & 3,2 \\
\hline Magdeburg - Hamburg & 1,3 & 1,6 & 2,5 \\
\hline \multicolumn{4}{|c|}{ Odra } \\
\hline \multicolumn{4}{|c|}{ Węgiel } \\
\hline Wrocław - Szczecin & 0,5 & & 0,7 \\
\hline Wrocław - Frankfurt n. Odrą & 0,7 & 0,9 & 1,2 \\
\hline Wrocław - Berlin & 0,9 & 1,0 & 1,1 \\
\hline Opole - Wrocław & 0,7 & 0,7 & 0,8 \\
\hline Szczecin-Gorzów & 1,4 & 1,4 & 1,6 \\
\hline Szczecin-Berlin & 1,1 & & 1,4 \\
\hline \multicolumn{4}{|c|}{ Zboże i cukier } \\
\hline Frankfurt n. Odrą - Szczecin & 1,9 & 2,2 & 2,5 \\
\hline Głogów - Szczecin & 1,0 & 1,1 & 1,3 \\
\hline Wrocław - Szczecin & 0,4 & 0,5 & 0,6 \\
\hline Szczecin - Magdeburg & 1,2 & 1,3 & 1,8 \\
\hline Szczecin - Drezno & 1,2 & 1,3 & 1,6 \\
\hline Wrocław - Hamburg & 1,1 & 1,2 & 1,3 \\
\hline $\begin{array}{l}\text { Szczecin - Berlin } \\
\text { (żyto, pszenica) }\end{array}$ & 1,6 & & 2,1 \\
\hline Szczecin - Berlin (owies) & 1,8 & & 2,3 \\
\hline Wrocław - Berlin & 1,3 & 1,4 & 1,4 \\
\hline Poznań - Berlin & 1,1 & 1,3 & 1,5 \\
\hline \multicolumn{4}{|c|}{ Ładunki } \\
\hline $\begin{array}{l}\text { Szczecin - Wrocław, } \\
\text { Wrocław - Szczecin }\end{array}$ & 0,8 & & 1,0 \\
\hline Szczecin - Hamburg & 0,9 & 1,4 & 1,8 \\
\hline Wrocław - Berlin & 1,8 & 2,1 & 2,4 \\
\hline
\end{tabular}

Źródło: Preussischen Ministerium der öffentlichen Arbeiten, Führers auf den deutschen Schiffartstrassen, Berlin 1893, Tab. IV. 
Przewozy kolejowe dla analizowanego obszaru stanowiły w roku 1895 blisko 29,5\% ogólnych przewozów (tkm) Królewskich Kolei Pruskich. Informacje dla obszaru badanych wód śródlądowych, na tle statystyki przewozów kolejowych, przedstawiono w tab. 10.

Zauważalny jest wzrost transportu zarówno przy użyciu kolei, jak i przy wykorzystaniu dróg wodnych.

Tabela 10. Transport śródlądowy na tle transportu kolejowego na obszarze Łaba - Odra w latach 1882-1895

\begin{tabular}{|c|c|c|c|c|c|c|}
\hline \multirow{2}{*}{ Rok } & \multicolumn{3}{|c|}{ Transport wodny Łaba - Odra } & \multicolumn{2}{c|}{ Transport kolejowy Łaba - Odra } \\
\cline { 2 - 7 } & tys. Mg & mln tkm & $1886=100$ & tys. Mg & mln tkm & $1886=100$ \\
\hline 1882 & 5544,20 & 1658,30 & 82,71 & & & \\
\hline 1883 & 6147,00 & 1888,80 & 94,21 & & & \\
\hline 1884 & 6786,90 & 2026,10 & 101,06 & & & \\
\hline 1885 & 6808,80 & 2004,90 & 100,00 & 28090,00 & 3535 & 100,00 \\
\hline 1886 & 7149,80 & 2182,60 & 108,86 & 29207,50 & 3580 & 101,27 \\
\hline 1887 & 7664,30 & 2226,50 & 111,05 & 30254,20 & 3700 & 104,67 \\
\hline 1888 & 8647,00 & 2696,00 & 134,47 & 36585,30 & 4450 & 125,88 \\
\hline 1889 & 8950,70 & 2793,80 & 139,35 & 37289,30 & 4535 & 128,29 \\
\hline 1890 & 9978,10 & 3263,10 & 162,76 & 39061,80 & 4700 & 132,96 \\
\hline 1891 & 10185,20 & 3276,60 & 163,43 & 42784,10 & 5120 & 144,84 \\
\hline 1892 & 9569,50 & 3248,90 & 162,05 & 39798,30 & 4795 & 135,64 \\
\hline 1893 & 9648,10 & 3257,60 & 162,48 & 41845,90 & 5120 & 144,84 \\
\hline 1894 & 11506,90 & 3848,80 & 191,97 & 43503,30 & 4940 & 139,75 \\
\hline 1895 & 10889,50 & 3641,50 & 181,63 & 48310,20 & 5630 & 159,26 \\
\hline
\end{tabular}

Źródło: E. Heubach, Die Verkehrsentwickelung auf dem Wasserstrassen und Eisenbahnen des Elbe-Oder Gebietes in dem Zeitraum von 1882-1895, Berlin 1898, s. 24-25.

Jeśli przyjąć, że rozmiary przetransportowanych tkm dla roku 1885 są równe 100, to przez dziesięć lat:

- dla transportu śródlądowego Odra - Łaba zanotowano wzrost o blisko 82\%,

- dla przewozów kolejowych zanotowano wzrost o ponad 59\%. (rys. 19). 


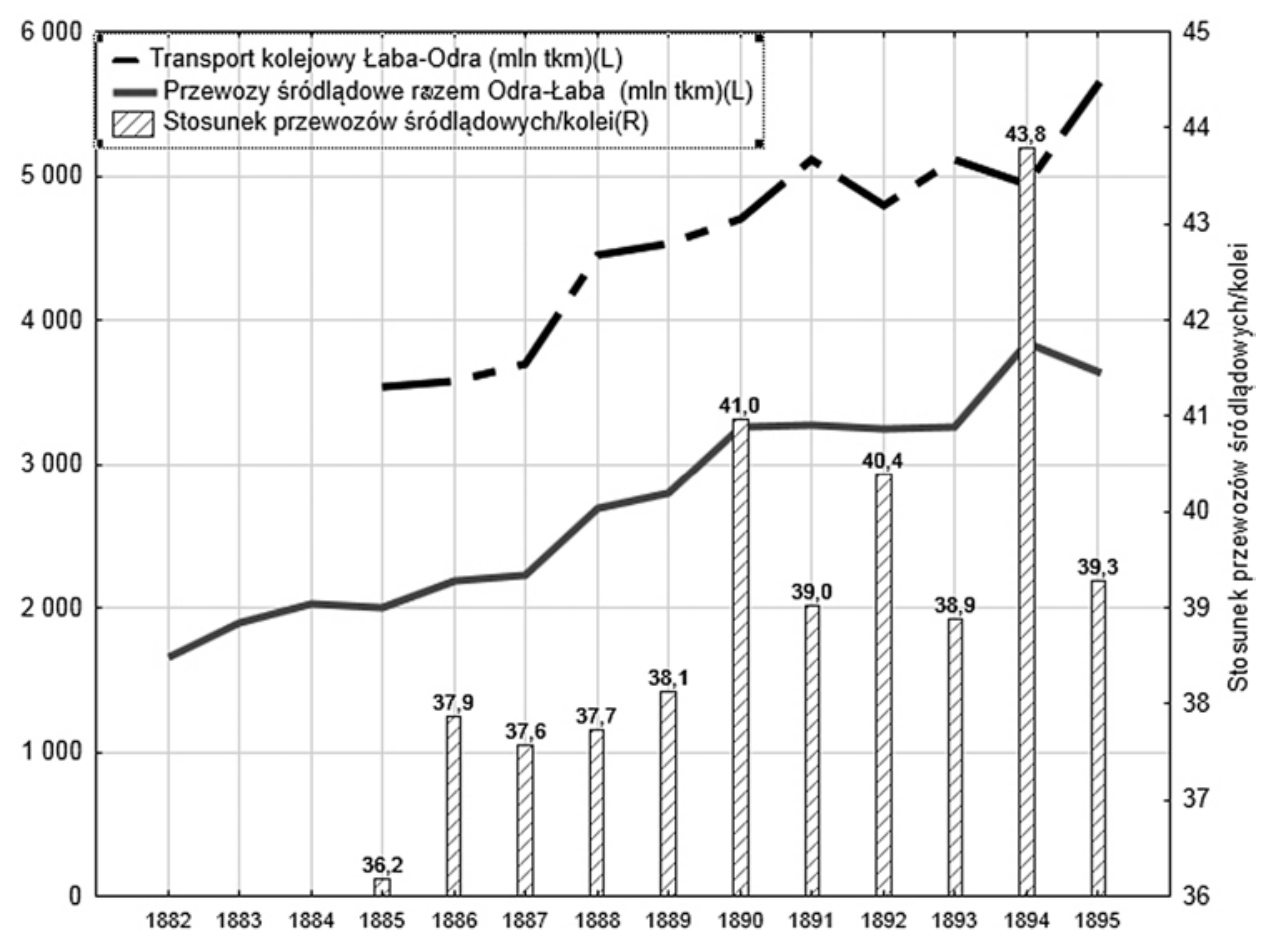

Rys. 19. Transport śródlądowy na tle transportu kolejowego na obszarze Łaba - Odra w latach 1882-1895 (mln tkm) z uwzględnieniem udziału transportu śródlądowego w przewozach ogólnych (\%)

Źródło: obliczenia własne na podstawie danych z tab. 10.

Jeszcze ciekawsze wnioski wynikają z analizy transportu śródlądowego i jego udziału w transporcie ogólnym na obszarze rzek Łaba-Odra. W 1885 r., transport wodny stanowił około 36\% ogółu przewozów w tkm. Niezależnie od rozwoju kolei, transport śródlądowy ciągle zwiększał swój udział w przewozach ogółem; i tak: do końca lat osiemdziesiątych XIX w. udział ten wzrósł do 38\%, przekraczając w 1890 i 1892 r. ponad 40\% przewozów, a w 1894 r. osiągnął blisko 44\% ogółu przewozów.

Równie interesująca jest analiza dotycząca udziału w przewozach podstawowych dóbr: węgla, zbóż, drewna, na analizowanym obszarze (Elba - Odra).

$\mathrm{W}$ analizowanym dziesięcioleciu przewozy, niezależnie od formy transportu, wzrosły z $35 \mathrm{mln} \mathrm{Mg} \mathrm{w} 1885$ r. do blisko $60 \mathrm{mln} \mathrm{Mg} \mathrm{w} 1895$ r. Blisko 28,8 mln $\mathrm{Mg}$ w powyższych obrotach stanowił transport węgla, 2,5 mln Mg transport drewna oraz 1,2 mln Mg transport zbóż chlebowych.

W 1885 r. przewozy kolejowe stanowiły blisko 80\% ogółu transportu, w dziesięć lat później utrzymywały się na poziomie około $82 \%$. Biorąc pod uwagę cią- 
gły przyrost linii kolejowych w stosunku do, właściwie stałej, liczby długości żeglownych wód śródlądowych należy uznać, ze transport wodny był ciągle bardzo dobrą alternatywą dla transportu kolejowego. Nie bez powodu w latach dziewięćdziesiątych XIX w., odnosząc się do wysokich taryf kolejowych wspomniany August Köttgen pisze: „Bedeutend billiger ist natürlich der Wasserweg” [Dużo taniej jest oczywiście (transportem) drogami wodnymi].

Tabela 11. Struktura przewozów kolejowych i śródlądowych wodnych na obszarze Łaba - Odra dla wybranych grup produktów (1885-1895)

\begin{tabular}{|c|c|c|c|c|c|c|c|c|}
\hline \multirow{2}{*}{ Rok } & \multicolumn{9}{|c|}{ Przewozy } \\
\cline { 2 - 9 } & \multicolumn{2}{|c|}{ razem (\%) } & \multicolumn{2}{|c|}{ węgiel } & \multicolumn{2}{c|}{ zboża chlebowe } & \multicolumn{2}{c|}{ drewno } \\
\cline { 2 - 9 } & kolej & $\begin{array}{c}\text { drogi } \\
\text { wodne }\end{array}$ & kolej & $\begin{array}{c}\text { drogi } \\
\text { wodne }\end{array}$ & kolej & $\begin{array}{c}\text { drogi } \\
\text { wodne }\end{array}$ & kolej & $\begin{array}{c}\text { drogi } \\
\text { wodne }\end{array}$ \\
\hline 1885 & 80,0 & 20,0 & - & - & - & - & - & - \\
\hline 1886 & 80,5 & 19,5 & 89,5 & 10,5 & - & - & - & - \\
\hline 1887 & 79,8 & 20,2 & 89,6 & 10,4 & 68,1 & 31,9 & 63,8 & 36,2 \\
\hline 1888 & 81,2 & 18,8 & 88,9 & 11,1 & 68,3 & 31,7 & 64,8 & 35,2 \\
\hline 1889 & 80,8 & 19,2 & 89,8 & 10,2 & 59 & 41 & 65,3 & 34,7 \\
\hline 1890 & 79,7 & 20,3 & 87,8 & 12,2 & 72,8 & 27,2 & 62,8 & 37,2 \\
\hline 1891 & 80,8 & 19,2 & 88,0 & 12,0 & - & - & - & - \\
\hline 1892 & 80,8 & 19,2 & 87,7 & 12,3 & 69,7 & 30,3 & 72,4 & 27,6 \\
\hline 1893 & 81,4 & 18,6 & 89,0 & 11,0 & 81,3 & 18,7 & 73,8 & 26,2 \\
\hline 1894 & 79,2 & 20,8 & 86,4 & 13,6 & 61,8 & 38,2 & 76,0 & 24,0 \\
\hline 1895 & 81,8 & 18,2 & 87,4 & 12,6 & 70,6 & 29,4 & 77,7 & 22,3 \\
\hline
\end{tabular}

Źródło: E. Heubach, Die Verkehrsentwickelung auf dem Wasserstrassen und Eisenbahnen des Elbe - Oder Gebietes in dem Zeitraum von 1882-1895, Berlin 1898, s. 44-45.

Transport śródlądowy był tańszy, szczególnie na dalsze odległości. Jak wykazuje E. Heubach, transport wodny na odległość $350 \mathrm{~km}$ był porównywalny z transportem kolejowym na odległość $120 \mathrm{~km}^{41}$.

Na rzece Łabie w okresie 1885-1895 ilość przewiezionych towarów (wyrażona w tkm) wzrosła o blisko 89\%, a średnia długość transportu wynosiła $350 \mathrm{~km}$. W latach 1882-1895 transport Odrą (w tkm) wzrósł o 420\%, a średnia długość przewozu powiększyła się ze 106 do $240 \mathrm{~km}$. W tym samym czasie transport trasą wodną Märkische Wasserstrassen od strony Łaby wzrósł o 105\%, od strony Odry o $96 \%$.

${ }^{41}$ E. Heubach, op. cit., s. 61-62. 
Jeśli analizować przewozy kolejami pruskimi, to ponad 47\% tych przewozów stanowiły przewozy tzw. Ausnahmetarifklasse (2,7 pf/1tkm), 42,5\% przewozy ze specjalną taryfą w klasach I-III $(4,10 \mathrm{pf} / 1 \mathrm{tkm})$. Na podstawie powyższych danych można wskazać, że rywalizacja pomiędzy transportem śródlądowym i kolejowym:

- była gwarancją obniżek cen frachtu;

- wywarła dość niekorzystny wpływ na rozwój sektora kolejowego w latach siedemdziesiątych XIX w., gdyż transport wodny był tańszy, szczególnie na dalsze odległości, co obniżało efektywność sektora kolejowego;

- rywalizacja na obszarze Odra - Łaba sprawiała, że oba rodzaje transportu dążyły do wprowadzania nowinek, które oznaczały korzystniejszy fracht;

- znacjonalizowane koleje pruskie próbowały poprzez ustalenie specjalnych stawek frachtu wzmocnić pozycję transportu kolejowego, ale nadal transport wodny na dalsze odległości, mimo, że był wolniejszy ciągle pozostawał tańszy.

Schematyczne zestawienie wielkości przewozów w dorzeczach głównych rzek Łaby i Odry zostało przedstawione w opracowaniu Die Verkehrsentwickelung auf dem Wasserstrassen und Eisenbahnen des Elbe-Oder Gebietes in dem Zeitraum von 1882-1895 autorstwa E. Heubacha (rys. 20).

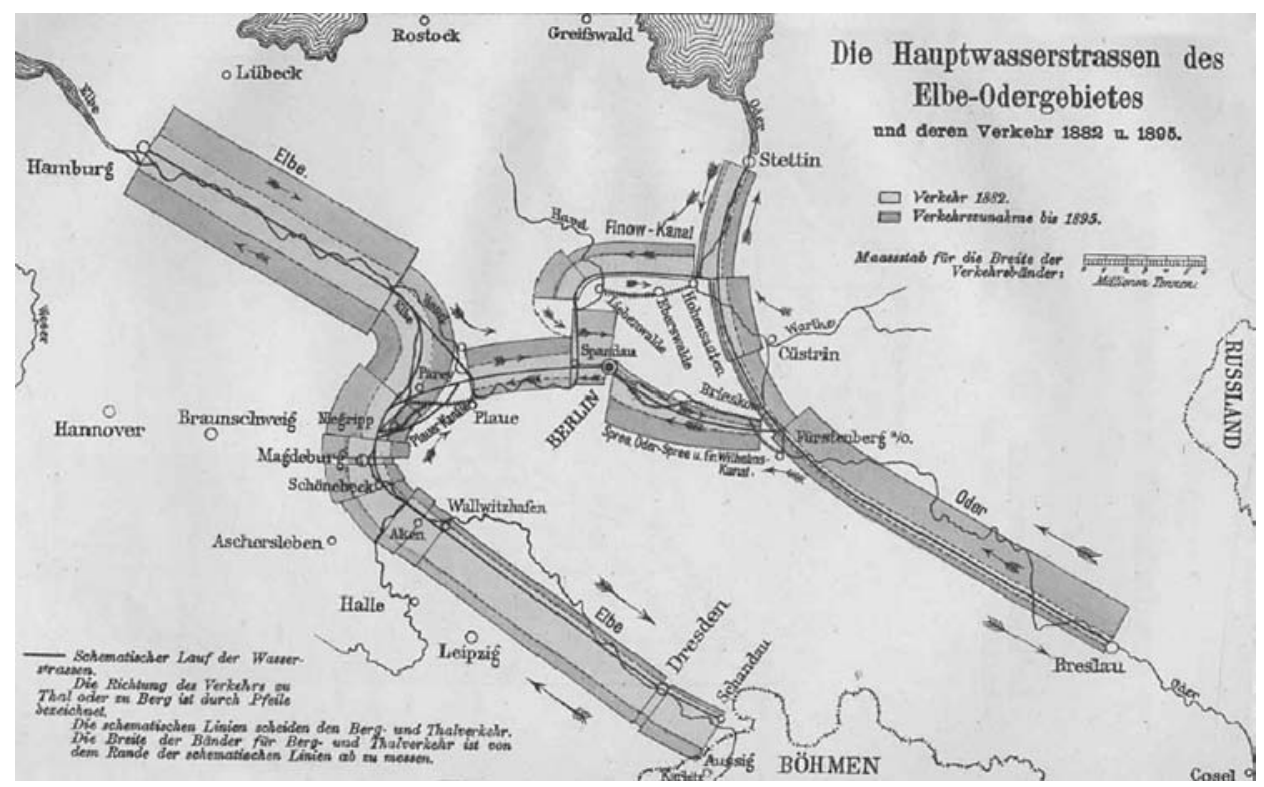

Rys. 20. Natężenie transportu śródlądowego na głównych obszarach rzek Łaba - Odra w 1882 r. i 1895 r. $(\mathrm{mln} \mathrm{Mg})$

Źródło: E. Heubach, Die Verkehrsentwickelung auf dem Wasserstrassen und Eisenbahnen des Elbe-Oder Gebietes in dem Zeitraum von 1882-1895, Tafel I. 
Na początku XX w. rywalizację w przewozach towarowych wygrał zdecydowanie transport kolejowy. Wyraźnie ukazują to dane zawarte w tab. 12.

Tabela 12. Udział kategorii towarowych w całości przewozów linii kolejowych i śródląd. dróg wodnych Niemiec (1911)

\begin{tabular}{|c|c|c|c|c|c|}
\hline $\begin{array}{l}\text { Transporto- } \\
\text { wany artykuł/ } \\
\text { dobro }\end{array}$ & $\begin{array}{c}\text { Koleje } \\
(\mathrm{Mg})\end{array}$ & $\begin{array}{l}\text { Transport } \\
\text { wodny } \\
\text { śródlądowy } \\
\text { (Mg) }\end{array}$ & $\begin{array}{l}\text { Koleje - } \\
\text { udział } \\
\text { transportu } \\
\text { w całości } \\
(\%)\end{array}$ & $\begin{array}{c}\text { Transport } \\
\text { wodny } \\
\text { śródlądowy } \\
\text { udział całości } \\
\text { (\%) }\end{array}$ & $\begin{array}{l}\text { Indeks - } \\
\text { transport } \\
\text { śródlądowy } \\
\text { wodny } \\
\text { (transport } \\
\text { kolejowy } \\
=100 \text { ) }\end{array}$ \\
\hline 1 & 2 & 3 & 4 & 5 & 6 \\
\hline $\begin{array}{l}\text { Węgiel kamien- } \\
\text { ny, w tym } \\
\text { brykiet i koks }\end{array}$ & 135235441,00 & 21870450,00 & 32,07 & 26,83 & 16,17 \\
\hline $\begin{array}{l}\text { Węgiel brunat- } \\
\text { ny, w tym } \\
\text { brykiet i koks }\end{array}$ & 33694725,00 & 1517640,00 & 7,99 & 1,86 & 4,50 \\
\hline $\begin{array}{l}\text { Ziemia - } \\
\text { wszystkie } \\
\text { rodzaje }\end{array}$ & 24880511,00 & 11109345,00 & 5,90 & 13,63 & 44,65 \\
\hline $\begin{array}{l}\text { Kamień } \\
\text { i wyroby } \\
\text { kamieniarskie }\end{array}$ & 44273977,00 & 7045140,00 & 10,50 & 8,64 & 15,91 \\
\hline Wapno & 5238491,00 & 968558,00 & 1,24 & 1,19 & 18,49 \\
\hline Cement & 6608131,00 & 1363505,00 & 1,57 & 1,67 & 20,63 \\
\hline Rudy & 19730658,00 & 10058117,00 & 4,68 & 12,34 & 50,98 \\
\hline Surówka żelaza & 13020188,00 & 1179267,50 & 3,09 & 1,45 & 9,06 \\
\hline $\begin{array}{l}\text { Produkty } \\
\text { z żelaza i stali }\end{array}$ & 20320990,00 & 1970845,50 & 4,82 & 2,42 & 9,70 \\
\hline $\begin{array}{l}\text { Metale } \\
\text { nieszlachetne }\end{array}$ & 1253305,00 & 345403,00 & 0,30 & 0,42 & 27,56 \\
\hline Drewno & 21246785,00 & 6089772,50 & 5,04 & 7,47 & 28,66 \\
\hline Zboża & 14169063,00 & 6597297,50 & 3,36 & 8,09 & 46,56 \\
\hline $\begin{array}{l}\text { Produkty } \\
\text { przemysłu } \\
\text { młynarskiego }\end{array}$ & 7889844,00 & 877154,00 & 1,87 & 1,08 & 11,12 \\
\hline Buraki & 6378286,00 & 252445,50 & 1,51 & 0,31 & 3,96 \\
\hline Ziemniaki & 4880532,00 & 89315,00 & 1,16 & 0,11 & 1,83 \\
\hline $\begin{array}{l}\text { Owoce } \\
\text { i warzywa }\end{array}$ & 2106186,00 & 132291,00 & 0,50 & 0,16 & 6,28 \\
\hline Cukier & 2810542,00 & 1257022,50 & 0,67 & 1,54 & 44,73 \\
\hline
\end{tabular}


Tabela 12. (cd.)

\begin{tabular}{|l|r|r|r|r|r|}
\hline \multicolumn{1}{|c|}{1} & \multicolumn{1}{|c|}{2} & \multicolumn{1}{c|}{3} & \multicolumn{1}{c|}{4} & \multicolumn{1}{c|}{5} & \multicolumn{1}{c|}{6} \\
\hline Sól & 2008610,00 & 417342,50 & 0,48 & 0,51 & 20,78 \\
\hline $\begin{array}{l}\text { Siemię lniane } \\
\text { i rzepak }\end{array}$ & 344896,00 & 594325,00 & 0,08 & 0,73 & 172,32 \\
\hline $\begin{array}{l}\text { Oleje, tłuszcze, } \\
\text { tran }\end{array}$ & 920083,00 & 398800,50 & 0,22 & 0,49 & 43,34 \\
\hline Makuchy & 1864488,00 & 145834,50 & 0,44 & 0,18 & 7,82 \\
\hline $\begin{array}{l}\text { Ropa, inne } \\
\text { oleje }\end{array}$ & 1924433,00 & 885148,50 & 0,46 & 1,09 & 46,00 \\
\hline $\begin{array}{l}\text { Smoła, asfalt, } \\
\text { żywica }\end{array}$ & 1918728,00 & 363914,00 & 0,45 & 0,45 & 18,97 \\
\hline $\begin{array}{l}\text { Leki, } \\
\text { art. chemiczne }\end{array}$ & 3974419,00 & 602173,50 & 0,94 & 0,74 & 15,15 \\
\hline Nawozy & 2271835175,00 & 1871276,50 & 3,45 & 2,30 & 12,87 \\
\hline Piwo & 328866,00 & 233965,00 & 0,08 & 0,29 & 71,14 \\
\hline Kora, tarcica & 1134139,00 & 87779,50 & 0,27 & 0,11 & 7,74 \\
\hline $\begin{array}{l}\text { Szkło, } \\
\text { art. szklane }\end{array}$ & 2252017,00 & 319587,50 & 0,53 & 0,39 & 14,19 \\
\hline Papier, papa & 1759885,00 & 220730,00 & 0,42 & 0,27 & 12,54 \\
\hline $\begin{array}{l}\text { Wyroby } \\
\text { włókiennicze }\end{array}$ & 22743278,00 & 2575225,50 & 5,39 & 3,16 & 11,32 \\
\hline Inne & 4218475,00 & 81510601,50 & 100,00 & 100,00 & 19,33 \\
\hline Razem & 227000 & 0,54 & 0,09 & 3,12 \\
\hline
\end{tabular}

Źródło: Ch. Grotewold, Die Deutsche Schiffahrt in Wirtschaft und Recht, Stuttgart 1914, s. 414.

Wykorzystując transport kolejowy przewieziono w 1911 r. łącznie 421 $718475 \mathrm{Mg}$ ładunków, co stanowiło 80,67\% ogółu przewozów. Na transport śródlądowy przypadło tym samym 19,33\%. Około 1/3 przewiezionych towarów koleją stanowił transport węgla kamiennego, brykietu i koksu. Gdyby do tych kategorii towarowych dołączyć węgiel brunatny, wówczas ponad 40\% ilości transportu kolejowego stanowiłyby te dwie kopaliny. Dla transportu śródlądowego transport węgla kamiennego stanowił blisko $27 \%$ i mniej jak $2 \%$ węgla brunatnego. Znaczny odsetek przewożonych towarów przy użyciu transportu wodnego, obok węgla, stanowiły: rudy (12,34\%), wszelkie rodzaje ziemi (13,63\%), zboża $(8,09 \%)$, kamienie i wyroby kamieniarskie $(8,64 \%)$ i drewno $(7,47 \%)$.

W zasadzie dla większości przewozów towarowych, przy założeniu, że indeks dla przewozów kolejowych wynosi 100, transport śródlądowy przewyższał kolejowy jedynie w przypadku siemienia lnianego i rzepaku (indeks 172,32). Powyżej średniej dla transportu śródlądowego (19,33\%) znajdowały się przewozy m.in. rud, zboża, cukru. 
Wyniki dla transportu wodnego śródlądowego z roku 1912 pokazują, że tonaż wzrósł z 5.914.020 Mg w 1907 r. do 7.394 .657 (o 22, 25\%), co świadczy o jego rozwoju ${ }^{42}$.

Na rys. 21 zobrazowano w ocenie główne szlaki wodne w Cesarstwie Niemieckim w 1910 r. Do najważniejszych wodnych szlaków komunikacyjnych zaliczono: Ren, Łabę, Odrę, Wisłę, Wezerę, a także trasę marchijską i inne połączenia wodne z wykorzystaniem kanałów.

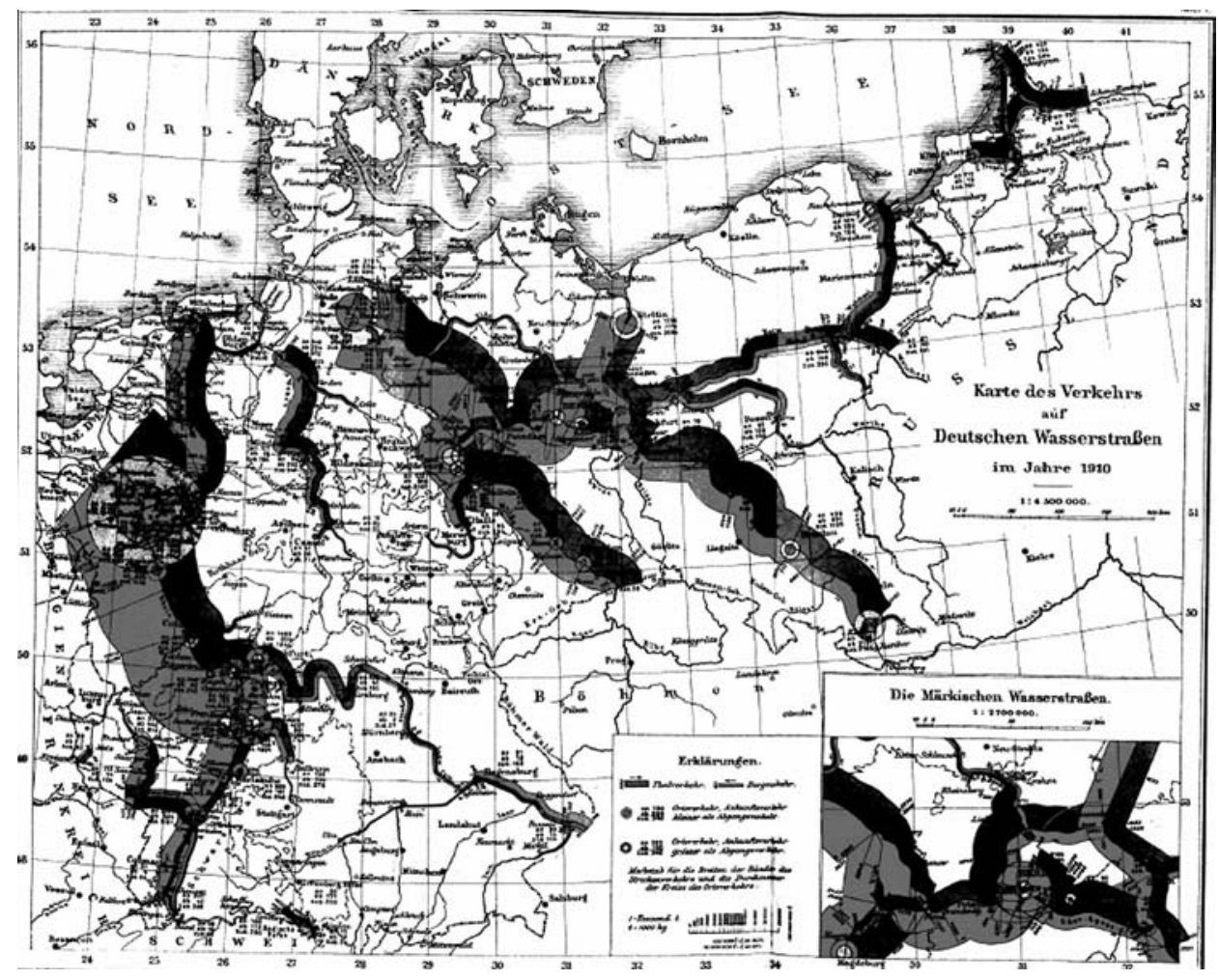

Rys. 21. Transport z uwzględnieniem natężenia dróg wodnych w Niemczech (1910 r.) $\mathrm{z}$ określeniem kierunku transportu oraz jego rozmiarów

Źródło: jak do rys. 16.

${ }^{42}$ Ch. Grotewold, Die Deutsche Schiffahrt in Wirtschaft und Recht, Stuttgart 1914, s. 667. 


\section{WPLYW KOLEI NA WZROST GOSPODARCZY W STANACH ZJEDNOCZONYCH I W EUROPIE ZACHODNIEJ}

Od początków rozbudowy transportu kolejowego w Anglii w 1826 r. do 1913 r. na świecie było niemal milion kilometrów torów kolejowych. Prawie połowa z nich była w Stanach Zjednoczonych. Kolejne 30\% z nich w Europie. Rozbudowa kolei, postrzegana jako ogromna i kosztowna inwestycja umożliwiła otwarcie nowych ziem na rozwój, zwiększyła efektywną wielkość rynków, zwiększyła zakres wewnętrznych migracji i urbanizacji, przyczyniła się do zmiany ekonomii lokalizacji przemysłu, a także miała wpływ na zwiększenie możliwości międzynarodowej specjalizacji ${ }^{43}$.

Wracając do rozbudowy sieci kolejowej w USA - tempo rozwoju linii od 1830 do 1913 r. zostało przedstawione na rys. 22.

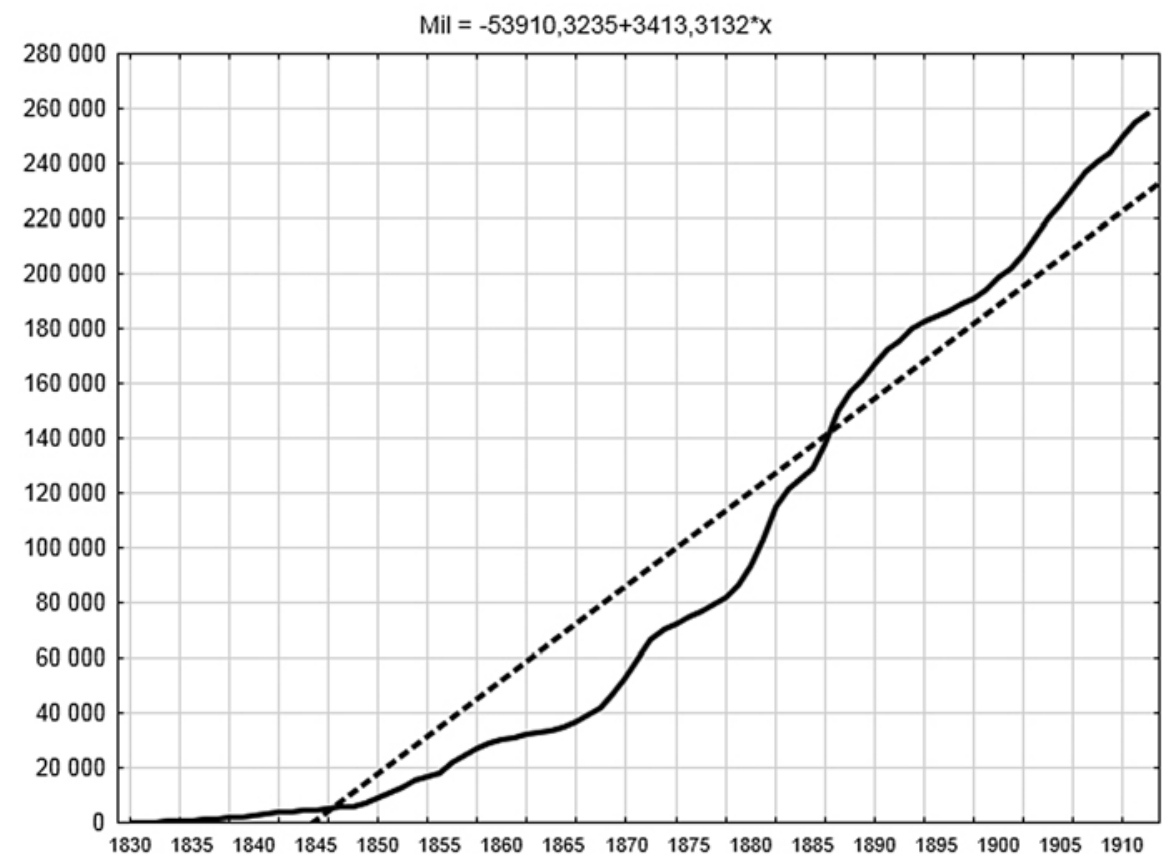

Rys. 22. Przyrost długości linii kolejowych w USA w latach 1830-1912 (mile) $\mathrm{z}$ podaniem trendu liniowego

Źródło: opracowanie własne na podstawie: Statistical Abstract of the United States, First Number, Washington 1879, s. 151; Statistical Abstract of the United States, Eleventh Number, New York 1888, s. 182; Statistical Abstract of the United States 1913, Thirty-Sixth Number, Washington 1914, s. 263.

${ }^{43}$ A. Maddison, Monitoring the World Economy 1820-1992, Paris 2000, s. 64; Jahrbuch für Volkswirthschaft und Statistik von O. Hüber, Fünfter Jahrgang, Leipzig 1857, s. 79. 
Średnie tempo przyrostu w jednym roku wyniosło 3413 mili (blisko 5495 $\mathrm{km}$ ). Chcąc dokonać analizy głównych źródeł przychodów kolei (osiągnięte przychody operacyjne: 2750677 USD) w USA należy podkreślić, że w 1910 r. kształtowały się one następująco:

- fracht kolejowy 1925553 tys. USD, co stanowiło 70 \% ogółu przychodów,

- przewozy pasażerskie 628992 tys. USD, co stanowiło 22,87\% ogółu przychodów,

- przesyłki pocztowe 48913 tys. USD, co stanowiło 1,78\% przychodów ogółem,

- pozostałe usługi 147219 tys. USD, co stanowiło 5,35\% ogółu przychodów.

W latach 1911-1913 przychody z tytułu frachtu spadły do około $69 \%$ ogółu przewozów, a z tytułu przewozów pasażerskich wzrosły do około $23 \%$ ogółu przewozów ${ }^{44}$.

W równie imponującym tempie rozwijało się kolejnictwo na obszarze Niemiec. Porównując przyrost długości linii kolejowych USA i Niemiec, autor przyjął indeks równy 100 dla 1913 r. Wyniki zaprezentowane zostały na rys. 23.

Dla przykładu, indeks 20\% stanu z 1913 r. niemiecka sieć kolejowa osiągnęła w 1863 r., w USA w 1870 r., 40\% odpowiednio w 1873 r. i 1881 r. Zauważalna jest większa dynamika rozbudowy kolei w USA w latach osiemdziesiątych XIX w., stąd indeks $60 \%$ osiągnięto w przypadku Niemiec w 1884 r., zaś w przypadku Stanów Zjednoczonych w $1887 \mathrm{r}$.

Koleje żelazne, będąc jedną z ważniejszych innowacji w XIX w., podlegały ocenom ich wpływu na wzrost i rozwój gospodarczy. Jedną z technik zaproponowaną przez Roberta Fogla jest koncepcja społecznych oszczędności social savings (SS).

R. Fogel po raz pierwszy zaprezentował technikę społecznych oszczędności w $1962 \mathrm{r}$. w artykule naukowym A quantitative approach to the study of railroads in American economic growth: a report of some preliminary findings $\mathrm{W}$,Journal of Economic History". Zagadnienie społecznych oszczędności rozwinął w książce z 1964 r. Railroads and American Economic Growth: Essays in Econometric History. Metodę szczegółowo opisał w artykule Notes on the Social Saving Controversy, w 1979 r. ${ }^{45}$

Jak napisał Fogel: „Określiłem społeczną oszczędność kolei, w danym roku, jako różnicę między rzeczywistymi kosztami wysyłki towarów w tym roku, a alternatywnym kosztem wysyłki dokładnie takiego samego towaru dokładnie do tego samego punktu bez użycia kolei żelaznych"46.

${ }^{44}$ Statistical Abstract of the United States 1913, Thirty-Sixth Number, Washington 1914, s. 275.

45 R. Fogel, Notes on the Social Saving Controversy, „Journal of Economic History” 1979, vol. XXXIX, no. 1.

46 Tamże, s. 2-3. 


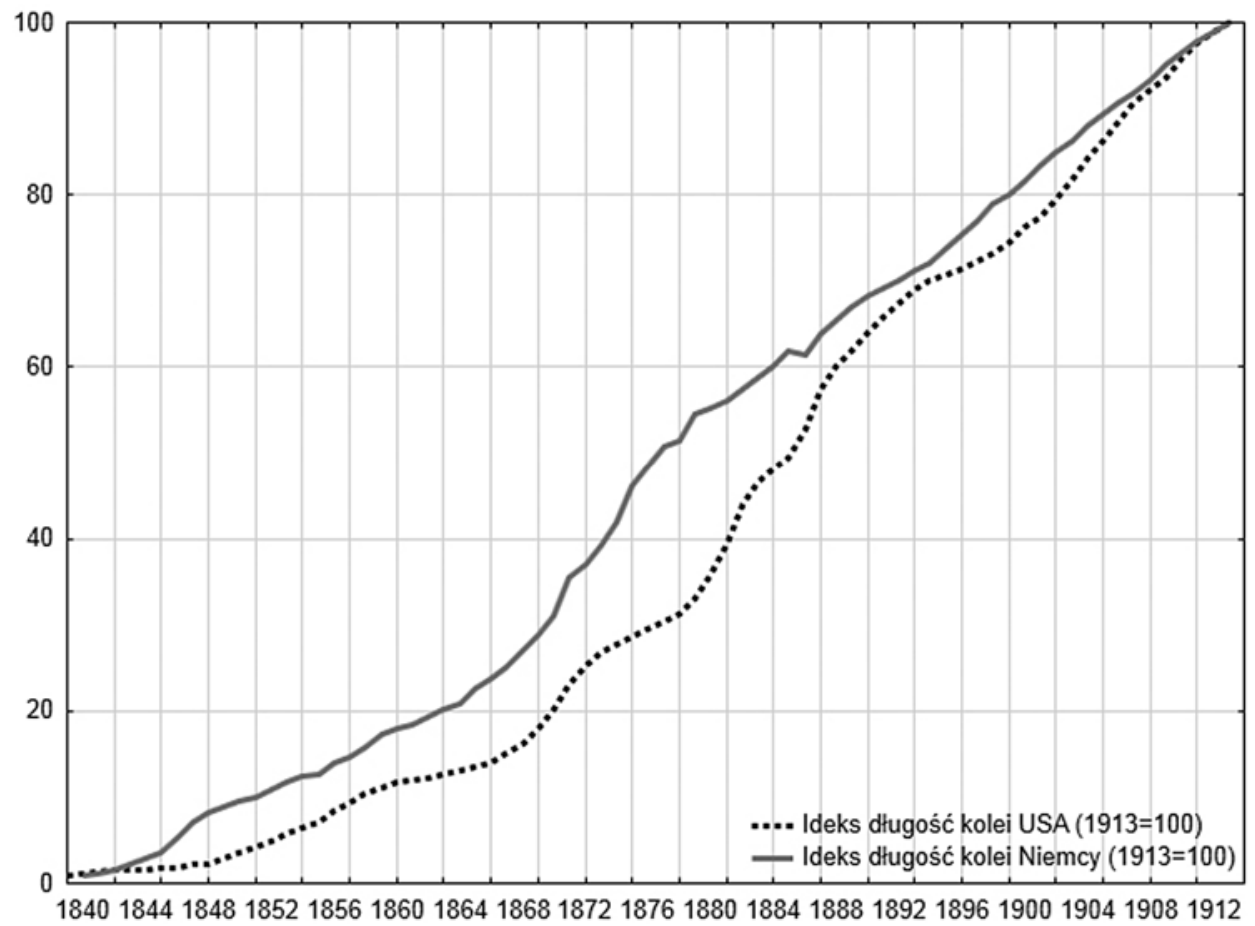

Rys. 23. Rozwój kolei w USA i Niemczech w latach 1840-1913 (1913=100)

Źródło: opracowanie własne na podstawie: (dla USA:) Statistical Abstract of the United States, First Number, Washington 1879, s. 151; Statistical Abstract of the United States, Eleventh Number, New York 1888, s. 182; Statistical Abstract of the United States 1913, Thirty-Sixth Number, Washington 1914, s. 263; Statistical Abstract of the United States 1915, Thirty-Eighth Number, Washington 1916, s. 263; (dla Niemiec:) Statistik des Verkehrs und Verbrauchs im Zollverein für die Jahre 1842-1864: Nach den veröffentlichten amtlichen Kommerzial-Übersichten etc, A. Bienengräber, Berlin 1868, Statistisches Jahrbuch für das Deutsche Reich, Berlin 1880-1914.

Koszty takie dla amerykańskich kolei określił dla roku 1890, posługując się transportem produktów rolnych, a także alternatywnym transportem, jakim był transport wodny śródlądowy z uwzględnieniem kanałów. Obliczenia R. Fogla pokazały, że społeczne oszczędności dla 1890 r. wynoszą około 1,8\% PKB.

Przedstawiając postać algebraiczną społecznych oszczędności Fogel założył:

$$
\begin{aligned}
& Q_{A}=a\left(L_{a}, K_{a^{\prime}} Q_{T a}\right) \\
& Q_{T}=w\left(L_{w}, K_{w}\right) \\
& Q_{T}=r\left(L_{r}, K_{r}\right)
\end{aligned}
$$

gdzie:

$Q_{T}$ - produkcja (output) dla transportu, 
$Q_{T a}-$ część $Q_{T}$ wykorzystana do produkcji $Q_{T a}$,

$Q_{T C}=Q_{T}-Q_{T a}$-transport zakupiony jako produkt końcowy,

$Q_{A}$ - produkcja wszystkich innych dóbr w sektorze,

$L-$ praca,

$K$ - kapitał,

$a$ - wszystkie inne dobra, wejścia (input),

$w$ - funkcja transportu (gorszy, mniej zaawansowany), nakłady,

$r$ - funkcja transportu (lepszy, bardziej zaawansowany), nakłady.

Czynnik $r$ przewyższa w, co jest wynikiem innowacji. Dla tej samej wielkości transportu $Q_{T}$ przy lepszej technologii $r$ może być zaoferowany przy mniejszym zaangażowaniu pracy i kapitału niż w przypadku technologii mniej zaawansowanej $w$.

Stąd też można zapisać, że:

$L_{w}=L_{r}+\Delta L$

$K_{w}=K_{r}+\Delta K$

Wówczas dochód narodowy na podstawie funkcji r wynosi: $Q_{A}+Q_{T C}$ gdzie $Q_{T C}$ odpowiada $Q_{T C}-Q_{T a}$

Substytucja czynnika w przez czynnik r w funkcji, utrzymując stałą ilość $Q_{T}$, wymaga przeniesienia przyrostu nakładów pracy $(\Delta L)$ i przyrostu nakładów kapitału $(\Delta K)$ do produkcji innych dóbr.

Po tych przekształceniach dochód narodowy $(Y)$ określony zostanie, jako:

$$
Y=Q_{A}{ }^{\prime}+Q_{T c}
$$

gdzie:

$Q_{A}{ }^{\prime}=a\left(L_{a}-\Delta L, K_{a}-\Delta K, Q_{T a}\right)$

Wynika stąd, że społeczne oszczędności mogą być ujemne, co oznacza stratę dochodu narodowego, spowodowaną przez podstawienie gorszej alternatywy dla lepszej technologii, co można przedstawić jako:

$$
\left(Q_{A}+Q_{T C}\right)-\left(Q_{A}{ }^{\prime}+Q_{T C}\right)=Q_{A}-Q_{A}{ }^{\prime} \approx \frac{\partial Q_{A}}{\partial L} \Delta L+\frac{\partial Q_{A}}{\partial K} \Delta K
$$

Po przekształceniach:

$$
\left(\frac{\partial Q_{A}}{\partial L} \Delta L+\frac{\partial Q_{A}}{\partial K} \Delta K\right) P_{A} \approx\left(Q_{A}-Q_{A}{ }^{\prime}\right) P_{A}
$$

Kilka założeń przyjętych dla potrzeb modelu - celem modelu, jak podkreślał R. Fogel nie jest kompletny i wyczerpujący opis zarówno gospodarki amerykańskiej lub innego kraju końca XIX w. Model jest zaprojektowany w taki sposób, aby ustalić górną granicę oszczędności zasobów spowodowanych implementacją nowej technologii i poprawą transportu.

Górna granica oszczędności osiągnięta zostaje poprzez przyjęcie, że elastyczność prosta popytu $\left(E_{D P}\right)$ wynosi 0 (popyt doskonale nieelastyczny, sztywny). 
Oznacza to brak reakcji transportu w przypadku lepszych (tańszych) form transportu. Jeśli elastyczność popytu jest większa niż 0 , wzrost kosztów transportu przyczynia się do spadku zakupów relatywnie droższego transportu, a więc prowadzi do zmniejszenia wykorzystania zasobów (to oznacza redukcję $\Delta L, \Delta K$ ). Ponadto wzrost kosztów transportu jest równoznaczny ze spadkiem dochodu narodowego. Tożsamość ta jest spowodowana założeniami przyjętymi do modelu, że popyt na transport jest doskonale nieelastyczny, a $\Delta L, \Delta K$ pochodzą z zasobów wcześniej zaangażowanych w produkcji $Q_{A}$, a nie z zasobów wcześniej wolnych (np. bezrobotnych).

Po R. Foglu kolejnym ekonomistą, który określił społeczne oszczędności sektora kolejowego był Albert Fishlow. Wykonując swoje obliczenia społecznych oszczędności dla kolei żelaznych w USA wybrał okres przez wybuchem wojny secesyjnej, a dokładnie 1859 r. Nawiązując do statystyk amerykańskich w 1859 r. długość sieci kolejowej wynosiła $28789 \mathrm{mil}^{47}$. Stanowiło to, zgodnie z obliczeniami własnymi autora około $11 \%$ stanu sieci kolejowej z $1913 \mathrm{r}$.

A. Fishlow, zgłębił różnicę kosztów transportu świadczonego zarówno przez kolej, drogi wodne, jak i dyliżansy (wozy) dla osób i towarów. Założył jednocześnie, że transport produktów rolnych stanowi 1/4 całości przewozów kolejowych, pozostałych dóbr $1 / 3$, zaś resztę przewozy pasażerskie ${ }^{48}$. Oszczędności społeczne wyniosły około 175 mld USD, co stanowiło około 4\% PKB. Jego analiza wykazała, że przed 1859 r. transport pasażerski kolejami przyniósł bezpośrednie korzyści, które były mniejsze niż połowa uzyskanych korzyści z frachtu towarowego. Jeszcze bardziej zaskakujące i pouczające było jego odkrycie, że wielkie arterie komunikacyjne stanowiły tylko $8 \%$ społecznych oszczędności kolei. Analiza A. Fishlowa niezbicie wykazała, że główne linie kolejowe (arterie) zostały zbudowane wzdłuż cieków wodnych, które były dobrymi substytutami dla samej kolei.

Jak wskazywano metoda społecznych oszczędności jest oparta na szacowaniu oszczędności kosztów w nową technologię w porównaniu $\mathrm{z}$ inną alternatywą technologią. Oszczędność w kosztach zasobów, porównuje się z przyrostem realnego dochodu narodowego. Społeczne oszczędności są zwykle wyrażone, jako odsetek dochodu narodowego (w stosunku do PKB, PNB, PNN).

Wpływ kolei na globalny wzrost gospodarczy został obliczony przy użyciu koncepcji społecznych oszczędności w wielu krajach, które były liderami we wczesnym wprowadzeniu i rozwoju sieci kolejowej. W zależności od kraju i długości badanego okresu udział ten wynosił (zwykle) w granicach 4-25\% $\mathrm{PKB}^{49}$.

${ }^{47}$ Statistical Abstract of the United States 1880, Third Number, Washington 1881, s. 158.

48 R. Fogel, Die neue Wirtschaftsgeschichte Forschungsergebnisse und Methoden, „Kölner Vorträge zur Sozial- und Wirtschaftsgeschichte" 1970, Heft 8, s. 17.

${ }^{49}$ P. O’Brien, Transport and Economic Development..., s. 1-27, są też dostępne przykłady niżych i wyższych społecznych oszczędności sektora kolejowego. 
Jak zauważa współczesny badacz Nicholas Crafts, jeśli interpretacja R. Fogla zostanie przyjęta, to może być użyta do oszacowania nie tylko w przypadku kolei, ale też określeniu, w większości przypadków, zysków z transferu nowej technologii ${ }^{50}$.

Obok szacunków wyrażonych kwotowo, nowe środki transportu np. analizowane koleje umożliwiały oszczędność czasu. Oszczędności czasu dla osób, które dojeżdżają do pracy lub innych przejazdów nie są ujmowane w PKB, ale mają wpływ na poprawę dobrobytu. Wartość tego rodzaju oszczędności jest częścią społecznego szacunku oszczędności. Dla przykładu, Terry Gourvish oszczędności czasu w przypadku Wielkiej Brytanii powstałe w wyniku podróży koleją w $1865 \mathrm{r}$. szacował na poziomie $1 \mathrm{mln} £^{51}$.

Szacunki społecznych oszczędności w przypadku kolei żelaznych dla różnych krajów przedstawiono w tab. 13. Jeśli interpretacja R. Fogla zostaje przyjęta, to prezentowane dane można uznać za górną granicę oszacowania korzyści z rozwoju technologii w dziedzinie kolejnictwa.

Tabela 13. Wskaźnik społecznych oszczędności (SS) kolei dla wybranych krajów (\% PKB)

\begin{tabular}{|c|c|c|}
\hline Kraj/rodzaj przewozów & Rok & $\%$ PKB \\
\hline 1 & 2 & 3 \\
\hline \multicolumn{3}{|c|}{ Anglia i Walia } \\
\hline $\mathrm{F}$ & 1865 & 4,1 \\
\hline $\mathrm{F}$ & 1890 & $11,0(29,1-31,6)$ \\
\hline $\mathrm{P}+\mathrm{F}$ & $1843-1913$ & $1,5-14 \%$ \\
\hline \multicolumn{3}{|c|}{ Argentyna } \\
\hline $\mathrm{F}$ & 1913 & 26 \\
\hline \multicolumn{3}{|c|}{ Belgia } \\
\hline $\mathrm{P}+\mathrm{F}$ & 1846 & 1,0 \\
\hline $\mathrm{P}+\mathrm{F}$ & 1865 & 2,5 \\
\hline $\mathrm{P}+\mathrm{F}$ & 1912 & 4,5 \\
\hline \multicolumn{3}{|c|}{ Brazylia } \\
\hline $\mathrm{P}$ & 1913 & 4,6 \\
\hline $\mathrm{F}$ & 1913 & $18,0-38$ \\
\hline \multicolumn{3}{|c|}{ Chiny } \\
\hline $\mathrm{P}+\mathrm{F}$ & 1933 & 0,5 \\
\hline
\end{tabular}

${ }^{50}$ N. Crafts, Social Savings as a Measure of The Contribution of a New Technology to Economic Growth, Department of Economic History London School of Economics, Working Paper 2004, no. 6 , s. 2.

${ }^{51}$ T. Gourvish, Railways and the British economy, 1830-1914, [w:] Economic History Society Studies in Economic and Social History, London 1980, s. 59. 
Tabela 13. (cd.)

\begin{tabular}{|l|c|c|}
\hline \multicolumn{1}{|c|}{2} & 3 \\
\hline \multicolumn{3}{|c|}{ Francja } \\
\hline P & 1872 & 1,7 \\
\hline F & 1872 & 5,8 \\
\hline F & Hiszpania \\
\hline F & 1878 & $7,5(11,8)$ \\
\hline \multicolumn{3}{|c|}{ Indie } \\
\hline F & 1900 & $11,0(18,5)$ \\
\hline \multicolumn{3}{|c|}{ Kolumbia } \\
\hline F & 1924 & 9,0 \\
\hline \multicolumn{3}{|c|}{ Meksyk } \\
\hline F & 1895 & 4,8 \\
\hline F & 1910 & 14,6 \\
\hline \multicolumn{3}{|c|}{ Rosja } \\
\hline P & 1907 & $24,9-38,5$ \\
\hline F & 1907 & 1,6 \\
\hline & USA & 4,6 \\
\hline P & 1859 & 1,6 \\
\hline F & 1859 \\
\hline P & 1890 \\
\hline F & 1890 & 3,7 \\
\hline
\end{tabular}

Objaśnienia: F - fracht kolejowy, $\mathrm{P}$ - przewozy osobowe.

Źródło: N. Crafts, Social Savings as a Measure of The Contribution of a New Technology to Economic Growth, Department of Economic History London School of Economics, Working Paper 2004, no. 06; G.R. Hawke, Railways and Economic Growth in England and Wales, 1840-1870, Oxford 1970, s. 196; A. Fishlow, American Railroads and the Transformation of the Antebellum Economy, Cambridge 1965, s. 37, 52; J. Metzer, Railroads in Tsarist Russia: Direct Gains and Implications, „Explorations in Economic History” 1976, no. 13, s. 90; F. Caron, France, [w:] Railways and the Economic Development of Western Europe, 1830-1914, ed. P. O'Brien, Oxford 1983, s. 44; J. H. Coatsworth, Indispensable railroads in a backward economy: the case of Mexico, ,Journal of Economic History" 1979, vol. 39(4), s. 939-960; J. Boyd, G.M. Walton, The social savings from nineteenth century rail passenger services, „Explorations in Economic History” 1972, no. 9, s. 233-254; M. Laffut, Belgium, [w:] Railways and the Economic..., s. 203-226; W. Summerhill, Big social savings in a small laggard economy: railroad-led growth in Brazil, ,Journal of Economic History" 2005, vol. 65(1), s. 72-102; R. W. Huenemann, The Dragon and the Iron Horse: The Economics of Railroads in China, 1876-1937, Harvard East Asian Monographs, Cambridge, MA 1983; J. Foreman-Peck, Railways and the late Victorian economic growth, [w:] J. Foreman-Peck (ed.), New Perspectives on the Late Victorian Economy: Essays in Quantitative Economic History, 1860-1914, Cambridge 1991, s. 73-95. 
Analizując powyższe dane łatwo zauważyć, że:

1. Początkowo korzyści i udział kolei żelaznych w generowaniu PKB były stosunkowo niewielkie. W połowie lat sześćdziesiątych XIX w. dla Anglii z Walią i Belgii oszczędności stanowiły jedynie 4,1\% i 2,5\% PKB. We Francji poziom oszczędności w 1872 r. wynosił 5,8\% PKB.

2. Kolejne lata rozbudowy sieci kolejowej wpływały na wzrost udziału kolei w tworzeniu PKB. Obok coraz większej gęstości sieci kolejowej, poziomu nakładów inwestycyjnych, stosowane były także bardziej wydajne składy kolejowe (parowozy, wagony).

3. Korzyści z zastosowania transportu kolejowego są mocno uzależnione od dostępnych alternatywnych rodzajów transportu, w tym czasie głównie naturalnego transportu wodnego, ale także kanałów, regulacji rzek, rozwoju żeglugi przybrzeżnej. Korzyści z kolei początkowo często były dość małe w porównaniu do relatywnie taniego transportu wodnego, jeśli porównane były natomiast z transportem drogowym korzyści z kolei już były dość duże.

R. Fremdling przyznaje, że gdyby posłużyć się koncepcją social savings dla niemieckich kolei z około roku 1880 i analizować przewozy węgla kamiennego lub brunatnego, ewentualnie innych towarów masowych, to wówczas wynik byłby ujemny. Oznaczać to może, że inne alternatywne rodzaje transportu dla gospodarki niemieckiej były tańsze, co w pwenien sposób potwierdza przeprowadzona analiza dla transportu wodnego i kolejowego dla dorzecza Odry, Łaby.

4. Opłaty uiszczane przez pasażerów kolei często były wyższe niż alternatywnych środków transportu, co odzwierciedla gotowość do płacenia za prędkość i wygodę, a podróż koleją traktować należy jako dostępne nowe dobro.

Jak zauważa Tim Leunig, analizując dostępne dane dotyczące kolei w Anglii i Walii, w ciągu XIX w. koszty podróży w trzeciej klasie spadły w stosunku do otrzymywanych wynagrodzeń pracowników. W 1865 r. średnio pracownik za swoją stawkę godzinową mógł podróżować tylko 3,3 mili, w 1912 r. mógł podróżować już 10,4 mili. Mimo że spadek cen i coraz gęstsza sieć kolejowa zachęcała do podróżowania pociągiem, to podróż koleją była luksusem i do tego była około trzy razy droższa w stosunku do współczesnych zarobków ${ }^{52}$.

Gary Hawke wskazuje, że przeciętna społeczna stopa zwrotu z inwestycji kolejowych wahała się w granicach 15\%, podczas, gdy prywatna stopa zwrotu była na poziomie 5\%. Jak szacuje John Armstrong, w 1910 r. ponad 60\% krajowego frachtu dotyczyła transportu morskiego ${ }^{53}$.

${ }^{52}$ T. Leunig, Time is Money: A Re-assessment of the Passenger Social Savings From Victorian British Railways, Department of Economic History London School of Economics, Working Paper 2005, no. 9, s. 42.

53 J. Armstrong, The Role of Coastal Shipping in UK Transport: an Estimate of Comparative Traffic Movements in 1910, „Journal of Transport History” 1987, no. 8, s. 164-178. 
Jednak prezentowane dane dotyczące społecznych oszczędności nie mogą być traktowane jako jednoznaczne wskaźniki względnego udziału kolei w generowaniu wzrostu gospodarczego w danym kraju, gdyż:

- dostępne w literaturze obliczenia społecznych oszczędności dotyczą różnych krajów, różnych lat, wykonane przy użyciu różnych metodologii, a wobec braku niektórych danych szacunki też mogą być zawodne, stąd wyciągnięcie jednoznacznych wniosków może być błędne;

- znaczenie społecznych oszczędności może być znacznie mniejsze, jeśli przyjmiemy, że elastyczność cenowa popytu jest wysoka. Wówczas szybko spadające ceny, zgodnie z koncepcją elastyczności, prowadzą do zwiększenia popytu (i na odwrót), stąd też T. Leunig propaguje wykorzystanie w analizie wpływu rozwoju technologii nadwyżki konsumenta.

Na rys. 24 zaprezentowano sposób obliczania społecznych oszczędności, przy założeniu, że krzywa popytu $\mathrm{D}_{\mathrm{T}}$ jest doskonale nieelastyczna (popyt sztywny): gdzie:

$\mathrm{D}_{\mathrm{T}}$ - popyt na usługi transportowe,

$\mathrm{S}_{\mathrm{C}}$ - podaż alternatywnych usług transportowe (bez kolei),

$\mathrm{S}_{\mathrm{R}}$ - podaż alternatywnych usług transportowych (z kolejami),

$\mathrm{R}_{\mathrm{C}}$ - środki wydane na transport (brak kolei),

$\mathrm{R}_{\mathrm{r}}$ - środki wydane na transport (z udziałem kolei).

W ostatnim rozdziale pracy autor zaprezentuje także koncepcję społecznych oszczędności z uwzględnieniem nadwyżki konsumenta.

Koncepcja R. Fogla spotkała się z krytyką, zwłaszcza za szczególnie niski poziom społecznych oszczędności wykazany dla 1890 r. Niektórzy badacze, jak Dave Donaldson, Richard Hornbeck wskazują, że założenie o braku sieci kolejowej nie tylko oznaczałoby konieczność korzystania z alternatywnych źródeł transportu, lecz także oznaczałoby zmniejszenie całkowitej wartości amerykańskiej ziemi rolnej o $73 \%$ i spadek PKB o $6,3 \%$, czyli ponad dwukrotnie więcej niż społeczne szacunki oszczędności określone w pracy R. Fogla.

$\mathrm{Z}$ kolei proponowana przez R. Fogla rozbudowa kanału Midwestern złagodziłaby jedynie o $8 \%$ straty z powodu rezygnacji z transportu kolejowego ${ }^{54}$.

Podsumowując niniejszy podrozdział należy zauważyć, że niezależnie od krytyki, jaka dotyczy obliczania społecznych oszczędności, w przypadku sektora kolejowego wskaźnik ten stał się ważnym elementem określenia skutków oddziaływania innowacji, jaką w warunkach XIX w. była rozbudowa kolei.

${ }^{54}$ D. Donaldson, R. Hornbeck, Railroads and American Economic Growth: a Market Access Approach, https://economics.uchicago.edu/workshops/Hornbeck\%20Richard\%20-\%20Railroads.pdf 


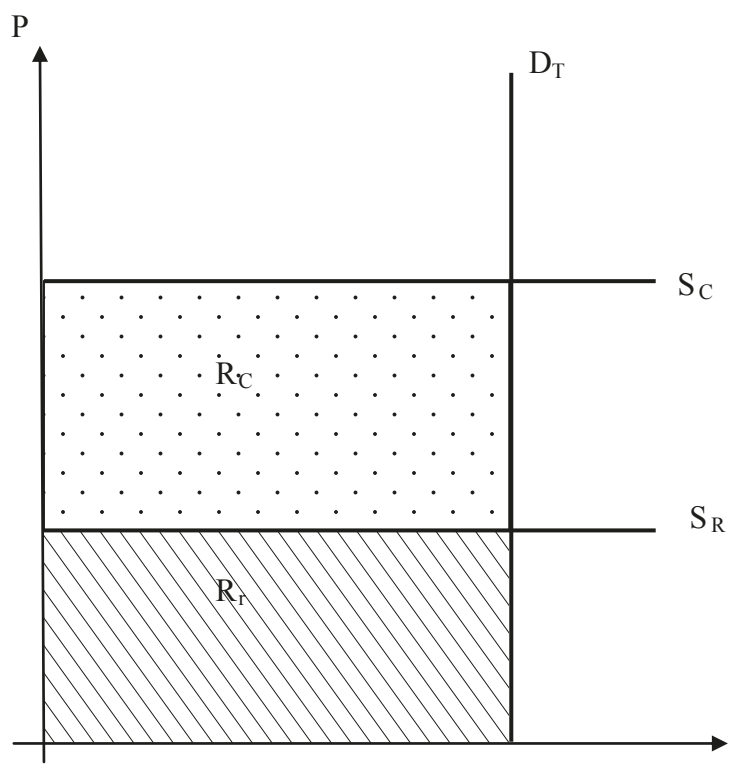

Q

Rysunek obrazuje popyt na usługi transportowe przy założeniu, że ujmowany jest transport kolejowy $\left(\mathrm{S}_{\mathrm{R}}\right)$ lub wykorzystany jest jedynie transport alternatywny $\left(\mathrm{S}_{\mathrm{C}}\right)$. W przypadku, koncepcji social savings należałoby określić, sumę wydatków (przychodów), czyli obszar $\mathrm{R}_{\mathrm{C}}$, który to oznaczałby, jakie oszczędności mogły zaistnieć w gospodarce, w wyniku rozwoju sektora kolejowego.

Rys. 24. Popyt na transport przy uwzględnieniu sektora kolejowego i z uwzględnieniem braku sektora kolejowego

Źródło: opracowanie własne. 



\section{ROZDZIAL III \\ CZYNNIKI WZROSTU GOSPODARCZEGO NIEMIEC}

\section{UWARUNKOWANIA DEMOGRAFICZNE}

Jednym z ważniejszych zmian, przesłanek wzrostu i rozwoju gospodarczego był szybki, niespotykany dotąd w historii przyrost ludności. Jeszcze w XVIII w. przyrost ludności w Niemczech był bardzo nierównomierny - liczba populacji spadała podczas fali wojen oraz klęsk nieurodzaju, chorób. Dopiero od $1770 \mathrm{r}$. obserwuje się nadwyżkę narodzin nad zmarłymi, co oznaczało wzrost populacji.

Ludność świata w początkach XIX w. przekroczyła 1 mld, a już w $1870 \mathrm{r}$. liczba ta wzrosła do 1,3 mld osób. Europę zamieszkiwało około $25 \%$ populacji świata. Niemcy, obok Rosji, Francji i Wielkiej Brytanii, należały do najludniejszych państw europejskich.

Tempo wzrostu ludności w Niemczech i Wielkiej Brytanii przekraczało 1\% rocznie, co oznaczało podwojenie liczby ludności w ciągu 70 lat. W słabo uprzemysłowionej Rosji tempo wzrostu ludności przekraczało $2 \%$ rocznie ${ }^{1}$.

W okresie 1800-1830 liczba ludności Niemiec (państw niemieckich) wzrosła z 24 do 30 mln, osiągając średnie roczne tempo wzrostu 0,7\%. Do 1837 r. ludność Związku Niemieckiego powiększyła się do 40,1 mln osób, a w 1914 r. - do 67 mln. Na Austrię i Prusy przypadało około $60 \%$ całej ludności krajów niemieckich. W najszybszym tempie przybywało mieszkańców na obszarze Prus (koniec XIX w. około 1/3 ogółu ludności)².

${ }^{1}$ J. Skodlarski, R. Matera, Gospodarka światowa. Geneza i rozwój, Warszawa 2004, s. 101105.

${ }^{2}$ W. Czapliński, A. Galos, W. Korta, Historia Niemiec, Wrocław-Warszawa-Kraków-Gdańsk 1981, s. 485. 
Na rys. 25 zobrazowano przyrost demograficzny w wybranych krajach europejskich (w tym w Niemczech) i USA w latach 1820-1913.

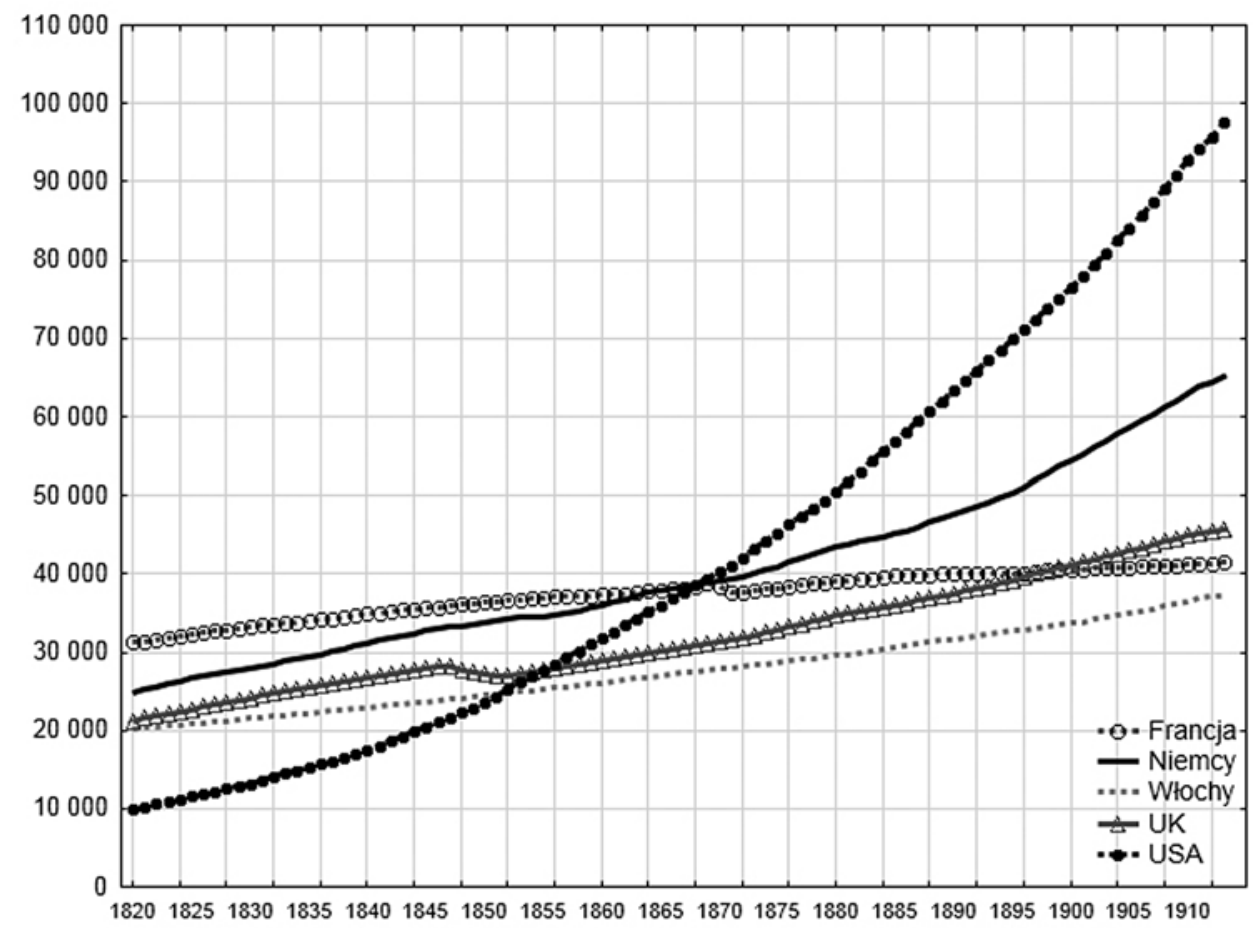

Rys. 25. Przyrost demograficzny w wybranych krajach Europy Zachodniej i USA w latach 1820-1913 (tys. osób)

Źródło: opracowanie własne na podstawie: A. Maddison, Historical Statistics for the World Economy: 1-2003 AD, www.sais-jhu.edu/library/subjectguides/stats.htm [dostęp 02.11.2010]. 
Nie sposób nie zauważyć dokonujących się zmian w miejscu zamieszkania ludności niemieckiej. Jeszcze w 1816 r. około $80 \%$ populacji Prus było mieszkańcami wsi. W 1858 r. liczba ta spadała do poziomu $45 \%$, co stanowiło $16,12 \mathrm{mln}$ osób. W 1816 r. liczba obywateli mieszkających poza wsią wynosiła zaledwie 4,62 mln osób, w 1858 liczba ta wzrosła do 19,38 mln (rys. 26) . $^{3}$.

W $1871 \mathrm{r}$. zaledwie 5\% ludności mieszkało w dużych miastach, ale liczba ta wzrastała bardzo szybko. W 1885 r. w dużych miastach mieszkało już 10\% mieszkańców, w 1905 r. ponad 20\%.

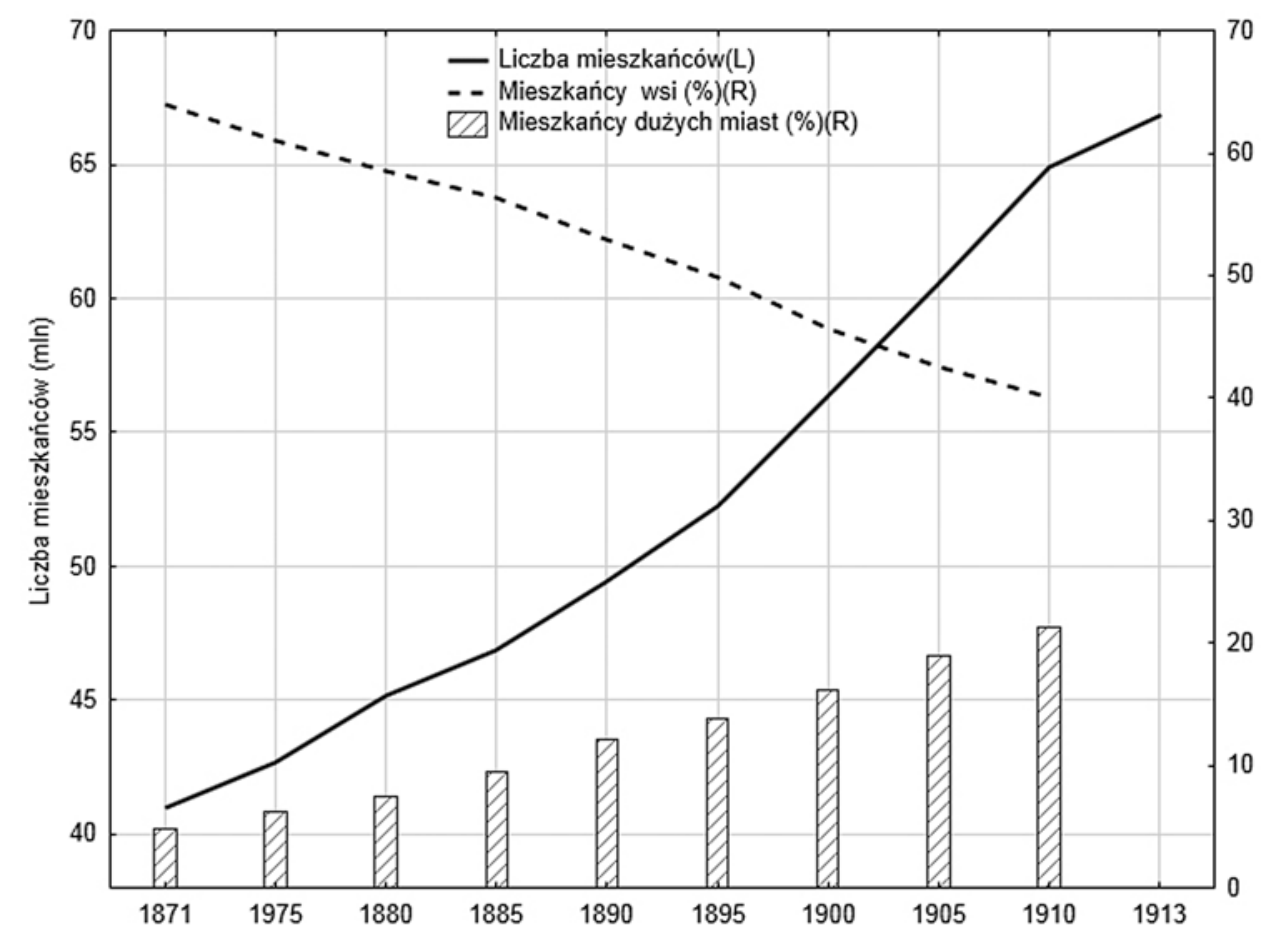

Rys. 26. Industrializacja i urbanizacja w Niemczech (1871-1913).

Źródło: opracowanie własne na podstawie: J. Frerich, M. Frey, Handbuch der Geschichte der Sozialpolitik in Deutschland, Bd. 1, München 1993, s. 86.

Przyspieszony wzrost liczby ludności, zwłaszcza populacji miejskiej wywarł istotny wpływ na wielkość produktu globalnego (PKB).

${ }^{3}$ H.J. Teutenberg, Die Deutsche Landwirtschaft beim Eintritt in die Phase der Hochindustrialisierung, Köln 1977, s. 21. 
Na rys. 27 przedstawiono statystyczną zależność pomiędzy wzrostem liczby ludności a wielkością PKB w latach 1840-1913 r. dla gospodarki Niemiec (ceteris paribus).
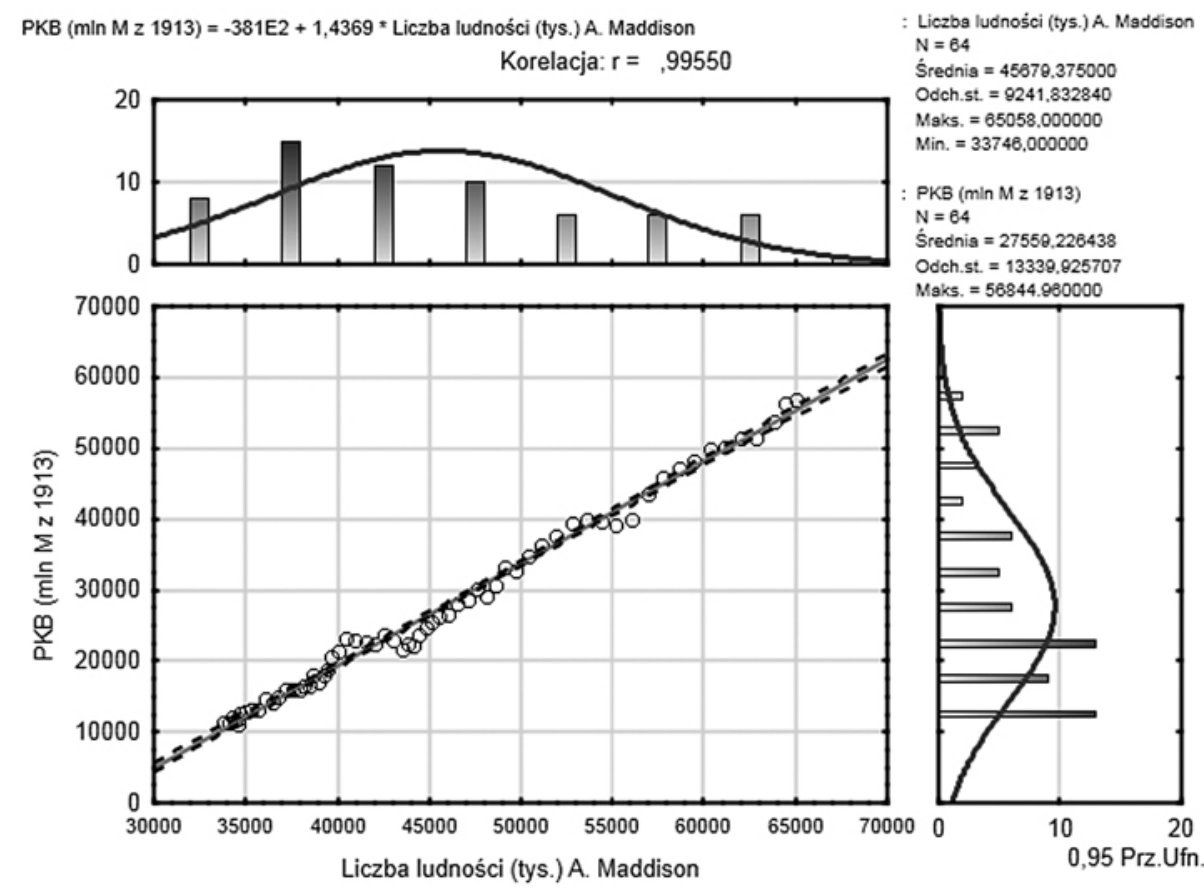

Rys. 27. Wykres rozrzutu PKB (mln marek), liczba ludności Niemiec (tys.) w latach 1840-1913

Źródło: jak do rys. 25.

Współczynnik korelacji $r$ Pearsona pomiędzy zmiennymi jest wysoki i wynosi 0,9955 . Na podstawie wyznaczonej linii trendu, można uznać, że wzrost liczby ludności o jedną jednostkę (tysiąc osób) powoduje przyrost poziomu PKB o ponad 1,4 jednostki (1,4 mln marek) (ceteris paribus).

Chcąc wyjaśnić przyczyny szybkiego wzrostu liczby ludności należy rozpatrywać to $\mathrm{w}$ połączeniu $\mathrm{z}$ ekspansją produkcji w rolnictwie. Większe rozmiary produkcji rolnej oznaczały większą podaż żywności, a także oznaczały większy popyt na pracę w tym sektorze. Świadomość, że świadczona praca wpływa na status materialny, w tym osiągnięcie nadwyżki produkcji nad konsumpcją sprawiały, że notowano większą liczbę narodzin i jej nadwyżkę nad liczbą zgonów. To oczywiście wpływało na naturalny wzrost ludności ${ }^{4}$. Podobnie było z rozwojem przemysłu, w którym tysiące osób znajdowały zatrudnienie.

${ }^{4}$ T. Pierenkemper, R. Tilly, The German Economy During the Nineteenth Century, New YorkOxford 2004, s. 90-93. 
Jak zauważają Janusz Skodlarski i Rafał Matera przyrostu ludności nie można łączyć jedynie z postępującym procesem industrializacji. Podają choćby przykład Rosji, w której tempo rocznego wzrostu liczby ludności przekraczało $2 \%$, a mimo to kraj był zacofany i słabo uprzemysłowiony ${ }^{5}$.

Przedstawiając wzrost liczby ludności dla XIX w. i tempo wzrostu PKB per capita Niemiec można również zauważyć, że mimo wzrostu liczby ludności zauważalny jest również wzrost produktu na osobę - w latach pięćdziesiątych XIX w. średnio na 1 mieszkańca Niemiec przypadało 350 marek w cenach z 1913 r., w początkach wieku XX było to już około $800-850$ marek (rys. 28).

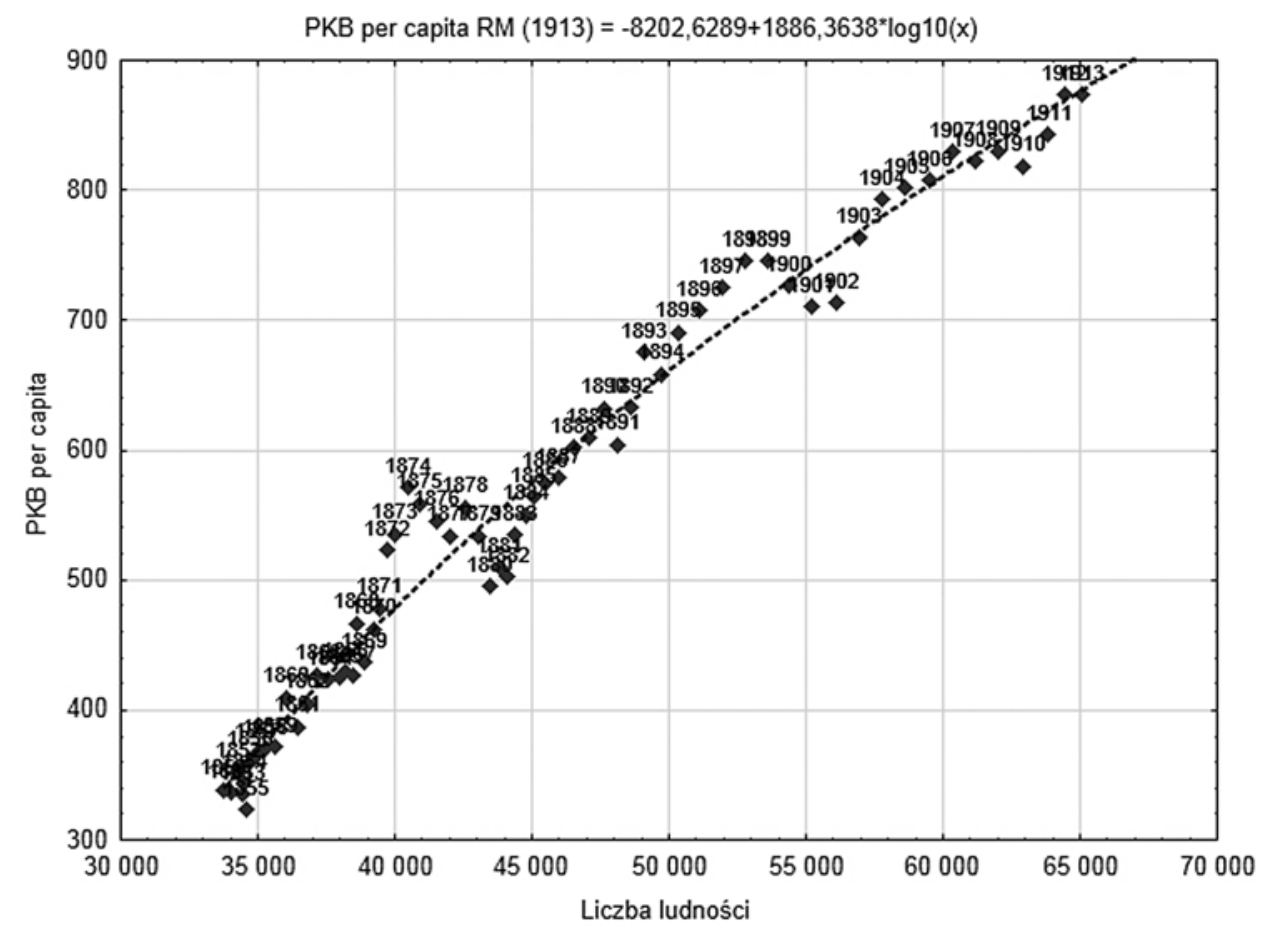

Rys. 28. Rozrzut PKB per capita (w markach, 1913 r.) względem liczby ludności (tys. osób) z określeniem linii trendu

Źródło: opracowanie własne na podstawie danych: W.G. Hoffmann, Das Wachstum der deutschen Wirtschaft seit der Mitte des 19. Jahrhunderts, Berlin 1965; A. Maddison, Historical Statistics for the World Economy: 1-2003 AD, www.sais-jhu.edu/library/subjectguides/stats.htm [dostęp 02.11.2010].

5 J. Skodlarski, R. Matera, op. cit., s. 101 i n. 
Nadal ważnym czynnikiem kreującym popyt na żywność i inne środki konsumpcyjne były wydatki gospodarstw domowych, mimo że ich tempo w II połowie XIX w. miało tendencję malejącą.

Na podstawie dostępnych danych statystycznych można zauważyć, że procentowy udział konsumpcji gospodarstw domowych w stosunku do Produktu Narodowego Netto (PNN) w latach 1850-1854 - 1910-1913 zmniejszył się z 84,4\% do $74,3 \%$, tj. o blisko $10 \%$. Konsumpcja gospodarstw domowych, mimo jej wzrostu w ujęciu finansowym z blisko 9,2 mld marek z lat 1850-1854 do ponad $37 \mathrm{mld}$ marek w latach 1910-1913 wykazuje zdecydowanie mniejsze tempo wzrostu niż sam PNN w tych latach.

Tempo średniego wzrostu PNN w analizowanym okresie wynosiło $2,6 \%$, przy czym wzrost konsumpcji oscylował w okolicach 2,3\%. Zostało to zobrazowane na rys. 29.

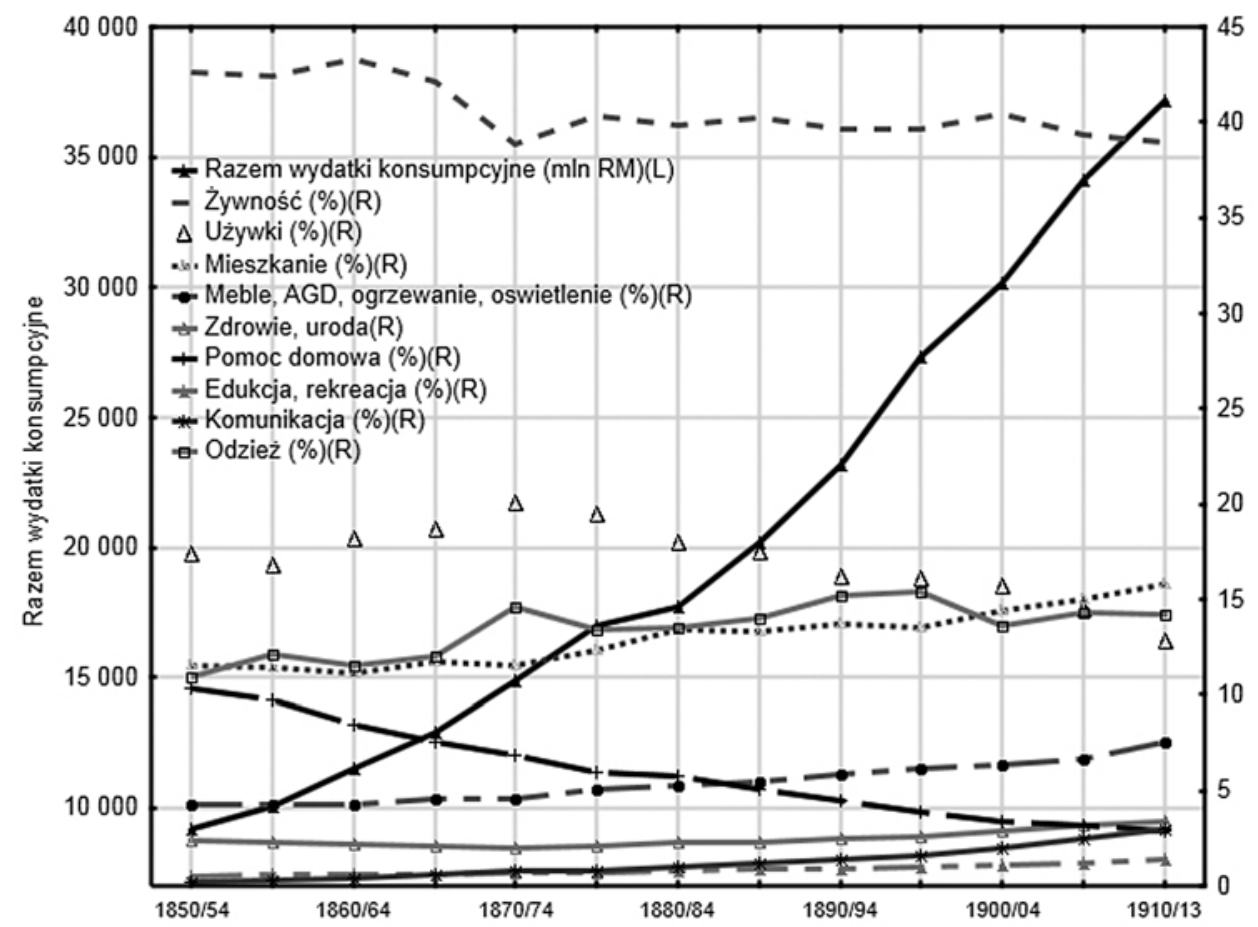

Rys. 29. Wydatki gospodarstw domowych (mln marek) z podziałem na określone grupy (\%) na tle ogólnych wydatków konsumpcyjnych

Źródło: W.G. Hoffmann, Das Wachstum der deutschen Wirtschaft seit der Mitte des 19. Jahrhunderts, Berlin 1965, s. 147. 
W trakcie analizowanego okresu nastąpiły istotne zmiany w strukturze konsumpcji gospodarstw domowych. Tradycyjnie analizę wydatków gospodarstw domowych należy rozpocząć od żywności. W tym czasie w przeważającej części na wydatki konsumpcyjne składały się zakupy żywności, choć zauważalny jest ich spadek o kilka punktów procentowych. Wydatki te spadły z $43 \% \mathrm{w}$ latach pięćdziesiątych XIX w. do 39\% w latach 1910-1913. W tym czasie tylko w kilku okresach rosły wydatki na żywność, będąc silnie skorelowane ze wzrostem wydatków konsumpcyjnych ogółem. W ujęciu finansowym wynosiły (w cenach stałych z 1913 r.) w okresie 1850/54 - 4 mld marek, w okresie 1910-1913 blisko 15 mld marek.

W 1850 r. z 258 marek (w cenach z 1913 r.) wydawanych przez osobę na konsumpcję, średnio 110 marek przypadało na żywność. Do wybuchu I wojny światowej wydatki w ujęciu finansowym rosły średniorocznie o $1,3 \%$, aby w tym czasie podwoić się. Wobec przytoczonych danych, analizując wydatki na żywność na każdego mieszkańca, przy założeniu, że poziom jego dochodów wzrasta w wyniku wzrostu PNN, dochodzimy do potwierdzenia znanego ekonomistom prawa Ernesta Engla. Mówi ono, że w miarę powiększania dochodów realnych na mieszkańca procentowy udział wydatków na żywność maleje. Oznacza to, że elastyczność dochodowa popytu względem dochodu jest ujemna (mniejsza niż 1). Wydatki na pozostałe dobra konsumpcyjne $\mathrm{z}$ reguły wzrastały w analizowanym okresie. Wyjątkiem od tej reguly są wydatki na pomoc domową, które znacznie się zmniejszały, a także znaczne wahania wydatków na używki.

W XIX w. nasilały się procesy emigracyjne i w przypadku gospodarki niemieckiej podstawową ich przyczyną były względy ekonomiczne. Procesy emigracyjne, szczególnie emigracja międzynarodowa w tym transatlantycka ze względu na swoje rozmiary decydowały o podaży pracy. Do lat sześćdziesiątych XIX w. niemiecka emigracja była szczególnie nasilona w południowych krajach (Wirtembergia, Badenia, Palatynat). Małe karłowate gospodarstwa rolne, w tym niewystarczająca podaż ziemi i kapitału skłaniały do poszukiwania innych, lepszych warunków życia.

Podobnie w części wschodniej Prus (East Elbian Prussia) nasilały się ruchy emigracyjne - rywalizacja z tanim zbożem zza oceanu była zabójcza dla mniejszych gospodarstw rolnych, co wpływało na szukanie lepszych warunków życia poza tym obszarem. Szukano głównie lepszych warunków życia w USA, choć poziom emigracji przybierał różne wielkości. Emigracja nasilała się szczególnie w połowie lat pięćdziesiątych (depresja lat pięćdziesiątych, w tym kryzys w rolnictwie), XIX w., początku lat siedemdziesiątych i w całej dekadzie lat osiemdziesiątych XIX w. ${ }^{6}$ Wojna secesyjna w USA ograniczyła falę emigracji. Jak szacuje B. Mitchell w latach 1881-1890 z Niemiec wyemigrowało 1342 tys. osób.

${ }^{6}$ P. Marschalck, Deutsche Überseewanderungen im 19. Jahrhundert. Ein Beitrag zur soziologischen Theorie der Bevölkerung, Stuttgart 1973, s. 35-37. 
Można wysnuć wniosek, że poprawa funkcjonowania gospodarki, w tym większe tempo wzrostu gospodarczego zanotowanego w Niemczech w latach dziewięćdziesiątych XIX w. sprawiło, że wzrósł popyt na pracę. To z kolei skutecznie hamowało rozmiary emigracji ludności ${ }^{7}$. Emigracja w całym dziesięcioleciu wyniosła 527 tys. osób ${ }^{8}$. Na poniższym rysunku przedstawiono wahania liczby emigrantów wraz z określeniem linii trendu (rys. 30).

Oczywiście rozmiary emigracji wpływały na rozwój usług morskich, w tym na przychody miast portowych (Hamburg, Brema), dla których transport był lukratywnym zajęciem.

Jak dowodzą T. Pierenkemper i R. Tilly interesującym epizodem dotyczącym procesów imigracyjnych był obszar na wschód od Łaby. Imigracja dotyczyła siły roboczej zaangażowanej w rolnictwie w $1880 \mathrm{r}$. i przyczyniła się do sezonowych niedoborów pracy. Wówczas posiadacze ziemscy korzystali z taniej siły roboczej z carskiej Rosji, Królestwa Polskiego, Ukrainy. W samych Prusach w latach 1911-1913 liczbę pracowników-emigrantów szacuje się na blisko $1 \mathrm{mln}$ osób. ${ }^{9}$

Wzrost populacji w Niemczech i migracje ludności wpłynęły na ukształtowanie krajowego rynku pracy, a w tym:

- wielkość i strukturę siły roboczej,

- zmiany jakościowe dotyczące siły roboczej,

- zmiany w warunkach życia (zarobki, dochody, liczba godzin pracy),

- efekty instytucjonalne, w tym regulacje prawne, stowarzyszenia zawodowe.

W trakcie analizy zmian społecznych w Niemczech należy uwzględnić przemiany, jakie się dokonały $\mathrm{w}$ trakcie analizowanego okresu w strukturze PNN. Najważniejszymi składnikami tej miary są m.in. obok konsumpcji poziom inwestycji ${ }^{10}$.

Niemniej istotny, aczkolwiek trudno mierzalny był wpływ na postęp gospodarczy rozwoju oświaty. Egzekwowanie obowiązku szkolnego i ustanowienia przez państwo finansowania i kontroli systemu oświaty nastąpiło w Prusach. Wynikało ono z trzech czynników:

- postrzegania szkoły i wykształcenia, jako narzędzia rozwoju świadomości państwowej i narodowej;

- czystego interesu gospodarczego poprzez rozwój gospodarki i administracji publicznej, zwłaszcza w wyniku zatrudniania wykwalifikowanej siły roboczej;

- emancypacyjnego interesu jednostek, poprzez edukację, zmianę życia prywatnego (kwalifikacyjna funkcja szkoły).

7 J. Williamson, The Evolution of Global Markets since 1830: Background Evidence and Hypotheses, „Economic History Review”1995, no. 32, s. 141-146.

${ }^{8}$ B. R. Mitchell, International Historical Statistics: Europe, 1750-2000, London, 2003, s. 129.

9 T. Pirenkamper, R. Tilly, op. cit., s. 98-100.

${ }^{10}$ Omówiony w innych częściach pracy. 


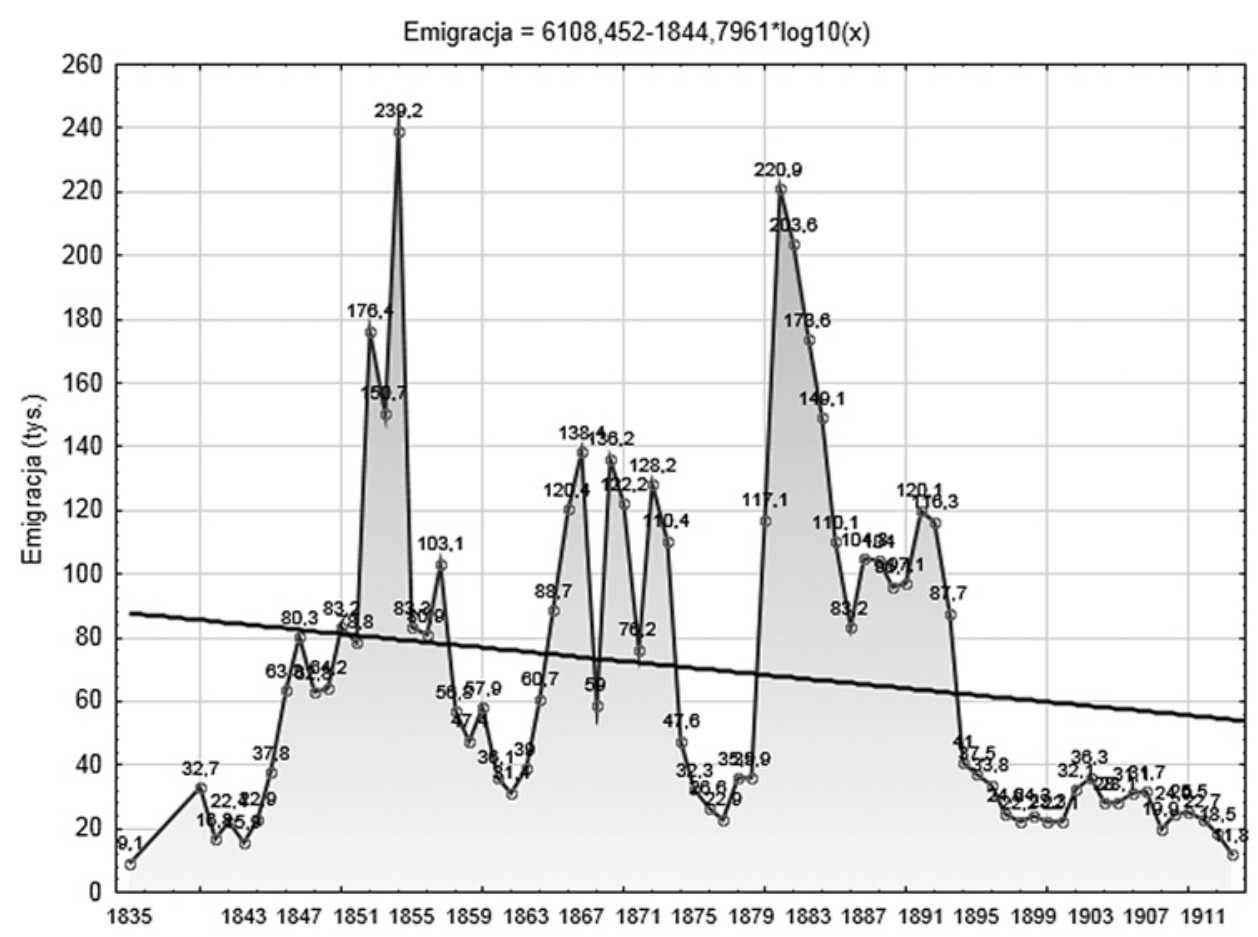

Rys. 30. Emigracja niemiecka w latach 1835-1913 (tys. osób) z określeniem linii trendu

Źródło: opracowanie własne na podstawie: P. Marschalck, Deutsche Überseewanderungen im 19. Jahrhundert. Ein Beitrag zur soziologischen Theorie der Bevölkerung, Stuttgart 1973, s. 35-37.

Już w wieku XVIII w Prusach, podobnie jak w innych państwach niemieckich, wielokrotnie ogłaszano konieczność powszechnej edukacji. Udało się to zrealizować dopiero w XIX w. Na początku wieku nieznacznie ponad połowa młodzieży pobierała naukę w szkole, w końcu XIX w. niemal wszyscy. W $1850 \mathrm{r}$. w Prusach około 80\% dorosłych osób było piśmiennych, w 1900 r. odsetek ten wzrósł do $88 \%$, dla przykładu we Włoszech ten współczynnik wynosił odpowiednio $20-25 \%$ i $52 \%{ }^{11}$.

11 C. Cipolla, Literacy and Development in the West, Baltimore1969, s. 693. 


\section{PRZESLANKI POLITYCZNO-USTROJOWE I GOSPODARCZO-SPOLECZNE}

W XVIII w., kiedy państwa Europy Zachodniej wkroczyły na drogę rozwoju kapitalistycznego, Niemcy były rozbite na liczne państwa i księstwa. Wśród państw niemieckich niewątpliwie pierwsze miejsce zajmowała monarchia austriacka. Na drugie miejsce wysunęły się Prusy. Król pruski Fryderyk Wilhelm I (1713-1740) dążył przede wszystkim do umocnienia finansów państwa i rozbudowy armii. Drastyczne podatki spowodowały pomnożenie dochodów, które w większości przeznaczano na wojsko (z 7 mln talarów globalnego dochodu państwo pruskie pod koniec jego panowania przeznaczało na wojsko $5-6 \mathrm{mln}$ ). Fryderyk Wilhelm I, tworząc silną armię oraz sprawną administrację położył fundamenty pod przyszłą potęgę Prus ${ }^{12}$.

$\mathrm{W}$ czasie wojen $\mathrm{z}$ Napoleonem ważną rolę ogrywała idea zjednoczenia wszystkich krajów niemieckich, w celu utworzenia jednego państwa niemieckiego. Uwieńczeniem tych prób było stworzenie w 1815 r. Związku Niemieckiego oraz Reichstagu - parlamentu niemieckiego. Związek Państw Niemieckich obejmował 34 państwa i 4 wolne miasta. Mimo mnogości krajów, jedynie sześć państw niemieckich (oprócz Austrii) w 1816 r. liczyło ponad jeden milion mieszkańców, a mianowicie: Prusy, Bawaria, Hanower, Wirtembergia, Saksonia i Badenia ${ }^{13}$. Jeśli nie wyłączać 4 wolnych miast, 22 księstwa i elektoraty liczyły mniej niż 1\% ogólnej powierzchni Związku Niemieckiego.

$\mathrm{Na}$ mapie przedstawionej na rys. 31 uwidocznione zostały granice państw niemieckich będących członkami Związku Niemieckiego.

Suwerenność członków Związku była ograniczona w niewielkim stopniu: nikt nie mógł wystąpić ze Związku i nie wolno było zawierać sojuszów wymierzonych przeciw niemu. Władze Związku były słabe. Sejm związkowy i Wyższa Rada zajmowały się sprawami drugorzędnymi ${ }^{14}$.

Pod względem politycznym w łonie Związku Niemieckiego ścierały się dwa obszary:

- państwa południowe ciążyły ku Austrii,

- państwa północne ciążyły ku Prusom.

${ }_{12}$ W. Czapliński, A. Galos, W. Korta, op. cit., s. 381, 383, 386.

${ }_{13}$ Por. M. Dubiecki, Rys dziejów najnowszych od r. 1815 po 1875. Z krótkim rzutem oka na dzieje lat 1876-1878, Wilno 1880, s 11.

${ }^{14}$ W. Czapliński, A. Galos, W. Korta, op. cit., s. 481-482. 


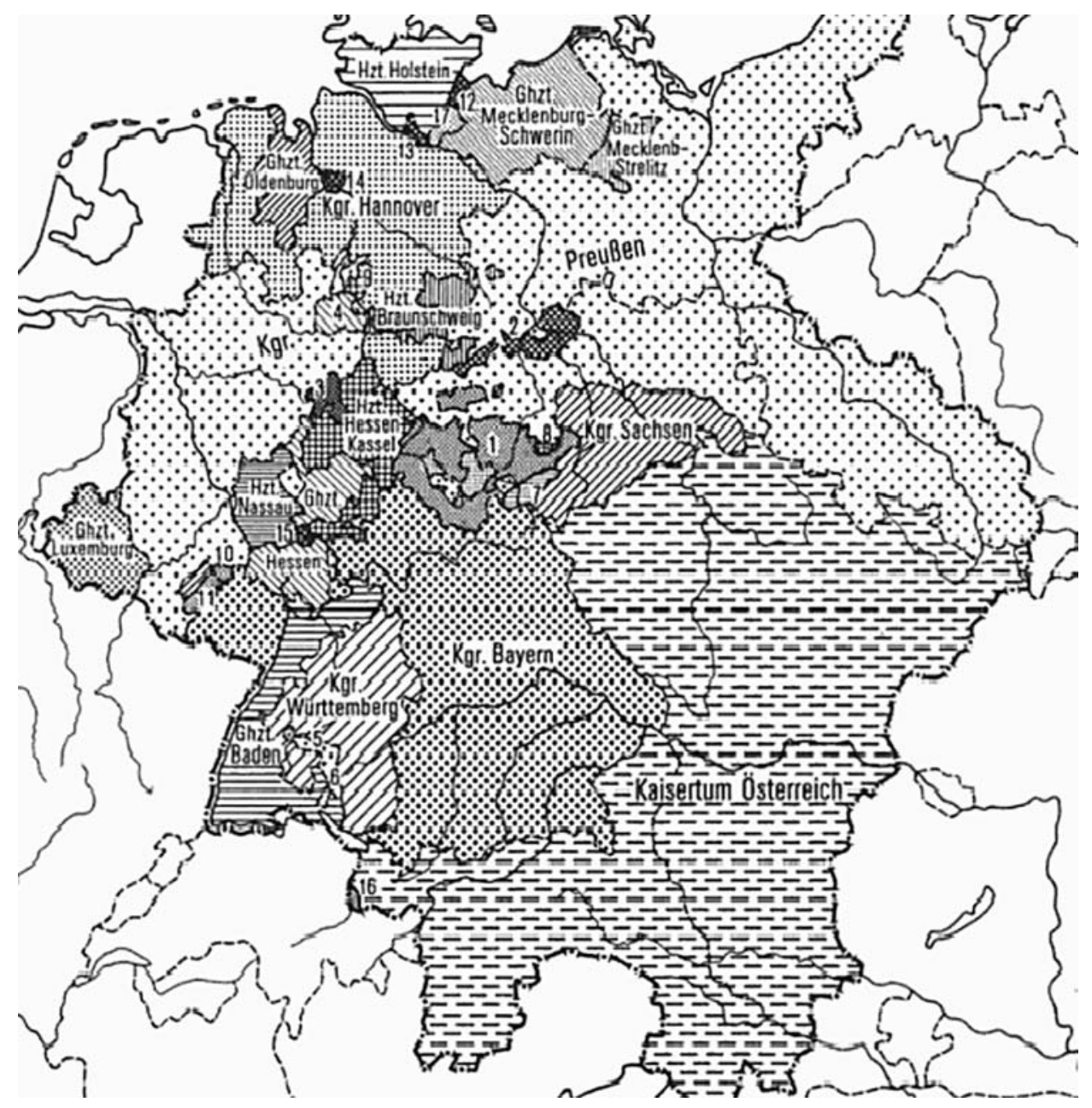

Rys. 31. Kraje Związku Niemieckiego w 1815 r.

Źródło: H. Kiesewetter, Region und Industrie in Europa 1815-1995, „Grundzüge der modernen Wirtschaftsgeschichte" 2000, Nr. 2, s. 39.

Państwa północne pierwsze poderwały się do walki z Napoleonem, a wśród obywateli wzrosło znaczenie ruchu patriotyczno-narodowego. Państwa południowe przodowały natomiast w sferze przemian społecznych. Państwa te otrzymały najwcześniej konstytucje (Księstwo Sasko-Weimarskie - 1816 r., Bawaria, Badenia - 1818 r., Wirtembergia - 1819 r., Księstwo Hesji - Darmstadt - 1820 r.).

Formalny prymat $\mathrm{w}$ Związku przejęła Austria, ale szybko okazało się, że na funkcjonowanie Związku negatywny wpływ miała jej rywalizacja z Prusami. W konsekwencji doprowadziło to do unicestwienia parlamentu i całego 
Związku Niemieckiego ${ }^{15}$. W przyszłości to największe państwa Związku (Austria, Prusy, Bawaria, Saksonia) miały istotny wpływ na rozwój przemysłu i krzewienie industrializacji w pozostałych krajach niemieckich.

Na obszar Niemiec napływały prądy liberalne. Okres napoleoński pozostawił po sobie trwały ślad. Na początku XIX w. patriotyczne i światłe grupy, wywodzące się z elit niemieckich, przystąpiły do reformowania gospodarki. Najwcześniej podjęto je w Prusach. Geneza reform tkwiła w rozpaczliwej sytuacji finansowej państwa po przegranej wojnie i skutkach blokady kontynentalnej ${ }^{16}$.

Wybitny reformator Prus Heinrich Friedrich Karl Stein podjął trzy wielkie dzieła: reformę agrarną, ordynację miejską i reorganizację urzędów. Największe znaczenie miało uwłaszczenie chłopów (edykty z lat: 1807, 1811, 1816, 1821, 1827,1850 i 1857). Chłopi otrzymali ziemię na własność i zniesione zostały powinności feudalne. Reforma agrarna umocniła pozycję obszarników (junkrów) pruskich. Przejęli oni ok. 1/3 ziemi chłopskiej ${ }^{17}$. Zmieniono też ustrój najwyższych władz państwowych (utworzono rząd na czele z kanclerzem), rozpoczęto reorganizację administracji i wprowadzono nowy system podatkowy ${ }^{18}$. Powyższe reformy zapoczątkowały pruską drogę do kapitalizmu.

Nader ważnym etapem na drodze prowadzącej do gospodarki rynkowej na ziemi niemieckiej było utworzenie Związku Celnego w 1834 r. Na obszarze Związku zamieszkiwało 5/6 obywateli niemieckich (nie licząc Austrii). Poza jego granicami pozostały kraje północnozachodnie, związane gospodarczo z Anglią. Wstępowały one stopniowo do Związku Celnego w następnych dziesięcioleciach (ostatnie w 1867 r.). Do Związku nie należała Austria, co zapowiadało jej usunięcie z przyszłych Niemiec. Utworzenie Związku Celnego miało wprawdzie podłoże gospodarcze, ale w następnych latach wywarło wpływ na stosunki polityczne i przyczyniło się do zjednoczenia Niemiec pod kierownictwem Prus ${ }^{19}$.

Postęp techniczny i technologiczny przyczynił się do dalszego rozwoju gospodarki niemieckiej. Początkowo Niemcy korzystali z dorobku rewolucji przemysłowej w Anglii. Transfer technologii z Wielkiej Brytanii nie był bezkrytycznym kopiowaniem wynalazków angielskich. Był to raczej długotrwały proces przystosowania techniki i technologii do lokalnych warunków niemieckich.

Przemysłowcy niemieccy nie ograniczali się do importu innowacji. Przedstawiciele nauki, inżynierowie i konstruktorzy wnieśli własny wkład do rewolucji przemysłowej. O zasługach w rozwój motoryzacji G. Daimlera i R. Diesla była już mowa wcześniej. Bracia Wilhelm Friedrich i Werner Siemensowie byli genialnymi konstruktorami. Wilhelm Siemens wraz z bratem Friedrichem zbudowali

\footnotetext{
${ }^{15}$ A. Czubiński, Wybrane problemy historii Niemiec w XIX i XX wieku, Poznań 1992, s. 5.

16 W. Czapliński, A. Galos, W. Korta, op. cit., s. 460.

17 W. Grabska, Ekonomiczna ekspansja Niemiec na Wschód w latach 1870-1939, WrocławWarszawa-Kraków 1964, s. 8 i n.

18 W. Czapliński, A. Galos, W. Korta, op. cit., s. 460-464.

19 Tamże, s. 489-490.
} 
piec z regeneracją ciepła spalin. Wynalazek ten został wykorzystany przez Francuza Paula Martina przy budowie pieca do wytopu stali. Piec braci Siemensów został również zastosowany do przemysłowej produkcji szkła. W. Siemens skonstruował m.in. pierwszy model kolei elektrycznej. Do praktycznego użytkowania energii elektrycznej przyczyniły się istotnie osiągnięcia fizyka Jerzego Ohma. Dzięki Niemcom: Fryderykowi Wohlerowi i Justusowi Liebigowi dokonał się postęp w dziedzinie chemii organicznej. J. Liebig pierwszy na wielką skalę zajął się problemem stosowania nawozów mineralnych $\mathrm{w}$ rolnictwie ${ }^{20}$.

Postęp techniczny wpłynął na przyśpieszenie uprzemysłowienia. Pierwsza faza industrializacji rozpoczyna się po 1835 r. W Zagłębiu Ruhry i na Górnym Śląsku rozwija się górnictwo i hutnictwo. W 1850 r. wydobywano 6,7 mln Mg węgla. Pod względem technicznym Śląsk początkowo wyprzedzał zachodnie okręgi Niemiec. W końcu XVIII w. w Gliwicach uruchomiono wielki piec, w którym zastosowano koks do wytopu surówki. Do 1808 r. zbudowano na Górnym Śląsku jeszcze pięć takich pieców. Nowoczesnym zakładem była Huta Królewska, gdzie na początku XIX w. uruchomiono cztery wielkie piece. Od połowy XIX w. rozpoczynają wielką karierę zakłady metalurgiczne Kruppa w Essen. W 1865 r. zatrudniano w nich 8 tys. robotników. W latach 1800-1840 produkcja stali wzrosła z 40 do 208 tys. Mg. Ogółem produkcja przemysłowa w tym czasie w Związku Niemieckim potroiła się ${ }^{21}$.

$\mathrm{W}$ omawianym okresie rozwój gospodarki hamowały różne czynniki. Brakowało kapitałów, a wolność gospodarcza przedsiębiorców była często ograniczana. Główne jednak przyczyny związane były z rozbiciem politycznym Niemiec. Podział kraju uniemożliwiał prowadzenie jednolitej polityki ekonomicznej. Rynek niemiecki zalewały towary z zachodniej Europy, co skutecznie hamowało wzrost własnej produkcji. Po zwycięskiej wojnie z Danią w 1864 r. Prusy parły zdecydowanie do zjednoczenia Niemiec. Kanclerz Otto von Bismarck dysponował silną armią i miał poparcie junkrów pruskich, rozbudzonych nacjonalistycznie, a także mieszczaństwa niemieckiego ${ }^{22}$.

Na drodze do zjednoczenia stała Austria i jej zwolennicy w Związku Niemieckim. Zwycięstwo Prus nad Austrią 1866 r., a następnie wygrana wojna z Francją (1870-1871 r.) otworzyły drogę do zjednoczenia Niemiec pod egidą Prus.

Przełomowym wydarzeniem w dziejach Niemiec był dzień 18 stycznia 1871 r., kiedy powstała Rzesza, jako państwo federalne. Na jej czele stanął król pruski, noszący tytuł cesarza niemieckiego. Zjednoczenie narodowe stanowiło rewolucyjny postęp w stosunku do stanu sprzed lat zaledwie pięciu, gdy Niemcy były rozbite na 33 państwa ${ }^{23}$.

${ }^{20}$ M. Żywczyński, Historia powszechna, 1789-1870, Warszawa 1990, s. 206.

${ }^{21}$ W. Czapliński, A. Galos, W. Korta, op. cit., s. 487; W. Rusiński, Zarys historii gospodarczej powszechnej, Warszawa 1970, s. 188-189.

${ }_{22}$ M. Żywczyński, op. cit., s. 500-501.

${ }_{23}$ J. Krasuski, Historia Niemiec, Wrocław-Warszawa-Kraków 2004, s. 230-231. 
Konstytucję Rzeszy uchwalił parlament (Reichstag) 16 kwietnia 1871 r.; przygotowując ją wzorowano się ściśle na konstytucji Związku Północnoniemieckiego, co zapewniało całkowitą przewagę Prusom. Rzesza stała się federacją 25 państw: 4 królestw, 6 wielkich księstw, 12 księstw i 3 wolnych miast. Rządy poszczególnych państw były reprezentowane w Radzie Federalnej (Bundesrat), rozporządzając w niej liczbą głosów stosowną do swej wielkości. Rada Federalna miała łącznie z parlamentem władzę ustawodawczą. Parlament mógł być wcześniej rozwiązany na mocy uchwały Rady i zgody cesarza. Cesarz niemiecki posiadał dużą władzę. Reprezentował on Rzeszę na zewnątrz, sprawował naczelne dowództwo nad armią, mianował i zwalniał urzędników państwowych, zwoływał, odraczał i zamykał posiedzenia Rady Związku i parlamentu oraz ogłaszał ustawy ${ }^{24}$.

Szerokie uprawnienia skupiał w swoim ręku kanclerz Rzeszy, mianowany przez cesarza. Był on kierownikiem polityki wewnętrznej i zagranicznej, i równocześnie zwierzchnikiem całej administracji państwowej. Kanclerz był odpowiedzialny wyłącznie przed cesarzem. Rzesza nie miała rządu odpowiedzialnego przed parlamentem ${ }^{25}$.

Prawie całą dziedzinę polityki wewnętrznej pozostawiono w kompetencji państw związkowych. Ustawy Rzeszy miały pierwszeństwo przed ustawami państw związkowych, co stwarzało możliwość rozszerzania uprawnień władz centralnych. Dotyczyło to zwłaszcza skarbowości ${ }^{26}$.

Zjednoczone Niemcy, wzmocnione politycznie i gospodarczo po wygranej wojnie z Francją, miały dogodne warunki do dalszego rozwoju ekonomicznego. Sprzyjał im też nowy układ kształtujący się od 1870 r. - gospodarka monopolistyczna. Na jej bazie Rzesza rozbuduje siłę militarną państwa i będzie parła do następnej wojny.

\section{ROZWÓJ PRZEMYSEU}

Po zjednoczeniu Niemcy rozpoczęły w szybkim tempie nadrabiać opóźnienia w stosunku do uprzemysłowionych państw Zachodu. W polityce gospodarczej położono nacisk na rozwój przemysłu ciężkiego oraz na „przemysły młode”, oparte na najnowszych technologiach, zwłaszcza na przemysł chemiczny i elektrotechniczny. Wzrostowi produkcji sprzyjała monopolizacja gospodarki oraz przygotowania Niemiec do wojny.

W latach 1911-1913 w Niemczech w przemyśle ciężkim dominowały wielkie przedsiębiorstwa. Sześć spośród dwudziestu pięciu największych niemieckich firm funkcjonowało w górnictwie lub przemyśle metalowym. Aktywa 1/3

\footnotetext{
${ }^{24}$ K. Koranyi, Powszechna historia państwa i prawa, t. IV, Warszawa 1967, s. 315-316.

${ }_{25}$ Tamże, s. 316.

26 J. Krasuski, op. cit., s. 232.
} 
wielkich przedsiębiorstw reprezentowane były w przemyśle ciężkim. Ważnym sektorem był transport z ogromnymi kompaniami żeglugowymi HAPAG i Norddeutscher Lloyd. Kolejne sektory z dużymi przedsiębiorstwami to przemysł elektrotechniczny, chemiczny, maszynowy (np. Bayer, BASF, Siemens, AEG, Krupp).

Biorąc pod uwagę rozwój niemieckiej gospodarki w latach 1850-1913 wyniki te nie są zaskakujące. Wielu ekonomistów, w tym W.W. Rostow, uważało, że hutnictwo żelaza, stali i węgla było jednym z wiodących sektorów niemieckiego uprzemysłowienia. W porównaniu do innych krajów europejskich może zastanawiać brak w grupie dużych przedsiębiorstw korporacji kolejowych, skoro w wielu krajach, w tym Niemczech, sieć dróg żelaznych odnotowała swój silny rozwój. Wyjaśnieniem jest przeprowadzona od 1870 r. m.in. z inicjatywy Prus nacjonalizacja kolei. Dla przykładu, spośród 60512 km dróg żelaznych w 1912 r. jedynie $5 \%$ było w posiadaniu prywatnych przedsiębiorstw.

Wspomniany R. Tilly w swoich badaniach podkreśla potrzebę uwzględnienia rozwoju wielkiego biznesu, jako kluczowego czynnika dla rozwoju gospodarczego w krajach uprzemysłowionych ${ }^{27}$. Poniższe zestawienie prezentuje kartelizację gospodarki niemieckiej na przełomie XIX i XX w. w porównaniu do gospodarki Austrii i Węgier (tab. 14).

Tabela. 14. Liczba krajowych karteli w Niemczech, Austrii, Węgrzech

\begin{tabular}{|l|c|c|c|}
\hline \multicolumn{1}{|c|}{ Lata } & Niemcy & Austria & Węgry \\
\hline 1865 & 4 & & \\
\hline 1887 & 70 & & 8 \\
\hline $1890-1891$ & 117 & 50 & \\
\hline $1900-1902$ & 300 & 100 & 50 \\
\hline $1905-1906$ & 385 & 120 & \\
\hline $1911-1912$ & $550-660$ & & \\
\hline
\end{tabular}

Źródło: H. Wagenführ, Kartelle in Deutschland, Nürnberg 1931; J. Fear, Cartels and Competition: Neither Markets nor Hierarchies, http://www.hbs.edu/faculty/Publication\%20Files/07-011. pdf [dostęp 10.11.2012].

Liczba krajowych karteli w przypadku Niemiec wzrosła z kilku w latach sześćdziesiątych XIX w., do 300 na początku XX w., aby tuż przed wybuchem I wojny światowej osiągnąć liczbę blisko 700 .

Najnowsze badania dotyczące dużych podmiotów gospodarczych w warunkach XX w. z wykorzystaniem m.in. analizy benchmarkingowej były przeprowadzone w ramach projektu The Performance of European Business in the 20th

${ }^{27}$ R. Tilly, Großunternehmen: Schlüssel zur Wirtschafts- und Sozialgeschichte der Industrieländer?, „Geschichte und Gesellschaft” 1993, Nr. 19, s. 530-548. 
Century. Gospodarka niemiecka poddana była analizie m.in. przez naukowców Uniwersytetu w Kolonii.

Spośród analizowanych przedsiębiorstw najlepsze wyniki (wskaźnik ROE return on equity) uzyskały m.in. Bayer $-26,7 \%$, Hoechst $-26,7 \%$, BASF $22,7 \%$, Phoenix AG für Bergbau und Hüttenbetrieb - 22,3\%, Siemens \& Halske AG - 20,1\%, Krupp - 16,8\%, Berliner Elektricitäts - Werke - 16,0\%, Maschinenbau-Anstalt „Humboldt” - 15,1\%, Siemens - Schuckertwerke GmbH 14,3\%, AEG - 13,0\%.

Ujemny wynik ROE uzyskały z kolei: Berliner Terrain - und Bau AG (-42.2\%), Tapeten-Industrie AG - 0,3\%, Handelsgesellschaft für Grundbesitz $1,6 \%$, Ostafrikanische Eisenbahngesellschaft - 1,6\%, Vulkan-Werke - 4,6\% ${ }^{28}$.

Trzy najlepsze rezultaty uzyskały firmy działające w przemyśle chemicznym i trzy największe firmy elektryczne. $Z$ kolei kartele z trzech gałęzi gospodarki węgla, żelaza i stali, i potasu są uważane za najważniejsze i najbardziej skuteczne w Niemczech (tab. 15) ${ }^{29}$.

Tabela 15. Kartelizacja niemieckiej gospodarki - wskaźnik zatrudnienia, udział w produkcji (1907 r.)

\begin{tabular}{|l|c|c|c|}
\hline \multicolumn{1}{|c|}{ Branża } & $\begin{array}{c}\text { Zatrudnieni w 20 } \\
\text { największych } \\
\text { przedsiębiorstwach } \\
(\%)\end{array}$ & Liczba karteli & $\begin{array}{c}\text { Udział karteli } \\
\text { w produkcji brutto } \\
(\%)\end{array}$ \\
\hline Górnictwo & 5,60 & 19 & 74 \\
\hline Hutnictwo żelaza i stali & 21,50 & 62 & 20 \\
\hline Konstrukcje żelazne i stalowe & 4,37 & 0 & 2 \\
\hline Maszyny i urządzenia & 5,75 & 1 & 9 \\
\hline Przemysł elektryczny & 32,50 & 2 & 5 \\
\hline Mechanika precyzyjna, optyka & 16,25 & 1 & 36 \\
\hline Przemysł chemiczny & 19,00 & 32 & 89 \\
\hline Przemysł szklarski & 19,10 & 10 & 5 \\
\hline Cementownie & 23,35 & & \\
\hline Papiernictwo & 13,00 & 6 & \\
\hline Przemysł skórzany & 11,75 & 31 & \\
\hline Przemysł tekstylny & & & \\
\hline
\end{tabular}

Źródło: H. Pohl, Die Konzentration in der deutschen Wirtschaft vom ausgehenden 19. Jahrhundert bis 1945, [w:] H. Pohl, W. Treue, Die Konzentration in der deutschen Wirtschaft seit dem 19. Jahrhundert, „Zeitschrift für Unternehmensgeschichte”1987, Beiheft 11, s. 4-44.

${ }^{28}$ D. Dammers, H. Fischer, The Performance of German Big Business in the 20th Century, „Cologne Economic History Paper” 2009, no. 1.

${ }_{29}$ J. Kleeberg, German Cartels: Myths and Realities, http://econ.barnard.columbia.edu/econhist/papers/Kleeberg German Cartels.pdf. 
Jak wspomniano powyżej, wielkie przedsiębiorstwa uzyskiwały większe korzyści skali produkcji, co umożliwiło spadek jednostkowych kosztów wytwarzania i skuteczne konkurowanie z innymi uczestnikami rynku. Duże firmy z racji przychodów mogły również przeznaczać zwiększone środki na inwestycje. Związki monopolistyczne przyspieszyły rozwój sił wytwórczych, stąd też kapitalizm monopolistyczny był bardziej wydajnym od kapitalizmu wolnokonkurencyjnego. $Z$ rozwojem wielkich organizacji monopolistycznych następowała koncentracja kapitału i operacji finansowych w bankowości.

Rozwój przemysłu (w tym ciężkiego) po połowie lat pięćdziesiątych XIX w. ma swoje odzwierciedlenie w zapotrzebowaniu na surowce, $\mathrm{w}$ tym węgiel kamienny, węgiel brunatny, rudy żelaza. Dynamikę wzrostu zapotrzebowania na te trzy kopaliny obrazuje rys. 32 .

Największy wzrost produkcji i zapotrzebowania był na węgiel kamienny indeks z 1,1\% (1835 r.) w stosunku do roku 1913 r. szybko wzrastał: w $1860 \mathrm{r}$. wyniósł 6,5\%, w 1880 r. -24,7\%, w $1900-57,5 \%$, w $1910-84,6 \%$.

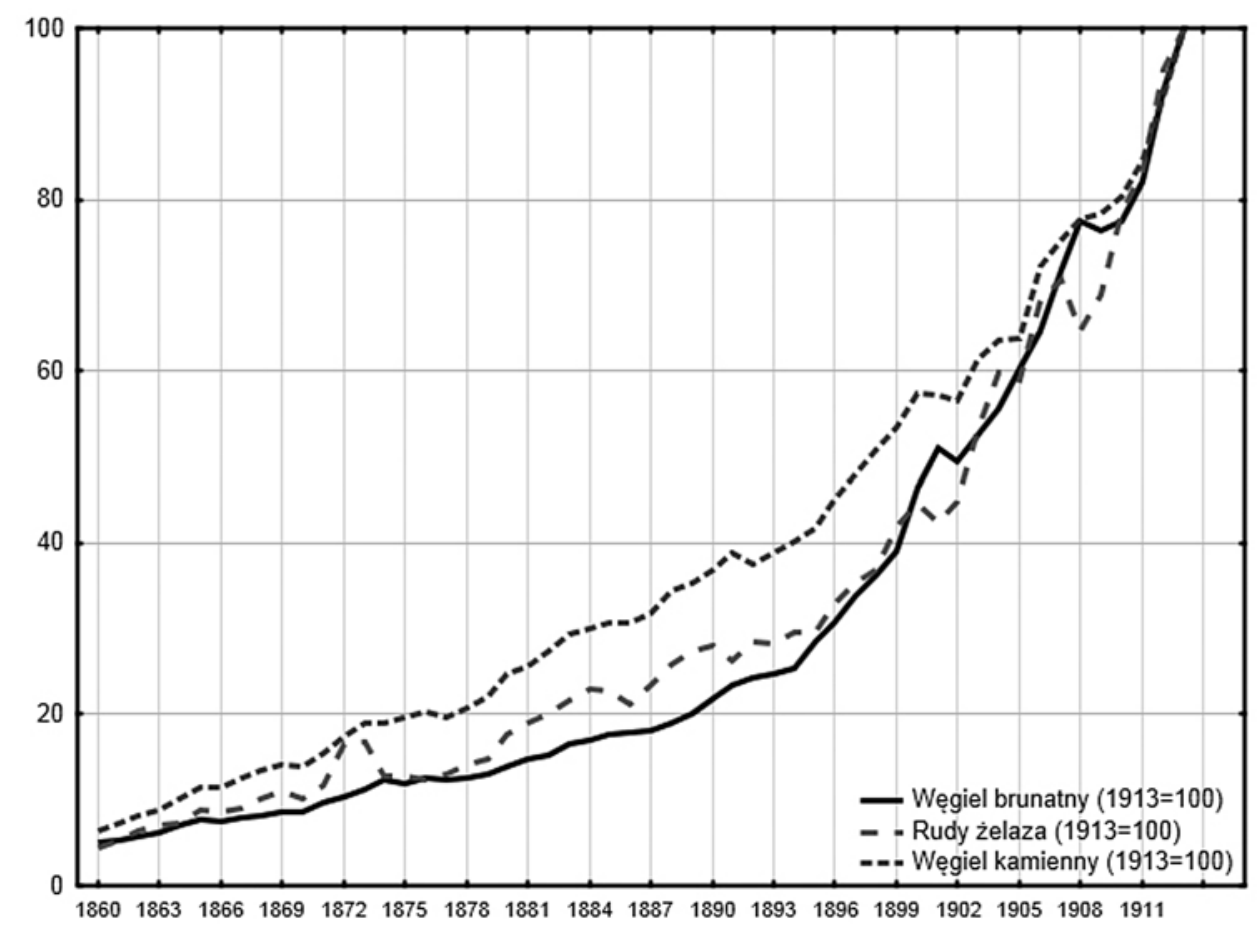

Rys. 32. Indeks - produkcja węgla kamiennego, węgla brunatnego oraz rudy żelaza - Niemcy $(1913=100)$

Źródło:jak do rys. 29, s. 147. 
Zdumiewająca jest budowa pozycji światowej Niemiec, jako producenta surówki żelaza. Na poniższym wykresie przestawiono produkcję surówki w tys. $\mathrm{Mg}$ metrycznych dla Wielkiej Brytanii, Niemiec, Francji, Belgii w latach 1880-1910 (rys. 33).

W 1880 r. niemieckie huty wytwarzały 2729 tys. Mg surówki, w 1910 r. 14794 tys. Mg. Daje to imponujący średni wzrost produkcji rocznej o ponad 400 tys. Mg. W 1910 r. Niemcy produkowały o ponad 4622 tys. Mg surówki więcej niż Wielka Brytania. Równie imponujący wzrost produkcji osiągnięto w produkcji stali: w 1880 r. Niemcy wytwarzały, w Mg metrycznych, 1548 tys. stali, w tym czasie Wielka Brytania wykazywała produkcję w wysokości 3730 tys. stali. W trzydzieści lat później Niemcy wytwarzały 13149 tys. Mg metrycznych stali, Zjednoczone Królestwo jedynie 7613 tys. Mg.

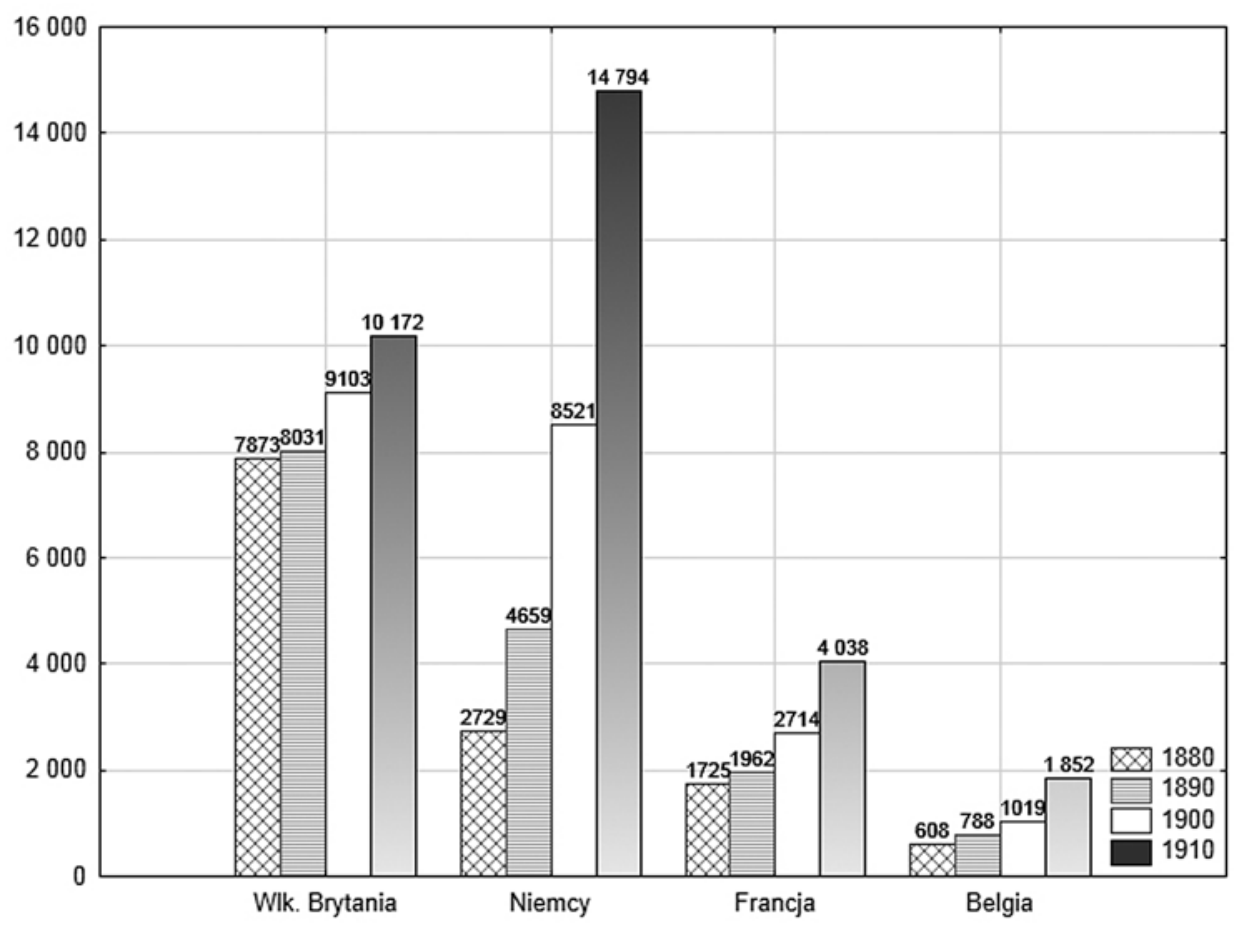

Rys. 33. Produkcja surówki hutniczej w wybranych krajach europejskich w latach 1880-1910 (tys. Mg metrycznych)

Źródło: opracowanie własne na podstawie: J.H. Clapham, The Economic Development of France and Germany 1815-1914, Cambridge 1921, s. 285.

W latach 1890-1910 Niemcy stały się liderem w produkcji surówki i stali. Jedynie Stany Zjednoczone wytwarzały więcej. Szybko wzrastał udział Niemiec w produkcji światowej (tab. 16). 
Tabela 16. Rynkowy udział wybranych państw w produkcji przemysłowej w latach 1830-1913 (\%)

\begin{tabular}{|c|c|c|c|c|c|c|c|}
\hline \multirow{2}{*}{ Rok } & \multicolumn{7}{|c|}{ Kraj } \\
\cline { 2 - 8 } & USA & $\begin{array}{c}\text { Wielka } \\
\text { Brytania }\end{array}$ & Niemcy & Francja & Rosja & $\begin{array}{c}\text { Inne kraje } \\
\text { rozwinięte }\end{array}$ & Pozostałe \\
\hline 1830 & 2,4 & 9,5 & 3,5 & 5,2 & 5,6 & 13,3 & 60,5 \\
\hline 1860 & 7,2 & 19,9 & 4,9 & 7,9 & 7,8 & 15,7 & 36,6 \\
\hline 1913 & 32 & 13,6 & 14,8 & 6,1 & 8,2 & 17,8 & 7,5 \\
\hline
\end{tabular}

Źródło: P. Bairoch, International industrialization levels from 1750 to 1980, „The Journal of European History" 1982, no. 2, s. 269-333.

Niemcy wysunęły się na pierwsze miejsce w Europie w przemyśle chemicznym. Zespół przedsiębiorstw Badische Anilin-und Soda-Werke wytwarzał przed I wojną światową 1/3 światowej produkcji siarczanu amonu i $10 \%$ kwasu siarkowego. W 1913 r. w Niemczech wyprodukowano 75\% światowej produkcji aniliny, produktu wyjściowego w produkcji barwników syntetycznych. Ponadto Niemcy były czołowym światowym producentem aspiryny Bayera i syntetycznej farby indygo ${ }^{30}$.

Przyśpieszenie gospodarki niemieckiej po 1834 r., a zwłaszcza po 1870 r. dobitnie potwierdzają dane zawarte $\mathrm{w}$ tab. 17. Rozbite politycznie Niemcy, przed uformowaniem Niemieckiego Związku Celnego miały udział 3,5\% w produkcji światowej, blisko trzykrotnie mniej niż Anglia. W czterdzieści lat później gospodarka niemiecka wytwarzała już $13,2 \%$ produkcji światowej, a jej wzrost był tylko niższy od USA.

Tabela 17. Udział w światowej produkcji przemysłowej oraz udział w produkcji przemysłowej poszczególnych krajów „czwórki” (\%)

\begin{tabular}{|l|r|r|r|r|r|r|r|}
\hline \multirow{2}{*}{ Kraj } & \multicolumn{7}{|c|}{ Lata } \\
\cline { 2 - 9 } & 1830 & 1860 & 1870 & $1880-1885$ & $1896-1900$ & $1906-1910$ & 1913 \\
\hline \multicolumn{7}{|c|}{ udział w produkcji światowej } \\
\hline Anglia & 9,5 & 19,9 & 31,8 & 26,6 & 19,5 & 14,7 & 14,0 \\
\hline USA & 2,4 & 7,2 & 23,3 & 28,6 & 30,1 & 35,3 & 35,8 \\
\hline Francja & 5,2 & 7,9 & 10,3 & 8,6 & 7,1 & 6,4 & 6,4 \\
\hline Niemcy & 3,5 & 4,9 & 13,2 & 13,9 & 16,6 & 15,9 & 15,7 \\
\hline Razem & 20,6 & 39,9 & 78,6 & 77,7 & 73,3 & 72,3 & 71,9 \\
\hline
\end{tabular}

${ }^{30}$ W. Rusiński, Zarys historii gospodarczej powszechnej, Warszawa, 1970, s. 328. 
Tabela 17. (cd.)

\begin{tabular}{|l|r|r|r|r|r|r|r|}
\hline \multicolumn{7}{|c|}{ udział w produkcji ,czwórki” } \\
\hline Anglia & 46,1 & 49,9 & 40,5 & 34,2 & 26,6 & 20,3 & 19,5 \\
\hline USA & 11,6 & 18,0 & 29,6 & 36,8 & 41,1 & 48,8 & 49,8 \\
\hline Francja & 25,2 & 19,8 & 13,1 & 11,1 & 9,7 & 8,9 & 8,9 \\
\hline Niemcy & 16,7 & 12,3 & 16,8 & 17,9 & 22,6 & 22,0 & 21,8 \\
\hline Razem & 100,00 & 100,00 & 100,00 & 100,00 & 100,00 & 100,00 & 100,00 \\
\hline
\end{tabular}

Źródło: P. Kennedy, Mocarstwa świata. Narodziny, rozkwit, upadek, Warszawa 1994, s. 154 (dla 1830 r. i 1860 r.); T. Kuczynski, Das Wachstum der Industrieproduktion in der kapitalistischen Hauptländern (England, USA, Frankreich, Deutschland) und seine regionale Verteilung von 1830 bis 1913. Versuch einer statistischen Rekonstruktion, „Jahrbuch für Wirtschaftsgeschichte, Sonderband: Umwälzung der deutschen Wirtschaft im 19. Jahrhundert", Akademie der Wissenschaften der DDR Institut für Wirtschaftsgeschichte, Berlin 1989, s. 184.

Około 1890 r. Niemcy wysunęły się przed Wielką Brytanią, uzyskując prymat w Europie pod względem udziału w globalnej produkcji przemysłowej. Przed wybuchem I wojny światowej stały się najpotężniejszym mocarstwem przemysłowym Europy. W 1913 r. produkcja przemysłowa Niemiec wynosiła od 14,8 do $15,7 \%$ światowej wytwórczości przemysłowej ${ }^{31}$. Kraj ten produkował więcej surówki żelaza niż Anglia i Francja oraz więcej stali niż Anglia, Francja i Rosja łącznie. Potencjał hutniczy miał decydujące znaczenie dla dynamicznie rozwijającego się sektora zbrojeniowego ${ }^{32}$.

Przemysłowcy niemieccy korzystali ze szczodrej pomocy kredytowej państwa, zakładając nowe firmy o najwyższym standardzie technicznym. Stopniowo rosła stopa inwestycji w gospodarce niemieckiej.

Poniżej zaprezentowano kształtowanie się stopy inwestycji netto dla gospodarki niemieckiej w latach 1850-1913 na tle wzrostu Produktu Narodowego Netto (PNN) w cenach rynkowych z 1913 r. Oszacowano także trend wzrostowy wydatków inwestycyjnych w postaci funkcji logarytmicznej (rys. 34).

Łatwo zauważyć, że w latach pięćdziesiątych XIX w. stopa inwestycji wynosiła dla lat 1850/54 -7,9\%, dla lat 1855/59-6,7\%. W latach sześćdziesiątych (1860/64) stopa inwestycji netto wzrosła do $11 \%$ PNN (w cenach stałych z 1913 r.). Inwestycje netto można szacować na poziomie 1,53 mld marek. Poza niewielkim spadkiem stopy inwestycji $\mathrm{w}$ drugiej połowie lat sześćdziesiątych do $9,5 \%$ wynosiła ona pomiędzy $10,3 \%$ do $12,7 \%$ w latach 1870-1894. Na przełomie wieków XIX i XX stopa inwestycji kształtowała się na poziomie 13,5-15,5\% PNN (w cenach stałych z 1913 r.).

${ }^{31}$ Por. dane w tab. 16 i 17.

32 S. Kurowski, Historyczny proces wzrostu gospodarczego, Warszawa, 1963, s. 119-120; J. Skodlarski, M. Matera, op. cit., s. 143. 


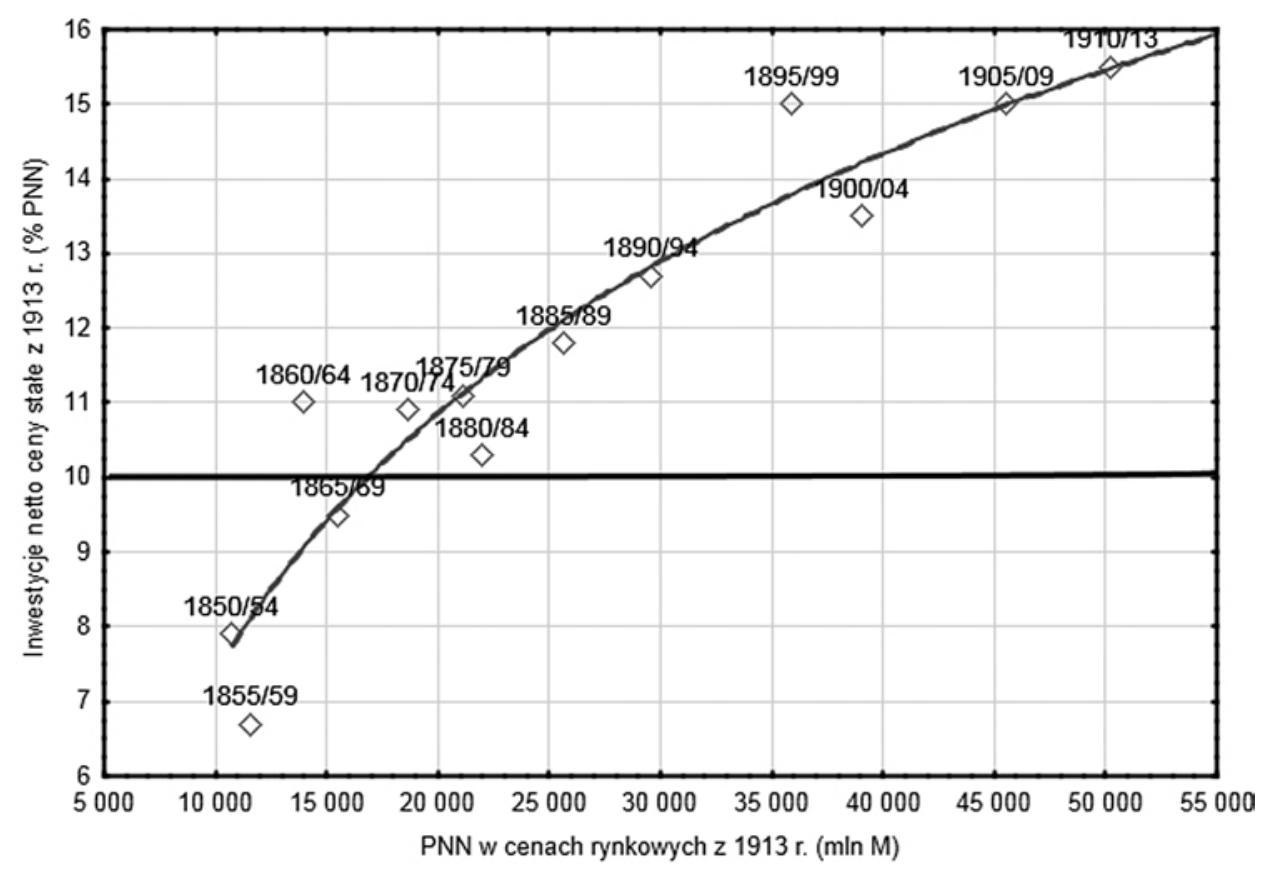

Rys. 34. Stopa inwestycji netto na tle PNN (\%) z oszacowanym trendem

Źródło: jak do rys. 29, s. 104-105.

Oszacowana na rys. 34 linia trendu wyniosła:

stopa inwestycji netto ${ }_{t}=-38,8045+5,015 * \ln \left(P N N_{t}\right)$,

gdzie $t$ oznacza wybrany okres. Współczynnik korelacji liniowej $r$ Pearsona wynosi 0,907 .

W dalszej części pracy analizie poddana zostanie struktura inwestycji, w tym dotyczących kolei. W analizowanym czasie można zaobserwować znaczne wahania w istotnym składniku PNN - prywatnej konsumpcji. Wskaźnik ten w połowie XIX w. dla Niemiec wynosił $85-86 \%$ PNN. Wraz ze wzrostem stopy inwestycji netto wydatki na konsumpcję zmniejszały się. Na przełomie lat siedemdziesiątych i osiemdziesiątych XIX w. wydatki konsumpcyjne spadły do poziomu 80,3\% PNN, zaś w okresie 1910-1913 obniżyły się do poziomu 74\%. Tak duży spadek oznaczać może spadek kosztów utrzymania, lub spadek wydatków na żywność, w wyniku wzrostu dochodów realnych.

$\mathrm{Na}$ rys. 35 przedstawiono poziom inwestycji netto w mln marek, zarówno w cenach bieżących, jak i cenach stałych z 1913 r. W cenach bieżących daje się zauważyć znaczny wzrost poziomu inwestycji w latach siedemdziesiątych 
(1870-74 - 2, 282 mld marek), ale po uwzględnieniu indeksu cenowego poziom inwestycji jest znacznie niższy. Wyjaśnieniem tego wyjątku jest napływ złota $\mathrm{w}$ wyniku otrzymania bezprecedensowej reparacji wojennej po wygranej w 1871 r. wojnie z Francją i towarzyszący temu procesowi wzrost cen.

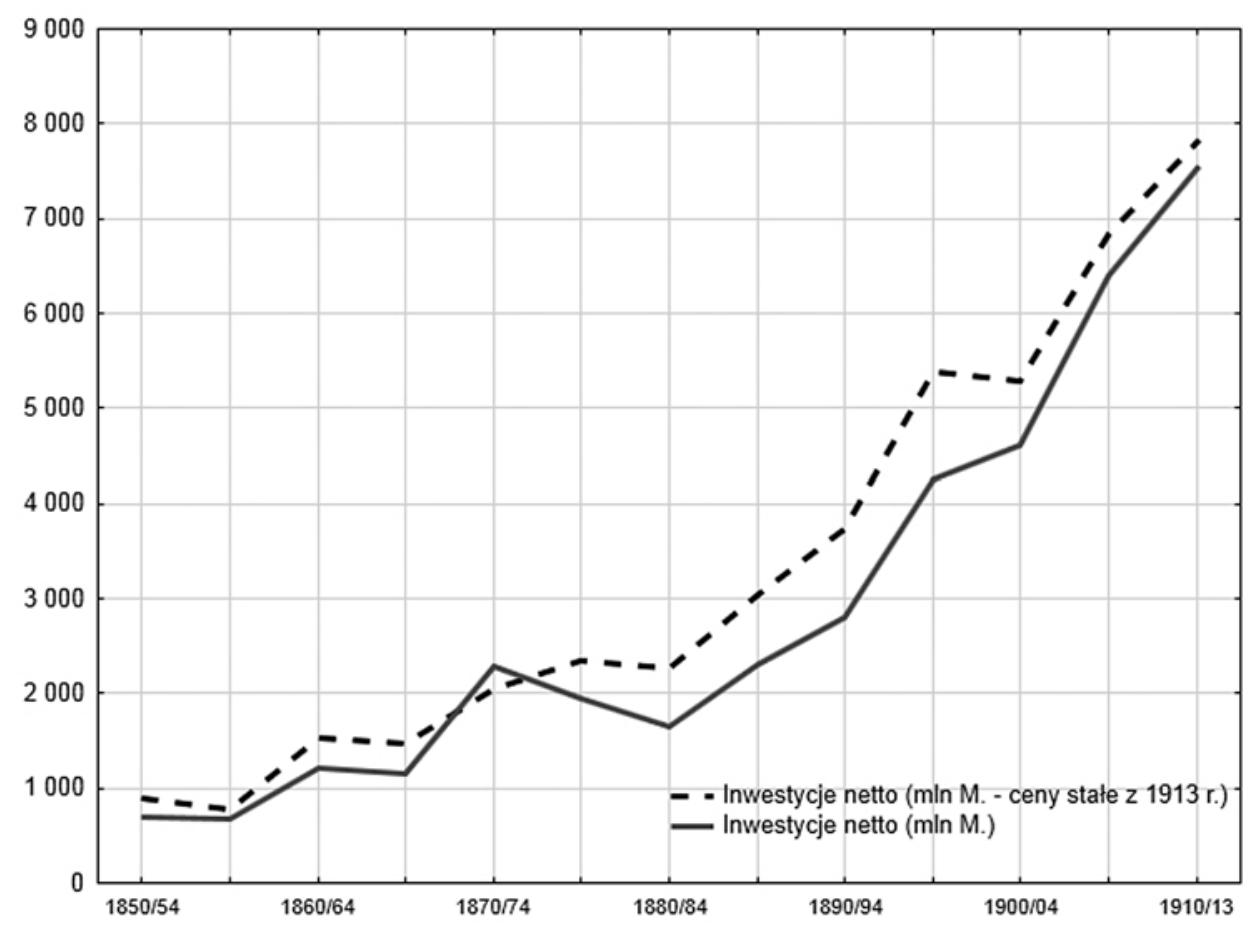

Rys. 35. Poziom inwestycji netto w Niemczech w cenach bieżących i stałych (z 1913 r.) w latach 1850-1913 (mln marek)

Źródło: jak do rys. 29, s. 104-105.

Szczególnie godny uwagi był wzrost łącznych inwestycji netto w koleje z okresu 1851-1854, wynoszący 11,9\%, w latach 1875-1879 osiągnął poziom $25,8 \%$ PNN. W tym czasie mamy do czynienia z bezprecedensowym poziomem wydatków inwestycyjnych na rozbudowę kolei.

Trzeba przyznać, ze większość badaczy, łącznie z W. Rostowem, uznaje, że w przypadku Niemiec po 1850 r. zostały stworzone wstępne warunki dla industrializacji gospodarki ${ }^{33}$.

Kolejną miarą opisującą niemiecką gospodarkę są zmiany w strukturze zainwestowanego kapitału. W połowie XIX w. niemal połowa zainwestowanego kapi-

33 W.W. Rostow, Stages of Economic Growth: A Non-Communist Manifesto, Cambridge, 1960; W.W. Rostow, Politics and Stages of Growth, Warszawa, 1973. 
tału przypadała na rolnictwo, co w odniesieniu do cen z 1913 r., stanowiło 24,86 mld marek. $\mathrm{Z}$ biegiem czasu udział rolnictwa w zainwestowanym kapitale systematycznie spadał na rzecz innych sektorów gospodarki, m.in. przemysłu, kolei żelaznych. W 1913 r. pierwszy sektor gospodarki miał udział w zainwestowanym kapitale w wysokości $21,1 \%$, a przemysł $32,8 \%$.

W przypadku kolei wartość procentowa w stosunku do całej gospodarki wzrastała do 1885 r. osiągając imponujący wskaźnik 11,4\% (11,23 mld marek) wszystkich inwestycji w gospodarce. W tym czasie powierzchnia Niemiec pokryta została gęstą siecią kolejową. W późniejszym okresie poziom inwestycji kolejowych stopniowo zmniejszał się osiągając poziom 9\% w 1913 r. (rys. 36).

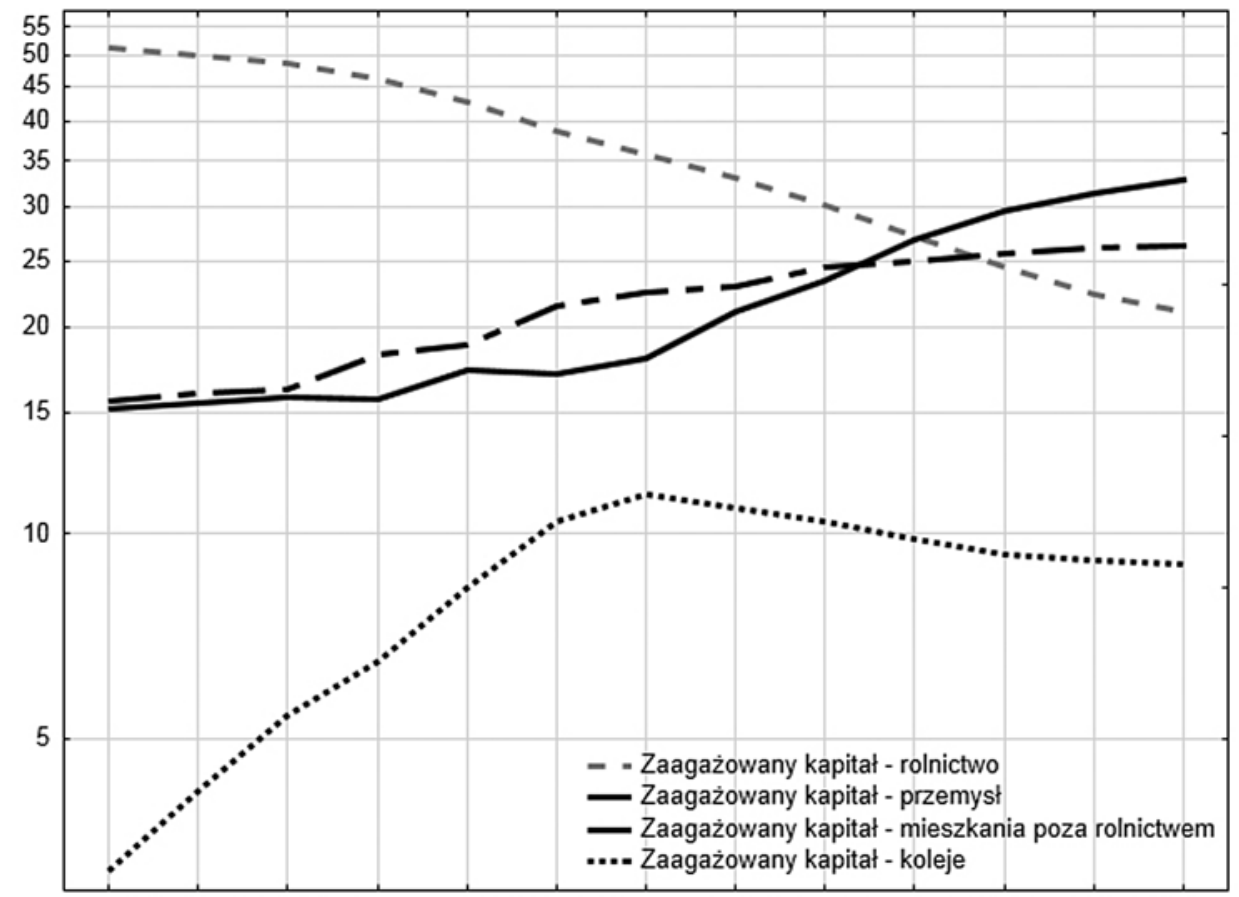

1850/54 1855/59 1860/64 1865/69 1870/74 1875/79 1880/84 1885/89 1890/94 $1895 / 99 \quad 1900 / 04$ 1905/09 $1910 / 13$

Rys. 36. Zaangażowany kapitał w podziale na poszczególne sektory gospodarki w latach 1850-1913 (\%).

Źródło: jak do rys. 35 .

Szczególną rolę na etapie industrializacji gospodarek w XIX w. odegrały banki, gdyż były instytucjami mającymi wpływ na kreowanie kapitału finansowego.

Do połowy XIX w. w warunkach Niemiec pozyskiwanie obcego kapitału (kredytu) odbywało się głównie za pośrednictwem banków prywatnych, które pożyczały własny kapitał. Jednakże, wzrost popytu w gospodarce na obce finan- 
sowanie rozpoczął etap pośrednictwa banków w handlu papierami wartościowymi. Na początku XIX w. rodzina Rothschildów należała do głównych prywatnych bankierów we Frankfurcie, gdzie Meyer Amschel Rothschild założył Bank MA Rothschild\&Söhne (1810 r.). Obecność braci Rothschildów była kluczowa we wszystkich ważnych centrach finansowych. Do około 1860 r. Frankfurt był najważniejszym centrum bankowości. Innymi ważnymi prywatnymi bankami we Frankfurcie były: Jacob SH Stern (1805 r.), Lazard Speyer-Ellissen (1846 r.), Erlanger\& Söhne (1859 r.). Bankowość rozwijała się także w Kolonii (Westfalia). Najważniejszymi prywatnymi bankami były Sal. Oppenheim\&Cie (1789), i A. Schaaffhausen (1790 r.).

Wraz z erą budowy kolei wzrastało znaczenie Berlina i głównych prywatnych banków Gebr. Schickler (1796 r.), S. Bleichröder (1803 r.), Mendelssohn\&Co (1805 r.), R. Warschauer\&Co (1849 r.).

Rozwój sieci kolejowej i finansowanie kolejnych szlaków stanowiło wielkie wyzwanie dla prywatnych bankierów. W konsekwencji, różne prywatne banki współpracowały nieformalnie i formalnie poprzez zakładanie syndykatów i zakładanie nowych banków. W gruncie rzeczy większość banków akcyjnych było tworzonych przez prywatnych bankierów i było wynikiem reorganizacji istniejących prywatnych banków. W taki sposób powstały między latami 1848-1870 cztery największe banki: A. Schaaffhausen'scher Bankverein ${ }^{34}$, Disconto Gesellschaft, Bank für Handel und Industrie, Berliner Handelsgesellschaf. W drugiej fazie tworzenia banków akcyjnych po 1870 r. zostały założone m.in.: Deutsche Bank i Dresdner Bank. Od końca XIX w., w sektorze bankowym następował silny proces koncentracji. Większość banków prywatnych została przejęta przez grupę wielkich banków. (np. Bank Rothschildów we Frankfurcie został przejęty przez Disconto-Gesellschaft w 1901 r. $)^{35}$.

W ostatnim ćwierćwieczu XIX w. niemieckie banki akcyjne zaliczyć można do banków uniwersalnych (universal banking, mixed banking), biorących udział we wszystkich typach bankowości. Były zaangażowane w finansowanie przemysłu, handlu i rządów, działając zarówno na rynku krajowym, jak i międzynarodowym.

Charakterystyczną cechą gospodarki niemieckiej było ścisłe powiązanie przemysłu z bankami. Inaczej niż we Francji, Wielkiej Brytanii lub USA, banki zajmowały się nie tylko udzielaniem kredytu, lecz prowadziły bezpośrednią politykę inwestycyjną w przemyśle. Doprowadziło to po 1890 r. do ścisłego splecenia się kapitału bankowego z przemysłowym w postaci tzw. kapitału finansowego. Kapitał ten nie rozwinął się tak bardzo, jak w Niemczech ${ }^{36}$.

\footnotetext{
${ }^{34}$ Najstarszy bank akcyjny w Niemczech (1848 r.).

${ }_{35}$ K.E. Born, Geld und Banken im 19. und 20. Jahrhundert, Stuttgart 1977.

36 J. Krasuski, op. cit., s. 246.
} 
Wracając do rynku pieniężnego - na początku XIX w. blisko 80\% środków pieniężnych w obrocie to monety, wśród których przeważały złote i srebrne. Dużą trudnością były różne waluty funkcjonujące w rozbitych politycznie krajach niemieckich. Spośród różnorodnych walut, najważniejsze były dwie: talary i guldeny. Talary były walutą Prus, a także funkcjonowały w państwach północnych (Niemiec). Guldeny były powszechne w południowych państwach niemieckich. Obydwie waluty oparte były na standardzie waluty srebrnej. Dużą trudnością było ustalanie za każdym razem kursu wymiany obydwu walut. W końcu dla obydwu walut ustalono parytet wymiany na stałym poziomie równym $233,855 \mathrm{~g}$ srebra. To było odpowiednio 14 talarów i 24,5 guldena. 1 talar był równy 1,75 guldena. W 1857 r., po zwarciu traktatu walutowego w Wiedniu do wymienionych walut dołączono florena austriackiego ( 1,5 florena $=1$ talar $=1,75$ guldena $)$.

Najważniejszym krokiem w unifikacji niemieckiej waluty było politycznie zjednoczenie w 1871 r. Rozeszły się drogi unii walutowej Niemiec i Austrii - po wojnie w 1867 r. powstał Związek Północnoniemiecki i Austro-Węgry. W $1870 \mathrm{r}$. stosowane były już banknoty, jako substytut pieniądza. W $1871 \mathrm{r}$. wprowadzono do obiegu nową walutę - markę - 1 marka równa była 100 fenigom i 1/3 dotychczasowemu talarowi pruskiemu. Jak dodaje D. Lindenlaub w latach 1871-1876, w zjednoczonej Rzeszy, obowiązywało jeszcze siedem systemów monetarnych ${ }^{37}$.

Zasadniczą zmianą, jaką przeprowadzono odnoście waluty, była zmiana dotychczasowego standardu waluty ze srebrnego na walutę złotą. Zmiana taka była kosztowna, a środki pochodziły m.in. z wypłaty reparacji wojennej w wysokości 5 mld franków w złocie. Utworzono także nowy bank centralny - Reichsbank, którego celem była standaryzacja i unifikacja wspólnej dla federacyjnych państw waluty.

Integracja monetarna, jak wspomniano, nastąpiła już w łonie Niemieckiego Związku Celnego. Wówczas najważniejszym i najsilniejszym bankiem był Centralny Królewski Bank Pruski (Königlich-Preußische Hauptbank). Bank wpływał na podaż pieniądza. $Z$ całą pewnością prowadzona polityka pieniężna i integracja monetarna pozytywnie wpływała na stabilność ekonomiczną i możliwość angażowania prywatnych kapitałów np. w rozbudowę kolei. Jak podkreśla Janusz Kaliński proces upowszechniania gold standard trwał do końca XIX w., dając równocześnie przewagę ekonomiczną państwom, które posiadały własne kopalnie złota lub znaczne rezerwy tego kruszcu. Do państw przodujących należały Wielka Brytania i Stany Zjednoczone, a także Niemcy ${ }^{38}$.

Budując wielorównaniowy model ekonometryczny mający na celu określenie czynników wzrostu gospodarczego w warunkach XIX w. J. Foreman-Peck,

${ }^{37}$ D. Lindenlaub, The Confidence in a New Currency: The Introduction of the Mark in Germany 1871-1876, [w:] Centres and Peripheries in Banking. The Historical Development of Financial Markets, eds. P. Cottrell, E. Lange, U. Olsson, Burlington 2007, s. 125.

38 J. Kaliński, Historia gospodarcza XIX $i$ XX w., Warszawa 2008, s. 66. 
do jednej ze zmiennych egzogenicznych wyjaśniającej zmienną endogeniczną (PKB per capita) przyjął standard waluty złotej. Waluta złota okazała się czynnikiem istotnym ${ }^{39}$.

Na rys. 37 przedstawiono kształtowanie się inflacji, nominalnej i realnej stopy oprocentowania. Stopa oprocentowania w zasadzie wahała się w okolicach 4\%. Realna stopa oprocentowania odznaczała jednak się dużymi zmianami, że względu na tempo inflacji, która w latach osiemdziesiątych i dziewięćdziesiątych XIX w. było ujemne (deflacja).

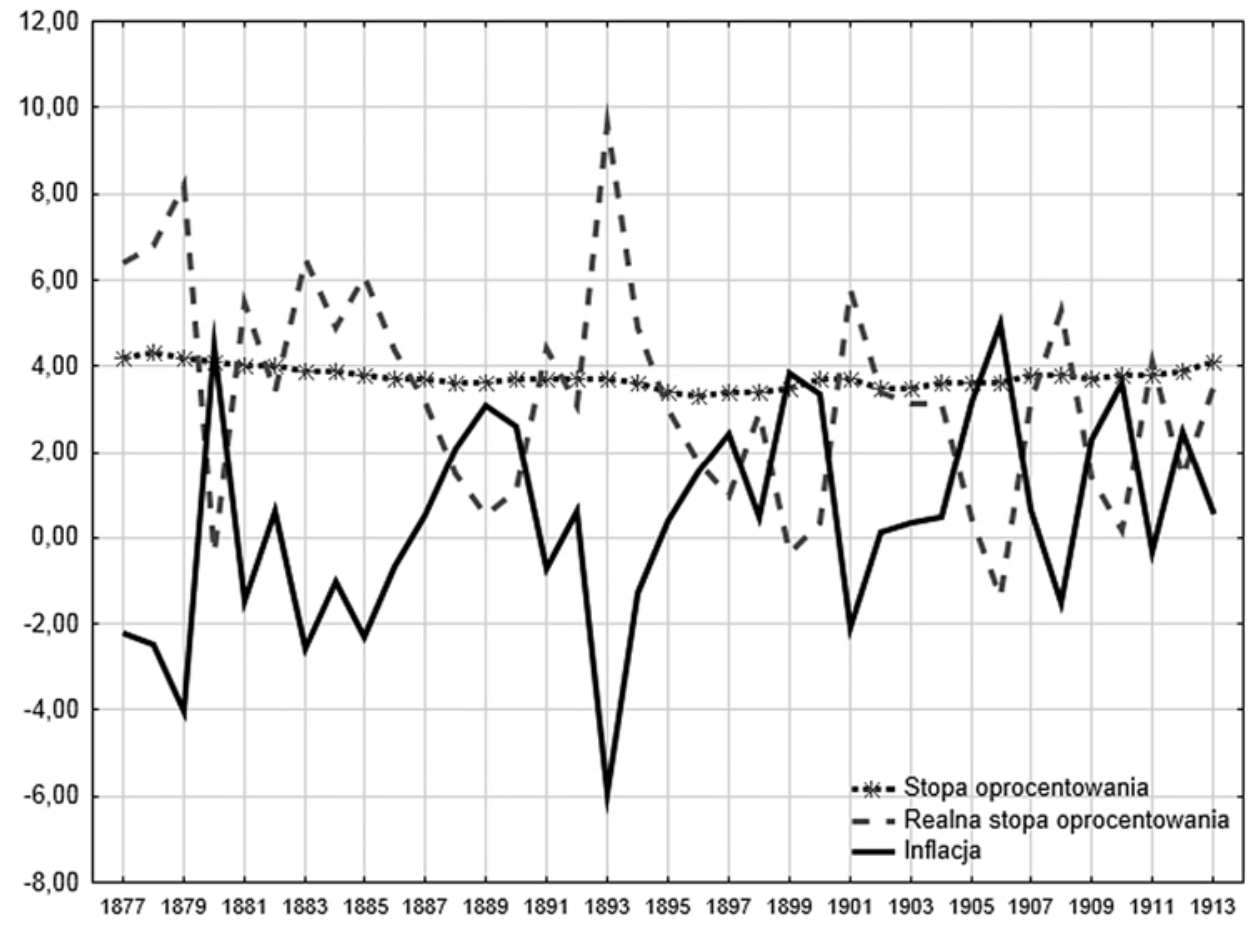

Rys. 37. Nominalna i realna stopa oprocentowania na tle inflacji w Niemczech w latach 1877-1913

Źródło: Deutsche Bundesbank, Deutsches Geld - und Bankwesen in Zahlen 1876-1975, Frankfurt am Mein 1976.

Należy zauważyć, że otrzymane reparacje wojenne z Francji zwiększyły pomiędzy latami 1871-1873 liczbę pieniądza (agregat pieniężny M3) o blisko 40,5\% (rys. 38). Mimo prób podejmowanych przez bank centralny nie udało się ograniczyć podaży pieniądza. Jak wynika $\mathrm{z}$ danych statystycznych, produkt na-

39 J. Foreman-Peck, A Model of Later Nineteenth Century European Economic Development, „Revista de Historia Económica” 1995, Second Series, vol. 13, s. 460-467. 
rodowy w latach $1870-1874$ wzrósł w ujęciu realnym o blisko $28 \%$, produkcja przemysłowa wzrosła o $45 \%$. Wzrost gospodarczy pozostawał w tyle w stosunku do wzrostu podaży pieniądza, stąd zanotowano zwiększoną inflację. W porównaniu do lat sześćdziesiątych XIX w. stopa inflacji wzrosła z blisko $0,5 \%$ do $5,8 \%$ w skali roku (rys. 38).

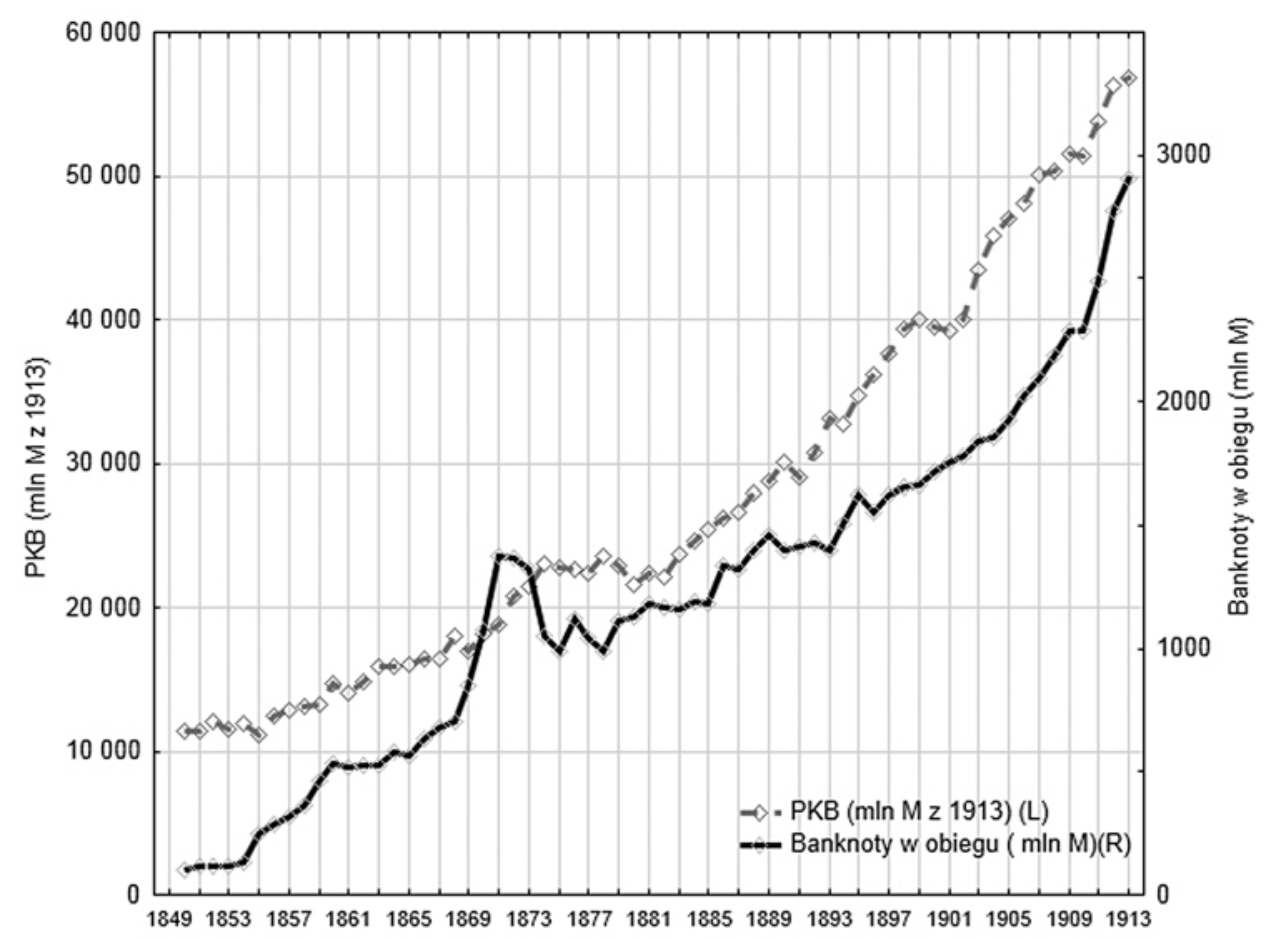

Rys. 38. Liczba banknotów w obiegu (mln marek) na tle poziomu PKB w latach 1860-1913

Źródło: B.R. Mitchell, International Historical Statistics: Europe, 1750-2000, London 2003, s. 785,787 .

Zauważalny był w szczególności wzrost cen dóbr inwestycyjnych; o blisko $11,1 \%$ rocznie $^{40}$. Dla porównania ceny dóbr konsumpcyjnych wzrastały w tempie $4,2 \%$.

Analizując rozwój bankowości w XIX i początkach XX w. w Niemczech W.G. Hoffmann wyróżnił następujące rodzaje banków:

- Notenbanken (banki centralne, emisyjne),

- Kreditbanken,

${ }^{40}$ C. Burhop, Die Kreditbanken in der Gründerzeit, „Schriftenreihe des Instituts für Bankhistorische Forschung" 2004, Bd. 21, s. 23-24. 
- Kreditgenossenschaften (banki spółdzielcze),

- Sparkassen (banki oszczędnościowe),

- Hypothekenbanken und Landwirtschaftliche Kreditinstitute.

Zaangażowanie banków we wspieraniu głównych sektorów gospodarki, w tym kolei, przemysłu ciężkiego doprowadziły do rozwoju banków uniwersalnych. Po 1873 r. i zakończeniu wypłaty reparacji wojennych zauważalny był spadek tempa wzrostu i rozwoju gospodarczego Niemiec. W kolejnych latach w sektorze bankowym zachodziły procesy konsolidacji prowadzące do powstania bardzo dużych banków. W rezultacie przed wybuchem I wojny światowej w Niemczech funkcjonowało 8 „Dużych Banków”, w tym tzw. „4-D Banken” (Deutsche, Dresdner, Darmstädter, Disconto-Geselschaft) i 86 regionalnych banków kredytowych. W 1913 r. pięć dużych banków i banki stowarzyszone, dysponowały około 7 mld marek, czyli blisko połową aktywów wszystkich banków uniwersalnych. W tym samym roku trzema największymi przedsiębiorstwami w Niemczech były banki, a spośród 25 największych firm, 17 było bankami ${ }^{41}$. Takiej ekspozycji banków nie spotykamy w żadnym innym kraju będącym w trakcie industrializacji, jest to rzeczywiście fenomen typowy dla Niemiec, który do dziś budzi wiele kontrowersji.

Wracając do analizy sektora bankowego, R. Tilly określa trzy ważne cechy bankowości niemieckiej:

1) rozwój bankowości centralnej i kontrola podaży pieniądza (Notenbanken - banki emisyjne). Przykładem może być Königlich-Preußische Hauptbank, funkcjonujący od 1841 r., który został przemianowany w 1870 r. na Reichsbank. Bank centralny regulował podaż pieniądza i system finansowy;

2) rozwój innych instytucji, poza bankami komercyjnymi, np. banków hipotecznych, towarzystw ubezpieczeniowych, banków spółdzielczych, i mające w nich udziały grupy pracowników i chłopów (farmerów), banki te miały szczególne znaczenie w finansowaniu drobnych inicjatyw dotyczących tzw. small business;

3) finansowanie wielu inicjatyw gospodarczych odbywało się bez udziału sektora bankowego. Typowe było samofinansowanie lub finansowanie poprzez emisję papierów wartościowych - akcji lub obligacji.

Aktywa z podziałem na grupy instytucji finansowych w Niemczech zobrazowano w tab. 18.

${ }^{41}$ R. Tilly, Banken und Industrialisierung in Deutschland: Qauntifizierungsversuche, [w:] Entwicklung und Aufgaben von Versicherungen und Banken in der Industrialisierung in Deutschland, ed. F.W. Henning, Berlin 1980, s. 165-93. 
Tabela 18. Aktywa instytucji finansowych w Niemczech w latach 1860-1913 (mld marek)

\begin{tabular}{|l|c|c|c|c|}
\hline \multirow{2}{*}{\multicolumn{1}{|c|}{ Rodzaj instytucji }} & \multicolumn{4}{c|}{ Rok } \\
\cline { 2 - 5 } & 1860 & 1880 & 1900 & 1913 \\
\hline Banki emisyjne & 0,95 & 1,57 & 2,57 & 4,03 \\
\hline Banki komercyjne & 0,39 & 1,35 & 6,96 & 22,04 \\
\hline Banki prywatne & 1,5 & 2,5 & 3,5 & 4 \\
\hline Banki oszczędnościowe & 0,51 & 2,78 & 9,45 & 22,56 \\
\hline Spółdzielnie kredytowe & 0,01 & 0,59 & 1,68 & 6,17 \\
\hline Banki hipoteczne & 0,09 & 1,85 & 7,5 & 13,55 \\
\hline Banki krajowe publiczne i hipoteczne & 0,68 & 1,76 & 4,05 & 7,2 \\
\hline Pozostałe & 0,07 & 0,79 & 4,12 & 10,92 \\
\hline Razem & 4,25 & 13,5 & 40,5 & 91,00 \\
\hline
\end{tabular}

Źródło: T. Pierenkemper, R. Tilly, The German Economy During the Nineteenth Century, New York-Oxford 2004, s. 115.

\section{POSTĘP W ROLNICTWIE NIEMIECKIM}

Po 1870 r. rolnictwo niemieckie szybko dostosowało się do wymogów kapitalistycznego rynku. Nie było to zadanie łatwe, ponieważ rolnictwo europejskie trawił ciężki, długotrwały kryzys agrarny (lata 1873-1896). Niemcy, mimo tego kryzysu, wykazywały największy w Europie przyrost produkcji zbożowej: wynosił on w latach 1870-1913 około 66\%. Globalne zbiory ziemniaków zwiększyły się dwukrotnie. Ogółem produkcja rolna w tym okresie wzrosła o prawie $90 \%{ }^{42}$.

Duży wpływ na poprawę sytuacji rolnictwa niemieckiego miała rezygnacja $\mathrm{z}$ jednostronnej struktury rolnej. Przystąpiono do zwiększania areału upraw roślin przemysłowych - buraków cukrowych, kartofli, lnu i konopi oraz rozwoju hodowli. Na ich bazie rozwijało się przetwórstwo produktów rolnych, zwłaszcza przemysł spożywczy, cukrowniczy i gorzelniany ${ }^{43}$. Intensyfikacji produkcji rolnej sprzyjał wzrost poziomu agrotechniki (wiedzy, mechanizacji, stosowania nawozów sztucznych). Skuteczną pomoc niósł również rolnikom rząd Rzeszy, utrzymując taryfy celne na opłacalnym poziomie i udzielając producentom korzystnych kredytów ${ }^{44}$.

\footnotetext{
${ }^{42}$ W. Rusiński, op. cit., s. 363.

${ }^{43}$ W. Czapliński, A. Galos, W. Korta, op. cit., s. 592.

${ }^{44}$ W. Rusiński, op. cit., s. 363.
} 
W rezultacie wymienionych powyżej korzystnych uwarunkowań, zwiększyła się wydatnie wydajność plonów $\mathrm{z}$ hektara. W Niemczech zbiory pszenicy wzrosły w okresie 1880-1914 z 13,3 q z ha do około 20 q z ha; dla porównania w Anglii - z 16,7 do 22 q, Holandii - z 15,3 do 26 q, a we Francji z 10,9 do 13 q z ha" ${ }^{45}$.

Mimo wyraźnego wzrostu produkcji, rolnictwo, a szczególnie uprawa zbóż, w Europie Zachodniej stawało się mało opłacalne, dotychczasowi eksporterzy (np. Prusy) stanęli w obliczu inwazji taniego zboża z innych regionów świata. John Clapham w swojej książce The Economic Development of France and Germany z 1921 r. zauważa, że dwudziestolecie 1870-1890 było decydujące dla gospodarki Niemiec. W tym czasie otwarte morza i rozwinięta sieć kolejowa, połączyły pola uprawne Polski, czarnoziemy rosyjskie, połacie zbóż z Rumunii. Rozbudowa coraz gęstszej sieci dróg lądowych, spływ rzekami i kanałami stwarzały wiele możliwości transportu m.in. zbóż ${ }^{46}$. Niemcy, będąc eksporterem żywności, w tym zbóż, dość szybko stały się ich importerem.

Problem protekcjonizmu agrarnego, mimo nacisków ze strony niektórych grup społecznych, nie został rozwiązany w ramach Niemieckiego Związku Celnego (NZC), a także po przekształceniu go w Północnoniemiecki Związek (18661871). Wkrótce rozwiązanie tego problemu stanęło m.in. przed politykami utworzonego Cesarstwa Niemieckiego.

Najbardziej odczuwalny był import zboża z Rosji - pruskie prowincje wschodnie, niedawno będące eksporterem zbóż, stanęły w obliczu konkurencji taniego rosyjskiego zboża. Potwierdzają to liczne dane statystyczne, dla przykładu w 1877 r. Niemcy importowały z Rosji blisko 2 mln Mg żyta, owsa i jęczmienia, kiedy jeszcze w $1875 \mathrm{r}$. import kształtował się w granicach $1 \mathrm{mln}$ Mg. Mniejszym problemem był import pszenicy, która ze względu na słabe gleby, np. w Prusach Wschodnich, nie była tak powszechnie uprawianym zbożem jak żyto i owies.

Ożywiona wymiana handlowa, w tym zbożami, prowadziła do dużej konkurencji i jest przykładem postępującej konwergencji cen zobrazowanej na przykładzie cen pszenicy w Anglii i Walii oraz w Berlinie w latach 1881-1911 (rys. 39).

Areał głównych roślin uprawnych został przedstawiony na rys. 40. Zauważyć można wzrost areału uprawy ziemniaka - w $1880 \mathrm{r}$. wynosił on około $2,8 \mathrm{mln}$ ha, w 1912 r. zwiększył się o blisko 0,5 mln ha. Kartofle, jako ważny artykuł spożywczy, stały się także źródłem pożywienia dla hodowanych zwierząt. Ziemniaki miały także swój udział w rozwoju przemysłu poprzez użycie bulw przy destylacji alkoholu używanego do celów przemysłowych, a także zajęły ważne miejsce w płodozmianie i zmianowaniu roślin.

45 The European Economy 1750-1914. A Thematic Approach, eds. D. H. Aldcroft, S. P. Ville, Manchester 1966, s. 92; W. Rusiński, op. cit., s. 362.

46 J.H. Clapham, The Economic Development of France and Germany 1815-1914, Cambridge 1921, s. 210. 


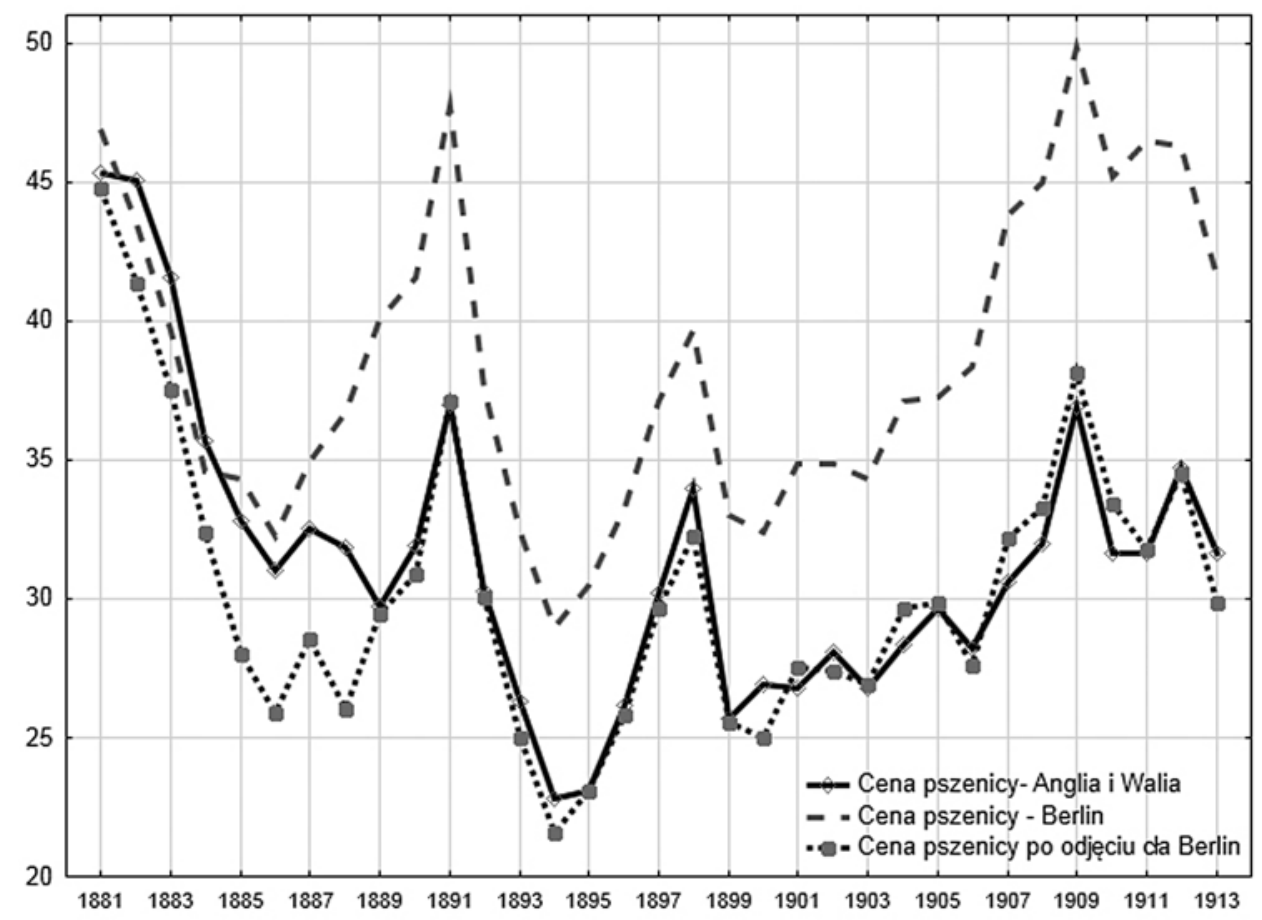

Rys. 39. Cena pszenicy (1 kwarta, 8 buszli) Niemcy, Anglia i Walia w latach 1881-1913, jako przykład konwergencji cen na rynku zbóż

Źródło: opracowanie własne na podstawie: http://www.sfu.ca/ djacks/data/prices/Germany/ prices.html [dostęp 01.06.2012].

W 1912 r. w produkcji zbóż w Niemczech nadal dominowało żyto (wzrost o około $0,5 \mathrm{mln}$ ha), areał pól obsiewanych pszenicą utrzymał się na niezmiennym poziomie.

Od 1858-1864 do 1874-1880 tempo wzrostu w rolnictwie niemieckim spadło do $0,4 \%$ rocznie, w 1874 r., zakończyła się także wypłata reparacji wojennych.

W latach siedemdziesiątych XIX w. kontynent europejski został zalany tanimi zbożami m.in. z USA. Spadek rolniczych dochodów realnych spowodował zmianę postrzegania przez klasę junkierską zalet wolnego handlu z lat sześćdziesiątych. Do 1870 r., jako eksporterzy zbóż, byli zwolennikami wolnego handlu. Właściciele ziemscy (junkrzy), mający swe oparcie w Partii Konserwatywnej, byli siłą polityczną, która zaczęła opowiadać się za realizacją polityki protekcjonizmu. Pod koniec 1870 r. w Niemczech sformowały się dwa bloki polityczne: konserwatyści i centrum, opowiadające się za polityką protekcjonistyczną oraz pozostałe siły, które popierały politykę wolnego handlu. 


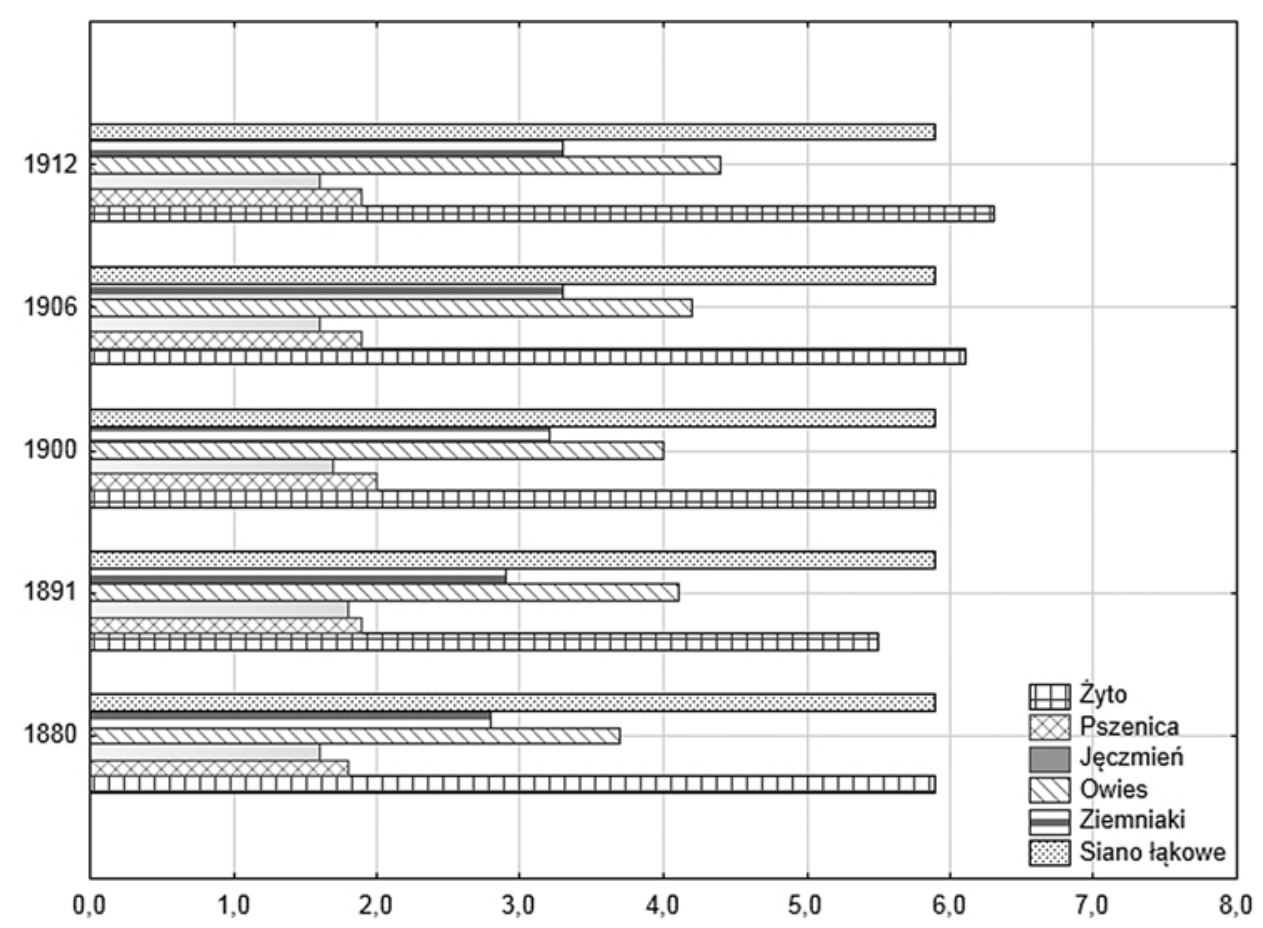

Rys. 40. Główne rośliny uprawne w Niemczech w latach 1880-1912 (mln ha)

Źródło: jak do rys. 33, s. 218.

Wybory z dnia 30 lipca 1878 r. wyłoniły ponad 200 posłów Reichstagu przeciwników wolnego handlu. Koalicja popierająca protekcjonistyczną politykę miała - spośród 397 głosów - 210. W wyborach w 1878 r. zwolennicy wolnego handlu ponieśli klęskę, w szczególności dotyczyło to Prus Wschodnich, w których jeszcze w 1877 r. rozkład głosów był niemal równomierny dla zwolenników polityki protekcjonistycznej i free trade $e^{47}$.

Alexander Gerschenkron i James Sheehan uważają, że porażka liberałów wystąpiła z powodu antysocjalistycznej kampanii rządu, który w połączeniu ze skłonnościami konserwatywnymi junkrów i ich oddziaływaniem na masy robotników wiejskich, przyniosło zwycięstwo konserwatystom ${ }^{48}$.

Zmiana sposobu głosowania na obszarach wiejskich odegrała decydującą rolę w układzie sił w Reichstagu w 1878 r. Ronald Rogowski, na przykładzie mo-

${ }^{47}$ S. Lehmann, The German Elections in the 1870s: Why Germany Turned From Liberalism to Protectionism, Bonn 2009, s. 4-5.

48 A. Gerschenkron, Bread and Democracy in Germany, Berkeley 1943; J. Sheehan, Klasse und Partei im Kaiserreich: Einige Gedanken zur Sozialgeschichte der deutschen Politik, [w:] Innenpolitische Probleme des Bismarck-Reiches, München 1983. 
delu Heckschera-Ohlina-Samuelsona, dla gospodarki światowej składającej się z trzech czynników produkcji: ziemi, pracy i kapitału, konkluduje, że Niemcy do około połowy 1870 były dość bogate w zasoby pracy i ziemi, ale stosunkowo rzadki był kapitał. Peter Gourevitch utrzymuje, że zmianę zachowania wyborców w 1878 r. można tłumaczyć zmianami w bilansie handlowym. Niektóre sektory gospodarki stanęły przed ryzykiem konkurencji, podczas gdy inne, takie jak rolnictwo, odwróciły się od polityki eksportowej. Większość najemnych pracowników trafiła do sektorów narażonych na konkurencję, dlatego głosowali oni za ochroną celną ${ }^{49}$.

W odróżnieniu od Wielkiej Brytanii, w Niemczech głównym źródłem dochodów klasy junkierskiej były przychody z uprawy zbóż, zdecydowanie mniejsze przychody były z prowadzenia produkcji zwierzęcej ${ }^{50}$. Szybko rosło w siłę lobby opowiadające się za taryfami importowymi dla zbóż. W warunkach Niemiec wprowadzono ogólne taryfy importowe, nie tylko na produkty rolne, ale także na produkty przemysłowe. Za zgodą „żelaznego kanclerza” nastąpił polityczny sojusz junkrów i przemysłowców niemieckich. W 1892 r. wyższe cła wprowadziła także Francja.

Niemiecka ustawa celna z 15 lipca 1879 r. wprowadzała w życie nowe stawki celne, w duchu protekcjonistycznym. Tendencje protekcjonistyczne zostały wzmocnione w kolejnych zmianach stawek taryfowych w latach: 1881, 1883, $1885,1887 \mathrm{r}^{51}$

${ }^{49}$ R. Rogowski, Commerce and Coalitions: How Trade Affects Domestic Political Alignments, Princeton 1989.

${ }^{50} \mathrm{~S}$. Webb, Agricultural protection in Wilhelminian Germany forging an empire with pork and rye,[w:] Selected Cliometric Studies on German Economic History, eds. J. Komlos, S. Eddie, Stuttgart 1997, s. 66-82.

${ }_{51}$ A Jacobs, H. Richter, Die Großhandelspreise in Deutschland von 1792 bis 1934, „Sonderhefte des Instituts für Konjunkturforschung"1935, Nr. 37, s. 51. 
Na rys. 41 zaprezentowano średnie efektywne cła ad valorem na wybrane produkty rolne i przemysłowe w Niemczech w latach 1879-1913.

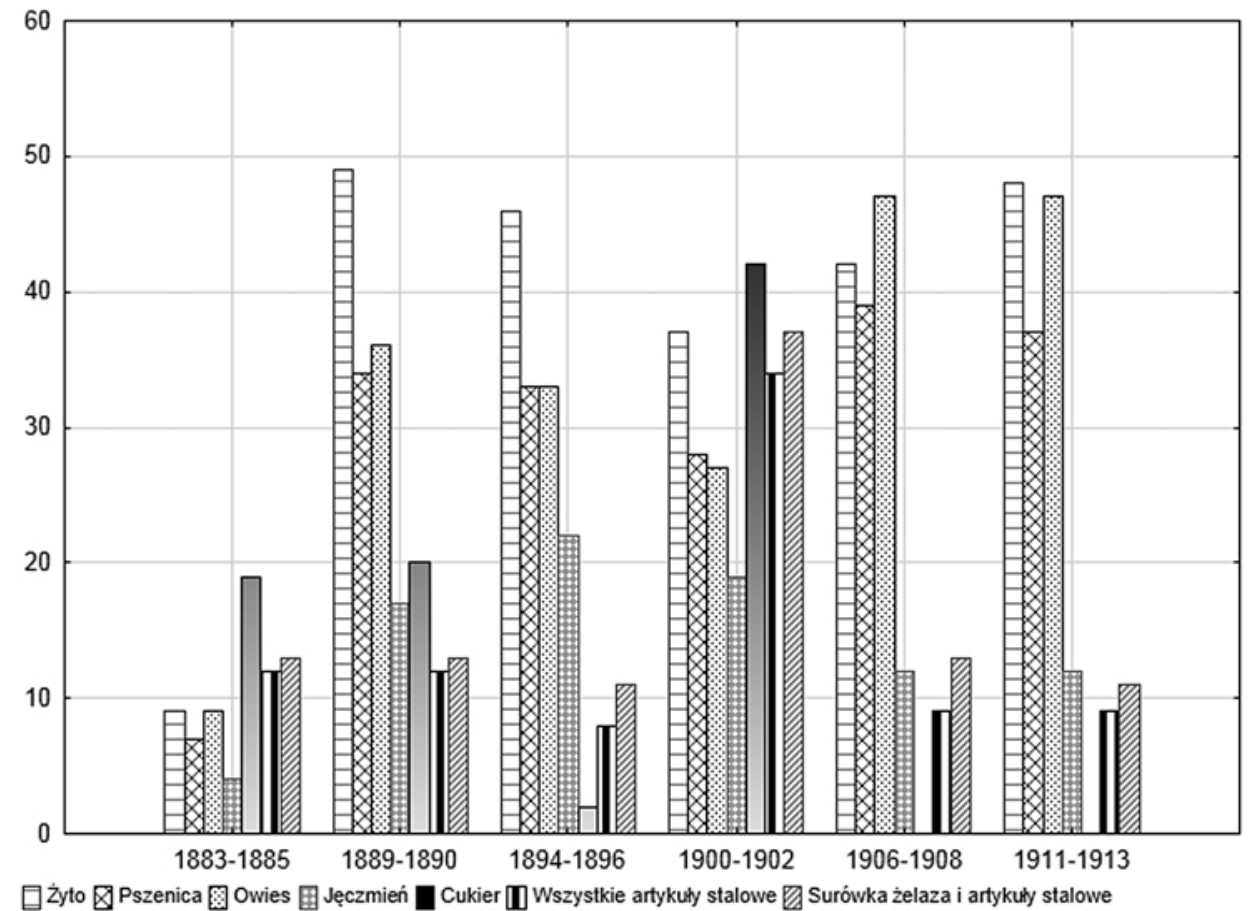

Rys. 41. Cła efektywne ad valorem na wybrane grupy towarów w Niemczech w latach 1879-1913 (\%)

Źródło: opracowanie własne na podstawie: S. Webb, Agricultural protection in Wilhelminian Germany forging an empire with pork and rye, [w:] Selected Cliometric Studies on German Economic History, eds. J. Komlos, S. Eddie, Stuttgart 1997, s. 66-82.

Mimo protekcjonistycznej polityki po roku 1879 daje się zauważyć dalszy wzrost ujemnego salda w handlu zbożem dla Niemiec, szczególnie w handlu pszenicą, ale także poprawę bilansu wymiany dla żyta (rys. 42) i owsa. Opłaty celne przyczyniły się do wzrostu cen krajowych (ponad poziom cen światowych), zapewniając jednocześnie wzrost dochodów junkierstwa i budżetu cesarstwa z tytułu ceł.

O sile junkrów w rolnictwie mogą świadczyć poniższe dane statystyczne: spośród niemal 25,8 mln ha ziemi rolniczej w Prusach w 1907 r. blisko 29\% (8,3 mln ha) należało do gospodarstw liczących ponad 100 ha, gospodarstwa o powierzchni 20-100 ha stanowily najliczniejszą grupę, tj. 33\% (około 8,5 mln ha). Kolejna grupa - gospodarstwa o powierzchni 5-20 ha, stanowiły $28 \%$ ogółu po- 
wierzchni użytków rolnych (około 7,1 mln ha). Gospodarstwa o powierzchni 2-5 ha i poniżej 2 ha stanowiły łącznie $8 \%$ powierzchni (około $2 \mathrm{mln}$ ha). Blisko 59\% użytków rolnych stanowiły grunty orne ${ }^{52}$.

Sojusz junkrów i przemysłowców był tylko tymczasowy. W 1890 r., niemiecki przemysł był w znacznie lepszej pozycji konkurencyjnej i zmierzał do zapobieżenia skutkom wysokich kosztów żywności i płac. Ponadto przemysłowcy niemieccy byli świadomi, że w reakcji na niemiecką politykę taryfową Stany Zjednoczone nałożyły również stosowne cła. Mimo tego, polityczna siła junkrów pozwalała na dalszy wzrost protekcji celnej. W 1892 r. odstąpiono od autonomicznego ustalania taryf celnych przez poszczególne rządy landów. W 1902 r. wprowadzono powszechną taryfę celną, która z założenia była protekcjonistyczna. Praktycznie do wybuchu I wojny światowej została ona tylko nieznacznie zmieniona.

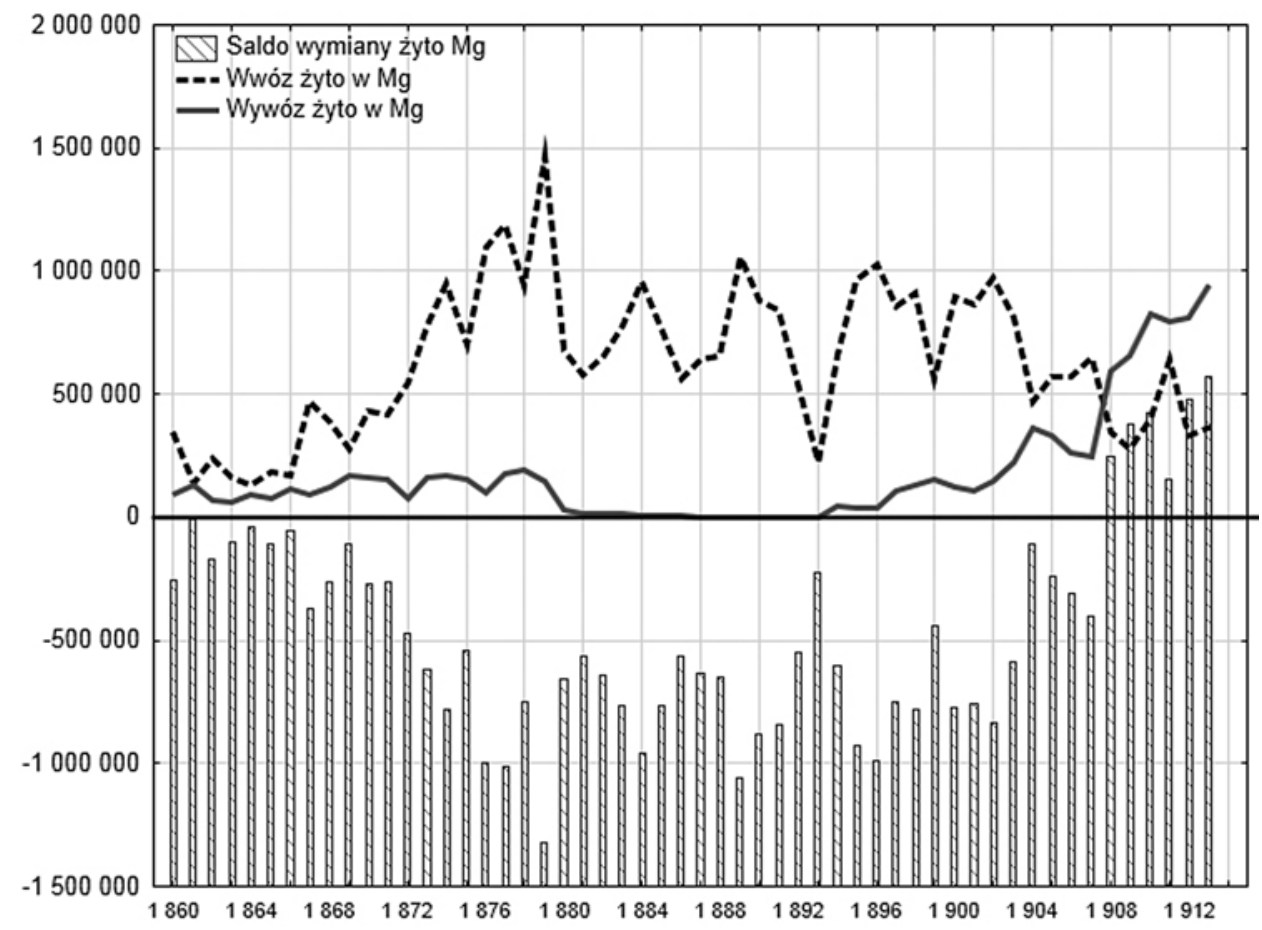

Rys. 42. Wwóz, wywóz i saldo wymiany handlowej Niemiec w obrocie żytem w latach 1860-1913 (Mg)

Źródło: obliczenia własne na podstawie: Statistisches Jahrbuch für das Deutsche Reich, Berlin 1881-1914, VII. Handel des Deutschen Zollgebiets mit dem Auslande; A. Bienengräber, Statistik des Verkehrs und Verbrauchs im Zollverein für die Jahre 1842-1864: Nach den veröffentlichten amtlichen Kommerzial-Übersichten etc., Berlin 1868.

52 Statistisches Jahrbuch für den Preussichen Staat, Berlin 1915, s. 118-123. 
Interesy wybranych grup społecznych $\mathrm{w}$ aspekcie prowadzonej polityki celnej zostały zobrazowane na rys. 43 .

\section{Taryfy na produkty rolne}

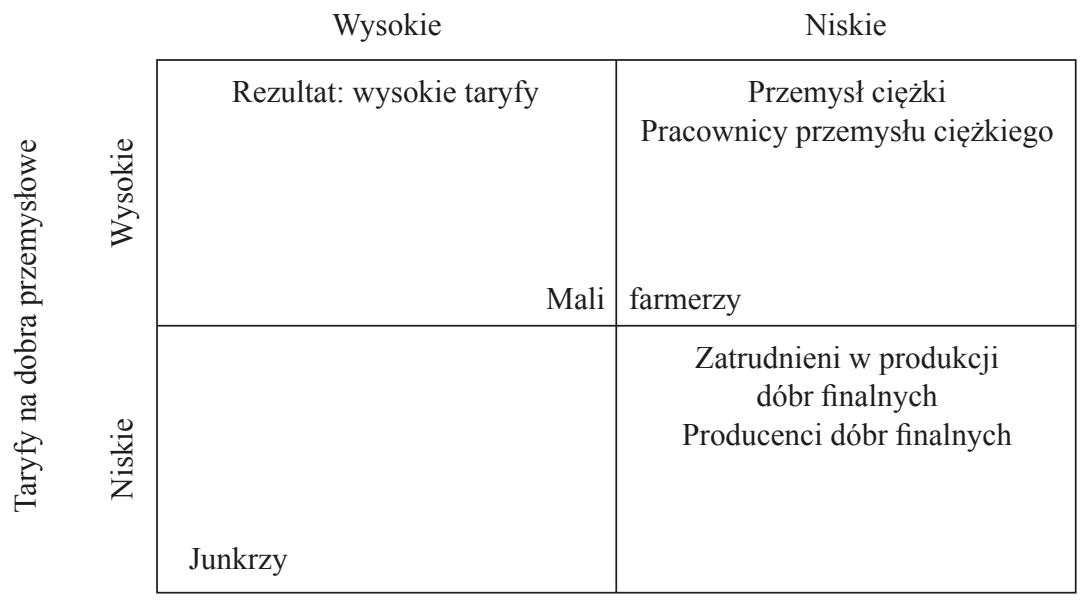

Rys. 43. Interesy wybranych grup społecznych w kontekście ceł na produkty przemysłowe i rolne w Niemczech

Źródło: International Political Economy. Perspectives on Global Power and Wealth, eds. J.A. Frieden, D.A. Lake, London-New York 2003, s. 95.

Junkrzy, strzegąc swoich interesów, zainteresowani byli z jednej strony znaczną protekcją celną dotyczącą ceł na produkty i surowce rolne, a z drugiej niskimi cłami na dobra przemysłowe będące dla nich środkami produkcji. Dla odróżnienia, właściciele niewielkich gospodarstw rolnych nie byli zainteresowani wysoką protekcją na surowce rolne, gdyż stanowiły one dla nich źródło pożywienia dla hodowanych zwierząt. Stąd „unia żelaza i żyta” zawarta między junkrami a przemysłowcami z definicji mogła być jedynie tymczasowa.

Na rys. 44 przedstawiono saldo wymiany handlowej trzech zbóż (żyta, pszenicy i owsa) na tle ogólnego salda handlowego NZC i zjednoczonych Niemiec. 


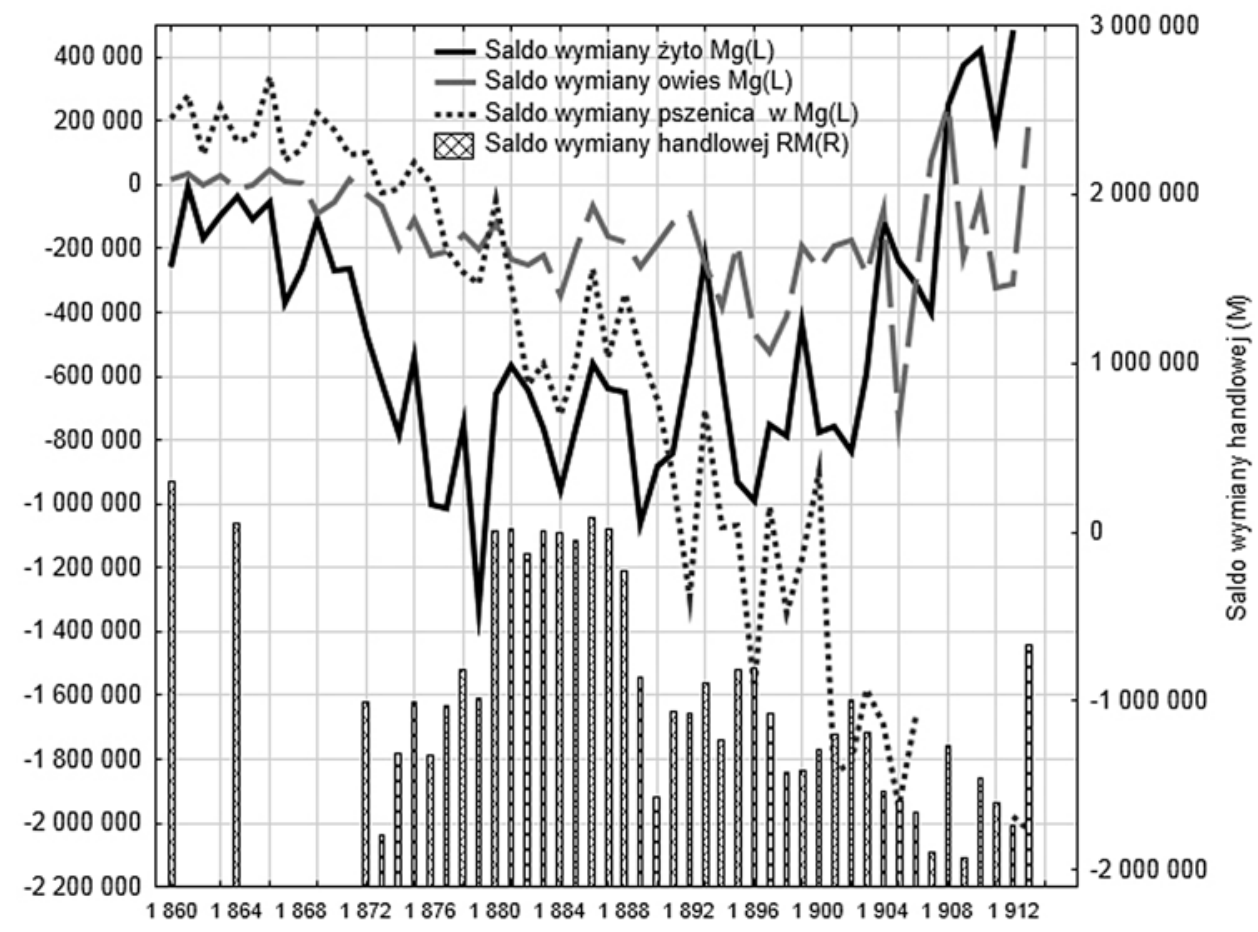

Rys. 44. Saldo wymiany handlowej zbożami na tle salda handlowego NZC i Niemiec (1860-1913)

Źródło: jak do rys. 42.

\section{WYMIANA HANDLOWA W OKRESIE NIEMIECKIEGO ZWIĄZKU CELNEGO. HANDEL ZAGRANICZNY RZESZY NIEMIECKIEJ}

Niemcy ze względu na mnogość państw i państewek były usiane komorami celnymi, które unicestwiały handel i przemysł, stanowiąc jednocześnie prawdziwe przekleństwo rozwoju ryku narodowego. Jak podają Józef Kuliszer oraz Alfred Jacobs i Hans Richter w 1790 r. istniało w Niemczech około 1800 granic celnych, a na początku XIX w. w samych Prusach było 67 lokalnych taryf celnych i tyle samo granic celnych ${ }^{53}$.

Wprawdzie w pierwszym dwudziestoleciu XIX w. zmniejszono liczbę wewnętrznych granic celnych, ale jak pisze Wacław Stankiewicz: „kupiec wiozący

53 J. Kuliszer, Powszechna historia gospodarcza średniowiecza i czasów nowożytnych, t. II, Warszawa 1961, s. 502;A. Jacobs, H. Richter, Die Großhandelspreise in Deutschland von 1792 bis 1934, „Sonderhefte des Instituts für Konjunkturforschung”1935, Nr. 37, s. 50-51. 
towary z Hamburga do Berlina musiał przekraczać dziesięć granic państwowych i celnych, a po drodze z Magdeburga do Drezna $(180 \mathrm{~km})$ płacić 16 razy cło!’”54

Stąd też walka o likwidację ceł wewnętrznych wysunęła się, obok walki z ustrojem cechowym, na główne miejsce w działaniach rządu Królestwa Prus. Dla zintensyfikowania tych działań niemały wpływ miał kształt granic Królestwa Prus. Zwraca na to uwagę Janusz Iwaszkiewicz w Wielkiej Historii Powszechnej:

Po 1815 r. posiadłości Prus składały się z dwóch części, niemających żadnego połączenia. Granice były nadmiernie wyciągnięte, poprzecinane wyrzynającymi się terytoriami innych państw niemieckich, do tego stan prowincji wschodnich, rolniczych przeważnie różnił się zasadniczo od uprzemysłowionych, zachodnich. Naturalnym dążeniem rządu pruskiego było związanie tych części przez włączenie rozdzielających je krajów niemieckich w jeden obszar celny ${ }^{55}$.

Już 28 maja 1818 r. w Prusach wprowadzono ustawę handlową i celną, na mocy której zniesiono cła pomiędzy prowincjami pruskimi. Ustawa wchodziła w życie od początku stycznia 1819 r. i wprowadzała dwie taryfy dla prowincji zachodnich Prus i jedną taryfę dla prowincji wschodnich (na wschód od rzeki Łaby (Elby)). Zgodnie z ustawą, co trzy lata rewidowano taryfy celne ${ }^{56}$.

Był to pierwszy etap unifikacji celnej. Prusy stworzyły na swym terytorium, obejmującym znaczną część terytorium Niemiec, jednolity rynek. Jednakże 38 granic celnych w obrębie Niemiec paraliżowało dalej wymianę wewnętrzną, gdyż każde z państw niemieckich traktowało sąsiednie jako zagranicę.

Władze gospodarcze państwa pruskiego szybko zrozumiały, że rozdrobnienie Niemiec, brak jednolitego rynku i niska siła nabywcza licznych warstw społecznych stały się przeszkodą nie do przebycia na drodze do dalszego rozwoju gospodarczego kraju ${ }^{57}$. Dlatego korzystając ze swojego stanowiska i nadarzających się okoliczności, Prusy zaczęły skupiać dokoła swoich posiadłości małe niemieckie państwa, aby włączać je w zakres swych interesów i stopniowo kojarzyć je z sobą ${ }^{58}$.

Jednak dopiero pod koniec lat dwudziestych XIX w. padają stopniowo bariery hamujące handel i oddzielające Niemców od siebie. Dnia 1 lipca 1828 weszła W życie unia celna pomiędzy Prusami a Badenią i Wirtembergią ${ }^{59}$. W ślad za nią poszły inne niemieckie państwa, zawierając między sobą porozumienia bilateralne w sprawie taryf celnych. Jednym z nim było porozumienie pomiędzy Prusami a Hesją-Darmstadt zawarte w lutym 1828 r., a rozszerzone w 1832 r. o Hesję-Kassel. Ważnym wydarzeniem było przyjęcie pruskiego systemu taryfowego przez dwa kolejne kraje - Bawarię i Wirtembergię.

${ }^{54}$ W. Stankiewicz, Historia myśli ekonomicznej, Warszawa, 1983, s. 243.

55 Wielka Historia Powszechna, red. J. Dąbrowski, O. Halecki, M. Kukiel, S. Lam, t. VI/3 Od Wielkiej Rewolucji do Wojny Światowej 1789-1914 Poznań 1999, (reprint, 1934), s. 166 i n.

${ }_{56}$ A. Jacobs, H. Richter, op. cit., s. 50-51.

${ }^{57}$ Por. W. Grabska, op. cit., s. 8-10.

${ }_{58}$ M. Dubiecki, op. cit., s. 162-163 i n.

59 S. Mathias, S. Pollard, The Cambridge Economic History of Europe, vol. VIII, The Industrial Economics: The Development of Economic and Social Policies, Cambridge 1989, s. 16 i n. 
Na mocy tych porozumień na obszarze Niemiec funkcjonowały: środkowoniemiecki związek celny (unia Saksonii z Hesją, Brunszwikiem, Hanowerem, Oldenburgiem, państwami turyńskimi, Bremą, Frankfurtem), północny związek celny (Prusy, Hesja-Darmstadt) i południowoniemiecki związek celny (Bawaria, Wirtembergia).

W 1829 r. z inicjatywy pruskiego ministra finansów Friedricha von Motza i Johanna Cotty został zawarty traktat handlowy pomiędzy związkiem północnym a południowoniemieckim, w myśl którego oba związki postanowiły znieść częściowo pobierane przez siebie cła, a częściowo obniżyć je o $25 \%$, i w przyszłości przystosowywać do siebie oba systemy celne. Wobec tego faktu, Saksonia i państwa turyńskie nolens volens musiały przyłączyć się do Związku Celnego.

Kolejnym krokiem po zniesieniu wewnętrznych barier celnych w Prusach było stworzenie z dniem 31 grudnia 1831 r. związku celnego pomiędzy Prusami a Hesją. Związek obejmował powierzchnię 5278,72 niemieckich mil kwadratowych (około $296928 \mathrm{~km}^{2}$ ).

Trzy lata później (1834 r.) utworzono Niemiecki Związek Celny (Deutscher Zollverein), którego głównym inicjatorem były Prusy. Związek w 1834 r. obejmował (po wstąpieniu Bawarii, Saksonii, Turyngii, Hesji - Kassel i wielu mniejszych państw) 7732,34 niemieckich mil kwadratowych (około $\left.434944,2 \mathrm{~km}^{2}\right)^{60}$.

W roku 1836, po przystąpieniu Badenii, Nassau i Frankfurtu n. Menem, powierzchnia Związku wynosiła już 8088,54 niemieckich mil kwadratowych (około $454980,4 \mathrm{~km}^{2}$ ).

Umowa z 1834 r. obowiązywała do 1 stycznia 1842 r. Następna umowa miała obowiązywać w latach 1842-1854 r. W kolejnym okresie obowiązywania umowy (lata 1854-1865) obszar Związku obejmował już 9047,44 niemieckich mil kwadratowych (około $508918,5 \mathrm{~km}^{2}$ ) (tab. 19) ${ }^{61}$.

Pierwsza niemiecka taryfa celna z 1834 r. podlegała kolejnym zmianom w latach: $1837,1840,1842,1846,1848,1851,1854,1857,1860,1865,1868,1870$, 1873. Jak zauważają A. Jacobs i H. Richter kolejne taryfy celne, praktycznie do połowy lat siedemdziesiątych XIX w., były odpowiedzią na prowadzoną przez wiele państw europejskich politykę wolnego handlu¹.

Dzięki ustawom celnym i rozszerzaniu Niemieckiego Związku Celnego kształtował się niemiecki (jako całość) rynek ekonomiczny. Poza tym rynkiem pozostawała Austria. W 1834 r. Związek zjednoczył pod względem handlowym około 24-25 mln ludności. W 1850 r. Zollverein obejmował około $34 \mathrm{mln}$ mieszkańców w porównaniu do 27,5 mln w Zjednoczonym Królestwie, 32,5 mln w Austrii, 35,6 mln we Francji, 24,1 mln we Włoszech, $15 \mathrm{mln}$ w Hiszpanii, i 72,5 mln w Rosji, była to liczba niemała - powstał duży niemiecki rynek wewnętrzny ${ }^{62}$.

${ }^{60}$ H. Rau, Vergleichender Statistik des Handels der Deutschen Staaten, Wiedeń 1863, s. 53.

${ }^{61}$ Do Związku nie należały m.in.: Austria, Meklemburgia, Szlezwik-Holsztyn.

${ }^{62}$ P. Mathias, S. Pollard, op. cit., s. 16. 
Tabela 19. Kraje członkowskie Niemieckiego Związku Celnego - powierzchnia (1865 r.)

\begin{tabular}{|l|c|c|}
\hline \multicolumn{1}{|c|}{ Kraj } & $\begin{array}{c}\text { Powierzchnia } \\
\text { (w milach niemieckich) }\end{array}$ & $\begin{array}{c}\text { Udział w powierzchni Niemieckiego } \\
\text { Związku Celnego (w \%) }\end{array}$ \\
\hline Prusy & 5212,97 & 57,62 \\
\hline Bawaria & 1389,35 & 15,36 \\
\hline Hanower & 705,12 & 7,79 \\
\hline Wirtembergia & 354,29 & 3,92 \\
\hline Badenia & 279,70 & 3,09 \\
\hline Saksonia & 271,67 & 3,00 \\
\hline Turyngia & 229,83 & 2,54 \\
\hline Elekt. Hesji & 160,99 & 1,78 \\
\hline Wlk. Ks. Hesji & 153,91 & 1,70 \\
\hline Oldenburg & 97,82 & 1,08 \\
\hline Nassau & 85,19 & 0,94 \\
\hline Brunszwik & 58,01 & 0,64 \\
\hline Luksemburg & 47,00 & 0,52 \\
\hline Frankfurt n. M. & 1,59 & 0,02 \\
\hline Razem & $\mathbf{9 0 4 7 , 4 4}$ & $\mathbf{1 0 0 , 0 0}$ \\
\hline
\end{tabular}

Źródło: A. Bienengräber, Statistik des Verkehrs und Verbrauchs im Zollverein für die Jahre 1842-1864: Nach den veröffentlichten amtlichen Kommerzial-Übersichten etc., Berlin 1868, s. 8.

Początkowo poza Związkiem Celnym pozostawały terytoria nadmorskie (Hanower, Oldenburg, Szlezwik, Holsztyn, Meklemburg, miasta hanzeatyckie), było to wielkie osłabienie Związku, gdyż członkowie unii nie mieli swobodnego dostępu do portów Morza Północnego ${ }^{63}$.

W Związku zarysowała się wyraźna dominacja Prus, jednakże, obok powierzchni, istotne było położenie geograficzne poszczególnych państw. To dlatego Prusy zabiegały o przystąpienie Hanoweru, dostrzegając ich porty i dostęp do Morza Północnego.

W 1851 udało się przyłączyć do Związku Hanower i Oldenburg, którym obiecano przywileje. W 1864 r. kraje członkowskie Związku liczyły blisko $36 \mathrm{mln}$ ludności. Królestwo Prus stanowiło blisko 58\% powierzchni Związku, Bawaria ponad $15 \%$, Hanower blisko $8 \%$, Wirtembergia i Badenia ponad 3\%, Saksonia 3\%. Kierownictwo Związkiem, jako największe państwo objęły Prusy.

Mimo różnego potencjału państw (ekonomicznego i politycznego) w Związku panowała zasada równości i jednomyślności. Miało to zapewnić bezpieczeństwo interesów mniejszych państw. Państwom członkowskim przysługiwało prawo weta.

${ }_{63}$ Por. A. Doering Manteuffel, Die deutsche Frage und das europäische Staatensystem 18151871, [w:] Enzyklopädie deutscher Geschichte, t. 15, München 1993, s. 19 i n. 
Decyzje podjęte przez Ogólną Konferencję Związku dotyczące przepisów celnych nie wymagały ratyfikacji przez państwa członkowskie.

Przychody Związku wynikały z ceł wwozowych, wywozowych i tranzytowych. Później wprowadzono także podatek od produkcji cukru buraczanego (od 1844 r.). Sposób podziału został określony w artykule 22 umowy o przystąpieniu do Związku z 1833 r. Z zapisu wynikało, że przychody Związku Celnego, po odjęciu kosztów dzielone będą pomiędzy kraje członkowskie w wysokości odpowiadającej odsetkowi, jaki stanowiła ludność kraju w stosunku do całkowitej liczby ludności zamieszkałej w granicach Związku.

Zasadniczo Królestwu Prus z liczbą ludności 19,6 mln przypadało ponad $54,7 \%$ w uzyskiwanych dochodach (rys. 45). Ze względu na niski poziom zaludnienia Prus Wschodnich był to odsetek mniejszy niż udział Prus w powierzchni całkowitej Zollverein (blisko 58\%). Na Bawarię przypadało niemal 13,5\%, $\mathrm{Na}$ Saksonię 6,5\%, na Hanower niemal 5,5\%, Wirtembergię blisko 4,9\%, Badenię blisko $4 \%$, Turyngię nieco ponad 3\%. Pozostali członkowie posiadali udziały poniżej 3\% (Elektorat Hesji, Wielkie Księstwo Hesji, Nassau, Brunszwik, Frankfurt, Luksemburg, Oldenburg).

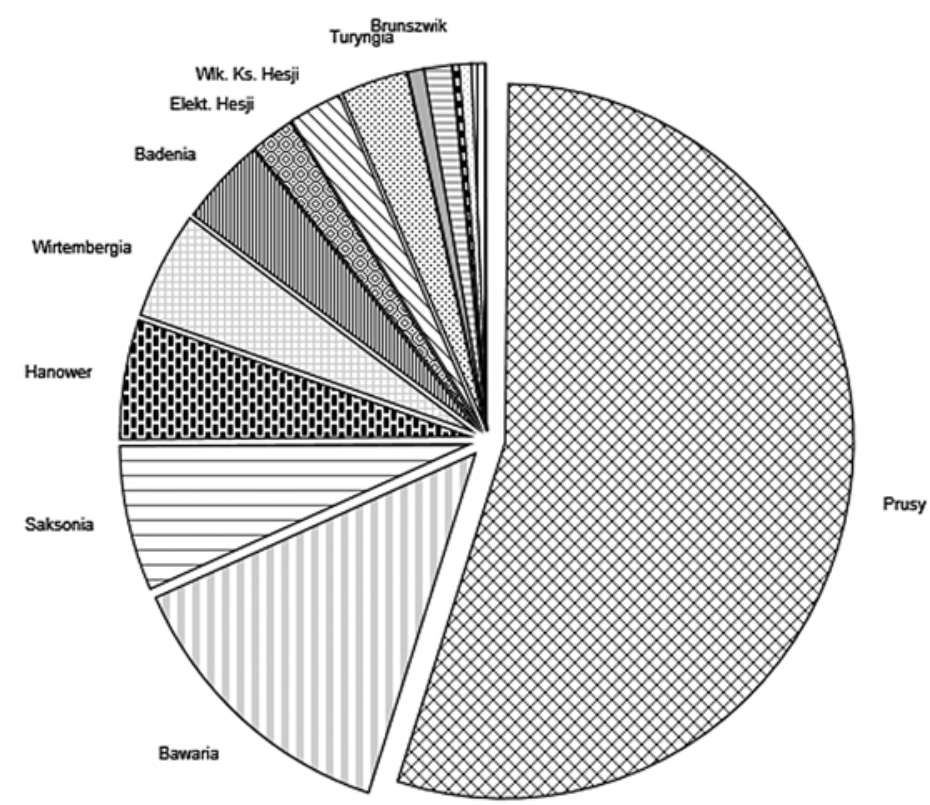

Rys. 45. Udział poszczególnych krajów członkowskich w podziale przychodów Związku Celnego (1865 r.)

Źródło: opracowanie własne na podstawie: A. Bienengräber, Statistik des Verkehrs und Verbrauchs im Zollverein für die Jahre 1842-1864: Nach den veröffentlichten amtlichen Kommerzial-Übersichten etc., Berlin 1868, s. 9-12. 
Związek, co do handlu i cła stanowił względem państw zagranicznych oddzielną całość - zniesiono wewnętrzne bariery celne, a jednocześnie odgrodzono się jednolitą taryfą celną od zalewu konkurencyjnych towarów angielskich. Opłata celna pobierana była na wspólnych granicach ${ }^{64}$.

Niemiecki Związek Celny był pod względem handlu i ceł całością. W latach pięćdziesiątych i sześćdziesiątych XIX w. Niemcy, jak pododaje J. Kuliszer, stały się narodową jednostką handlową, jednolitym obszarem celnym sięgającym do wybrzeży morskich ${ }^{65}$, co zostało zobrazowane na rys. 46 , z uwzględnieniem granic powstałego w $1871 \mathrm{r}$. Cesarstwa Niemieckiego.

W 1835 r. Prusy zawarly odrębny traktat handlowy z Austrią, ale dopiero traktat z Francją z 1862 r. umożliwił Prusom i pozostałym państwom Niemieckiego Związku Celnego realizację polityki wolnego handlu. W 1840 r. Związek zawarł traktat handlowy z Imperium Otomańskim (Osmańskim), a w $1841 \mathrm{r}$. układ handlowo-żeglugowy z Wielką Brytanią. W 1844 r. zawarto układ handlowo-żeglugowy z Belgią, a w 1845 r. z Sardynią. Oczywiście umowy te korzystnie wpływały na wysokość uzyskiwanych dochodów z tytułu ceł, które w $1845 \mathrm{r}$. przekroczyły $25 \mathrm{mln}$ talarów.

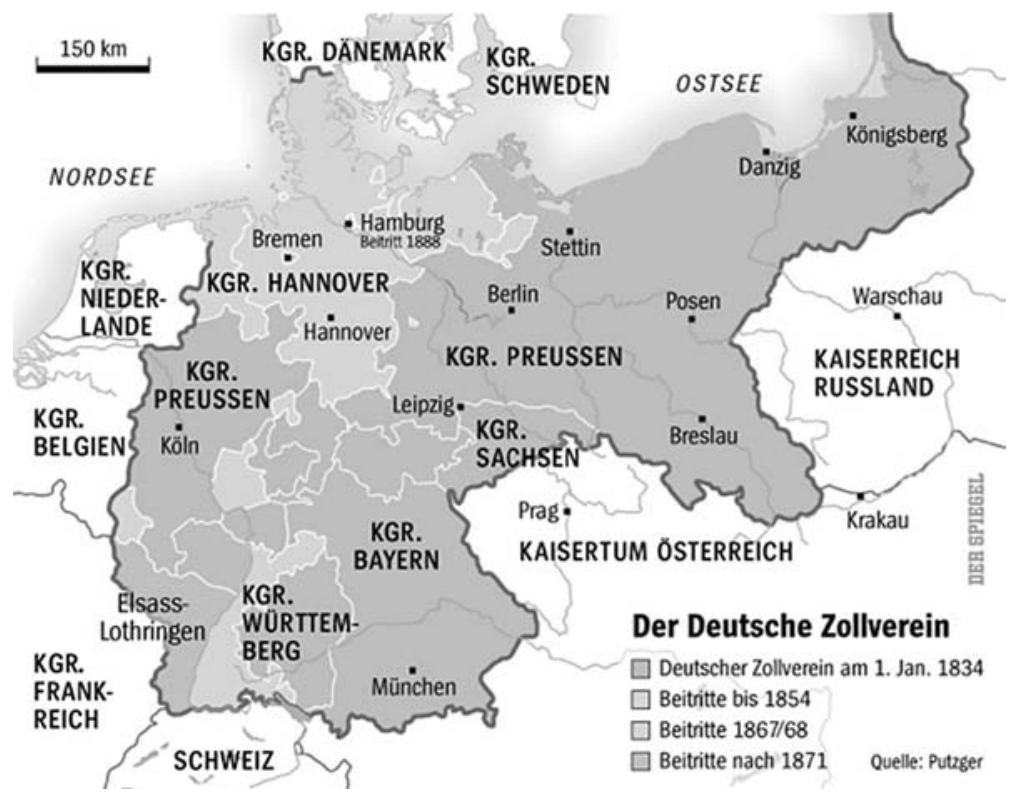

Rys. 46. Niemiecki Związek Celny przyrost terytorialny w latach 1834-1871

Źródło:http://www.spiegel.de/spiegel/spiegelspecialgeschichte/d-50620319.html

${ }^{64} \mathrm{Z}$ jednej strony 10-procentowa taryfa była protekcyjna w porównaniu do małych państw i liberalna w odniesieniu do ówczesnych dużych państw.

${ }^{65}$ J. Kuliszer, op. cit. s. 504. 
W ciągu 30 lat istnienia Niemieckiego Związku Celnego ogólne przychody z ceł wzrosły o ponad $78 \%$, osiągając w roku 1864 poziom ponad 21,6 mln talarów (przy wzroście obrotów handlowych o ponad 300\%). Największy udział w obrotach przypadł Prusom około 11,3 mln talarów (tab. 20).

W wyniku coraz bardziej liberalnej polityki handlowej po 1845 r. przychody $\mathrm{z}$ ceł spadały, w stosunku do ciągle wzrastającej liczby ludności Związku (rys. 47.). Jednocześnie daje się zauważyć szybki wzrost obrotów handlowych (tab. 20). Obroty te w 1834 r. wynosily ponad 249,5 mln talarów, w 1860 wzrosły do 831,45 mln talarów (wzrost o ponad 333\%).

Tabela 20. Przychody z opłat celnych w krajach Niemieckiego Związku Celnego w latach 1834-1864 (w talarach)

\begin{tabular}{|l|c|c|c|c|c|c|c|}
\hline \multirow{2}{*}{ Kraj } & \multicolumn{7}{|c|}{ Rok } \\
\cline { 2 - 8 } & 1834 & 1840 & 1845 & 1850 & 1855 & 1859 & 1864 \\
\hline Prusy & 7101727 & 10478339 & 13865974 & 11338632 & 11849519 & 10607079 & 11023709 \\
\hline Bawaria & 2205174 & 3161044 & 3872223 & 3046298 & 3066941 & 2681555 & 2759908 \\
\hline Saksonia & 827718 & 1208922 & 1549239 & 1293682 & 1372598 & 1247227 & 1297263 \\
\hline $\begin{array}{l}\text { Wirtember- } \\
\text { gia }\end{array}$ & 846969 & 1220474 & 1515557 & 1215085 & 1164407 & 981165 & 1011410 \\
\hline Badenia & - & 924663 & 1160658 & 915641 & 910126 & 774100 & 802759 \\
\hline $\begin{array}{l}\text { Elekt. } \\
\text { Hesji }\end{array}$ & 332336 & 477653 & 626641 & 492333 & 488616 & 406067 & 417728 \\
\hline $\begin{array}{l}\text { Wlk. Ks. } \\
\text { Hesji }\end{array}$ & 393584 & 580078 & 735827 & 580717 & 581430 & 500766 & 514012 \\
\hline Turyngia & 471253 & 681677 & 858207 & 693099 & 707792 & 613444 & 623681 \\
\hline Brunszwik & - & - & 210341 & 167844 & 169234 & 146147 & 150617 \\
\hline Nassau & - & 280791 & 359153 & 286474 & 288242 & 252866 & 267046 \\
\hline $\begin{array}{l}\text { Frankfurt } \\
\text { n. Menem }\end{array}$ & - & 173043 & 212562 & 184904 & 194673 & 178129 & 187129 \\
\hline $\begin{array}{l}\text { Luksem- } \\
\text { burg }\end{array}$ & - & - & 156725 & 127718 & 129409 & 111525 & 116223 \\
\hline Hanower & - & - & - & - & 2386421 & 2125221 & 2201240 \\
\hline Oldenburg & - & - & - & - & 296993 & 269813 & 275136 \\
\hline Razem & 12178761 & 19186684 & 25123107 & 20342427 & 23606401 & 20895104 & 21647861 \\
\hline
\end{tabular}

Źródło: opracowanie własne na podstawie: Jahrbuch für Volkswirthschaft uns Statistik, Herausgegeben von O. Hübner, Siebenter Jahrgang, Leipzig 1861, s. 30-31; A. Bienengräber, Statistik des Verkehrs und Verbrauchs im Zollverein für die Jahre 1842-1864: Nach den veröffentlichten amtlichen Kommerzial-Übersichten etc., Berlin 1868, s. 15. 


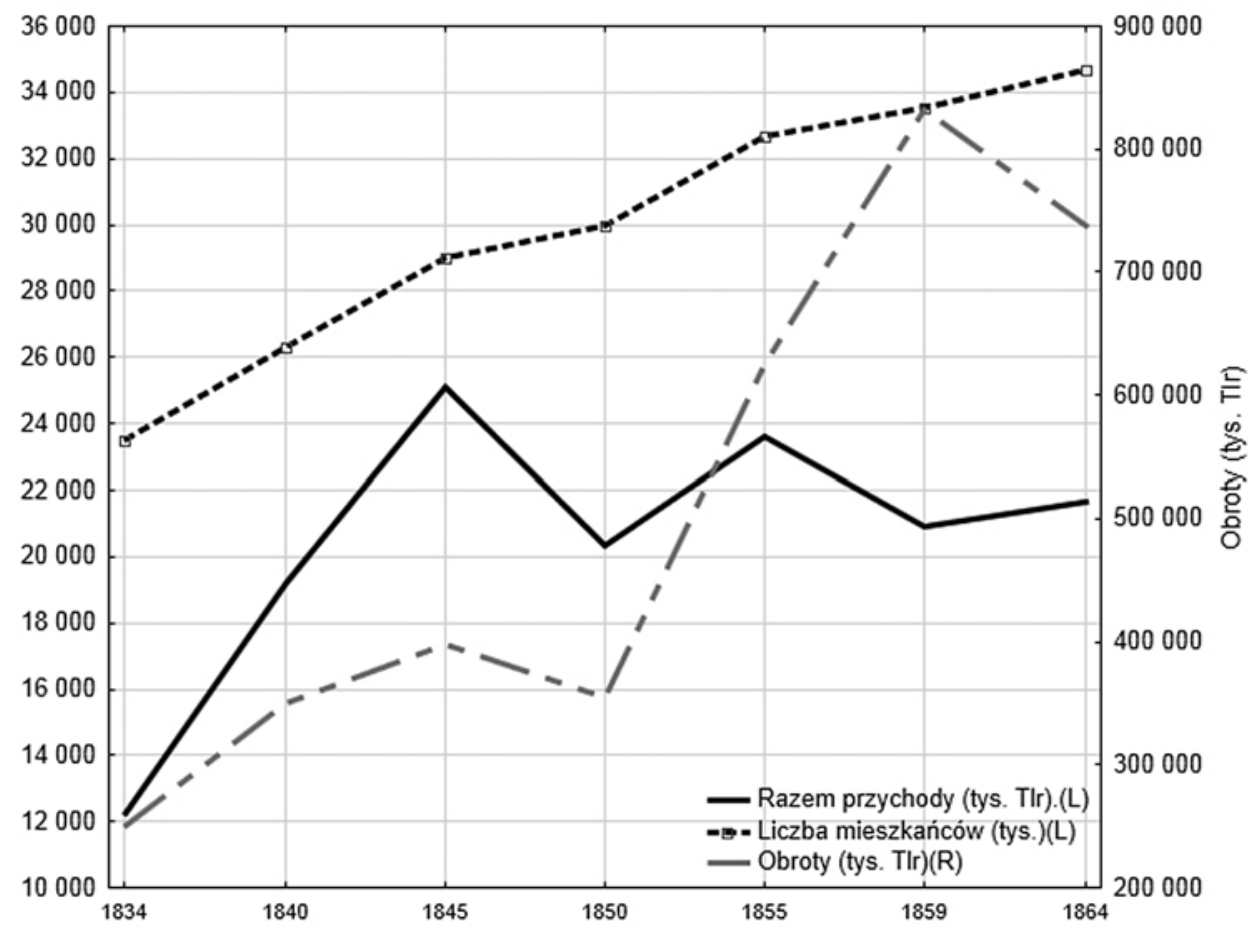

Rys. 47. Przychody netto z ceł Niemieckiego Związku Celnego na tle wzrostu ludności (1834-1864)

Źródło: opracowanie własne na podstawie tab. 20.

Wdrażana idea wolnego handlu przyniosła wymierne efekty. W 1864 r. po 31 latach funkcjonowania Niemieckiego Związku Celnego wartości obrotów (wwóz i wywóz) przekroczyły 737,4 mln talarów. Obroty wzrosły blisko trzykrotnie. Biorąc pod uwagę szybki wzrost populacji, w przeliczeniu na 1 mieszkańca obroty wyniosły ponad 21 talarów i w ciągu badanego okresu podwoiły się (tab. 21).

Tabela 21. Wartość wwozu i wywozu towarów w Niemieckim Związku Celnym (1834-1864)

\begin{tabular}{|c|c|c|c|c|c|c|}
\hline \multirow{3}{*}{ Rok } & \multicolumn{2}{|c|}{ Wartość } & Suma & \multirow{3}{*}{$\begin{array}{l}\text { Liczba lud- } \\
\text { ności (mln) }\end{array}$} & \multirow{3}{*}{$\begin{array}{l}\text { Wartość na } 1 \\
\text { mieszkańca } \\
\text { (wtalarach) }\end{array}$} & \multirow{3}{*}{$\begin{array}{c}\text { Dynamika } \\
\text { wwóz i wy- } \\
\text { wóz (1834 = } \\
100)\end{array}$} \\
\hline & wwozu & wywozu & $\begin{array}{l}\text { wwóz } \\
\text { i wywóz }\end{array}$ & & & \\
\hline & \multicolumn{3}{|c|}{ w talarach } & & & \\
\hline 1 & 2 & 3 & 4 & 5 & 6 & 7 \\
\hline 1834 & 105943598 & 143622605 & 249566203 & 23,5 & 10,6 & - \\
\hline 1836 & 128392662 & 170558094 & 298950756 & 25,1 & 11,9 & 119,79 \\
\hline
\end{tabular}


Tabela 21. (cd.)

\begin{tabular}{|c|c|c|c|c|c|c|}
\hline 1 & 2 & 3 & 4 & 5 & 6 & 7 \\
\hline 1838 & 153701112 & 176523419 & 330224531 & 26,0 & 12,7 & 132,32 \\
\hline 1840 & 167778494 & 182959844 & 350738338 & 26,3 & 13,3 & 140,54 \\
\hline 1845 & 219693099 & 178035650 & 397728749 & 29,0 & 13,7 & 159,37 \\
\hline 1850 & 181659146 & 172948116 & 354607262 & 30,0 & 11,8 & 142,09 \\
\hline 1855 & 315764875 & 308567411 & 624332286 & 32,7 & 19,1 & 250,17 \\
\hline 1858 & 321528183 & 350830702 & 672358885 & 33,5 & 20,1 & 269,41 \\
\hline 1860 & 365060000 & 466390000 & 831450000 & 33,7 & 24,7 & 333,16 \\
\hline 1864 & 360380000 & 377050000 & 737430000 & 34,7 & 21,3 & 295,48 \\
\hline
\end{tabular}

Źródło: opracowanie własne na podstawie: A. Bienengräber, Statistik des Verkehrs und Verbrauchs im Zollverein für die Jahre 1842-1864: Nach den veröffentlichten amtlichen KommerzialÜbersichten etc., Berlin 1868, s. 458-459, Jahrbuch für Volkswirthschaft uns Statistik von O. Hübner, Siebenter Jahrgang, Leipzig 1861, s. 9-10.

Wyniki uzyskane w 1864 r. nie są imponujące, czego przyczyną była na wojna secesyjna w Stanach Zjednoczonych i wojna z Danią, które spowodowały blokadę portów Morza Bałtyckiego i Północnego. Dla porównania, w 1860 r. zsumowana wartość wwozu i wywozu wyniosła blisko 831,5 mln talarów, co dawało 24,7 talara na 1 mieszkańca.

Analizując wysokość obrotów handlowych nie sposób nie uwzględnić głównych kierunków handlu Niemieckiego Związku Celnego. Wyniki zaprezentowano w tab. 22.

Tabela 22. Kierunki i wartość obrotów handlowych Niemieckiego Związku Celnego (1864 r.).

\begin{tabular}{|c|c|c|c|c|c|}
\hline \multirow[b]{2}{*}{ Kierunek } & \multicolumn{2}{|c|}{ Wwóz } & \multicolumn{2}{|c|}{ Wywóz } & \multirow{2}{*}{$\begin{array}{l}\text { Saldo wy- } \\
\text { miany } \\
\text { (w talarach) }\end{array}$} \\
\hline & $\begin{array}{c}\text { wartość } \\
\text { (w talarach) }\end{array}$ & $(\%)$ & $\begin{array}{c}\text { wartość } \\
\text { (w talarach) }\end{array}$ & $(\%)$ & \\
\hline 1 & 2 & 3 & 4 & 5 & 6 \\
\hline Rosja i Polska & 34245874 & 9,50 & 17786226 & 4,72 & -16459648 \\
\hline Holandia & 66171498 & 18,36 & 53176120 & 14,1 & -12995378 \\
\hline Austria & 69881256 & 19,39 & 57738283 & 15,31 & -12142973 \\
\hline Poczta, inne & 9823732 & 2,73 & 94626 & 0,03 & -9729106 \\
\hline Morze Północne & 8509720 & 2,36 & 3051380 & 0,81 & -5458340 \\
\hline Brema & 21749802 & 6,04 & 18878234 & 5,01 & -2871568 \\
\hline
\end{tabular}


Tabela 22. (cd.)

\begin{tabular}{|l|r|r|r|r|r|}
\hline \multicolumn{1}{|c|}{1} & \multicolumn{1}{c|}{2} & \multicolumn{1}{c|}{3} & \multicolumn{1}{c|}{4} & \multicolumn{1}{c|}{5} & \multicolumn{1}{c|}{6} \\
\hline Meklemburgia & 2759317 & 0,77 & 1858217 & 0,49 & -901100 \\
\hline $\begin{array}{l}\text { Holsztyn } \\
\text { i Lauenburg }\end{array}$ & 1431103 & 0,40 & 6687201 & 1,77 & 5256098 \\
\hline Francja & 12849633 & 3,57 & 19627453 & 5,21 & 6777820 \\
\hline Hamburg & 64894622 & 18,01 & 74129740 & 19,66 & 9235118 \\
\hline Szwajcaria & 16677062 & 4,63 & 34917807 & 9,26 & 18240745 \\
\hline $\begin{array}{l}\text { Morze } \\
\text { Bałtyckie }\end{array}$ & 18239568 & 5,06 & 36909364 & 9,79 & 18669796 \\
\hline Belgia & 33149978 & 9,20 & 52196569 & 13,84 & 19046591 \\
\hline Razem & $\mathbf{3 6 0 3 8 3 1 6 5}$ & $\mathbf{1 0 0 , 0 0}$ & $\mathbf{3 7 7} \mathbf{0 5 1 2 2 0}$ & $\mathbf{1 0 0 , 0 0}$ & $\mathbf{1 6} \mathbf{6 6 8 \mathbf { 0 5 5 }}$ \\
\hline
\end{tabular}

Źródło: A. Bienengräber, Statistik des Verkehrs und Verbrauchs im Zollverein für die Jahre 1842-1864: Nach den veröffentlichten amtlichen Kommerzial-Übersichten etc., Berlin 1868, s. 460.

Wartość wymienianych towarów wyniosła blisko 737,5 mln talarów, w tym wwożonych do krajów Niemieckiego Związku Celnego oszacowano na ponad 360,3 mln talarów, wywożonych na ponad $377 \mathrm{mln}$ talarów. Osiągnięto tym samym nadwyżkę w obrotach handlowych z zagranicą w wysokości $16,67 \mathrm{mln}$ talarów. Dominowały: wwóz towarów z Austrii (19,39\%), Holandii (18,36\%), Hamburga $(18,01 \%)$. Wywóz towarów kierowany był podobnie głównie do Hamburga (19,66\%), Austrii (15,31\%), Holandii (14,10\%), Belgii (13,84\%).

Ze względu na pewne trudności dotyczące handlu z Wielką Brytanią, Danią, Szwecją, Norwegią czy nawet Rosją (tab. 22) uwzględniono kierunek na Morze Północne i Bałtyckie.

Największy deficyt w obrotach handlowych osiągnięto w wymianie z Rosją i Królestwem Kongresowym. Powodem był ograniczony wolny handel ze strony Rosji, a nawet w stosunku do wielu artykułów zakaz importu (prohibicja). Z Rosji wwożono głównie drewno, produkty rolne (rośliny, zwierzęta), terpentynę, futra, kawior, olej świeży, surowy jedwab, o wartości ponad 34,2 mln talarów. Do Rosji wywożono głównie wyroby chemiczne, indygo, żelazo i wyroby stalowe, szkło, artykuły spożywcze, wyroby tytoniowe. Prusy - największe państwo Związku Celnego już w końcu lat pięćdziesiątych zajmowało drugie (po Austrii) miejsce w obrotach z Rosją.

Idea wolnego handlu, zapożyczona z Anglii, znalazła wielu gorliwych zwolenników na kontynencie europejskim. Proces ten trwał wiele lat i święcił swój triumf w latach sześćdziesiątych XIX w. W tab. 23 przedstawiono poziom średnich stawek celnych w wybranych krajach europejskich i USA w latach 18571875. 
Tabela 23. Poziom stawek celnych ad valorem dla wybranych grup towarowych w wybranych krajach europejskich i USA w latach 1857- 1873 (\% wartości importu)

\begin{tabular}{|c|c|c|c|c|c|c|c|c|c|}
\hline \multirow{2}{*}{ Kraj } & \multicolumn{9}{|c|}{ Rok } \\
\hline & 1857 & 1859 & 1861 & 1863 & 1865 & 1867 & 1869 & 1871 & 1873 \\
\hline \multicolumn{10}{|c|}{ Surówka żelaza } \\
\hline 1 & 2 & 3 & 4 & 5 & 6 & 7 & 8 & 9 & 10 \\
\hline Wlk. Brytania & 0,0 & 0,0 & 0,0 & 0,0 & 0,0 & 0,0 & 0,0 & 0,0 & 0,0 \\
\hline Francja & 19,1 & 19,2 & 17,6 & 18,7 & 8,9 & 13,1 & 0,7 & 9,5 & 5,2 \\
\hline Niemcy* & 23,1 & 30,4 & 32,3 & 26,9 & 21,9 & 24,5 & 14,9 & 6,9 & 4,0 \\
\hline Belgia & 18,2 & 10,0 & 5,6 & 9,8 & 6,7 & 5,4 & 4,6 & 4,7 & 3,2 \\
\hline Holandia & 0,0 & 0,0 & 0,0 & 0,0 & 0,0 & 0,0 & 0,0 & 0,0 & 0,0 \\
\hline Austro-Węgry & 15,0 & 15,5 & 15,4 & 15,6 & 16,2 & 16,1 & 10,0 & 10,0 & 10,0 \\
\hline USA & 27,4 & 24,0 & 29,8 & 47,0 & 52,6 & 50,5 & 50,1 & 34,6 & 21,2 \\
\hline \multicolumn{10}{|c|}{ Przędza bawełniana } \\
\hline Wlk. Brytania & 0,0 & 0,0 & 0,0 & 0,0 & 0,0 & 0,0 & 0,0 & 0,0 & 0,0 \\
\hline Francja & 36,1 & 36,1 & 10,7 & 6,5 & 5,5 & 10,0 & 9,3 & 6,5 & 7,3 \\
\hline Niemcy* & 10,7 & 10,1 & 8,9 & 4,4 & 4,4 & 4,4 & 5,3 & 5,8 & 5,5 \\
\hline Belgia & 2,6 & 4,6 & 4,9 & 1,6 & 1,7 & 2,5 & 2,0 & 2,1 & 2,6 \\
\hline Holandia & 1,2 & 1,1 & 1,0 & 0,1 & 0,1 & 0,1 & 0,1 & 0,1 & 0,1 \\
\hline Austro-Węgry & 6,6 & 6,5 & 7,2 & 3,0 & 4,4 & 6,2 & 5,6 & 5,6 & 5,6 \\
\hline USA & 22,4 & 19,0 & 24,1 & 40,0 & 31,1 & 63,5 & 61,6 & 51,7 & 45,0 \\
\hline \multicolumn{10}{|c|}{ Sztaby żelaza i stal } \\
\hline Wlk. Brytania & 0,0 & 0,0 & 0,0 & 0,0 & 0,0 & 0,0 & 0,0 & 0,0 & 0,0 \\
\hline Francja & 10,9 & 10,1 & 5,8 & 7,0 & 2,6 & 2,4 & 2,1 & 5,8 & 4,7 \\
\hline Niemcy* & 29,4 & 31,2 & 25,7 & 27,8 & 16,5 & 17,8 & 15,5 & 14,2 & 11,8 \\
\hline Belgia & 2,9 & 3,3 & 3,2 & 4,1 & 2,4 & 1,5 & 1,9 & 2,0 & 2,0 \\
\hline Holandia & 0,0 & 0,0 & 0,0 & 0,0 & 0,0 & 0,0 & 0,0 & 0,0 & 0,0 \\
\hline Austro-Węgry & 15,7 & 21,1 & 20,1 & 10,9 & 11,1 & 8,6 & 22,1 & 22,1 & 20,6 \\
\hline USA & 23,1 & 17,8 & 21,8 & 37,5 & 36,4 & 40,2 & 43,6 & 40,2 & 27,1 \\
\hline \multicolumn{10}{|c|}{ Wino } \\
\hline Wlk. Brytania & 68,6 & 89,4 & 36,2 & 36,6 & 40,9 & 32,8 & 32,8 & 26,1 & 25,8 \\
\hline Francja & 0,4 & 0,5 & 0,7 & 0,6 & 0,7 & 0,8 & 0,8 & 6,0 & 11,0 \\
\hline Niemcy* & 39,3 & 62,9 & 47,6 & 53,1 & 41,3 & 37,6 & 24,8 & 27,3 & 22,1 \\
\hline Belgia & 0,5 & 0,6 & 0,8 & 0,6 & 0,5 & 0,5 & 0,5 & 0,5 & 0,5 \\
\hline Holandia & 0,1 & 0,1 & 0,1 & 0,0 & 0,0 & 0,0 & 0,0 & 0,0 & 0,0 \\
\hline Austro-Węgry & 32,8 & 27,6 & 31,4 & 31,6 & 30,5 & 23,6 & 16,4 & 18,2 & 18,1 \\
\hline USA & 35,7 & 30,0 & 34,9 & 40,0 & 81,7 & 77,1 & 77,0 & 81,5 & 69,0 \\
\hline \multicolumn{10}{|c|}{ Pszenica } \\
\hline Wlk. Brytania & 1,8 & 2,3 & 1,8 & 2,3 & 2,7 & 1,7 & 0,7 & 0,0 & 0,0 \\
\hline Francja & 0,7 & 1,1 & 1,1 & 1,1 & 0,1 & 1,0 & 0,7 & 1,5 & 0,9 \\
\hline Niemcy* & 1,6 & 2,2 & 0,2 & 0,5 & 0,2 & 0,0 & 0,0 & 0,0 & 0,0 \\
\hline Belgia & 0,0 & 2,5 & 1,7 & 2,2 & 2,4 & 1,6 & 2,1 & 1,5 & 0,0 \\
\hline Holandia & 0,0 & 0,0 & 0,0 & 0,6 & 0,6 & 0,4 & 0,5 & 0,5 & 0,4 \\
\hline Austro-Węgry & 2,7 & 1,0 & 1,2 & 3,1 & 1,2 & 0,5 & 0,4 & 0,8 & 0,5 \\
\hline USA & 15,2 & 15,0 & 20,2 & 23,7 & 12,0 & 11,8 & 16,5 & 14,1 & 14,8 \\
\hline
\end{tabular}


Tabela 23. (cd.)

\begin{tabular}{|l|r|r|r|r|r|r|r|r|r|}
\hline \multicolumn{1}{|c|}{1} & 2 & 3 & 4 & 5 & 6 & 7 & 8 & 9 & 10 \\
\hline \multicolumn{7}{|c|}{ Żyto } \\
\hline Wlk. Brytania & 2,8 & 3,2 & 2,8 & 3,4 & 4,0 & 2,9 & 1,6 & 0,0 & 0,0 \\
Francja & 1,1 & 1,7 & 1,0 & 0,4 & 3,0 & 0,2 & 0,0 & 0,0 & 0,3 \\
Niemcy* & 0,7 & 0,7 & 0,7 & 0,6 & 0,2 & 0,0 & 0,0 & 0,0 & 0,0 \\
Belgia & 0,0 & 3,6 & 2,6 & 3,2 & 3,7 & 2,3 & 2,9 & 1,9 & 0,0 \\
Holandia & 0,0 & 0,1 & 0,0 & 0,8 & 1,0 & 0,7 & 0,7 & 0,8 & 0,7 \\
Austro-Węgry & 5,7 & 2,5 & 2,3 & 2,2 & 4,4 & 0,5 & 0,6 & 3,6 & 1,8 \\
USA & 15,0 & 15,0 & 15,0 & 23,8 & 14,5 & 18,3 & 18,8 & 21,5 & 13,1 \\
\hline \multicolumn{7}{|c|}{ Surówka żelaza } \\
\hline Wlk. Brytania & 0,0 & 0,0 & 0,0 & 0,0 & 0,0 & 0,0 & 0,0 & 0,0 & 0,0 \\
Francja & 19,1 & 19,2 & 17,6 & 18,7 & 8,9 & 13,1 & 0,7 & 5,2 & 7,5 \\
Niemcy* & 23,1 & 30,4 & 32,3 & 26,9 & 21,9 & 24,5 & 14,9 & 4,0 & 0,0 \\
Belgia & 18,2 & 10,0 & 5,6 & 9,8 & 6,7 & 5,4 & 4,6 & 3,2 & 3,5 \\
Holandia & 0,0 & 0,0 & 0,0 & 0,0 & 0,0 & 0,0 & 0,0 & 0,0 & 0,0 \\
Austro-Węgry & 15,0 & 15,5 & 15,4 & 15,6 & 16,2 & 16,1 & 10,0 & 10,0 & 10,0 \\
USA & 27,4 & 24,0 & 29,8 & 47,0 & 52,6 & 50,5 & 34,6 & 21,2 & 28,9 \\
\hline
\end{tabular}

* Do 1871 r. kraje Niemieckiego Związku Celnego (Deutscher Zollverein), od 1871 r. Cesarstwo Niemieckie.

Źródło: opracowanie własne na podstawie: M. Lampe, Bilateral Trade Flows in Europe, 1857-1875. A new dataset, ,Research in Economic History” 2008, vol. 26, s. 135-140.

Jak wynika z tab. 23 i z rys. 48 niemieckie średnie stawki celne w okresie 1857-1875 kształtowały się na poziomie zbliżonym do stawek francuskich, a w latach siedemdziesiątych XIX w. Niemcy prowadziły najbardziej liberalną politykę handlową spośród krajów kontynentalnej Europy. W 1875 r. średni poziom ceł wynosił $4-6 \%{ }^{66}$.

W latach 1861-1870 zawarto 120 traktatów handlowych, w których powszechnie stosowano klauzulę największego uprzywilejowania. I tak: Włochy podpisały 24 traktaty bilateralne, Francja i Belgia po 19, Niemcy - 18, Austria -14 , Wielka Brytania $-8^{67}$. Traktaty liberalizowały wymianę między państwami, choć nie znosiły ceł zupełnie ${ }^{68}$. W rezultacie zawsze, kiedy wchodził w życie nowy traktat, następowała ogólna obniżka ceł. Przez około 10 lat Europa była bliższa pełnej wolności handlu niż kiedykolwiek potem, aż do końca II wojny światowej. Rozwój transportu - budowa kolei, statków parowych,

${ }^{66}$ P. Bairoch, European Trade Policy, 1815-1914, [w:] P. Mathias, S. Pollard Sidney (eds.), Cambridge Economic History of Europe, vol. 8, Cambridge 1989, s. 41.

${ }^{67}$ S. Schmidt, 1860-1914 Europa zwischen Liberalismus und Protektion, Seminararbeit, Norderstedt 2004, s. 8-9.

${ }^{68}$ J. Ciepielewski, I. Kostrowicka, Z. Landau, J. Tomaszewski, Dzieje gospodarcze świata do roku 1980, Warszawa 1985, s. 188. 
kanałów przyczyniły się również do radykalnego zmniejszenia kosztów dostawy, czasu przewozu, a zarazem zwiększenia korzyści z handlu, w tym obniżki cen towarów.

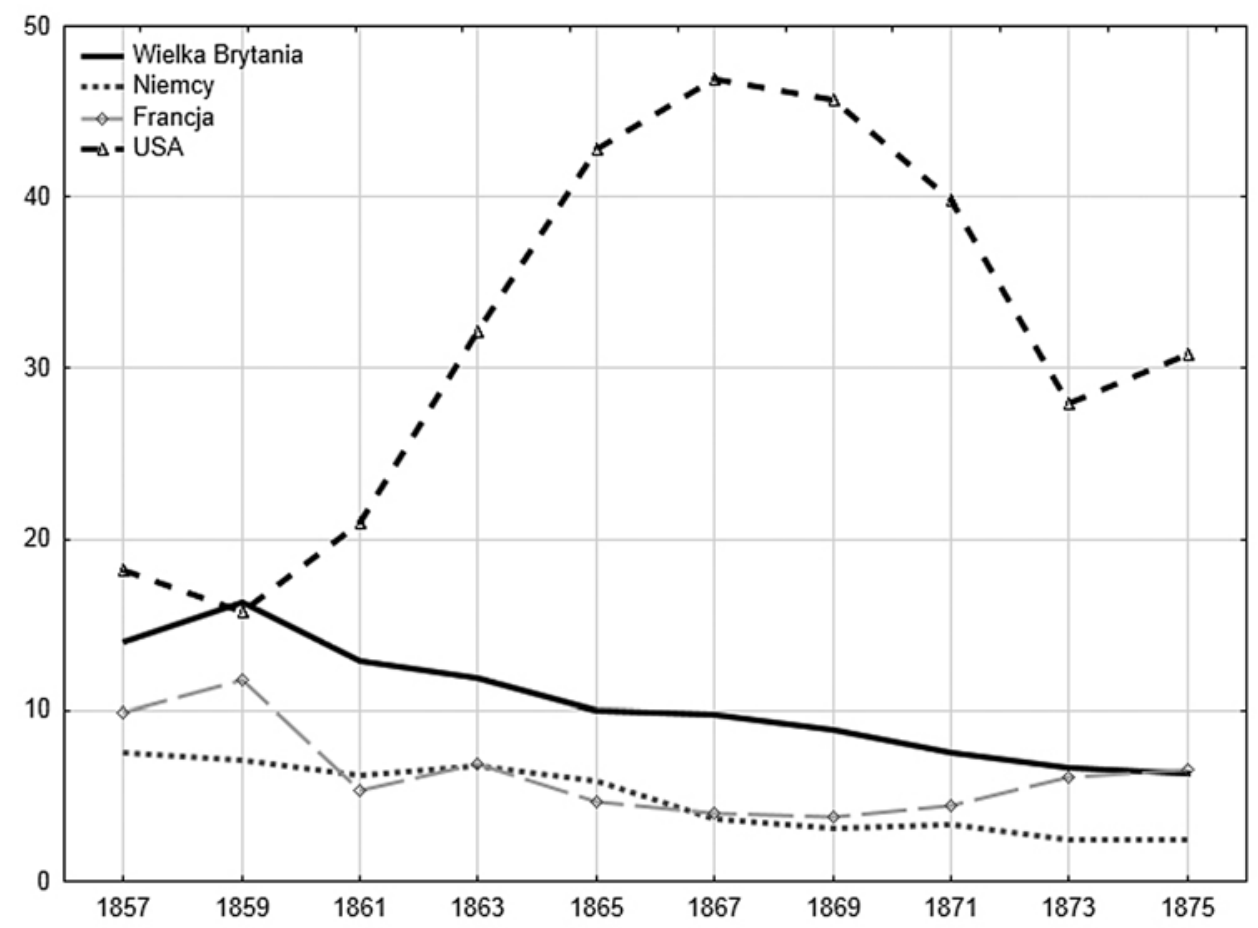

Rys. 48. Średnie stawki celne w wybranych krajach europejskich i USA w latach 1856-1875 (\%)

Źródło: opracowanie własne na podstawie: M. Lampe, Bilateral Trade Flows in Europe, 1857-1875. A new dataset, „Research in Economic History” 2008, vol. 26, s. 135-140.

Sieć traktatów miała ogromny wpływ na tempo obrotów w handlu międzynarodowym. Według szacunków, średni roczny wskaźnik wzrostu obrotów handlowych w latach 1785-1830 wynosił 1,37\%/rok, w latach 1820-1840 2,81\%/rok, w 1840-1860 - 4,84\%/rok, aby w latach 1860-1870 osiągnąć 5,53\%/rok. W latach 1800-1870 wartość obrotów w handlu światowym zwiększyła się ośmiokrotnie z około 280 mln funtów szterlingów w 1800 r., do ponad 2,2 mld funtów szterlingów w 1870 r. ${ }^{69} \mathrm{~W} 1860$ r. udział 7 państw (Wielka Brytania, Francja, Niemiecki Związek Celny, Austro-Węgry, Holandia, Belgia i USA) w światowym

${ }^{69}$ J. Skodlarski, R. Matera, op. cit., s. 119. 
eksporcie wynosił około $62 \%{ }^{70}$. W 1875 r. udział Europy i Ameryki Północnej w generowaniu tych obrotów wynosił ponad $80 \%{ }^{71}$.

Dane statystyczne zawarte w tab. 24 obrazują wielkość obrotów handlowych dla wybranych krajów, jednocześnie zawierają informację o flocie handlowej i długości linii kolejowych.

Tabela 24. Charakterystyka obrotów handlowych dla wybranych krajów (1865-1866)

\begin{tabular}{|l|c|r|r|r|r|}
\hline \multirow{2}{*}{ Kraj } & \multirow{2}{*}{$\begin{array}{c}\text { Wartość ob- } \\
\text { rotów (w mln } \\
\text { talarów) }\end{array}$} & \multicolumn{2}{|c|}{ Flota handlowa } & \multirow{2}{*}{$\begin{array}{c}\text { Dlugość linii } \\
\text { kolejowych } \\
\text { (w km) }\end{array}$} & $\begin{array}{c}\text { Liczba } \\
\text { mieszkańców }\end{array}$ \\
\cline { 3 - 4 } $\begin{array}{l}\text { Wielka } \\
\text { Brytania }\end{array}$ & 2500 & 28787 & 5852473 & 24621 & 29935404 \\
\hline Francja & 1600 & 15259 & 1008084 & 14908 & 38067094 \\
\hline Niemcy & 1400 & 6489 & 1331651 & 14455 & 36585600 \\
\hline Belgia & 550 & 112 & 35509 & 2566 & 4984451 \\
\hline Holandia & 480 & 2303 & 538676 & 1049 & 3552665 \\
\hline Austria & 400 & 3266 & 310401 & 6305 & 35292547 \\
\hline Rosja & 380 & 3708 & 399930 & 4494 & 67260431 \\
\hline Szwajcaria & 280 & - & & 1295 & 2510494 \\
\hline Włochy & 250 & 15767 & 707788 & 4840 & 24368787 \\
\hline Hiszpania & 150 & 4849 & 395270 & 5110 & 16302625 \\
\hline $\begin{array}{l}\text { Turcja } \\
\text { z Egiptem }\end{array}$ & 180 & 3600 & 203000 & 1184 & 17500000 \\
\hline Szwecja & 120 & 3155 & 355044 & 1732 & 4070061 \\
\hline Dania & 75 & 3649 & 160278 & 478 & 1608095 \\
\hline Norwegia & 30 & 5407 & 776500 & 315 & 1701478 \\
\hline
\end{tabular}

Źródło: opracowanie własne na podstawie: K. Scherzer, Einige Mittheilungen über den Welthandel und die wichtigsten Weltverkehrsmittel, „Geographisches Jahrbuch”, Gotha 1868, s. 343-344.

Łatwo zauważyć, że w tym czasie pozycja Wielkiej Brytanii z obrotami 2,5 mld talarów była niepodważalna. W latach czterdziestych XIX w. udział Wielkiej Brytanii w handlu światowym wynosił ponad $30 \%$, w 1870 wciąż $25 \%$ obrotów przypadało na ten kraj. Niemcy zajmowały trzecie miejsce z 1,4 mld talarów ${ }^{72}$.

${ }^{70}$ M. Lampe, Bilateral Trade Flows in Europe, 1857-1875. A new dataset, „Research in Economic History" 2008, vol. 26 .

${ }^{71}$ P. Sidney, The Europeanization of the international economy 1800-1870, [w:] D. Aldcroft, A. Sutcliffe (eds.), Europe in the International Economy 1500 to 2000, Cheltenham 1999, s. 50-51.

${ }^{72}$ S.B. Clough; European Economic History. The Economic Development of Western Civilization, New York 1968, s.338. 
Po zjednoczeniu handel zagraniczny Rzeszy, podobnie jak i cała gospodarka, rozwijał się bardzo dynamicznie. W latach 1880-1913 jego obroty wzrosły 3-krotnie, a udział w handlu światowym zwiększył się z 9 do $12 \%$. Niemcy stały się najgroźniejszym konkurentem Wielkiej Brytanii na rynkach światowych. Wyprzedzały w międzynarodowej wymianie towarowe Stany Zjednoczone i zdecydowanie - Francję (tab. 25).

Tabela 25. Obroty w handlu zagranicznym przodujących krajów w latach 1875-1913 (mln ówczesnych franków)

\begin{tabular}{|l|r|r|r|r|}
\hline \multirow{2}{*}{ Kraj } & \multicolumn{2}{|c|}{1875} & \multicolumn{2}{c|}{1913} \\
\cline { 2 - 5 } & import & eksport & import & eksport \\
\hline Anglia & 9424 & 7106 & 19330 & 15775 \\
\hline Niemcy & 3907 & 3065 & 12960 & 12120 \\
\hline Stany Zjednoczone & 2724 & 2590 & 9183 & 11536 \\
\hline Francja & 3537 & 3837 & 8421 & 6870 \\
\hline Holandia & 1376 & 1072 & 7836 & 6166 \\
\hline Belgia & 1307 & 1102 & 5050 & 3715 \\
\hline Austro-Węgry & - & - & 3771 & 3066 \\
\hline Rosja & 490 & 376 & 3004 & 3323 \\
\hline Włochy & 1171 & 1101 & 3573 & 2461 \\
\hline Japonia & 100 & 103 & 1890 & 1630 \\
\hline
\end{tabular}

Źródło: W. Rusiński, Zarys historii gospodarczej powszechnej, Warszawa, 1970, s. 382.

Jak wynika z danych w tab. 25 import Niemiec przewyższał nieznacznie eksport. Saldo ujemne pokrywano z usług i dochodów z inwestycji zagranicznych. Nadwyżkę importu nad eksportem powodowały wzmożone zakupy surowców i żywności oraz relatywnie wysoka stopa życiowa. Strukturę handlu zagranicznego kształtował szybki wzrost gospodarczy. W wywozie przeważały towary przetworzone (niemal 75\% całego eksportu) tj. wyroby przemysłu metalowego, elektrotechnicznego, włókienniczego i chemicznego ${ }^{73}$.

W 1913 r. Niemcy wywiozły za granicę towarów gotowych na kwotę 7,5 mld marek, a sprowadziły do kraju surowców za 5 mld marek i żywności za 3 mld marek $^{74}$. Eksport maszyn wyniósł, w markach, ponad $544 \mathrm{mln}$, węgla $-368 \mathrm{mln}$, cukru - $212 \mathrm{mln}$ i żyta - $110 \mathrm{mln}$, natomiast ważniejsze pozycje w imporcie stanowiły: bawełna - $604 \mathrm{mln}$, jęczmien - $462 \mathrm{mln}$, wełna - $452 \mathrm{mln}$, pszenica - 399 $\mathrm{mln}$, kawa $-251 \mathrm{mln}$ i jedwab $-168 \mathrm{mln}^{75}$.

\footnotetext{
${ }^{73}$ J. Krasucki, op. cit., s. 247; J. Skodlarski, R. Matera, op. cit., s. 146.

${ }^{74}$ W. Czapliński, A. Galos, W. Korta, op. cit., s. 593.

75 Tamże.
} 
Trend dotyczący kształtowania się indeksu dla eksportu, PKB per capita i długości szlaków kolejowych przedstawia rys. 49.

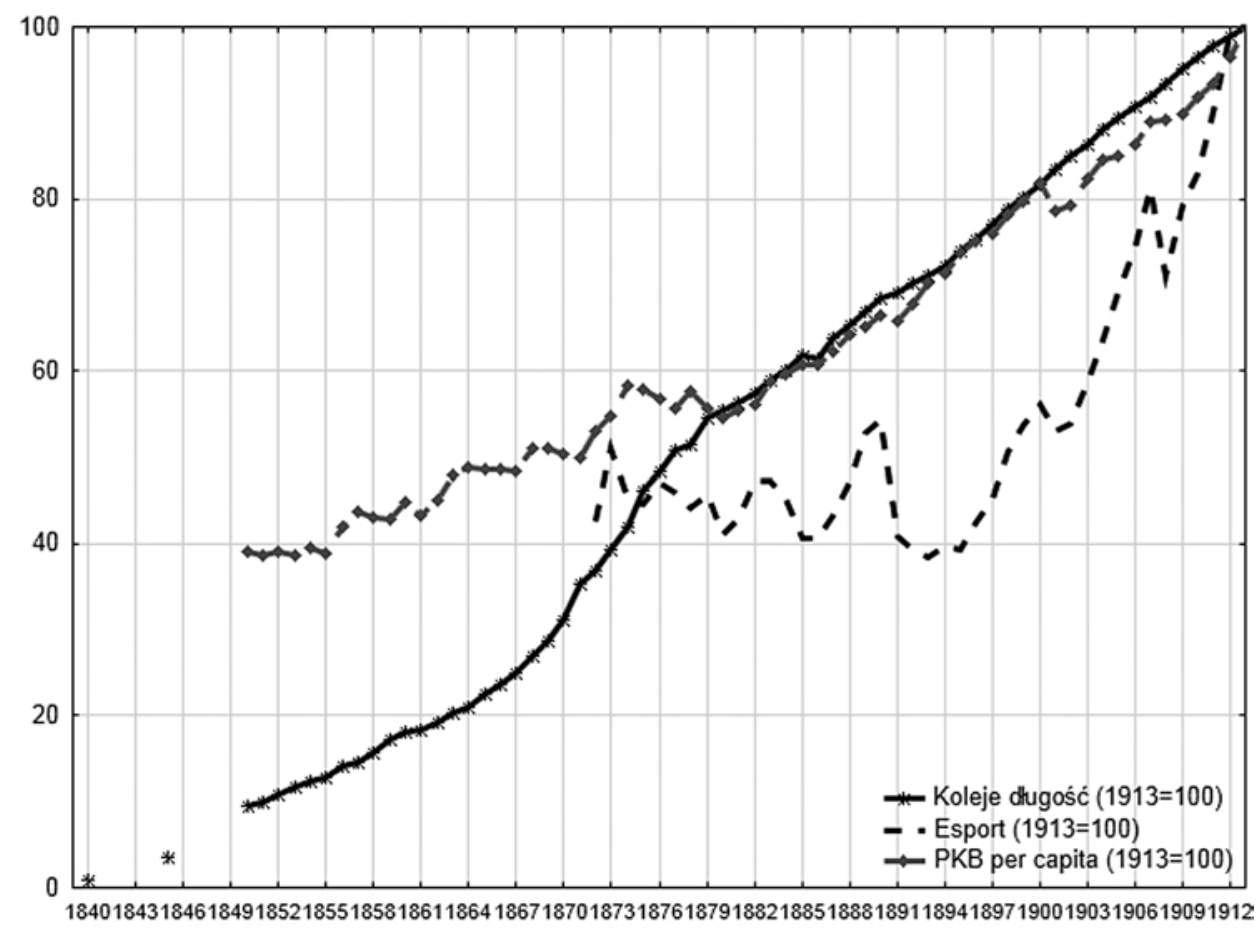

Rys. 49. Indeks dla długości szlaków kolejowych, eksportu i PKB per capita $(1913=100)$

Źródło: jak do rys. 29.

Indeks bardzo szybko wzrastał dla sektora kolejowego - z kilkunastu procent w latach pięćdziesiątych XIX w., aby przekroczyć 50\% w końcu lat siedemdziesiątych XIX w. W tym czasie daje się zauważyć znaczne wahania indeksu w przypadku eksportu. Wartość 50\% dla indeksu z 1913 r. dało się przekroczyć dopiero z początkiem XX w. Natomiast od początku lat dziewięćdziesiątych XIX w. dostrzegalny jest szybki wzrost indeksu.

Handel Rzeszy kierował się głównie do Europy. W 1912 r. do państw europejskich wywieziono 75\% wszystkich towarów. Największym odbiorcą niemieckich towarów była Wielka Brytania i Austro-Wegry. Importowano najwięcej z Rosji (15,5\%) ogółu przywozu, Stanów Zjednoczonych (13,3\%), a następnie z Anglii, Austro-Wegier i Francji. ${ }^{76}$

76 W. Czapliński, A. Galos, W. Korta, op. cit., s. 592-593; W. Rusiński, op. cit., s. 383. 


\section{ZMIANA STRUKTURY GOSPODARCZEJ. DOCHÓD NARODOWY}

Postęp w zakresie industrializacji wpłynął na przyspieszenie zmian strukturalnych w gospodarce niemieckiej.

Wymownym wskaźnikiem jest tutaj zmiana w strukturze zatrudnienia. Coraz mniejszy odsetek osób czynnych zawodowo znajdował zatrudnienie w rolnictwie. Na koniec XIX w. liczba osób zatrudnionych w przemyśle po raz pierwszy w historii przekroczyła liczbę zatrudnionych w rolnictwie (rys. 50).

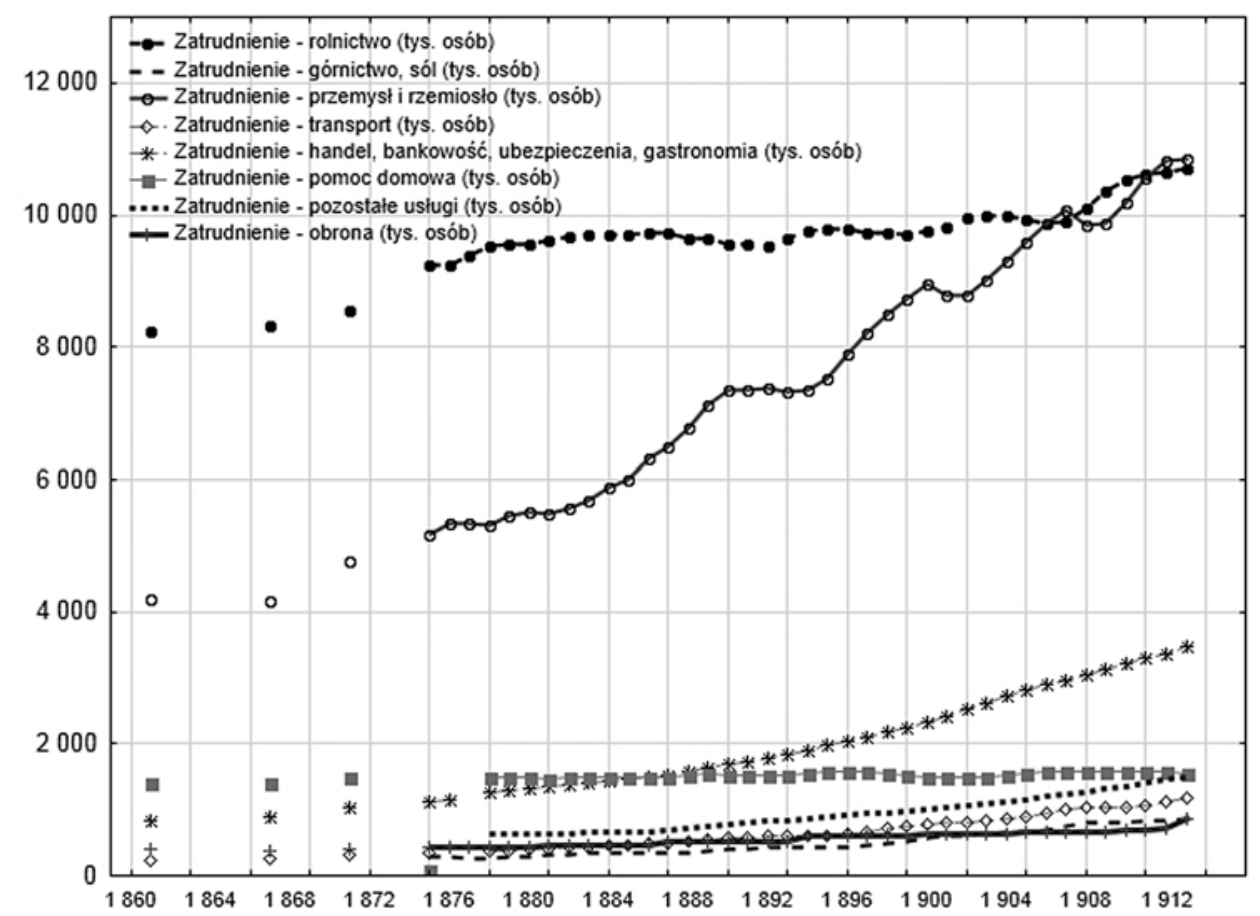

Rys. 50. Zatrudnienie w wybranych sektorach gospodarki (tys. osób) w latach 1860-1913

Źródło: jak do rys. 29, s. 147.

W latach 1870-1913 średnie roczne zatrudnienie w:

- transporcie wzrastało o 3,34\%;

- sektorze usług wzrastało o 3,1\%,

- przemyśle rosło o 2,2\%;

- rolnictwie rosło o $0,16 \%$.

Udział rolnictwa w zatrudnieniu ogółem w latach 1871-1914 zmniejszył się o 50\% i wynosił w 1914 r. około 35\%. Mimo spadku procentowego udziału za- 
trudnionych w rolnictwie w stosunku do całej gospodarki względna liczba pracowników związana z pierwszym sektorem gospodarki wzrosła w latach 18821907 z 8,2 mln do prawie 9,9 milionów (rys. 51). Daje się zauważyć wzrost liczby zatrudnionych w przemyśle, handlu, transporcie.

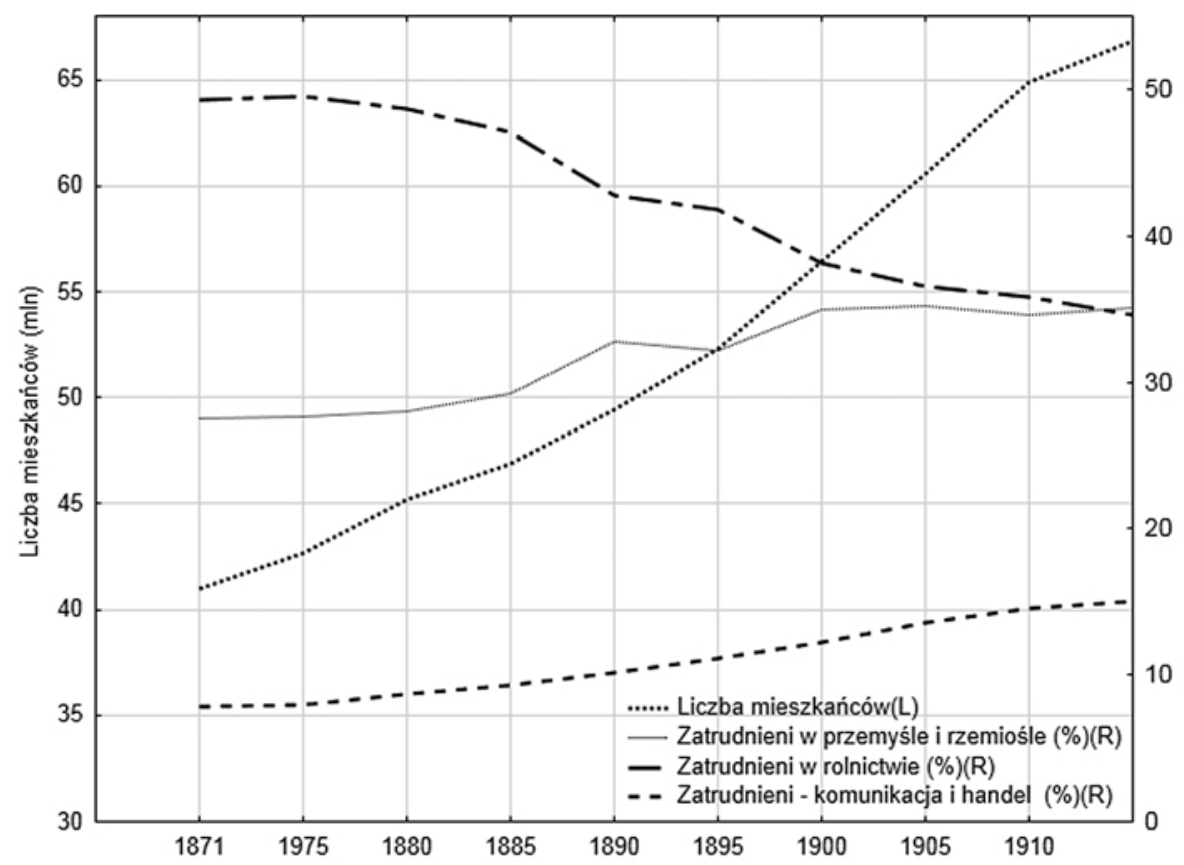

Rys. 51. Zatrudnienie w wybranych sektorach gospodarki (\%) na tle liczby ludności (mln) w latach 1871-1913

Źródło: jak do rys. 26, s. 86.

W połowie XIX w. 54,6\% ogółu zatrudnionych pracowało w rolnictwie, udział ten spadł do 35,1\% w latach 1910-1913. W tym czasie zwiększył się odsetek zatrudnionych w przemyśle i rzemiośle - z 24,3 do 35,1\%.

W trakcie szybkiego wzrostu gospodarczego najważniejszym dla niemieckiej gospodarki był przemysł wydobywczy, hutnictwo żelaza, przemysł metalowy. W 1913 r. 26,8\% ogółu zatrudnionych znajdowało miejsca pracy w górnictwie, przemyśle i rzemiośle. Szybko wzrastała liczba zatrudnionych w przemyśle chemicznym i rzemiośle. Trzykrotnie zwiększył się stan zatrudnienia w komunikacji i przeszło dwukrotnie w handlu, bankowości i ubezpieczeniach. Rosło też zatrudnienie w sektorze usług. W 1870 wynosiło ono już $22 \%$ ogółu zatrudnionych w gospodarce (w Wielkiej Brytanii - 35\%, w Stanach Zjednoczonych - 26\%, we Francji - 23\% ${ }^{77}$.

77 A. Maddison, Phases of Capitalist Development, Oxford, 1982, s. 205. 
W analizowanym okresie zauważalny jest wzrost liczby zatrudnionych $\mathrm{w}$ gospodarce - w latach pięćdziesiątych XIX w. zatrudnienie wynosiło 15126 tys. osób, co stanowiło 43,9\% ogółu ludności. W latach 1910-1913 udział ten wzrósł do 30243 tys. osób, co stanowiło 46\% ludności.

Średnia stopa wzrostu zatrudnienia i produktywności pracy oraz kapitałochłonności dla lat 1850-1913 w rolnictwie, przemyśle i kolejnictwie została przedstawiona $\mathrm{w}$ tab. 26.

Tabela 26. Średnia stopa wzrostu zatrudnienia, produktywności pracy, intensywności kapitału dla niemieckiej gospodarki (1850-1913)

\begin{tabular}{|l|c|c|c|}
\hline \multicolumn{1}{|c|}{ Gałąź gospodarki } & Zatrudnienie & Produktywność pracy & Intensywność kapitału \\
\hline Rolnictwo & 0,4 & 1,2 & 0,7 \\
\hline Przemysł & 1,9 & 1,7 & 2,0 \\
\hline Koleje & $6,0^{*}$ & 1,5 & $-0,9$ \\
\hline
\end{tabular}

*Od 1852 r.

Źródło: W.G. Hoffmann,Das Wachstum der deutschen Wirtschaft seit der Mitte des 19. Jahrhunderts, Berlin 1965, s 37, 52.

Rozwój gospodarki rynkowej w Niemczech, a zwłaszcza po 1870 r., przekłada się na wzrost dochodu narodowego, a co najważniejsze do poprawy stopy życiowej społeczeństwa niemieckiego.

W 1850 r. dochody pracowników uzyskiwane w rolnictwie stanowiły 44\% ogółu dochodów w gospodarce. Dochody pracowników zatrudnionych w przemyśle i rzemiośle stanowiły $25 \%$ ogółu dochodów, ponad 7\% stanowiły dochody uzyskiwane z usług pomocy domowej, dochody z tytułu handlu, bakowości, i ubezpieczeń wynosiły - 5,8 \%. W dwadzieścia lat później (okres 1870-1874) dochody pracowników zatrudnionych w rolnictwie spadły do blisko $38 \%$ całkowitych dochodów według sektorów gospodarki, dochody pracowników zatrudnionych w przemyśle wzrosły do ponad $30 \%$, podobnie z sektorów handel, bankowość, ubezpieczenia wzrosły do blisko 7\%, spadł udział dochodów z tytułu pomocy domowej do 6\%. W okresie 1910-1913 uzyskiwane dochody pracowników w rolnictwie stanowiły zaledwie $21,6 \%$, w przemyśle i rzemiośle blisko $40 \%$, w handlu, bankowości, ubezpieczeniach blisko $11,5 \%$, w transporcie $5 \%{ }^{78}$.

Produkt Narodowy Netto (PNN) wyrażony w cenach z 1913 r. wzrósł z 9,5 mld marek (1850 r.) do 48,5 mld marek (1913 r.), osiągając średnią stopę wzrostu w latach 1850-1872 - 2,6\%, a w okresie 1873-1913-2,8\%. Potwierdzeniem są dwie inne miary makroekonomiczne Produkt Krajowy Brutto (PKB) oraz PKB per capita w latach 1860-1913 wyrażone w USD (rys. 52.). Przy czym PKB

78 W.G. Hoffmann, op. cit., s. 95. 
per capita w latach 1860-1913 osiągnął średnią stopę wzrostu 1,46\%, zaś w okresie 1870-1913-1,54\%. W 1850 r. wartość wytworzonego produktu na 1 mieszkańca wynosiła średnio 1428 USD (z 1990 r.), w 1913 r. 3648 USD (z 1990 r.).

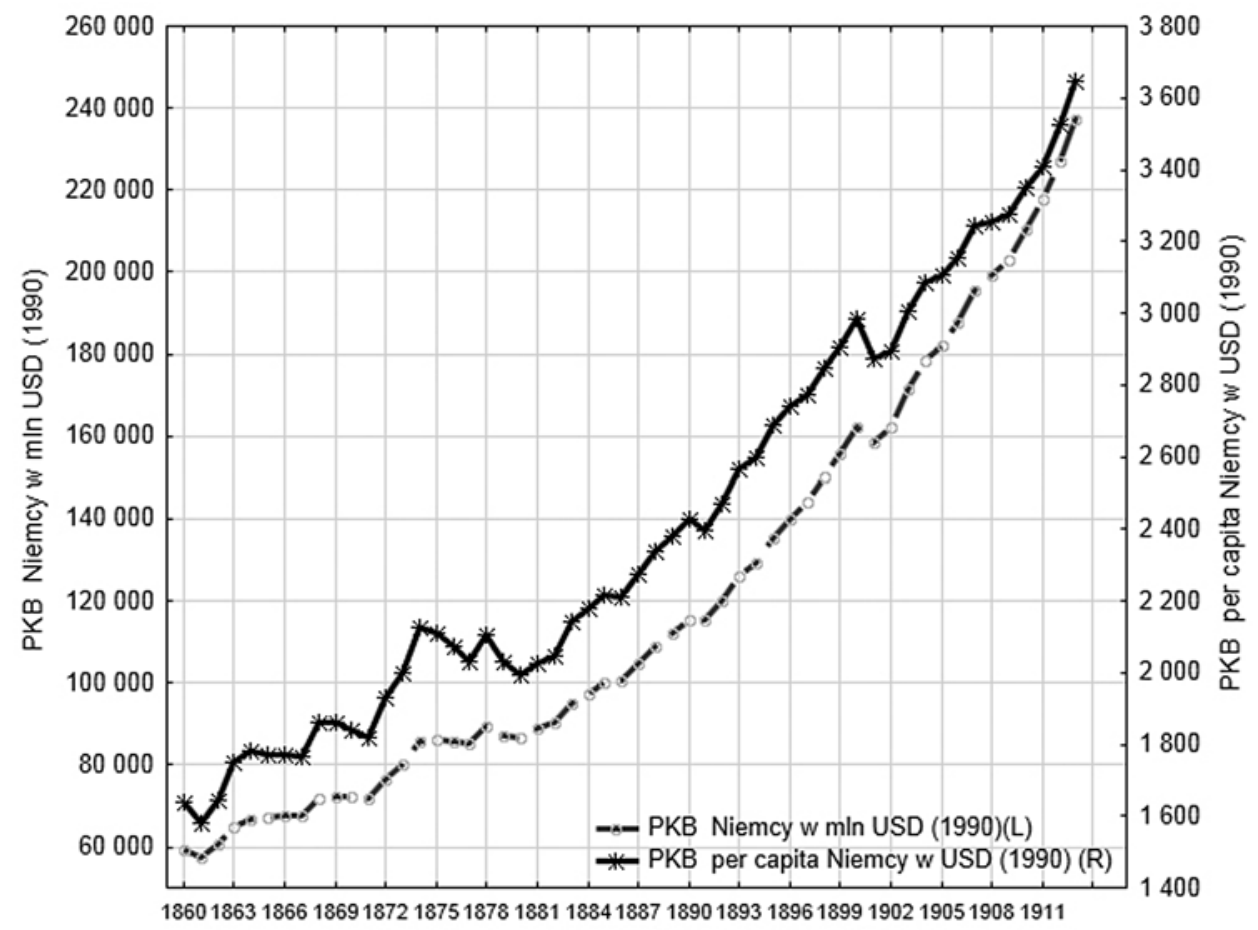

Rys. 52. Wzrost PKB i PKB per capita w Niemczech w latach 1860-1913

Źródło: opracowanie własne na podstawie: A. Maddison, Historical Statistics for the World Economy: 1-2003 AD, www.sais-jhu.edu/library/subjectguides/stats.htm [dostęp 02.11.2010].

Równie interesująca jest dynamika wzrostu PKB i PNN na tle wzrostu PKB per capita $1860-1913$ (rys. 53).

Zgodnie z danymi statystycznymi prezentowanymi przez W.G. Hoffmanna wyraźny jest wzrost PKB w przeliczeniu na osobę z 338 marek w 1850 r., do blisko 874 marek w 1913 r. Wzrost ten jest zdecydowanie niższy niż ogólnego PKB ze względu na znaczne tempo przyrostu ludności. Stopy wzrostu (PKB, PNN) obrazują cykliczność wzrostu i rozwoju gospodarczego - z reguły były powyżej zera, ale pod koniec lat osiemdziesiątych XIX w., na początku lat dziewięćdziesiątych, na początku XX wieku stopy były ujemne. Ujemne stopy wzrostu PNN zanotowano w latach: 1857-1859, 1865-1867, 1874-1880, 1891, 1901. Stopę wzrostu powyżej przeciętnej odnotowano w latach: 1855-1857, 1863-1865, 1870-1874, 1886-1890, 1903-1906, 1910-1913. 


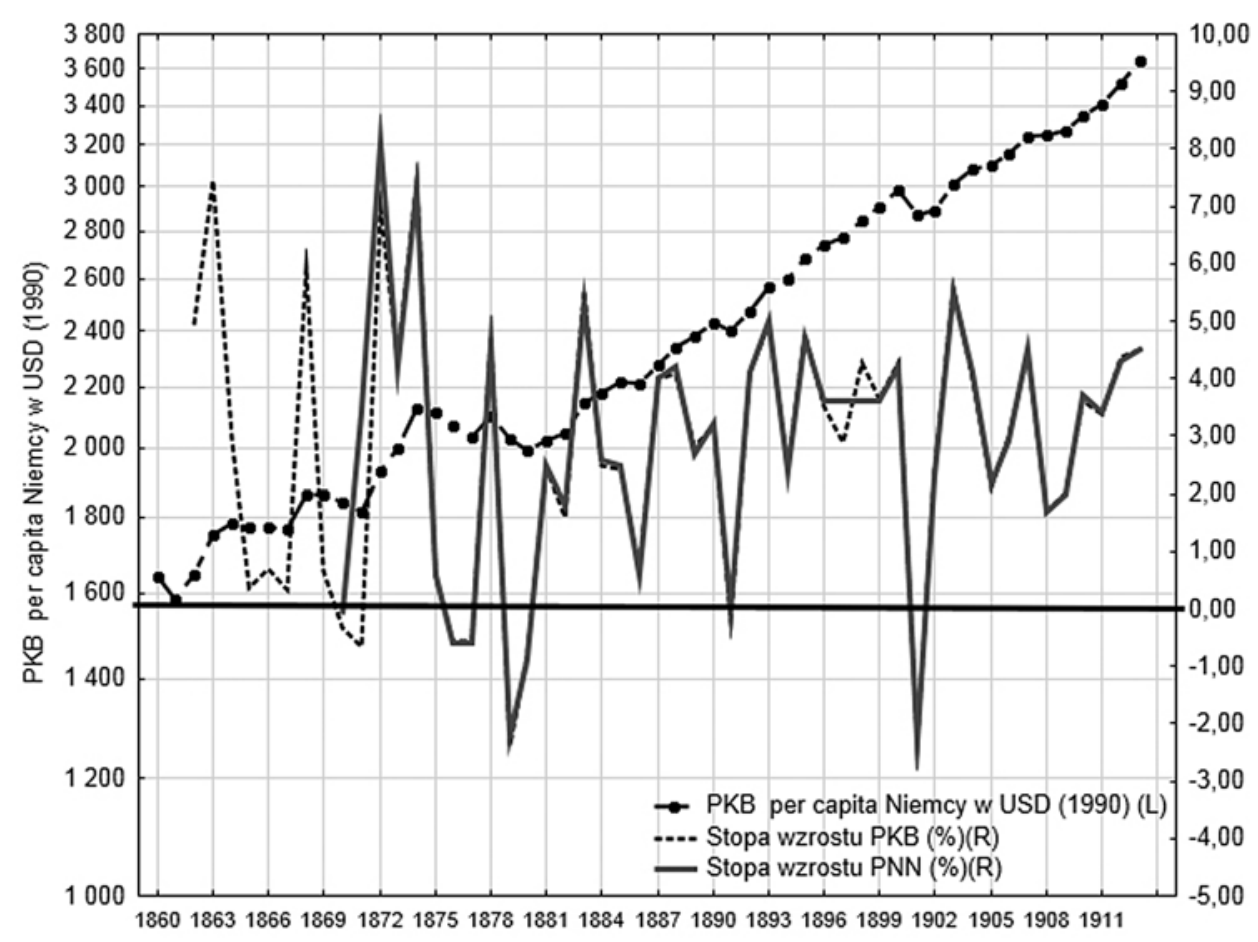

Rys. 53. PKB per capita, stopa wzrostu PKB i PNN dla gospodarki niemieckiej w latach 1860-1913

Źródło: opracowanie własne na podstawie: W.G. Hoffmann, Das Wachstum der deutschen Wirtschaft seit der Mitte des 19. Jahrhunderts, Berlin 1965; A. Maddison, A.; Historical Statistics for the World Economy: 1-2003 AD, www.sais-jhu.edu/library/subjectguides/stats.htm [dostęp 02.11.2010].

Wracając do notowanego długookresowego wzrostu gospodarczego, w tym zaprezentowanej powyżej stopy wzrostu PNN, istotnym elementem jest oszacowanie i analiza wzrostu czynników produkcji (kapitału i pracy). W latach 1870 1913, średni roczny wzrost produktywności dla poszczególnych czynników produkcji wyniósł:

- kapital, wzrost o $2,03 \%$,

- praca, wzrost o $0,055 \%$,

- razem produktywność czynników produkcji wzrost o 1,67\%. 
Kształtowanie się stóp wzrostu PNN na tle wzrostu całkowitej produktywności czynników produkcji przedstawiono na rys. 54.

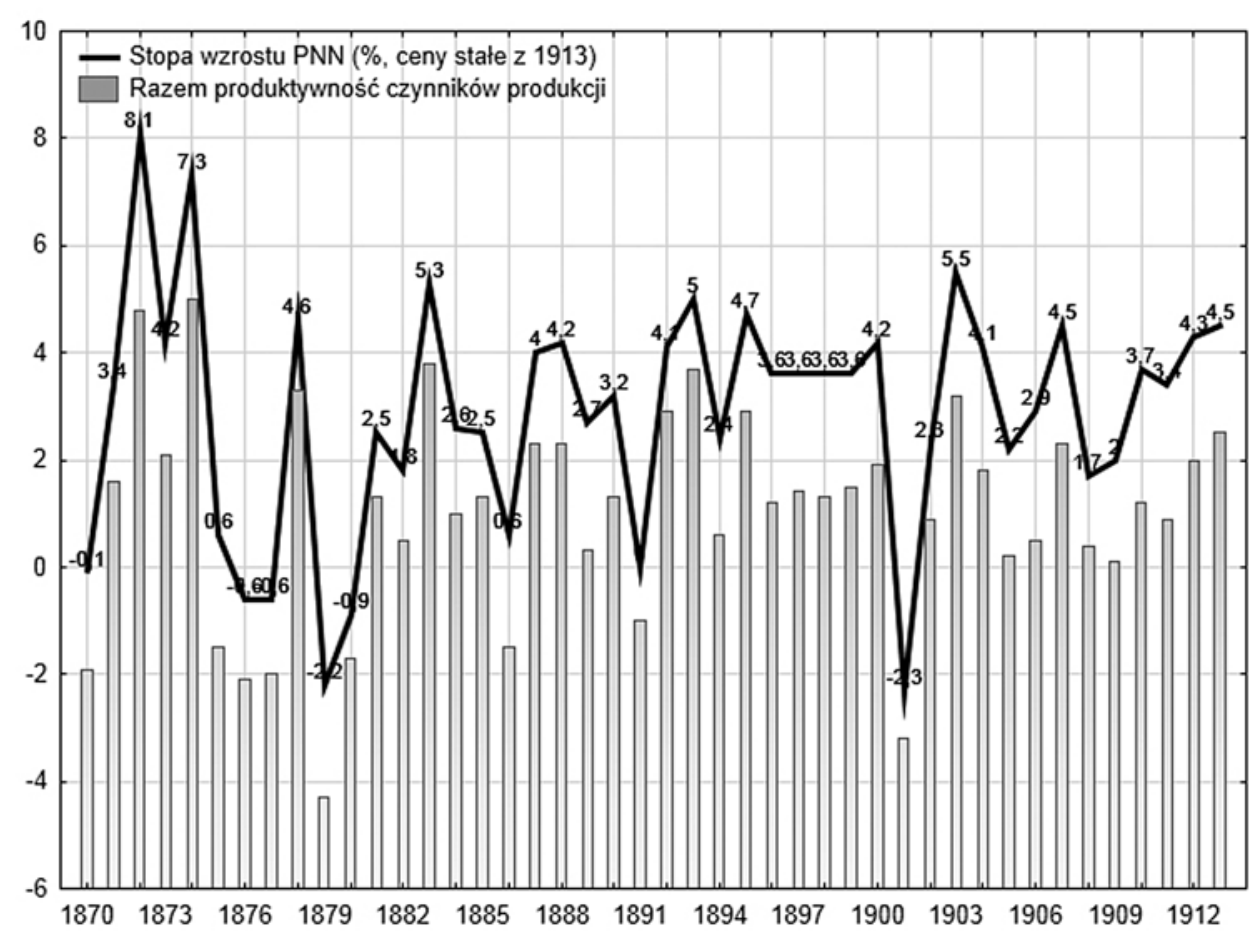

Rys. 54. Stopa wzrostu PNN na tle stopy wzrostu produktywności czynników produkcji (\%) dla gospodarki Niemiec w latach 1870-1913

Źródło:jak do rys. 29, s. $26-27$.

Dla obliczenia tempa wzrostu całkowitej produktywności czynników produkcji (FP), zgodnie z założeniami przyjętymi przez W.G. Hoffmanna użyto formuły:

$$
F P=\left(\frac{Y_{t}}{Y_{t-1}}-1\right)-\left(\frac{K_{t}}{K_{t-1}}-1\right) \frac{K E_{t}}{E_{t}}-\left(\frac{A_{t}}{A_{t-1}}-1\right) \frac{A E_{t}}{E_{t}},
$$

gdzie:

$Y-$ PNN w cenach z $1913 \mathrm{r}$.,

$K$ - kapitał w cenach z 1913 r.,

$A$ - zatrudnienie,

$K E$ - przychody z kapitału,

$A E$ - przychody z pracy,

$E$ - przychody ogółem w cenach bieżących.

Stopa wzrostu PNN jest w całym badanym szeregu czasowym wyższa niż 
stopa wzrostu wynikająca z całkowitej produktywności czynników produkcji. Zależność tę próbował wyjaśnić R. Solow ${ }^{79}$, który koncentruje się na czterech zmiennych: produkcie $(Y)$, kapitale $(K)$, sile roboczej $(L)$ oraz czynniku A, określanego, jako „wiedza”, „efektywność pracy”" Jak szacuje W.G. Hoffman techniczny postęp, który jest wyjaśnieniem tzw. reszty Solowa - w latach 1850-1913 dla Niemiec, wynosił średnio 1,5\%.

Oczywiście postęp techniczny nie jest wielkością autonomiczną, a w znacznym stopniu na jego skalę wpływają inwestycje. W gospodarce niemieckiej istotną wielkością mającą wpływ na wydajność pracy były wydatki na edukację, zakup patentów, gdyż to one teoretycznie oddziałują na postęp techniczny, organizacyjny, wykształcenie pracowników, a tym samym wzrost wydajności pracy. Zgodnie z rachunkiem korelacji przeprowadzonym przez W. G. Hoffmana dla lat 1878-1913 wzrost udzielonych patentów o 1\% oznaczał wzrost produktywności pracy o $0,35 \%^{81}$. Do 1913 r. wydatki na edukację i wychowanie każdego ucznia w wieku 6-14 lat wzrastały średnio o 3,8\%, a liczba uczniów i studentów wzrosła z 3688915 w 1850 r. do 9988483 osób w 1913 r. Średnia roczna liczba patentów wzrosła z $4416 \mathrm{w}$ połowie lat siedemdziesiątych XIX w. do $19154 \mathrm{w} 1913 \mathrm{r}$. $\mathrm{W}$ trakcie budowy podstaw nowoczesnego ładu kapitalistycznego, z uwzględnieniem dokonującego się postępu technicznego i wzrostu produktywności, przedmiotem analizy musi być struktura wytwarzania PNN z uwzględnieniem sektorów gospodarki.

Zauważalne jest zmniejszenie roli pierwszego sektora gospodarki - jeszcze w połowie XIX w. sektor rolniczy miał udział blisko 45\% w tworzeniu PNN Niemiec. Przed wybuchem I wojny świtowej udział ten spadł do poziomu $23,4 \%$ PNN.

W latach dziewięćdziesiątych XIX w. po raz pierwszy w historii Niemiec to przemysł, a nie rolnictwo miał największy odsetek w tworzeniu PNN (34\%). W kolejnych latach udział ten jeszcze bardziej wzrastał, a w latach 1910-1913 wyniósł blisko $41 \%$.

Równie interesujący jest udział komunikacji (w tym kolei) w tworzeniu PNN. Udział ten $\mathrm{w}$ trakcie analizowanych 63 lat wzrósł ponad dziewięciokrotnie, z poziomu $0,7 \% \mathrm{w}$ połowie XIX w. do $6,4 \% \mathrm{w} 1913 \mathrm{r}$. W trakcie analizowanego okresu odnotowano średnioroczny wzrost o $3,6 \%$, zauważalny jest spadek udziału z zakresu pomocy domowej, a także stopniowy wzrost znaczenia handlu, bankowości i ubezpieczeń (rys. 55).

${ }^{79}$ R. Solow, Technical Progress, Capital Formation and Economic Growth, „The American Economic Review" 1962, vol. 52, s. 76.

${ }^{80}$ D. Romer, Makroekonomia dla zaawansowanych, Warszawa 2000, s. 23 i n.

${ }^{81}$ Współczynnik determinacji $\mathrm{R}=0,94$, a średni błąd 0,0693 


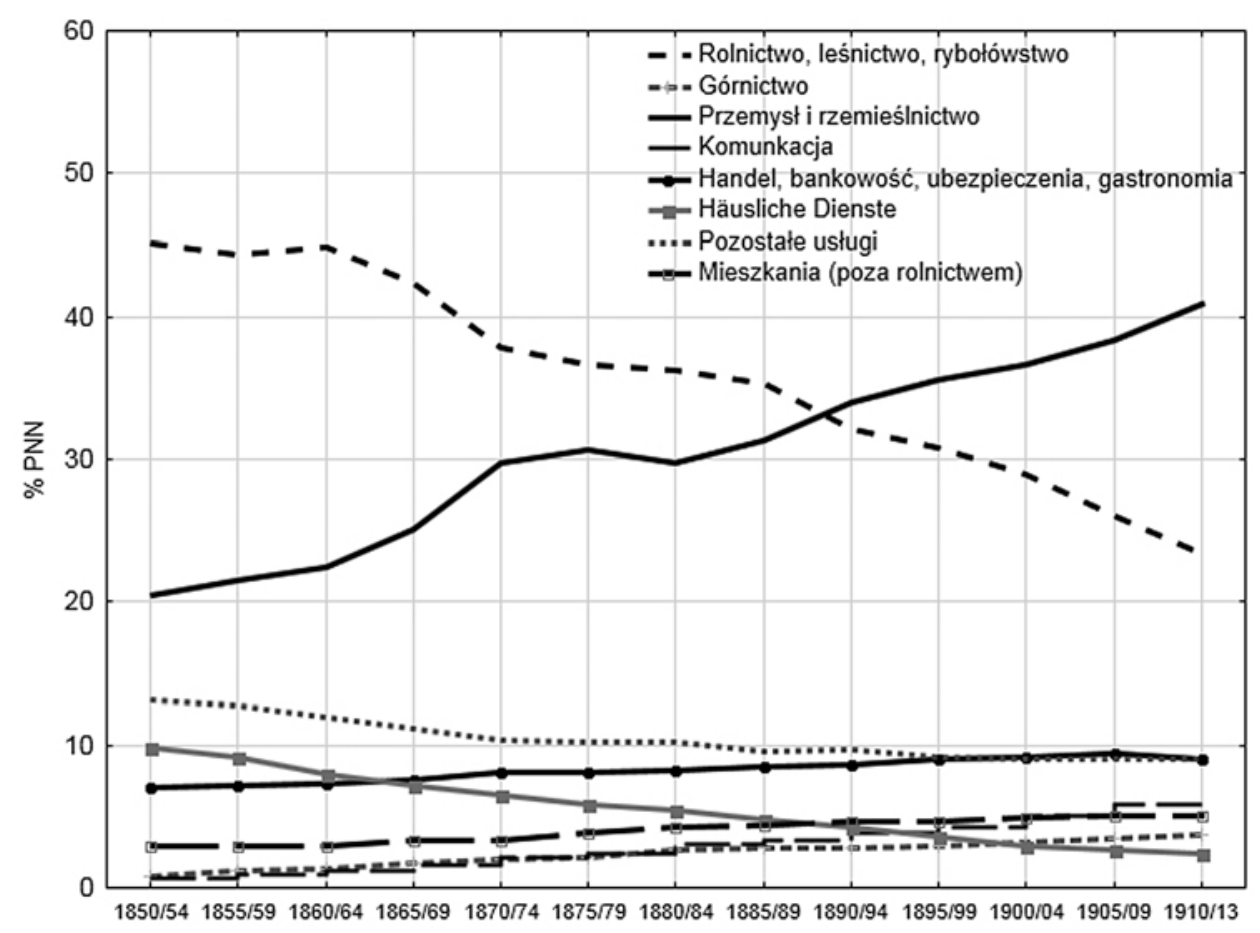

Rys. 55. Struktura sektorowa wytwarzanego PNN Niemiec w latach 1850-1913 (\%)

Źródło: jak do rys. 54.

Analiza struktury PNN w odniesieniu do sektorów gospodarki w ujęciu wartościowym potwierdza powyższe dane wyrażone w \% (rys. 56).

Warto przyjrzeć się bliżej relacji dotyczącej odsetka zatrudnionych w rolnictwie w stosunku do PKB per capita Niemiec w dłuższym okresie czasowym (1860-1913). Analizy dokonano dla szeregu czasowego 1860-1913. Na wykresie prezentującym rozrzut - PKB per capita - \% zatrudnienie w rolnictwie oszacowano funkcję wykładniczą (rys. 57). Zależność jest odwrotnie proporcjonalna im mniejszy odsetek ludności pozostawał w rolnictwie tym wyższa dynamika PKB per capita. Dla przykładu w 1860 r. z rolnictwem związanych było 53,92 \% ludności czynnej zawodowo (8195 tys. osób), a PKB per capita w tym czasie dla Niemiec wyniósł 409,07 marek, (w cenach z 1913 r.), 1639 USD (w cenach z 1990 r.). Po powstaniu Rzeszy Niemieckiej w 1871 r. w rolnictwie pozostawało już 49,26\% ogółu zatrudnionych, choć liczba pracujących w rolnictwie wzrosła do 8541 tys. osób, ale wzrost ten był mniejszy niż przyrost demograficzny.

W 1896 r. liczba zatrudnionych w rolnictwie spadła do 40,93\% ogółu zatrudnionych, choć zatrudnienie w rolnictwie nadal wzrastało i wyniosło 9778 tys. osób. 


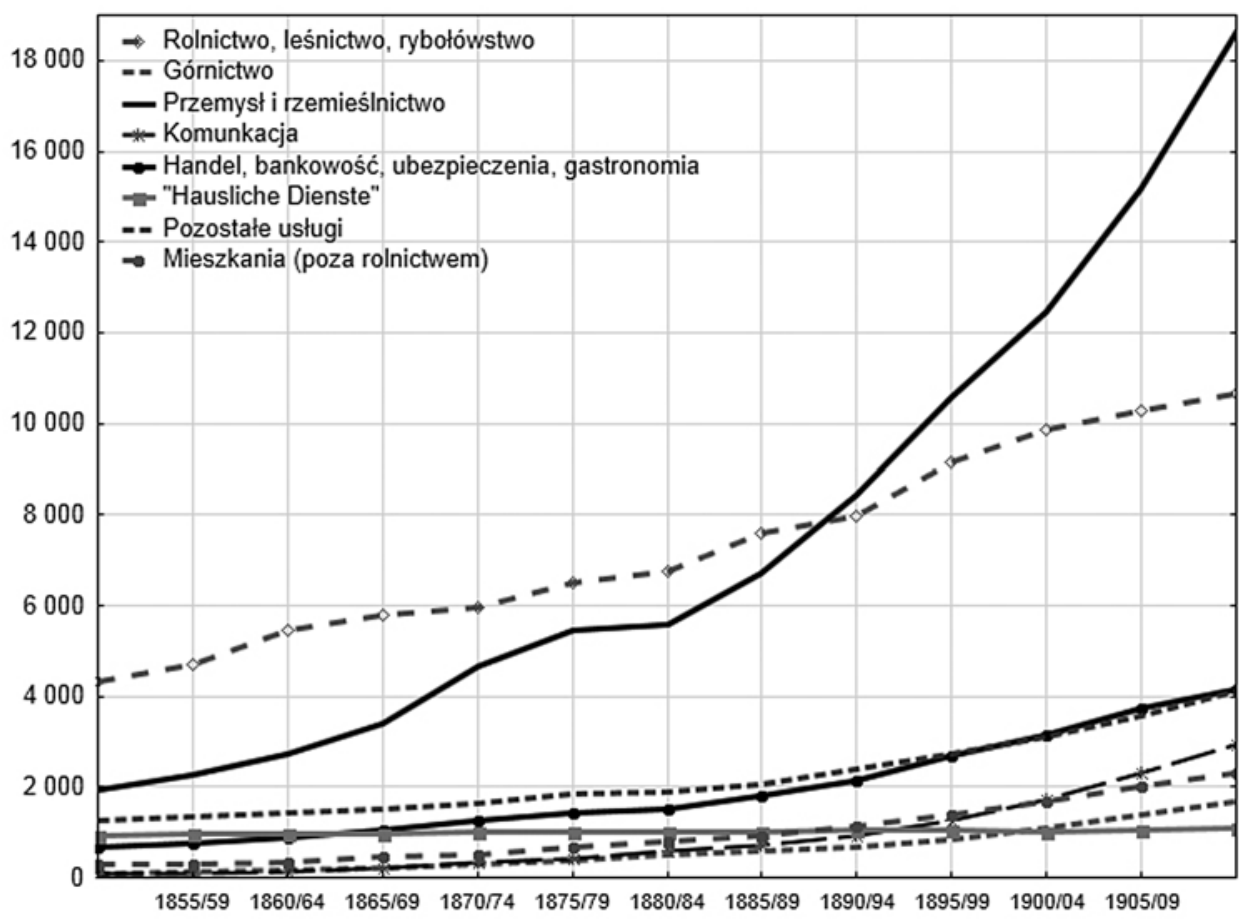

Rys. 56. Struktura PNN Niemiec w latach 1850-1913 (mln marek w cenach stałych z 1913 r.)

Źródło: jak do rys. 54.

W tym czasie PKB per capita wyniósł 707 marek (w cenach z 1913 r.), 2740 USD (w cenach z 1990 r.). Bezpośrednio przed I wojną światową odsetek zatrudnionych w rolnictwie spadł do $34,56 \%$ ogółu zatrudnionych, ale liczba pracowników w pierwszym sektorze wzrosła do 10701 tys. osób, a PKB per capita wyniósł: blisko 873 marek (w cenach z 1913 r.), 3648 USD (w cenach z 1990 r.). Na podstawie oszacowanej linii trendu można wykazać, że średnio spadek liczby zatrudnionych w rolnictwie o 1\% oznaczał wzrost PKB per capita o 3,76\% (ceteris paribus).

$\mathrm{W}$ tym czasie zatrudnienie $\mathrm{w}$ rolnictwie np. w Wielkiej Brytanii wyniosło jedynie 11,8\% ogółu zatrudnionych, w Belgii 23,2\%, w Szwajcarii 26,8\%, w rolniczej Hiszpanii 56,3\%.

Warto przytoczyć kilka spostrzeżeń Simona Kuznetsa dotyczących udziału pierwszego sektora w tworzeniu PKB, a mianowicie:

- w USA w latach czterdziestych XIX w., w Niemczech w latach pięćdziesiątych XIX w., we Włoszech w latach sześćdziesiątych XIX w., w Danii i Kanadzie w latach siedemdziesiątych XIX w. udział rolnictwa w tworzeniu PKB wynosił od 40\% do 60\% (w przypadku Anglii był to XVIII w.); 
- we wszystkich krajach rozwiniętych udział sektora A (rolnictwa) obniżył się w istotnym stopniu w długich okresach. W większości krajów, których dotyczył szybki wzrost gospodarczy w XIX w. odnotowano spadek udziału rolnictwa, który wynosił 20 do 30 punktów procentowych. Oznaczało to, że już w latach sześćdziesiątych XX w. udział rolnictwa spadł do poziomu poniżej 10\%;

- w krajach rozwiniętych ogólnie obserwowany spadek udziału sektora A szedł w parze $\mathrm{z}$ równie ogólnym długookresowym wzrostem produktu na osobę, chociaż stopa tego wzrostu była zróżnicowana;

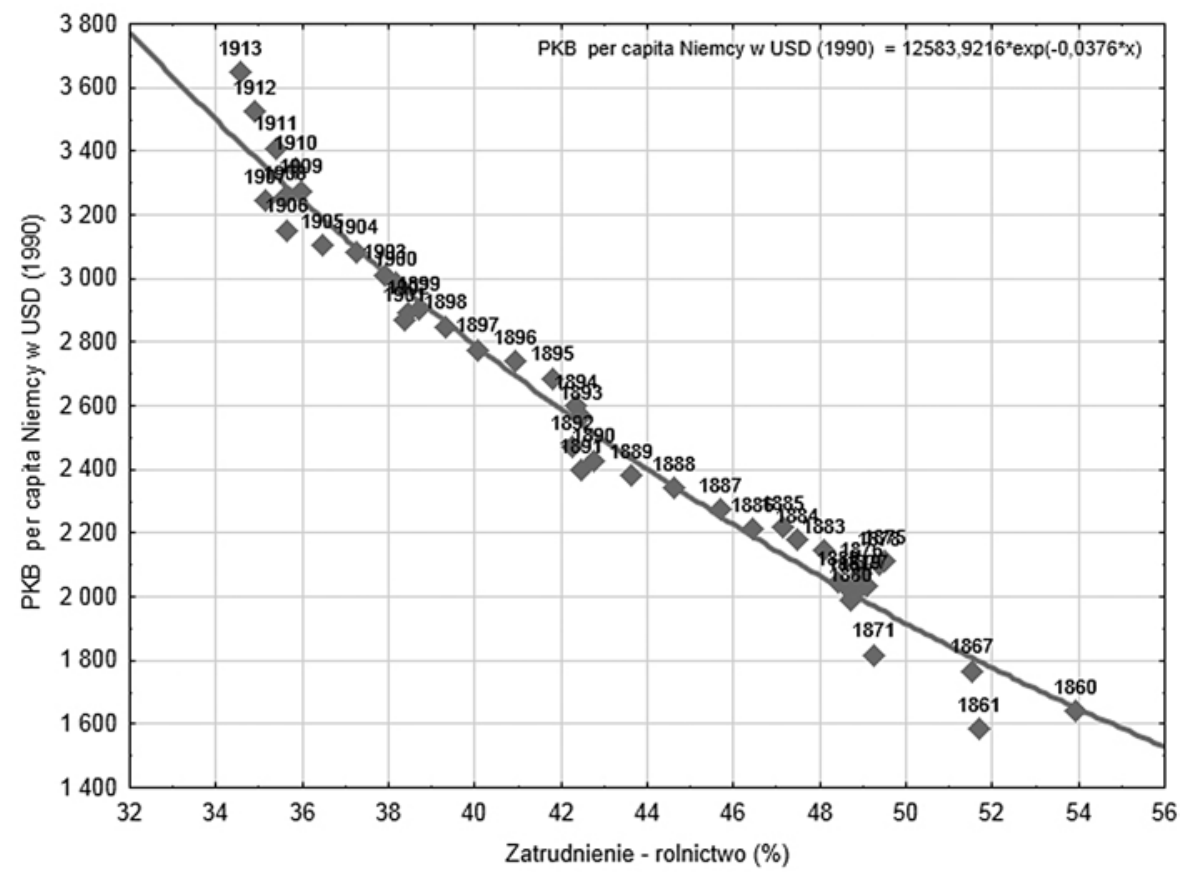

Rys. 57. Poziom PKB per capita (USD z 1990 r.), a zatrudnienie (\%) w rolnictwie w Niemczech w latach 1860-1913

Źródło: opracowanie własne na podstawie danych: W.G. Hoffmann, Das Wachstum der deutschen Wirtschaft seit der Mitte des 19. Jahrhunderts, Berlin 1965; A. Maddison, Historical Statistics for the World Economy: 1-2003 AD, www.sais-jhu.edu/library/subjectguides/stats. htm [dostęp 02.11.2010].

- w większości krajów rozwiniętych, dla których obok sektora A wyodrębniono sektor I (przemysł) i sektor S (usługi), udział sektora I wzrastał w istotnym stopniu równoważąc w znacznej mierze lub całkowicie spadek udziału sektora A, a udział sektora $\mathrm{S}$ nieco wzrastał lub obniżał się;

- charakterystyczny dla wzrostu udziału sektora I wyraża się wzrostem z 22$25 \%$ przez przejściem do nowoczesnego wzrostu gospodarczego, do poziomu 
od $47 \%$ do niemal $60 \%$. Ten wzrost o 25 do 30 punktów procentowych jest taki sam jest spadek charakterystyczny dla spadku sektora $\mathrm{A}^{82}$.

Równie pouczająca jest analiza dotycząca osób zatrudnionych w przemyśle wraz z górnictwem dla gospodarki niemieckiej w latach 1860-1913. Oszacowana funkcja trendu (wykładnicza) wynosi: PKB per capita Niemcy w USD (1990) $=$ $380,0142 \times \exp (0,0563 \times \mathrm{x})$.

Interpretując ten wynik (oszacowaną funkcję trendu) należy wskazać, że jeśli zatrudnienie w przemyśle i górnictwie wzrosłoby o $1 \%$, wówczas PKB zwiększyłby się o około 5,63\% (ceteris paribus).

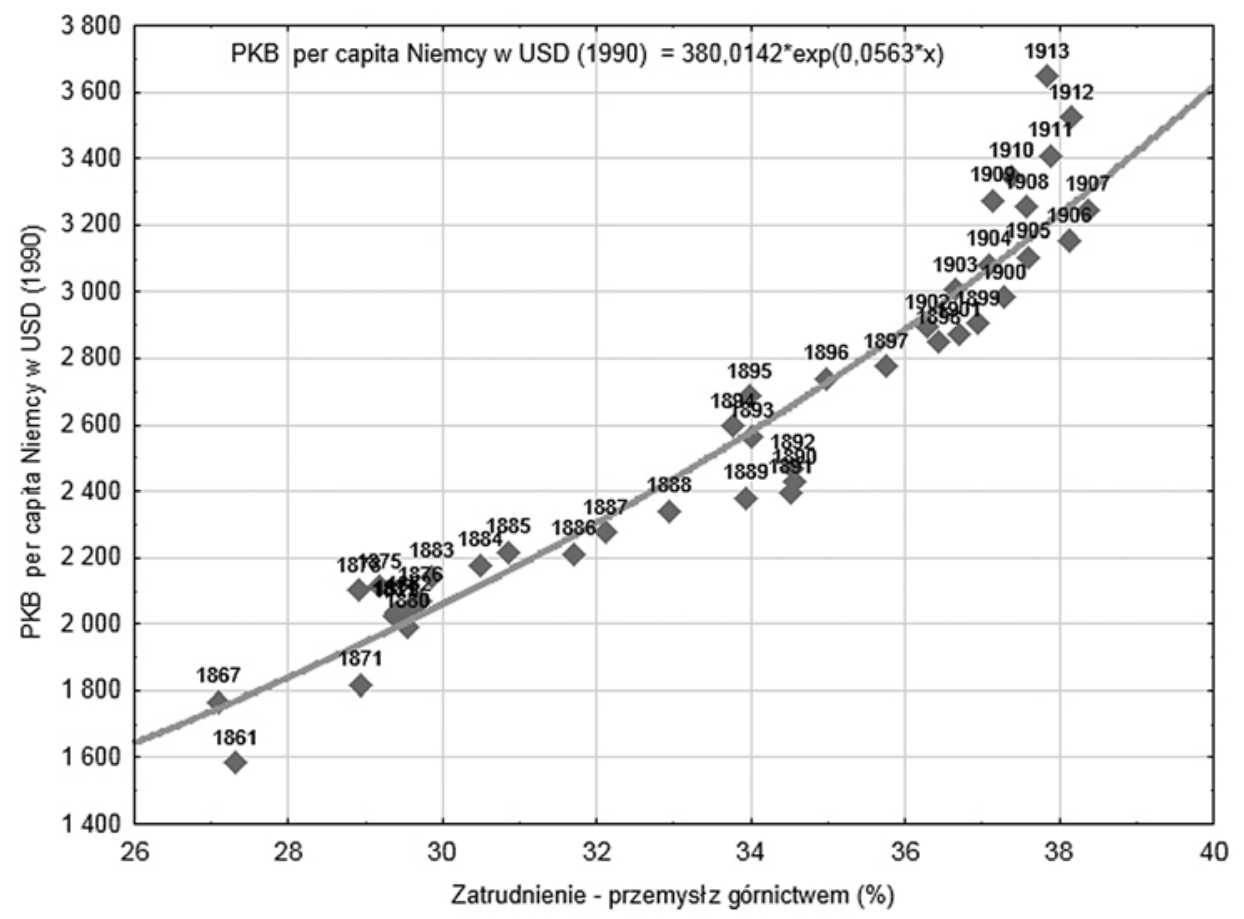

Rys. 58. Poziom PKB per capita (USD z 1990 r.), a zatrudnienie (\%) w przemyśle z górnictwem w Niemczech w latach 1860-1913

Źródło: jak do rys. 57.

Udział sektora I (przemysł), jak wskazywał S. Kuznets, wykazuje ścisłą zależność dodatnią z produktem na osobę, rosnąc w miarę przechodzenia kraju o niskim dochodzie do grona krajów rozwiniętych.

Przedstawiona analiza dotycząca gospodarki Niemiec jak potwierdzeniem powyższego sformułowania.

${ }^{82}$ S. Kuznets; Wzrost gospodarczy narodów. Produkt. Struktura, Warszawa 1976, s. 148-161. 



\section{ROZDZIAL IV \\ ZASTOSOWANIE WYBRANYCH MIAR \\ I MODELOWANIA EKONOMETRYCZNEGO W WERYFIKACJI ISTOTNYCH CZYNNIKÓW WZROSTU GOSPODARCZEGO NIEMIEC}

W dalszej części rozprawy autor przedstawia analizę danych dotyczących rozwoju niemieckich kolei przy wykorzystaniu koncepcji social savings, z uwzględnieniem nadwyżki konsumenta, a także całkowitej produktywności (Total Factor Productivity, TFP) oraz modelowania ekonometrycznego.

Przed obliczeniem tych miar autor pragnie zobrazować udział przychodów kolei (output) w kreowaniu PKB Niemiec (indeks output/PKB).

Na rys. 59 zaprezentowano dane statystyczne dla szeregu czasowego 18501913. Należy zauważyć, że udział przychodów z tytułu przewozów kolejowych w stosunku do PKB w przypadku Niemiec stale wzrastał. W początku lat pięćdziesiątych XIX w. udział ten wahał się w okolicach $0,7-0,9 \%$ w stosunku do PKB. W latach siedemdziesiątych XIX w. udział wzrósł z 2,62\% w 1870 r., do 3,68\% w 1879 r. W kolejnych latach wzrost udziału przychodów z kolei nie był już tak szybki, a poziom 5\% PKB został przekroczony dopiero w 1900 r. Średnie roczne tempo wzrostu po 1879 r. przekraczało nieznacznie 1\%. Przed wybuchem I wojny światowej, w $1913 \mathrm{r}$. przychody z tytułu transportu kolejowego stanowiły $5,81 \%$ PKB. Określona linia trendu obrazuje, że począwszy od ostatniej dekady XIX w. dynamika wzrostu produkcji kolei wyraźnie słabnie (rys. 59). Dla przykładu w Argentynie, Brazylii, Meksyku udział przychodów kolejowych w stosunku do PKB wynosił pomiędzy 3.5\% i 6\%, w Urugwaju poziom ten kształtował się $\mathrm{w}$ granicach $2,5 \%{ }^{1}$.

1 A. Herranz-Loncán, Role of railways in export-led growth: the case of Uruguay, 1870-1913, „Economic History of Developing Regions” 2011, vol. 26, s. 2. 


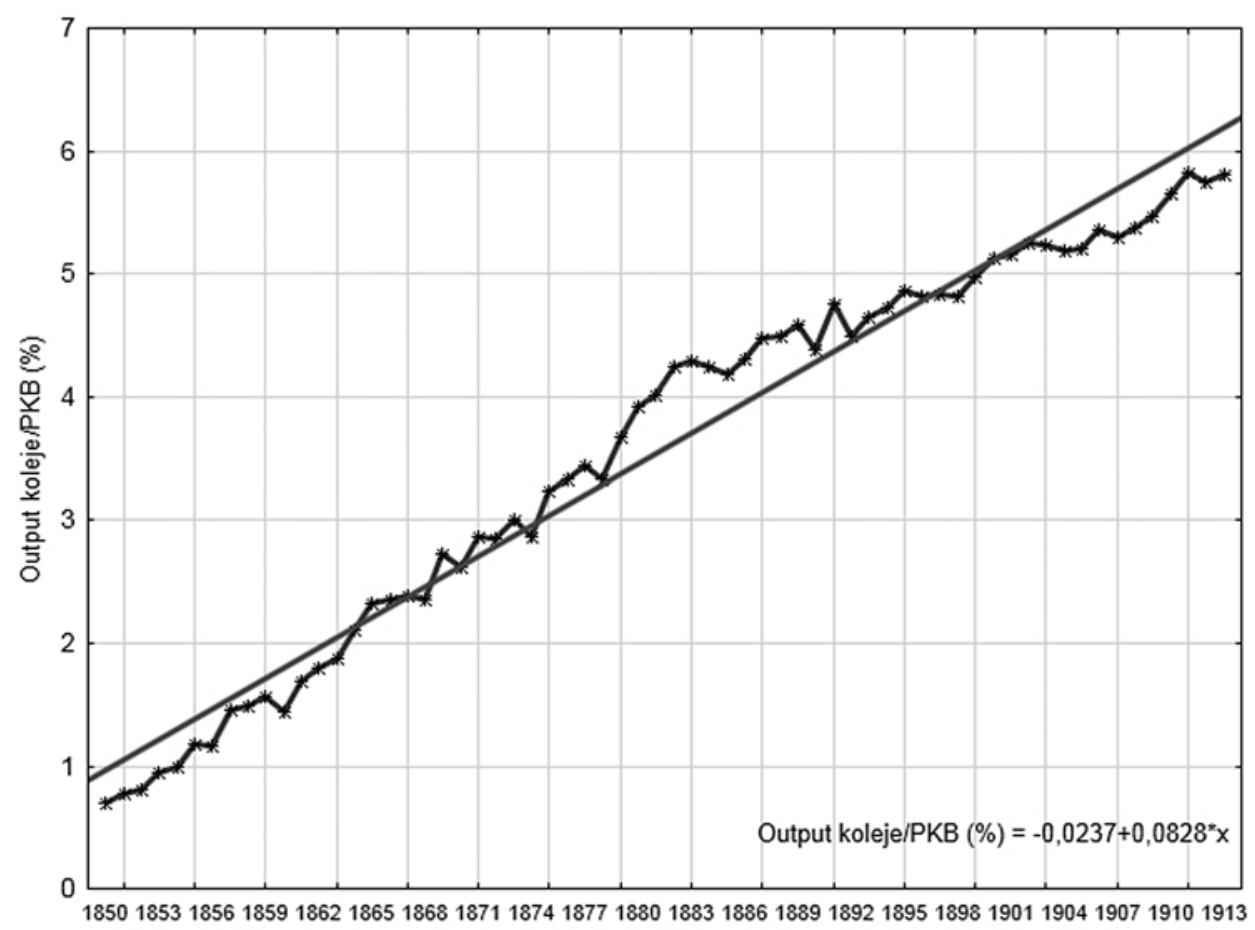

Rys. 59. Output/Produkt Krajowy Brutto (PKB) (\%) oraz liniowy trend wzrostowy

Źródło: opracowanie własne na podstawie obliczonych danych z tab. 37; W.G. Hoffmann, Das Wachstum der deutschen Wirtschaft seit der Mitte des 19. Jahrhunderts, Berlin 1965.

\section{WZROST PRODUKTYWNOŚCI W WIODĄCYCH SEKTORACH GOSPODARKI NA PRZYKLADZIE KOLEI I INNYCH RODZAJÓW TRANSPORTU}

Wzrastającym obrotom handlowym towarzyszyła rozbudowa dróg żelaznych w Niemczech, całej Europie i USA oraz ożywiony ruch w transporcie śródlądowym i transporcie morskim.

W przypadku Niemiec zarówno transport kolejowy osobowy, jak i towarowy szybko przekroczyły $1 \mathrm{mld}$ tkm (1855 r.) i 1 mld pkm (1854 r.).

Najwygodniejszym wskaźnikiem pomiaru wzrostu każdego sektora gospodarki jest analiza wzrostu produkcji. W przypadku transportu, jego wkład w ogólny produkt, przy szybko obniżających się cenach za 1 kilometr, określony może być przez analizę przewozów wyrażonych w tonokilometrach $(\mathrm{tkm})$ oraz pasażerokilometrach (pkm). 
Analizując przewozy kolejowe towarów w latach 1840-1913 zauważyć można załamanie trendu wzrostowego w 1874 r. Jak podkreśla Rainer Fremdling, w latach 1840-1873 r. średni roczny wzrost przewozów towarowych wynosił $30,4 \%$, a przewozów pasażerskich $15,3 \%$. Po 1873 r. nadal odnotowano ekspansję w przewozach kolejowych, ale już nie z takim natężeniem. W latach 1873 1913 dla przewozów towarowych średnie roczne tempo wzrostu wyniosło 4,86\%, a dla przewozów pasażerskich 5,3\%.

Przyczyn szybkiego wzrostu i późniejszego spowolnienia produkcyjności kolei należy szukać w rozwoju innych sektorów gospodarki. Dla przykładu, w latach 1850-1879 średnie tempo wzrostu wynosiło:

- dla wydobycia węgla kamiennego - 7,5\%,

- produkcja surówki hutniczej - 8,4\%,

- dla produkcji przędzy - 7,3\%,

- dla produkcji wyrobów bawełnianych $-3,9 \%{ }^{2}$.

W tym czasie tempo przyrostu przewozów towarowych wzrastało o około $16,3 \%$, a przewozów pasażerskich o około $8,8 \%$. Tezę o szybkim wzroście produkcji kolejnictwa na tle przemysłu i rolnictwa potwierdzają dane przedstawione przez Waltera Hoffmanna ${ }^{3}$.

Analiza regresji wielorakiej dla danych statystycznych za okres 1860-1913 (PKB Niemiec, przewozy w tkm) potwierdza dużą zależność wzrostu PKB Niemiec od wielkości przewozów towarów kolejami, transportem morskim, transportem śródlądowym - współczynnik $\mathrm{R}^{2}$ wynosi 0,99 . Współczynniki strukturalne $\mathbf{b}$ są istotne zarówno dla przewozów koleją, jak i transportu morskiego.

W trakcie lat 1860-1913 liczba przewożonych towarów wzrosła w przypadku kolei niemal 42-krotnie, a w latach 1873-1913 liczba tkm dla transportu morskiego niemal 12-krotnie (rys. 60).

Ceny frachtu śródlądowego wodnego z uwzględnieniem kanałów w Niemczech spadały, począwszy od połowy wieku XIX do I wojny światowej. Przyczyną tego była konkurencja, wywierająca coraz większą presję, z rozwijającym się transportem kolejowym, a także z rozwojem budowy floty oraz przesłanki techniczne, które też dotyczyły tego rodzaju transportu. Cena frachtu śródlądowego obniżała się wolniej niż kolejowego, ale nie sposób nie zauważyć, że stawki frachtu wodnego były już w latach osiemdziesiątych i dziewięćdziesiątych XIX w. relatywnie niskie. Dla przykładu, stawka frachtu wodnego dla przewozu towarów masowych (w tym zbóż) na początku XX w. była w porównaniu do kolejowego o połowę niższa. Duże ładunki węgla przewożone były Renem z zagłębia Ruhry do Mannheim po cenie około 6 marek w 1854 r. i 2,7 marki za tonę metryczną w 1900 r.

${ }^{2}$ R. Fremdling, Eisenbahnen und deutsches Wirtschaftswachstum 1840-1879. Ein Beitrag zur Entwicklungstheorie und zur Theorie der Infrastruktur, Dortmund 1985, s. 14-22.

${ }^{3}$ W. Hoffmann, Das Wachstum der deutschen Wirtschaft seit der Mitte des 19. Jahrhunderts, Berlin 1965, s 506-507. 


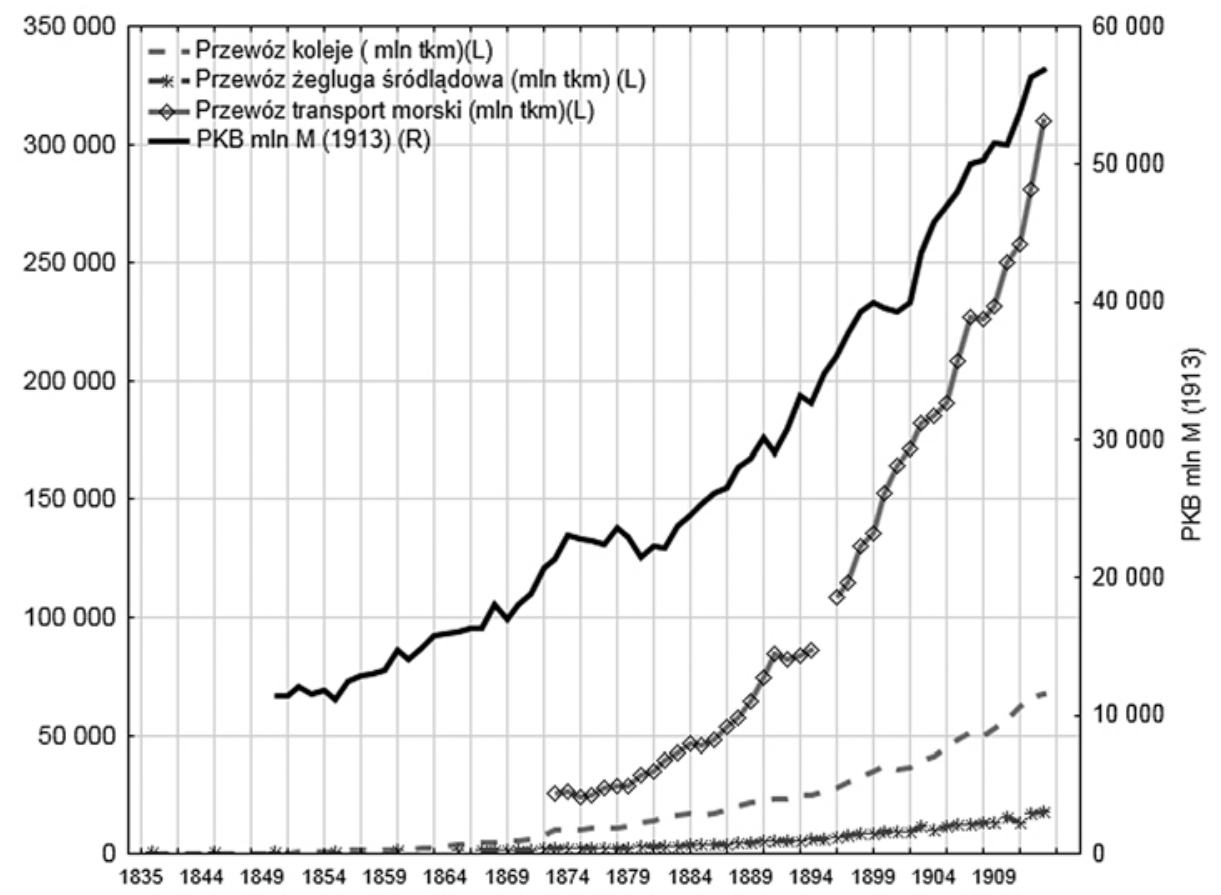

Rys. 60. Przewozy towarów z uwzględnieniem przewozów kolejowych, śródlądowych i morskich (mln tkm) na tle PKB Niemiec w latach 1840-1913

Źródło: Statistisches Jahrbuch für das Deutsche Reich, Berlin 1885-1913; W.G. Hoffmann, Das Wachstum der deutschen Wirtschaft seit der Mitte des 19. Jahrhunderts, Berlin 1965, s. 417-418.

W północnej części Niemiec dużo ważniejszy był fracht wodny, bo on praktycznie decydował o konkurencyjności niemieckiego węgla. Stawka frachtu za $1 \mathrm{Mg}$ Wezerą pomiędzy Bremą a Minden spadła z 17, 4 marek w 1853 r. do 7 marek w 1900 r. Stawka frachtu Elbą i Hawelą decydowała o konkurencyjnej cenie węgla brytyjskiego w Berlinie.

Wraz z rozwojem kolei i zastojem w budowie kanałów na niektórych obszarach na znaczeniu traciła sieć rzeczna - dla przykładu węgiel z zagłębia Ruhry przesyłany był wagonami kolejowymi w kierunku północnym, choć transport kolejowy wcale nie był tańszy.

Berlin został połączony z okręgami przemysłowymi Ruhry i Górnego Śląska dopiero w 1847 r., co ułatwiło transport węgla. Węgiel brytyjski nadal był transportowany drogą wodną.

Wysokie taryfy kolejowe uniemożliwiły Niemcom konkurencję z tańszym węglem brytyjskim, przesyłanym przez Morze Północne do niemieckich portów i dalej w głąb kraju drogą wodną. Ten rodzaj transportu sprawiał, że brytyjski węgiel, nawet w latach 1898-1909, był ciągle tańszy. 
W tab. 27 autor przedstawił wysokość taryf dla transportu wodnego w kierunku Berlina na przełomie XIX i XX w.

Tabela 27. Cena frachtu wodnego z wybranych miejsc do Berlina w latach 1898-1909

\begin{tabular}{|l|c|c|c|c|c|c|c|c|}
\hline \multirow{2}{*}{ Rok } & \multicolumn{2}{|c|}{ Hamburg } & \multicolumn{2}{c|}{ Szczecin } & \multicolumn{2}{c|}{ Wrocław } & \multicolumn{2}{c|}{ Kędzierzyn-Koźle } \\
\cline { 2 - 9 } & $\begin{array}{c}\text { marek/ } \\
\mathrm{Mg}\end{array}$ & $\mathrm{pf} / 1 \mathrm{tkm}$ & $\begin{array}{c}\text { marek/ } \\
\mathrm{Mg}\end{array}$ & $\mathrm{pf} / 1 \mathrm{tkm}$ & $\begin{array}{c}\text { marek/ } \\
\mathrm{Mg}\end{array}$ & $\mathrm{pf} / 1 \mathrm{tkm}$ & $\begin{array}{c}\text { marek/ } \\
\mathrm{Mg}\end{array}$ & $\mathrm{pf} / 1 \mathrm{tkm}$ \\
\hline 1898 & 4,95 & 1,24 & & & 4,00 & 0,90 & 6,15 & 1,02 \\
\hline 1899 & 2,95 & 0,73 & & & 3,65 & 0,82 & 5,90 & 0,98 \\
\hline 1900 & 4,15 & 1,04 & & & 4,05 & 0,91 & 5,95 & 0,99 \\
\hline 1901 & 4,25 & 1,06 & & & 4,15 & 0,94 & 6,75 & 1,12 \\
\hline 1902 & 3,75 & 0,94 & & & 3,45 & 0,78 & 5,50 & 0,91 \\
\hline 1903 & 3,95 & 0,99 & & & 3,20 & 0,72 & 5,65 & 0,94 \\
\hline 1904 & 4,50 & 1,13 & & & 4,20 & 0,95 & 6,00 & 0,99 \\
\hline 1905 & 3,30 & 0,83 & 2,85 & 1,59 & 3,30 & 0,74 & 5,80 & 0,96 \\
\hline 1906 & 2,85 & 0,71 & & & 3,15 & 0,71 & 5,50 & 0,91 \\
\hline 1907 & 3,15 & 0,79 & & & 3,15 & 0,71 & 5,40 & 0,89 \\
\hline 1908 & 2,70 & 0,68 & 2,75 & 1,54 & 3,10 & 0,70 & 5,30 & 0,88 \\
\hline 1909 & 3,20 & 0,80 & 2,75 & 1,54 & 3,35 & 0,76 & 5,65 & 0,94 \\
\hline
\end{tabular}

Źródło: E.F. Zentgraf, Der Wettbewerb auf dem Berliner Kohlenmarkt mit besonderer Berücksichtigung der jüngsten Vergangenheit, Essen 1913.

Dlatego przed $1850 \mathrm{r}$. wysokie ceny frachtu kolejowego nie pozwalały na powszechne korzystanie i transport węgla tym środkiem lokomocji. Jak podają Toni Pierenkemper i Richard Tilly w $1850 \mathrm{r}$. fracht towarowy pruskimi kolejami wynosił zaledwie $1 \%$ całości transportu, w dziesięć lat później udział ten wzrósł do $14 \%{ }^{4}$.

Dopiero kampania Einpfennigtarif, która oznaczała wyznaczenie preferencyjnej stawki 2,2 pf/tkm pozwoliła skutecznie konkurować ceną węgla niemieckiego na rynku berlińskim. Specjalne składy kolejowe przewoziły krajowy węgiel do Berlina od 1849 r. W latach pięćdziesiątych XIX w. taryfy kolejowe z reguły były wyższe niż wspomniane 2,2 pf/tkm - w Prusach wynosiły one 4,7 pf/tkm w 1858 r., 4,1 pf/tkm w 1862 r., 3,9 pf/tkm w 1863 r., 3,2 pf/tkm w 1872 r.

Węgiel niemiecki wypierał z rynku droższy węgiel brytyjski, dzięki transportowi kolejowemu oferowany był na nowych rynkach np. w Berlinie. Węgiel z Saary oferowany był w Bawarii, Badenii, Wirtembergii. Poniżej zobrazowano wysokość taryf kolejowych dla przewozów towarowych (pf/tkm) oraz pasażerskich (pf/pkm) (rys. 61).

${ }^{4}$ T. Pierenkemper, R. Tilly, The German Economy During the Nineteenth Century, New York -Oxford 2004, s. 6. 


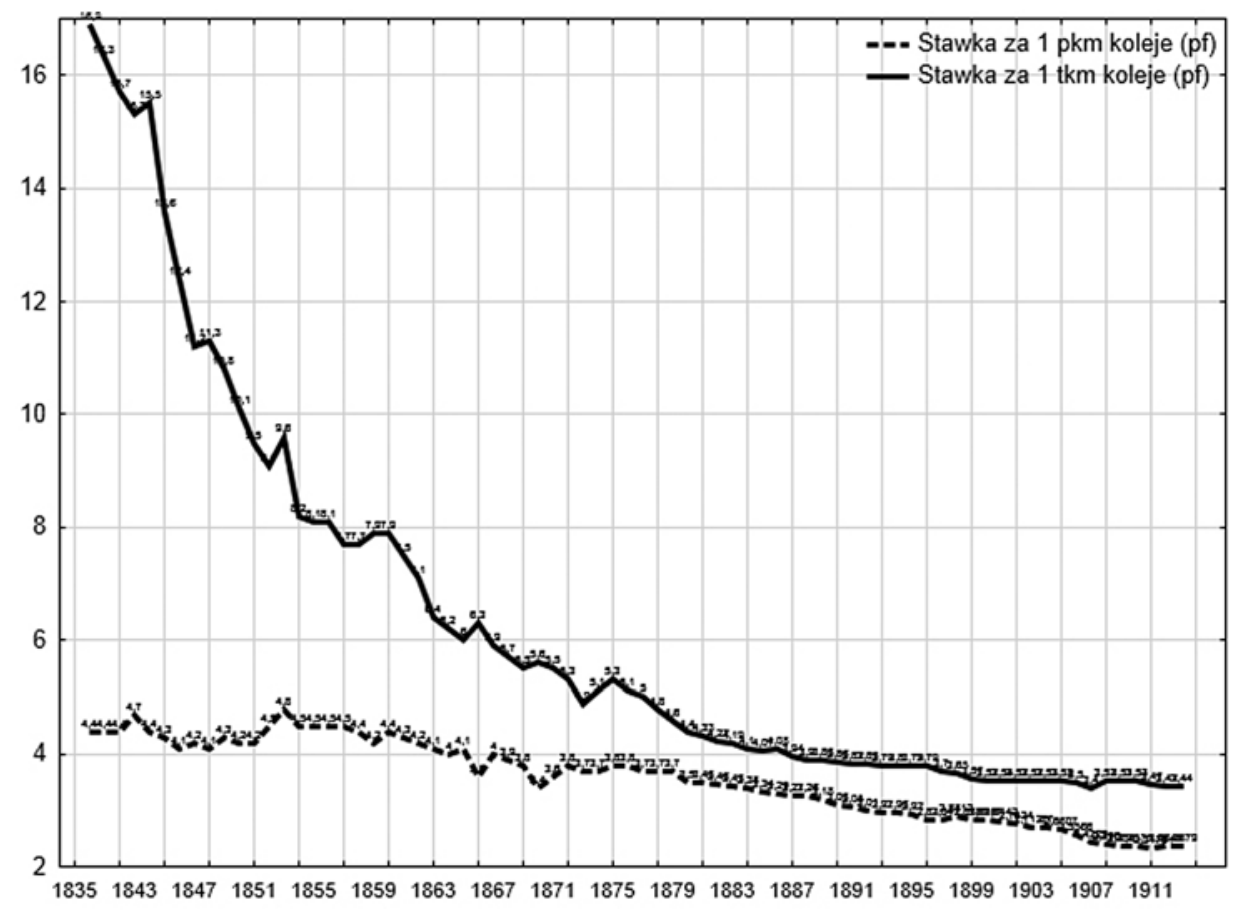

Rys. 61. Stawki frachtu towarowego (pf/1 tkm) i przewozów pasażerskich (pf/1 pkm) koleją w Niemczech w latach 1840-1913

Źródło: opracowanie własne na podstawie: W.G. Hoffmann, Das Wachstum der deutschen Wirtschaft seit der Mitte des 19. Jahrhunderts, Berlin 1965, s 204-204, R. Fremdling, Eisenbahnen und deutsches Wirtschaftswachstum 1840-1879. Ein Beitrag zur Entwicklungstheorie und zur Theorie der Infrastruktur, Dortmund 1985, s. 28-29.

Podsumowując - coraz lepiej rozwinięta sieć kolejowa była substytutem transportu wodnego. Dodać należy, że ze względu na układ sieci rzek w Niemczech początkowo odczuwalny był brak naturalnych głównych dróg wodnych w kierunkach wschód-zachód. Rozbudowa kolei wzmacniała siłę i możliwości transportu w różnych kierunkach, dając możliwość konkurowania z innymi dostawcami dóbr (jak przykład dotyczący węgla). W przyszłości rozbudowa kanałów stała się potwierdzeniem, że i wobec kolei istnieje substytut, nie wspominając o późniejszej rozbudowie bitych dróg lądowych.

Średnia cena transportu kolejowego spadała w latach 1840-1879 o około $73 \%$. Przyrost produktywności sektora kolejowego, choć imponujący na tle innych sektorów gospodarki niemieckiej, nie jest wystarczającym powodem, aby uznać go za najważniejszy sektor gospodarki.

Równie użyteczne są dane dotyczące zatrudnienia w kolejnictwie, jako odsetka ogółu zatrudnionych w gospodarce oraz analiza wartości dodanej w tworzeniu 
produktu narodowego generowanej przez sektor kolejowy. W tym zakresie autor posłużył się danymi statystycznymi prezentowanymi przez R. Fremdlinga (lata 1840-1879) oraz W.G. Hoffmanna (lata 1879-1913), a także rocznikami statystycznymi Rzeszy.

Obok liczby zatrudnionych w sektorze kolejowym w latach 1840-1913, uwzględniono odsetek zatrudnionych w porównaniu do wybranych sektorów gospodarki narodowej - rolnictwa z leśnictwem, przemysłu i rzemiosła, górnictwa, a także w stosunku do ogółu zatrudnionych.

Liczba pracujących w sektorze kolejowym nie uwzględnia pracowników zatrudnionych przy budowie sieci kolejowej, zawiera zaś urzędników i robotników dniówkowych (Tagelöhner).

Na początku rozbudowy sieci kolejowej (1840 r.) w sektorze zatrudnionych było około 1650 osób. W 1850 r. zatrudnienie wzrosło do 26 tys. osób. W 1870 r. liczba zatrudnionych wyniosła już 161 tys. osób. W latach 1870-1913 średnie roczne tempo wzrostu zatrudnienia wynosiło 3,75\%. W efekcie w $1913 \mathrm{r}$. w analizowanym sektorze znajdowało zatrudnienie 782,7 tys. osób, co stanowiło ponad 2,5\% ogółu zatrudnionych w niemieckiej gospodarce.

W trakcie rozwoju kolei wskaźnik zatrudnienia w sektorze kolejowym w stosunku do całej gospodarki stale wzrastał - w $1871 \mathrm{r}$. wynosił zaledwie $1 \%$, w 1900 r. przekroczył 2,10\%.Wyniki obliczeń zaprezentowano na rys. 62 .

Początkowo udział zatrudnionych w kolejnictwie w stosunku do niemal wszystkich wybranych sektorów gospodarki wyraźnie wzrastał (lata 1840-1875). W drugiej połowie lat siedemdziesiątych XIX w. zauważalna jest pewna stabilizacja w stosunku do zatrudnienia w przemyśle oraz górnictwie. Wzrastał natomiast odsetek zatrudnionych w kolejnictwie w porównaniu do pracowników zatrudnionych $\mathrm{w}$ rolnictwie, co oczywiście wynikało z wolnego spadku udziału procentowego zatrudnionych w rolnictwie w stosunku do ogółu zatrudnionych. Mimo rosnącej liczby pracowników sektora kolejowego oraz wzrostu odsetka w zatrudnieniu ogółem, są to niewystarczające dowody na precyzyjne określenie czy też potwierdzenie dużego wpływu na wzrost i rozwój gospodarczy Niemiec. 


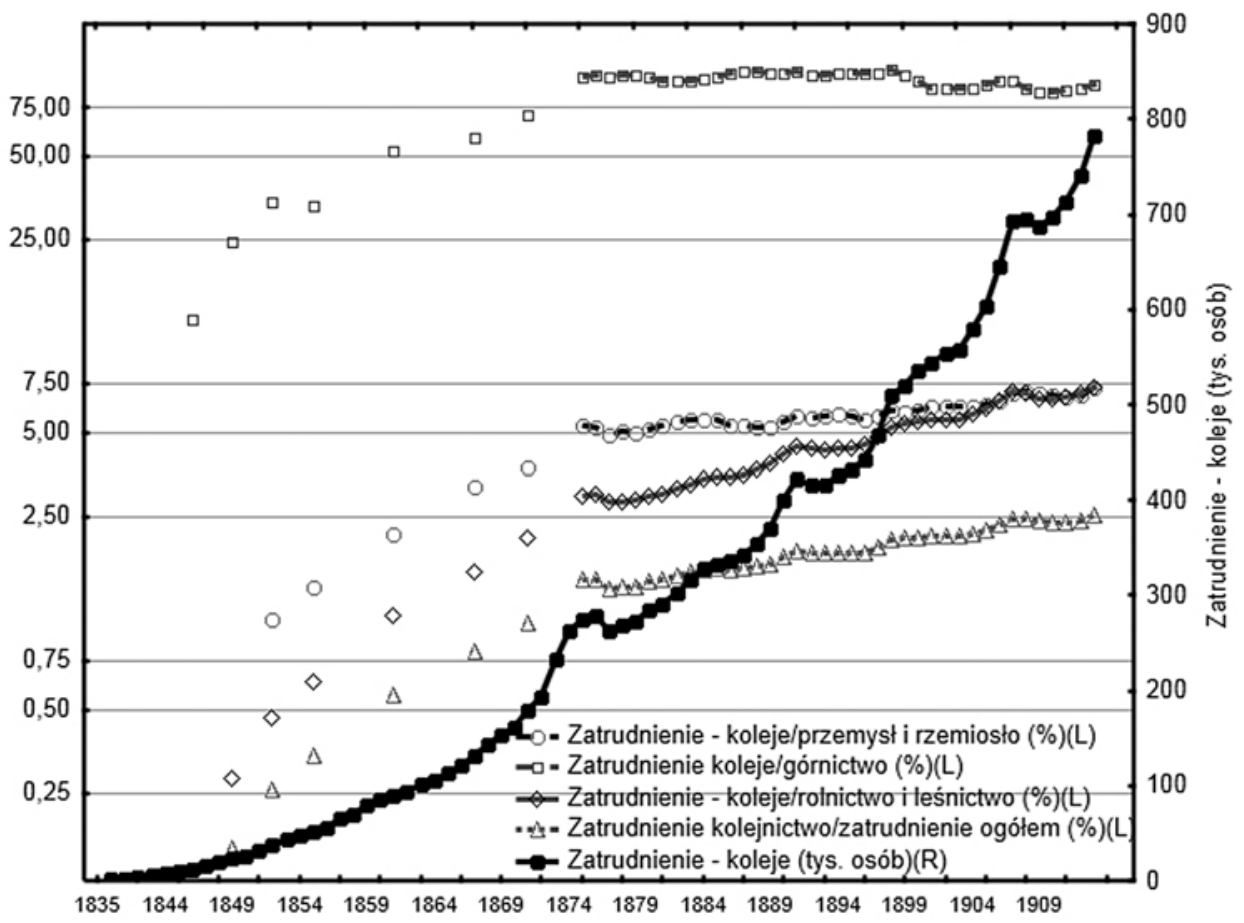

Rys. 62. Zatrudnienie w niemieckim sektorze kolejowym w latach 1840-1913 (tys. osób), oraz wskaźnik zatrudnienia kolejnictwo - wybrane sektory gospodarki (\%)

Źródło: opracowanie własne na podstawie: W.G. Hoffmann, Das Wachstum der deutschen Wirtschaft seit der Mitte des 19. Jahrhunderts, Berlin 1965, s. 204-205; R. Fremdling, Eisenbahnen und deutsches Wirtschaftswachstum 1840-1879. Ein Beitrag zur Entwicklungstheorie und zur Theorie der Infrastruktur, Dortmund 1985, s. 24, Statistisches Jahrbuch für das Deutsche Reich, Berlin, 1882-1914.

Istotnym czynnikiem dla oceny roli kolejnictwa obok powyższych jest także oszacowanie, jaki był udział procentowy sektora kolejowego w tworzeniu wartości dodanej w gospodarce. Dane statystyczne przedstawione przez W.G. Hoffmanna zawierają informacje dotyczące komunikacji, bez wyłączenia sektora kolejowego. 


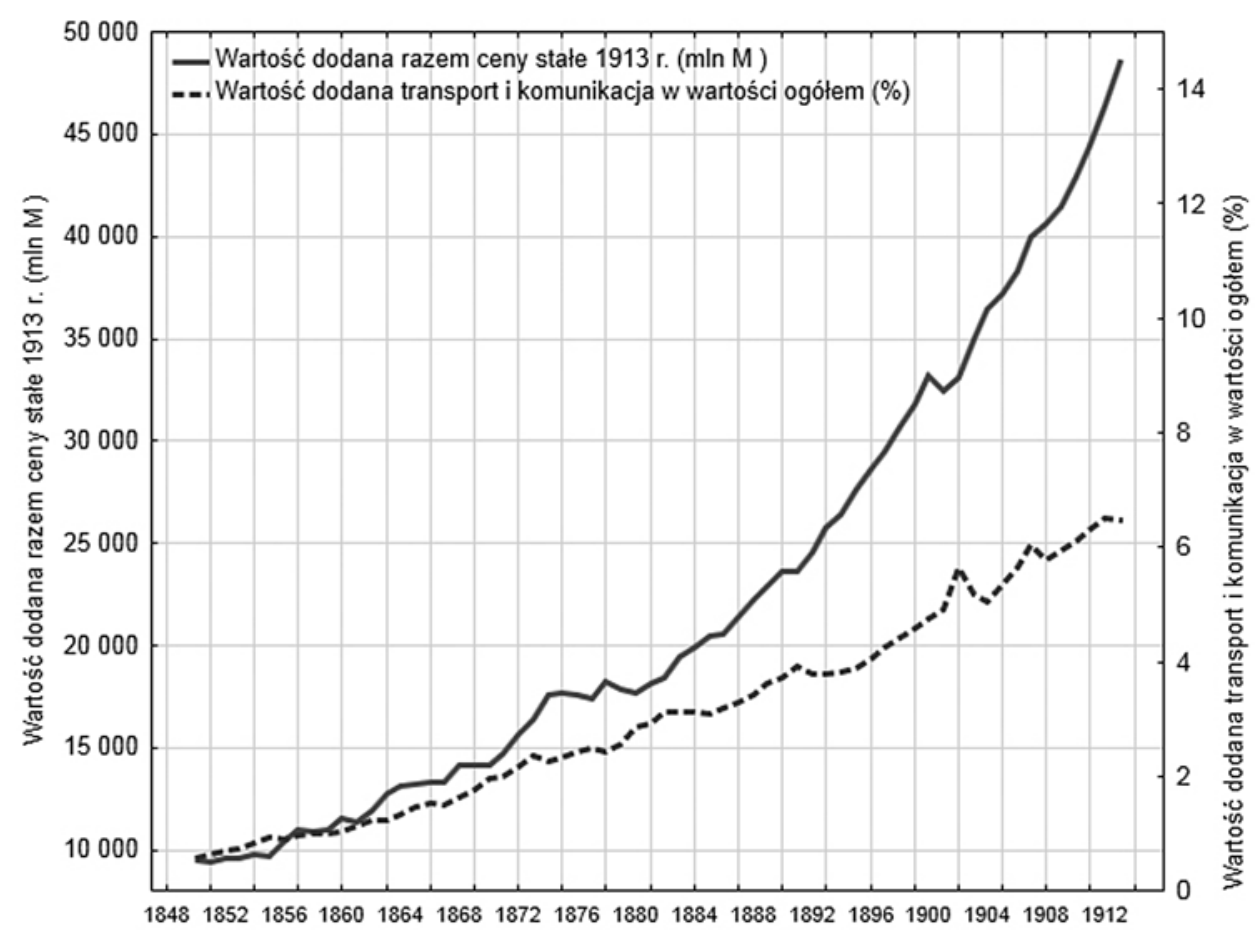

Rys. 63. Wartość dodana w gospodarce niemieckiej w latach 1850-1913 (mln marek) na tle udziału sektora transportowego (\%)

Źródło: obliczenia własne na podstawie: W.G. Hoffmann, Das Wachstum der deutschen Wirtschaft seit der Mitte des 19. Jahrhunderts, Berlin 1965, s 204-204.

Z danych zawartych na rys. 63 można wywnioskować, że udział sektora transportowego w kreowaniu wartości dodanej w gospodarce wzrastał systematycznie z 0,5\% w $1850 \mathrm{r}$. do niemal 6,5\% w $1913 \mathrm{r}$.

Nieco inne szacunki można znaleźć w pracy R. Fremdlinga, który analizuje okres 1840-1879 r., mianowicie jego obliczenia wartości dodanej są nieco wyższe niż przedstawione powyżej. Wynika to z przyjętej metody obliczania - zsumowania przychodów z płac w sektorze kolejowym i przychodów kapitałowych. Według tych szacunków udział sektora w tworzeniu ogólnej wartości dodanej wyniósł w latach 1875-1879 około 4,7\%, gdyby uwzględnić także zatrudnienie przy rozbudowie kolei wówczas otrzymalibyśmy $6,5 \%{ }^{5}$. Równie wysokie wskaźniki dotyczą zatrudnionych $\mathrm{w}$ sektorze kolejowym w porównaniu do przemysłu: w 1850-1854-3\% (uwzględniając zatrudnienie w budowie dróg żelaznych 4,6\%), w latach $1865-1869-8,5 \%$ (11,4\%), zaś w latach $1875-1879-11,1 \%(15,3 \%)$.

${ }^{5}$ R. Fremdling, op. cit., s. 26. 
Chcąc określić, w jakim stopniu oferowane przez kolej przewozy towarowe i pasażerskie wpływały na wartość dodaną należy prześledzić powyższą rycinę. Wyraźnie można zauważyć szybki wzrost przewozów kolejowych - towarowych, które w 1913 r. stanowiły ponad 39\% tworzonej wartości przez transport. W tym czasie przewozy pasażerskie stanowiły blisko $22 \%$. Powyższa analiza potwierdza, że do końca lat siedemdziesiątych XIX w. wzrastała waga sektora kolejowego, podobnie, jak i górnictwa. Wspomniane sektory były tak samo ważne dla niemieckiej industrializacji, jak rozwój przemysłu bawełnianego w Wielkiej Brytanii na początku XIX w., którego udział w kreowaniu wartości dodanej wynosił 7-8\% ${ }^{6}$. Wzrost sektora kolejowego w Wielkiej Brytanii osiągnął swe apogeum w 1905 r. wyniósł wówczas $6 \% \mathrm{w}$ stosunku do wartości generowanej w całej gospodarce.

Ulokowany kapitał jest czynnikiem produkcji, którego wzrost ściśle uzależniony jest od poziomu inwestycji. W latach $1880-1884$ poziom zaangażowanego kapitału w sektorze osiągnął 11,4\% ogółu kapitału w gospodarce. Kapitał zainwestowany w sektorze kolejowym w $1850 \mathrm{r}$. w stosunku do przemysłu wynosił nieco więcej niż $15 \%$, aby w 1879 r. osiągnąc $62 \%$. (rys. 64).

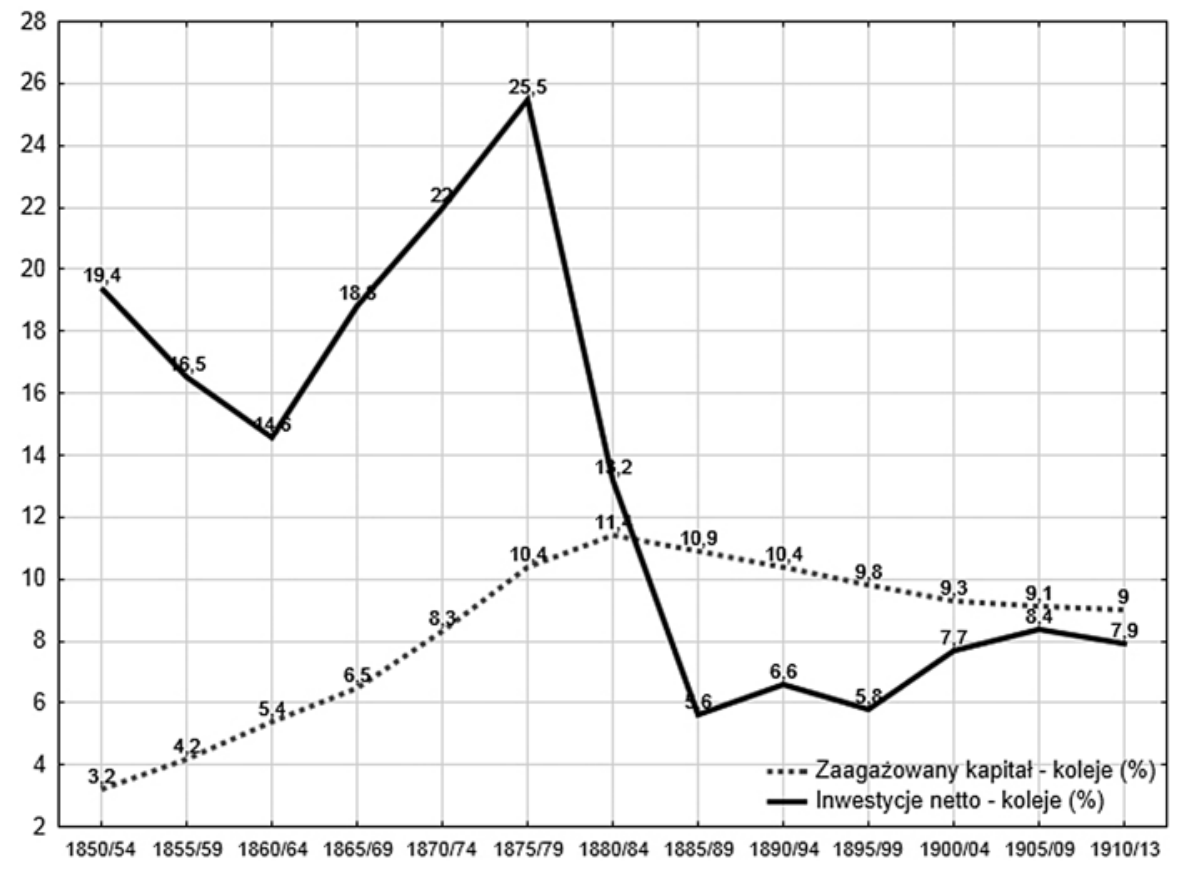

Rys. 64. Zaangażowany kapitał i poziom inwestycji w sektorze kolejowym (1850-1913)

Źródło: jak do rys.63.

${ }^{6}$ P. Deane, H. Habakkuk, The Take-Off in Britain, [w:] The Economics of Take-Off into Sustained Growth, ed. W.W. Rostow, London 1963, s. 70. 
Poziom inwestycji w koleje w stosunku do wydatków inwestycyjnych ogółem wrastał od lat sześćdziesiątych XIX w. z 14,6\% do 25,5\% w końcu lat siedemdziesiątych XIX w. Oznacza to, że średnie roczne tempo przyrostu wydatków inwestycyjnych w niemieckim kolejnictwie wynosiło 18,3\%. W późniejszym okresie inwestycje w sektorze kolejowym spadły do poziomu kilku procent. Na początku XX w. i tuż przed wybuchem I wojny światowej poziom inwestycji wynosił 7-8\% ogółu wydatków inwestycyjnych. Niestety brak jest danych dotyczących poziomu inwestycji w latach czterdziestych XIX w.

\section{WPLYW KOLEI NA WZROST GOSPODARCZY: CAPITAL TERM, SPOLECZNE OSZCZĘDNOŚCI (SOCIAL SAVINGS) Z WYKORZYSTANIEM NADWYŻKI KONSUMENTA}

W tym podrozdziale określone zostaną dwa ważne mierniki ukazujące wpływ kolei na wzrost gospodarczy Niemiec.

Jednym ze sposobów obliczenia wpływu kolei na wzrost gospodarczy jest the capital term. W tym celu obliczono stopę wzrostu kapitału zakładowego kolei per capita i poziomu przychodów netto kolei w stosunku do poziomu PKB Niemiec ${ }^{7}$. Autor określił trzy okresy czasowe:

- okres 1850-1870, w którym średnie tempo przyrostu linii kolejowych wyniosło $9,9 \%$,

- okres 1871-1900, ze średnim rocznym tempem przyrostu linii kolejowych $2,56 \%$,

- okres 1901-1913, ze średnim rocznym tempem przyrostu linii kolejowych $1,52 \%{ }^{8}$

7 Por. A. Herranz-Loncán, The Contribution of Railways to Economic Growth in Latin America before 1914: a Growth Accounting Approachs, http://www.ub.edu/histeco/pdf/herranz-DT01.pdf [dostęp 10.09.2012], s. 1-15.

${ }^{8}$ Pierwszy okres to czas, w którym powstał szkielet linii kolejowych z okresu Niemieckiego Związku Celnego do czasów zjednoczenia Niemiec. Drugi okres obejmuje początki zjednoczonego Cesarstwa Niemieckiego i kończy się w 1900 r. W okresie tym nasilona była nacjonalizacja kolei prywatnych, ponadto szeroko dostępne są wiarygodne dane statystyczne dotyczące kolei, w tym wielkości kapitału i poziomu przychodów netto w markach prezentowane m.in. w rocznikach statystycznych Statistisches Jahrbuch für das Deutsche Reich oraz pracy W.G. Hoffmanna: Das Wachstum der deutschen Wirtschaft seit der Mitte des 19. Jahrhunderts. To także lata względnie szybko wzrastającego PKB Niemiec, okres napływu kontrybucji wojennej dla Niemiec. Trzeci okres zdominowały przygotowania gospodarki do rozpoczęcia działań wojennych. 
Wpływ kolei na wzrost gospodarczy Niemiec został przedstawiony w tab. 28. Obliczono m.in.:

- stopę wzrostu kapitału zakładowego, dla której widoczny jest trend spadkowy z 4,5\% w pierwszym okresie, do $2,77 \%$ w okresie drugim, aby osiągnąć poziom $1,78 \mathrm{w}$ okresie trzecim;

- stopę przychodów netto kolei do poziomu PKB, która uwidacznia zupełnie inną tendencję niż powyższa, tj. wyraźny wzrost przychodów z kolejnictwa, który z 2,5\% w pierwszym okresie osiągnął poziom ponad 4\% w okresie trzecim. Dla roku 1913 wyniósł zaś ponad 5,81\%;

- capital term, który dla ostatniego okresu wyniósł nieznacznie ponad 7\%.

Podsumowując wskaźniki zawarte w tab. 28 daje się zauważyć w pierwszym i drugim okresie znaczący udział kolei w generowanym dochodzie narodowym, natomiast w trzecim okresie (1900-1913) udział, obliczony, jako suma capital term i TFP term, zmniejszył się do 0,15. Dla przykładu w Wielkiej Brytanii dla lat 1850-1870 całkowity wpływ kolei wynosił 0,26 , w latach 1870-1910-0,07 zaś w przypadku Hiszpanii wyniósł on w latach 1850-1912 - 0,069-0,0929.

Tabela 28. Wpływ kolei na wzrost gospodarczy w Niemczech w wybranych okresach: the capital term, TFP term, całkowity udział kolei

\begin{tabular}{|l|c|c|c|}
\hline \multicolumn{1}{|c|}{ Wyszczególnienie } & $1850-1870$ & $1871-1900$ & $1901-1913$ \\
\hline a) Stopa wzrostu kapitału kolei (\%) & 4,50 & 2,77 & 1,78 \\
\hline b) Stopa przychodów netto do poziomu PKB (\%) & 2,50 & 4,90 & 4,02 \\
\hline $\begin{array}{l}\text { c) Udział kolei w dochodzie narodowym } \\
\text { capital term }(\mathrm{a} \times \text { b) }\end{array}$ & 0,11 & 0,14 & 0,07 \\
\hline d) Wzrost TFP (\%) & 3,84 & 1,94 & 1,49 \\
\hline e) Poziom kolei w produkcji ogólnej (\%) & 1,79 & 4,27 & 5,40 \\
\hline f) Udział kolei „TFP term” (d $\times$ e) & 0,069 & 0,083 & 0,080 \\
\hline g) Całkowity wpływ kolei (c+f) & 0,18 & 0,22 & 0,15 \\
\hline
\end{tabular}

Źródło: obliczenia własne na podstawie danych statystycznych: W.G. Hoffmann, Das Wachstum der deutschen Wirtschaft seit der Mitte des 19. Jahrhunderts, Berlin 1965; Statistisches Jahrbuch für das Deutsche Reich, Berlin 1880-1914.

Dla zobrazowania zmian w poziomie PKB, zaangażowanego kapitału w kolejnictwie, a także uzyskiwanych przychodów sektora w latach 1871-1913 przygotowano poniższy rys. 65 .

9 A. Herranz-Loncan, The contribution of railways to economic growth in Latin America before 1914: a growth accounting approach, "MPRA Paper" 2011, no. 33578, http://mpra.ub.uni-muenchen.de/33578 [dostęp 10.09.2012], s. 10. 


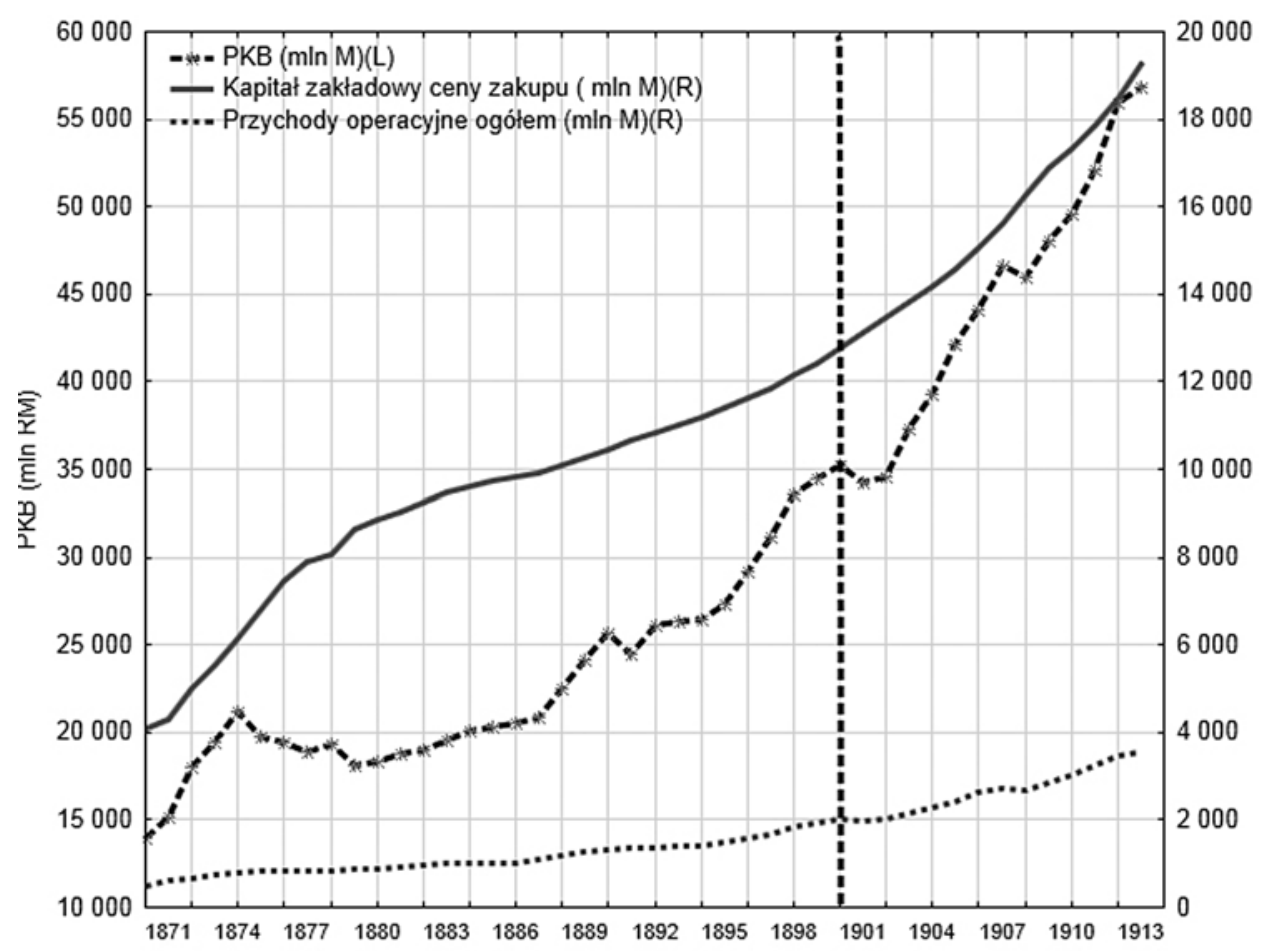

Rys. 65. PKB Niemiec, przychody netto sektora kolejowego, kapitał zakładowy kolei (mln marek) w latach 1871-1913

Źródło: obliczenia własne na podstawie: Statistisches Jahrbuch für das Deutsche Reich, Berlin 1871-1914.

W całym analizowanym okresie wzrastają przychody operacyjne niemieckich kolei, biorąc po uwagę spadek taryf kolejowych, świadczy to o wzroście przewozów i coraz większym znaczeniu gospodarczym tego środka lokomocji. W analizowanym okresie średnie roczne tempo wzrostu przychodów operacyjnych oscylowało $\mathrm{w}$ granicach $4 \%$, co oznacza podwojenie przychodów w ciągu ok. 20 lat.

Kapitał zakładowy $\mathrm{w}$ dekadzie lat siedemdziesiątych przyrastał średnio w każdym roku o 8,8\%, zaś w okresie 1880-1913 średnie tempo przyrostu spadło do $2,2 \%$.

Powyższe obliczenia ukazują znaczną rolę sektora kolejowego na tle wzrostu PKB, choć to znaczenie jest coraz mniejsze, począwszy od końca XIX i początków XX w.

Drugą miarą spośród znanych narzędzi i technik dla oszacowania oszczędności kosztów z nowej technologii w porównaniu z inną alternatywą, i jest szerzej opisana we wstępie, koncepcja społecznych oszczędności. T. Leunig podkreśla, 
że koncepcja social savings jest niezwykle istotną miarą używaną przez ekonomistów i historyków gospodarczych w celu określenia wartości zmian technologicznych, łącznie $z$ badaniem ich wpływu na zmiany w całej gospodarce. Dodaje, że zaletą metody jest możliwość jej zastosowania w warunkach ograniczonego dostępu do danych historycznych ${ }^{10}$.

Jak autor wspominał, społeczne oszczędności w przypadku sektora kolejowego Niemiec nie zostały praktycznie obliczone. R. Fremdling jedynie, krytykując samą koncepcję społecznych oszczędności, wskazuje, że gdyby próbować je obliczać dla lat osiemdziesiątych XIX w., to prawdopodobnie w przypadku Niemiec byłyby ujemne ${ }^{11}$.

Aby uwiarygodnić rolę kolei autor postanowił obliczyć społeczne oszczędności dla frachtu kolejowego, głównie dotyczącego przewozu ładunków masowych dla 1909 r. Przyjęto, dla alternatywy frachtu kolejowego (zgodnie z równaniem 7) dwa warianty (tab. 29):

$$
\begin{aligned}
& \mathrm{P}_{\text {тоI }}=0,8 \mathrm{P}_{\mathrm{W}}+0,1 \mathrm{P}_{\mathrm{K}}+0,1 \mathrm{P}_{\mathrm{P}}(\text { kolumna 4. }) \\
& \mathrm{P}_{\text {TоII }}=0,7 \mathrm{P}_{\mathrm{W}}+0,2 \mathrm{P}_{\mathrm{K}}+0,1 \mathrm{P}_{\mathrm{P}}(\text { kolumna } 3 .)
\end{aligned}
$$

gdzie:

$\mathrm{P}_{\mathrm{W}}$ - stawka dla transportu śródlądowego wodnego, określono na podstawie stawki średniego frachtu śródlądowego dla węgla kamiennego,

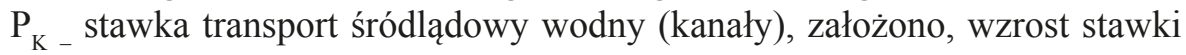
frachtu transportu wodnego o $0,5 \mathrm{pf} / \mathrm{tkm}$,

$\mathrm{P}_{\mathrm{P}}$ - stawka transport konny (furmanki), określono w wysokości 40pf/tkm.

Stawka frachtu dla transportu kolejowego została przyjęta, jako:

- kolumna 3 - średnia w wysokości 3,51pf/tkm, stawka taka ponadto była zawarta w Spezialtarife II $^{12}$,

- kolumna 4 - stawka frachtu dla przewozów towarów masowych w tym węgla (Spezialtarife III) w wysokości 2,2 pf/tkm, jako 32\%, a 68\% stawka średnia $3,51 \mathrm{pf} / \mathrm{tkm}^{13}$.

Uzyskane wyniki prezentowane są w tab. 29.

Obliczenia wskazują, że społeczne oszczędności w przypadku Niemiec są stosunkowo niewielkie. Gdyby je odnieść jedynie do prezentowanych społecznych oszczędności w przypadku innych krajów, i obliczeń innych autorów (tab. 13), to rzeczywiście są one niewysokie.

${ }_{10}$ T. Leunig, Social savings, [w:] D. Greasley, L. Oxley, Economics and History. Surveys in Cliometrics, Oxford 2011, s. 25-46.

${ }^{11}$ R. Fremdling, op. cit., s. 73.

${ }^{12}$ L. Sympher, Die wirtschaftliche Bedeutung des Rhein-Elbe-Kanals, Bd. 1, Berlin 1899, s. $30-31$.

13 Por. Statistisches Jahrbuch für das Deutsche Reich, Berlin 1913, s. 123. 
W jakiś sposób usprawiedliwia to niechęć do obliczenia społecznych oszczędności w przypadku kolei i ukazywanie znaczenia sektora kolejowego, jako podstawowego sektora wzrostu, spotykanego w literaturze niemieckiej. Wydaje się, że podawane przez autora pracy przykłady dotyczące rynku węgla kamiennego i zbóż faktycznie potwierdzają tezę, że alternatywny transport wodny był rzeczywiście tańszy. Trzeba jednak zwrócić uwagę, że transport wodny nie był również pozbawiony słabości, np.: niski poziom zanurzenia na wielu rzekach, większe uzależnienie od warunków klimatycznych, niska prędkość, wysokie koszty transportu lądowego towarów do cieków wodnych.

Tabela 29. Społeczne oszczędności sektora kolejowego w Niemczech (1909 r.)

\begin{tabular}{|c|l|c|c|}
\hline Lp. & \multicolumn{1}{|c|}{ Opis } & \multicolumn{2}{|c|}{1909} \\
\hline $\mathbf{1}$ & \multicolumn{1}{|c|}{$\mathbf{3}$} & $\mathbf{4}$ \\
\hline 1 & Przewozy kolejowe $(\mathrm{mln}$ tkm) & 52800,00 & 52800,000 \\
\hline 2 & Stawka za 1 tkm przewozu koleją (pf) & 0,0351 & 0,0310 \\
\hline 3 & Alternatywna stawka za 1 tkm (pf) & 0,0540 & 0,0533 \\
\hline 4 & Wartość przewozów kolejowych $(1 \times 2)$ & 1853,28 & 1636,800 \\
\hline 5 & Wartość przewozów, jako alternatywa kolei $(1 \times 3)$ & 2851,20 & 2814,240 \\
\hline 6 & Społeczne oszczędności (mln marek) & 997,92 & 1117,440 \\
\hline 7 & Stopa oszczędności $(\%$ PKB) & $\mathbf{2 , 0 8}$ & $\mathbf{2 , 3 2}$ \\
\hline
\end{tabular}

Źródło: obliczenia własne na podstawie: Statistisches Jahrbuch für das Deutsche Reich, Berlin 1871-1914; W.G. Hoffmann, Das Wachstum der deutschen Wirtschaft seit der Mitte des 19. Jahrhunderts, Berlin 1965; R. Fremdling, Eisenbahnen und deutsches Wirtschaftswachstum 1840-1879. Ein Beitrag zur Entwicklungstheorie und zur Theorie der Infrastruktur, Dortmund 1985.

Wracając do obliczeń, należy jeszcze dodać, że nie ujęto w nich planowanego kanału Rhein-Elbe-Kanal, który, z racji połączenia dwóch kluczowych rzek znacznie skracał długość frachtu rzecznego. Można jednak zakładać, że wówczas społeczne oszczędności byłyby jeszcze mniejsze. Z zależności od przyjętych dwóch różnych założeń do obliczeń społeczne oszczędności wynosiły nieznacznie ponad $2 \%$ w skali do PKB.

Takie wyniki obliczeń potwierdzają założoną hipotezę badawczą, że rola kolei przez pryzmat społecznych oszczędności w stosunku do poziomu PKB była zdecydowanie niższa niż jest to przyjęte w literaturze, w tym literaturze niemieckiej.

Uzasadnia to też powód i przyczynę, że niemieccy naukowcy (jak wspomniani R. Fremdling, R. Tilly, T. Pierenkemper i inni) ujmują znaczenie kolei, jako kluczowego sektora, koncentrując się na efektach „w przód” i „w tył”, mniej eksponując zażartą rywalizację transportu kolejowego i wodnego w końcu XIX i początkach XX w. 
Wracając do koncepcji społecznych oszczędności postuluje się, aby uwzględnić w jej obliczaniu standardową miarę dobrobytu, propagowanej przez wielu ekonomistów, jaką jest nadwyżka konsumenta (CS - consumer surplus). Również autor obliczone powyżej wyniki poddał jeszcze weryfikacji (ze względu na tę miarę).

W warunkach istnienia konkurencji, obszar pomiędzy krzywą popytu a ceną dobra określa, w jakim stopniu przedsiębiorstwa dokonały transferu zasobów na dobra, których wartość w ocenie konsumentów przewyższają ich koszty (gdzie koszty z kolei są określane przez konkurencyjne zastosowania dla tych zasobów). Jak zauważa N. Craft jest to najlepsza definicja dla osiąganej wartości dobrobytu w przypadku wprowadzenia nowej technologii. T. Leunig wskazuje koncepcję nadwyżki konsumenta, jako inną dodatkową miarę określająca społeczne oszczędności z zastosowania nowej technologii ${ }^{14}$.

Po publikacji R. Fogla, J. Boyd i G.M. Walton poddali w wątpliwość celowość wyliczania społecznej oszczędności na założeniu, że współczynnik elastyczności popytu wynosi 0 . Dla przypomnienia, współczynnik ten oznacza, że popyt nie reaguje na zmiany ceny. W zasadzie można uznać, że społeczne oszczędności oszacowane w ten sposób określają, zgodnie z argumentami R. Fogla, górną granicę oszczędności.

Badania ekonometrycznych szacunków elastyczności popytu dla transportu pasażerskiego przeprowadzone przez J. Boyda i G.M. Waltona w okresie po II wojnie światowej doprowadziły ich do wniosku, że wskaźnik ten wynosi [1]. Ilustracją graficzną nadwyżki konsumenta jest pole powierzchni pomiędzy prostą $P=P_{0}$ (gdzie $\mathrm{P}_{0}$ jest ceną równowagi rynkowej) a krzywą popytu $D=f(q)$ oraz osią pionową układu współrzędnych (rys. 24). Stąd nadwyżką konsumenta można nazwać całkowitą korzyść finansową ogółu konsumentów, którzy byliby skłonni nabyć jednostkę danego dobra, po cenie wyższej niż cena równowagi rynkowej $P_{0}$ Dokładna wielkość tej miary uzależniona jest od kształtu krzywej popytu.

Można to przedstawić algebraicznie, jako

$$
\Delta C S=\left(P_{t-1}-P_{t}\right) Q_{t-1}+\alpha\left(P_{t-1}-P_{t}\right)\left(Q_{t}-Q_{t-1}\right)
$$

gdzie:

$\alpha$ - parametr determinujący kształt krzywej popytu,

$Q-$ ilość,

$t$ - czas po wprowadzeniu innowacji,

$t-1$ - czas przed wprowadzeniem innowacji.

Chcąc określić zależność pomiędzy społecznymi oszczędnościami, a nadwyżką konsumenta i złożeniu, że $\mathrm{Q}_{\mathrm{t}}=1$ otrzymujemy:

$$
\frac{\Delta C S}{S S} \alpha+(1-\alpha) Q t-1
$$

${ }^{14}$ T. Leunig, op. cit., s. 22-28. 
Przy takiej konstrukcji równania występują trzy różne kategorie, w zależności od parametru $\alpha$, a mianowicie, kiedy parametr przyjmuje wartość $\alpha>1, \alpha=1, \alpha<1$.

Jeśli $\alpha>1$, wówczas rozpatrujemy dobra Giffena, dla których krzywa popytu jest pozytywnie nachylona, wówczas iloraz $\frac{\Delta C S}{S S}>1$. Oznaczałoby to, że wraz ze spadkiem ceny produktu, jego konsumpcja też spada, co wyjaśnić można jako przewagę efektu dochodowego nad efektem substytucyjnym. Wówczas ilość $Q_{t}$ pomnożona przez cenę byłaby mniejsza niż $Q_{t-1}$ pomnożona prze cenę przed wprowadzeniem innowacji. Stąd dla dóbr Giffena społeczne oszczędności SS byłyby mniejsze niż nadwyżka konsumenta $C S$.

Jeśli $\alpha=1$, wówczas popyt byłby doskonale nieelastyczny. Oznacza to, że obliczone społeczne oszczędności SS byłyby równe nadwyżce konsumenta $C S$, co oznaczałoby, że można byłoby zastosować równanie 7).

Trzecia możliwość, jeśli $\alpha<1$, to $\frac{\Delta C S}{S S}<1$, co oznacza, że społeczne oszczędności SS są większe od nadwyżki konsumenta $C S$.

Jeżeli elastyczność popytu jest stała dla danego popytu, wówczas możemy przyjąć, że:

$$
Q=P^{\mathrm{e}}
$$

gdzie:

$e$ - elastyczność popytu.

Chcąc określić nadwyżkę konsumenta posłużyć się można następującym równaniem (wzrost nadwyżki konsumenta jest związany z $Q$ z uwzględnieniem $P$ ):

$$
\Delta C S=\int{ }_{P_{t}}^{P_{t-1}} P^{e} d p=\frac{1}{e+1}\left(P_{t-1}^{e+1}-P_{t}^{e+1}\right)
$$

Aby określić relację pomiędzy zmianą wartości nadwyżki konsumenta a estymacją społecznych oszczędności w przypadku stałej elastyczności popytu należy równanie (17) i równanie (15) przedstawić, jako funkcję ceny i elastyczności popytu, a następnie podzielić przez równanie $S S=\left(P_{t-1}-P\right) Q_{t}$. Otrzymamy wówczas:

$$
\frac{\Delta C S}{S S}=\frac{P_{r}^{e+1}-1}{(e+1)\left(P_{r}-1\right)}
$$

gdzie:

$P_{\mathrm{r}}=\frac{P_{t-1}}{P_{t}}-$ stosunek cen przed i po innowacji.

$\mathrm{Z}^{\mathrm{r}}$ równań (16)-(18) wynika, że wielkość odchylenia $\frac{\Delta C S}{S S}$ zależy nie tylko od stopnia elastyczności prostej popytu, ale także od $P_{r}$.

Jak dowodzi R. Fogel, nawet przy bardzo nieelastycznej krzywej popytu dla frachtu i przewozów pasażerskich $(\mathrm{e}=-0,4)$, obliczenia oparte na założeniu, że elastyczność jest równa 0 , może oznaczać, że $\frac{\Delta C S}{S S}$ zmieni się nawet o $46 \%{ }^{15}$.

${ }^{15}$ R. Fogel, Notes on the Social Saving Controversy, „Journal of Economic History” 1979, vol. XXXIX, no 1, s. 11-12. 
Na rys. 66 autor przedstawił zależności $\frac{\Delta C S}{S S} \mathrm{w}$ stosunku do stopnia elastyczności popytu i zmian cen. Autor posłużył się różnymi stopniami elastyczności popytu na tle elastyczności e $=-1,381$ oszacowanej dla wydatków na transport przez W.G. Hoffmanna. Stopień elastyczności popytu na wydatki transportowe w przypadku Niemiec zmieniał się znacznie w latach 1850-1913, podobnie, jak suma wydatków przeznaczonych przez gospodarstwa domowe na ten rodzaj zakupów. Jak zauważa W. Hoffmann, w połowie XIX w. średnio jedna osoba wydawała 40 pf (w cenach z 1913 r.), na transport, wydatki wzrastały bardzo szybko i w $1913 \mathrm{r}$. wyniosły 18 marek na osobę. Wykorzystując powyższe formuły oraz obliczone społeczne oszczędności sektora kolejowego autor obliczył uzyskaną nadwyżkę konsumenta.

Jak powyżej wskazano, w przypadku Niemiec wskaźnik elastyczności popytu wyniósł $(-1,38)$, co oznacza, że popyt na usługi transportowe był stosunkowo elastyczny. Z drugiej strony spadek cen frachtu nowej (koleje) i dotychczasowej technologii nie był znaczny i dla obu alternatyw wyniósł pomiędzy 1,5-1,7.

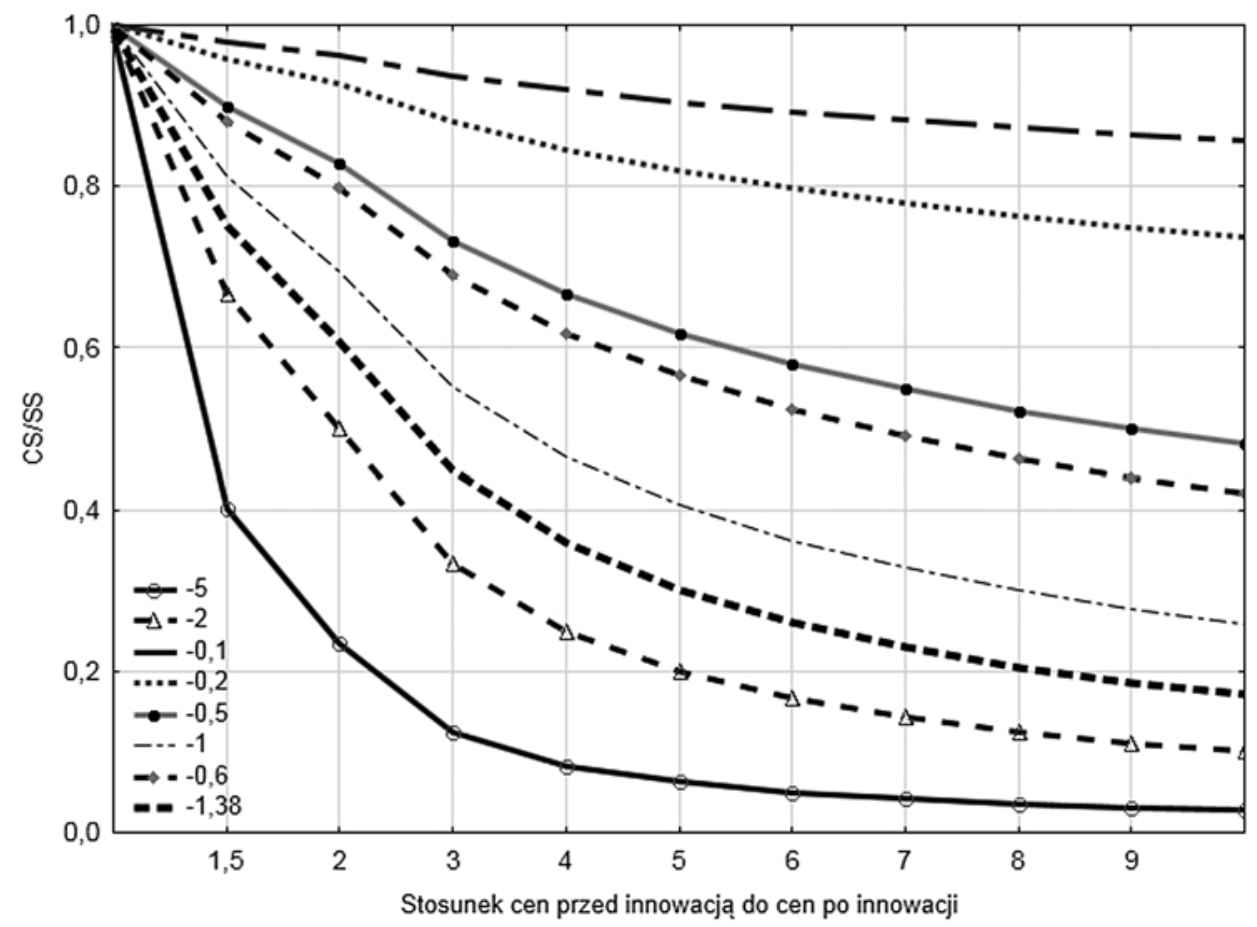

Rys. 66. Stosunek zmiany nadwyżki konsumenta do społecznych oszczędności w zależności od stopnia elastyczności popytu i spadku cen

Źródło: opracowanie własne, stopnień elastyczności popytu dla transportu w przypadku Niemiec na podstawie: W.G. Hoffmann, Das Wachstum der deutschen Wirtschaft seit der Mitte des 19. Jahrhunderts, Berlin 1965, s. 135. Pozostałe stopnie elastyczności przyjęte przez autora. 
Stosując powyższe formuły i stopień elastyczności popytu społeczne oszczędności sektora kolejowego z uwzględnieniem nadwyżki konsumenta wyniosły dla dwóch analizowanych przypadków (tab. 30, kolumna 3 i 4) odpowiednio 736,31 mln marek i 760,74 mln marek. Wykazane oszczędności w stosunku do poziomu PKB (1909 r.) wyniosły 1,53\%/1,58\%.

Tabela 30. Społeczne oszczędności sektora kolejowego w Niemczech z uwzględnieniem nadwyżki konsumenta (1909 r.)

\begin{tabular}{|c|l|c|c|}
\hline Lp. & \multicolumn{1}{|c|}{ Opis } & \multicolumn{2}{|c|}{1909} \\
\hline $\mathbf{1}$ & \multicolumn{1}{|c|}{$\mathbf{2}$} & $\mathbf{3}$ & $\mathbf{4}$ \\
\hline 1 & Społeczne oszczędności (\% PKB) & 2,08 & 2,32 \\
\hline 2 & $\begin{array}{l}\text { Stopa oszczędności z uwzględnieniem nadwyżki } \\
\text { konsumenta (\% PKB) }\end{array}$ & 1,53 & 1,58 \\
\hline
\end{tabular}

Źródło: obliczenia własne z wykorzystaniem danych z tab. 29.

Powyższe obliczenia są potwierdzeniem założenia w hipotezie badawczej o zdecydowanie mniejszym wpływie kolei na wzrost gospodarczy niż wynikałoby to z przedstawionej analizy prac dotyczących roli sektora kolejowego w przypadku Niemiec. Zakładając, że popyt na przewozy był stosunkowo elastyczny, czyli krzywa popytu nie była sztywna, wówczas nadwyżka konsumenta staje się automatycznie dużo niższa.

\section{RACHUNEK WZROSTU Z WYKORZYSTANIEM CAŁKOWITEJ PRODUKTYWNOŚCI CZYNNIKÓW PRODUKCJI (TFP), PRODUKCJI (OUTPUT), WSKAŹNIKA INPUT NA PRZYKLADZIE SEKTORA KOLEJOWEGO}

Metodologia rachunku wzrostu, jest częstym sposobem oceny skutków ekonomicznych wpływających na wzrost gospodarczy. Jak zauważa N. Crafts rachunek wzrostu może być również odpowiednią metodologią do oceny skutków rozwoju kolei na wzrost gospodarczy ${ }^{16}$.

Wpływ innowacji na wzrost TFP już dawno został zauważony. Wzrost ten odzwierciedla większą efektywność wykorzystania siły roboczej i kapitału i jest napędzany $\mathrm{m}$.in. innowacjami technologicznymi i nietechnologicznymi - zmia-

${ }^{16}$ N. Crafts, The Contribution of New Technology to Economic Growth: Lessons from Economic History, „Revista de Historia Económica. Journal of Iberian and Latin American Economic History” 2010, vol. 28 (3), s. 409-440. 
nami organizacyjnymi, ulepszonymi praktykami zarządzania, udoskonalonymi sposobami produkcji dóbr i usług ${ }^{17}$.

Postęp techniczny oznacza spadek cen wyjściowych (output), które, jako „efekt w przód" wpływają na inne sektory gospodarki. Jednak postęp technologiczny w odróżnieniu od pozostałych stóp wzrostu całkowitej produktywności czynników produkcji, nie wynika ze wzrostu innych czynników produkcji takich jak kapitał i praca. Ponadto wzrost produktywności, można utożsamiać ze wspomnianą już resztą Solowa.

Czysty (ucieleśniony) postęp techniczny zaobserwować można w sektorze kolejowym, analizując np. liczbę KM (koni mechanicznych) dla budowanych lokomotyw.

Warto wspomnieć, że w 1835 r. niemiecki przemysł maszynowy nie był w stanie wytwarzać szyn kolejowych, parowozów, innych dóbr inwestycyjnych niezbędnych dla rozbudowy kolei. W tym czasie w Niemczech było zaledwie 7 wielkich pieców hutniczych używających koksu, ulokowanych na Śląsku. ${ }^{18}$ Więcej niż $90 \%$ produkcji hutniczej odbywało się przy użyciu węgla drzewnego, z piecami o niskiej wydajności. W interesie niemieckiego przemysłu i dalszej rozbudowy kolei leżało zapewnienie możliwości produkcji walcowanej stali dla potrzeb produkcji szyn kolejowych, a także rodzimej produkcji lokomotyw. Do lat czterdziestych XIX w. Niemcy zmuszone były importować zarówno szyny kolejowe, jak i parowozy. W 1838 r. w użyciu pruskich kolei było 7 parowozów (w tym: 6 z Anglii, 1 z Belgii), w 1841 r. spośród 20 parowozów, 19 było z Anglii, 1 z Belgii. W 1842 r. spośród 28 lokomotyw 22 pochodziły z zagranicy (w tym: 12 z Anglii) 6 parowozów było już produkcji niemieckiej. W 1853 r. pruskie koleje używały już 729 lokomotyw, głównie produkcji niemieckich fabryk, jak Borsig Berlin (414 sztuk), Wöhlert Berlin (34 sztuki), E. Kessler Karlsruhe (34 sztuki), Hamburg-Magdeburger-Dampfschiffahrt-Comp. Buckau (15 sztuk), a także angielskich: R. Stephenson Newcastle (76 sztuk), Sharp \& Cp. Manchester (64 sztuki), belgijskich: J. Cockerill/Seraing Soc. Cockerill (46 sztuk), a także amerykańskich - W. Norris Philadelphia (11 sztuk). W latach pięćdziesiątych XIX w. lokomotywy niemieckie zdominowały krajowy rynek parowozów.

W 1909 r. koleje niemieckie dysponowały 26612 lokomotywami, 55923 wagonami pasażerskimi, 557965 wagonami towarowymi (z wagonami do przewozu przesyłek). Oznaczało to, że na każde $100 \mathrm{~km}$ trakcji kolejowej, średnio przypadało 46 lokomotyw, 98 wagonów pasażerskich, 958 wagonów towarowych. W tym samym roku niemieckie koleje przewiozły 1457 mln pasażerów i blisko 519,2 mln Mg towarów. Dla porównania jeszcze w 1900 r. niemieckie

${ }^{17}$ M. Noga, Co decyduje o rozwoju gospodarczym?, [w:] Wzrost gospodarczy a innowacje, red. J. Koch, Wrocław 2008.

18 J. Myszczyszyn, Rola koksu i żelaza w industrializacji świata, „Kultura i Historia” 2009, nr 16, http://www.kulturaihistoria.umcs.lublin.pl/archives/1476. 
koleje transportowały: $848092 \mathrm{mln}$ pasażerów i blisko $359 \mathrm{mln} \mathrm{Mg}$ towarów i przesyłek ${ }^{19}$. W tym czasie (1900-1909 r.) średnio w każdym roku liczba przewiezionych pasażerów wzrastała w tempie $6,44 \%$, zaś w przypadku przewozów towarowych $4,83 \%$.

W 1911 r. niemieckie koleje miały na stanie 31243 lokomotywy, w tym 324 elektryczne ${ }^{20}$.

W pierwszych latach budowy niemieckich lokomotyw, parowóz posiadał moc od 40 do $50 \mathrm{KM}$. Z powodu wyższego wolumenu transportu w następujących dekadach moc znacznie wzrastała. W 1870 r. moc lokomotywy wyniosła 336 KM. W kolejnych latach redukowano moc lokomotyw.

Postęp techniczny dokonywał się także w produkcji stali, jako materiału niezbędnego do rozbudowy dróg żelaznych. Podobnie było z postępem w przygotowaniu i użyciu drewna. Jak dodaje R. Fremdling, często dla osiągnięcia postępu technicznego uzyskanie wyższej efektywności wiązało się z metodą ,prób i błędów”.

Obok opisanych przykładów ucieleśnionego postępu technicznego w niemieckiej gospodarce i kolei dokonywał się nieucieleśniony postęp techniczny (np. korzystne zmiany w organizacji pracy).

Niemieckie spółki kolejowe zamierzały realizować konsekwentnie swoje cele, zakładając różnego rodzaju związki. Jednym z problemów spółek była reforma kolei, zgodnie z ustawą z 1838 r. o wywłaszczeniu pod budowę sieci kolejowej, 30-letnia ochrona przed konkurencją w działalności danej linii kolejowej, a także państwowa kontrola w spółkach. W 1846 r. założono Verein Deutscher Eisenbahn - Verwaltungen (Niemiecki Związek Administracji Kolei). Za główny cel Związek stawiał sobie ułatwienie jednolitej definicji środków (zasobów), wyposażenia i standardów w zakresie usług kolejowych między różnymi administracjami. Nie osiągnięto większych sukcesów dotyczących wysokości taryf przewozowych. Poszczególne spółki często stosowały swoje własne taryfy, a konkurencja pomiędzy nimi warunkowała obniżanie taryf przewozowych.

W nawiązaniu do powyższych rozważań teoretycznych koniecznym kryterium identyfikacji wiodących sektorów w gospodarce, w tym kolejnictwa jest postęp w produktywności. Postęp określa zdolność sektora do zaoferowania produktów o niższych cenach jednostkowych, a tym samym wywołuje np. efekty wyprzedzające inne branże.

Część wzrostu sektora, która nie może być wywołana wzrostem produkcji czynników, jest zwykle określana, jako pozostałość czynnika postępu technologicznego. Należy podkreślić, że tylko wówczas możemy mówić o postępie technicznym i jego wpływie na rozwój sektora, jeśli spadek cen wyjściowych nie wynika ze spadkowego trendu cen wejściowych (cen czynników produkcji), lecz ze wzrostu produktywności w sektorze.

19 Statistisches Jahrbuch für das Deutsche Reich, Berlin 1911, s. 157.

${ }^{20}$ Statistisches Jahrbuch für den Preussischen Staat, Berlin 1915, s. 245-246. 
W tym celu znany badacz historii gospodarczej, w tym kolei w USA, A. Fishlow oparł swoją analizę sektora kolejowego na zaproponowanym przez J. Kendricka pomiarze postępu technicznego z wykorzystaniem indeksu produktywności czynników produkcji ${ }^{21}$.

Podobnie w przypadku analizy niemieckich kolei R. Fremdling określił całkowitą produkcyjność czynników produkcji w latach 1840-187922.

Określenie indeksu wydajności czynników produkcji TFP jest ilorazem wielkości indeksu wyjść output i ważonego indeksu wejść input. Jednocześnie bardziej nas interesuje wymiar fizyczny, a nie wartościowy dotyczący wydajności czynników produkcji. Stąd też A. Fishlow zaproponował łączony indeks (link-relative form) obliczony dla określonego szeregu czasowego złożonego z dwóch fizycznych wymiarów: przewiezionych towarów wyrażonych w tonokilometrach $(\mathrm{tkm})$ oraz liczby przewiezionych pasażerów wyrażonych w pasażerokilometrach (pkm).

Dla obliczeń indeksu output w latach 1840-1913 autor niniejszej pracy wykorzystał następującą formułę, przyjętą przez A. Fishlowa i R. Fremdlinga:

$$
\begin{aligned}
& \frac{\mathrm{O}_{\mathrm{t}}}{\mathrm{O}_{1913}}=\frac{\mathrm{pkm}_{\mathrm{t}} \frac{\left(\mathrm{P}_{\mathrm{t}}+\mathrm{P}_{\mathrm{t}+1}\right)}{2}+\mathrm{tkm}_{\mathrm{t}} \frac{\left(\mathrm{T}_{\mathrm{t}}+\mathrm{T}_{\mathrm{t}+1}\right)}{2}}{\mathrm{pkm}_{\mathrm{t}+1} \frac{\left(\mathrm{P}_{\mathrm{t}}+\mathrm{P}_{\mathrm{t}+1}\right)}{2}+\mathrm{tkm}_{\mathrm{t}+1} \frac{\left(\mathrm{T}_{\mathrm{t}}+\mathrm{T}_{\mathrm{t}+1}\right)}{2}} \times \\
& \times \frac{\mathrm{pkm}_{\mathrm{t}+1} \frac{\left(\mathrm{P}_{\mathrm{t}+1}+\mathrm{P}_{\mathrm{t}+2}\right)}{2}+\mathrm{tkm}_{\mathrm{t}+1} \frac{\left(\mathrm{T}_{\mathrm{t}+1}+\mathrm{T}_{\mathrm{t}+2}\right)}{2}}{\mathrm{pkm}_{\mathrm{t}+2} \frac{\left(\mathrm{P}_{\mathrm{t}+1}+\mathrm{P}_{\mathrm{t}+2}\right)}{2}+\mathrm{tkm}_{\mathrm{t}+2} \frac{\left(\mathrm{T}_{\mathrm{t}+1}+\mathrm{T}_{\mathrm{t}+2}\right)}{2}} \times \\
& \ldots \times \frac{\mathrm{pkm}_{1912} \frac{\left(\mathrm{P}_{1912}+\mathrm{P}_{1913}\right)}{2}+\mathrm{tkm}_{1913} \frac{\left(\mathrm{T}_{1912}+\mathrm{T}_{1913}\right)}{2}}{\mathrm{pkm}_{1913} \frac{\left(\mathrm{P}_{1912}+\mathrm{P}_{1913}\right)}{2}+\mathrm{tkm}_{1913} \frac{\left(\mathrm{T}_{1912}+\mathrm{T}_{1913)}\right)}{2}} \times 100
\end{aligned}
$$

gdzie:

$\mathrm{P}$ - cena transportu ( $\mathrm{pf} / 1 \mathrm{pkm})$,

$\mathrm{T}$ - cena transportu $(\mathrm{pf} / 1 \mathrm{tkm})$.

$\frac{O_{t}}{O_{I 913}}$ - indeks output (wyjść, produkcji) dla okresu $t$ w porównaniu do $1913 \mathrm{r}$.

Na podstawie równania (19) został określony indeks output, przy założeniu, że dla ostatniego analizowanego roku (1913) indeks wynosi 100. Obliczenie indeksu dla output, input i całkowitej produktywności ułatwi późniejszą analizę i wnioskowanie.

${ }^{21}$ A. Fishlow, Productivity and technological change in the railroad sector, 1840-1910, ,Studies in Income and Wealth" 1966, vol. 30, s. 583-646.

${ }^{22}$ R. Fremdling, op. cit., s. 36-42. 
Indeks output na tle liczby przewozów osobowych (mld pkm) i towarowych (mld tkm) został zobrazowany na rys. 67. Wartość wskaźnika output dla lat 1840 -1913 została wykazana w tab. 37 (aneks).

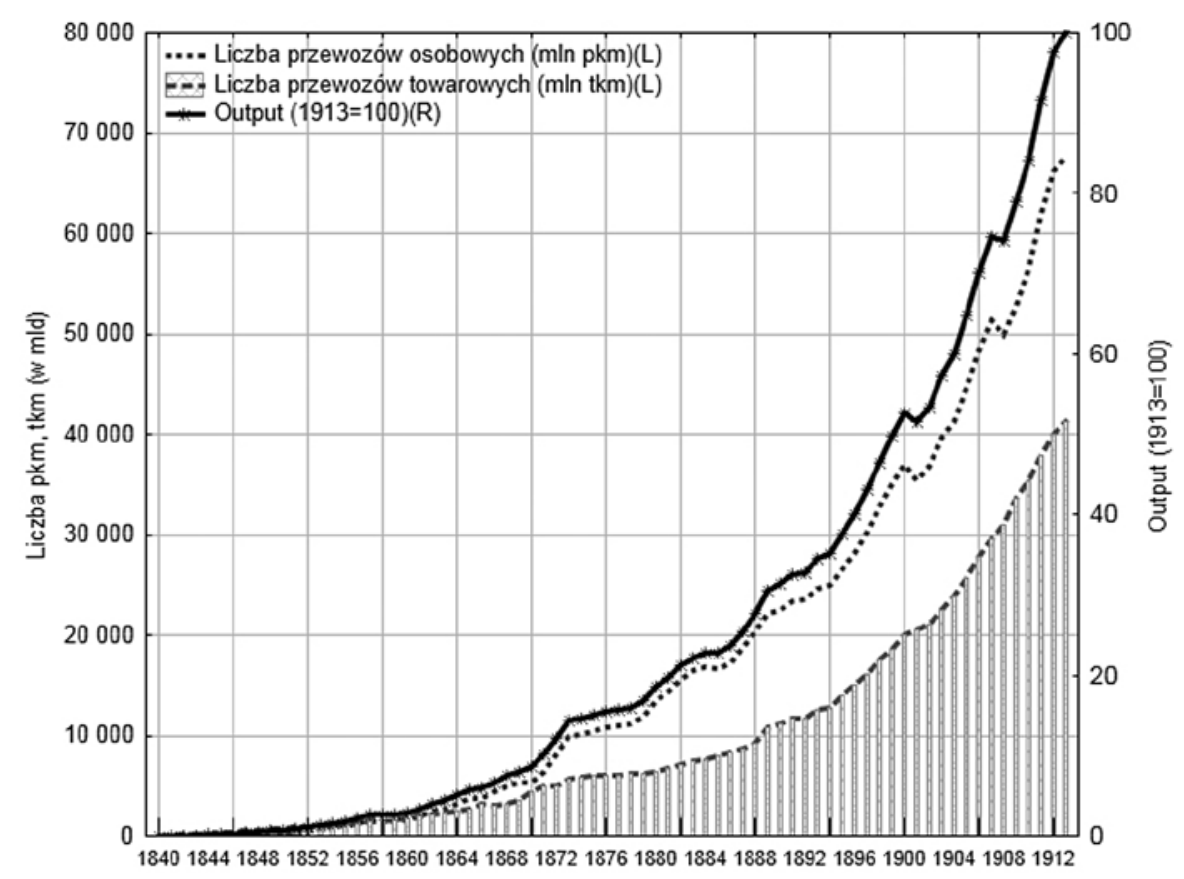

Rys. 67. Indeks output na tle dynamiki przewozów osobowych (pkm) i towarowych (tkm) dla kolei niemieckich (1840-1913)

Źródło: opracowanie własne na podstawie danych z tab.37.

W początkowym stadium rozwoju niemieckich linii kolejowych (1840-1860) wskaźnik output wzrastał stosunkowo szybko - średnio o $22 \%$ w skali roku. Mimo to wskaźnik w stosunku do 1913 r. (100) wyniósł w 1860 r. zaledwie 2,85, a przewozy kolejowe przekroczyły: 1,6 mld tkm i 1,7 mld pkm.

W kolejnym dwudziestoleciu (1861-1880) analizowany wskaźnik wzrastał średnio o 9,02\% rocznie i w 1880 r. indeks osiągnął wielkość 18,60. Przewozy wyrażone w tkm wyniosły 13,5 mld; przewozy pasażerskie blisko $6,5 \mathrm{mld}$ pkm.

W dwudziestoleciu (1881-1900) analizowany wskaźnik wzrastał średnio już tylko o około 5\% rocznie i w 1900 r. indeks output osiągnął wartość niemal 53; przewozy wyrażone $\mathrm{w}$ tkm wyniosły $37 \mathrm{mld}$; natomiast przewozy pasażerskie blisko 20 mld pkm.

W latach 1901-1913 wskaźnik output wzrastał średnio o około 5,7\% rocznie i w 1913 r. indeks output osiągnął wartość 100; przewozy wyrażone w tkm wyniosły $67,7 \mathrm{mld}$; przewozy pasażerskie ponad $41 \mathrm{mld}$ pkm. 
Gdyby analizować okres po nacjonalizacji kolei w Niemczech, czyli po 1880 r. wskaźnik średniego wzrostu rocznego w latach 1880-1913 wyniósłby blisko $5,1 \%$.

Równie interesująca i potwierdzającą szybki wzrost sektora kolejowego jest analiza porównawcza kolejowego indeksu output oraz PKB i PKB per capita, przy założeniu, że poszczególne indeksy przyjmują 100 dla roku bazowego (1913). Graficznie zostało to zobrazowane na rys. 68.

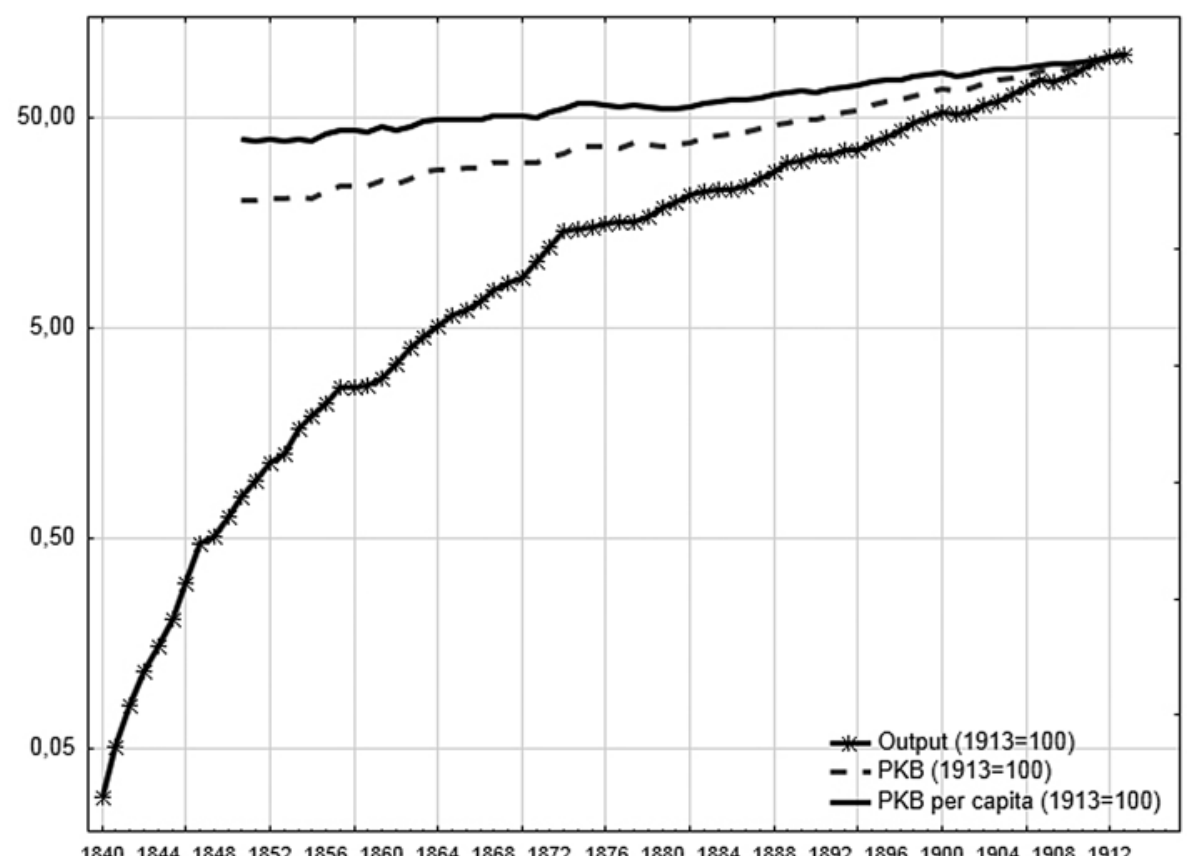

Rys. 68. Indeks output na tle indeksu PKB per capita i PKB $(1913=100)$ skala logarytmiczna

Źródło: opracowanie własne na podstawie danych z tab. 37 oraz obliczeń własnych.

Dość łatwo można wysnuć wniosek, że indeks output w latach 1850-1913 wzrastał stosunkowo szybko w porównaniu do dwóch pozostałych indeksów charakteryzujących sprawność gospodarki, i tak:

- w dziesięcioleciu 1850-1860 średnio indeks output wzrastał o 13,55\%, a w tym czasie indeks PKB notował średni wzrost o 2,15\%, natomiast PKB per capita zaledwie o $1,6 \%$;

- w latach 1861-1900 indeks output wzrastał średnio w tempie 6,35\% rocznie, kiedy indeks PKB wzrastał o blisko 2,5\%, a PKB per capita o 1,5\%;

- w latach 1901-1913, jak wspomniano powyżej indeks output dla sektora kolejowego rósł średnio o 5,7\% w skali roku, PKB o 2,94\%, a PKB per capita o 1,55\%. 
Przytoczona analiza jest pewnym dowodem dla zwolenników, że rzeczywiście sektor kolejowy można uznać za wiodący w warunkach Niemiec, jeszcze w latach siedemdziesiątych XIX w. Późniejsze tempo wzrostu sektora kolejowego było, począwszy od lat osiemdziesiątych XIX w., już relatywnie niewielkie.

Kolejnym krokiem w próbie oszacowania współczynnika całkowitej produktywności było określenie produkcyjności siły roboczej i kapitału. Wyposażenie kapitałowe jest interpretowane jako zasób kapitału w cenach nabycia, a jego zmiany stanowią inwestycje netto w cenach bieżących.

Autor posłużył się zestawieniem kapitału w cenach z 1913 r. oraz w cenach bieżących tudzież w cenach zakupu przedstawionych przez W.G. Hoffmanna, R. Fremdlinga (dla lat 1840-1879) oraz z roczników statystycznych Statistisches Jahrbuch für das Deutsche Reich z lat 1880-1916.

$\mathrm{Z}$ kolei dane statystyczne dotyczące liczby zatrudnionych w sektorze kolejowym zostały wykorzystane z obliczeń R. Fremdlinga (od $1840 \mathrm{r}$.) oraz z roczników statystycznych Statistisches Jahrbuch für das Deutsche Reich za lata 1880$1916^{23}$.

Dla obliczenia wkładu pracy w indeks TFP niezbędne było oszacowanie liczby godzin pracy w trakcie dnia i pomnożenie przez liczbę dni pracy. Te dane również prezentuje R. Fremdling ${ }^{24}$.

Jak zauważa R. Fremdling, nie ma potrzeby, aby dla obliczenia indeksu input liczyć zużycie pośrednie, jak to czynił A. Fishlow ${ }^{25}$. W celu otrzymania zużycia pośredniego należy od wartości obrotów (przychodów całkowitych) w danym roku odjąć znane wartości przychodów z pracy oraz wartości kapitału.

Poniżej przedstawiono indeks całkowitej produktywności, przy założeniu, że rok $1913=100$, obliczony zgodnie $\mathrm{z}$ formułą:

$$
\operatorname{TFP}_{t / 0}=\frac{\frac{O_{t}}{O_{0}} 100}{\frac{w_{0} L_{0}}{P_{0} O_{0}} \frac{L_{t}}{L_{0}}+\frac{i_{0} K_{0}}{P_{0} O_{0}} \frac{K_{t}}{K_{0}}+\frac{r_{0} R_{0}}{P_{0} O_{0}} \frac{R_{t}}{R_{0}}}
$$

gdzie:

TFP - całkowita produkcyjność czynników produkcji,

$O$ - indeks output,

$L, K, R$ - nakłady odpowiednio: praca, kapitał, zużycie pośrednie w okresie bazowym (1913) i analizowanych latach, (input),

$w_{0}, i_{0}, r_{0}$ - cena jednostki pracy, kapitału, zużycia pośredniego dla wejścia

0 i $t$-okres bazowy i odpowiedni okres porównywany.

${ }^{23}$ Statistisches Jahrbuch für das Deutsche Reich, Berlin 1880-1916.

${ }^{24}$ R. Fremdling, op. cit., s. 176.

${ }^{25}$ A. Fishlow dla tych potrzeb szacował zużycie paliwa, Productivity..., s. 618 i n. 
Po przekształceniu wzoru, wartość wejść (input) w cenach dla roku bazowego będzie mieć postać, jak we wzorze (21).

$$
T F P_{t / 0}=\frac{P_{0} O_{t}}{w_{0} L_{t}+i_{0} K_{t}+r_{0} R_{t}}
$$

Jak wskazuje J. Kendrick, powyższy zapis jest miarą technologicznych zmian, gdyż zmiany technologiczne to nic innego, jak to stosunek indeksu cenowego wejść do indeksu wyjść. W przypadku, kiedy spadają relatywne ceny wyjścia w stosunku do cen wejścia występują zmiany i na odwrót.

Jeśli podzielimy powyższe równanie przez $P_{t} O_{t}$ (pamiętając, że $\mathrm{P}_{\mathrm{t}} \mathrm{O}_{\mathrm{t}}=w_{t} L_{t}+$ $i_{t} K_{t}+r_{t} R_{t}$ ) otrzymamy:

$$
T F P_{t / 0}=\frac{\frac{P_{0} O_{t}}{P_{t} O_{t}}}{\frac{w_{0} L_{t}+i_{0} K_{t}+r_{0} R_{t}}{w_{t} L_{t}+i_{t} K_{t}+r_{t} R_{t}}}=\frac{\frac{w_{t} L_{t}+i_{t} K_{t}+r_{t} R_{t}}{w_{0} L_{t}+i_{0} K_{t}+r_{0} R_{t}}}{\frac{P_{t} O_{t}}{P_{0} O_{t}}}
$$

gdzie: licznik jest indeksem wejść (input), a mianownik indeksem wyjść (output).

Aby obliczyć koszt produkcji wyjścia dla roku bazowego (1913) z uwzględnieniem technologii innego $t$ roku (np. 1840) równanie wyrażamy, jako:

$$
C_{0}^{t}=P_{0}^{t} O_{0}=O_{0}\left(w_{0} \frac{L_{t}}{O_{t}}+i_{0} \frac{K_{t}}{O_{t}}+r_{0} \frac{R_{t}}{O_{t}}\right)
$$

oznacza to, że hipotetyczny koszt w wartościach z 1913 r. jest równy wartości wyjścia (output) $\mathrm{O}_{0}$ pomnożonej przez jednostkowe koszty wejścia $\frac{L_{t}}{O_{t}}, \frac{K_{t}}{O_{t}}, \frac{R_{t}}{O_{t}}$ wyrażone w cenach $\mathrm{w}_{0}, \mathrm{i}_{0}, \mathrm{r}_{0} \mathrm{z} 1913 \mathrm{r}$.

Dzieląc obie strony równania przez $P_{t}$ i $O_{0}$ otrzymujemy:

$$
\frac{P_{0}^{t}}{P_{t}}=\frac{w_{0} L_{t}+i_{0} K_{t}+r_{0} R_{t}}{w_{t} L_{t}+i_{t} K_{t}+r_{t} R_{t}}
$$

jak łatwo zauważyć postać powyższą możemy przekształcić do:

$$
\frac{P_{0}}{P_{0}^{t}}=T F P_{t / 0}
$$

Stąd wskaźnik całkowitej produktywności czynników produkcji jest niczym innym, jak stosunkiem rzeczywistej ceny produkcji w roku bazowym (1913) do ceny, która występowała przy braku zmiany współczynnika technologicznego.

$\mathrm{P}_{0}=P_{0}^{t}$, jeśli macierz współczynników technicznych, $\mathrm{L} / \mathrm{O}, \mathrm{K} / \mathrm{O}$ i R/O, pozostaje stała, 
$\mathrm{P}_{0}>P_{0}^{t}$, jeśli technologia w poprzedzającym okresie $t$ jest lepsza,

$\mathrm{P}<P_{0}^{t}$, jeśli technologia $\mathrm{w}$ okresie poprzedzającym $t$ jest gorsza.

W celu oceny usługi stymulatora postępu konieczny jest pomiar cen wyjściowych, które spadły w stosunku do cen nakładów. Jest to typowe, że oprócz spadających cen wyjściowych następuje poprawa jakości oferowanych produktów (usług).

Wyniki obliczeń dla indeksu TFP, output i input dla kolei w Niemieckiego Związku Celnego i Niemiec autor przedstawił na rys. 69.

$\mathrm{Z}$ rysunku jednoznacznie wynika, że w analizowanym okresie wzrasta całkowita produkcyjność, przy znacznym spadku cen frachtu kolejowego, na co już autor zwracał uwagę. Zazwyczaj tempo wzrostu TFP jest określane jako postęp technologiczny, którego nie jesteśmy w stanie wyjaśnić jedynie wzrostem czynników produkcji. Tempo wzrostu całkowitej produktywności czynników produkcji $\left(W_{\text {TFP }}\right)$ jest różnicą między stopą wzrostu produkcji $\left(W_{\mathrm{O}}\right)$ i stopą wzrostu wejść $\left(W_{\text {Inp }}\right)$, gdzie: $W_{\text {TFP }}=W_{\mathrm{O}}-W_{\text {Inp. }}$

Dzięki powyższemu równaniu jesteśmy w stanie określić, w jakim stopniu (procencie) stopa wzrostu produktywności została wywołana w wyniku postępu technicznego.

W początkowej fazie budowy kolei w Niemieckim Związku Celnym i Niemczech w latach 1840-1879 średnio 21\% wzrostu całkowitej produktywności można przypisać postępowi technicznemu. Jak dodaje R. Fremdling w latach 18491873 wskaźnik ten wynosił nawet około $36 \%{ }^{26}$. Z kolei według obliczeń własnych autora, w latach 1874-1880 wskaźnik wzrostu TFP wynosi około 8,9\%, a postępowi technicznemu można przypisać około $26,6 \%$ całkowitego TFP. W latach 1881-1913 średni roczny wskaźnik wzrostu TFP obniżył się do 1,7\%.

Dla przykładu, w produkcji węgla w Zagłębiu Ruhry w latach 1882-1874 Carl-Ludwig Holtfrerich przypisał około $19 \%$ postępowi technicznemu ${ }^{27}$. W produkcji przędzy (1820-1913) Günter Kirchhain oszacował udział postępu technicznego na $57 \%{ }^{28}$.

Spadek cen frachtu na przewozy kolejowe przy jednoczesnym wzroście przychodów z tytułu świadczonych usług był wyrazem dokonujących się innowacji $\mathrm{w}$ analizowanym sektorze.

${ }^{26}$ R. Fremdling, op. cit., s. 41.

27 C. L. Holtfrerich, Quantitative Wirtschaftsgeschichte des Ruhrkohlenbergbaus im 19. Jahrhundert. Eine Führungssektoranalyse, Dortmund 1973, s. 110.

${ }^{28}$ G. Kirchhain, Das Wachstum der deutschen Baumwollidustrie im 19. Jahrhundert. Eine historische Modellstudie zur empirischen Wachstumsforschung, Münster 1973, s. 205. 


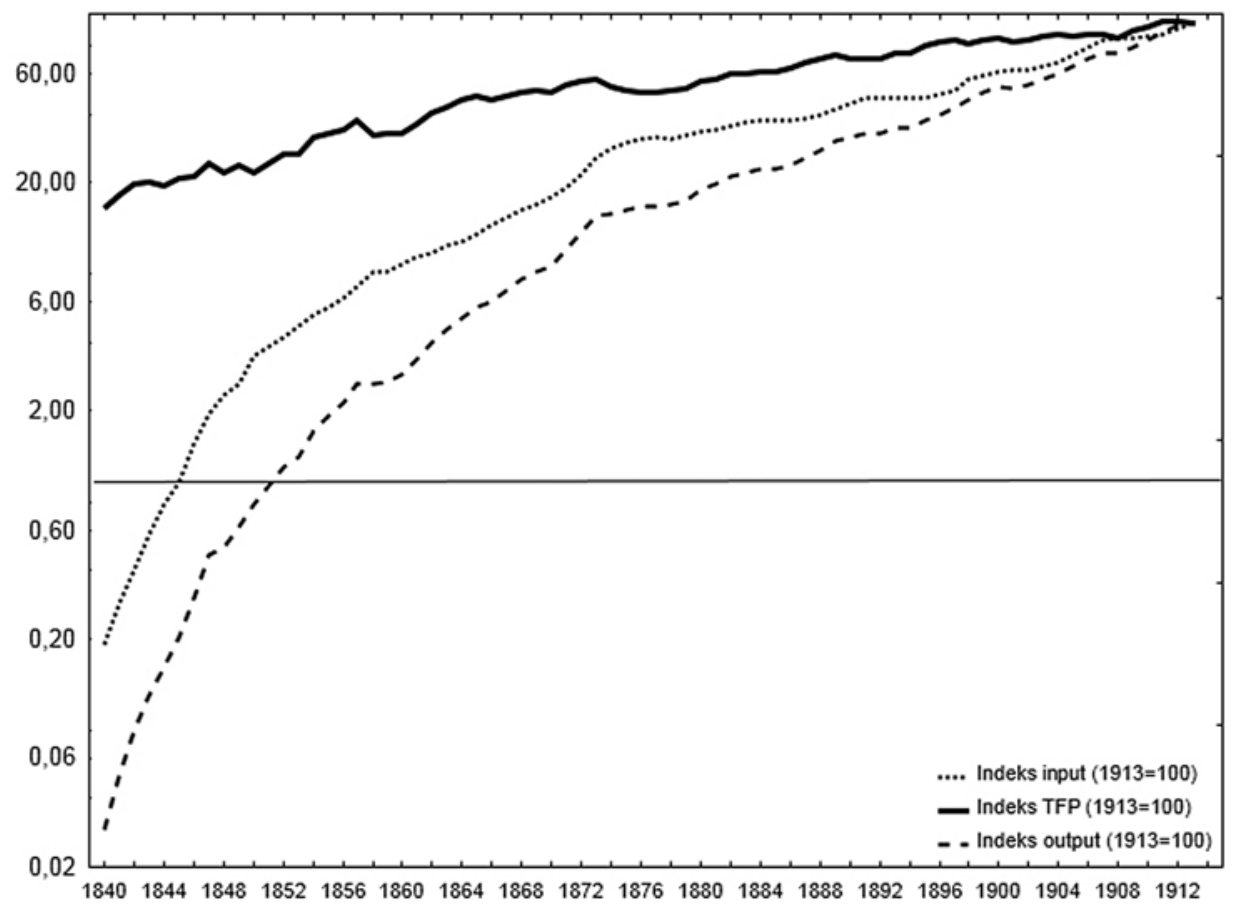

Rys. 69. Indeks całkowitej produkcyjności, output i input dla sektora kolejowego w Niemieckim Związku Celnym i Niemczech $(1840-1913,1913=100)$ skala logarytmiczna.

Źródło: obliczenia własne z wykorzystaniem danych: R. Fremdling, Eisenbahnen und deutsches Wirtschaftswachstum 1840-1879. Ein Beitrag zur Entwicklungstheorie und zur Theorie der Infrastruktur, Dortmund 1985; W.G. Hoffmann, Das Wachstum der deutschen Wirtschaft seit der Mitte des 19. Jahrhunderts, Berlin 1965; Statistisches Jahrbuch für das Deutsche Reich, Berlin 1880-1916.

Z łatwością można zauważyć, że najszybszy wzrost zanotował indeks output - z wartości blisko 0,03 w 1840 r. do wartości 100 dla roku bazowego.

W początkowym stadium rozwoju niemieckich linii kolejowych (1840-1860) wskaźnik input wzrastał średnio o $18,24 \%$ w skali roku, zaś TFP o 3,85\%. W kolejnym dwudziestoleciu (1861-1880) analizowane wskaźniki wzrastały odpowiednio średnio o 7,6\% i 1,41\% rocznie; w dwudziestoleciu (1881-1900) o około 2,82\% i 2,17\%; w latach 1901-1913 wskaźnik input wzrastał średnio o około 4,05\%, a wskaźnik TFP o 1,63\%. Gdyby analizować okres po nacjonalizacji kolei w Niemczech, czyli po 1880 r., wskaźnik średniego wzrostu rocznego w latach 1880-1913 wyniósłby blisko 5,1\% rocznie.

Dla dokonania szczegółowej analizy sektora kolejowego w Niemczech w latach 1840-1913 autor na podstawie własnych obliczeń prezentuje na rys. 70 oraz w tab. 38 (aneks) następujące współczynniki: 
- współczynnik kapitału (K/O),

- intensywność kapitału $(\mathrm{K} / \mathrm{N})$,

- produktywność pracy $(\mathrm{O} / \mathrm{N})$,

- produktywność kapitału $(\mathrm{O} / \mathrm{K})$, gdzie:

K - kapitał zakładowy (mln marek z 1913 r.),

$\mathrm{N}$ - siła robocza (w tys. osób),

O - output (w mln marek z 1913 r.).

Kapitał zaangażowany w koleje obejmuje całą materialną infrastrukturę: sieć kolejową, konstrukcje podziemne i naziemne (mosty, wiadukty, tunele), budynki, a także lokomotywy, park wagonowy itd. Kapitał w początkach 1840 r. wynosił blisko 82 mln marek (w cenach stałych z 1913 r.), w 1913 r. było to niemal 23 mld marek.

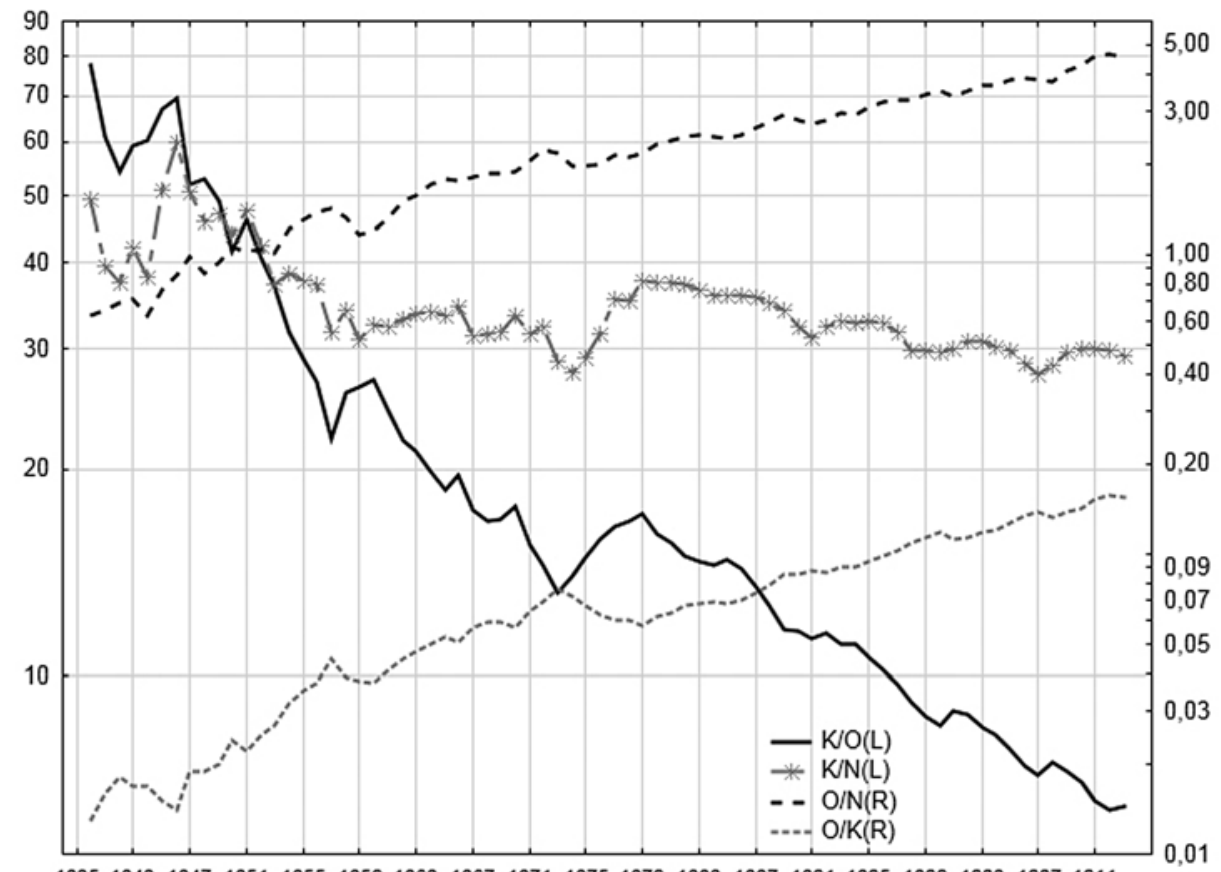

$1835184318471851185518591863 \quad 1867 \quad 1871 \quad 1875 \quad 18791883 \quad 1887 \quad 189118951899190319071911$

Rys. 70. Współczynnik kapitału, intensywność kapitału, produktywność pracy, produktywność kapitału - koleje niemieckie (w cenach z 1913 r.)

Źródło: obliczenia własne.

Od początków rozwoju kolei w Niemczech zatrudnienie w tym sektorze wzrosło z 1,6 tys. osób w 1840 r. do 85,6 tys. osób w 1860, co oznaczało średni wzrost roczny o ponad $18 \%$. W $1864 \mathrm{r}$. liczba zatrudnionych przekroczyła 
101 tys. osób, a w 1879 r. powiększyła się do blisko 270 tys. osób (1,4\% ogółu zatrudnionych), a średnie tempo roczne przyrostu zatrudnienia w kolejnictwie wyniosło $6,89 \%$.

W 1900 r. zatrudnienie przekroczyło 520 tys. osób (blisko 2,1\% ogółu zatrudnionych), ale średnie tempo wzrostu liczby zatrudnionych w latach 1881-1900 wyniosło tylko 3,05\%.W $1913 \mathrm{r}$. w kolejnictwie zatrudnienie znalazło prawie 783 tys. osób (2,53\% ogółu zatrudnionych), a średnie tempo wzrostu zatrudnienia w skali roku w latach 1901-1913 wyniosło 3,57\%.

W okresie 1835-1913 zmiany poszczególnych współczynników przedstawiały się następująco:

1) współczynnik kapitału w latach 1840-1879 zmniejszał się w średnim rocznym tempie o 4,44\%, w latach 1880-1913 spadek ten był niższy i wyniósł rocznie $2,85 \%$. Oczywiście świadczy to o tym, że przyrosty kapitału były zdecydowanie niższe od przyrostu produkcji sektora. Świadczyć to może o większej wydajności zaangażowanego kapitału. Jest to w przypadku kolejnictwa pewna prawidłowość, gdyż należy zaangażować znaczny kapitał; w przypadku budowy kolejnych szlaków i wzroście liczby przewiezionych tkm i pkm na 1 km linii kolejowych wskaźnik K/O maleje;

2) wskaźnik intensywności kapitału K/N w latach 1840-1879 malał w średnim rocznym tempie o 1,14\%, w latach 1880-1913 spadek ten wyniósł w skali roku $0,08 \%$. Początkowo wskaźnik przyjmował wartość 50 i 59. Natomiast począwszy od lat pięćdziesiątych XIX w. nie przekroczył progu 40, natomiast w początkach XX w. wskaźnik obniżył się do 30;

3) wskaźnik produktywności pracy $\mathrm{O} / \mathrm{N}$, w latach 1840-1879 wzrastał w średnim rocznym tempie o 3,31\%, w latach 1880-1913 rocznie o 2,02\%. Zakładając, że średnio współczynnik produktywność pracy wynosił w początkach lat czterdziestych XIX w. 0,63, to w 1895 r. przekroczył wartość 3, w 1910 r. wartość 4, aby w 1913 r. zbliżyć się do 3,5;

4) wskaźnik produktywności kapitału O/K, w latach 1840-1879 wzrastał w średnim rocznym tempie o $4,45 \%$, w latach $1880-1913$ rocznie o $2,85 \%$. W początkach lat czterdziestych XIX w. produkcja output w stosunku do wartości zaangażowanego kapitału wynosiła $1,3 \%$, ale już w 1852 r. wzrosła do poziomu $2,6 \%$, w 1864 r. osiągnęła poziom 5\%, a przed 1878 r. wskaźnik ten oscylował wokół 6\% i przekroczył 10\% jeszcze w końcu XIX w. W 1913 r. wyniósł blisko 15,5\%.

Biorąc $\mathrm{z}$ kolei pod uwagę kształtowanie się kapitału zakładowego i produkcji sektora w mln marek z 1913 r. zauważymy, że:

1) - kapitał zakładowy w latach 1840-1879, czyli do czasu masowej nacjonalizacji kolei rósł w średnim rocznym tempie $10,41 \%$, po nacjonalizacji, w latach 1880-1913 już zaledwie o 2,22\%, osiągając wartość w 1913 r. 22,9 mld marek,

2) - produkcja output wzrastała w latach 1840-1879 o 14,46\%, a w okresie 1880-1913 w tempie 5,07\%, osiągając w $1913 \mathrm{r}$. wartość ponad 3,5 mld marek. 
Zauważalny jest wzrost produkcji w stosunku do wartości kapitału zakładowego - mimo spadku cen przewozów kolejowych, co może świadczyć o dokonującym się postępie i wzroście wydajności zaangażowanych czynników produkcji.

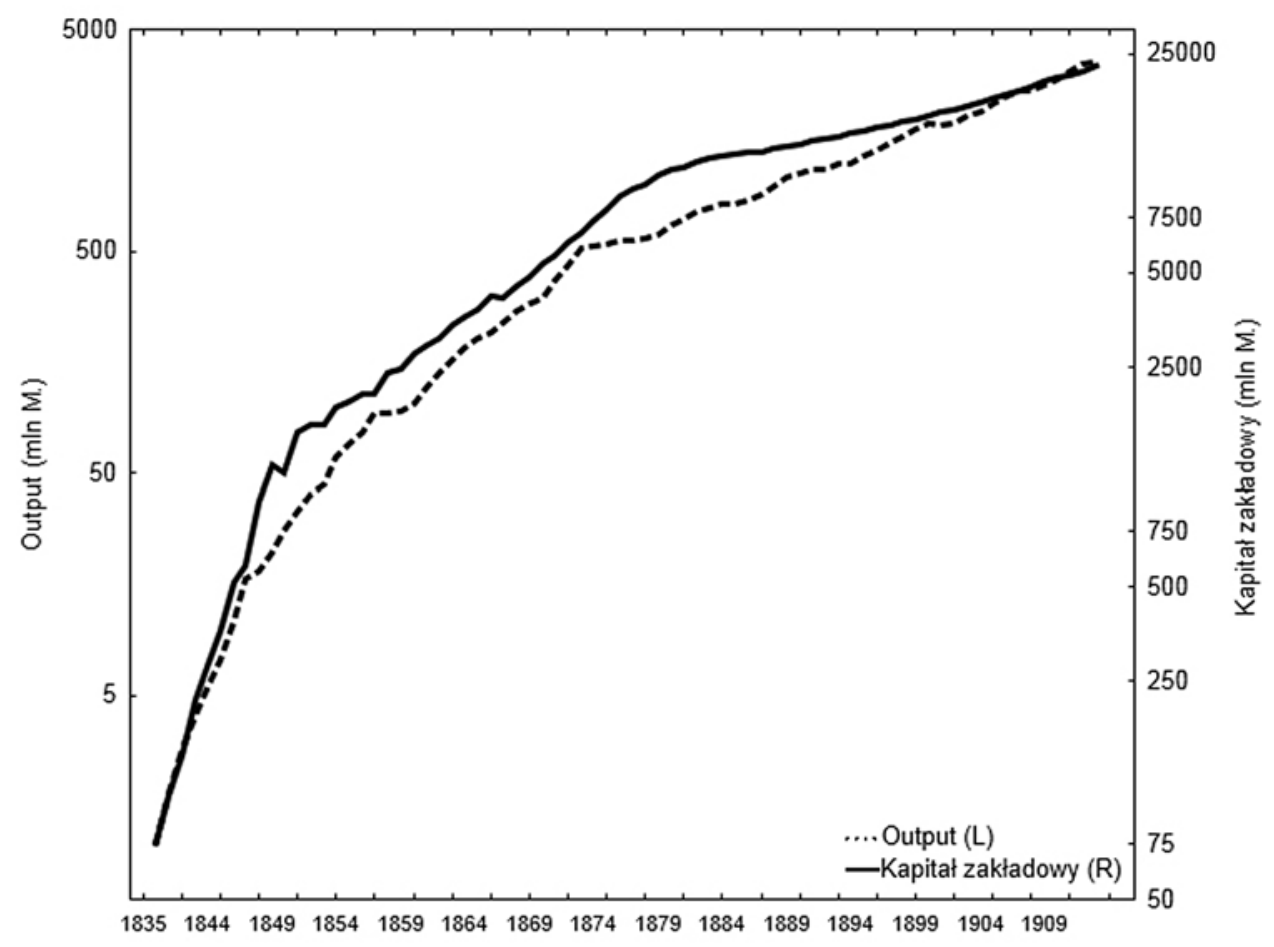

Rys. 71. Output i kapitał zakładowy dla kolei w Niemczech (1835-1913, w cenach stałych z 1913 r.).

Źródło: obliczenia własne (output), R. Fremdling, Eisenbahnen und deutsches Wirtschaftswachstum 1840-1879. Ein Beitrag zur Entwicklungstheorie und zur Theorie der Infrastruktur, Dortmund 1985; Statistisches Jahrbuch für das Deutsche Reich, Berlin 1871-1916.

Zauważalna jest także silna korelacja pomiędzy wartością kapitału zakładowego a poziomem produkcji - współczynnik korelacji $r$ Pearsona wyniósł 0,94. 


\section{WYKORZYSTANIE MODELOWANIA EKONOMETRYCZNEGO W OCENIE WPLYWU KOLEI ŻELAZNYCH I INNYCH CZYNNIKÓW NA WZROST PKB}

Autor, budując model ekonometryczny dotyczący oceny wpływu kolei żelaznych na wzrost gospodarczy, zastosował klasyfikację czynników na gospodarcze (ekonomiczne, makroekonomiczne, instytucjonalne) oraz z otoczenia gospodarki (demograficzne, społeczne, geograficzne i środowiskowe, infrastrukturalne). Posłużono się danymi statystycznymi dotyczącymi PKB oraz PKB per capita zaczerpniętymi m.in. z prac Waltera Hoffmanna, Angusa Maddisona, Briana Mitchella $^{29}$. W celu wyeliminowania wzrostu cen przyjęto obie powyższe miary w cenach stałych z 1913 r. (niemiecka marka). Ponadto obliczono wskaźnik wzrostu PKB i PKB per capita zakładając, że rokiem bazowym był $1913 \mathrm{r}$.

Produkt Krajowy Brutto per capita jest jednym z podstawowych mierników wzrostu gospodarczego, stąd też głównym celem w tym rozdziale jest określenie przyczyn jego wzrostu w warunkach XIX w. z uwzględnieniem założonej hipotezy badawczej oraz przyjętych celów szczegółowych. PKB per capita jest zmienną endogeniczną (objaśnianą).

Jak argumentowano $\mathrm{w}$ poprzednich rozdziałach obok postępu $\mathrm{w}$ rolnictwie, rozwoju przemysłu, zmiany struktury gospodarki charakterystyczne dla okresu XIX w. stało się krzewienie kultury i oświaty - wzrost liczby uczniów i studentów, rozwój instytucji, tożsamości narodowych, tak widoczny w przypadku Niemiec. $\mathrm{Z}$ drugiej strony swobodny przepływ ludzi, towarów, w połączeniu z radykalną poprawą transportu i urządzeń komunikacyjnych, jako źródeł innowacji, wpływał na zbieżność gospodarek krajowych. Zauważalna w warunkach Niemiec jest także zmiana polityki handlowej i celnej oraz podkreślana przez wielu ekonomistów i historyków gospodarczych rola przemysłu ciężkiego (w tym: górnictwa i hutnictwa).

James Foreman-Peck podkreśla, że procesowi rozwoju gospodarczego sprzyjały także: przyjęty przez większość państw standard waluty złotej, klauzula największego uprzywilejowania w przypadku wymiany handlowej ${ }^{30}$, rozwój obok szlaków kolejowych, żeglugi śródlądowej, transportu morskiego, zastosowanie wynalazków np. telegrafu itd. Przyspieszało to szybką dyfuzję rozwoju gospodarczego w poszczególnych krajach europejskich ${ }^{31}$. Wymienione czynniki, jak

29 W.G. Hoffmann, op. cit.; A. Maddison, Historical Statistics for the World Economy: 1-2003 AD, www.saisjhu.edu/library/subjectguides/stats.htm [dostęp 02.11.2010]; A. Maddison, The World Economy, Paris 2006; B.R. Mitchel, International Historical Statistics: Europe, 1750-2000, London 2003.

${ }^{30}$ Dotyczy to oczywiście okresu wolnej wymiany handlowej w latach sześćdziesiątych i siedemdziesiątych XIX w. W przypadku Niemiec polityka taka została utrzymana do końca lat siedemdziesiątych XIX w.

31 J. Foreman-Peck, A Model of Later Nineteenth Century European Economic Development, „Revista de Historia Económica” 1995, Second Series, vol. 13(03), s. 441-471. 
dowodzi J. Foreman-Peck są warunkami wstępnymi dla rozwoju modelowania w warunkach XIX w.

Wracając do postępu technologicznego, przyjmuje się, że nowa technologia może być zaimplementowana, jeżeli w gospodarce dostępne są zasoby kapitału. Stąd modele wzrostu powstałe w latach pięćdziesiątych i sześćdziesiątych XX w. pozostawiały centralne miejsce w rozwoju gospodarczym akumulacji kapitału, stopie oszczędności oraz ich wzajemnych zależnościach w określeniu długookresowych ścieżek wzrostu.

J. Foreman-Peck dowodzi, że akumulacja kapitału w przypadku Wielkiej Brytanii została wymuszona nie przez sferę produkcji, lecz przez konieczność rozwoju infrastruktury, w szczególności kolei ${ }^{32}$. W warunkach Niemiec, jak analizowano wcześniej, w końcu lat siedemdziesiątych XIX w. inwestycje netto w koleje wyniosły $25,5 \%$ ogółu inwestycji, a zaangażowany kapitał w kolejnictwie w tym samym czasie wynosił 11,4\% ogółu kapitału w gospodarce (rys. 64).

Jak słusznie zauważa J. Foreman-Peck, mimo powstania wielu modeli, za pomocą, których istnieje możliwość testowania czynników wpływających na wzrost i rozwój gospodarczy, to jednak użycie takich modeli w warunkach XIX w. jest często ograniczone. Zgodnie z teorią ekonomii trzema najważniejszymi wyznacznikami ścieżki długookresowego wzrostu produkcji są: siła robocza, kapitał, technologia.

Autor zaproponował użycie dwóch modeli ekonometrycznych:

- model poziomu PKB per capita i czynników wpływających na wzrost tej miary,

- model dynamiki PKB per capita i czynników wpływających.

W zaproponowanych modelach PKB per capita jest zmienną endogeniczną (objaśnianą), pozostałe są zmiennymi objaśniającymi. Wszystkie zmienne wyrażone w postaci pieniężnej zostały wyrażone w cenach stałych (z 1913 r.). Użycie cen stałych pozwoliło wyeliminować wpływ inflacji (zmian cen) na pomiar określonych zmiennych dla analizowanego szeregu czasowego 1850-1913. Ceny realne obliczono korzystając z indeksów cen (deflatorów), zawartych w pracy Alfreda Jacobsa i Hansa Richtera: Die Großhandelspreise in Deutschland von 1792 bis $1934^{33}$.

$\mathrm{Z}$ ponad 140 zmiennych statystycznych opisujących gospodarkę niemiecką dla szeregu czasowego 1850-1913 zostało przypisanych do wspomnianych grup czynników, z których autor pozostawił kilka zmiennych objaśniających. Wybierając we wstępnym etapie zmienne objaśniające zmienną endogeniczną autor kierował się ustaleniami przyjętymi w poprzednich rozdziałach niniejszej pracy, w tym określeniem roli sektora kolejowego w generowaniu poziomu PKB per capita.

32 S. Pollard, S., Peaceful Conquest: The Industrialization of Europe 1760-1970, Oxford 1981.

33 A. Jacobs, H. Richter, Die Großhandelspreise in Deutschland von 1792 bis 1934, HamburgBerlin 1935. 
Oto uzasadnienie poszczególnych zmiennych:

- długość szlaków kolejowych (w km) - zmienna ma związek z tematem niniejszej rozprawy, jednocześnie traktowana jest jako kapitał (fizyczny) rzeczowy, w stosunku do którego można założyć, że jest wyrazem innowacyjności i przykładem dokonującego się postępu technicznego, w warunkach XIX w. ${ }^{34}$;

- stopa inwestycji - wyrażona w ujęciu pieniężnym, w cenach stałych. Na poziom inwestycji wpływa (ceteris paribus) wysokość stopy procentowej. Zgodnie z założeniami ekonomicznymi inwestycje mają zasadniczy wpływ na rozwój, rozbudowę i utrzymanie kapitału rzeczowego. W modelu wzięto pod uwagę poziom inwestycji w stosunku do osiągniętego PKB;

- emigracja - jak określono w rozdziale III, podstawową przyczyną procesów emigracyjnych były względy ekonomiczne. Do lat sześćdziesiątych XIX w. niemiecka emigracja była szczególnie nasilona w południowych krajach (Wirtembergia, Badenia, Palatynat). Małe karłowate gospodarstwa rolne, w tym niewystarczająca podaż ziemi i kapitału, skłaniały do poszukiwania innych, lepszych warunków życia. Ponadto procesy emigracyjne nasilały się w czasie kryzysów ekonomicznych. Uznano także, że ten czynnik mógł mieć wpływ na późniejsze spowolnienie tempa wzrostu gospodarczego. Można założyć, że emigranci przenosili cały kapitał ludzki, natomiast $\mathrm{z}$ reguły pozostawiali kapitał rzeczowy, co było mało korzystne dla kraju, który emigranci opuszczali. Zmienną obliczono jako odsetek w stosunku do liczby zatrudnionych w gospodarce narodowej;

- odsetek uczniów i studentów w stosunku do liczby zatrudnionych - unaoczniał rozwój kapitału ludzkiego. Burton Weisbrod już w latach sześćdziesiątych XX w. pisał w swej pracy, że wzrostu gospodarczego nie należy wiązać jedynie ze zmianami dotyczącymi kapitału rzeczowego, ale także zmianami dotyczącymi siły roboczej. Inwestowanie w ludzi umożliwia bowiem wykorzystanie postępu technicznego i jego dalszy rozwój. Inwestowanie w edukację rozszerza wiedzę, co prowadzi do wzrostu produktywności i dalszego postępu, np. medycyny. Do wzrostu gospodarczego przyczynia się, więc zarówno inwestowanie w kapitał fizyczny, jak i w kapitał ludzki, do którego B. Weisbrod, podobnie jak Theodore Schultz, zaliczał przede wszystkim zdrowie i szkolnictwo ${ }^{35}$. Walka z analfabetyzmem i rozwój szkolnictwa wyższego, w tym politechnicznego, w Niemczech były w ocenie autora ważnym czynnikiem determinującym budowę nowoczesnego społeczeństwa;

${ }^{34}$ M. Mata, J. Love, A Reversal in the Historical Role of Tariffs in Economic Growth? The Cases of Brazil and Portugal, Est. econ., São Paulo 2008, vol. 38, no. 3, s. 461-492.

${ }_{35}$ B. Weisbrod, Education and Investment in Human Capital, ,Journal of Political Economy” 1962, no. 70, s. 106-123, cyt.: „With a rapid pace of technological change, adaptability (which may be a noteworthy out- put of additional education) becomes important" [Wraz z szybkim tempem zmian technologicznych zdolności adaptacyjne (w kontekście wartości dodanej edukcji) należy postrzegać, jako istotny czynnik]; T. Schultz, Investment in Human Capital, „The American Economic Review” 1961, vol. 51, no. 1. 
- postęp w rolnictwie przejawiający się wzrostem wydajności pracy, wprowadzeniem maszyn, nawozów mineralnych, nowoczesnego płodozmianu itd. skutkujący „odpływem” części siły roboczej do innych działów gospodarki narodowej (przemysł, usługi). Stąd uwzględniono zmienną - odsetek zatrudnionych w rolnictwie w porównaniu do całkowitej liczby zatrudnionych w gospodarce narodowej.

Siłę roboczą tworzy tylko część ludności, a ponadto w warunkach XIX w. istotnym wyznacznikiem było przemieszczanie ludności z pierwszego sektora gospodarki do sektora przemysłowego i sektora usług. Obok liczby aktywnych zawodowo siła robocza jest w ujęciu szerszym zwana kapitałem ludzkim. Jak zauważa David Begg, wzrost poziomu wykształcenia, podnoszenie kwalifikacji, nabywanie doświadczenia pozwalają zatrudnionym zwiększać produkcję przy danym zasobie kapitału rzeczowego.

W modelu dynamiki spośród powyższych zmiennych uwzględniono odpowiednio dynamikę: przyrostu PKB per capita, długości linii kolejowych, inwestycji, zatrudnienia $\mathrm{w}$ rolnictwie.

Wykorzystano następującą postać modelu ekonometrycznego:

$$
Y_{\mathrm{PKB} 1850-1913}=\beta_{0}+\beta_{1} x_{t 1}+\beta_{2} x_{t 2}+\beta_{3} x_{t 3}+\beta_{4} x_{t 4}+\beta_{5} x_{t 5}+\beta_{n} x_{t n}+\varepsilon
$$

gdzie:

$Y_{\text {PKB1850-1913 }}$ - poziom PKB per capita Niemiec w latach 1850-1913 (w markach, w cenach z 1913 r.), lub dynamika PKB per capita ${ }^{36}$,

$x_{t 1}-x_{t n}-$ wybrane zmienne objaśniające charakteryzujące gospodarkę Niemiec, opisane pod określonym równaniem,

$\beta_{0}-\beta_{n}$ - parametry strukturalne,

$\varepsilon-$ składnik losowy.

Konstruując postać funkcyjną modelu ekonometrycznego oprócz faktu, że najczęściej konstruuje się modele liniowe oraz zapis funkcyjny, dla którego istnieje możliwość ekonomicznej interpretacji parametrów modelu, autor nawiązał do przedstawionej w pracy funkcji produkcji Cobba-Douglasa.

Wobec faktu, że funkcja ma postać funkcji potęgowej, aby sprowadzić ją do postaci liniowej stosuje się logarytmowanie stronami. Jeśli przyjąć, że użyto w modelu dla $x$ zmiennych objaśniających funkcja przybierze postać ogólną:

$$
\ln Y_{\text {PKB1850-1913 }}=\ln \beta_{0}+\beta_{1} \ln \mathrm{x}_{t 1}+\beta_{2} \ln \mathrm{x}_{t 2}+\beta_{3} \ln \mathrm{x}_{t 3}+\beta_{4} \ln \mathrm{x}_{t 4}+\beta_{5} \ln \mathrm{x}_{t 5}+\beta_{n} \ln \mathrm{x}_{t n}+\varepsilon
$$

Po przekształceniu parametry strukturalne $\beta_{1}-\beta_{n}$ określają elastyczność PKB per capita względem zmiennych objaśniających, które oznaczają względną zmia-

${ }^{36}$ W zależności od modelu - pierwszy model - model poziomu PKB per capita, drugi-model dynamiki PKB per capita. 
nę wielkości PKB per capita (w \%) spowodowaną względną zmianą tylko jednego z wyróżnionych czynników o $1 \%$, przy ustalonym poziomie pozostałych czynników (ceteris paribus).

$\mathrm{W}$ modelach ekonometrycznych opartych na szeregach czasowych często wykorzystuje się zmienne opóźnione o $p$ lub $n$ okresów. Stąd oznaczenie $(t-n)-$ oznacza opóźnienie czasowe, gdzie $n$ oznacza liczbę okresów (lat). Głównym celem użycia zmiennych opóźnionych było wyeliminowanie endogeniczności zmiennych objaśniających.

Po określeniu specyfikacji modelu i zebraniu informacji statystycznych z zakładanego szeregu czasowego obok doboru zmiennych objaśnianych na podstawie własnej wiedzy ekonomicznej i ogólnej analizy statystycznej dokonano oceny wybranych w pierwszym etapie zmiennych, wykorzystując statystykę opisową zmiennych kandydatek. W tym celu utworzył macierz $\mathbf{X}=\left[\mathrm{x}_{\mathrm{tj}}\right]$ i wektory $\mathbf{y}=\left[\mathrm{y}_{\mathrm{i}}\right]$ zawierające dane statystyczne. Obserwacje $x_{t j}(t=1,2, \ldots n ; j=1,2 \ldots k)$ były realizacjami potencjalnych zmiennych objaśniających, a $y_{i}$-zmiennej objaśnianej. Określono zmienność dla wybranych danych statystycznych. W tym celu obliczono współczynnik zmienności, zgodnie z wzorem:

$$
V_{j}=\frac{S_{j}}{\bar{X}_{j}}
$$

gdzie:

$V_{j}$ - współczynnik zmienności,

$\bar{X}_{j}=\frac{1}{N} \sum_{n=1}^{N} x_{j n}-$ średnia arytmetyczna $j$-tej zmiennej objaśniającej,

$S_{j}=\sqrt{\frac{1}{N} \sum_{n=1}^{N}\left(x_{j n}-\bar{x}_{j}\right)^{2}}-$ odchylenie standardowe $j$-tej zmiennej objaśniającej.

Założono, że z pierwotnego zbioru zmiennych objaśniających zostaną usunięte zmienne, dla których $V_{j}<0,1^{37}$.

\section{Model poziomu PKB per capita}

$\mathrm{W}$ zastosowanym modelu przedstawiono czynniki mające, $\mathrm{w}$ ocenie autora, wpływ na poziom PKB per capita krajów niemieckich, zrzeszonych w Niemieckim Związku Celnym i Niemczech w latach 1850-1913.

Poziom PKB per capita w latach 1850-1913 w cenach stałych (z 1913 r.) dla gospodarki niemieckiej został przedstawiony w rozdziale III (rys. 52, 53). Szerzej również opisano PKB, PKB per capita, PNN (rozdz. III, podrozdz. 6).

${ }^{37}$ D. Witkowska, Podstawy ekonometrii i teorii prognozowania, Kraków 2005, s. 30 i n. 
Podsumowując, PKB per capita wyrażony w cenach z 1913 r. wzrósł z 312 marek w 1850 r. do 783 marek w 1913 r. Średnioroczny wzrost w tym okresie wyniósł blisko 1,5\%. Zauważalny jest nierównomierny wzrost PKB per capita, dość powolny wzrost $\mathrm{w}$ latach pięćdziesiątych XIX w. (średnio 1,2\%), bardzo szybki wzrost w połowie latach siedemdziesiątych XIX w. (nawet o 14,5\% rocznie), zakończony silnym spadkiem w końcu lat siedemdziesiątych XIX w. Trend spadkowy w końcu lat siedemdziesiątych i początku lat osiemdziesiątych XIX w. ('średnio spadek $-2,46 \%$ rocznie). Stopniowy wzrost PKB per capita w latach 1883-1913 - średnio o 1,63\% rocznie.

Biorąc pod uwagę założoną hipotezę badawczą oraz cele szczegółowe autor, budując model poziomu PKB per capita, skoncentrował się na:

- określeniu wpływu rozwoju kolejnictwa na poziom wzrostu gospodarczego, biorąc pod uwagę długość linii kolejowych, wyrażoną w km. Jak wspomniano zmienna ta w warunkach XIX w., utożsamiana jest $\mathrm{z}$ kapitałem fizycznym;

- zbadaniu wpływu innych zmiennych wpływających na poziom PKB per capita, w tym: poziomu inwestycji, stopnia emigracji, odsetka uczniów i studentów, odsetka zatrudnienia w rolnictwie.

$\mathrm{W}$ tab. 31 zostały przedstawione miary wymienione powyżej.

Tabela 31. Wartości współczynnika zmienności oraz innych statystyk opisowych dla analizowanych zmiennych objaśniających

\begin{tabular}{|l|c|c|c|c|c|c|c|}
\hline \multicolumn{1}{|c|}{ Zmienna } & $\mathrm{N}$ & Średnia & Mediana & Min. & Maks. & $\mathrm{Sj}$ & $V_{j}$ \\
\hline Długość linii $(\mathrm{km})(t-1)$ & 64 & 31721,6 & 34110 & 5443 & 60521 & 17715,1 & 0,56 \\
\hline $\begin{array}{l}\text { Poziom inwestycji } \\
(\% \text { PKB) }(t-1)\end{array}$ & 64 & 10,27 & 10,45 & 1,121 & 16,89 & 3,43 & 0,33 \\
\hline $\begin{array}{l}\text { Poziom emigracji } \\
(\% \text { zatrudnionych) }(t-1)\end{array}$ & 64 & 0,41 & 0,37 & 0,061 & 1,58 & 0,33 & 0,78 \\
\hline $\begin{array}{l}\text { Poziom uczniów } \\
\text { studentów } \\
(\% \text { zatrudnionych) }(t-3)\end{array}$ & 64 & 30,60 & 32,44 & 24,482 & 34,60 & 3,55 & 0,12 \\
\hline $\begin{array}{l}\text { Poziom zatrudnienia rol- } \\
\text { nictwo (\% zatrudnionych) }\end{array}$ & 64 & 46,41 & 48,69 & 34,905 & 56,02 & 6,58 & 0,14 \\
\hline
\end{tabular}

Źródło: opracowanie własne (dotyczy tab. 31-36).

Najmniejszą zmiennością $(0,12)$ charakteryzowała się zmienna (\% liczby uczniów i studentów, jako \% zatrudnienia w gospodarce). Mimo niskiej wartości współczynnik zmienności przekracza swoją wartością założoną wartość graniczną $V_{j}$, więc zmienna nie została wyeliminowana. 
W kolejnym etapie wyznaczono współczynniki korelacji $r$ Pearsona między rozpatrywanymi zmiennymi objaśniającymi, a zmienną objaśnianą. Jednocześnie założono, że wartość krytyczna korelacji wyznaczona została ze wzoru:

$$
r^{*}=\sqrt{\frac{t_{\alpha, N-2}^{2}}{N-2+t_{\alpha, N-2}^{2}}} \approx 0,246
$$

gdzie:

$t_{\alpha, N-2}^{2}$ - wartość statystyki odczytana $\mathrm{z}$ tablic rozkładu $t$-Studenta dla poziomu istotności $0,05 \mathrm{i}(N-2)$ stopni swobody.

Ze zbioru należało, zatem usunąć zmienne, które nie są istotnie skorelowane ze zmienną endogeniczną zgodnie z zapisem:

$$
|r| \leq r^{*}
$$

W tab. 32 przedstawiono wartości współczynnika korelacji $r$ Pearsona

Tabela 32. Wartości współczynnika korelacji $r$ Pearsona pomiędzy zmiennymi objaśnianymi a zmienną endogeniczną

\begin{tabular}{|l|c|}
\hline \multicolumn{1}{|c|}{ Zmienna objaśniająca } & $\begin{array}{c}\text { Współczynnik. korelacji ze zmienną } \\
\text { endogeniczną }\end{array}$ \\
\hline Długość linii kolejowych $(\mathrm{km})(t-1)$ & 0,975 \\
\hline Poziom inwestycji (\% PKB) $(t-1)$ & 0,572 \\
\hline Poziom emigracji (\% zatrudnionych) $(t-1)$ & $-0,625$ \\
\hline Poziom uczniów studentów (\% zatrudnionych) $(t-3)$ & 0,860 \\
\hline Poziom zatrudnienia rolnictwo (\% zatrudnionych) & $-0,984$ \\
\hline
\end{tabular}

Wszystkie zmienne objaśniające okazały się istotnie skorelowane ze zmienną objaśnianą. Najniższą wartością bezwzględną współczynnika korelacji r Pearsona cechowała się zmienna poziom inwestycji $(\% \mathrm{PKB})-(t-1)-(0,572)$ oraz zmienna poziom emigracji (\% zatrudnionych) $(t-1)-(-0,625)$. Obie te zmienne przekroczyły zakładaną granicę $|0,246|$. Zmienna „kolejowa”, czyli długość linii $(\mathrm{km})(t-1)$ charakteryzowała się najwyższym współczynnikiem korelacji $r$ Pearsona $|0,975|$.

W kolejnym etapie oszacowano współczynniki korelacji $r$ Pearsona pomiędzy wszystkimi zmiennymi. Zgodnie z warunkami doboru zmiennych objaśniających do modelu istotne było, aby zmienne nie były silnie skorelowane względem siebie (tab. 33). 
Wobec otrzymanych wyników zadecydowano, że wszystkie zmienne kandydatki zostały zakwalifikowane do estymacji przyjętego modelu.

Tabela 33. Wartości współczynnika korelacji $r$ Pearsona pomiędzy zmiennymi objaśnianymi a zmienną endogeniczną

\begin{tabular}{|c|c|c|c|c|c|c|}
\hline \multirow[b]{2}{*}{ Zmienna } & \multirow[b]{2}{*}{$\begin{array}{c}\text { PKB } \\
\text { per capita } \\
\text { (marki) }\end{array}$} & \multirow[b]{2}{*}{$\begin{array}{l}\text { Długość } \\
\text { linii } \\
(\mathrm{km}) \\
(\mathrm{t}-1)\end{array}$} & \multicolumn{4}{|c|}{ Poziom } \\
\hline & & & $\begin{array}{c}\text { inwestycji } \\
(\% \mathrm{PKB}) \\
(t-1)\end{array}$ & $\begin{array}{l}\text { emigracji } \\
\text { (\% zatrud- } \\
\text { nionych) } \\
(t-1)\end{array}$ & $\begin{array}{c}\text { uczniów } \\
\text { i studen- } \\
\text { tów } \\
\text { (\% zatrud- } \\
\text { nionych) } \\
(t-3) \\
\end{array}$ & $\begin{array}{l}\text { zatrudnie- } \\
\text { nia rolnic- } \\
\text { two } \\
\text { (\% zatrud- } \\
\text { nionych) }\end{array}$ \\
\hline PKB per capita (marki) & 1,000 & 0,975 & 0,572 & $-0,625$ & 0,860 & $-0,984$ \\
\hline $\begin{array}{l}\text { Długość linii } \\
\text { kolejowych }(\mathrm{km})(t-1)\end{array}$ & 0,975 & 1,000 & 0,549 & $-0,558$ & 0,910 & $-0,972$ \\
\hline $\begin{array}{l}\text { Poziom inwestycji } \\
(\% \text { PKB })(t-1)\end{array}$ & 0,572 & 0,549 & 1,000 & $-0,372$ & 0,539 & $-0,542$ \\
\hline $\begin{array}{l}\text { Poziom emigracji } \\
(\% \text { zatrudnionych })(t-1)\end{array}$ & $-0,625$ & $-0,558$ & $-0,372$ & 1,000 & $-0,450$ & 0,607 \\
\hline $\begin{array}{l}\text { Poziom uczniów } \\
\text { studentów } \\
\text { (\% zatrudnionych) }(t-3)\end{array}$ & 0,860 & 0,910 & 0,539 & $-0,450$ & 1,000 & $-0,822$ \\
\hline $\begin{array}{l}\text { Poziom zatrudnienia } \\
\text { rolnictwo } \\
\text { (\% zatrudnionych) }\end{array}$ & $-0,984$ & $-0,972$ & $-0,542$ & 0,607 & $-0,822$ & 1,000 \\
\hline
\end{tabular}

W celu estymacji parametrów strukturalnych powyższego modelu została użyta metoda najmniejszych kwadratów (MNK). Powszechność użycia MNK spowodowana jest m.in. tym, że daje estymatory zgodne, nieobciążone i najefektywniejsze, nawet bez założenia normalności rozkładu rozpatrywanych zmiennych $^{38}$. Wykorzystując regresję wieloraką MNK oszacowano następujące wyniki (tab. 34).

${ }^{38}$ T. Grabiński, S. Wydmus, Szacownie liniowych funkcji trendu metoda najmniejszych kwadratów przy pomocy wzorów uproszczonych, „Wiadomości Statystyczne” 1975, nr 4, s. 20. 
Tabela 34. Wyniki estymacji dla parametrów strukturalnych modelu MNK (1850-1913)

\begin{tabular}{|l|c|c|c|c|}
\hline \multicolumn{1}{|c|}{ Zmienna } & $\beta$ & $\begin{array}{c}\text { Błąd } \\
\text { standardowy } \beta\end{array}$ & Statystyka $t$ & $p$ \\
\hline Wyraz wolny & 7,071 & 0,520694 & 13,5793 & 0,000000 \\
\hline$(\ln )$ Długość linii $(\mathrm{km})(t-1)$ & 0,1388 & 0,038131 & 3,64076 & 0,000581 \\
\hline $\begin{array}{l}(\ln ) \text { Poziom inwestycji }(\% \text { PKB) } \\
(t-1)\end{array}$ & 0,0149 & 0,011441 & 1,30766 & 0,196148 \\
\hline $\begin{array}{l}(\ln ) \text { Poziom emigracji } \\
(\% \text { zatrudnionych) }(t-1)\end{array}$ & $-0,0256$ & 0,009555 & $-2,67895$ & 0,009594 \\
\hline $\begin{array}{l}(\ln ) \text { Poziom uczniów studentów } \\
(\% \text { zatrudnionych) }(t-3)\end{array}$ & 0,3761 & 0,177632 & 2,11726 & 0,038537 \\
\hline $\begin{array}{l}(\ln ) \text { Poziom zatrudnienia rolnictwo } \\
(\% \text { zatrudnionych) }\end{array}$ & $-0,9200$ & 0,099538 & $-9,24297$ & 0,000000 \\
\hline
\end{tabular}

Dla powyższego etapu modelowania współczynnik determinacji $\mathrm{R}^{2}$ wyniósł 98,11\% a jego wartość skorygowana 97,94\%. Oznacza, że zostało objaśniono 97,94\% zmienności zmiennej objaśnianej.

Stąd też współczynnik zbieżności $\varphi^{2}$ wyniósł - 1,89\%, a jego wartość skorygowana $-2,06 \%$.

Średni błąd standardowy estymacji $S_{E}$ wyniósł 0, 04196 czyli $\left(\frac{S_{E}}{\bar{Y}}=0,00734\right)$ $0,73 \%$, co oznacza, że średnie wartości zmiennej objaśnianej generowane przez model różniły się od jej wartości empirycznych średnio o około $0,73 \%$.

Kolejnym etapem weryfikacji modelu było sprawdzenie statystycznej istotności ocen parametrów strukturalnych. Zakładając, że składnik losowy modelu ma wielowymiarowy rozkład normalny, postawiono hipotezę zerową $H_{0}: \alpha_{i}=0$, wobec hipotezy alternatywnej $H_{1}: \alpha_{i} \neq 0$. Hipoteza zerowa zakładała, że parametr $\alpha_{i}$ nieistotnie różni się od zera, a jej odrzucenie oznaczało przyjęcie hipotezy alternatywnej $H_{1}$, głoszącej, że wartość parametru istotnie różni się od zera (czyli zmienna $X_{i}$ wywiera istotny wpływ na zmienną objaśnianą).

Test istotności pozwalający na weryfikację hipotezy $H_{0}: \alpha_{i}=0$ oparty był na rozkładzie statystyki $t$-Studenta. Parametry wartości statystyki $t$ (tzw. t empirycznego) podane są w tab. 34. Statystyka $t$-Studenta dla 62 stopni swobody i 0.05 poziomu istotności przybiera wartość krytyczną $t_{\alpha}=1,999$.

Dla czterech parametrów spełniona jest nierówność $|\mathrm{t}|>\mathrm{t}_{\alpha}$

Dla zmiennej - poziom inwestycji (\% PKB) ( $t-1)$ statystyka $|\mathrm{t}|<\mathrm{t}_{\alpha}$, więc zmienna okazała się nieistotna. Współczynnik DW dla reszt wynosi 1,31. Na rys. 72 zobrazowano przebieg reszt surowych. 
Surowe reszty vs. (In) PKB per capita

Surowe reszty $=-, 1169+, 01853^{*}($ In) PKB per capita

Korelacja: $r=, 13614$

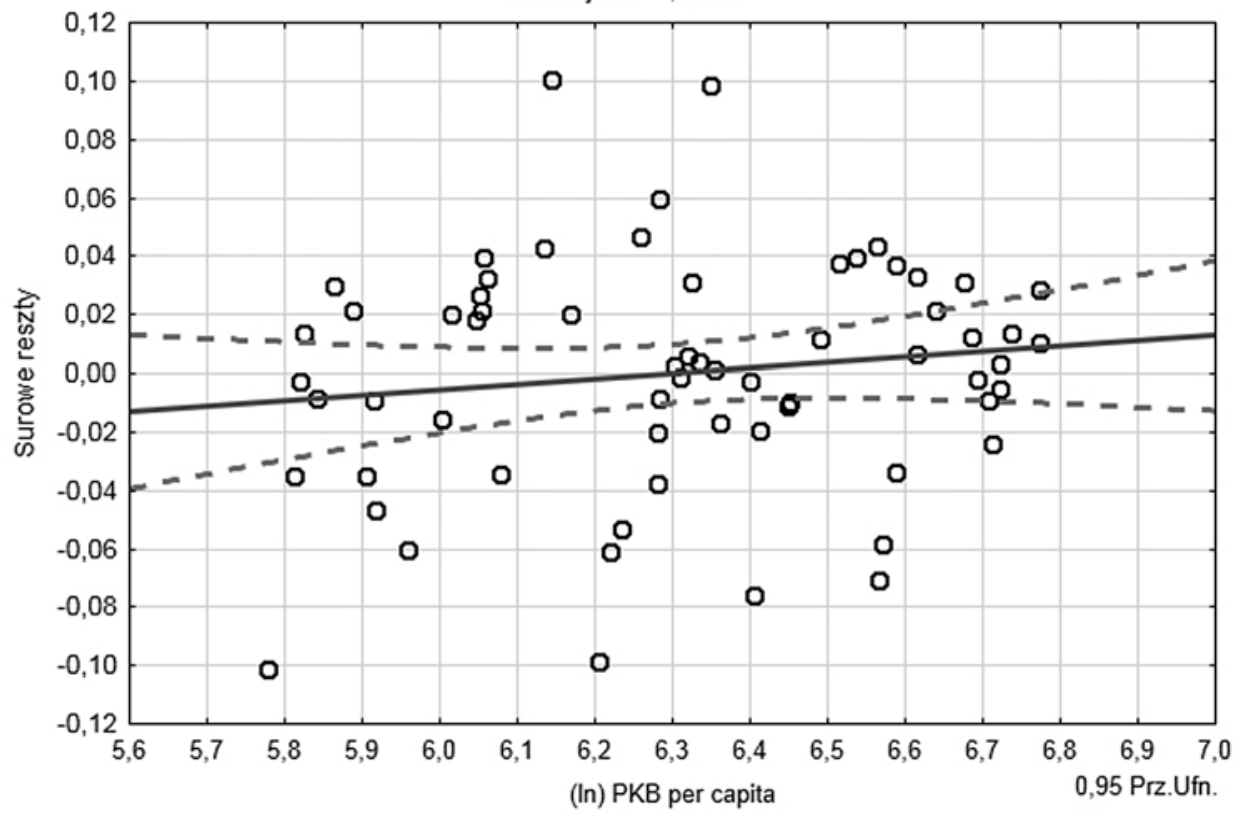

Rys. 72. Reszty surowe dla zmiennej endogenicznej przy poziomie ufności 0,95

Źródło: opracowanie własne (dotyczy rys.72-77). 


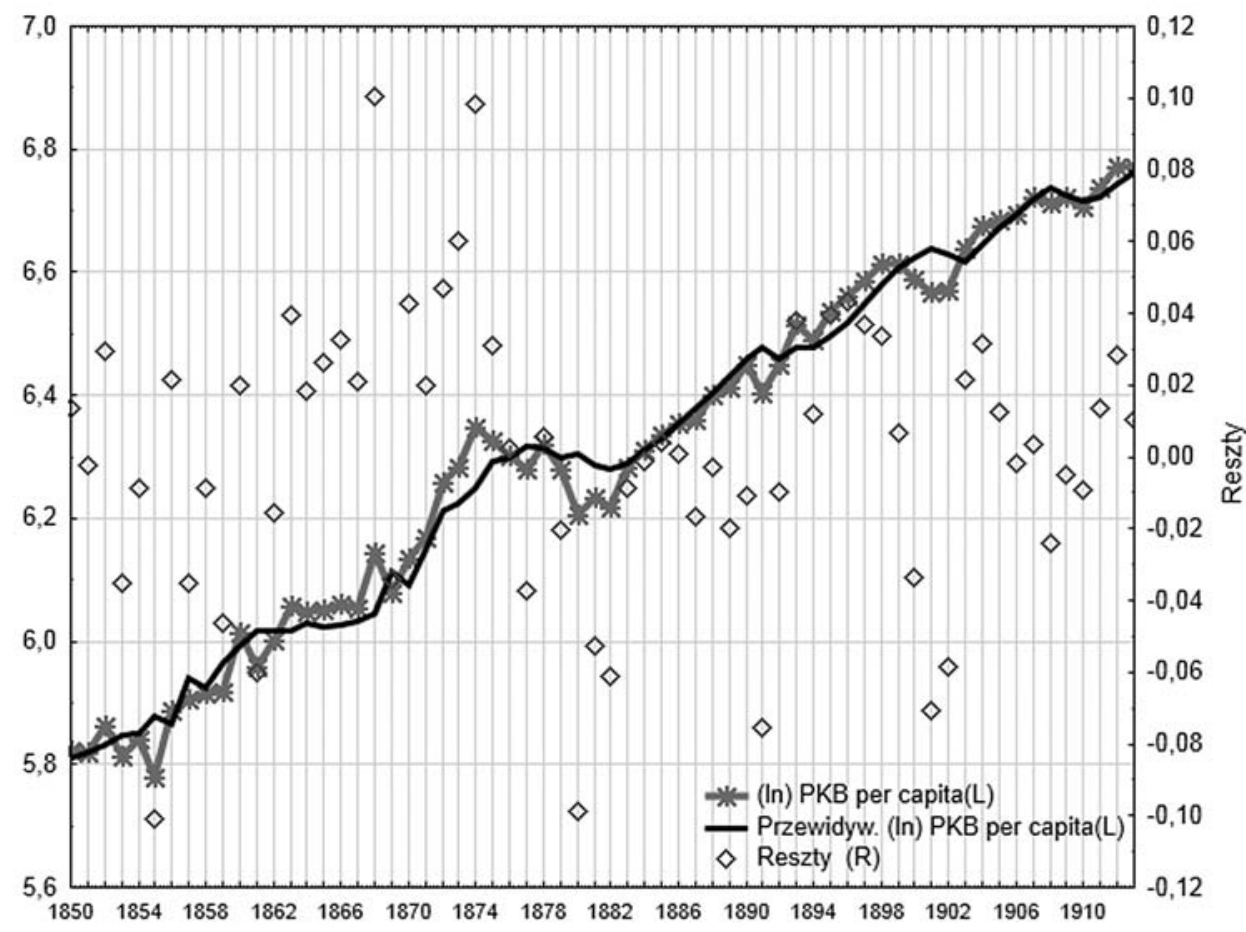

Rys. 73. Rzeczywisty i estymowany przebieg (ln) PKB per capita z uwzględnieniem reszt surowych

Oszacowane wartości strukturalne pozwalają zapisać funkcję $\ln Y_{P K B 1850-1913,}$ jako:

$$
\begin{gathered}
\ln Y_{\text {PKB1850-1913 }}=\ln 7,0004+0,1447 \ln R L_{t-1}-0,0257 \ln E M_{t-1}+0,3751 \ln S T_{t-3}-0,9076 \ln A G \\
|t|
\end{gathered}
$$$$
R^{2}=0,9811 \quad \text { Skor. } R^{2}=0,9794 \quad D W=1,31 \quad S_{\mathrm{EE}}=0,042
$$

gdzie: kach,

$Y_{\text {PKB1850-1913 }}$ - poziom PKB per capita Niemiec w latach 1850-1913 w mar-

$R L_{t-1}$ - długość linii kolejowych $(\mathrm{km})(t-1)$,

$E M_{t-1}-$ poziom emigracji (jako \% zatrudnionych) $(t-1)$,

$S T_{t-3}$ - poziom uczniów i studentów (jako \% zatrudnionych) ( $\left.t-3\right)$,

$A G$ - poziom zatrudnienia w rolnictwie jako (\% zatrudnionych),

$\ln -$ logarytm naturalny. 
Oceny parametrów strukturalnych (przy założeniu ceteris paribus) prowadzą do następujących wniosków:

a) wzrost długości szlaków kolejowych wyrażonych w km o 1\% wpływał na wzrost poziomu PBK per capita Niemiec o około $0,14 \%$,

b) wzrost poziomu emigracji, wyrażonej, jako procent w stosunku do ogólnej liczby osób zatrudnionych o $1 \%$ wpływał na spadek PKB per capita o blisko $0,026 \%$,

c) wzrost odsetka uczniów i studentów w stosunku do liczby zatrudnionych w gospodarce o $1 \%$ wywoływał wzrost PKB per capita o blisko $0,38 \%$,

d) spadek odsetka pracujących w rolnictwie w stosunku do całkowitej liczby zatrudnionych o $1 \%$ wpływał na wzrost PKB per capita o blisko $0,91 \%$,

Spośród czterech istotnych zmiennych objaśniających wzrost dwóch (długość linii kolejowych i odsetek uczniów i studentów w stosunku do liczby pracujących) wpływał pozytywnie na wzrost PKB per capita.

Dwie zmienne - poziom emigracji i odsetek zatrudnienia w rolnictwie wpływał odwrotnie proporcjonalnie na wzrost PKB per capita, z założeniem, że ograniczenie liczby pracujących w rolnictwie było na ogół zjawiskiem pozytywnym dla gospodarki. Po wprowadzeniu zmiennej binarnej $U_{-}$(przyjmuje wartość 1 dla lat: $1872-1874^{39}$, dla pozostałych wynosi 0 ) postać modelu:

$$
\begin{gathered}
\ln Y_{\text {PKB1850-1913 }}=\ln 7,7178+0,2005 \ln R L_{t-1}-0,0250 \ln E M_{t-1}-0,9182 \ln A G+0,0693 U_{-} \\
|t| \quad(17,62) \quad(14,36) \quad(3,06) \quad(1,21) \quad(5,16) \\
R^{2}=0,986 \quad \text { Skor. } R^{2}=0,9848 \quad D W=1,54 \quad S_{\mathrm{EE}}=0,036
\end{gathered}
$$

39 Okres napływu kontrybucji wojennej. 
Rzeczywisty i estymowany przebieg PKB per capita na tle obserwowanych reszt zamieszczono na rys. 74 .

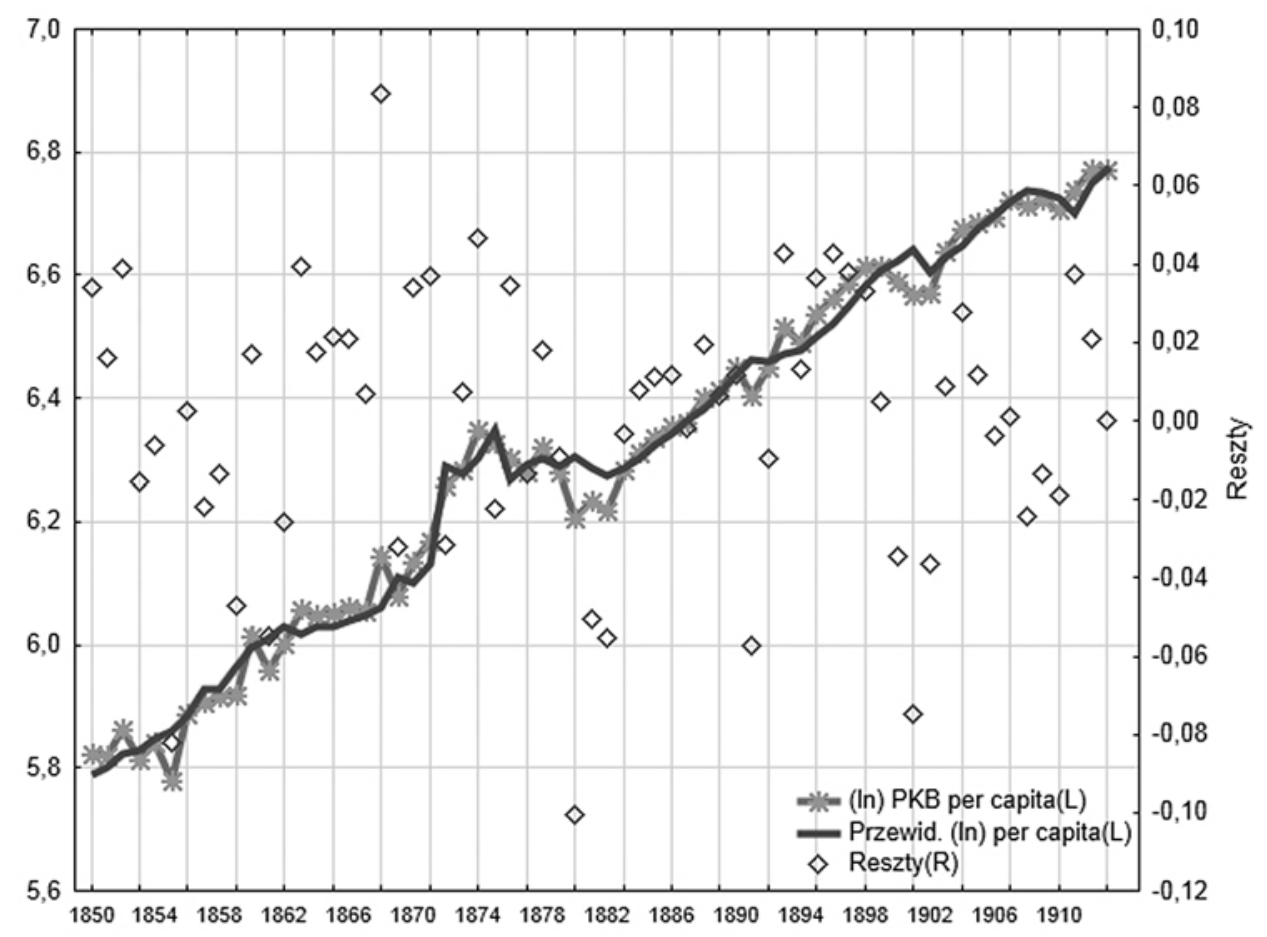

Rys. 74. Rzeczywisty i estymowany przebieg (ln) PKB per capita z uwzględnieniem zmiennej binarnej i reszt

Podsumowując powyższe obliczenia, z włączeniem zmiennej binarnej, należy zauważyć, że istotnymi czynnikami mającymi wpływ na objaśnienie zmiennej endogenicznej PKB per capita (tożsame ze wzrostem gospodarczym Niemiec) w okresie 1850-1913 były:

1. Długość szlaków kolejowych wyrażonych w km - wzrost o 1\% wpływał na wzrost PKB per capita w wymiarze około $0,14 \%$ (przy uwzględnieniu zmiennej binarnej $0,2 \%$ ). Jak wspominano, zmienna ta z jednej strony utożsamiała kapitał rzeczowy, innowacje, a także postęp techniczny w tym sektorze. Warto w tym miejscu dokonać analizy, w jakim tempie przyrastała długość linii kolejowych. W tym celu zostały wyodrębnione dwa okresy:

a) lata 1850-1879, czyli okres, w którym szybko rozbudowywano sieć kolejową, przed okresem nacjonalizacji, często z zaangażowaniem prywatnych kapitałów. To okres, dla którego m.in. R. Fremdling wysnuł wnioski o określeniu kolei, jako kluczowego sektora wzrostu, mającego wpływ na inne sektory, poprzez efekty ekonomiczne: „w przód” i „w tył” (Vorwärtskopplungseffekte, Rückwärtskopplungseffekte). 
W latach 1850-1879 średnie tempo przyrostu szlaków kolejowych wynosiło około $6,1 \%$ w skali roku. W tym samym czasie poziom PKB per capita wzrastał średnio o 1,99\%. Hipotetycznie oznaczałoby, że (ceteris paribus) przyrost kapitału fizycznego, w postaci linii kolejowych o 6,1\% wpływałby na wzrost PKB per capita o blisko $0,85 \%$. Wynik taki jest potwierdzeniem, że sektor kolejowy miał szczególnie duży wpływ na wzrost gospodarczy w tym okresie, co uzasadnia jego rangę jako sektora wzrostu;

b) po okresie nacjonalizacji kolei w Niemczech, i dalszym spadku taryf przewozowych, często w ostrej rywalizacji z transportem wodnym, tempo przyrostu nowych szlaków kolejowych w latach 1880-1913 wyniosło już tylko 1,83\%, w tym czasie PKB per capita przyrastał w tempie - 1,69\% rocznie. Hipotetycznie średnio notowany wzrost tempa budów nowych linii kolejowych wpływał na wzrost już jedynie o około $0,33 \%$ poziomu PKB per capita.

Jest to potwierdzenie, że kolej wpływała pozytywnie na wzrost gospodarczy kraju, ale jej wpływ był szczególnie wysoki do końca lat siedemdziesiątych XIX w. Wówczas był to jeden z ważnych sektorów wzrostowych. Począwszy od początku lat osiemdziesiątych XIX w. udział ten nie był już tak wielki, co może wynikać z faktu, że transport wodny śródlądowy, a także przybrzeżny ciągle pozostawał konkurencyjny (cenowo) wobec transportu kolejowego. Nie należy też zapominać o rozwoju innych gałęzi przemysłu (np. przemysł ciężki, chemiczny, elektryczny). W przyszłości bowiem wiele powstałych linii kolejowych wobec braku rentowności zostanie zlikwidowanych, a rozwijający się transport kołowy będzie bardziej konkurencyjny,

2. Czynniki demograficzne, w tym analizowany przez autora poziom emigracji. Wzrost emigracji negatywnie wpływał na wzrost poziomu PKB per capita. Jak wskazano w poprzednich rozdziałach, emigracja w Niemczech okresowo przybierała na sile, stąd zmienną opóźniono o jeden okres czasowy (1 rok). Średnio wzrost poziomu emigracji o $1 \%$ wywoływał spadek PKB per capita o $0,026 \%$ (przy uwzględnieniu zmiennej binarnej o 0,025\%). Dodać należy, że zmienna ta wyraźnie słabiej oddziaływała na wzrost PKB per capita, w porównaniu do pozostałych,

3. Znaczenie rozwoju kapitału ludzkiego, jako odsetka liczby uczniów i studentów w stosunku do ogółu zatrudnionych jest potwierdzeniem, że zmienna ta pozytywnie oddziaływała na poziom wzrostu gospodarczego wyrażonego, jako PKB per capita. Zmienna została opóźniona o 3 lata. Dla przykładu, w latach 1880-1890 średni przyrost roczny liczby uczniów i studentów wynosił $0,83 \%$, a przyrost PKB per capita 2,43\%. Hipotetycznie oznaczałoby, ceteris paribus, że czynnik ten wpływał średnio na wzrost PKB per capita w tym okresie o $0,32 \%{ }^{40}$.

${ }^{40}$ Po wprowadzeniu zmiennej binarnej zmienna okazała się nieistotna. 
4. Spadek zatrudnienia $w$ rolnictwie, okazał się istotny $i$ był ujemnie skorelowany z tempem wzrostu gospodarczego. Jest to jedynie potwierdzeniem, że wraz $\mathrm{z}$ budową fundamentów gospodarki kapitalistycznej, zmniejszało się znaczenie rolnictwa, zarówno w tworzeniu PKB, jak i odsetka zatrudnionych w sektorze gospodarce narodowej. Jak autor prezentował w poprzednich rozdziałach, odpływ ludności z rolnictwa był w przypadku Niemiec bardzo powolny. W rolnictwie ciągle pozostawał znacznych odsetek liczby ogółu zatrudnionych w gospodarce narodowej (szerzej w rozdz. III).

Zastanawiająca jest natomiast niska istotność statystyki $t$ dla poziomu inwestycji. Odsetek inwestycji w stosunku do PKB w cenach stałych i bieżących łącznie z opóźnieniem o jeden okres nie był istotny dla wyjaśnienia zmiennej endogenicznej. Jest natomiast jasne, że inwestycje, tak czy inaczej, miały wpływ na poziom kapitału rzeczowego wyrażonego choćby w długości linii kolejowych. Skłoniło to autora do przygotowania drugiego modelu ekonometrycznego - modelu z uwzględnieniem dynamiki PKB per capita.

\section{Model dynamiki PKB per capita z uwzględnieniem zmiennej „kolejowej”}

Do przedstawienia i scharakteryzowania czynników mających wpływ na dynamikę PKB per capita w krajach członkowskich Niemieckiego Związku Celnego i Niemczech w latach 1853-1913 wykorzystano opracowany model.

Na rys. 75 zobrazowano dynamikę PKB per capita w latach 1850-1913 w cenach stałych $(1913 \text { r. })^{41}$.

Zauważalne są duże wahania poziomu zmiennej - najniższe poziomy (spadki poniżej 4\%) występowały w latach $1853,1855,1861,1869,1880,1891$. Najwyższe tempo przyrostu zmiennej obserwowane jest w latach: 1856, 1860, 1868, $1870,1872,1874,1893,1903$, przekraczając ponad 6\% wzrostu w stosunku do poprzedniego roku.

Zmienną endogeniczną logarytmowano.

Zmienną endogeniczną: dynamika PKB per capita wyjaśniano, wykorzystując następujące zmienne objaśniające:

- dynamikę przyrostu długości linii kolejowych,

- stopę inwestycji w stosunku do poziomu PKB,

- poziom emigracji (\% zatrudnionych),

- odsetek uczniów i studentów (\% zatrudnionych),

- dynamikę zatrudnionych w rolnictwie (\% zatrudnionych).

${ }^{41}$ Dynamika PKB oraz PNN na tle poziomu PKB per capita została zaprezentowana w III rozdz. (rys. 53). 


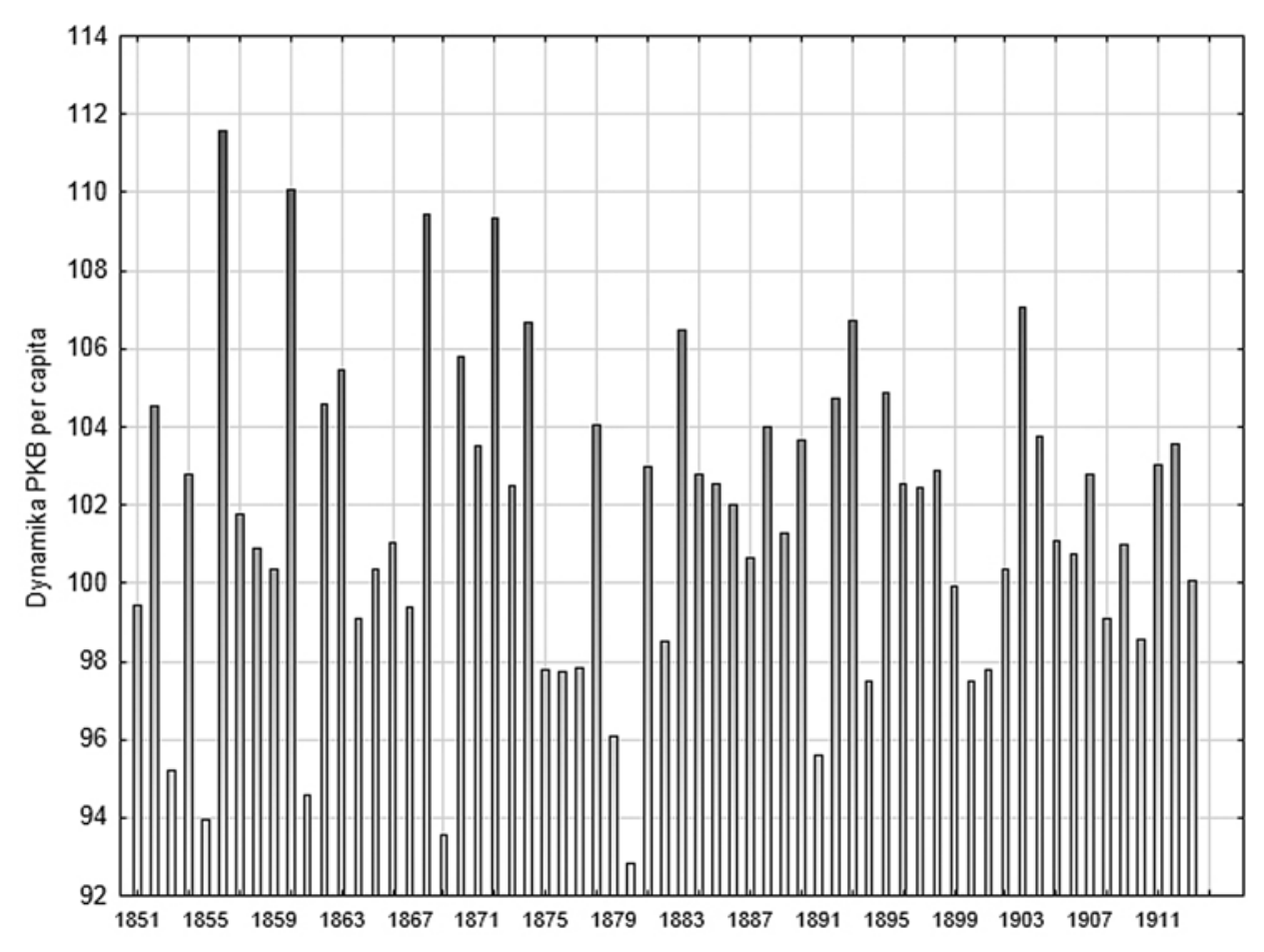

Rys. 75. Dynamika PKB per capita Niemiec 1850-1913, (rok poprzedzający = 100)

Uzyskane wyniki są przedstawione w tab. 35 .

Tabela 35. Wyniki estymacji dla parametrów strukturalnych modelu MNK (1853-1913)

\begin{tabular}{|l|c|c|c|c|}
\hline \multicolumn{1}{|c|}{ Zmienna } & $\beta$ & $\begin{array}{c}\text { Błąd standard- } \\
\text {-owy } \beta\end{array}$ & Statystyka t & $p$ \\
\hline Wyraz wolny & 4,546758 & 0,019353 & 234,9363 & 0,000000 \\
\hline Inwestycje $(t-3)$ & 0,005701 & 0,001476 & 3,8615 & 0,000290 \\
\hline Długość kolei $(t-3)$ & 0,004111 & 0,001726 & 2,3823 & 0,020565 \\
\hline Rolnictwo $(t-1)$ & $-0,004284$ & 0,004016 & $-1,0668$ & 0,290553 \\
\hline
\end{tabular}

Dla powyższego etapu modelowania współczynnik determinacji $\mathrm{R}^{2}$ wyniósł jedynie $24,81 \%$, a jego wartość skorygowana $20,84 \%$. Oznacza, że zostało objaśniono 24,81\% zmienności zmiennej objaśnianej. 
Postać modelu:

$$
\begin{gathered}
Y_{\mathrm{PKB} 1853-1913}=\exp ^{\wedge}\left(4,546758+0,005701 I N W_{t-3}+0,004111 R L_{t-3}\right) \\
|t|
\end{gathered}
$$$$
\mathrm{R}^{2}=0,2481 \quad \text { Skor. } \mathrm{R}^{2}=0,2084 \quad \mathrm{~S}_{\mathrm{E}}=0,0358 \quad \mathrm{DW}=2,23 \quad \mathrm{p}<, 00095
$$

gdzie:

$I N W$ - stopa inwestycji w stosunku do poziomu PKB $(t-3)$,

$R L$ - dynamika przyrostu linii kolejowych $(t-3)$.

Na rys. 76 przedstawiono rzeczywisty i estymowany przebieg dynamiki PKB per capita.

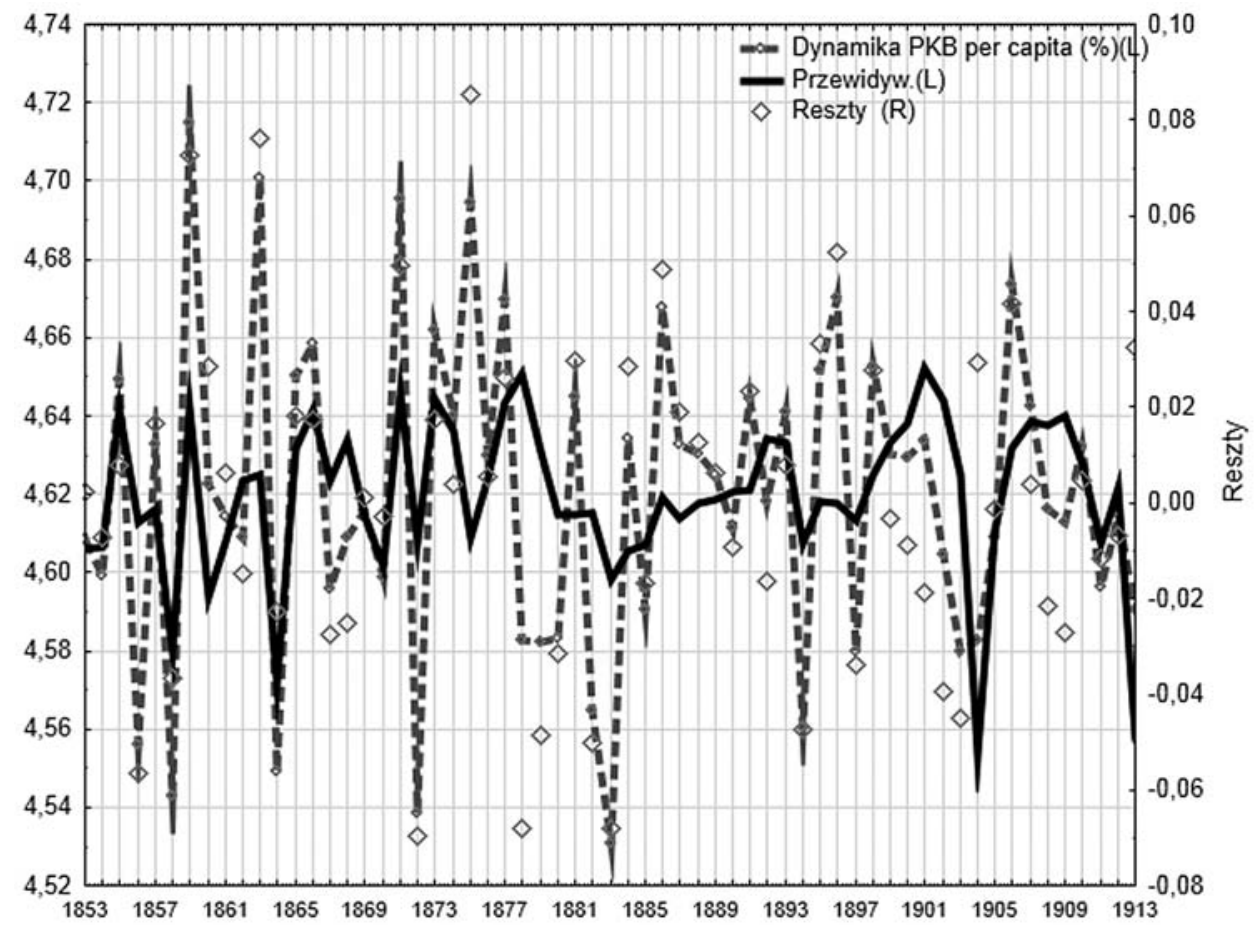

Rys. 76. Rzeczywisty i estymowany przebieg dynamiki PKB per capita (1853-1913) $\mathrm{z}$ uwzględnieniem reszt surowych

Opóźniając zmienną - dynamika odsetek zatrudnienia w rolnictwie zbudowano model z wyższym współczynnikiem R. Wynik estymacji przedstawiono w tab. 36. 
Tabela 36. Wyniki estymacji dla parametrów strukturalnych modelu MNK (1853-1913)

\begin{tabular}{|l|c|c|c|c|}
\hline \multicolumn{1}{|c|}{ Zmienna } & $\beta$ & Błąd standardowy $\beta$ & Statystyka $t$ & $p$ \\
\hline Wyraz wolny & 4,519405 & 0,021235 & 212,8291 & 0,000000 \\
\hline Inwestycje $(t-3)$ & 0,006908 & 0,001494 & 4,6235 & 0,000023 \\
\hline Długość kolei $(t-3)$ & 0,003846 & 0,001702 & 2,2602 & 0,027719 \\
\hline Rolnictwo $(t-2)$ & 0,008354 & 0,003945 & 2,1174 & 0,038677 \\
\hline Emigracja $(t-2)$ & 0,025210 & 0,015183 & 1,6604 & 0,102432 \\
\hline
\end{tabular}

Postać modelu:

$$
\begin{gathered}
Y_{\mathrm{PKB} 1853-1913}=\exp ^{\wedge}\left(4,519405+0,006908 I N W_{t-3}+0,003846 R L_{t-3}+0,008354 A G R_{t-2}\right) \\
|t| \\
(212,82)
\end{gathered}
$$

$\mathrm{R}^{2}=0,3086 \quad$ Skor. $\mathrm{R}^{2}=0,259 \quad \mathrm{~S}_{\mathrm{E}}=0,0347 \quad \mathrm{DW}=2,18 \quad \mathrm{p}<, 00031$ gdzie:

$I N W$ - stopa inwestycji w stosunku do poziomu PKB $(t-3)$,

$R L$ - dynamika przyrostu linii kolejowych $(t-3)$,

$A G R$-odsetek zatrudnionych w rolnictwie $(t-2)$.

Objaśniając dwie pierwsze zmienne potwierdzamy, że istnieje pozytywny wpływ inwestycji oraz dynamiki przyrostu długości nowych szlaków kolejowych w stosunku do dynamiki PKB per capita (wzrost dynamiki inwestycji o 1\% wpływał na wzrost dynamiki $P K B$ per capita o ponad 0,69\%, wzrost dynamiki przyrostu długości linii kolejowych o 1\% oznaczał wzrost PKB per capita o 0,38\%)

W przypadku rolnictwa, procentowy wzrost zatrudnienia w rolnictwie wpływałby pozytywnie na dynamikę PKB per capita, co jest odmienne w porównaniu do uzyskanych wyników modelu poziomu PKB per capita. Próbując wyjaśnić to zjawisko, można nawiązać do hipotezy Paula Bairocha ${ }^{42}$. Hipoteza ta zakłada, że w warunkach XIX w. polityka neoprotekcjonizmu (wysokich ceł, w tym dotyczących artykułów rolnych) okazała się czynnikiem pozytywnie skorelowanym z poziomem wzrostu gospodarczego.

${ }^{42}$ P. Bairoch, Free trade and European Economic Development in the 19th Century, „European Economic Review" 1972, no. 3, s. 211-245; P. Bairoch, European Trade Policy, 1815-1914, [w:] P. Mathias, S. Pollard (eds.), The Industrial Economies: The Development of Economic and Social Policies, The Cambridge Economic History of Europe, vol. VIII, Cambridge 1989, s. 1-60. 
Na rys. 77 przedstawiono rzeczywisty i estymowany przebieg dynamiki PKB per capita.

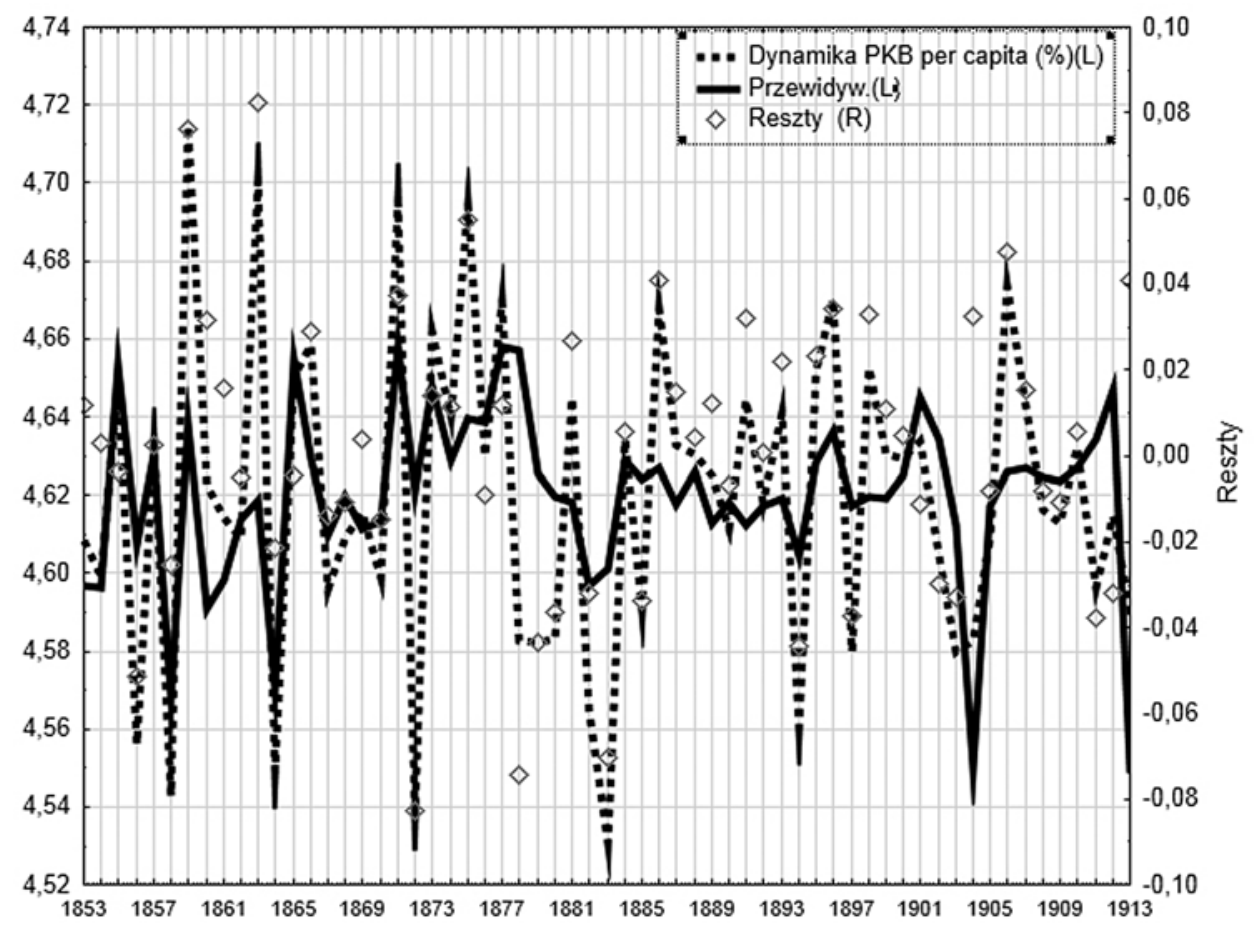

Rys. 77. Rzeczywisty i estymowany przebieg dynamiki PKB per capita (1853-1913) $\mathrm{z}$ uwzględnieniem reszt surowych

Kończąc niniejszy podrozdział autor pragnie zauważyć, że prezentowane modele ekonometryczne są bardzo uproszczone i należą do modeli jednorównaniowych. Ze względu na przyjęte uproszczenia, modelowanie ekonometryczne jest tylko dodatkowym uzupełnieniem wcześniejszych rozważań. Jednocześnie wyniki otrzymane przy zastosowaniu modelowania ekonometrycznego potwierdziły wpływ sektora kolejowego i innych czynników na wzrost gospodarczy Niemiec. 


\section{WNIOSKI KOŃCOWE}

Dynamiczny rozwój gospodarki Niemiec datuje się od lat pięćdziesiątych XIX w. - w tym czasie szybko wzrastał PKB oraz PKB per capita, jest to także okres wzrostu znaczenia transportu, w tym rozbudowy sieci kolejowej.

W historii gospodarczej dotyczącej XIX w. mocno osadzony jest pogląd o roli transportu kolejowego, jako „największego czynnika produkcyjności w historii”, a zarazem koniecznego czynnika rozwoju przemysłu i całej gospodarki. Potwierdzają to liczne prace przywoływane przez autora, łącznie z Waltem Rostowem, Friedrichem Listem.

Trzeba też przyznać, że w niemieckiej historii gospodarczej silnie podkreślana jest teoria wiodących sektorów gospodarki, do których zalicza się również kolejnictwo. Teoria wzrostu i sektory wiodące są silnie eksponowane w pracach Alberta Hirschmana. Uczony podkreśla, że poszczególne sektory charakteryzowały się „nierównomiernym wzrostem”, a sektory wiodące wpływały na powstanie i rozwój innych sektorów gospodarki. Ważnym aspektem pozostaje także efekt rozlewania się (Spillovereffekte) ${ }^{43}$.

W warunkach Niemiec rozwój sektora kolejowego spełnił jeszcze kilka odmiennych funkcji, w tym:

- czynnika integrującego rozczłonkowane państwa niemieckie,

- budowy świadomości i tożsamości narodu niemieckiego,

- możliwości efektywnego funkcjonowania Niemieckiego Związku Celnego,

- połączenia rozległych ziem Królestwa Prus, w szczególności rolniczych prowincji wschodnich z silnie uprzemysłowionymi prowincjami zachodnimi, co wynikało z kształtu granic,

- ważnego elementu budowy pozycji militarnej.

Stąd do lat sześćdziesiątych XX w. i rozwoju paradygmatu New Economic History w zasadzie nikt nie negował ogromnej roli rozwoju transportu, w tym kolejnictwa, we wzroście gospodarczym poszczególnych państw.

Zupełnie inne postrzeganie znaczenia sektora kolejowego wywarło dzieło Roberta Fogla. Na podstawie empirycznego wnioskowania typowego w paradygmacie New Economic History, R. Fogel zaproponował koncepcję społecznych oszczędności. Porównując, w warunkach USA, cenę frachtu kolejowego z innymi alternatywnymi możliwościami transportu oszacował dodatkowe koszty, które zostałyby poniesione bez istnienia kolei. Oszczędności w przypadku USA dla 1890 r. wynosiły jedynie 4,7\% w stosunku do PKB. W późniejszym okresie obliczono społeczne oszczędności w przypadku sektora kolejowego dla wielu krajów świata. Obecnie koncepcja social savings jest użyteczna nie tylko dla badania wpływu oddziaływania kolei na generowanie PKB, ale także oceny innowacji.

\footnotetext{
${ }^{43}$ A. Hirschman, Die Strategie der wirtschaftlichen Entwicklung, Stuttgart 1967, s. 94 i n.
} 
Zarówno Nicholas Crafts, jak i inni współcześni badacze wykazują użyteczność tej metody w badaniu innych efektów dotyczących zarówno zmian technologicznych, jak i wzrostu gospodarczego.

Mimo rozwoju kliometrii w USA i Wielkiej Brytanii, daje się zauważyć dużą ostrożność w aplikowaniu metod ekonometrycznych przez pozostałych naukowców europejskich.

W dotychczasowej literaturze dotyczącej gospodarki Niemiec, zależność między rozwojem kolei żelaznych i wzrostem gospodarczym była głównie analizowana poprzez obliczenie inwestycji indukowanych w wyniku rozbudowy kolei w stosunku do innych branż, łącznie z ukazaniem ekonomicznych ,efektów w przód” i ,efektów w tył”. Kolej natomiast ukazywana była jako jeden z kluczowych sektorów wzrostu ${ }^{44}$. Zauważyć natomiast należy, że w warunkach Niemiec równie szybko rozwijały się inne sektory gospodarki, np.: przemysł wydobywczy, włókienniczy, maszynowy, chemiczny, elektryczny, hutniczy, w tym stalowy.

Niemieccy naukowcy wykazują, że zapotrzebowanie na żelazo, węgiel, infrastrukturę kolejową wywołane budową kolei było motorem napędowym niemieckiej rewolucji przemysłowej. Jednocześnie w ocenie autora, paradoksalnie wysokie koszty frachtu kolejowego przez kilka dziesiątków lat w XIX w. sprawiały, że w północnych Niemczech, w tym w Berlinie, konkurencyjny np. węgiel angielski, ciągle był transportowany z użyciem dróg wodnych, a zboża były również transportowane drogą wodną.

Ogólnie rzecz biorąc, rozbudowa linii kolejowych wpływała na wzrost łącznej wydajności, dzięki redukcji kosztów transportu, ale proces ten był powolny i do końca lat siedemdziesiątych XIX w. dość chimeryczny.

Rozbudowa szlaków kolejowych stymulowała integrację rynków i przyczyniała się do większej mobilności siły roboczej, a także sprzyjała powstawaniu ekonomii skali i sprzyjała rozwojowi wielkich aglomeracji. Gęsta sieć kolejowa ułatwiała eksploatację zasobów naturalnych i stymulowała wzrost inwestycji, ale jednocześnie bywała mało konkurencyjna wobec przewozów wodnych.

Rozbudowa kolei wymagała ogromnych środków finansowych - początkowo były to środki głównie prywatne, zaś od lat siedemdziesiątych XIX w. środki państwowe. W drugiej połowie lat siedemdziesiątych XIX w. inwestycje netto w kolejnictwie przybrały niespotykany poziom $25,5 \%$ poziomu ogółu inwestycji. Inwestycje te mogły w innych alternatywnych rodzajach działalności przyspieszyć wzrost gospodarczy kraju, w tym rozwój ośrodków przemysłowych, w częściach wschodnich Rzeszy Niemieckiej, a także rozwój sektora usług.

Przeprowadzona przez autora pracy analiza efektywności transportu wodnego śródlądowego i kolejowego potwierdza tezę, że transport wodny, był często tańszą alternatywną dla przewozu towarów masowych, w tym tak ważnych surowców jak węgiel i zboże. Na stosunkowo niską efektywność niemieckiego trans-

${ }^{44}$ R. Fremdling, op. cit., T. Pierenkemper, R. Tilly, op. cit., s. 63. 
portu kolejowego wpływały wysokie stawki frachtu, a także niejednolita polityka względem taryf przewozowych. Układ głównych rzek płynących w cesarstwie, łącznie z rozbudową sieci kanałów pozwalał praktycznie od początków istnienia kolei do I wojny światowej skutecznie konkurować z przewozami ładunków masowych. Nie sposób nie zauważyć, że mimo zażartej konkurencji pomiędzy transportem kolejowym a wodnym, kolej uczestniczyła w 80\% przewozów. Nie można nie zauważyć roli kolei w masowym transporcie pasażerskim i w aspekcie działań militarnych.

Należy dodać, że założona przez autora pracy hipoteza badawcza, że społeczne oszczędności w przypadku sektora kolejowego w Niemczech są niewysokie została potwierdzona, o czym świadczą obliczenia w IV rozdziale pracy. Mianowicie, społeczne oszczędności uwzględniając jedynie przewozy towarowe dla 1909 r. wyniosły nieco powyżej 2\% poziomu PKB $(2,08-2,32)$. Oszczędności te są jeszcze znacznie niższe dla zastosowanej koncepcji nadwyżki konsumenta i wyniosły $1,53-1,58 \%$ PKB.

Obliczenia te w jakiś sposób uzasadniają ostrożność niemieckich naukowców do stosowania miary, jaką są społeczne oszczędności w warunkach Niemiec, pokazując również, że rozbudowa sieci kanałów wodnych, regulacja rzek, transport przybrzeżny był ważną alternatywą przewozów kolejowych.

Zastosowane przez autora w podrozdziale 4.4. modelowanie ekonometryczne dotyczące poszukiwań istotnych determinant wzrostu gospodarczego Niemiec potwierdziło, ze kolej, jako ucieleśnienie kapitału rzeczowego wpływała na poziom i dynamikę PKB per capita Niemiec. Jednocześnie wyniki wskazały na inne istotne czynniki wzrostu gospodarczego, jak stopa inwestycji, rozwój szkolnictwa i oświaty (kapitału ludzkiego) przejawiający się odsetkiem uczniów i studentów, a także negatywne oddziaływanie procesów emigracyjnych.

Wyniki badań potwierdzają także, że istotny wpływ na budowę nowoczesnego społeczeństwa i poziomu dobrobytu miała struktura zatrudnienia w poszczególnych sektorach gospodarki, w tym poziom zatrudnienia w rolnictwie. Poziom ten niestety był ciągle wysoki i mimo spadku odsetka zatrudnionych w rolnictwie stosunku do całkowitej liczby zatrudnionych w ujęciu liczbowym ciągle wzrastał. 


\section{ANEKS}

Tabela 37. Indeks output dla kolei w latach 1840-1913 (1913=100)

\begin{tabular}{|c|c|c|c|c|c|}
\hline \multirow[b]{2}{*}{ Rok } & \multicolumn{2}{|c|}{ Liczba przewozów } & \multirow{2}{*}{$\begin{array}{c}\text { Taryfa } \\
\text { (pf/1pkm) }\end{array}$} & \multirow{2}{*}{$\begin{array}{c}\text { Taryfa } \\
\text { (pf/1tkm) }\end{array}$} & \multirow{2}{*}{$\begin{array}{l}\text { Indeks output } \\
(1913=100)\end{array}$} \\
\hline & $\begin{array}{l}\text { osobowych } \\
(\mathrm{mln} \text { pkm) }\end{array}$ & $\begin{array}{l}\text { towarowych } \\
(\mathrm{mln} \text { tkm) }\end{array}$ & & & \\
\hline 1 & 2 & 3 & 4 & 5 & 6 \\
\hline 1840 & 3 & 62 & 16,90 & 4,40 & 0,03 \\
\hline 1841 & 8 & 97 & 16,30 & 4,40 & 0,05 \\
\hline 1842 & 15 & 145 & 15,70 & 4,40 & 0,08 \\
\hline 1843 & 26 & 185 & 15,30 & 4,70 & 0,11 \\
\hline 1844 & 33 & 256 & 15,50 & 4,40 & 0,15 \\
\hline 1845 & 51 & 309 & 13,60 & 4,30 & 0,20 \\
\hline 1846 & 82 & 428 & 12,40 & 4,10 & 0,30 \\
\hline 1847 & 160 & 547 & 11,20 & 4,20 & 0,47 \\
\hline 1848 & 168 & 615 & 11,30 & 4,10 & 0,51 \\
\hline 1849 & 234 & 664 & 10,80 & 4,30 & 0,63 \\
\hline 1850 & 303 & 783 & 10,10 & 4,20 & 0,78 \\
\hline 1851 & 394 & 865 & 9,50 & 4,20 & 0,94 \\
\hline 1852 & 527 & 914 & 9,10 & 4,50 & 1,14 \\
\hline 1853 & 621 & 935 & 9,60 & 4,80 & 1,26 \\
\hline 1854 & 898 & 1041 & 8,20 & 4,50 & 1,64 \\
\hline 1855 & 1095 & 1090 & 8,10 & 4,50 & 1,89 \\
\hline 1856 & 1241 & 1263 & 8,10 & 4,50 & 2,16 \\
\hline 1857 & 1531 & 1457 & 7,70 & 4,50 & 2,61 \\
\hline 1858 & 1505 & 1491 & 7,70 & 4,40 & 2,60 \\
\hline 1859 & 1475 & 1637 & 7,90 & 4,20 & 2,65 \\
\hline 1860 & 1630 & 1733 & 7,90 & 4,40 & 2,89 \\
\hline 1861 & 1970 & 1901 & 7,50 & 4,30 & 3,37 \\
\hline 1862 & 2420 & 2064 & 7,10 & 4,20 & 3,97 \\
\hline 1863 & 2750 & 2360 & 6,40 & 4,10 & 4,54 \\
\hline 1864 & 3150 & 2571 & 6,20 & 4,00 & 5,11 \\
\hline 1865 & 3660 & 2676 & 6,00 & 4,10 & 5,73 \\
\hline 1866 & 3680 & 3132 & 6,30 & 3,60 & 6,02 \\
\hline
\end{tabular}


Tabela 37. (cd.)

\begin{tabular}{|c|c|c|c|c|c|}
\hline 1 & 2 & 3 & 4 & 5 & 6 \\
\hline 1867 & 4380 & 2978 & 5,90 & 4,00 & 6,69 \\
\hline 1868 & 5040 & 3213 & 5,70 & 3,90 & 7,55 \\
\hline 1869 & 5330 & 3534 & 5,50 & 3,80 & 8,08 \\
\hline 1870 & 5300 & 4373 & 5,60 & 3,40 & 8,61 \\
\hline 1871 & 6400 & 5021 & 5,50 & 3,60 & 10,24 \\
\hline 1872 & 8200 & 5012 & 5,30 & 3,80 & 12,13 \\
\hline 1873 & 9900 & 5693 & 4,90 & 3,70 & 14,38 \\
\hline 1874 & 10100 & 5844 & 5,10 & 3,70 & 14,70 \\
\hline 1875 & 10400 & 5994 & 5,30 & 3,80 & 15,12 \\
\hline 1876 & 10800 & 6109 & 5,10 & 3,80 & 15,61 \\
\hline 1877 & 11000 & 6111 & 5,00 & 3,70 & 15,82 \\
\hline 1878 & 11100 & 6153 & 4,80 & 3,70 & 15,94 \\
\hline 1879 & 11900 & 6148 & 4,60 & 3,70 & 16,74 \\
\hline 1880 & 13500 & 6479 & 4,40 & 3,50 & 18,62 \\
\hline 1881 & 14300 & 6782 & 4,33 & 3,48 & 19,66 \\
\hline 1882 & 15600 & 7063 & 4,22 & 3,46 & 21,17 \\
\hline 1883 & 16400 & 7368 & 4,19 & 3,43 & 22,22 \\
\hline 1884 & 16800 & 7689 & 4,10 & 3,38 & 22,86 \\
\hline 1885 & 16600 & 7932 & 4,07 & 3,34 & 22,85 \\
\hline 1886 & 17200 & 8364 & 4,08 & 3,29 & 23,80 \\
\hline 1887 & 18700 & 8708 & 3,94 & 3,27 & 25,56 \\
\hline 1888 & 20400 & 9209 & 3,90 & 3,26 & 27,66 \\
\hline 1889 & 22100 & 10772 & 3,88 & 3,18 & 30,59 \\
\hline 1890 & 22500 & 11224 & 3,86 & 3,08 & 31,36 \\
\hline 1891 & 23400 & 11679 & 3,82 & 3,05 & 32,62 \\
\hline 1892 & 23500 & 11782 & 3,83 & 3,01 & 32,81 \\
\hline 1893 & 24700 & 12552 & 3,79 & 2,97 & 34,62 \\
\hline 1894 & 25000 & 12810 & 3,80 & 2,96 & 35,12 \\
\hline 1895 & 26600 & 13917 & 3,79 & 2,92 & 37,59 \\
\hline 1896 & 28100 & 15111 & 3,79 & 2,83 & 40,03 \\
\hline 1897 & 30300 & 16192 & 3,70 & 2,84 & 43,08 \\
\hline 1898 & 32700 & 17554 & 3,65 & 2,88 & 46,53 \\
\hline 1899 & 35100 & 18595 & 3,57 & 2,84 & 49,75 \\
\hline
\end{tabular}


Tabela 37. (cd.)

\begin{tabular}{|c|c|c|c|c|c|}
\hline 1 & 2 & 3 & 4 & 5 & 6 \\
\hline 1900 & 37000 & 19999 & 3,52 & 2,82 & 52,74 \\
\hline 1901 & 35400 & 20525 & 3,54 & 2,81 & 51,52 \\
\hline 1902 & 36800 & 21028 & 3,52 & 2,75 & 53,33 \\
\hline 1903 & 39600 & 22508 & 3,52 & 2,71 & 57,30 \\
\hline 1904 & 41200 & 23835 & 3,53 & 2,70 & 59,93 \\
\hline 1905 & 44600 & 25632 & 3,52 & 2,66 & 64,75 \\
\hline 1906 & 48300 & 27732 & 3,50 & 2,56 & 70,12 \\
\hline 1907 & 51300 & 29647 & 3,40 & 2,42 & 74,63 \\
\hline 1908 & 49900 & 30972 & 3,52 & 2,40 & 74,13 \\
\hline 1909 & 52800 & 33663 & 3,51 & 2,36 & 79,07 \\
\hline 1910 & 56400 & 35419 & 3,53 & 2,36 & 84,08 \\
\hline 1911 & 62000 & 37855 & 3,47 & 2,35 & 91,66 \\
\hline 1912 & 66200 & 39933 & 3,42 & 2,36 & 97,52 \\
\hline 1913 & 67700 & 41210 & 3,44 & 2,37 & 100,00 \\
\hline
\end{tabular}

Źródło: obliczenia własne z wykorzystaniem danych źródłowych: Statistisches Jahrbuch für das Deutsche Reich, Berlin 1885-1913; W.G. Hoffmann, Das Wachstum der deutschen Wirtschaft seit der Mitte des 19. Jahrhunderts, Berlin 1965, R. Fremdling, Eisenbahnen und deutsches Wirtschaftswachstum 1840-1879. Ein Beitrag zur Entwicklungstheorie und zur Theorie der Infrastruktur, Dortmund 1985, s. 17-19.

Tabela 38. Współczynnik kapitału, intensywność kapitału, produktywność pracy, produktywność kapitału - koleje niemieckie (w cenach z 1913 r.)

\begin{tabular}{|c|c|c|c|c|}
\hline Rok & $\frac{\mathrm{K}}{\mathrm{O}}$ & $\frac{\mathrm{K}}{\mathrm{N}}$ & $\frac{\mathrm{O}}{\mathrm{N}}$ & $\frac{\mathrm{O}}{\mathrm{K}}$ \\
\hline 1 & 2 & 3 & 4 & 5 \\
\hline 1840 & 78,20 & 49,59 & 0,63 & 0,013 \\
\hline 1841 & 61,12 & 39,54 & 0,65 & 0,016 \\
\hline 1842 & 54,16 & 37,48 & 0,69 & 0,018 \\
\hline 1843 & 59,08 & 42,09 & 0,71 & 0,017 \\
\hline 1844 & 60,34 & 38,30 & 0,63 & 0,017 \\
\hline 1845 & 66,85 & 51,04 & 0,76 & 0,015 \\
\hline 1846 & 69,30 & 59,84 & 0,86 & 0,014 \\
\hline 1847 & 51,89 & 50,86 & 0,98 & 0,019 \\
\hline
\end{tabular}


Tabela 38. (cd.)

\begin{tabular}{|c|c|c|c|c|}
\hline 1 & 2 & 3 & 4 & 5 \\
\hline 1848 & 52,84 & 45,86 & 0,87 & 0,019 \\
\hline 1849 & 49,24 & 47,00 & 0,95 & 0,020 \\
\hline 1850 & 41,54 & 44,09 & 1,06 & 0,024 \\
\hline 1851 & 46,36 & 47,71 & 1,03 & 0,022 \\
\hline 1852 & 40,51 & 42,46 & 1,05 & 0,025 \\
\hline 1853 & 36,94 & 37,26 & 1,01 & 0,027 \\
\hline 1854 & 31,66 & 38,76 & 1,22 & 0,032 \\
\hline 1855 & 28,85 & 37,68 & 1,31 & 0,035 \\
\hline 1856 & 26,81 & 37,17 & 1,39 & 0,037 \\
\hline 1857 & 22,20 & 31,71 & 1,43 & 0,045 \\
\hline 1858 & 25,96 & 34,21 & 1,32 & 0,039 \\
\hline 1859 & 26,35 & 30,96 & 1,17 & 0,038 \\
\hline 1860 & 27,08 & 32,47 & 1,20 & 0,037 \\
\hline 1861 & 24,36 & 32,39 & 1,33 & 0,041 \\
\hline 1862 & 22,04 & 33,16 & 1,50 & 0,045 \\
\hline 1863 & 21,26 & 33,67 & 1,58 & 0,047 \\
\hline 1864 & 19,82 & 34,05 & 1,72 & 0,050 \\
\hline 1865 & 18,71 & 33,55 & 1,79 & 0,053 \\
\hline 1866 & 19,65 & 34,61 & 1,76 & 0,051 \\
\hline 1867 & 17,40 & 31,40 & 1,80 & 0,057 \\
\hline 1868 & 16,84 & 31,48 & 1,87 & 0,059 \\
\hline 1869 & 16,95 & 31,67 & 1,87 & 0,059 \\
\hline 1870 & 17,61 & 33,48 & 1,90 & 0,057 \\
\hline 1871 & 15,49 & 31,60 & 2,04 & 0,065 \\
\hline 1872 & 14,54 & 32,40 & 2,23 & 0,069 \\
\hline 1873 & 13,19 & 28,79 & 2,18 & 0,076 \\
\hline 1874 & 13,97 & 27,70 & 1,98 & 0,072 \\
\hline 1875 & 14,83 & 29,09 & 1,96 & 0,067 \\
\hline 1876 & 15,78 & 31,50 & 2,00 & 0,063 \\
\hline 1877 & 16,54 & 35,43 & 2,14 & 0,060 \\
\hline 1878 & 16,78 & 35,33 & 2,11 & 0,060 \\
\hline 1879 & 17,27 & 37,68 & 2,18 & 0,058 \\
\hline 1880 & 16,07 & 37,39 & 2,33 & 0,062 \\
\hline
\end{tabular}


Tabela 38. (cd.)

\begin{tabular}{|c|c|c|c|c|}
\hline 1 & 2 & 3 & 4 & 5 \\
\hline 1881 & 15,59 & 37,49 & 2,40 & 0,064 \\
\hline 1882 & 14,99 & 37,17 & 2,48 & 0,067 \\
\hline 1883 & 14,68 & 36,53 & 2,49 & 0,068 \\
\hline 1884 & 14,53 & 35,95 & 2,48 & 0,069 \\
\hline 1885 & 14,73 & 35,90 & 2,44 & 0,068 \\
\hline 1886 & 14,30 & 35,94 & 2,51 & 0,070 \\
\hline 1887 & 13,44 & 35,59 & 2,65 & 0,074 \\
\hline 1888 & 12,65 & 35,00 & 2,77 & 0,079 \\
\hline 1889 & 11,65 & 34,14 & 2,93 & 0,086 \\
\hline 1890 & 11,58 & 32,30 & 2,79 & 0,086 \\
\hline 1891 & 11,36 & 31,14 & 2,74 & 0,088 \\
\hline 1892 & 11,52 & 32,26 & 2,80 & 0,087 \\
\hline 1893 & 11,13 & 32,90 & 2,96 & 0,090 \\
\hline 1894 & 11,15 & 32,67 & 2,93 & 0,090 \\
\hline 1895 & 10,66 & 33,00 & 3,10 & 0,094 \\
\hline 1896 & 10,20 & 32,82 & 3,22 & 0,098 \\
\hline 1897 & 9,69 & 31,73 & 3,27 & 0,103 \\
\hline 1898 & 9,18 & 29,80 & 3,25 & 0,109 \\
\hline 1899 & 8,76 & 29,79 & 3,40 & 0,114 \\
\hline 1900 & 8,46 & 29,61 & 3,50 & 0,118 \\
\hline 1901 & 8,90 & 29,94 & 3,37 & 0,112 \\
\hline 1902 & 8,81 & 30,73 & 3,49 & 0,114 \\
\hline 1903 & 8,41 & 30,73 & 3,65 & 0,119 \\
\hline 1904 & 8,24 & 30,28 & 3,68 & 0,121 \\
\hline 1905 & 7,80 & 29,76 & 3,81 & 0,128 \\
\hline 1906 & 7,42 & 28,65 & 3,86 & 0,135 \\
\hline 1907 & 7,19 & 27,57 & 3,83 & 0,139 \\
\hline 1908 & 7,50 & 28,41 & 3,79 & 0,133 \\
\hline 1909 & 7,27 & 29,72 & 4,09 & 0,138 \\
\hline 1910 & 7,01 & 30,07 & 4,29 & 0,143 \\
\hline 1911 & 6,59 & 30,12 & 4,57 & 0,152 \\
\hline 1912 & 6,38 & 29,87 & 4,68 & 0,157 \\
\hline 1913 & 6,44 & 29,26 & 4,54 & 0,155 \\
\hline
\end{tabular}

Źródło: opracowanie własne. 
Tabela 39. Wartość dodana przewozów kolejowych na tle innych rodzajów transportu w latach 1850-1913 (mln marek, ceny stałe z 1913 r.)

\begin{tabular}{|c|c|c|c|c|c|}
\hline \multirow{3}{*}{ Lata } & \multicolumn{5}{|c|}{ Wartość dodana } \\
\hline & \multicolumn{4}{|c|}{ przewozy } & \multirow{2}{*}{$\begin{array}{l}\text { transport, } \\
\text { komunikacja }\end{array}$} \\
\hline & kolejowe & $\begin{array}{c}\text { kolejowe } \\
\text { (pasażerskie) }\end{array}$ & $\begin{array}{l}\text { śródlądowe } \\
\text { (towarowe) }\end{array}$ & $\begin{array}{c}\text { morskie } \\
\text { (towarowe) }\end{array}$ & \\
\hline 1 & 2 & 3 & 4 & 5 & 6 \\
\hline 1850 & 5 & 12 & 5 & 7 & 53 \\
\hline 1851 & 8 & 13 & 5 & 7 & 60 \\
\hline 1852 & 12 & 13 & 5 & 7 & 66 \\
\hline 1853 & 14 & 13 & 6 & 7 & 69 \\
\hline 1854 & 21 & 15 & 6 & 8 & 82 \\
\hline 1855 & 27 & 16 & 7 & 8 & 91 \\
\hline 1856 & 26 & 19 & 7 & 9 & 94 \\
\hline 1857 & 32 & 22 & 7 & 10 & 107 \\
\hline 1858 & 32 & 23 & 7 & 11 & 110 \\
\hline 1859 & 31 & 24 & 7 & 11 & 110 \\
\hline 1860 & 35 & 26 & 8 & 11 & 120 \\
\hline 1861 & 43 & 28 & 8 & 11 & 129 \\
\hline 1862 & 53 & 31 & 8 & 11 & 145 \\
\hline 1863 & 60 & 35 & 8 & 12 & 157 \\
\hline 1864 & 68 & 40 & 9 & 12 & 176 \\
\hline 1865 & 80 & 41 & 9 & 13 & 192 \\
\hline 1866 & 80 & 52 & 9 & 13 & 204 \\
\hline 1867 & 80 & 45 & 10 & 13 & 201 \\
\hline 1868 & 95 & 51 & 10 & 13 & 230 \\
\hline 1869 & 110 & 55 & 11 & 14 & 252 \\
\hline 1870 & 116 & 74 & 11 & 14 & 280 \\
\hline 1871 & 116 & 82 & 10 & 14 & 292 \\
\hline 1872 & 149 & 82 & 13 & 15 & 336 \\
\hline 1873 & 180 & 94 & 13 & 16 & 387 \\
\hline 1874 & 183 & 96 & 13 & 17 & 399 \\
\hline 1875 & 189 & 99 & 14 & 15 & 412 \\
\hline 1876 & 196 & 101 & 14 & 16 & 425 \\
\hline 1877 & 200 & 101 & 15 & 18 & 434 \\
\hline 1878 & 202 & 102 & 14 & 18 & 440 \\
\hline 1879 & 216 & 101 & 16 & 18 & 456 \\
\hline 1880 & 245 & 107 & 18 & 21 & 506 \\
\hline
\end{tabular}


Tabela 39. (cd.)

\begin{tabular}{|c|c|c|c|c|c|}
\hline 1 & 2 & 3 & 4 & 5 & 6 \\
\hline 1881 & 260 & 112 & 17 & 22 & 532 \\
\hline 1882 & 283 & 117 & 19 & 25 & 573 \\
\hline 1883 & 298 & 122 & 21 & 27 & 604 \\
\hline 1884 & 305 & 127 & 22 & 30 & 623 \\
\hline 1885 & 302 & 130 & 23 & 29 & 629 \\
\hline 1886 & 312 & 139 & 25 & 31 & 658 \\
\hline 1887 & 340 & 144 & 25 & 34 & 702 \\
\hline 1888 & 371 & 153 & 28 & 37 & 761 \\
\hline 1889 & 402 & 168 & 30 & 41 & 827 \\
\hline 1890 & 409 & 186 & 34 & 47 & 878 \\
\hline 1891 & 425 & 195 & 34 & 54 & 922 \\
\hline 1892 & 427 & 196 & 31 & 52 & 931 \\
\hline 1893 & 449 & 210 & 34 & 53 & 978 \\
\hline 1894 & 454 & 213 & 38 & 55 & 1007 \\
\hline 1895 & 483 & 231 & 37 & 60 & 1073 \\
\hline 1896 & 511 & 251 & 45 & 69 & 1158 \\
\hline 1897 & 550 & 270 & 48 & 73 & 1252 \\
\hline 1898 & 594 & 292 & 51 & 83 & 1356 \\
\hline 1899 & 638 & 310 & 54 & 86 & 1453 \\
\hline 1900 & 672 & 333 & 57 & 98 & 1576 \\
\hline 1901 & 643 & 342 & 56 & 105 & 1595 \\
\hline 1902 & 669 & 350 & 57 & 109 & 1868 \\
\hline 1903 & 719 & 373 & 70 & 116 & 1814 \\
\hline 1904 & 749 & 396 & 61 & 118 & 1839 \\
\hline 1905 & 810 & 426 & 71 & 122 & 1984 \\
\hline 1906 & 878 & 460 & 75 & 133 & 2164 \\
\hline 1907 & 932 & 592 & 77 & 145 & 2410 \\
\hline 1908 & 907 & 513 & 79 & 145 & 2344 \\
\hline 1909 & 959 & 558 & 81 & 148 & 2470 \\
\hline 1910 & 1025 & 589 & 93 & 160 & 2621 \\
\hline 1911 & 1126 & 630 & 78 & 165 & 2806 \\
\hline 1912 & 1203 & 663 & 103 & 180 & 3014 \\
\hline 1913 & 1230 & 683 & 108 & 198 & 3146 \\
\hline
\end{tabular}

Źródło: W.G. Hoffmann, Das Wachstum der deutschen Wirtschaft seit der Mitte des 19. Jahrhunderts, Berlin 1965, s 204-204. 


\section{BIBLIOGRAFIA}

\section{WYKAZ ŹRÓDEL}

Jahrbuch für Volkswirtschaft uns Statistik von O. Hübner, Siebenter Jahrgang, Leipzig 1861.

Preussischen Ministerium der öffentlichen Arbeiten, Führers auf den deutschen Schiffartstrassen, Berlin 1893, Tab. IV.

Preussischen Ministerium der öffentlichen Arbeiten, Führers auf den deutschen Schiffartstrassen, Berlin 1893, Tab. IV.

Statistical Abstract of the United States 1878, First Number, Washington 1879.

Statistical Abstract of the United States 1880, Third Number, Washington 1881.

Statistical Abstract of the United States 1887, Eleventh Number, New York 1888.

Statistical Abstract of the United States 1880, Third Number, Washington 1881.

Statistical Abstract of the United States 1913, Thirty-Sixth Number, Washington 1914.

Statistical Abstract of the United States 1915, Thirty-Eight Number, Washington 1916.

Statistik des Verkehrs und Verbrauchs im Zollverein für die Jahre 1842-1864: Nach den veröffentlichten amtlichen Kommerzial-Übersichten etc, von Bienengräber A., Berlin 1868.

Statistisches Jahrbuch für das Deutsche Reich, Berlin 1880, IX Verkehr und Verkehrsstraßen.

Statistisches Jahrbuch für das Deutsche Reich, Berlin 1880.

Statistisches Jahrbuch für das Deutsche Reich, Berlin 1881.

Statistisches Jahrbuch für das Deutsche Reich, Berlin 1882.

Statistisches Jahrbuch für das Deutsche Reich, Berlin 1883.

Statistisches Jahrbuch für das Deutsche Reich, Berlin 1884.

Statistisches Jahrbuch für das Deutsche Reich, Berlin 1885.

Statistisches Jahrbuch für das Deutsche Reich, Berlin 1886.

Statistisches Jahrbuch für das Deutsche Reich, Berlin 1887.

Statistisches Jahrbuch für das Deutsche Reich, Berlin 1888.

Statistisches Jahrbuch für das Deutsche Reich, Berlin 1889.

Statistisches Jahrbuch für das Deutsche Reich, Berlin 1890.

Statistisches Jahrbuch für das Deutsche Reich, Berlin 1891.

Statistisches Jahrbuch für das Deutsche Reich, Berlin 1892.

Statistisches Jahrbuch für das Deutsche Reich, Berlin 1893.

Statistisches Jahrbuch für das Deutsche Reich, Berlin 1894.

Statistisches Jahrbuch für das Deutsche Reich, Berlin 1895.

Statistisches Jahrbuch für das Deutsche Reich, Berlin 1896.

Statistisches Jahrbuch für das Deutsche Reich, Berlin 1897.

Statistisches Jahrbuch für das Deutsche Reich, Berlin 1898.

Statistisches Jahrbuch für das Deutsche Reich, Berlin 1899.

Statistisches Jahrbuch für das Deutsche Reich, Berlin 1900.

Statistisches Jahrbuch für das Deutsche Reich, Berlin 1901. 
Statistisches Jahrbuch für das Deutsche Reich, Berlin 1902.

Statistisches Jahrbuch für das Deutsche Reich, Berlin 1903.

Statistisches Jahrbuch für das Deutsche Reich, Berlin 1904.

Statistisches Jahrbuch für das Deutsche Reich, Berlin 1905.

Statistisches Jahrbuch für das Deutsche Reich, Berlin 1906.

Statistisches Jahrbuch für das Deutsche Reich, Berlin 1907.

Statistisches Jahrbuch für das Deutsche Reich, Berlin 1908.

Statistisches Jahrbuch für das Deutsche Reich, Berlin 1909.

Statistisches Jahrbuch für das Deutsche Reich, Berlin 1910.

Statistisches Jahrbuch für das Deutsche Reich, Berlin 1911.

Statistisches Jahrbuch für das Deutsche Reich, Berlin 1912.

Statistisches Jahrbuch für das Deutsche Reich, Berlin 1913.

Statistisches Jahrbuch für das Deutsche Reich, Berlin 1914.

Statistisches Jahrbuch für das Deutsche Reich, Berlin 1915.

Statistisches Jahrbuch für den Preussischen Staat, Berlin 1915.

Statistisches Jahrbuch für den Preussischen Staat, Berlin 1916.

Vergleichender Statistik des Handels der Deutschen Staaten, Rau H., Wien 1863.

\section{WYKAZ OPRACOWAŃ}

Abramovitz M., Resource and Output Trends in the United States since 1870, Occasional Paper 52, New York 1956.

Armstrong J., The Role of Coastal Shipping in UK Transport: an Estimate of Comparative Traffic Movements in 1910, „Journal of Transport History” 1987, no. 8.

Ashton T.S., The Industrial Revolution (1760-1830), London 1948.

Aymler G., The State's Servants the Civil Service of the English Republic, 1649-1660, London 1973.

Bairoch P., European Trade Policy, 1815-1914, [w:] P. Mathias, S. Pollard (eds.), The Industrial Economies: The Development of Economic and Social Policies, The Cambridge Economic History of Europe, vol. VIII, Cambridge 1989.

Bairoch P., Free trade and European Economic Development in the 19th Century, „European Economic Review" 1972, no. 3.

Bairoch P., International industrialization levels from 1750 to 1980, „The Journal of European History" 1982, no. 2.

Baszkiewicz J., Historia Francji, Wrocław-Warszawa-Kraków 2004.

Blum O., Jacobi R., Verkehr und Betrieb der Eisenbahnen, Berlin 1925.

Borchard K., Staatsverbrauch und öffentliche Investitionen 1780-1850, Göttingen 1968.

Born K. E., Geld und Banken im 19. und 20. Jahrhundert, Stuttgart, 1977.

Boyd J., Walton G. M., The social savings from nineteenth century rail passenger services, „Explorations in Economic History" 1972, no. 9.

Deutsche Bundesbank, Deutsches Geld - und Bankwessen in Zahlen 1876-1975, Frankfurt am Main 1976.

Burhop C., Die Kreditbanken in der Gründerzeit, ,, Schriftenreihe des Instituts für Bankhistorische Forschung" 2004, Bd. 21.

Cameron R., Historia gospodarcza świata. Od paleolitu do czasów najnowszych, Warszawa 1996.

Ciepielewski J., Kostrowicka I., Landau Z., Tomaszewski J., Dzieje gospodarcze świata do roku 1980, Warszawa 1985.

Cipolla C., Literacy and Development in the West, Baltimore, MD 1969. 
Clapham J. H., The Economic Development Of France And Germany 1815-1914, Cambridge 1921.

Clemens M., Williamson J., Why Did Tariff-Growth Correlation Reverse after 1950?, NBER Working Paper 2002, no. 9181.

Clough S. B., European Economic History. The Economic Development of Western Civilization, New York 1968.

Coatsworth J. H., Indispensable railroads in a backward economy: the case of Mexico, „, Journal of Economic History" 1979, vol. 39 (4).

Court H.B., A Concise Economic History of Britain from 1750 to Recent Times, Cambridge 1954.

Crafts N., Social Savings as a Measure of The Contribution of a New Technology to Economic Growth, Department of Economic History London School of Economics, Working Paper 2004, no. 6 .

Crafts N., Steam as a General Purpose Technology: A Growth Accounting Perspective, Working Paper 2003, no. 75.

Crafts N., The Contribution of New Technology to Economic Growth: Lessons from Economic History, „Revista de Historia Económica. Journal of Iberian and Latin American Economic History" 2010, vol. 28(3).

Chodak S., Systemy partyjne Europy Zachodniej. Pochodzenie, ewolucja, funkcje społeczne, Warszawa 1961.

Czapliński W., Galos A., Korta W., Historia Niemiec, Wrocław-Warszawa-Kraków-Gdańsk 1981.

Czubiński A., Wybrane problemy historii Niemiec w XIX i XX wieku, Poznań, 1992.

Dammers D., Fischer H., The Performance of German Big Business in the 20th Century, „Cologne Economic History Paper" 2009, no. 1.

Das Deutsche Eisenbahnwesen der Gegenwart, Bd.1 und 2, Berlin 1911.

Deane P., Habakkuk H., The Take-off in Britain, [w:] The Economics of Take-Off into Sustained Growth, ed. W.W. Rostow, London 1963.

Doering-Manteuffel A., Die deutsche Frage und das europäische Staatensystem 1815-1871, [w:] Enzyklopädie deutscher Geschichte, Bd.15, München 1993.

Donaldson D., Hornbeck R., Railroads and American Economic Growth: a Market Access Approach, https://economics.uchicago.edu/workshops/Hornbeck\%20Richard\%20-\%20Railroads.pdf

Dubiecki M., Rys dziejów najnowszych od r. 1815 po 1875. Z krótkim rzutem oka na dzieje lat 18761878, Wilno 1880.

Dumke R., Clio's Climacteric? Betrachtungen über Stand und Entwicklungstendenzen der Cliometrischen Wirtschaftsgeschichte, „Vierteljahrschrift für Sozial- und Wirtschaftsgeschichte"1986, Nr. 73.

Eddie S., Cliometric: what is it, whither came it forth?, [w:] Selected Cliometric Studies on German Economic History, eds. J. Komlos, S. Eddie, Stuttgart 1997.

Feinstein C.H., National Income, Expenditure and Output of the United Kingdom, 1855-1965, Cambridge 1972

Fear J., Cartels and Competition: Neither Markets nor Hierarchies, http://www.hbs.edu/faculty/ Publication\%20Files/07-011.pd

Ferguson N., Potega pieniąza. Finansowa historia świata, Kraków 2010.

Fishlow A., American Railroads and the Transformation of the Antebellum Economy, Cambridge 1965.

Fishlow A., Productivity and Technological Change in the Railroad Sector, 1840-1910, [w:] Output, Employment and Productivity in the United States after 1800, „Studies in Income and Wealth" 1966, vol. 30.

Fogel R., A Quantitative Approach to the Study of Railroads in American Economic Growth: A Report of Some Preliminary Findings, "Journal of Economic History" 1962, no. 22. 
Fogel R., Die neue Wirtschaftsgeschichte Forschungsergebnisse und Methoden, „Kölner Vorträge zur Sozial- und Wirtschaftsgeschichte" 1970, Heft 8.

Fogel R., Notes on the Social Saving Controversy, "Journal of Economic History" 1979, vol. XXXIX, no. 1.

Fogel R., Railroads and American Economic Growth: Essays in Econometric History. Baltimore 1964.

Foreman-Peck J., A Model of Later Nineteenth Century European Economic Development, „Revista de Historia Económica" 1995, Second Series, vol. 13.

Foreman-Peck J., Railways and the late Victorian economic growth, [w:] J. Foreman-Peck (ed.), New Perspectives on the Late Victorian Economy: Essays in Quantitative Economic History, 1860-1914, Cambridge 1991.

Fremdling R., Eisenbahnen und deutsches Wirtschaftswachstum 1840-1879. Ein Beitrag zur Entwicklungstheorie und zur Theorie der Infrastruktur, Dortmund 1985.

Frerich J., Frey M., Handbuch der Geschichte der Sozialpolitik in Deutschland, Bd. 1, München 1993.

Gerschenkron A., Bread and Democracy in Germany, Berkeley 1943.

Ginsbert J., Drogi żelazne Rzplitej, Warszawa 1935.

Gourvish T., Railways and the British economy, 1830-1914, „Economic History Society Studies in Economic and Social History" 1980, .

Grabiński T., Wydmus S., Szacownie liniowych funkcji trendu metoda najmniejszych kwadratów przy pomocy wzorów uproszczonych, „Wiadomości Statystyczne” 1975, nr 4.

Grabska W., Ekonomiczna ekspansja Niemiec na Wschód w latach 1870-1939, Wrocław-Warszawa-Kraków 1964.

Grotewold Ch., Die Deutsche Schiffahrt in Wirtschaft und Recht, Stuttgart 1914.

Hawke G.R., Railways and Economic Growth in England and Wales, 1840-1870, Oxford 1970.

Henning F.W., Eisenbahnbau und Entwicklung der Eisenindustrie in Deutschland, Archiv und Wirtsch. Jg. 1973, Nr. 6.

Herranz-Loncán A., Role of railways in export-led growth: the case of Uruguay, 1870-1913, „Economic History of Developing Regions" 2011, vol. 26.

Herranz-Loncan A., The contribution of railways to economic growth in Latin America before 1914: a growth accounting approach, MPRA Paper 2011, no. 33578, http://mpra.ub.uni-muenchen.de/33578.

Herranz-Loncán A., The Contribution of Railways to Economic Growth in Latin America before 1914: a Growth Accounting Approachs, http://www.ub.edu/histeco/pdf/herranz-DT01.pdf.

Heubach E., Die Verkehrsentwickelung auf dem Wasserstrassen und Eisenbahnen des Elbe-Oder Gebietes in dem Zeitraum von 1882-1895, Berlin 1898.

Hirschman A., Die Strategie der wirtschaftlichen Entwicklung, Stuttgart 1967.

Hirschmann A., The Strategy of Economic Development, New Haven 1958.

Hoffmann W.G., British Industry 1700-1950, Oxford 1955.

Hoffmann W.G., Das Wachstum der deutschen Wirtschaft seit der Mitte des 19. Jahrhunderts, Berlin 1965 .

Holtfrerich C.L., Quantitative Wirtschaftsgeschichte des Ruhrkohlenbergbaus im 19. Jahrhundert. Eine Führungssektoranalyse, Dortmund 1973.

http://www.sfu.ca/ djacks/data/prices/Germany/prices.html

http://www.spiegel.de/spiegel/spiegelspecialgeschichte/d-50620319.html

http://www.wsv.de/wasserstrassen/historisches/binnenschifffahrt/index.html

Huenemann R. W., The Dragon and the Iron Horse: The Economics of Railroads in China, 1876-1937, Harvard East Asian Monographs, Cambridge 1983.

International political economy. Perspectives on global power and wealth, eds. J.A. Frieden, D.A. Lake, London-New York 2003. 
Jacobs A., Richter H., Die Großhandelspreise in Deutschland von 1792 bis 1934, „Sonderhefte des Instituts für Konjunkturforschung" 1935, Nr. 37.

Kaliński J., Historia gospodarcza XIX i XX w., Warszawa 2008.

Kendrick J., Vaccara B., New Developments in Productivity Measurement, Chicago 1980.

Kennedy P., Mocarstwa świata. Narodziny, rozkwit, upadek, Warszawa 1994.

Kędzierski J.Z., Dzieje Anglii, 1485-1939, t. II, 1830-1939, Wrocław-Warszawa-KrakówGdańsk-Lódź 1986.

Kiesewetter H., Industrielle Revolution in Deutschland: Regionen als Wachstumsmotoren, Stuttgart 2004.

Kiesewetter H., Region und Industrie in Europa 1815-1995, „Grundzüge der modernen Wirtschaftsgeschichte" 2000, Bd. 2.

Kirchhain G., Das Wachstum der deutschen Baumwollidustrie im 19. Jahrhundert. Eine historische Modellstudie zur empirischen Wachstumsforschung, Münster 1973.

Kleeberg J., German Cartels: Myths and Realities, http://econ.barnard.columbia.edu/econhist/papers/Kleeberg German Cartels.pdf.

Koranyi K., Powszechna historia państwa i prawa, t. IV, Warszawa 1967.

Köttgen A., Studien über Getreideverkehr und Getreidepreise in Deutschland, „Staatwissenschaftliche Studien" 1890, Bd. 3, Heft 2.

Koźmian S., O działaniach i dziełach Bismarcka, Kraków 1902.

Krasuski J., Historia Niemiec, Wrocław-Warszawa-Kraków 2004.

Kuczynski T., Das Wachstum der Industrieproduktion in der kapitalistischen Hauptländern (England, USA, Frankreich, Deutschland) und seine regionale Verteilung von 1830 bis 1913. Versuch einer statistischen Rekonstruktion, Jahrbuch für Wirtschaftsgeschichte, Sonderband: Umwälzung der deutschen Wirtschaft im 19. Jahrhundert, Berlin 1989

Kula W., Problemy i metody historii gospodarczej, Warszawa 1983.

Kuliszer J., Powszechna historia gospodarcza średniowiecza i czasów nowożytnych, t. II, Warszawa 1961.

Kurowski S., Historyczny proces wzrostu gospodarczego, Warszawa, 1963.

Kuznets S., Wzrost gospodarczy narodów. Produkt, struktura, Warszawa 1976.

Lampe M., Bilateral Trade Flows in Europe, 1857-1875. A new dataset, „Research in Economic History" 2008, no. 26.

Lehmann S., The German Elections in the 1870s: Why Germany Turned from Liberalism to Protectionism, Bonn 2009.

Leunig T., Social savings, [w:] D. Greasley, L. Oxley, Economics and History. Surveys in Cliometrics, Oxford 2011.

Leunig T., Time is Money: A Re-assessment of the Passenger Social Savings From Victorian British Railways, Department of Economic History London School of Economics Working Paper 2005, no. 9 .

Lindenlaub D., The Confidence in a New Currency: The Introduction of the Mark in Germany 1871-1876, [w:] Centres and Peripheries in Banking. The Historical Development of Financial Markets, eds. P. Cottrell, E. Lange, U. Olsson, Burlington 2007.

List F., Das Nationale System der Politischen Ökonomie, Jena 1910.

List F., Über ein sächsisches Eisenbahn-System als Grundlage eines allgemeinen deutschen Eisenbahn-Systems, und insbesondere über die Anlegung einer Eisenbahn von Leipzig nach Dresden, Leipzig 1833.

Lubbe A., Imperium europejskie? Ekspansja Europy a powstanie gospodarki światowej, Warszawa 1982.

Maddison A., Historical Statistics for the World Economy: 1-2003 AD, www.saisjhu.edu/library/ subjectguides/stats.htm [dostęp 02.11.2010]. 
Maddison A., Monitoring the World Economy 1820-1992, Paris 2000.

Maddison A., Phases of Capitalist Development, Oxford, 1982.

Maddison A., The World Economy, Paris, 2006.

Maddison A., The World Economy: A. Millenial Perspective, Paris 2002.

Mantoux P., Rewolucja przemysłowa w XVIII w. Zarys dziejów powstania wielkiego nowoczesnego przemystu w Anglii, Warszawa 1957.

Marschalck P., Deutsche Überseewanderungen im 19. Jahrhundert. Ein Beitrag zur soziologischen Theorie der Bevölkerung, Stuttgart 1973.

Mata M., Love J., A Reversal in the Historical Role of Tariffs in Economic Growth? The Cases of Brazil and Portugal, Est. econ., São Paulo 2008, vol. 38, no. 3.

Mathias S., Pollard S (eds.), The Industrial Economies: The Development of Economic and Social Policies, The Cambridge Economic History of Europe, vol. VIII, Cambridge 1989.

Metzer J., Railroads in Tsarist Russia: Direct Gains and Implications, „Explorations in Economic History" 1976, no. 13.

Milo W., Badania ekonometryczne z zastosowaniem mikrokomputerów. Podstawy metodologiczne, Łódź 1997.

Mitchell B.R., International Historical Statistics: Europe, 1750-2000. London 2003.

Mitchell B.R., European Historical Statistics 1750-1970, New York 1975.

Montesquieu, O duchu praw, Warszawa 1957.

Moulton H., Waterways versus Railways, Boston-New York 1912.

Myszczyszyn J., Rola koksu i żelaza w industrializacji świata, „Kultura i Historia” 2009, nr 16, http://www.kulturaihistoria.umcs.lublin.pl/archives/1476.

Myszczyszyn J., Wplyw maszyny parowej na rozwój gospodarczy świata w XIX $i$ XX w., „Kultura i Historia" 2009, nr 16/, http://www.kulturaihistoria.umcs.lublin.pl/archives/1473

Neider J., Transport międzynarodowy, Warszawa 2012.

Noga M., Co decyduje o rozwoju gospodarczym, [w:] Wzrost gospodarczy a innowacje, red. J. Koch, Wrocław 2008.

Nördling W., Die Selbstkosten des Eisenbahn-Transportes und die Wasserstrassen-Frage in Frankreich, Preussen und Oesterreichs, Wien 1885.

O'Brien P., The New Economic History Of The Railways, London-Worcester 1977.

O'Brien P., Transport and Economic Development in Europe 1789-1914, [w:] Railways and the Economic Development of Western Europe, 1830-1914, ed. P. O'Brien, Oxford 1983.

Oliner S.D., Sichel D.E., Information Technology and Productivity: Where Are We Now and Where Are We Going, „Federal Reserve Bank of Atlanta Economic Review” 2002, vol. 87, no. 3,.

Pajewski J., Historia powszechna 1871-1918, Warszawa 1994.

Pamiętnik wystawy przemystowej w Bochum od 19-27 lipca 1913 r., Oberhausen (Nadrenia) 1914.

Pastusiak L., Prezydenci, t. 2, Stany Zjednoczone od Andrew Johnsona do Franklina D. Roosevelta, Warszawa 1987.

Pierenkemper T., Tilly R., The German Economy During the Nineteenth Century, New YorkOxford 2004.

Pohl H., Die Konzentration in der deutschen Wirtschaft vom ausgehenden 19. Jahrhundert bis 1945, [w:] H. Pohl, W. Treue, Die Konzentration in der deutschen Wirtschaft seit dem 19. Jahrhundert. Zeitschrift für Unternehmensgeschichte, Beiheft 11, Wiesbaden 1987.

Pollard S., Peaceful Conquest: The Industrialization of Europe 1760-1970, Oxford 1981.

Pomorski J., Paradygmat New Economic History. Studium z teorii rozwoju nauki, Lublin 1986.

Price R., Historia Francji, Poznań 2001.

Railways and the Economic Development of Western Europe, 1830-1914, ed. P. O'Brien, London 1983. 
Rogowski R., Commerce and Coalitions: How Trade Affects Domestic Political Alignments, Princeton 1989.

Romer D., Makroekonomia dla zaawansowanych, Warszawa 2000.

Rostow W.W., Politics and Stages of Growth, Warszawa 1973.

Rostow W.W., The Process of Economic Growth, New York 1962.

Rostow W.W., The Stages of Economic Growth: A Non Communist Manifesto, Cambridge 1990.

Rostow W.W., The Stages of Economic Growth: A Non-Communist Manifesto, Cambridge 1960.

Rousseau J.J., Umowa spoleczna, Warszawa 1918.

Rozwój polskiej gospodarki - perspektywy i uwarunkowania, red. G. Kołodko, Warszawa 2002.

Rusiński W., Zarys historii gospodarczej powszechnej, Warszawa 1970.

Rusiński W., Zarys historii gospodarczej powszechnej. Czasy nowożytne i najnowsze (1500-1939), Warszawa 1970.

Savage Ch., An Economic History of Transport, London 1959.

Sax E., Die Verkehrsmittel in Volks- und Staatswirtschafts, 3. Bände, Berlin 1918-1922.

Scherzer K., Einige Mittheilungen über den Welthandel und die wichtigsten Weltverkehrsmittel, „Geographisches Jahrbuch”, Gotha 1868.

Schmidt S., 1860-1914 Europa zwischen Liberalismus und Protektion. Seminararbeit, Norderstedt 2004.

Schultz T., Investment in Human Capital, "The American Economic Review" 1961, vol. 51, no. 1.

Schumpeter J.A.,Teorie der wirtschaftlichen Entwicklung. Einer Untersuchung Unternehmergewinn, Kapital, Kredit, Zins und Konjunkturzyklen, Berlin 1964.

Sheehan J., Klasse und Partei im Kaiserreich: Einige Gedanken zur Sozialgeschichte der deutschen Politik, [w:] Innenpolitische Probleme des Bismarck-Reiches, München 1983.

Sidney P., The Europeanization of the international economy 1800-1870, [w:] D. Aldcroft, A. Sutcliffe (eds.), Europe in the international economy 1500 to 2000, Cheltenham 1999.

Skodlarski J., Historia gospodarcza, Warszawa 2012.

Skodlarski J., Matera R., Gospodarka Światowa. Geneza i rozwój, Warszawa 2004.

Solow R., Technical Progress, Capital Formation and Economic Growth, „The American Economic Review" 1962, vol. 52.

Sombart W., Der moderne Kapitalismus, Bd. II, Teil 1, Kapitel IV, München 1928.

Stankiewicz W., Historia myśli ekonomicznej, Warszawa 1983.

Stigler G., Trends in Output and Employment, New York 1947.

Stone L., The Causes of the English Revolutions 1529-1642, London 1972.

Summerhill W., Big social savings in a small laggard economy: railroad-led growth in Brazil, „Journal of Economic History” 2005, vol. 65 (1).

Sympher L., Die wirtschaftliche Bedeutung des Rhein-Elbe-Kanals. Bd. 1, Berlin 1899.

Sympher L., Die zukünftige Entwicklung der deutschen Wasserwirtschaft, Deutsche Weltwirtschaftliche Gesellschaft, Vereinsschriften, Heft 9, Berlin 1918.

Szpak J., Historia gospodarcza powszechna, Warszawa 2003.

Sztaudynger J.J., Wzrost gospodarczy, rodzina a godność życia, [w:] „Nauka-Etyka-Wiara”red. J. Ławrynowicz, A. Zabołotny, Warszawa 2011.

Sztaudynger J.J., Zatoń W., Kryzys gospodarczy a kryzys rodziny - analizy symulacyjne, „Prakseologia" 2010, nr 150.

Sztaudynger J.J., Wzrost gospodarczy a kapitat społeczny, prywatyzacja i inflacja, Warszawa 2005.

Teubert O., Die Binnenschiffahrt. Ein Handbuch für alle Beteiligten, Leipzig 1912.

Teutenberg H.J., Die Deutsche Landwirtschaft beim Eintritt in die Phase der Hochindustrialisierung, Köln 1977.

The European Economy 1750-1914. A Thematic Approach, eds. D.H. Aldcroft, S.P. Ville, Manchester 1966. 
Then V., Eisenbahnen und Eisenbahnunternehmer in der Industriellen Revolution, Ein preußisch/ deutsch-englischer Vergleich, „Kritische Studien zur Geschichtswissenschaft”1997, Bd. 120.

Tilly R., Banken und Industrialisierung in Deutschland: Qauntifizierungsversuche, in Entwicklung und Aufgaben von Versicherungen und Banken in der Industrialisierung, ed. F.W. Henning, Schriften des Vereins für Sozialpolitik, Berlin 1980.

Tilly R., Cliometrics in Germany: An Introductory Essay, [w:] Selected Cliometric Studies on German Economic History, eds. J. Komlos, S. Eddie, Stuttgart 1997.

Tilly R., Großunternehmen: Schlüssel zur Wirtschafts- und Sozialgeschichte der Industrieländer?, „Geschichte und Gesellschaft” 1993, Nr. 19.

Traveleyan G.M., Historia Anglii, Warszawa 1965.

Urlich F., Staffeltarife und Wasserstrassen, Berlin 1894.

Viljoen S., Economic Systems in World History, London 1974.

Wagenführ H., Kartelle in Deutschland, Nürnberg 1931.

Webb S., Agricultural protection in Wilhelminian Germany forging an empire with pork and rye, [w:] Selected Cliometric Studies on German Economic History, eds. J. Komlos, S. Eddie, Stuttgart 1997.

Weber M., Die Protestantische Ethik und der Geist des Kapitalismus, „Archiv für Sozialwissenschaft und Sozialpolitik" 1904, Nr. 20.

Weisbrod B., Education and Investment in Human Capital, „Journal of Political Economy” 1962, no. 70 .

Wielka Historia Powszechna, red. J. Dąbrowski, O. Halecki, O. Kukiel, S. Lam, t. VI, cz. 3, Od Wielkiej Rewolucji do Wojny Światowej 1789-1914, Poznań 1999 (reprint 1934).

Williamson J., Milner Ch., The World Economy. A Textbook in International Economics, New York 1991.

Williamson J., The Evolution of Global Markets since 1830: Background Evidence and Hypotheses, „Economic History Review”1995, no. 32.

Witkowska D., Podstawy ekonometrii i teorii prognozowania, Kraków 2005.

Wójcik Z., Historia powszechna XVI-XVII wieku, Warszawa 1991.

Zentgraf E., Der Wettbewerb auf dem Berliner Kohlenmarkt mit besonderer Berücksichtigung der jüngsten Vergangenheit, Münster 1913.

Ziegler D., Eisenbahnen und Staat im Zeitalter der Industrialisierung. Die Eisenbahnpolitik der Deutschen Staaten im Vergleich, VSAG, 1996, Beihefte127.

Zins H., Historia Anglii, Wrocław 2009.

Żywczyński M., Historia powszechna, 1789-1870, Warszawa 1990. 


\section{SPIS TABEL}

Tabela 1. Wskaźniki makroekonomiczne dla wybranych krajów w roku 1870 i $1913 \ldots \ldots \ldots \ldots \ldots \ldots \ldots . . . .41$

Tabela 2. Niemieckie drogi wodne śródlądowe - stan na koniec 1877 r. ....................................... 48

Tabela 3. Wybrane inwestycje w ramach rozbudowy dróg wodnych w Niemczech (1880-1916) 49

Tabela 4. Rywalizacja pomiędzy transportem wodnym i kolejowym - berliński rynek węgla w latach 1846-1910.

Tabela 5. Wybrane niemieckie prywatne spółki kolejowe (1847 r.) _.................................................... 57

Tabela 6. Kapitał akcyjny, przychody i wydatki kolei w wybranych krajach europejskich (1859 r.).

Tabela 7. Rozwój niemieckiej sieci kolejowej z podziałem na kraje w wybranych latach (1839-1914).

Tabela 8. Stawki frachtu na rzece Łaba dla wybranych towarów i kierunków w latach 1871$1892(\mathrm{pf} / \mathrm{tkm})$.

Tabela 9. Stawki frachtu na rzekach: Łaba, Odra w latach dziewięćdziesiątych XIX w. dla wybranych odcinków i towarów (pf/tkm)

Tabela 10. Transport śródlądowy na tle transportu kolejowego na obszarze Łaba-Odra w latach 1882-1895

Tabela 11. Struktura przewozów kolejowych i śródlądowych wodnych na obszarze Łaba-Odra dla wybranych grup produktów (1885-1895)

Tabela 12. Udział kategorii towarowych w całości przewozów linii kolejowych i śródląd. dróg wodnych Niemiec (1911)

Tabela 13. Wskaźnik społecznych oszczędności (SS) kolei dla wybranych krajów (\% PKB)

Tabela 14. Liczba krajowych karteli w Niemczech, Austrii, Węgrzech 48 9 57

Tabela 15. Kartelizacja niemieckiej gospodarki - wskaźnik zatrudnienia, udział w produkcji (1907 r.)

Tabela 16. Rynkowy udział wybranych państw w produkcji przemysłowej w latach 1830-1913 (\%) Tabela 17. Udział w światowej produkcji przemysłowej (\%) oraz udział w produkcji przemysłowej poszczególnych krajów „czwórki”

Tabela 18. Aktywa instytucji finansowych w Niemczech w latach 1860-1913 (mld marek) Tabela 19. Kraje członkowskie Niemieckiego Związku Celnego - powierzchnia (1865 r.). Tabela 20. Przychody z opłat celnych w krajach Niemieckiego Związku Celnego w latach 1834-1864 (w talarach)

Tabela 21. Wartość wwozu i wywozu towarów w Niemieckim Związku Celnym (1834-1864)

Tabela 22. Kierunki i wartość obrotów handlowych Niemieckiego Związku Celnego (1864 r.) Tabela 23. Poziom stawek celnych ad valorem dla wybranych grup towarowych w wybranych krajach europejskich i USA w latach 1857-1873 (\% wartości importu)

Tabela 24. Charakterystyka obrotów handlowych dla wybranych krajów (1865-1866) 143

Tabela 25. Obroty w handlu zagranicznym przodujących krajów w latach 1875-1913 (mln ówczesnych franków) 
Tabela 26. Średnia stopa wzrostu zatrudnienia, produktywności pracy, intensywności kapitału dla niemieckiej gospodarki (1850-1913)

Tabela 27. Cena frachtu wodnego z wybranych miejsc do Berlina w latach 1898-1909

Tabela 28. Wpływ kolei na wzrost gospodarczy w Niemczech w wybranych okresach: the capital term, TFP term, całkowity udział kolei

Tabela 29. Społeczne oszczędności sektora kolejowego w Niemczech (1909 r.)

Tabela 30. Społeczne oszczędności sektora kolejowego w Niemczech z uwzględnieniem nadwyżki konsumenta (1909 r.)

Tabela 31. Wartości współczynnika zmienności oraz innych statystyk opisowych dla analizowanych zmiennych objaśniających

Tabela32. Wartości współczynnika korelacji $r$ Pearsona pomiędzy zmiennymi objaśnianymi a zmienną endogeniczną

Tabela 33. Wartości współczynnika korelacji $r$ Pearsona pomiędzy zmiennymi objaśnianymi a zmienną endogeniczną

Tabela34. Wyniki estymacji dla parametrów strukturalnych modelu MNK (1850-1913)

Tabela35. Wyniki estymacji dla parametrów strukturalnych modelu MNK (1853-1913)

Tabela36. Wyniki estymacji dla parametrów strukturalnych modelu MNK (1853-1913)

Tabela 37. Indeks output dla kolei w latach 1840-1913 $(1913=100)$

Tabela 38. Współczynnik kapitału, intensywność kapitału, produktywność pracy, produktywność kapitału - koleje niemieckie (w cenach z 1913 r.)

Tabela 39. Wartość dodana przewozów kolejowych na tle innych rodzajów transportu w latach 1850-1913 (mln marek, ceny stałe z 1913 r.) 


\section{SPIS RYSUNKÓW}

Rys. 1. Wskaźnik produkcji przemysłowej dla wybranych krajów europejskich w latach 1850-1913 $(1913=100)$

Rys. 2. Wskaźnik produkcji przemysłowej Niemiec z uwzględnieniem przemysłu tekstylnego, produkcji metali, surówki żelaza, górnictwa i wydobycia węgla kamiennego $(1913=100)$.

Rys. 3. Wzrost liczby ludności Europy Zachodniej z uwzględnieniem 12 krajów i 30 krajów na tle wzrostu liczby ludności Francji, Niemiec, Włoch i Wlk. Brytanii (skala logarytmiczna) Rys.4. Schematyczne przedstawienie zależności między rozwojem transportu a wzrostem gospodarczym

Rys. 5. Dynamika przewozów kolejowych i śródlądowych na tle udziału sektora kolejowego w transporcie w latach 1835-1913

Rys.6. Niemiecka sieć kolei żelaznych według planów F. Lista (1833 r.)

Rys. 7. Długość linii kolejowych w państwach niemieckich (z Austrią) w $1856 \mathrm{r}$.

Rys. 8. Niemiecka sieć kolejowa stan na $1850 \mathrm{r}$.

Rys. 9. Długość państwowych i prywatnych szlaków kolejowych w Niemczech na tle całkowitej długości linii kolejowych w latach 1860-1913 (km)

Rys. 10. Długość linii kolejowych w wybranych krajach europejskich w latach 1840$1914(\mathrm{~km})$

Rys. 11. Niemiecka sieć kolejowa stan na $1870 \mathrm{r}$.

Rys. 12. Liczba przewiezionych towarów (mln tkm) i osób (mln pkm) w latach 1840-1871

Rys. 13. Długość linii kolejowej $(\mathrm{km})$ na tle gęstości kolejowej $\left(\mathrm{km} / 1000 \mathrm{~km}{ }^{2}, \mathrm{~km} / 100\right.$ tys. mieszkańców) w latach 1835-1913

Rys. 14. Długość szlaków kolejowych $(\mathrm{km})$ na tle przewozów kolejowych, morskich i śródlądowych (mln tkm) w latach 1840-1913

Rys. 15. Niemiecka sieć kolejowa stan na $1913 \mathrm{r}$.

Rys. 16. Główne kierunki transportu kolejowego towarów z uwzględnieniem ilości przesyłanych i odbieranych

Rys. 17. Szlaki wodne śródlądowe na obszarze Niemiec

Rys. 18. Rozwój przewozów śródlądowych w latach 1882-1895 (mln tkm)

Rys. 19. Transport śródlądowy na tle transportu kolejowego na obszarze Łaba-Odra w latach 1882-1895 (mln tkm) z uwzględnieniem udziału transportu śródlądowego w przewozach ogólnych (\%)

Rys. 20. Natężenie transportu śródlądowego na głównych obszarach rzek Łaba-Odra w 1882 r. i 1895 r. (mln Mg)

Rys. 21. Transport z uwzględnieniem natężenia dróg wodnych w Niemczech (1910 r.) z określeniem kierunku transportu oraz jego rozmiarów

Rys. 22. Przyrost długości linii kolejowych w USA w latach 1830-1912 (mile) z podaniem trendu liniowego

Rys. 23. Rozwój kolei w USA i Niemczech w latach $1840-1913(1913=100)$ 
Rys. 24. Popyt na transport przy uwzględnieniu sektora kolejowego i z uwzględnieniem braku sektora kolejowego

Rys. 25. Przyrost demograficzny w wybranych krajach Europy Zachodniej i USA w latach 1820-1890 (tys. osób)

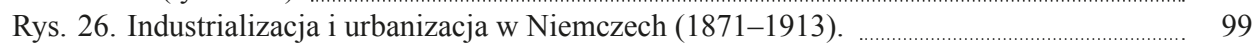

Rys. 27. Wykres rozrzutu PKB (mln marek), liczba ludności Niemiec (tys.) w latach 1840-1913 100

Rys. 28. Rozrzut PKB per capita (w markach, z 1913) względem liczby ludności (tys. osób) $\mathrm{z}$ określeniem linii trendu.

Rys. 29. Wydatki gospodarstw domowych (mln M.) z podziałem na określone grupy (\%) na tle ogólnych wydatków konsumpcyjnych

Rys. 30. Emigracja niemiecka w latach 1835-1913 r. (tys. osób) z określeniem linii trendu ..... 105

Rys. 32. Indeks - produkcja węgla kamiennego, węgla brunatnego oraz rudy żelaza - Niemcy $(1913=100)$.

Rys. 33. Produkcja surówki hutniczej w wybranych krajach europejskich w latach 1880-1910 (tys. Mg metrycznych).

Rys. 35. Poziom inwestycji netto w Niemczech w cenach bieżących i stałych (z 1913 r.) w latach 1850-1913 (mln marek).

Rys. 36. Zaangażowany kapitał w podziale na poszczególne sektory gospodarki w latach 1850-1913 (\%).

Rys. 37. Nominalna i realna stopa oprocentowania na tle inflacji w Niemczech w latach 18771913.

Rys. 38. Ilość banknotów w obiegu (mln marek) na tle poziomu PKB w latach 1860-1913.

Rys. 39. Cena pszenicy (1 kwarta, 8 buszli) Niemcy, Anglia i Walia w latach 1881-1913, jako przykład konwergencji cen na rynku zbóż

Rys. 40. Główne rośliny uprawne w Niemczech w latach 1880-1912 r. (mln ha)

Rys. 41. Cła efektywne ad valorem na wybrane grupy towarów w Niemczech w latach 1879$1913(\%)$

Rys. 42. Wwóz, wywóz i saldo wymiany handlowej Niemiec w obrocie żytem w latach 1860 $1913(\mathrm{Mg})$

Rys. 43. Interesy wybranych grup społecznych w kontekście ceł na produkty przemysłowe i rolne w Niemczech

Rys. 44. Saldo wymiany handlowej zbożami na tle salda handlowego NZC i Niemiec (18601913)

Rys. 45. Udział poszczególnych krajów członkowskich w podziale przychodów Związku Celnego (1865 r.)

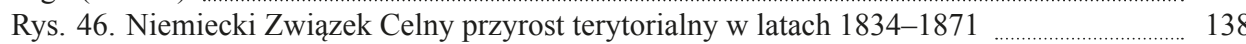

Rys. 47. Przychody netto z ceł Niemieckiego Związku Celnego na tle wzrostu ludności (1834-1864)

Rys. 48. Średnie stawki celne w wybranych krajach europejskich i USA w latach 1856-1875

(\%)

Rys. 49. Indeks dla długości szlaków kolejowych, eksportu i PKB per capita $(1913=100) \ldots 148$

Rys. 50. Zatrudnienie w wybranych sektorach gospodarki (tys. osób) w latach 1860-1913 _...... 149

Rys. 51. Zatrudnienie w wybranych sektorach gospodarki (\%) na tle liczby ludności (mln) w latach 1871-1913

Rys. 53. PKB per capita, stopa wzrostu PKB i PNN dla gospodarki niemieckiej w latach 1860-1913. 
Rys. 54. Stopa wzrostu PNN na tle stopy wzrostu produktywności czynników produkcji (\%) dla gospodarki Niemiec w latach 1870-1913

Rys. 55. Struktura sektorowa wytwarzanego PNN Niemiec w latach 1850-1913 (\%). ................. 156

Rys. 56. Struktura PNN Niemiec w latach 1850-1913 (mln M. w cenach stałych z 1913 r.) .... 157

Rys. 57. Poziom PKB per capita (USD z 1990 r.), a zatrudnienie (\%) w rolnictwie w Niemczech w latach 1860-1913

Rys. 58. Poziom PKB per capita (USD z 1990 r.), a zatrudnienie (\%) w przemyśle z górnictwem w Niemczech w latach 1860-1913

Rys. 59. Output/Produkt Krajowy Brutto (PKB) (\%) oraz liniowy trend wzrostowy

Rys. 60. Przewozy towarów z uwzględnieniem przewozów kolejowych, śródlądowych i morskich (mln tkm) na tle PKB Niemiec w latach 1840-1913

Rys. 61. Stawki frachtu towarowego (pf/1 tkm) i przewozów pasażerskich (pf/1 pkm) koleją w Niemczech w latach 1840-1913

Rys. 62. Zatrudnienie w niemieckim sektorze kolejowym w latach 1840-1913 (tys. osób), oraz wskaźnik zatrudnienia kolejnictwo - wybrane sektory gospodarki (\%)

Rys. 63. Wartość dodana w gospodarce niemieckiej w latach 1850-1913 (mln marek) na tle udziału sektora transportowego (\%)

Rys. 64. Zaangażowany kapitał i poziom inwestycji w sektorze kolejowym (1850-1913).

Rys. 65. PKB Niemiec, przychody netto sektora kolejowego, kapitał zakładowy kolei (mln marek) w latach 1871-1913

Rys. 66. Stosunek zmiany nadwyżki konsumenta do społecznych oszczędności w zależności od stopnia elastyczności popytu i spadku cen

Rys. 67. Indeks output na tle dynamiki przewozów osobowych (pkm) i towarowych (tkm) dla kolei niemieckich (1840-1913)

Rys. 68. Indeks output na tle indeksu PKB per capita i PKB $(1913=100)$ skala logarytmiczna Rys. 69. Indeks całkowitej produkcyjności, output i input dla sektora kolejowego w Niemieckim Związku Celnym i Niemczech $(1840-1913,1913=100)$ skala logarytmiczna

Rys. 70. Współczynnik kapitału, intensywność kapitału, produktywność pracy, produktywność kapitału - koleje niemieckie (w cenach z 1913 r.)

Rys. 71. Output i kapitał zakładowy dla kolei w Niemczech (1835-1913, w cenach stałych z 1913 r.)

Rys. 72. Reszty surowe dla zmiennej endogenicznej przy poziomie ufności 0,95

Rys. 73. Rzeczywisty i estymowany przebieg $(\ln )$ PKB per capita z uwzględnieniem reszt surowych

Rys. 74. Rzeczywisty i estymowany przebieg (ln) PKB per capita z uwzględnieniem zmiennej binarnej i reszt

Rys. 75. Dynamika PKB per capita Niemiec 1850-1913, (rok poprzedzający $=100)$.

Rys. 76. Rzeczywisty i estymowany przebieg dynamiki PKB per capita (1853-1913) $\mathrm{z}$ uwzględnieniem reszt surowych

Rys. 77. Rzeczywisty i estymowany przebieg dynamiki PKB per capita (1853-1913) $\mathrm{z}$ uwzględnieniem reszt surowych 



\section{OD REDAKCJI}

Doktor Janusz Myszczyszyn jest adiunktem w Katedrze Ekonomii Wydziatu Ekonomicznego Zachodniopomorskiego Uniwersytetu Technologicznego w Szczecinie. Od 2010 r. jest Kierownikiem Pracowni Mikroekonomii. W roku 2004 obronił pracę doktorską pt. Możliwości wzrostu efektywności ekonomicznej wybranych firm agrobiznesu w wyniku implementacji ZSI.

W początkowym okresie pracy naukowej, obejmującym lata 1995-1999, autor prowadził $\mathrm{m}$.in. badania $\mathrm{w}$ zakresie bezrobocia ukrytego $\mathrm{w}$ rolnictwie chłopskim, zmian w strukturze wydatków gospodarstw domowych oraz zastosowania analizy technicznej i fundamentalnej w przewidywaniu kursów akcji. Praca magisterska pt. Zastosowanie analizy fundamentalnej w przewidywaniu kursów akcji (1996) została nagrodzona (III miejsce) w konkursie na najlepszą pracę magisterską w Akademii Rolniczej w Szczecinie.

W latach 1998-2012, Janusz Myszczyszyn, aktywnie uczestniczył, jako certyfikowany konsultant i kierownik zespołów wdrożeniowych $\mathrm{w}$ implementacji systemów informatycznych klasy ERP (w tym: Great Plains Dynamics, CDN XL, CDN OPT!MA, SAP Business One) w blisko trzydziestu firmach regionu. Wynikiem zaangażowania $\mathrm{w}$ rozwój kontaktów z gospodarką były m.in. opracowania z zakresu analizy potrzeb i projektów funkcjonalnych systemów ERP. Jego aktywność naukowa w tym zakresie zaowocowała, obok przygotowania rozprawy doktorskiej, publikacjami i prezentacjami na konferencjach naukowych zagadnień z zakresu wykorzystania narzędzi informatycznych w zarządzaniu współczesną organizacją gospodarczą.

W 2010 r. został recenzentem zewnętrznym w projekcie PITWIN (Portal Innowacyjnego Transferu Wiedzy w Nauce) realizowanym przez Wyższą Szkołę Handlową w Kielcach. Na swoim koncie ma kilka recenzji artykułów naukowych publikowanych w monografiach naukowych. Od 2010 r., jako niezależny ekspert zespołu ds. analizy ekonomiczno-finansowej Komisji Oceniającej Projekty w ramach Regionalnego Programu Operacyjnego Województwa Zachodniopomorskiego na lata 2007-2013 dokonał ocen kilkunastu projektów (w tym kilku projektów indywidualnych). Uczestniczył również, jako ekspert w Zespole Ekspertów Zewnętrznych ds. Analiz Delphi Narodowego Programu Foresight Polska 2020.

Owocem wieloletniej aktywności naukowej Janusza Myszczyszyna są 53 opracowania naukowe (w tym: 47 artykułów naukowych, 47 samodzielnych publikacji, 20 opracowań z zakresu historii gospodarczej), współautorstwo pozycji 
dydaktycznej, autorstwo monografii naukowej. Wyniki badań autora zaprezentowano na blisko 35 konferencjach naukowych i seminariach. W latach 2005-2010 autor prowadził indywidualne badania, jako kierownik w ramach grantów wewnątrzuczelnianych, m.in.: Badanie oddziatywania systemów informatycznych klasy ERP na budowe organizacji opartej na procesach, Ocena funkcjonowania wspólnotowego systemu ekozarządzania i audytu EMAS w Polsce w aspekcie idei zrównoważonego rozwoju.

Autor jest laureatem trzech nagród Rektora Zachodniopomorskiego Uniwersytetu Technologicznego w Szczecinie. Aktywnie włącza się w prace organizacyjne Uczelni - w latach 2011-2012 był członkiem Wydziałowej Komisji ds. Jakości Kształcenia, członkiem konkursu „Być przedsiębiorczym”, jest opiekunem roku na kierunku zarządzanie.

Doktor Janusz Myszczyszyn prowadzi m.in. zajęcia dydaktyczne z: mikroekonomii, makroekonomii, ekonomii, historii myśli ekonomicznej, historii gospodarczej, zarządzania sektorem publicznym, zarządzania jakością na kierunkach ekonomia, zarządzanie, architektura krajobrazu oraz seminaria licencjackie i magisterskie na kierunku zarządzanie, ekonomia. Jest promotorem i recenzentem kilkunastu prac licencjackich i magisterskich. Aktywnie uczestniczy w promowaniu ruchu studenckiego, będąc od 2003 r. inicjatorem i opiekunem (wielokrotnie nagradzanego) Studenckiego Koła Naukowego „Inwestor”. Fascynuje go historia powszechna, historia gospodarcza, w tym problemy wzrostu i rozwoju gospodarczego świata. Jest członkiem Polskiego Towarzystwa Historii Gospodarczej. 